http://dx.doi.org/10.18778/7525-811-0
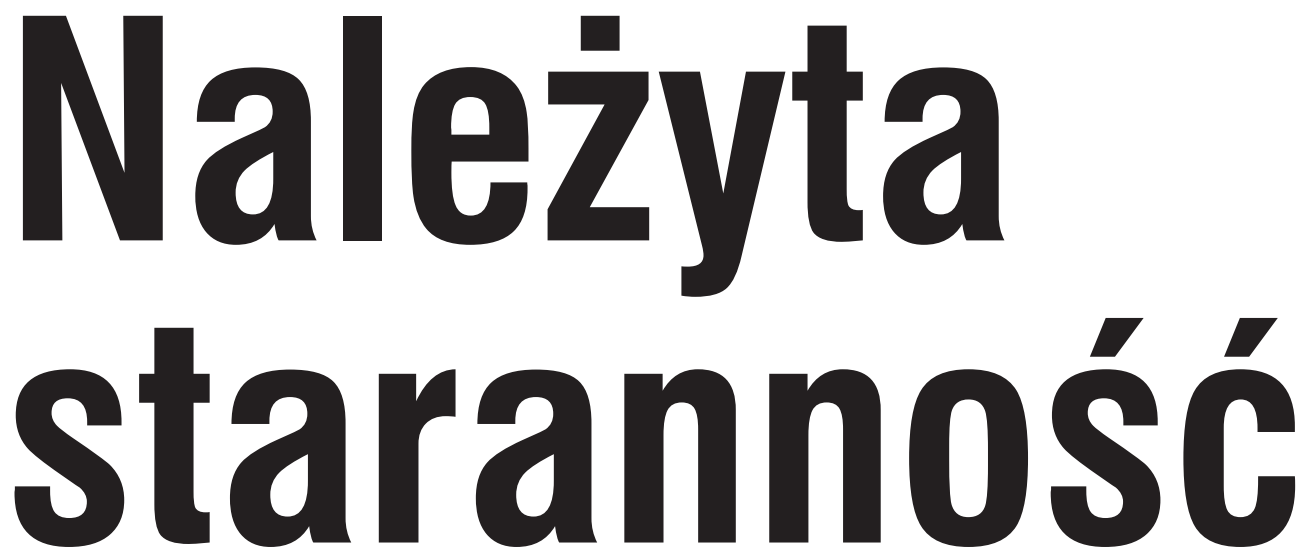

w prawie międzynarodowym 
$\frac{3}{40}$ 


\section{Joanna Kulesza}
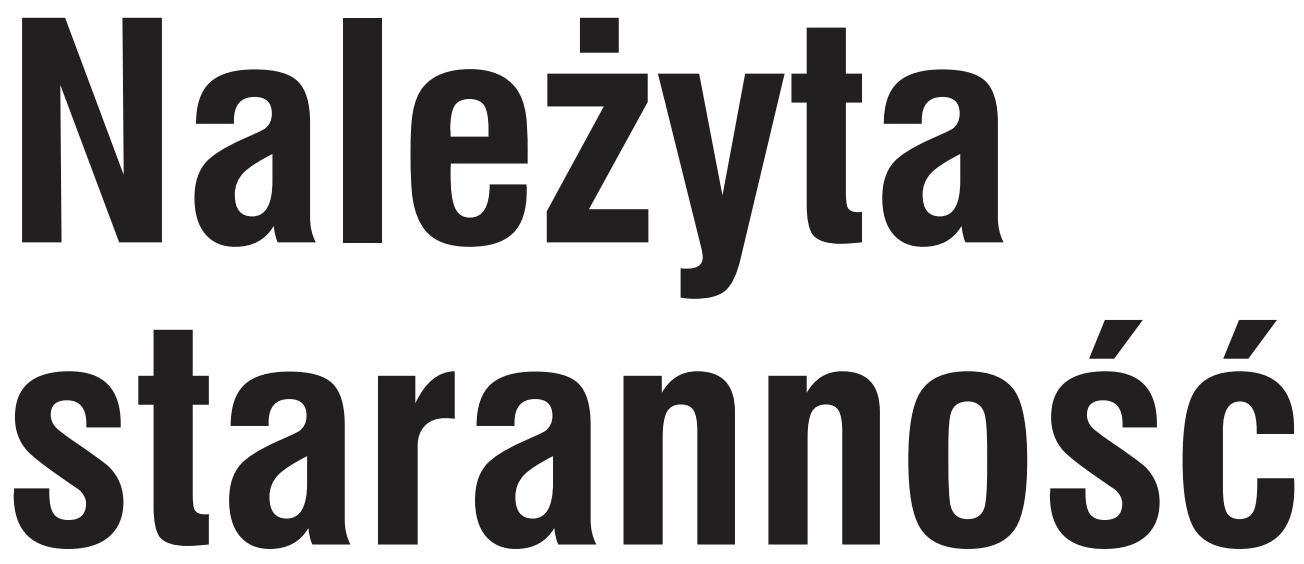

w prawie międzynarodowym

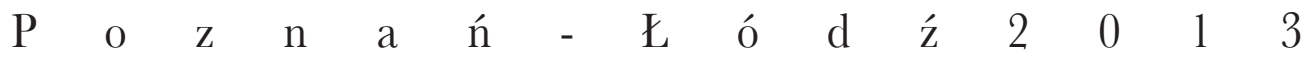


Joanna Kulesza - Katedra Prawa Międzynarodowego i Stosunków Międzynarodowych

Wydział Prawa i Administracji

Uniwersytet Łódzki, 90-232 Łódź, ul. Kopcińskiego 8/12

e-mail: joannakulesza@gmail.com

\author{
RECENZENT \\ Piotr Daranowski \\ REDAKCJA I KOREKTA \\ Magdalena Górna \\ OKŁADKE PROJEKTOWAE \\ Dariusz Gtowacki
}

Praca sfinansowana ze środków Wydziału Prawa i Administracji

Uniwersytetu Łódzkiego

C Copyright by Uniwersytet Łódzki, Łódź 2013

(C) Copyright for this edition by Ars boni et aequi Przedsiębiorstwo Wydawnicze, Poznań 2013

All rights reserved

Wydrukowano z gotowych materiałów dostarczonych do Wydawnictwa UŁ

Wydanie I. W.06229.13.0.M

ISBN 978-83-60550-41-0 (Ars boni et aequi)

ISBN 978-83-7525-811-0 (Wydawnictwo Uniwersytetu Łódzkiego)

EISBN 978-8-3796-9910-0

\author{
Wydawcy \\ Ars boni et aequi Przedsiębiorstwo Wydawnicze - Michał Rozwadowski \\ 60-351 Poznań, ul. Zakręt 26/1 \\ tel. (61) 86883 23, tel./faks (61) 8671827 \\ e-mail: książki@arsboni.com.pl
}

Wydawnictwo Uniwersytetu Łódzkiego

90-131 Łódź, ul. Lindleya 8

www.wydawnictwo.uni.lodz.pl

e-mail: ksiegarnia@uni.lodz.pl

tel. (42) 66558 63, faks (42) 6655862

Druk i oprawa: Quick Druk 


\section{Spis treści}

Wykaz skrótów . . . . . . . . . . . . . . . . . . . 9

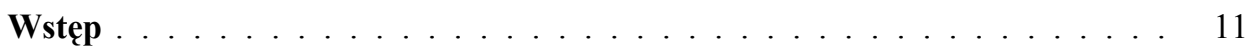

Kwestie terminologiczne . . . . . . . . . . . . . . . . . . . . 17

Wina a odpowiedzialność w prawie międzynarodowym . . . . . . . . . . . 26

Należyta staranność w prawie krajowym . . . . . . . . . . . . . . . . . . . 30

\section{Rozdział 1}

GENEZA ZASADY NALEŻYTEJ STARANNOŚCI . . . . . . . . . . . . . . 33

1.1. Państwo jako kolektyw - odpowiedzialność zbiorowa w czasach starożytnych i średniowieczu . . . . . . . . . . . . . . . . 33

1.2. Odpowiedzialność indywidualna władcy - grocjańska koncepcja winy w epoce absolutyzmu . . . . . . . . . . . . . . . . . . . . . . . 38

1.3. Oświeceniowe koncepcje odpowiedzialności państw . . . . . . . . . . . . . 42

1.4. Odpowiedzialność pośrednia (zastępcza) państwa według Oppenheima . . . 48

1.5. Odpowiedzialność obiektywna według Anzilottiego . . . . . . . . . . . . 50

1.6. Spuścizna Anzilottiego w pracach Ago . . . . . . . . . . . . . . . . . 52

\section{Rozdzial 2}

NALEŻYTA STARANNOŚĆ W ORZECZNICTWIE MIEDDYNARODOWYM . . . . . . . . . . . . . . . 57

2.1. Sprawa statku Caroline (1837) . . . . . . . . . . . . . . . . . . 57

2.2. Należyta staranność a odmowa wymiaru sprawiedliwości . . . . . . . . . 59

2.3. Sprawa statku Alabama (1872) . . . . . . . . . . . . . . . . . . . 69

2.4. Sprawa De Brissot i innych (1885) . . . . . . . . . . . . . . 71

2.5. Sprawa Lovetta i innych (1892) . . . . . . . . . . . . . . . . . 73

2.6. Sprawa Davis $(1903) \ldots \ldots \ldots$. . . . . . . . . . . . . . . . . . . . .

2.7. Sprawa Tellini $(1923) \ldots \ldots \ldots \ldots$. . . . . . . . . . . . . . . . . . . . . . . . . . . .

2.8. Sprawa Noyes (1933) . . . . . . . . . . . . . . . . . . . . . . . . . . . . 77

2.9. Sprawa Denham (1933) . . . . . . . . . . . . . . . . . 78

2.10. Sprawa Adams (1933) . . . . . . . . . . . . . . . . . . . . . 79

2.11. Sprawa Terytorium Saary (1933) . . . . . . . . . . . . . . . . 80

2.12. Sprawa huty w Trail (1941) . . . . . . . . . . . . . . . . . . . . . 80

2.13. Sprawa cieśniny Korfu (1949) _ . . . . . . . . . . . . . . . . . . . . . . . . . 84

2.14. Sprawa zatrucia Renu przez firmę Sandoz (1986) . . . . . . . . . . . . . . 85

2.15. Sprawa zakładników amerykańskich w Teheranie (1980) . . . . . . . . . . 88

2.16. Sprawa oddziałów contras w Nikaragui (1986) . . . . . . . . . . . . . . . . 92

2.17. Sprawa Tadiča (1999) . . . . . . . . . . . . . . . . . . . . . . 94

2.18. Sprawa ludobójstwa w Srebrenicy (2007) . . . . . . . . . . . . . . 96 
2.19. Kwestia legalności użycia broni nuklearnej (1996) . . . . . . . . . . . . . . 98

2.20. Sprawa zapory Gabcikovo-Nagymaros na Dunaju (1997) . . . . . . . . . . 100

2.21. Sprawa młynów rzecznych (Argentyna p. Urugwajowi, 2010) . . . . . . . . 103

2.22. Podsumowanie . . . . . . . . . . . . . . . . . 105

\section{Rozdzial 3 \\ ODPOWIEDZIALNOŚĆ PAŃSTWA (STATE RESPONSIBILITY)}

ZA BRAK NALEŻYTEJ STARANNOŚCI . . . . . . . . . . . . . . . . . . . . 107

3.1. Uwagi wstępne. . . . . . . . . . . . . . . . . . . . . . . 107

3.2. Prace Ligi Narodów nad zasadami odpowiedzialności państw . . . . . . . . 108

3.3. Prace Komisji Prawa Międzynarodowego nad zasadami odpowiedzialności

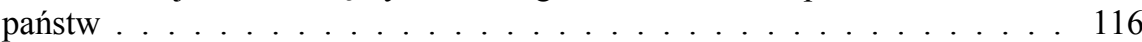

3.4. Należyta staranność w pracach KPM . . . . . . . . . . . . . . . 127

3.5. Zasady odpowiedzialności międzynarodowej państw . . . . . . . . 141

3.6. Przypisanie państwu czynu międzynarodowo bezprawnego . . . . . . . . . 144

3.7. Odpowiedzialność państwa za działania jego organów . . . . . . . . . . . . 146

3.8. Odpowiedzialność państwa za podmioty wykonujące elementy władzy państwowej . . . . . . . . . . . . . . . . . 147

3.9. Odpowiedzialność państwa za osoby prywatne działające pod kierownictwem lub kontrolą państwa . . . . . . . . . . . . . . . . . . 148

3.10. Problem tzw. odpowiedzialności pośredniej (zastępczej) państwa za działania osób prywatnych . . . . . . . . . . . . . . . 150

3.11. Okoliczności wyłączające bezprawność … . . . . . . . . . . 155

\section{Rozdział 4}

\section{ODPOWIEDZIALNOŚĆ MIĘDZYNARODOWA (INTERNATIONAL} LIABILITY) ZA BRAK NALEŻYTEJ STARANNOŚCI

4.1. Należyta staranność a zasada dobrosąsiedztwa - uwagi wstępne . . . . . . . 157

4.2. Geneza powstania i historia rozwoju obszaru badań nad odpowiedzialnością międzynarodowa. . . . . . . . . . . . . . . . . . . . . . 159

4.3. Zasady odpowiedzialności międzynarodowej za szkodliwe konsekwencje czynów niezakazanych prawem międzynarodowym . . . . . . . . . . . 161

4.4. Teorie odpowiedzialności międzynarodowej za czyny niezakazane prawem międzynarodowym. . . . . . . . . . . . . . . . . . . . 167

4.5. Aplikacja reguł odpowiedzialności międzynarodowej . . . . . . . . . . . . 169

4.6. Należyta staranność a ryzyko i szkoda w reżimie odpowiedzialności międzynarodowej . . . . . . . . . . . . . . . . . . 172

4.7. Pojęcie szkody transgranicznej . . . . . . . . . . . . . . . . . . . . 198

4.8. Krytyka metodologii KPM . . . . . . . . . . . . . . . . . 202

\section{Rozdzial 5}

NALEŻYTA STARANNOŚĆ W REŻIMACH TRAKTATOWYCH . . . . . . 215

5.1. Uwagi wstępne. . . . . . . . . . . . . . . . . . . . . . . 215

5.2. Należyta staranność $\mathrm{w}$ międzynarodowym prawie środowiska . . . . . . . . 218

5.3. Odpowiedzialność państwa w międzynarodowym prawie środowiska . . . . 221

5.4. Prawo morza . . . . . . . . . . . . . . . . . . . . . . 231

5.5. Prawo międzynarodowych cieków wodnych . . . . . . . . . . . 235 
5.6. Ochrona cudzoziemców . . . . . . . . . . . . . . . . . . . 238

5.7. Należyta staranność $\mathrm{w}$ prawie dyplomatycznym . . . . . . . . . . . . . 243

5.8. Ochrona cudzoziemców a obowiązki państwa wysyłającego . . . . . . . . . 248

5.9. Bezpieczeństwo międzynarodowe a należyta staranność . . . . . . . . . . . 249

5.10. Należyta staranność przy zapobieganiu przestępstwom o charakterze terrorystycznym . . . . . . . . . . . . . . . . . 254

5.11. Cyberterroryzm i cyberbezpieczeństwo a zasada należytej staranności. . . . 259

\section{Rozdzial 6}

ZASADA NALEŻYTEJ STARANNOŚCI W PRAWIE

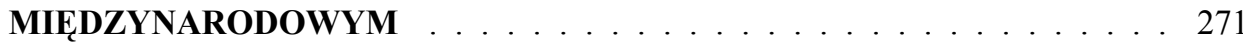

6.1. Zasady ogólne prawa międzynarodowego . . . . . . . . . . . . . 271

6.2. Zasada odpowiedzialności międzynarodowej . . . . . . . . . . . . . 280

6.3. Zasada należytej staranności _ . . . . . . . . . . . . . . . . . 283

6.4. Konsekwencje naruszenia zasady należytej staranności _ . . . . . . . . . 292

Podsumowanie . . . . . . . . . . . . . . . . . . . . . . . . . . . . . . . . . . . . 299

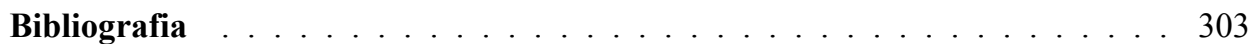

Akty prawa krajowego . . . . . . . . . . . . . . . . . . . . 303

Umowy międzynarodowe i inne źródła prawa międzynarodowego . . . . . . . . . 303

Raporty Komisji Prawa Międzynarodowego i inne dokumenty miękkiego

prawa międzynarodowego . . . . . . . . . . . . . . . 305

Artykuły i monografie . . . . . . . . . . . . . . . . . . . . . . . . . 307

Orzeczenia. . . . . . . . . . . . . . . . . . . . . . . . . . 317

Artykuły prasowe i inne źródła . . . . . . . . . . . . . . . . . . . . 318 



\section{Wykaz skrótów}

\begin{tabular}{|c|c|}
\hline CBDR & $\begin{array}{l}\text { - wspólna ale zróżnicowana odpowiedzialność } \\
\text { (Common But Differentiated Responsibility) }\end{array}$ \\
\hline CCIT & $\begin{array}{l}\text { - Kompleksowa konwencja ws. zwalczania terroryzmu } \\
\text { (Comprehensive Convention on International Terrorism) }\end{array}$ \\
\hline DNS & - Domain Name System \\
\hline Dz.U. & - Dziennik Ustaw \\
\hline EIA & $\begin{array}{l}\text { - ocena oddziaływania na środowisko } \\
\text { (Environmental Impact Assesment) }\end{array}$ \\
\hline EKPC & - Europejska Konwencja Praw Człowieka \\
\hline ETPC & - Europejski Trybunał Praw Człowieka \\
\hline ETS & - European Treaty Series \\
\hline GCTS & $\begin{array}{l}\text { - Globalna Strategia Zwalczania Terroryzmu } \\
\text { (Global Counter-Terrorism Strategy) }\end{array}$ \\
\hline I.C.J. Reports & - International Court of Justice Reports \\
\hline ICANN & $\begin{array}{l}\text { - Internetowa Korporacja ds. Przyznanych Nazw i Numerów } \\
\text { (Internet Corporation for Assigned Names and Numbers) }\end{array}$ \\
\hline IETF & - Zespół ds. Inżynierii Internetu (Internet Engineering Task Force) \\
\hline IGF & - Forum Zarządzania Internetem (Internet Governance Forum) \\
\hline ILA & - International Law Association \\
\hline ILM & - International Law Materials \\
\hline IMCO & - Intergovernmental Maritime Consullative Organisation \\
\hline IMO & - International Maritime Organisation \\
\hline KNZ & - Karta Narodów Zjednoczonych \\
\hline KoPM & - Konwencja Narodów Zjednoczonych o prawie morza \\
\hline KPM & - Komisja Prawa Międzynarodowego \\
\hline KWPT & - Konwencja wiedeńska o prawie traktatów \\
\hline KWSD & - Konwencja wiedeńska o stosunkach dyplomatycznych \\
\hline KWSK & - Konwencja wiedeńska o stosunkach konsularnych \\
\hline LN & - Liga Narodów \\
\hline MARPOL & $\begin{array}{l}\text { - Międzynarodowa Konwencja o zapobieganiu zanieczyszczaniu morza } \\
\text { przez statki (International Convention for the Prevention of Pollution } \\
\text { from Ships) }\end{array}$ \\
\hline MTK & - Międzynarodowy Trybunał Karny \\
\hline MTKJ & - Międzynarodowy Trybunał Karny ds. Zbrodni w byłej Jugosławii \\
\hline MTS & - Międzynarodowy Trybunał Sprawiedliwości \\
\hline ONZ & - Organizacja Narodów Zjednoczonych \\
\hline P.C.I.J. & - Publications of the Permanent Court of International Justice \\
\hline $\mathrm{PiP}$ & - Państwo i Prawo \\
\hline R.I.A.A. & - Reports of International Arbitral Awards \\
\hline $\mathrm{RdC}$ & - Recueil des Cours de l'Académie de droit international de La Haye \\
\hline RE & - Rada Europy \\
\hline
\end{tabular}




$\begin{array}{ll}\text { RfC } & - \text { Requests for Comments } \\ \text { RGDIP } & - \text { Revue generale de droit international public } \\ \text { STSM } & - \text { Stały Trybunał Sprawiedliwości Międzynarodowej } \\ \text { U.N. Doc } & - \text { United Nations Document } \\ \text { U.N.T.S. } & - \text { United Nations Treaty Series } \\ \text { UCLAs } & - \text { Uniterally Controlled Latino Assets } \\ \text { WGIG } & - \text { Grupa Robocza ds. Zarzadzania Internetem } \\ & \quad \text { (Working Group on Internet Governance) } \\ \text { WSIS } & - \text { Światowy Szczyt Społeczeństwa Informacyjnego } \\ & \quad \text { (World Summit on the Information Society) } \\ \text { Y.I.L.C. } & - \text { Yearbook of the International Law Commission } \\ \text { ZO ONZ } & - \text { Zgromadzenie Ogólne ONZ }\end{array}$




\section{Wstęp}

Znaczenie pojęcia należytej staranności wciaż rośnie, wykraczajac poza kwestię szkód wyrzqdzonych przez osoby fizyczne, znajdujqce się na terytorium państwa. Naglaca jest potrzeba zdefiniowania odpowiedzialności międzynarodowej $i$ odpowiedzialności państwa za czyny niosqce szkody lub niebezpieczeństwo ich powstania w zwiqzku z realizacja niebezpiecznych przedsięwzięć ${ }^{1}$.

Pemmaraju Sreenivasa Rao, Specjalny Sprawozdawca Komisji Prawa Międzynarodowego ONZ ds. odpowiedzialności międzynarodowej, $1999 \mathrm{r}$.

Należyta staranność (ang. due diligence, niem. anzuwendenden Sorgfalt, fr. diligence requise) to pojęcie wpisane w treść zasady międzynarodowej odpowiedzialności państw. Choć jest ono kluczowe dla ustalenia odpowiedzialności państwa za zaniechanie, nie doczekało się jak dotąd wszechstronnego omówienia w literaturze przedmiotu. Ten stan rzeczy przypisać należy niedookreślonej naturze owej figury retorycznej, która ma służyć za miarę działań państwa w danych okolicznościach, co czyni zeń niezmiernie elastyczną, ale i trudną do opisania klauzulę prawną. Jednocześnie w dobie „prywatyzowania” relacji międzynarodowych, zarówno gospodarczych, jak i politycznych, a więc w sytuacji, w której stosunki polityczne i prawne kształtują nie tylko organy państw, ale także globalne korporacje czy międzynarodowe organizacje przestępcze, wytyczenie zakresu działań, jakie powinny podjąć państwa przy zapobieganiu szkodliwym konsekwencjom aktywności podmiotów działających w ich jurysdykcji zyskuje na znaczeniu. Jest ono istotne zarówno przy określaniu reguł odpowiedzialności państwa za tolerowanie popełnianych w jego władzy przestępstw o charakterze terrorystycznym, skierowanych przeciwko innym suwerenom, jak i w kontekście pytania o właściwe procedury upoważniania międzynarodowych korporacji do zarządzania przedsięwzięciami realizowanymi na jego terytorium, których niepowodzenie lub nieprzewidziany przebieg mogłyby negatywnie wpłynąc na miliony istnień. $Z$ tych powodów państwa intensywnie negocjują przebieg granic wymaganych od siebie wzajemnie wysiłków. Opis stanu tej debaty do roku 2013 jest przedmiotem niniejszego wywodu. Jej podsumowanie, i zarazem cel przeprowadzonej analizy stanowi propozycja uznania obowiązku wykazywania przez państwa należytej staranności przy realizacji ich międzynarodowych zobowiązań za jedną z zasad prawa międzynarodowego. Autorka przy-

${ }^{1}$ Drugi raport Specjalnego Sprawozdawcy P. S. Rao, 1999, U.N. Doc. A/CN.4/501 (dalej: Drugi raport Rao, U.N. Doc. A/CN.4/501), pkt 29, s. 6. 
łącza się tym samym do poglądów m.in. Pissilo Mazzeschiego, Dahma i Boyla, opisujących współczesny reżim odpowiedzialności międzynarodowej jako odpowiedzialność obiektywna. Uznaje wynikający z prawa zwyczajowego obowiązek wykazywania należytej staranności przy realizacji zobowiązań międzynarodowych za kryterium przypisania państwom odpowiedzialności za zaniechania ich organów, sprzeczne z treścią prawa międzynarodowego, odrzucając dyskusyjną przesłankę winy państwa lub jego organu. Należyta staranność, opisana szczegółowo $\mathrm{w}$ treści reżimów traktatowych, dotyczących odpowiedzialności państw na zasadzie ryzyka (podsumowanych w pracach Komisji Prawa Międzynarodowego poświęconych odpowiedzialności międzynarodowej za czyny niezakazane prawem międzynarodowym oraz $\mathrm{w}$ dorobku orzeczniczym, związanym $\mathrm{z}$ odpowiedzialnością państw za szkody transgraniczne), pozwala na zidentyfikowanie cech modelu „dobrego rządu”, aplikowalnego do każdego z państw. Cechy te stanowią treść zasady należytej staranności, wymagającej od państw podjęcia wszelkich racjonalnych środków celem zapobiegania znaczącym szkodom innych suwerenów. $Z$ dogmatycznego punktu widzenia samo naruszenie tak pojmowanej normy międzynarodowej może stać się podstawą odpowiedzialności państwa. Analiza stanowisk państw zmusza jednak, na obecnym etapie rozwoju prawa międzynarodowego, do uwzględnienia przesłanki szkody materialnej jako niezbędnego elementu przypisania odpowiedzialności państwu za zaniechanie jego organów. Brak należytej staranności organów państwa analizowany powinien być w opaciu o obiektywne kryteria, takie jak istnienie zarówno wiążącej państwo normy traktatowej lub zwyczajowej, która została naruszona, jak i faktycznej możliwości zapobiegania jej naruszeniu, którą dysponowały jego organy. Zakres owego obowiązku omówiony został szczegółowo w treści pracy. Podobnie jak dobra wiara, należyta staranność wymagana jest przy realizacji wszelkich zobowiązań międzynarodowych do określonego postępowania (ang. obligations of conduct), także tych, w treści których nie została wprost przywołana, choć z wyłączeniem zobowiązań o charakterze skutkowym.

Zawarta $\mathrm{w}$ treści książki analiza bogatego dorobku doktryny i praktyki prawa międzynarodowego, opisujących reguły międzynarodowej odpowiedzialności, poprowadzona została celem identyfikacji treści owej zasady. Tym samym, poza zakresem niniejszej analizy pozostaje wiele kluczowych zagadnień odpowiedzialności międzynarodowej, dotyczących m.in. definicji i działań organów państwa, ewolucji prawa odpowiedzialności międzynarodowej, w tym roli winy w jej przypisaniu, zagadnienie odpowiedzialności państw za naruszanie praw człowieka, rozróżnienie pojęć ,siły” i ,agresji” w prawie międzynarodowym. $\mathrm{W}$ treści rozprawy poruszonych zostało wiele zagadnień pobocznych, niezbędnych dla rekonstrukcji treści zasady należytej staranności w prawie międzynarodowym, lecz których szczegółowy opis znacznie wybiega poza zakres prezentowanego studium. Wśród nich wymienić należy kwestie definicji i znaczenia terminów: „terroryzm”, „suwerenność państwa” (por. rozdz. V) czy „środki odwetowe" i „sankcje w prawie międzynarodowym” (por. rozdz. VI). Także treść zasad: dobrego sąsiedztwa i ciągłego rozwoju (rozdz. IV) omówiona 
została jedynie w zakresie niezbędnym dla ustalenia roli należytej staranności w stosowaniu prawa odpowiedzialności międzynarodowej.

Punktem wyjścia badań stanowiących podstawę niniejszej książki była analiza dorobku doktryny z zakresu odpowiedzialności w prawie międzynarodowym, począwszy od koncepcji odpowiedzialności zbiorowej za działania jednostek, aplikowanej względem społeczności średniowiecznych. Następnie należyta staranność analizowana była w kontekście odpowiedzialności władcy za „jego” państwo, w oparciu o grocjańską koncepcję winy z epoki absolutyzmu. Ewolucja myślenia o odpowiedzialności państw, w tym odejście od grocjańskiej teorii winy jako koniecznego elementu odpowiedzialności, przedstawiona została na przykładzie prac de Vattela i Halla. Omówiono także koncepcje współczesne, w których należyta staranność przywoływana bywa przy uzasadnianiu kontrowersyjnej koncepcji „odpowiedzialności zastępczej” państwa, zaproponowanej przez Oppenheima czy „odpowiedzialności obiektywnej” według Anzilottiego. Prace tego ostatniego badacza wywarły silny wpływ na XX-wieczne rozważania czynione przez najwybitniejszych prawników międzynarodowych na forum Komisji Prawa Międzynarodowego. Ich dyskusjom ton nadał pierwszy specjalny sprawozdawca ds. odpowiedzialności państw, Roberto Ago, pozostający pod silnym wpływem idei swojego rodaka, Anzilottiego, czemu wyraz dał w trakcie prac Komisji i w treści sporządzonych przez nią dokumentów. Owa ewolucja myśli prawniczej dotyczyła odpowiedzialności państw, a w jej kontekście zagadnienia należytej staranności, omówiona została w rozdziale pierwszym.

Przegląd stanowisk doktryny stanowić miał w zamierzeniu autorki punkt wyjścia do prześledzenia ewolucji orzecznictwa sądów i trybunałów międzynarodowych, dotyczących odpowiedzialności państwa, w których niedołożenie przez nie należytej staranności stanowiło istotny element przedstawionego sędziom sporu lub jego rozstrzygnięcia. Analizę orzecznictwa rozpoczyna opis judykatów XIX-wiecznych, dotyczących statków: Caroline i Alabama. Większość stanów faktycznych, w których państwa pociagane były do odpowiedzialności za brak należytej staranności na przełomie XIX i XX wieku, dotyczyła szkód, jakie na ich terytoriach ponosili cudzoziemcy i to ten obszar orzecznictwa omówiony jest szczegółowo w oparciu o decyzje komisji dwustronnych działających na obszarze obu Ameryk i Europy. Orzeczenia XX-wieczne dotyczyły rzadziej szkód wyrządzonych cudzoziemcom, a częściej odpowiedzialności państwa za brak należytej ochrony udzielanej przedstawicielom dyplomatycznym państw obcych, które omówione zostały na przykładach spraw: Tellini i zakładników amerykańskich $\mathrm{w}$ Teheranie. Wiek XX przyniósł ponadto dwa nowe wyzwania, zmagania z którymi zostały dobrze odzwierciedlone w dorobku międzynarodowego wymiaru sprawiedliwości. Oto intensywny rozwój technologiczny przyniósł zagrożenia związane $\mathrm{z}$ transportem morskim ropy naftowej czy wykorzystaniem energii nuklearnej. Katastrofy naturalne spowodowane nierozważnym wykorzystaniem nowych technologii lub niedostatecznie wnikliwą analizą jego skutków dla środowiska naturalnego stały się przedmiotem orzeczeń trybunałów w sprawach: 
huty w Trail czy zatrucia Renu przez szwajcarską firmę Sandoz. Rozwój sądownictwa międzynarodowego pozwolił w tym samym czasie na postawienie trybunałom pytań najważniejszych dla budowania pokojowych relacji międzynarodowych, tj. pytań o granice ingerencji jednego państwa w sprawy wewnętrzne drugiego. Odpowiedzi na te pytania sądy międzynarodowe udzielały m.in. w sprawach wspieranych przez Stany Zjednoczone oddziałów contras w Nikaragui czy masakry w Srebrenicy. Te i inne orzeczenia omówione zostały w rozdziale drugim.

W rozdziałach kolejnych omówione zostały prace Ligii Narodów i Organizacji Narodów Zjednoczonych, dotyczące zagadnienia odpowiedzialności międzynarodowej w zakresie, w jakim obejmowały kwestię przedmiotową dla niniejszej rozprawy. Odzwierciedlając ewolucję prac obu organizacji, rozdział trzeci analizuje dokumenty poświęcone odpowiedzialności państwa (ang. state responsibility), ze szczególnym uwzględnieniem odpowiedzialności za brak należytej staranności po stronie organów państwowych, skutkujący naruszeniem jego zobowiązania, a więc niezgodny $\mathrm{z}$ międzynarodowym porządkiem prawnym. W toku tych rozważań autorka odniosła się do najważniejszych kwestii dotyczących odpowiedzialności międzynarodowej, takich jak rola i pojęcie organów państwa i podmiotów wykonujących elementy władzy państwowej, odpowiedzialność państwa za czyny osób działających pod jego kierownictwem lub kontrola, jak również problem tzw. odpowiedzialności pośredniej (zastępczej) państw za działania osób prywatnych. Szczególna uwaga poświęcona została roli, jaką KPM przypisuje wykazywanej przez organy państw przy realizacji międzynarodowych zobowiązań należytej staranności. W treści rozważań dotyczących odpowiedzialności państw za czyny zakazane prawem międzynarodowym należyta staranność opisana została przy okazji omawiania pojęcia przypisania państwu czynu międzynarodowo bezprawnego. Odpowiedzialność państwa za czyn sprzeczny z treścią jego międzynarodowych zobowiązań powstaje niezależnie od charakteru naruszanego obowiązku, który może wynikać z normy konwencyjnej lub zwyczajowej. Państwo może ponosić odpowiedzialność za zaniechania swoich organów, jeśli owe zaniechania prowadzą do naruszenia prawa międzynarodowego przez osoby prywatne pozostające we władzy państwa $^{2}$. Rola należytej staranności przy przypisywaniu państwu odpowiedzialności za czyn międzynarodowo bezprawny opisana została w treści rozdziału trzeciego.

W toku prac nad odpowiedzialnością państw KPM zidentyfikowała zagadnienie wymagające osobnej analizy: pytanie o zasady odpowiedzialności za

\footnotetext{
${ }^{2}$ Por.: Raport KPM, 2001, U.N. Doc. A/56/10, zał. 10, s. 38-39. Jest to zapis bardziej umiarkowany niż zawarty w pierwszym projekcie artykułów o odpowiedzialności państw z 1957 r., którego art. 10 stanowił wprost, iż państwo odpowiedzialne jest za szkody wyrządzone cudzoziemcom przez „zwykłe osoby prywatne”, jeśli jego przedstawiciele wykazali ,jawne niedbalstwo" (ang. officials of the State were manifesly negligent) przy przedsiębraniu „normalnych” środków zmierzających do zapobieżenia lub ukarania takich szkodliwych czynów. Zob także: Drugi raport Specjalnego Sprawozdawcy F.V. García-Amadora, 1957, U.N. Doc. A/CN.4/106 (dalej: Drugi raport García-Amadora), s. 121.
} 
działania niezakazane prawem międzynarodowym. W 1997 r. powołała w celu zbadania owego problemu grupę roboczą. W toku jej prac należyta staranność poddana została gruntownej analizie. Stała się kryterium oceny realizacji przez państwa obowiązku prewencji, tj. konieczności zapobiegania znaczącym szkodom transgranicznym, w tym analizy skutków działań realizowanych na ich terytorium oraz obowiązku międzynarodowej współpracy. Należyta staranność, wywodzona $\mathrm{z}$ zasady dobrosąsiedztwa, opisana została w treści licznych dokumentów międzynarodowego prawa środowiska i stanowi istotne kryterium oceny wypełniania przez państwa ich międzynarodowych zobowiązań, przede wszystkim, choć nie tylko, z zakresu międzynarodowego prawa środowiska. Treść obowiązku prewencji została szczegółowo opisana w Raporcie KPM z 2001 r., który zawierał dwa projekty: Projekt Artykułów Komisji Prawa Międzynarodowego dotyczący odpowiedzialności państwa za czyny niedozwolone (ang. Draft Articles on Responsibility of States for Internationally Wrongful Acts; dalej: Projekt artykułów o odpowiedzialności państw z 2001 r.) $)^{3}$ oraz Projekt artykułów o zapobieganiu szkodzie transgranicznej powstającej na skutek niebezpiecznej działalności (ang. Draft Articles on Prevention of Trans-boundary Harm from Hazardous Activities; dalej: Projekt artykułów o prewencji z 2001 r.) $)^{4}$. Art. 3 tego ostatniego dokumentu określa rolę należytej staranności w prawie odpowiedzialności międzynarodowej, opisaną w oparciu o analizę licznych porządków traktatowych i zwyczajowych. Inne dokumenty, które pozwalają określić miejsce zasady należytej staranności wśród norm odpowiedzialności międzynarodowej to: Projekt zasad dotyczących alokacji strat wynikających ze szkód transgranicznych spowodowanych działaniami niebezpiecznymi ${ }^{5}$ (ang. Draft principles on the allocation of loss in the case of transboundary harm arising out of hazardous activities ${ }^{6}$; dalej: Projekt zasad alokacji z 2006 r.) oraz Projekt artykułów o odpowiedzialności międzynarodowej za szkodliwe konsekwencje czynów niezakazanych prawem międzynarodowym (prewencja szkód transgranicznych wynikających z działań niebezpiecznych; ang. Draft articles on international liability for injurious consequences arising out of acts not prohibited by international law (prevention of transboundary damage from hazardous activities; dalej: Projekt artykułów o odpowiedzialności międzynarodowej z 1998 r.) $)^{7}$. Analiza prac Komisji przedstawiona $\mathrm{w}$ treści owych dokumentów opisana została w rozdziale

${ }^{3}$ Tłumaczenie za: M. M. Kenig-Witkowska, Międzynarodowe prawo środowiska, Warszawa 2011, s. 140.

${ }^{4}$ Por.: Raport KPM, 2001, U.N. Doc. A/56/10, zał. 10, w treści którego znalazły się oba dokumenty wraz z komentarzami: Projekt artykułów o odpowiedzialności państw z 2001 r., s. 59-365; Projekt artykułów o prewencji z 2001 r., s. 366-435.

${ }^{5}$ Por.: thum. M. M. Kenig-Witkowska, Prawnomiędzynarodowa odpowiedzialność za szkody transgraniczne $w$ środowisku. Uwagi na marginesie projektu zasad dotyczacych alokacji strat wynikajacych ze szkód transgranicznych spowodowanych działalnościq niebezpieczna, (w:) Prawo międzynarodowe - problemy $i$ wyzwania, Ksiegga pamiatkowa profesor Renaty Sonnenfeld-Tomporek, red. J. Menkes, Warszawa 2006, s. 311-355.

${ }^{6}$ Raport KPM, 2006, U.N. Doc. A/61/10, s. 101-182.

${ }^{7}$ Raport KPM, 1998, U.N. Doc. A/53/10, rozdz. IV, s. 19-42. 
czwartym. Tam też przedstawiono argumenty przeciwników metodologii KPM, odzwierciedlonej w omówionym podziale tematów badawczych. Podwójna rola należytej staranności, przejawiająca się w odwołaniu do niej zarówno w porządku norm opisujących odpowiedzialność państwa za czyny sprzeczne z treścią jego międzynarodowych zobowiązań, jak i odpowiedzialności międzynarodowej za czyny niezakazane prawem międzynarodowym, stała się jednym z argumentów krytyki doktryny, formułowanej względem zasadności i sposobu dokonania podziału obszarów badawczych przez Komisję w 1997 r. Meritum i przesłanie owej krytyki omówione zostały w tym samym rozdziale.

Należyta staranność obecna jest jednak nie tylko w komentarzach doktryny, orzecznictwie czy dokumentach miękkiego prawa narodowego, za jakie uznać można projekty Komisji i liczne raporty, towarzyszące pracom nad nimi. Obowiązek wykazywania należytej staranności przy realizacji międzynarodowych zobowiązań przez państwa zawarty został w licznych postanowieniach traktatowych. Ich przegląd oraz analiza treści zobowiązania do wykazywania należytej staranności przy realizacji postanowień traktatów międzynarodowego prawa środowiska, prawa morza, prawa dyplomatycznego czy umów mających na celu walkę z przestępczością międzynarodową jest przedmiotem rozdziału piątego.

Podsumowanie dokonanej analizy zawarte zostało w rozdziale ostatnim, szóstym. Celem autorki jest wykazanie, że należyta staranność zdefiniowana została w dorobku prawa międzynarodowego dostatecznie precyzyjnie, a jej rola jest na tyle znacząca, aby uznać ją za jedną z zasad prawa międzynarodowego. Przyłączając się do Pisillo Mazzeschiego, opisuje treść zasady należytej staranności w prawie międzynarodowym. Za Schwarzenbergerem kwalifikuje ją jako pomocniczą zasadę prawa międzynarodowego, służącą interpretacji zasad odpowiedzialności. W treści ostatniego rozdziału odnosi się także do konsekwencji naruszenia zasady należytej staranności, przypominając zapisane w Projekcie artykułów o odpowiedzialności państw z 2001 r. środki przysługujące ofiarom naruszenia każdego pierwotnego zobowiązania międzynarodowego, którego nie udało się załagodzić w sposób pokojowy. Odnosi się tutaj także do okoliczności wyłączających bezprawność naruszenia zobowiązania międzynarodowego, opisanych w tym samym projekcie.

Metodologia rozprawy oparta jest o analizę prac Komisji Prawa Międzynarodowego i to dokonany przez nią podział rodzajów odpowiedzialności w prawie międzynarodowym determinuje wybór zagadnień niniejszego opracowania. Szczególne znaczenie dla identyfikacji treści zasady należytej staranności i jej miejsca w porządku prawa międzynarodowego mają wspomniane powyżej cztery dokumenty miękkiego prawa międzynarodowego, opracowane na początku XXI wieku przez Komisję i stanowiące odzwierciedlenie powszechnej praktyki zwyczajowej. Projekt artykułów o odpowiedzialności międzynarodowej z 1998 r. oparty został na propozycji Julio Barbozy z 1996 r., w której omówił on szeroko treść obowiązku wykazywania należytej stranności przez państwa przy realizacji 
ich międzynarodowych zobowiązań (dalej: Projekt Barbozy) ${ }^{8}$. Jedynie część owych ustaleń przejęta została do tekstu Projektu artykułów o odpowiedzialności międzynarodowej z 1998 r., inne zostały wykorzystane w treści Projektu artykułów o prewencji z $2001 \mathrm{r}$.

Tok wywodu odzwierciedla chronologicznie rozwój zasady należytej staranności. Jej geneza i ewolucja opracowane zostały z wykorzystaniem historycznej metody badawczej. Autorka prześledziła odniesienia do należytej staranności począwszy od czasów antycznych, poprzez epokę grocjańską, aż po argumenty podnoszone $\mathrm{w}$ aktualnej dyskusji nad treścią owego terminu, stanowiącego przedmiot ożywionej wymiany dyplomatycznej i sporów doktryny. Zważywszy na kluczowe znaczenie miękkiego prawa międzynarodowego dla identyfikacji treści i miejsca pojęcia należytej staranności w dogmatyce prawa międzynarodowego, istotną rolę $\mathrm{w}$ metodologii rozprawy odegrała analiza dynamiczna raportów i projektów Komisji Prawa Międzynarodowego, połączona z syntezą tez przywoływanego w niej orzecznictwa. Celem wyjaśnienia stanowiska sądów, trybunałów i Komisji poczynione zostały liczne odwołania do literatury przedmiotu, zaś podsumowanie zawartych $\mathrm{w}$ nich stanowisk dokonane zostało $\mathrm{z}$ wykorzystaniem dogmatycznej metody badawczej.

\section{Kwestie terminologiczne}

Należyta staranność musi być omawiana w kontekście norm odpowiedzialności znanych prawu międzynarodowemu. Jak wskazano, szczegółowe ich omówienie znacznie wybiega poza ramy niniejszego opracowania. Dla jasności wywodu przydatne będzie więc skrótowe wyjaśnienie i usystematyzowanie używanej w nim terminologii.

Komisja Prawa Międzynarodowego, której dorobek stanowił pierwowzór struktury niniejszych rozważań i uzasadnia przyjętą metodologię, wyróżniła w swoich pracach dwa obszary badań nad odpowiedzialnością, znane prawu międzynarodowemu. Chronologicznie pierwsza, a przez to lepiej zbadania, jest odpowiedzialność państwa za działania zakazane prawem międzynarodowym określana angielskim terminem responsibility czy niemieckim: Verantwortlichkeit. Oba te terminy na język polski tłumaczyć należy jako „odpowiedzialność”.

Drugim obszarem prac Komisji, wyróżnionym podczas sesji ONZ w 1997 r. jako odrębny przedmiot badań, jest zagadnienie odpowiedzialności międzynarodowej za działania niezakazane prawem międzynarodowym, określane angielskim terminem liability czy niemieckim: Haftung. Polski język prawniczy nie zna jednak innego słowa dla opisania odpowiedzialności, a więc dosłowne

\footnotetext{
${ }^{8}$ Por.: Raport grupy roboczej ds. odpowiedzialności międzynarodowej za szkodliwe konsekwencje czynów niezakazanych prawem międzynarodowym, (w:) Raport KPM, 1996, U.N. Doc. A/51/10, zał. 1, s. 100-133 (dalej: Projekt Barbozy, U.N. Doc. A/51/10).
} 
tłumaczenie obu terminów rodziłoby niejasności ${ }^{9}$. Dlatego też w treści książki przyjęto założenie ich tłumaczenia w sposób opisowy.

Ponieważ angielski termin responsibility dotyczy odpowiedzialności państw za czyny sprzeczne z wiążącymi je normami prawa międzynarodowego, wszędzie tam, gdzie w angielskim tekście źródłowym użyte zostało angielskie słowo responsibility, w niniejszym opracowaniu użyto określenia „odpowiedzialność państwa" ${ }^{0}$. Kluczowe jest tu bowiem kryterium przypisania państwu czynu sprzecznego z jego międzynarodowym zobowiązaniem, tj. działania jego organów czy osób działających z jego upoważnienia, polecenia lub pod jego kontrolą, ale także zaniechania tychże, jeśli są sprzeczne $\mathrm{z}$ wiążącą państwo normą międzynarodową. KPM w komentarzach do Projektu artykułów o odpowiedzialności państw z $2001 \mathrm{r}$. zaznacza, że ich treść dotyczy wyłącznie państw ${ }^{11}$. Odpowiedzialność innych niż państwa podmiotów prawa międzynarodowego na zasadach opisanych przez Komisję w doktrynie prawa międzynarodowego pozostaje przedmiotem sporów. W 2003 r. KPM wyróżniła kwestię odpowiedzialności organizacji miedzynarodowych (ang. responsibility of international organizations) jako odrębny przedmiot jej prac, powołując Giorgio Gaję jako Specjalnego Sprawozdawcę, który przedłożył osiem raportów omawiających owo zagadnienie $^{12}$. Uwzględniając ową ewolucję Czapliński i Wyrozumska thumaczą pojęcie responsibility jako „tradycyjną odpowiedzialność deliktową podmiotów prawa międzynarodowego"13, ale też jako „odpowiedzialność za naruszenie prawa

${ }^{9}$ Rozróżnienie rodzajów odpowiedzialności, obecne w języku angielskim i niemieckim, nie jest natomiast możliwe w żadnym innym języku kongresowym. Por. np.: A. E. Boyle, State Responsibility and International Liability for Injurious Consequences of Acts not Prohibited by International Law: A necessary distinction?, International and Comparative Law Quarterly 1990, nr 39, s. 9; W. Czapliński, A. Wyrozumska, Prawo międzynarodowe publiczne, Warszawa 2004, s. 588 .

${ }^{10}$ Por.: J. Crawford, S, Olleson, The nature and forms of International responsibility, (w:) International Law, red. M. D. Evans, Oksford 2010, s. 455, gdzie autorzy piszą, iż zasadą rządzącą w tym obszarze prawa międzynarodowego jest zasada odpowiedzialności „niezależnej” (ang. principle (...) of independent responsibility) - odpowiedzialności państwa za własne działania.

${ }^{11}$ Por.: Projekt artykułów o odpowiedzialności państw z 2001 r., uwagi ogólne, pkt (d), s. 32, gdzie Komisja zaznacza, iż, artykuły dotyczą wyłącznie odpowiedzialności państw za czyny międzynarodowo bezprawne, pozostawiając poza zakresem zainteresowania Komisji odpowiedzialność organizacji międzynarodowych i innych podmiotów, niebędących państwami.

${ }^{12}$ W 2011 r. KPM przedłużyła jego mandat na kolejnych 6 lat. Podczas 63. sesji KPM w $2011 \mathrm{r}$. przedstawiony został Projekt artykułów o odpowiedzialności organizacji międzynarodowych, U.N. Doc. A/CN.4/L.778.

${ }^{13}$ Por.: W. Czapliński, A. Wyrozumska, op.cit., s. 588. Włączenie do tłumaczenia przymiotnika „deliktowa” nawiązuje do nomenklatury prawa cywilnego, choć stanowić może także odwołanie do Pierwszego Raportu J. Crawforda o ogólnych zagadnieniach projektu artykułów, podziale na „przestępstwa” i „odpowiedzialność deliktową” oraz art. 1-15 części pierwszej projektu, U.N. Doc. A/CN.4/490 (dalej: Pierwszy raport Crawforda, U.N. Doc. A/CN.4/490). Jednocześnie jednak M.M. Kenig-Witkowska thumaczy termin ,,liability”, przeciwstawiany przez KPM pojęciu „responsibility”, jako odpowiedzialność „cywilną”, por.: M.M. Kenig-Witkowska, Międzynarodowe prawo środowiska. Wybrane zagadnienia systemowe, Warszawa 2011, s. 140 i przypisy 16 i 18 poniżej. 
międzynarodowego"14. Autorka nie zdecydowała się na nawiązanie $\mathrm{w}$ treści niniejszego opracowania do odpowiedzialności deliktowej w prawie międzynarodowym, podążająć za rozumowaniem KPM. Ta, odwołując się do terminologii francuskiej, hiszpańskiej i angielskiej, za trafniejsze od terminu "delikt” (fr. délit, hiszp. delito, ang. tort, delict, delinquency) czy terminów mu pokrewnych, którym prawo wewnętrzne często nadaje szczególne znaczenie, uznała sformułowanie „fakt międzynarodowo bezprawny” (fr. fait internationalement illicite). Termin ten przedkłada także ponad podobnie brzmiący ,akt międzynarodowo bezprawny" (fr. acte internationalement illicite), bowiem odpowiedzialność państwa wynikać może zarówno z działań, jak i z zaniechań jego organów. W polskim języku prawniczym uzasadnione wydaje się więc użycie określenia „czyn międzynarodowo bezprawny” jako obejmującego zarówno działania, jak i zaniechania organów państwa ${ }^{15}$.

Reżim odpowiedzialności określany w pracach Komisji przy użyciu angielskiego terminu ,,liability”, opisywany bywa w polskiej literaturze przedmiotu jako „odpowiedzialność za działania prawnie niezakazane”16, który to termin stanowi bezpośrednie odwołanie do tytułu opracowanego przez Komisję w 1998 r. Projektu artykułów o odpowiedzialności międzynarodowej za szkodliwe konsekwencje czynów niezakazanych prawem międzynarodowym (ang. Draft articles on international liability for injurious consequences arising out of acts not prohibited by international law) ${ }^{17} . \mathrm{Z}$ dokumentacji prac nad owym obszarem badań wyłania się reżim oparty o cywilną odpowiedzialność podmiotów prywatnych, niosący za sobą istotne zobowiązania dla państw, choć Komisja w toku prowadzonych prac dość wcześnie zrezygnowała z terminu „state liability”, opisującego nierekomendowaną koncepcję zastępczej odpowiedzialności państwa za działania podmiotów prawnych, niezakazane prawem międzynarodowym ${ }^{18}$.

\footnotetext{
${ }^{14}$ W. Czapliński, A. Wyrozumska, op.cit., s. 588.

${ }^{15}$ Projekt artykułów o odpowiedzialności państw z 2001 r., s. 34.

${ }^{16}$ Por. np. R. Sonnenfeld, Kodyfikacja odpowiedzialności międzynarodowej państw, Warszawa 2002, s. 25. Czapliński i Wyrozumska thumaczą termin „,liability” podobnie, jako „odpowiedzialność za działania niezabronione”; por.: W. Czapliński, A. Wyrozumska, op.cit., s. 615.

${ }^{17}$ Projekt artykułów o odpowiedzialności międzynarodowej z 1998 r., s. 19-42.

${ }^{18} \mathrm{R}$. Sonnenfeld określa rolę państw w owym reżimie jako co najwyżej równą roli ubezpieczyciela. Por. R. Sonnenfeld, op.cit., s. 25. Teoretyczną możliwość rozważania „odpowiedzialności państwa za działania niezakazane prawem międzynarodowym” wskazał w treści swojego pierwszego raportu Specjalny Sprawozdawca J. Barboza, nie opatrując jej jednak swoją rekomendacją. Por.: Raport KPM, 1994 r., U.N. Doc. A/49/10, s. 155. Jak można przypuszczać, do tych prac odwołują się Czapliński i Wyrozumska, gdy używają terminu „odpowiedzialność za działania niezabronione" jako thumaczenie przywołanego przez autorów pojęcia „state liability”; por.: W. Czapliński, A. Wyrozumska, op.cit., s. 615. „State liability” pojawia się w projektach KPM jedynie w odniesieniu do reżimu odpowiedzialności za szkody kosmiczne, jako powszechnie przyjętego przez państwa reżimu traktatowego; por.: Projekt zasad alokacji z 2006 r., pkt (8), s. 112. W treści Projektu Artykułów o odpowiedzialności państw z 2001 r. Komisja przywołuje pojęcie ,state liability” jedynie w cytatach (np. Projekt artykułów o odpowiedzialności państw z 2001 r., przypis 176, s. 51), nie używa go w tekście własnym. Por. też: W. Czapliński, A. Wyrozumska, op.cit., s. 588, przyp. 1, gdzie odnoszą się do art. 139(2) Konwencji o prawie morza, w którym Komisja łączy pojęcie „,liability” z odpowiedzialnością państwa. Art. 139 (2) KoPM
} 
Ponieważ reżim ten wykracza poza krajowe ramy prawa cywilnego, zaś w prawie międzynarodowym reguły odpowiedzialności właściwe prawu cywilnemu i karnemu niejednokrotnie ulegają połączeniu, autorka nie zdecydowała się użyć terminu „odpowiedzialność cywilna”, choć pojawiał się on w polskiej literaturze przedmiotu jako odpowiednik angielskiego terminu , ,liability ${ }^{, 19}$. Dlatego też termin , ,iability” konsekwentnie thumaczony jest jako „odpowiedzialność międzynarodowa" za czyny niezakazane ${ }^{20}$. Jeśli zamierzeniem autorki było odniesienie do obu reżimów odpowiedzialności, czyniła to odwołując się do „odpowiedzialności w prawie międzynarodowym"21.

Podobny problem terminologiczny dotyczy pojęcia szkody. Komisja Prawa Międzynarodowego poświęciła wiele uwagi rozgraniczeniu anglojęzycznych terminów ,,damage " i , harm”, które oba w języku polskim oznaczają „,szkodę". „Harm” to termin używany dla określenia szkody grożącej, lecz nie powstałej a więc „szkody ewentualnej”22. „Damage” to termin określający faktycznie powstała, znacząca, „szkodę” wyrządzoną ludziom, mieniu lub środowisku natu-

stanowi: „, Without prejudice to the rules of international law (...) damage caused by the failure of a State Party or international organization to carry out its responsibilities under this Part shall entail liability; States Parties or international organizations acting together shall bear joint and several liability. A State Party shall not however be liable for damage caused by any failure to comply with this Part by a person whom it has sponsored (...) if the State Party has taken all necessary and appropriate measures to secure effective compliance (...)". Treść artykułu uznać można za dowód ścisłego połączenia reżimów: odpowiedzialności państw i odpowiedzialności międzynarodowej. Uwagi cytowanych autorów wpisują się więc w nurt krytyki wobec podziału reżimów odpowiedzialności w prawie międzynarodowym, dokonanego przez KPM w 1997 r., opisanej szczegółówo w dalszej części książki (por. rozdz. IV).

${ }^{19}$ Crawford i Olleson wskazują, iż krajowe systemy prawne rozróżniają odpowiedzialność karną i cywilną, w tym kontraktową czy deliktową (ang. crime, contract, tort, delict). Rozróżnienie to, wywodzone z prawa rzymskiego, tj. z prac Ulpiana, który pisał o zobowiązaniach kontraktowych, deliktowych i quasi-kontraktowych, jak np. bezpodstawne wzbogacenie, nie jest znane prawu międzynarodowemu. Normy odpowiedzialności państw stanowią jednolity system, niepodobny do systemów odpowiedzialności w porządkach krajowych. Por.: J. Crawford, S. Olleson, op.cit., s. 448. Zob także: M.M. Kenig-Witkowska, Międzynarodowe prawo..., s. 140. Jak słusznie pisał w 1922 r. J. Makowski, „wystrzegać się należy (...) przenoszenia do dziedziny prawa narodów pojęć i stosunków prawa cywilnego i karnego", zakres bowiem tej nauki dalece się od nich różni; por. J. Makowski, Prawo międzynarodowe, Warszawa 1922, s. 38. Podobnie uważa Ehrlich pisząc, iż nie uda się uzasadnić analogii odpowiedzialności podmiotów prawa międzynarodowego z odpowiedzialnością prywatnoprawną ,wobec odmiennego charakteru norm i podmiotów prawa międzynarodowego"; L. Ehrlich, Prawo międzynarodowe, Warszawa 1958, s. 638.

20 Por. M.N. Shaw, Prawo międzynarodowe, Warszawa 2005, s. 454: „Odpowiedzialność międzynarodowa różni się od odpowiedzialności państwa tym, że ta ostatnia zależy od uprzedniego naruszenia prawa międzynarodowego, podczas gdy ta pierwsza stanowi próbę rozwinięcia dziedziny prawa, w której państwo może ponosić odpowiedzialność międzynarodową za szkodliwe następstwa działalności, która jako taka nie jest niezgodna z prawem międzynarodowym".

${ }^{21} \mathrm{O}$ kwestiach terminologicznych, dotyczących odpowiedzialności, pisze A. Zbaraszewska, por.: A. Zbaraszewska, Prawnomiędzynarodowa odpowiedzialność za szkody transgraniczne w środowisku - problem prewencji, Ruch Prawniczy, Ekonomiczny i Socjologiczny 2008, nr 2, s. 113-115.

${ }^{22}$ Por. R. Sonnenfeld, op.cit., s. 21-22. 
ralnemu ${ }^{23}$. Termin ten obejmuje utratę życia lub uszczerbek na zdrowiu, utratę mienia lub jego uszczerbek, w tym mienia stanowiącego dziedzictwo kulturowe, szkodę $\mathrm{w}$ środowisku naturalnym, jak również koszty poniesione $\mathrm{w}$ związku $\mathrm{z}$ racjonalnie zastosowanymi środkami zmierzającymi do przywrócenia pierwotnego stanu mienia lub środowiska, w tym zasobów naturalnych, a także koszt podjętych racjonalnie środków reagowania ${ }^{24}$. „Szkoda” oznacza więc w niniejszej pracy szkody faktycznie poniesione, opisane przez Komisję terminem „damage”, podczas gdy „harm” tłumaczone jest jako „niebezpieczeństwo powstania szkody" lub „szkoda ewentualna”. To terminologiczne rozróżnienie ma znaczenie w kontekście obowiązku wykazywania najlepszych starań przy zapobieganiu szkodom, a więc ograniczaniu niebezpieczeństwa ich powstania. Odpowiedzialność za niedopełnienie tego obowiązku, któremu nie towarzyszy, szkoda powstała pozostaje przedmiotem sporu doktryny i orzecznictwa ${ }^{25}$. Nie jest bowiem jasne, czy państwa dopuszczają się naruszenia obowiązku prewencji poprzez sam fakt niepodjęcia racjonalnych działań zmierzających do uniknięcia czy ograniczenia szkód, czy ponosić ją winny dopiero, gdy szkoda ewentualna stanie się szkodą rzeczywistą.

Ostatnią kwesią terminologiczną godną omówienia jest status „należytej staranności" w prawie międzynarodowym, która opisywana jest w doktrynie i orzecznictwie niejednolicie. W piśmiennictwie używane są terminy: „koncepcja”, ${ }^{\text {, }}$, „doktryna”27, „wymóg”,28, „test”29 „obowiązek”,30 czy „zobowiązanie”31 należytej staranności. W pracach KPM określana jest ona najczęściej jako „standard”32

${ }^{23}$ Projekt zasad alokacji z 2006 r., komentarz (11) do zasady 1, s. 120. Rozróżnienie obu terminów i towarzysząca mu kontrowersja opisane zostały w rozdz. IV.

${ }^{24}$ Raport grupy roboczej ds. odpowiedzialności międzynarodowej, 2004 r., U.N. Doc. A/CN.4/L.661, pkt 2, s. 2.

${ }^{25}$ Por. rozdz. VI.

${ }^{26}$ L. Viikari, The Environmental Element in Space Law: Assessing the Present and Charting the Future, Haga 2008, s. 156.

27 J. A. Hessbruegge, The Historical Development of the Doctrines of Attribution and Due Diligence in International Law, New York University Journal of International Law and Politics 2004, nr 36, s. 267.

${ }^{28}$ W. Czapliński, A. Wyrozumska, op.cit., s. 593.

${ }^{29}$ B. A. Boczek, International Law: A Dictionary, Oksford 2005, s. 220.

${ }^{30}$ D. Freestone, E. Hey, The Precautionary Principle and International Law: The Challenge of Implementation, Alphen aan den Rijn 1996, s 88; N. Schrijver, F. Weiss, International Law And Sustainable Development: Principles And Practice, Haga 2004, s. 28; B. A. Boczek, op.cit., s. 113; R. Sonnenfeld, op.cit., s. 22.

${ }^{31}$ Raport grupy roboczej ds. odpowiedzialności międzynarodowej za szkodliwe konsekwencje wynikające z czynów niezakazanych prawem międzynarodowym, 1978 r., U.N. Doc. A/33/10, załącznik (dalej: Raport KPM, 1978 r., U.N. Doc. A/33/10), s. 151, pkt 19; Siódmy raport Riphagena, U.N. Doc. A/CN.4/397, pkt (7), s. 8.

32 Por.: Raport KPM, 1994 r., U.N. Doc. A/49/10, w treści którego Barboza szczegółów opisuje treść „standardu należytej staranności”, np. s. 169; Drugi raport García-Amadora, U.N. Doc. A/CN.4/106, pkt 4, s. 122, gdzie Specjalny Sprawozdawca pisze, iż „należyta staranność to standard, a nie definicja" (ang. due diligence is a standard and not a definition). 
i w ten sposób opisuje ją wielu współczesnych autorów ${ }^{33}$, choć pierwszy specjalny sprawozdawca ds. odpowiedzialności państw, García-Amador poświęcił „zasadzie" należytej stranności obszerną część uzasadnienia propozycji projektu artykułów, opisujących reguły międzynarodowej odpowiedzialności państw ${ }^{34}$. W XXI-wiecznych opracowaniach dotyczących prawa międzynarodowego, a $\mathrm{w}$ szczególności międzynarodowego prawa środowiska, często pojawia się odwołanie do „zasady” należytej staranności ${ }^{35}$. Jej stałe miejsce w tym obszarze prawa międzynarodowego odnotowała także $\mathrm{KPM}^{36}$. Pisillo Mazzeschi jako pierwszy obszernie opisał należytą staranność jako zasadę prawa międzynarodowego w $1992 \mathrm{r}^{37}$

W toku niniejszego wywodu należyta staranność opisywana jest w pracach poszczególnych autorów z użyciem przyjętej przez nich terminologii. W ostatnim rozdziale autorka omawia treść obowiązku wykazywania należytej staranności przy realizacji zobowiązań międzynarodowych, opisując ją jako zasadę prawa międzynarodowego.

Zagadnienie odpowiedzialności w prawie międzynarodowym niesie za sobą jeszcze jedno wyzwanie terminologiczne. KPM rozróżnia w swoich pracach odpowiedzialność na zasadzie ryzyka (ang. strict liability) ${ }^{38}$, odpowiedzialność

${ }^{33}$ Tak też np.: I. Brownlie, Principles of Public International Law, Oksford 2008, s. 440, 455; M. N. Shaw, op.cit., s. 451; K. N. Trapp, State Responsibility for International Terrorism, Oksford 2011, s. 64; F. F. Martin, International Human Rights And Humanitarian Law: Treaties, Cases And Analysis, Cambridge 2006, s. 72; B. A. Boczek, op.cit., s. 235; A. T. Gallagher, The International Law of Human Trafficking, Cambridge 2010, s. 241; M. M. Kenig-Witkowska, Międzynarodowe prawo..., s. 142.

${ }^{34}$ Drugi raport García-Amadora, U.N. Doc. A/CN.4/106, komentarz do artykułów 10 i 11, pkt 15., s. 122-123, omówiony szczegółowo poniżej.

${ }^{35}$ G. Dahm, J. Delbrück, Voelkerrecht, Berlin 2002, tom I/3, s. 948; T. Gazzini, The Changing Rules on the Use of Force in International Law, Manchester 2005, s.187; R. P. Barnidge Jr., The Due Diligence Principle Under International Law, International Community Law Review 2006, nr 8, s. 81 i n.; L. Viikari, op.cit., s. 155; N. Schrijver, Sovereignty over Natural Resources: Balancing Rights and Duties, Cambridge 2008, s. 127; N. Schrijver, Development Without Destruction: The UN and Global Resource Management, Indiana 2010, s. 50; O. Yoshida, The International Legal Régime for the Protection of the Stratospheric Ozone Layer: International Law, International Régimes, and Sustainable Development, Haga 2001, s. 65; C. Lehnardt, Private Militarfirmen und volkerrechtliche Verantwortlichkeit: Eine Untersuchung aus humanitarvoelkerrechtlicher und menschenrechtlicher Perspektive, Berlin 2011, s. 87.

${ }^{36}$ Projekt Barbozy, U.N. Doc. A/51/10, Komentarz (5) s. 110 przywołując sentencję rozstrzygnięcia arbitrażowego sporu pomiędzy Niemcami i Szwajcarią w 1986 r., dotyczącego zatrucia Renu przy mieście Sandoz.

${ }^{37}$ R. Pisillo Mazzeschi, The „Due Diligence” Rule and the Nature of the International Responsibility of States, German Yearbook of International Law 1992, nr 35, s. 9-49.

${ }^{38}$ Por. np.: Drugi raport Rao, U.N. Doc. A/CN.4/501, pkt 68, s. 23; J. Ellis, Has International Law Outgrown Trail Smelter?, (w:) Transboundary Harm in International Law, Lessons from the Trail Smelter Arbitration, red. R. M. Bratspies, R. A. Miller, Cambridge 2006, s. 60; T. Gehring, M. Jachtenfuchs, Liability for Transboundary Environmental Damage towards a General Liability Regime, European Journal of International Law 1993, nr 4, s. 96; I. Brownlie, System of the Law of Nations: State Responsibility, Oksford 1983, część I, s. 49-50; J. Willisch, State Responsibility for Technological Damage in International Law, Berlin 1978, s. 293-296, gdzie reżim odpowiedzialności za czyny niezakazane prawem międzynarodowym, zawarty w Projekcie artykułów o pre- 
absolutną (ang. absolute liability) $)^{39}$ oraz odpowiedzialność obiektywną (ang. objective responsibility $)^{40}$.

Termin , strict liability” opisany został w niniejszej pracy jako odpowiedzialność na zasadzie ryzyka, a więc ponoszona w przypadku powstania szkody pod nieobecność wyjątkowych okoliczności od niej zwalniających, takich jak konflikt zbrojny czy katastrofy naturalne ${ }^{41}$. Odpowiedzialność ta jest, co do zasady, niezależna od przesłanki winy, choć zdaniem niektórych autorów, aby przypisać państwu odpowiedzialność na zasadzie ryzyka, wykazany winien zostać związek przyczynowo-skutkowy pomiędzy działaniem lub zaniechaniem państwa a powstaniem szkody ${ }^{42}$. Dla oceny wystapienia owego zaniechania po stronie organu państwa przywoływany bywa standard należytej staranności. Odpowiedzialność na zasadzie ryzyka wywodzona może być jedynie z zapisów traktatowych ${ }^{43}$. Podobną dogmatycznie konstrukcją jest odpowiedzialność absolutna (ang. absolute liability), obciążająca podmiot odpowiedzialnością niezależną od istnienia związku przyczynowego pomiędzy jego działaniem a szkoda.

wencji z 2001 r., opisywany jest terminem , strict liability”. R. Sonnenfeld pisze o oparciu owego reżimu „na koncepcji ryzyka”, por.: R. Sonnenfeld, op.cit., s. 20. Ale por. ibidem, s. 17, gdzie autorka utożsamia odpowiedzialność absolutną z ,amerykańskim” terminem ,strict”, przywoływanym dla określania odpowiedzialności za działania szczególnie niebezpieczne. Podobnie: M. N. Shaw, Prawo..., s. 417 (thum. pod red. S. Sawickiego), gdzie polski termin ,absolutna” to w oryginale ,strict”, por.: M.N. Shaw, International Law, Cambridge 2010, s. 783. W thumaczeniu czytamy jednak także o „odpowiedzialności absolutnej” przy okazji opisu reguł odpowiedzialności za działania szczególnie niebezpieczne, gdzie Shaw używa w oryginalnie terminu ,absolute”, por. M. N. Shaw, Prawo..., s. 469 i M.N. Shaw, International..., s. 887. Przeciwstawiana przez Shawa w tym samym zdaniu odpowiedzialności ,absolutnej” odpowiedzialność „strict” pojawia się tu jako odpowiedzialność „całkowita”.

${ }^{39}$ Czwarty raport Specjalnego Sprawozdawcy R. Ago o międzynarodowo bezprawnym czynie państwa i źródłach odpowiedzialności międzynarodowej, 1972 r., U.N. Doc. A/CN.4/264, tom II; dalej: Czwarty raport Ago, U.N. Doc. A/CN.4/264, s. 120-121, pkt 138; por. też L. Viikari, op.cit., s. 151, 155. Odnośnie do thumaczenia terminów „,strict” i ,absolute” w polskiej literaturze przedmiotu, por. uwagi w przypisie poprzedzającym.

${ }^{40}$ Por.: np.: Piąty raport García-Amadora, U.N. Doc. A/CN.4/125, pkt 91, który w odwołaniu do rosnącej ilości zagrożeń niesionych przez nowe technologie sugeruje wprowadzenie nowych kategorii „obiektywnej odpowiedzialności”. O potrzebie odpowiedzialności obiektywnej w prawie środowiska pisze także M. M. Kenig-Witkowska, Prawnomiędzynarodowa..., s. 314. Ale por. Projekt zasad alokacji z 2006 r., s. 155, gdzie KPM zrównuje w znaczeniu termin ,,responsabilité pour risqué crée", opisujący odpowiedzialność na zasadzie ryzyka, z odpowiedzialnością obiektywną, opisaną „responsabilité objective”. Jednocześnie krytykuje rozróżnienie na element „obiektywny” (naruszenie prawa) i „subiektywny” przypisania odpowiedzialności. Por.: Projekt artykułów o odpowiedzialności państw z 2001 r., s. 34. Rozróżnienie to jest uwzględniane w doktrynie - o odpowiedzialności obiektywnej piszą np.: S. Linos-Alexander, The Classification of Obligations and the Multilateral Dimension of the Relations of International Responsibility, European Journal of International Law 2002, Vol. 13, Issue 5, s. 1127-1145; D. D. Caron, The ILC Articles on State Responsibility: The Paradoxical Relationship Between Form and Authority, American Journal of International Law 2002, Vol. 96, 2002, s. 857-873.

${ }^{41}$ Por. A. E. Boyle, Globalising Environmental Liability: The Interplay of National and International Law, Journal of Environmental Law 2005, nr 1(17), s. 13.

${ }^{42}$ Ibidem.

${ }^{43}$ Por. np.: W. Czapliński, A. Wyrozumska, op. cit., s. 615-616. 
z tym wyjątkiem, że nie istnieją żadne okoliczności od niej zwalniające. Ten rodzaj odpowiedzialności stanowi wyjątek w prawie odpowiedzialności międzynarodowej i wynikać może wyłącznie z postanowień traktatowych ${ }^{44}$. Termin „objective responsibility”, używany przez KPM rzadko, popularny jest natomiast $\mathrm{w}$ doktrynie, przede wszystkim w pracach dotyczących międzynarodowego prawa środowiska, zaś na potrzeby niniejszej pracy thumaczony jest jako „odpowiedzialność obiektywna"45. Jest ona opisywana jako odpowiedzialność wywodzona z obiektywnego przypisania państwu szkodliwych konsekwencji zaniechania jego organów, tj. braku ich należytej staranności, stanowiącego naruszenie obowiązku prewencji, prowadzącego do powstania szkody, w tym szkody ewentualnej, niezależnie od ich winy ${ }^{46}$. Niektórzy autorzy dopuszczają uznanie odpowiedzialności obiektywnej państwa wynikającej z samego faktu naruszenia obowiązku międzynarodowego, jednak stanowiska państw jednoznacznie wiążą jakąkolwiek odpowiedzialność z powstaniem szkody, przede wszystkim szkody materialnej ${ }^{47}$. Odpowiedzialność obiektywna przypomina tym samym odpowiedzialność na zasadzie ryzyka, dopuszczając przypisanie państwu szkodliwych skutków zaniechania jego organów, wynikających z braku należytej staranności. Odmiennie jednak niż odpowiedzialność na zasadzie ryzyka, przywołana może być w braku szczegółowej normy traktatowej. Obowiązek wykazania należytej staranności wywodzony więc być może także z treści ogólnej normy zwyczajowej, a państwo ponosić odpowiedzialność za jego naruszenie.

Czapliński i Wyrozumska podają w wątpliwość zasadność rozróżnienia na odpowiedzialność na zasadzie ryzyka i odpowiedzialność absolutną gdzie ta pierwsza dopuszcza przywołanie działania siły wyższej jako okoliczności egzoneracyjnej, w przypadku odpowiedzialności absolutnej natomiast okoliczności ją wyłączające nie istnieją ${ }^{48}$. Barcik i Srogosz wyróżniają odpowiedzialność abso-

${ }^{44}$ Zob. np.: Konwencja o międzynarodowej odpowiedzialności za szkody wyrządzone przez obiekty kosmiczne, sporządzona w Moskwie, Londynie i Waszyngtonie dnia 29 marca 1972 r. Dz.U. 1973, nr 27, poz. 154, której art. 2 stanowi, iż państwo wypuszczające obiekt jest bezwzględnie zobowiązane do zapłacenia odszkodowania za szkodę, którą wypuszczony przez nie obiekt kosmiczny wyrządził na powierzchni Ziemi lub statkowi powietrznemu podczas lotu.

${ }^{45}$ Por. przypis 40 powyżej oraz: L. F. E. Goldie, Concepts of Strict and Absolute Liability and the Ranking of Liability in Terms of Relative Exposure to Risk, Netherlands Yearbook of International Law 1985, nr 16, s. 175-248.

${ }^{46}$ Por. A. E. Boyle, Globalising..., s. 3; M. M. Kenig-Witkowska, Prawnomiędzynarodowa..., s. 314; R. Pisillo Mazzeschi, op.cit., s. 9-10; ale por.: W. Czapliński, Odpowiedzialność za naruszenie prawa międzynarodowego w zwiqzku z konfliktem zbrojnym, Warszawa 2009, s. 78, który wskazuje, że przypisanie odpowiedzialności państwu nie może ograniczać się jedynie do ustalenia związku przyczynowo-skutkowego. Sprzeciw wobec propozycji odpowiedzialności obiektywnej podziela A. Wyrozumska, por. W. Czapliński, A. Wyrozumska, op.cit., s. 615-616, podnosząc, iż istniejący reżim traktatowy dotyczy wyłącznie obowiązków podmiotów prywatnych. O ścisłej zależności obu reżimów odpowiedzialności mowa w rodziale IV.

${ }^{47}$ Por. szczegółowy opis traktatowych reżimów opartych o odpowiedzialność na zasadzie ryzyka w rozdz. V.

${ }^{48}$ Por.: W. Czapliński, A. Wyrozumska, op.cit., s. 617. 
lutną przy okazji omawiania reguł odpowiedzialności w prawie kosmicznym ${ }^{49}$. Ci sami autorzy utożsamiają odpowiedzialność na zasadzie ryzyka z odpowiedzialnością obiektywną ${ }^{50}$, terminem tym określają jednak całość odpowiedzialności międzynarodowej za czyny niezakazane prawem miedzynarodowym ${ }^{51}$. Przeciwstawiają jej „odpowiedzialność subiektywną”, opartą o koncepcję winy $^{52}$. Bierzanek i Symonides także wyróżniają „odpowiedzialność subiektywną"53, obok odpowiedzialności opartej na zasadzie ryzyka, tą ostatnią określając mianem „teorii ryzyka" 54 . Używają dla niej terminu „odpowiedzialność pośrednia", krytykowanego w doktrynie anglojęzycznej ${ }^{55}$, choć z kontekstu wywodu uznać należy, że przedmiotem ich rozważań jest nie określana tam tym terminem odpowiedzialność państwa za osoby prywatne, ale jego odpowiedzialność wtórna, oparta o zasady stanowiące przedmiot Projektu artykułów o odpowiedzialności państw z $2001 \mathrm{r}^{56} \mathrm{O}$ odpowiedzialności „pośredniej” państwa za podmioty prywatne piszą natomiast Barcik i Srogosz ${ }^{57}$.

Brak jednolitej terminologii $\mathrm{w}$ polskiej doktrynie prawa międzynarodowego przypisać należy specyfice dziedziny. Łączy ona bowiem terminologię i reguły właściwe krajowym porządkom prawa cywilnego i karnego w sposób nieznany żadnej innej gałęzi prawa, przez co odwołanie do polskiej terminologii musi nastręczać trudności. Polskie prawo karne koniecznie łączy odpowiedzialność z przesłanką winy. Prawo cywilne natomiast zna pojęcie odpowiedzialności bezwzględnej podmiotu prywatnego, która opisana została m.in. w art. $100 \mathrm{i} \mathrm{n}$. ustawy Prawo atomowe w odniesieniu do operatów instalacji atomowych ${ }^{58}$. Jak twierdzą niektórzy autorzy, nie jest to jednak odpowiedzialność absolutna w jej czystej formie, ustawodawca dopuszcza bowiem jej wyłączenie, jeśli szkoda nastąpiła w następstwie działań wojennych lub konfliktu zbrojnego, jednak z wyłączeniem siły wyższej ${ }^{59}$. Petrykowska-Lewaszkiewicz nazwała analogicz-

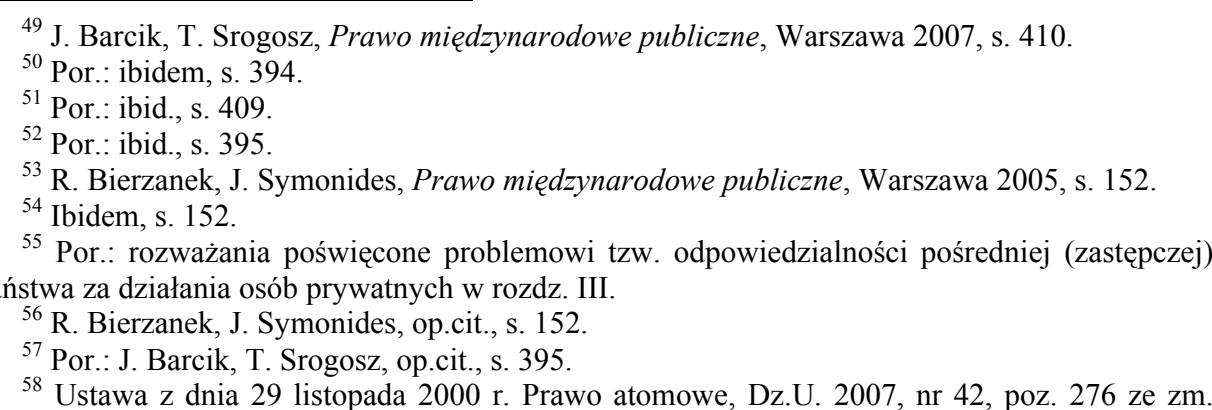
Odpowiedzialność ta nazywana bywa także odpowiedzialnością absolutną; por.: J. Kuźmicka-Sulikowska, Zasady odpowiedzialności deliktowej w świetle nowych tendencji $w$ ustawodawstwie polskim, Warszawa 2011, s. 254. T. Pajor natomiast uważał odpowiedzialność absolutną za szczególną postać odpowiedzialności na zasadzie ryzyka; por.: T. Pajor, Przemiany w funkcjach odpowiedzialności cywilnej [w:] Rozprawy z polskiego i europejskiego prawa prywatnego. Ksiega pamiatkowa ofiarowana Profesorowi Józefowi Skapskiemu, red. J. Panowicz-Lipska, Kraków 1994, s. 302; podaję za: por.: J. Kuźmicka-Sulikowska, op.cit., s. 254.

${ }^{59}$ Ibidem, s. 254. 
ne rozwiązanie zawarte w ustawie z 1986 r. odpowiedzialnością „niemal absolutną w swoim obiektywizmie", wskazując na hybrydowy charakter zawartej tam konstrukcji ${ }^{60}$. Kuźmicka-Sulikowska proponuje uznanie owej konstrukcji za przykład odpowiedzialności o charakterze obiektywnym, ale opartej na zasadzie ryzyka $^{61}$. Koncepcje te dowodzą, że terminologia i charakterystyka rodzajów odpowiedzialności przewidzianych w prawie krajowym nie ułatwia ich uogólnienia na poziomie międzynarodowym.

Odnotować należy także, iż termin „sustainable development”, w ślad za uwagami Kenig-Witkowskiej, przetłumaczony został w treści pracy jako opisujący zasadę ,ciągłego" rozwoju ${ }^{62}$.

\section{Wina a odpowiedzialność w prawie międzynarodowym}

Problem winy w międzynarodowym dialogu dotyczącym odpowiedzialności jest jednym $\mathrm{z}$ najbardziej kontrowersyjnych ${ }^{63}$. $\mathrm{O}$ ile $\mathrm{w}$ treści tej rozprawy jest on omawiany w kontekście rozważanych w niej zagadnień, o tyle w uwagach wstępnych wskazać należy argumenty przytaczane w toczącej się nad nim dyskusji, co pozwoli określić miejsce należytej staranności w konstrukcji reguł odpoiedzialności międzynarodowo prawnej - bowiem należyta staranność postrzegana bywa niekiedy jako element winy. We współczesnej doktrynie polskiej przeważa opinia o odrzuceniu winy jako przesłanki odpowiedzialności państwa, choć wśród autorów obcojęzycznych spór ten wydaje się wciąż aktualny ${ }^{64}$.

Stanowiska sądów i komentatorów prawa międzynarodowego odnośnie do winy są podzielone. Wytrwała mniejszość uznaje, że wina pojmowana abstrakcyjnie, w ujęciu właściwym tradycji prawa cywilnego (choć nieraz także ujmowana subiektywnie, jako psychiczne nastawienie sprawcy naruszenia ${ }^{65}$,

${ }^{60}$ Por.: B. Lewaszkiewicz-Petrykowska, Cywilna odpowiedzialność za szkodę jądrowa w polskim prawie atomowym, PiP 1987, nr 4, s. 30-42.

${ }^{61}$ J. Kuźmicka-Sulikowska, op.cit., s. 255 i s. 254-256, która krytykuje użycie terminu „odpowiedzialność absolutna" względem zapisów prawa atomowego.

${ }^{62}$ Por. M. M. Kenig-Witkowska, Koncepcja „sustainable development” w prawie międzynarodowym, PiP 1998, nr 8, s. 45.

${ }^{63}$ Jest to problem istotny dla całej nauki prawa; Por. ogólnie: T. Honoré, Responsibility and Fault, Portland 1999, który omawia trudności logiczne przy relatywizacji odpowiedzialności względem winy.

${ }^{64}$ Por. np.: R. Verheyen, Climate Change Damage And International Law: Prevention Duties And State Responsibility, Haga 2005. s. 169-183; W. Czapliński, op.cit., s. 78-79 i wskazana tam literatura. J. Symonides wymienia wśród polskich zwolenników koncepcji winy M. Iwanejko, A. Klafkowskiego i F. Przetacznika; por. J. Symonides, Odpowiedzialność państwa w prawie międzynarodowym, Studia Prawnicze, s. 30. O konieczności „udowodnienia winy państwa, którego organy zaniedbały przedsięwziąć czynności chroniące inne państwo przed naruszeniem jego praw" pisze także Ehrlich, por.: idem, op.cit., s. 643. O zależności dogmatycznej pomiędzy winą a odpowiedzialnością pisze obszernie T. Honore, op.cit., s. 14-67.

${ }^{65}$ Por. I. Brownlie, System..., s. 40, który dowodzi, że dowód winy jest łatwiejszy niż obiektywne przypisanie, jeśli ten pierwszy ma zostać przeprowadzony odnośnie do czynów lub zanie- 
w tym osoby pełniącej funkcję organu państwa) jest koniecznym warunkiem możliwości przypisania państwu odpowiedzialności, zwłaszcza w przypadku naruszenia zobowiązań pierwotnych, dotyczących ochrony środowiska ${ }^{66}$. Większość autorów wskazuje jednak, że ustalenie psychicznego nastawienia podmiotu owej odpowiedzialności, a więc państwa, nie jest możliwe, zaś w miejsce różnorodnie pojmowanej w porządkach krajowych cywilistycznej konstrukcji winy proponuje odwołanie do obszernego katalogu przesłanek obiektywnie wyłączających bezprawność czynu, zawartych w dokumentacji Komisji, w tym np. do siły wyższej ${ }^{67}$. Pojawiają się także poglądy usiłujące godzić obie koncepcje, odwołujące się do tzw. obiektywnej koncepcji winy ${ }^{68}$.

Pogląd pierwszy, historycznie starszy, wywodzony z prac Grocjusza ${ }^{69}$, z biegiem lat tracił na popularności, czego dowodem jest nieuwzględnienie przesłanki winy jako koniecznego elementu odpowiedzialności międzynarodowej przez Komisję Prawa Międzynarodowego w tekście zaproponowanych przez nią projektów artykułów i zasad dotyczących odpowiedzialności ${ }^{70}$. Komisja explicite wyłączyła winę umyślną z katalogu przesłanek odpowiedzialności, dopuszcza jednak, jak się zdaje, odwołanie do winy w treści normy pierwotnej, której naruszenie skutkować będzie odpowiedzialnością państwa. Wskazała bowiem, iż w przypadku braku szczegółowych odwołań do czynnika psychicznego w treści

chań osoby, działającej z upoważnienia lub na polecenie państwa. Łatwiej jest wykazać jej wolę działania wbrew ciążącym na państwie zobowiązaniom niż wykazać obiektywny związek przyczynowo-skutkowy oraz obowiązek działania.

${ }^{66}$ Wina jako element zobowiązania pierwotnego przywoływana jest szczególnie chętnie w kontekście odpowiedzialności za szkody w środowisku naturalnym, powstałe z przyczyn zależnych od operatora niebezpiecznego przedsięwzięcia, por. A.E. Boyle, Globalising..., s. 13. Zob. także: B. I. Bonafè, The Relationship Between State and Individual Responsibility for International Crimes, Haga 2009, s. 121-124 i cytowana tam literatura; A. A. Boczek, op.cit., s. 124-125. Analizę różnic pomiędzy karnistycznym a cywilistycznym ujęciem winy i nieumyślności w doktrynie polskiej przedstawił L. Dzikiewicz, zob.: L. Dzikiewicz, O pojęciu winy i jej trzech odmianach, PiP 1977, nr 1, s. 94-95. Por. także: J. Kuźmicka-Sulikowska, op.cit., s. 73-77. O winie jako przesłance odpowiedzialności deliktowej pisała B. Lewaszkiewicz-Petrykowska, por.: eadem, Wina jako podstawa odpowiedzialności z tytułu czynów niedozwolonych, Studia Prawniczo Ekonomiczne 1969 , nr 2, s. 87-104.

${ }^{67}$ Projekt artykułów o odpowiedzialności państw z 2001 r., komentarz do Rozdziału V, s. 71 i n. i do art. 23, s. 76-77. Dahm postrzega odwołanie do siły wyższej za alternatywę dla winy jako przesłanki odpowiedzialności; por.: G. Dahm, J. Delbrück, op.cit., s. 946.

${ }^{68}$ Por.: opisana poniżej propozycja A. E. Boyle'a, omówiona w: A.E. Boyle, Globalising..., s. 3. Por. też: Piąty raport García-Amadora, U.N. Doc. A/CN.4/125, pkt 91, który postuluje wprowadzenie nowych kategorii „obiektywnej odpowiedzialności” w reakcji na rosnącą ilość zagrożeń, wynikających ze stosowania nowych technologii. O istnieniu „odpowiedzialności obiektywnej” w treści reżimów traktatowych prawa środowiska pisze M. M. Kenig-Witkowska, Prawnomiędzynarodowa..., s. 314 .

${ }^{69}$ Koncepcja Grocjusza omówiona została szczegółow w rozdz. I poniżej. Zob. także: J. Symonides, op.cit., s. 43, gdzie autor wskazuje na nieliczne orzeczenia arbitrażowe, uznające ową koncepcję oraz przywołuje jej XIX i XX-wiecznych zwolenników.

${ }^{70} \mathrm{O}$ odstapieniu od ,wymogu winy organu naruszającego prawo międzynarodowe jako przesłanki odpowiedzialności w pracach kodyfikacyjnych KPM" piszą Czapliński i Wyrozumska, op.cit., s. 434, ale por.: poniżej. 
zobowiązania pierwotnego, znaczenie ma jedynie akt państwa, niezależnie od towarzyszącej mu motywacji ${ }^{71}$. Konstatację tę odczytywać można a contrario jako dopuszczenie odwołania do winy nieumyślnej, tj. lekkomyślności lub niedbalstwa, zawartego w treści zobowiązania pierwotnego, jako elementu oceny odpowiedzialności państwa ${ }^{72}$. Co więcej, jeśli państwu, na terytorium którego doszło do szkodliwego zdarzenia, oferowana była pomoc w jej zneutralizowaniu, a ono z takiej pomocy nie skorzystało wskutek niedbalstwa czy lekkomyślności - a więc jednej z postaci winy - to poczytać takie zaniechanie należy za brak należytej staranności ${ }^{73}$. Konsekwencje tego uwzględnienia winy przy ocenie zaniechania organu władzy przez Komisję istotne są dla opisu roli, jaką należyta staranność odgrywa przy przypisywaniu państwu odpowiedzialności za naruszenie prawa międzynarodowego ${ }^{74}$.

Szczegółowa analiza prac Komisji przyczyniła się do ożywienia raczej niż uspokojenia dyskusji nad udziałem winy w aplikowaniu reguł odpowiedzialności. Crawford i Olleson w monografii poświęconej odpowiedzialności państw wskazują że uwzględnienie winy przy analizie odpowiedzialności państwa zależeć będzie od specyfiki konkretnego przypadku, nie sposób więc zidentyfikować ogólnej zasady ${ }^{75}$. Autorzy ci dopuszczają obecność przesłanki winy w analizie międzynarodowej odpowiedzialności państw. Podobnie uważa Cheng, który $\mathrm{w}$ treści monografii poświęconej zasadom prawa międzynarodowego omawia należytą staranność przy okazji opisu ,zasady winy” jako koniecznego elementu międzynarodowej odpowiedzialności. Brak należytej staranności uważa za jedną $\mathrm{z}$ jej postaci: niedbalstwo jest postacią winy, choć nie jej immanentną częścią ${ }^{76}$. Przypisanie państwu odpowiedzialności, jego zdaniem, nie wymaga, co do zasady, dowodu złej wiary czy niedbalstwa, zależy jedynie od istnienia woli (ang. will) ${ }^{77}$. Zdaniem Zemanka natomiast należyta staranność jest obiektywną formą winy $^{78}$. Także postulujący uznanie należytej staranności za zasadę prawa międzynarodowego Pisillo Mazzeschi wskazuje, że niekiedy może ona być uznana za element specyficznie pojmowanej winy ${ }^{79}$. Dahm uznaje natomiast należytą

\footnotetext{
${ }^{71}$ Projekt artykułów o odpowiedzialności państw z 2001 r., komentarz (10) do art. 2, s. 36.

${ }^{72}$ Choć jednocześnie Komisja dopuszcza przywołanie siły wyższej jako okoliczności egzoneracyjnej, por.: Projekt artykułów o odpowiedzialności państw z 2001 r., art. 23, s. 76.

${ }^{73}$ Projekt Barbozy, U.N. Doc. A/51/10, komentarz do art. 22, pkt (9), s. 119. Por. też: Piąty raport García-Amadora, U.N. Doc. A/CN.4/125, pkt 88, s. 63 który pisze iż „w przypadku odpowiedzialności państw wynikjącej z niedbalstwa (lub innej formy wykonywania woli) organu lub przedstawiciela, to owo zaniedbanie lub wyraz woli (ang. volition) stanowi czyn sprzeczny z prawem międzynarodowym."

${ }^{74}$ Zagadnienie to omówione zostało w rozdz. VI.

${ }^{75}$ J. Crawford, S. Olleson, op.cit., s. 457-8.

${ }^{76}$ B. Cheng, General Principles of Law as Applied by International Courts and Tribunals, Cambridge 2006, s. 227-228.

${ }^{77}$ Ibidem, s. 227. Koncepcja Chenga opisana została szczegółowo w rozdziale ostatnim.

${ }^{78}$ K. Zemanek, Schuld- und Erfolgshaftung im Entwurf der Völkerrechtskommission über Staatenverantwortlichkeit, Bern 1980, s. 322-323. Por. też G. Dahm, J. Delbrück, op.cit., s. 946.

${ }^{79}$ Por. R. Pisillo Mazzeschi, op.cit., s. 9-10.
} 
staranność za element międzynarodowego zobowiązania państwa, ale nie pojmuje jej w kategoriach winy ${ }^{80}$. Odwołując się do orzecznictwa, opisuje należytą staranność jako osobną zasadę prawa międzynarodowego (niem. Grundsatz), decydującą o możliwości przypisania państwu odpowiedzialności międzynarodowej za naruszenie jego zobowiązania ${ }^{81}$.

$\mathrm{W}$ podobnym do Zemanka tonie wypowiada się Boyle, który proponuje przyjęcie koncepcji „winy obiektywnej” (ang. objective fault) jako wiodącej dla omawianego zagadnienia odpowiedzialności państwa za szkody transgraniczne, wynikające z zaniechań jego organów. Termin ten ma opisywać brak należytej staranności, naruszenie zobowiązania traktatowego lub popełnienie czynu zabronionego ${ }^{82}$. Jego zdaniem, jeśli państwa mogłyby być pociagane do odpowiedzialności bez wykazania tak pojmowanej ich winy, trudno o wiarygodne i liczne przykłady aplikowania zasad odpowiedzialności ${ }^{83}$. Propozycja Boyle'a oznacza zastosowanie pojęcia winy do konstrukcji obiektywnego przypisania i, jako taka, wydaje się godzić oba sprzeczne stanowiska. Podobnie w 1963 r. argumentował Ago, wskazując, iż transpozycja zasad odpowiedzialności na grunt prawa międzynarodowego winna być oparta na winie pojmowanej odmiennie niż w doktrynie porządków krajowych, bowiem w prawie międzynarodowym pojęcie należytej staranności nie jest koniecznie związane z niedbalstwem. Odpowiedzialność międzynarodowa państw może występować w prawie międzynarodowym także wówczas, gdy powstaniu szkody nie towarzyszy wina po stronie państwa. Dlatego też, wywodził Ago, odpowiedzialność państwa może mieć niekiedy charakter obiektywny ${ }^{84}$. Kenig-Witkowska $z$ kolei, w reakcji na praktyczne trudności z przypisaniem państwu odpowiedzialności za naruszenie zobowiązań międzynarodowych uznaje zapisy umów międzynarodowego prawa środowiska oraz orzecznictwa sądów dotyczących tego obszaru prawa międzynarodowego za potwierdzenie „obiektywnej odpowiedzialności” państw za szkody środowiskowe, tj. odpowiedzialności państwa za podmioty przez nie niekontrolowane ${ }^{85}$.

$\mathrm{O}$ ile wina ani szkoda nie są przywoływane bezpośrednio $\mathrm{w}$ opracowanym przez Komisję Projekcie artykułów o odpowiedzialności państw z 2001 r., o tyle zgodnie z jej komentarzem oba te czynniki wystapić mogą w treści normy pierwotnej, w tym normy obejmującej obowiązek prewencji, której naruszenie pozwoli na przypisanie państwu odpowiedzialości za działanie lub zaniechanie sprzeczne z jej treścią. W kontekście powyższego wywodu autorka przyłącza się do koncepcji Dahma, iż należyta staranność stanowi element porządku reguł międzynarodowej odpowiedzialności, niezależny od ewentualnej winy państwa

\footnotetext{
${ }^{80}$ Por.: G. Dahm, J. Delbrück, op.cit., s. 946. Por. też: R. Pisillo Mazzeschi, op.cit., s. 42 i n.

${ }^{81}$ Por.: G. Dahm, J. Delbrück, op.cit., s. 946.

${ }^{82}$ A.E. Boyle, Globalising..., s. 3.

${ }^{83}$ Ibidem.

${ }^{84}$ Raport KPM ,1963 r., U.N. Doc. A/CN.4/163, s. 249-250.

${ }^{85}$ Por. M. M. Kenig-Witkowska, Prawnomiędzynarodowa..., s. 314.
} 
lub jego organu. Jej brak analizowany powinien być w opaciu o obiektywne kryteria, takie jak istnienie normy traktatowej lub zwyczajowej wiążącej państwo, która została naruszona oraz faktyczna możliwość zapobiegania jej naruszeniu, którą dysponowały jego organy. Jest ona tym samym jedną z przesłanek obiektywnego przypisania państwu odpowiedzialności za zaniechanie jego organów, skutkującego szkodą lub niebezpieczeństwem jej powstania w konsekwencji naruszenia pierwotnej normy traktatowej lub zwyczajowej prawa międzynarodowego. Należyta staranność to przesłanka obiektywnego przypisania państwu odpowiedzialności za zaniechanie jego organu, sprzeczne z treścią międzynarodowego zobowiązania ciążącego na państwie. $Z$ dogmatycznego punktu widzenia samo naruszenie tak pojmowanej normy międzynarodowej może stać się podstawą odpowiedzialności państwa. Analiza stanowisk państw zmusza jednak na obecnym etapie rozwoju prawa międzynarodowego do uwzględnienia przesłanki szkody materialnej jako niezbędnego elementu przypisania odpowiedzialności państwu za zaniechanie jego organów. Podobnie jak dobra wiara, należyta staranność wymagana jest przy realizacji wszelkich zobowiązań międzynarodowych, także tych, w treści których nie została wprost przywołana, z wyłączeniem zobowiązań o charakterze skutkowym.

\section{Należyta staranność w prawie krajowym}

Pojęcie winy, a co za tym idzie, pojęcie należytej staranności omawianej zazwyczaj w jej kontekście, rodzi spory już na gruncie krajowych porządków prawnych. Jest przedmiotem dyskusji karnistów, cywilistów czy specjalistów prawa pracy, bowiem w każdej z gałęzi i dyscyplin prawniczych wina i należyta staranność pojmowane są odmienne ${ }^{86}$. Tym trudniejsze jest oddzielenie owych pojęć i ich usystematyzowanie na płaszczyźnie prawa międzynarodowego, nierozróżniającego dziedzin właściwych porządkom krajowym, czerpiącego $\mathrm{w}$ równej mierze $\mathrm{z}$ dorobku prawa cywilnego, co karnego, z systemów prawa stawionego, co common law. Jednak nakreślenie różnic w pojmowaniu należytej staranności na gruncie prawa krajowego stanowi dobry punkt wyjścia do rozważań dotyczących należytej staranności w prawie międzynarodowym.

Należyta staranność zawsze omawiana jest w kontekście winy i postrzegana przez większość przedstawicieli doktryny jako element od niej niezależny ${ }^{87}$. W polskim porządku prawnym, podobnie jak w licznych porządkach krajowych, należyta staranność jest pojęciem najlepiej zbadanym przez doktrynę prawa cywilnego. Prawo karne używa tego pojęcia do opisu nieumyślności, przypisując

\footnotetext{
${ }^{86}$ Por.: J. Kuźmicka-Sulikowska, op.cit., s. 73-77, gdzie autorka omawia różnice w pojmowaniu winy w prawie polskim.

${ }^{87}$ Por. np.: W. Warkałło, Gradacja winy a obowiqzek naprawienia szkody w świetle przepisów kodeksu cywilnego, Studia Prawnicze 1970, nr 26-27, s. 301-303, który omawia rolę przypisywaną winie w prawie cywilnym i karnym.
} 
analogiczne konsekwencje prawne obu jej postaciom: lekkomyślności i niedbalstwu, a więc - w tym ostatnim przypadku - brakowi należytej staranności ${ }^{88}$. Jednocześnie, opisane $\mathrm{w}$ doktrynie cywilistycznej niedbalstwo pojmowane jest szerzej niż w prawie karnym, ponieważ cywilnoprawny obowiązek odszkodowania powstaje także w tych sytuacjach, w których prawo karne nie przewiduje żadnych prawnych konsekwencji ${ }^{89}$. Niedbalstwo ujmowane jest więc odmiennie $\mathrm{w}$ prawie karnym i w prawie cywilnym.

Jak wspomniano, w prawie karnym jest ono, obok lekkomyślności, jedną z dwu postaci nieumyślności. Oznacza nieprzewidywanie przez sprawcę możliwości popełnienia czynu zabronionego, pomimo iż powinien on i mógł był ją przewidzieć $^{90}$. Kryteria oceny owej powinności opisywane są odmiennie w doktrynie prawa karnego. Zoll, reprezentatywnie dla polskiej doktryny prawa karnego, zalicza „naruszenie reguł ostrożności” do znamion przedmiotowych czynu zabronionego, badanych niezależnie od strony podmiotowej, tj. od winy spraw$\mathrm{cy}^{91}$. Giezek natomiast uznaje nieumyślność, a więc konsekwencje naruszenia reguł ostrożności, za „psychologiczny stan rzeczy”, wiążąc ocenę starannego albo niestarannego postępowania sprawcy $\mathrm{z}$ oceną jego nastawienia do możliwości popełnienia czynu ${ }^{92}$. Koncepcja Zolla bliższa jest więc opisanej powyżej międzynarodowo prawnej idei „winy obiektywnej”, której zwolennikiem jest Boyle czy „odpowiedzialności obiektywnej” według Kenig-Witkowskiej. W prawie cywilnym natomiast „niedbalstwo” jest synonimem winy nieumyślnej i definiowane jest jako niedołożenie należytej staranności ${ }^{93}$. Należyta staranność mieści się więc $\mathrm{w}$ treści pojęcia nieumyślności, utożsamianego z niedbalstwem prawo cywilne nie wyróżnia „lekkomyślności”, znanej prawu karnemu. Nieumyślność oceniana jest obiektywnie, niezależnie od winy, jako ,podmiotowa cecha postępowania sprawcy szkody”, a ocena braku należytej staranności czyniona jest $\mathrm{w}$ prawie cywilnym w odniesieniu do abstrakcyjnej możliwości powstania szkody $^{94}$. W prawie karnym nie znajduje natomiast odzwierciedlenia cywilistyczna konstrukcja rażącego niedbalstwa ${ }^{95}$. Te różnice przesądzają o niemożności ujednolicenia sposobów rozumienia pojęcia winy $\mathrm{w}$ polskiej nauce prawa $^{96}$. Pokazane powyżej różnice dogmatyczne pomiędzy dyscyplinami prawniczymi oraz trudności terminologiczne utrudniają jednoznaczne ujęcie zasady należytej staranności w prawie międzynarodowym, niemniej jednak próba taka została podjęta w treści niniejszej rozprawy.

${ }^{88}$ Por. np. Kodeks karny. Część ogólna. Komentarz, red. J. Giezek, Warszawa 2007, s. 72-73; Kodeks karny. Część ogólna. Komentarz, red. A. Zoll, Warszawa 2007, tom I, s. 118.

${ }^{89}$ Por.: J. Kuźmicka-Sulikowska, op.cit., s. 73; L. Dzikiewicz, op.cit., s. 94-95.

${ }^{90}$ Por. np. Kodeks karny. Część ogólna. Komentarz, red. J. Giezek..., s. 73.

${ }^{91}$ Por. Kodeks karny. Częśś ogólna. Komentarz, red. A. Zoll..., tom I, s. 119.

${ }^{92}$ Kodeks karny. Część ogólna. Komentarz, red. J. Giezek..., s. 73.

${ }^{93}$ J. Kuźmicka-Sulikowska, op.cit., s. 74.

${ }^{94}$ Ibidem.

${ }^{95}$ Por.: W. Warkałło, op.cit., s. 302.

${ }^{96}$ Por.: J. Kuźmicka-Sulikowska, op.cit., s. 73-74; L. Dzikiewicz, op.cit., s. 98. 



\section{Rozdzial I}

\section{GENEZA ZASADY NALEŻYTEJ STARANNOŚCI}

\subsection{Państwo jako kolektyw - odpowiedzialność zbiorowa w czasach starożytnych i średniowieczu}

Koncepcje opisujące w doktrynie prawa międzynarodowego zasady odpowiedzialności za czyny jednostek ulegały na przestrzeni wieków znaczącym modyfikacjom. Hessbruegge opisuje dwa główne nurty tej ewolucji, przeciwstawiając koncepcję przypisania odpowiedzialności (ang. attribution, imputability) zasadzie należytej staranności. Wywodzi, że determinujący wpływ na kształt współczesnego prawa międzynarodowego, a co za tym idzie, także na reguły międzynarodowej odpowiedzialności, wywarło piśmiennictwo europejskie, czerpiące pierwotnie z rzymskiej koncepcji prawa narodów (ius gentium), później zaś odzwierciadlające polityczny charakter porządku westfalskiego ${ }^{1}$.

Początki odpowiedzialności państw za czyny osób fizycznych sięgają czasów rzymskich. Społeczna specyfika tego okresu determinowała ich prawną kwalifikację. Podstawową jednostką społeczeństwa w starożytnym Rzymie była rodzina, na czele której stał najstarszy mężczyzna, zaś każdy jej członek miał ustalone miejsce, prawa i obowiązi ${ }^{2}$. Rodziny organizowały się w domy, te w plemiona, zaś wszystkie plemiona tworzyły wspólnotę ${ }^{3}$. Maine określał ową zależność mianem systemu kręgów koncentrycznych ${ }^{4}$. Kolektywne pojmowanie struktury społecznej powodowało, że także interakcja między wspólnotami rozumiana była grupowo. To całe wspólnoty kontaktowały się między sobą, choćby za pośrednictwem reprezentujących je jednostek, raczej niż interreagowali ich samodzielni, niezależni uczestnicy. Takie wyobrażenie relacji między społecznościami odzwierciedlone zostało w treści rzymskiego pojęcia prawa narodów: ius gentium.

${ }^{1}$ J. A. Hessbruegge, op.cit., s. 266-267.

${ }^{2}$ Por.: H. S. Maine, Ancient Law: Its Connection with the Early History of Society and its Relation to Modern Ideas, Londyn 1861, s. 128. Zob. też np.: C. S. Lobingier, The Evolution of the Roman Law: From Before the Twelve Tables to the Corpus Juris, Nowy Jork 1923, s. 30-33; M. Kuryłowicz, A. Wiliński, Rzymskie prawo prywatne: zarys wykładu, Kraków 2008, s. 117-118. Por. też: M. Safjan, Wyzwania dla państwa prawa, Kraków 2007, s. 94-95, gdzie autor opisuje szczególną rolę ojca rodziny (pater familias) w rzymskim systemie prawa prywatnego.

${ }^{3}$ H. S. Maine, op.cit., s. 128; C. S. Lobingier, op.cit., s. 30.

${ }^{4}$ H. S. Maine, op.cit., s. 128. 
Gajusz w „Instytucjach” określa ius gentium jako prawo, którym „posługują się wszystkie ludy” i którego „wszystkie ludy przestrzegają tak samo”, wskazując jako jego źródło „przyrodzony rozsądek” (naturalis ratio) ${ }^{5}$. Termin ten miał w czasach Gajusza kilka znaczen ${ }^{6}$. Określał zarówno przepisy prawa stanowionego, stosowane względem nieobywateli rzymskich, jak i sposób myślenia o prawie jako o wspólnocie wszystkich ludzi, niezależnie od ich pochodzenia ${ }^{7}$. Ius gentium było więc dla Gajusza tożsame $\mathrm{z}$ ius naturale, bowiem ich wspólnym źródłem był przyrodzony rozsądek. Ulpian wyróżniał jeszcze prawo naturalne (ius naturale) rozumiane jako prawo narodów, uznając oba porządki za równorzędne elementy trójpodziału współczesnych mu systemów prawnych, uzupełnianego przez prawo cywilne (ius civile) $)^{8}$. Jego zdaniem prawo narodów wspólne było wszystkim ludziom, podczas gdy prawo natury łączyło wszystkie żyjące istoty, także zwierzęta (quod natura omnia animalia docuit) ${ }^{9}$. Zdaniem Honoré prawo natury według Ulpiana moralnie przewyższało prawo narodów, ograniczone wyłącznie do rasy ludzkiej ${ }^{10}$. „Prawo narodów” - ius gentium, źródłosłów współczesnego niemieckiego Völkerrecht czy francuskiego droit des gens oznaczało wówczas także prawo międzynarodowe publiczne, a więc zbór reguł rządzących wzajemnymi relacjami pomiędzy społecznościami ${ }^{11}$.

Odmiennie interpretuje to ostatnie znaczenie terminu ius gentium Hessbruegge $^{12}$. Określa je nie tyle jako desygnujące prawo międzynarodowe publiczne w jego obecnym znaczeniu, co raczej opisujące rzymski porządek wewnętrzny, odnoszący się do stosunków międzynarodowych, w tym m.in. do okoliczności wypowiadania wojny i zawierania pokoju ${ }^{13}$. Tak pojmowane prawo narodów nie ograniczało się do opisu międzynarodowo prawnych konsekwencji zachowań przedstawicieli jednej wspólnoty czy uznanego sposobu wypowiadania wojny, ale, odwołując się do prawa sakralnego, uzależniało od dopełnienia

\footnotetext{
${ }^{5}$ Gajusz, Instytucje, 1.1, thum. C. Kunderewicz, Warszawa 1982, s. 28-29. Por. A. Tarwacka, O sprawiedliwości i prawie. 1 tytut 1 księgi Digestów. Tekst-tlumaczenie - komentarz, Zeszyty Prawnicze UKSW 2003, nr 3.2, s. 370; zob. także: W. Wołodkiewicz, Europa i prawo rzymskie. Szkice z historii europejskiej kultury prawnej, Kraków 2009, s. 300.

${ }^{6}$ Por.: M. Kaser, Römische Rechtsquellen und angewandte Juristenmethode: ausgewählte, zum Teil grundlegend erneuerte Abhandlungen, Wiedeń 1986, s. 91.

${ }^{7}$ Ibidem.

${ }^{8}$ Ulpian, Digesta, 1.1.1.3; (w:) A. Tarwacka, O sprawiedliwości i prawie. 1 tytut 1 księgi Digestów. Tekst - tlumaczenie - komentarz, Zeszyty Prawnicze UKSW 2003, nr 3.2, s. 357; inaczej Gajusz, który wyróżniał jedynie ius gentium i ius civile, pomijając prawo naturalne. Ibidem, s. 370. Por. też: R. Domingo, The New Global Law, Cambridge 2010, s. 10.

${ }^{9}$ Ulpian, Digesta, 1.1.1.4, s. 357; por. też: K. Wroczyński, O źródtach treści praw czlowieka, Człowiek w Kulturze 1998, nr 11, s. 165-166.

${ }^{10}$ T. Honoré, Ulpian, Pioneer of Human Rights, Oksford/Nowy Jork 2002, s. 80 za: R. Domingo, op.cit., s. 10.

${ }_{11}$ M. Kaser, op.cit. s. 91.

12 J. A. Hessbruegge, op.cit., s. 277, choć także odwołując się do Kasera, por.: M. Kaser, Ius Gentium, Kolonia 1993, s. 3-6.

${ }^{13}$ Zob. też: H. Wheaton, History of the Law of Nations in Europe and America, Nowy Jork 1845, s. 25-29.
} 
przewidzianych w nim rytuałów np. powodzenie lub klęskę na wojnie ${ }^{14}$. Z prawa sakralnego wywodzono także zasadę nietykalności posłańców i ambasadorów, prawo azylu czy wiążącą moc traktatów ${ }^{15}$.

Ius gentium straciło ów wyznaniowy charakter, gdy Imperium Rzymskie poszerzyło swoje granice i objęło nimi przedstawicieli różnych wyznań i kultur ${ }^{16}$. Rzymskie prawo narodów zdominowane zostało przez reguły prawa natury, oparte o zasadę słuszności (aequitas) ${ }^{17}$, choć celem ich dekodowania wciąż odwoływano się pomocniczo do systemów religijnych wspólnot zamieszkujących terytorium rosnącego imperium ${ }^{18}$. Według Hallecka, rzymskie ius gentium nie było systemem prawa pozytywnego ani zbiorem norm wywodzonych z orzecznictwa (ang. code of jurisprudence), ustanowionym decyzją wszystkich czy choćby większości narodów, wobec których miało być stosowane. Stanowiło raczej zbiór zasad prawa cywilnego, opisujących reguły interakcji pomiędzy obywatelami Imperium a przedstawicielami licznych i różnorodnych społeczeństw je zamieszkujących ${ }^{19}$. Służyło przede wszystkim rozstrzyganiu sporów $^{20}$. Identyfikując normy prawa narodów, Rzymianie czerpali $\mathrm{np}$. $\mathrm{z}$ greckiego dorobku w dziedzinie prawa morza ${ }^{21}$. Według Kasera dopuszczalne jest utożsamianie ius gentium $\mathrm{z}$ prawem zwyczajowym ${ }^{22}$. Znaczenie prawa narodów, rozumianego jako reguły interakcji obywateli z nieobywatelami, wzrosło w III w. p.n.e., wraz z ekspansją Imperium na ziemie włoskie ${ }^{23}$. Ius gentium określało już nie treść rytuałów mających przynieść zwycięstwo w wojnie, ale i sytuacje, w których społeczności tworzące Imperium mogły dochodzić swych praw na dro-

${ }^{14}$ Por.: np.: H. W. Halleck, International Law: Or, Rules Regulating the Intercourse of States in Peace and War, San Francisco 1861, s. 3; H. Wheaton, Elements of International Law, Boston 1866, s. XVI.

${ }^{15}$ H. W. Halleck, op.cit., s. 3; H. Wheaton, Elements of..., s. 4-5.

${ }^{16}$ Zob. np.: F. Bird, Moral Universalities as Cultural Commonalities, (w:) Ethical Universals in International Business, red. F. N. Brady, Berlin, Heidelberg, New York, Tokyo 1996, s. 110.

${ }^{17}$ Zob. np.: S. Whittaker, Good Faith in European Contract Law, Cambridge 2000, s. 77; R. W. Dyson, S. M. R. Stirk, Natural Law and Political Realism in the History of Political Thought: From the sophists to Machiavelli, Londyn-Paryż-Nowy Jork 2005, s. 130-131; C. Phillipson, The International Law and Custom of Ancient Greece and Rome, cz. I, Londyn 1911, s. 119-120.

${ }^{18}$ Por.: S. Wielgus, Polska średniowieczna doktryna ius gentium, Lublin 1996, s. 27. Zob. także: B. Tierney, The Idea of Natural Rights: Studies on Natural Rights, Natural Law, and Church Law, Grand Rapids 1997, s. 25-30, 51-55.

${ }^{19}$ H. W. Halleck, op.cit., s. 3, 4; A. Orakhelashvili, Research Handbook on the Theory and History of International Law, Northampton 2011, s. 13-14; A.A. Cançado Trindade, International Law for Humankind: Towards a New Jus Gentium, Haga 2010, s. 37 i n.; R. A. Macdonald, Metaphors of Multiplicity: Civil Society, Regimes and Legal Pluralism, Arizona Journal of International \& Comparative Law 1998, nr 15, s. 69; B. Esperanza, International Law Human Rights, and Latcrit Theory: Civil and Political Rights - An Introduction, University of Miami Inter-American Law Review 1996-1997, nr 28, s. 226-235.

${ }^{20}$ Por. np.: H. A. Rommen, Die Staatslehre des Franz Suarez S.J., Monachium 1947, s. 275; R. W. Dyson, S. M. R. Stirk, op.cit., s. 127-130.

${ }^{21}$ H. W. Halleck, op.cit., s. 3 .

${ }^{22}$ M. Kaser, Ius..., s. 6.

${ }^{23}$ Ibidem, s. 4. 
dze wojny. Stało się instrumentem ruchów społecznych, opartych na wspólnej ideologii, pozwalającej ustalić, kiedy wojna była sprawiedliwa (bellum justum et pium), uznawanej także poza granicami Imperium ${ }^{24}$. Wówczas wykształciły się $\mathrm{w}$ treści tego rzymskiego porządku prawnego reguły przypominające dzisiejszy reżim odpowiedzialności państw ${ }^{25}$. Swoje początki miały one w ewolucji rzymskiego prawa narodów, które wypracowało reguły odpowiedzialności społeczności za czyny jej uczestnika. Choć przytaczana przez Polibiusza teza o zobowiązaniu władcy do ukarania sprawców szkody wyrządzonej cudzoziemcom przypomina współczesną konstrukcję odpowiedzialności za odmowę wymiaru sprawiedliwości czy szerzej: odpowiedzialności państwa za zaniechanie sprzeczne $\mathrm{z}$ treścią jego międzynarodowego zobowiązania, ich geneza znacząco się różni ${ }^{26}$. W czasach starożytnych odpowiedzialność władcy nie wynikała $\mathrm{z}$ braku należytej staranności przy zapobieganiu szkodliwym skutkom działań jednostki, lecz z samego faktu naruszenia normy ius gentium przez jednego z jego podwładnych. Zależność taka odzwierciedla specyfikę starożytnych społeczeństw, w których zasadą była odpowiedzialność zbiorowa - jednostki nie działały we własnym imieniu i na własny rachunek, a jedynie jako przedstawiciele społeczności, do której należały ${ }^{27}$.

Tak rozumiana odpowiedzialność zbiorowa obecna była w średniowiecznej doktrynie prawa narodów. Berman, opisując ówczesne społeczności, wspomina o plemionach (niem. Stamm) składających się z grup, nie z jednostek: od domostw, poprzez grody, aż po słabo zintegrowane królestwa ${ }^{28}$. Ten niski poziom organizacji społecznej powodował, że reguły wzajemnej interakcji plemion oparte były o założenie odpowiedzialności zbiorowej ich członków (niem. Sippenhaftung $)^{29}$. Społeczeństwo średniowiecznego państwa postrzegane było jako całość, zaś działania każdego z jego członków, nawet nieumyślne, uznawane za działanie samego państwa. W odpowiedzi na szkodę wyrządzoną przez członka innej społeczności poszkodowani mogli domagać się od plemienia, do

\footnotetext{
${ }^{24}$ Por. też: B. Łapicki, Poglady prawne niewolników i proletariuszy rzymskich: studium historyczne na tle bazy gospodarczej $i$ antagonizmów klasowych, Wrocław 1955, s. 95, który pisze o „wojnie sprawiedliwej” rzymskiech niewolników. Zob. także: M. Kaser, Ius..., s. 28-29; A. Grafton, G. W. Most, S. Settis, The Classical Tradition, Harvard 2010, s. 972 . O genezie wojny sprawiedliwej w prawie narodów por. także: W. Czapliński, op.cit., s. 10-11.

${ }^{25}$ J. A. Hessbruegge, op.cit., s. 277. Por.: także J. B. Scott, The Catholic Conception of International Law: Francisco de Vitoria, Founder of the Modern Law of Nations, Francisco Suárez, Founder of the Modern Philosophy of Law in General and in Particular of the Law of Nations: a Critical Examination and a Justified Appreciation, Nowy Jork 1934, s. 157-160, gdzie opisana została ewolucja reguł odpowiedzialności międzynarodowej od prawa zwyczajowego do prawa narodów.

${ }^{26}$ Polibiusz, Dzieje, t. 2, Wrocław 1962, pkt 8, podaję za: W. Pająkowski, Ilirowie, Toruń 1981, s. 185.

${ }^{27}$ J. A. Hessbruegge, op.cit., 279.

${ }^{28}$ H. J. Berman, Law and Revolution: The Formation of the Western Legal Tradition, Harvard 1983 , s. 52.

${ }_{29}$ J. A. Hessbruegge, op.cit., 279; D. Anzilotti, Lehrbuch des Völkerrechts, Berlin, Lipsk 1929, s. 376-377; H. J. Berman, op.cit., s. 55-56.
} 
którego należał sprawca, krwawej zemsty albo rekompensaty w pieniądzu. Jeśli plemię sprawcy chciało zwolnić się od odpowiedzialności za czyn swojego członka, mogło zesłać go na banicję, stawiając poza prawem (niem. vogelfrei). Zamach na życie lub zdrowie banity nie powodował żadnych konsekwencji prawnych $^{30}$.

Omawiając ewolucję rzymskiego ius gentium warto wspomnieć o szczególnej roli, jaką wywarła na nią polska średniowieczna myśl prawnicza. Powszechnie przyjmuje się, że to Grocjusz jako pierwszy podał definicję prawa narodów $\mathrm{w}$ De iure belli ac pacis z $1625 \mathrm{r}^{31}$ Tymczasem polscy średniowieczni prawnicy: Paweł Włodkowic i Stanisław ze Skarbimierza w pierwszej połowie XIV w., tj. na ponad 200 lat wcześniej niż Grocjusz, przedstawili dojrzalszą od zachodnioeuropejskiej interpretację rzymskiego ius gentium, dając podstawy polskiej nauce „prawa narodów” ${ }^{32}$. Ich ujęcie rzymskiej koncepcji umknęło, jak się zdaje, zagranicznej nauce prawa międzynarodowego ${ }^{33}$, mimo obszernego opracowania ich dorobku przez Jasudowicza, Ehrlicha i Bełcha ${ }^{34}$. Włodkowic i Skarbimierczyk uznawali za źródło wszelkiego prawa naturę człowieka, z której wynikały wszelkie normy postępowania, wspólne ludziom. Z natury człowieka wywodzili powszechną moc obowiązująca prawa natury i co za tym idzie - prawa narodów jako najpełniejszego jego wyrazu. Wskazywali, za Gajuszem, iż skoro wydarzenia społeczne wynikają przede wszystkim z kierowanej rozsądkiem działalności ludzkiej, to on właśnie powinien stanowić źródło wszelkiej prawnej regulacji ${ }^{35}$. Człowiek może w pełni się realizować dopiero jako część wspólnoty złożonej z podobnych mu natura jednostek. Włodkowic pisał, że prawo narodów, a co za tym idzie, wszelkie prawo pozytywne, oparte być musi o prawo natury, bowiem w centrum prawa natury znajduje się człowiek, stanowiący podmiot regulacji ${ }^{36}$. Uznać więc należy, że polska średniowieczna nauka prawa międzynarodowego wpisywała się w nurt europejskiej ewolucji, także

${ }^{30}$ J. A. Hessbruegge, op.cit., 280. Por.: H. Maihold, Die Sippenhaft: Begründete Zweifel an einem Grundsatz des ,deutschen Rechts”, Mediaevistik 2005, nr 18, s. 117-144. Por. ogólnie: W. Schüpbach, Sippenhaftung: Roman, Zwickau 1996.

${ }^{31}$ Por.: np.: J. Makowski, op.cit., s. 21.

${ }^{32}$ Por.: S. Wielgus, op.cit., Lublin 1996, s. 45-48.

${ }^{33}$ Ibidem, s. 47.

${ }^{34}$ L. Ehrlich, Works of Paul Wladimiri; a Selection, Warszawa 1969; Stanislaus F. Belch, Paulus Vladimiri and his doctrine concerning international law and politics, Londyn-Haga-Paryż 1965. Zob. także M. Lachs, The Teacher In International Law: Teachings And Teaching, Haga 1987, s. 39-44; T. Jasudowicz, Włodkowica wizja porzadku prawnego, PiP 1993, nr 8, s. 27-39. T. Jasudowicz opracował wszechstronną analizę prac Włodkowica pod kątem wpływu na współczesną doktrynę praw człowieka, por.: T. Jasudowicz, Śladami Ludwika Ehrlicha: Do Pawła Włodkowica po nauke o prawach czlowieka, Torun 1995.

${ }^{35} \mathrm{~S}$. Wielgus, op.cit., s. 62 . O genezie ius naturale jako źródle prawa narodów zob. także: M. Goldie, Edmund Bohun And Jus Gentium In The Revolution Debate 1689-1693, The Historical Journal 1977, nr 20(3), s. 569-586; S. F. Belch, Paulus Vladimiri And His Doctrine Concerning International Law And Politics, Revue de l'histoire des religions 1969, nr 176(2), s. 225-227.

${ }^{36}$ Jest to koncepcja potwierdzana przez doktrynę międzynarodowego prawa praw człowieka; por.: T. Jasudowicz, op.cit., s. 49-52; S. Wielgus, op.cit., s. 63. 
w kwestii zagadnienia międzynarodowej odpowiedzialności, choć prace polskich pisarzy koncentrowały się wokół zaczątków późniejszej nauki prawa praw człowieka.

Mimo iż średniowiecze czerpało z dorobku rzymskiego ius gentium, przyjmując zasadę odpowiedzialności zbiorowej, równolegle w tym właśnie okresie rozwoju prawa międzynarodowego powstały zręby współczesnej koncepcji odpowiedzialności państw. Przełom XIV i XV w. to czas, w którym odmowa wymiaru sprawiedliwości, której dopuścił się suweren względem znajdujących się w jego władzy cudzoziemców mogła zostać uznana za podstawę jego odpowiedzialności wobec innych władców ${ }^{37}$. Odpowiedzialność władcy za odmowę ochrony prawnej cudzoziemcowi, stanowiąca podstawę roszczeń między władcami stojącymi na czele społeczności, raczej niż szkoda wyrządzona przez pojedynczego członka danej społeczności, stała się jednym ze zrębów współczesnej koncepcji odpowiedzialności państwa.

\subsection{Odpowiedzialność indywidualna władcy - grocjańska koncepcja winy w epoce absolutyzmu}

W dobie absolutyzmu wciąż obecne były w doktrynie stosunków międzynarodowych wpływy rzymskiego ius gentium i jego średniowiecznych zastosowań. Absolutyzm to także czas, w którym prawo międzynarodowe usamodzielniło się jako odrębna gałąź prawa. Wtedy właśnie za sprawą takich pisarzy prawa międzynarodowego jak Alberto Gentilis, oksfordzki profesor prawa cywilnego o włoskich korzeniach, czy Grocjusz, dedykujący swoje „Prawo wojny i pokoju” Ludwikowi XIII, zasady odpowiedzialności międzynarodowej poddane zostały dynamicznej ewolucji. Historyczne okoliczności epoki absolutyzmu, w którym państwo utożsamiane było z suwerenem (,„państwo to ja” Ludwika XIV) przyczyniły się do znaczących zmian w pojmowaniu odpowiedzialności państw, relacji między tworzącymi je społecznościami i rządzącymi suwerenami. Za podstawę odpowiedzialności międzynarodowej uznawana była wina władcy, a także działającego poprzez parlament narodu, lecz inaczej niż w średniowieczu nie mógł być uznany za jej podstawę odosobniony czyn uczestnika danej społeczności czy urzędnika umocowanego do działania przez władcę ${ }^{38}$.

Gentilis uważał prawo rzymskie za przydatne przy identyfikacji reguł międzynarodowego prawa zwyczajowego, zwłaszcza w wąskim ujęciu prawa narodów, opisywanego terminem ius inter gentes, a więc prawa zwyczajowego, określającego reguły interakcji pomiędzy społecznościami ${ }^{39}$. W „Trzech księgach o prawie wojny" przedstawia własne, świeckie i uniwersalne, ujęcie rzym-

\footnotetext{
${ }^{37}$ J. A. Hessbruegge, op.cit., s. 281.

${ }^{38}$ D. R. Coquillette, The civilian writers of Doctors' Commons, London: three centuries of juristic innovation in comparative, commercial, and international law, Berlin 1988, s. 65.

${ }^{39}$ Ibidem, s. 64.
} 
skiego ius gentium, oparte o badania praktyki międzynarodowej, nie zaś o rozważania dogmatyczne czy odwołania do prawa religijnego ${ }^{40}$. Pojmował on prawo narodów jako „przedmiot konsensusu wszystkich nacji” (maior pars orbis), sprowadzając zadanie nauki prawa międzynarodowego publicznego do pragmatycznej analizy praktyki państw ${ }^{41}$. Odwoływał się przy tym do pojęcia wspólnego dziedzictwa ludzkości (non unius est reipublicae sed omnium) ${ }^{42}$, opierając rozumienie prawa narodów o pojęcie przyrodzonego rozsądku oraz o słuszność znaną w stosunkach handlowych (aeqiutas mercatoria) ${ }^{43}$. W kontekście tych rozważań Gentilis poddawał analizie koncepcję wojny sprawiedliwej. Poszerzał znaną rzymskiemu ius gentium koncepcję odpowiedzialności zbiorowej o elementy nowatorskie, jak np. podział powodów wszczęcia wojny sprawiedliwej na „naturalne” i „ludzkie" ${ }^{4}$. W ramach pierwszej kategorii wskazywał okoliczności, w których uprawnienie wynikające z prawa natury zostało ograniczone lub odebrane, jak prawo kupców do uczestniczenia w handlu. W sytuacji ograniczenia prawa wynikającego z natury uzasadnione było, jego zdaniem, rozpoczęcie działań wojennych, wojna zaś była „sprawiedliwa”. Jako „ludzkie” powody wojny sprawiedliwej Gentilli wskazywał naruszenia prawa stanowionego, takie jak np. uchybienie wyjątkowemu statusowi przedstawicieli dyplomatycznych ${ }^{45}$. Naruszenia te, aby stały się podstawą odpowiedzialności państwa, musiały zostać dokonane przez stojącego na czele państwa władcę, nie np. przez jego pełnomocników, urzędników państwowych czy organy tworzące prawo tego państwa $^{46}$. Argumentował, że państwo może ponieść odpowiedzialność jedynie za akt, którego „treść rozważyło na forum reprezentującego je zgromadzenia”,47. Jako wytłumaczenie tej koncepcji można przywołać wspomnianą już specyfikę polityczną monarchii absolutnej - władza państwowa skupiona w ręku monarchy oznaczała odpowiedzialność państwa powiązaną ściśle z jego kompetencjami. Uznał więc Gentilis za fakt notoryjny brak odpowiedzialności całego społeczeństwa za czyny należących do niego jednostek, odżegnując się od starożytnej reguły odpowiedzialności zbiorowej. Jednocześnie formułował tezę o uznaniu „winy i odpowiedzialności” państwa, „które wie, jako że zostało ostrzeżone,

${ }^{40}$ Por.: ibid., s. 65 ; M. Lachs, op. cit., s. 62.

${ }^{41}$ Por.: T. E. Holland, An inaugural lecture on Albericus Gentilis, delivered at All Souls college, November 7, 1874, Londyn 1847, s. 34.

${ }_{42}$ T. Holland, op.cit., s. 33. Odwołanie to czyni przy okazji omawiania „filozofii wojny”, wskazując, iż jej uzasadnienie wywodzić można $\mathrm{z}$ tak własnie pojmowanego prawa międzynarodowego.

${ }^{43}$ Choć Gentilis nie uwzględnia samych relacji handlowych jako przedmiotu prawa międzynarodowego, nazywając je ,jakby” przedmiotem prawa narodów. Por.: D. R. Coquillette, op.cit., s. 64.

${ }^{44}$ A. Gentilis, De Jure Belli Libri Tres, Clarendon 1933, s. 86-98, podaję za: J. A. Hessbruegge, op.cit., 281.

${ }^{45}$ D. R. Coquillette, op.cit., s. 65-66.

${ }^{46}$ Będąc specjalistą prawa konstytucyjnego, jako organy państwa wskazywał Gentilis parlamenty, ale nie sądy. Por.: A. Gentilis, De Jure Belli Libri Tres, Clarendon 1933, s. 103; podaję za: J. A. Hessbruegge, op.cit., 281.

${ }^{47}$ J. A. Hessbruegge, op.cit., s. 281-282. 
i które powinno zapobiec naruszeniom dokonywanym przez swoich obywateli, bowiem działając $\mathrm{w}$ granicach własnej jurysdykcji może im zapobiec" ${ }^{, 4}$. W konsekwencji uznał, że powodem wszczęcia wojny sprawiedliwej być mógł ,grzech zaniechania" - sytuacja, w której ,jednostka dopuściła się naruszenia, zaś suweren czy naród nie dopełniły obowiązku jego zadośćuczynienia" ${ }^{\text {"4 }}$. Skutkiem tych rozważań był opisany w treści „Trzech ksiąg...” obowiązek ukarania albo wydania sprawcy. Jego niedopełnienie było uzasadnionym powodem wypowiedzenia wojny społeczności, która nie wymierzyła sprawiedliwości temu sprawcy. Gentilis uzupełnił więc teorię odpowiedzialności międzynarodowej o element opisywany współcześnie terminem łacińskim, choć nie zapożyczonym od piszącego łacina prekursora: aut dedere aut iudicare ${ }^{50}$.

Koncepcja odpowiedzialności zbiorowej nie znalazła odzwierciedlenia także w pracach Grocjusza, podążającego śladami Gentilisa. Według niego, odpowiedzialność w prawie międzynarodowym pojmowana być winna węziej jeszcze niż w ujęciu Gentilisa i oznaczać jedynie odpowiedzialność władcy jako osoby fizycznej $^{51}$. Tworząc zręby nauki prawa międzynarodowego, Grocjusz dokonał podziału na dwa rodzaje czynów, które mogły stać się podstawą odpowiedzialności odszkodowawczej państwa. Pierwsza z tych kategorii dotyczyła odpowiedzialności cywilnej. Opisując ją, Grocjusz opierał się na znanych sobie instytucjach prawa prywatnego, gdzie odpowiedzialność powiązana była zawsze z działaniem jednostki. Drugi rodzaj odpowiedzialności przypominał dzisiejszą odpowiedzialność karną $\mathrm{i}$ to te jego rozważania cieszą się większą popularnością wśród współczesnych pisarzy prawa międzynarodowego, choć wydawać by się mogło, że w mniejszym stopniu odzwierciedlaja jego specyfikę ${ }^{52}$. Sam Grocjusz, opisując zasady odpowiedzialności państwa, odwoływał się do reguł wspólnych obu wyróżnionym kategoriom, przy czym niezbędne było wykazanie udziału jednostki w powstaniu szkody, aby móc przypisać jej odpowiedzialność ${ }^{53}$. Bez wykazania winy władcy, skutkującej działaniami podwładnych, suweren stojący

${ }^{48}$ J. A. Hessbruegge, op.cit., 281-282. Jak pisał: „ten, kto wie o szkodzie wolny jest od winy za nią jedynie, jeśli nie był w stanie jej zapobiec. Tak więc państwo, które wie, bowiem zostało ostrzeżone, i które powinno zapobiec wykroczeniom swoich obywateli i korzystając z przysługujących mu uprawnień może im zapobiec, ponosić będzie winę i odpowiadać będzie za przestępstwo jeśli tego nie uczyni"; podaję za: J. A. Hessbruegge, op.cit., 281. Por.: także: F. F. Martin, op.cit., s. 72; J. B. Scott, Law, the State, and the International Community, Nowy Jork 2002, s. 193.

${ }^{49}$ J. A. Hessbruegge, op.cit., s. 282.

${ }^{50}$ Por.: Ibidem. Sam Gentilis nie formułował reguły wymierzenia sprawcy sprawiedliwości albo wydania go poszkodowanemu celem jej wymierzenia, pisząc iż Rzymianie zostaną zaspokojeni dokonanym czynem, czy będzie on karą czy uwolnieniem sprawcy, pozwalającym mu dokonać w przyszłości innych szkód, dających początek wojnie.

${ }^{51}$ Por.: J. Crawford, A. Pellet, S. Olleson, K. Parlett, The Law of International Responsibility, Oksford 2010, s. 258.

${ }^{52}$ Ibidem.

${ }^{53}$ H. Grocjusz, Trzy księgi o prawie wojny i pokoju, thum. R.; Bierzanek, Warszawa 1957, tom II, s. 8, gdzie wymienia jako podstawy odpowiedzialności: umowę, przestępstwo i przepis prawny. Por.: J. Crawford, A. Pellet, S. Olleson, K. Parlett, op.cit., s. 258. 
na czele państwa nie mógł ponosić odpowiedzialności międzynarodowej, co najwyżej podlegać prawu wewnętrznemu. Argumentował, że królowie nie mogą ponosić odpowiedzialności za swoich żołnierzy czy marynarzy, którzy wyrządzili szkodę sojusznikom wbrew otrzymanym rozkazom ${ }^{54}$. Przenosząc ową zasadę na grunt odpowiedzialności państw wskazywał, iż społeczność państwa nie ponosi odpowiedzialności na podstawie czynów jednostek, ale na podstawie własnego czynu lub zaniedbania ${ }^{55}$. Co więcej, żadna społeczność ani upoważniony przez nią organ nie ponoszą odpowiedzialności za szkodliwe działania jednostek, jeśli im nie pomagały lub nie były niedbałe przy zapobieganiu ich skutkom. Przywołując prawo rodyjskie wskazywał, że nie istnieje państwo, które nie musi radzić sobie z nieposłusznymi podwładnymi: tak jak ojciec nie odpowiada za działania swoich dzieci, a pan swoich sług, tak władca nie odpowiada za czyny jego podwładnych ${ }^{56}$. Domniemanie braku odpowiedzialności obalone więc może zostać poprzez wykazanie udziału państwa w powstaniu szkody niezależnie, czy będzie to udział czynny czy bierny, tj. poprzez zaniechanie. Grocjusz wyróżniał tym samym ,aktywną” współodpowiedzialność za czyny, w których państwo przyczynia się swoim działaniem do powstania naruszenia oraz „pasywną” współodpowiedzialność za jego zaniechania, kiedy to wykazuje niedbalstwo przy zapobieganiu takim naruszeniom ${ }^{57}$. Niedbalstwo może mieć postać tolerowania (patientia) albo udzielania przestępcy schronienia (receptus), tj. zaniechania ukarania albo wydania sprawcy, pomimo wiedzy o jego $\mathrm{czynach}^{58}$. Przyjmując fikcję prawną współsprawstwa dowodził, że władca może zostać uznany współwinnym szkody wywołanej przez podwładnego (obywatela), jeśli wie o takim naruszeniu, ale wbrew powinności mu nie zapobiegnie

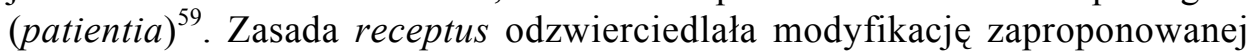
przez Gentilisa idei odpowiedzialności suwerena za brak postawienia sprawcy przed własnym sądem albo jego wydania, nazywanej później zasadą aut dedere aut iudicare. Zaniechanie państwa utożsamiał Grocjusz z jego winą, postrzegana jako niezależna od czynu osoby prywatnej. Odnosząc się do odpowiedzialności za zaniechanie potwierdzał odpowiedzialność królów i urzędników, którzy nie stosowali ,środków zaradczych” przeciwko rozbojom i piractwu, jakie mogli i powinni byli stosować ${ }^{60}$. Jego zdaniem ,wyrządza szkodę bezpośrednio ten, kto będąc prawnie zobowiązanym do zapobiegania wyrządzeniu szkody w drodze odpowiedniego nakazu albo przyjścia z pomocą" tego nie czyni ${ }^{61}$. Poszerzając

\footnotetext{
${ }^{54}$ H. Grocjusz, op.cit., s. 18.

${ }^{55}$ Ibidem, s. 113.

${ }^{56}$ Ibid., s.115-116; tak samo: J. Crawford, A. Pellet, S. Olleson, K. Parlett, op.cit., s. 258.

${ }^{57}$ H. Grocjusz, op.cit., s.113-114.

${ }^{58}$ Ibidem, s. 114. Por. : J. Crawford, A. Pellet, S. Olleson, K. Parlett, op.cit., s. 259; E. J. de Arechaga, International Law in the Part Third of a Century, RdC 1978, tom I, nr 159, s. 283-284; H. Mosler, The International Society As a Legal Community, Alphen aan der Rijn 1980, s. 163.

${ }^{59}$ H. Grocjusz, op.cit., s. 114.

${ }^{60}$ Ibidem, s. 17.

${ }^{61}$ Por. ibid., s. 11.
} 
koncepcję Gentilisa wskazywał na odpowiedzialność suwerena za udzielenie ochrony obywatelowi będącemu sprawcą szkody obcego państwa analogiczną do odpowiedzialności za ochronę każdego innego uciekiniera lub ukrywającego się na jego terytorium przed wymiarem sprawiedliwości, niezależnie od narodowości i miejsca popełnienia tego czynu ${ }^{62}$. Grocjusz wprowadził podział na „sprawiedliwość dopełniającą" i „sprawiedliwość atrybutywną”, stanowiący nieco zmodyfikowaną wersję arystotelejskiego podziału na sprawiedliwość wymienną i rozdzielczą. „Sprawiedliwość dopełniająca” obejmuje artysotelejską sprawiedliwość wymienną, dotycząca jedynie „,praw doskonałych”, tj. praw wykonalnych i egzekwowalnych ${ }^{63}$.

Myśl Grocjusza i Gentilisa znajduje odzwierciedlenie w pracach licznych autorów kolejnego pokolenia ${ }^{64}$. Zouch, następca Gentilisa w Oksfordzie, utożsamia odpowiedzialność międzynarodową z odpowiedzialnością suwerena ${ }^{65}$. Jak Grocjusz uznaje, że odpowiedzialność władcy zależeć będzie od jego ewentualnej winy, skutkującej naruszeniem prawa przez jego podwładnych. Bez możliwości wykazania takiej winy władcy odpowiedzialność międzynarodowa państwa nie może zostać skutecznie przywołana ${ }^{66}$. Autor ten idzie jednak dalej niż swój mistrz w ograniczaniu kręgu działań, ze które państwo ponosi odpowiedzialność. Nie przyjmuje bowiem grocjańskiej koncepcji receptus, nie uznaje faktu przebywania na terytorium państwa sprawców czynów popełnionych za granicą za tożsame $\mathrm{z}$ winą władcy, a obowiązek ekstradycji wynikać mógł jego zdaniem jedynie $\mathrm{z}$ treści traktatu ${ }^{67}$. Podobne rozumienie zasady aut dedere aut iudicare widoczne jest $\mathrm{w}$ dzisiejszej literaturze przedmiotu ${ }^{68}$.

\subsection{Oświeceniowe koncepcje odpowiedzialności państw}

Doktryna Grocjusza stała się inspiracją dla Pufendorfa ${ }^{69}$. Za interpretacja Hobbsa, utożsamiał on prawo międzynarodowe z dziedziną etyki i wskazywał prawo natury, wspólne wszystkim ludziom, jako jego treść ${ }^{70}$. Prawo to stosowane

${ }^{62}$ Ibid., s. 115.

${ }^{63}$ Por.: J. Crawford, A. Pellet, S. Olleson, K. Parlett, op.cit., s. 259.

${ }^{64}$ J. A. Hessbruegge, op.cit., s. 284.

${ }^{65}$ R. Zouch, Iuris et iudicii Fecialis, sive, Iuris inter Gentes, et Quaestionum de Eoden Explication, Waszyngton 1911, s. 106-107. Por. M. Lachs, op.cit., s. 67.

${ }^{66}$ R. Zouch, op.cit., s.106: „nie jest częścią prawa narodów odpowiedzialność władcy za czyny jego podwładnych wolne od jego winy".

${ }^{67}$ J. R. Zouch, op.cit., s. 107.

${ }^{68}$ Por. np.: M. Płachta, Zasada aut dedere aut iudicare $w$ dziedzinie międzynarodowej wspótpracy $w$ sprawach karnych, Palestra 2000, nr 7-8, s. 34; Z. Barwina, Zasada wzajemnego uznawania $w$ sprawach karnych, Warszawa 2012, s. 253; M. C. Bassiouni, E. M. Wise, Aut Dedere Aut Judicare: The Duty to Extradite Or Prosecute in International Law, Haga 1995, s. 23-41.

${ }^{69}$ Por. np.: S. Pufendorf, [Elementorum jurisprudentiae universalis libri duo] Two books of the Elements of universal jurisprudence, Indianapolis 2009, s. xii-xiii.

${ }^{70}$ Por.: E. de Vattel, Prawo narodów, Warszawa 1958, s. 37. 
być winno celem regulowania zachowań niezależnych społeczności: państw ${ }^{71}$. On także bez wątpliwości argumentował, że państwo nie może ponosić odpowiedzialności za swoich obywateli, bowiem niosłaby ona za sobą implikacje konieczności ingerencji państwa w swobody obywatelskie. Jak pisał: „niezależnie od tego, jak bardzo państwo egzekwować będzie swoją władzę, obywatelowi zawsze pozostanie wynikająca z prawa natury wolność”, aby wyrządzić szkodę innym państwom lub ich obywatelom. Pufendorf powtarzał także za Grocjuszem jego koncepcje patentia i receptus ${ }^{72}$, choć rozwijając ideę należytej staranności, wprowadził domniemanie winy państwa. Jego zdaniem, państwo może zostać uznane za winne niezapobieżenia szkodzie wyrządzonej przez podmiot prywatny wtedy, gdy nie da się wykazać, że winy takiej nie ponosi ${ }^{73}$. Odpowiedzialność władcy wynikała $\mathrm{z}$ obiektywnego naruszenia nadrzędnych zasad moralnych ${ }^{74}$. Inaczej jednak interpretował należytą staranność współczesny Pufendorfowi Textor, który wskazywał, że suweren winien uiścić odszkodowanie za czyny swoich podwładnych jedynie, jeśli sam zawinił w niezpobieżeniu im, tj. ponosił odpowiedzialność za czyny, którym mógł zapobiec albo na które pozwolił ${ }^{75}$. Ten pomysł stał się inspiracją dla pisarzy prawa międzynarodowego z końca XIX w., którzy wykorzystali go do wzmocnienia teoretycznej konstrukcji przypisania odpowiedzialności państwu, odchodząc od obecnej w teorii Pufendorfa koncepcji winy ${ }^{76}$.

Podsumowując, uznać można iż epoka absolutyzmu przyniosła rewolucję w pojmowaniu międzynarodowej odpowiedzialności państwa. Od odpowiedzialności zbiorowej całych społeczności za szkodliwe czyny ich pojedynczych uczestników, właściwej dla zhierarchizowanych społeczeństw plemiennych, rodząca się nauka prawa międzynarodowego przeszła do bardzo wąsko rozumianej odpowiedzialności państwa utożsamianej $\mathrm{z}$ odpowiedzialnością jego władcy, działającego lub powstrzymującego się od wymaganego prawem międzynarodowym działania albo takich samych działań najwyższych organów władzy prawodawczej. Zważywszy na specyfikę epoki, ta rewolucja jest uzasadniona. Państwo średniowieczne przypominało wspólnotę plemienną, zaś współcześni Gilianiemu czy Pufendorfowi całą władzę nad społecznością złożyli na ręce suwerena ${ }^{77}$. Do utożsamienia państwowości z osobą władcy przyczynił się także porządek westfalski, wprowadzony de facto treścią traktatów pokojowych podpisanych w 1648 r. w Münster i Osnabrück. Po wyniszczającej Europę wojnie trzydziestoletniej, władcy uznali swoją wzajemną równość i niezależność. Praktycznym przełożeniem tej suwerenności była swoboda władcy w sposobie rządzenia podległym mu terytorium. Oto władca zobowiązany został do władania

\footnotetext{
${ }^{71}$ S. Pufendorf, op.cit., s. 7-8.

${ }^{72}$ Ibidem, s. 21.

${ }^{73}$ J. A. Hessbruegge, op.cit., s. 285.

${ }^{74}$ Por.: J. Crawford, A. Pellet, S. Olleson, K. Parlett, op.cit, s. 47.

${ }^{75}$ J. W. Textor, Synopsis of the Law of Nations, Waszyngton 1916, s. 142.

${ }^{76}$ J. A. Hessbruegge, op.cit., s. 285

${ }^{77}$ Por.: J. A. Hessbruegge, op.cit., s. 285.
} 
państwem tak, aby zabezpieczać jego interesy, w imię enigmatycznej „racji stanu", odrębnej od interesów samego władcy czy społeczności zamieszkującej terytorium państwa ${ }^{78}$. Władca winien najlepiej znać jej treść i podjąć wszelkie kroki, by ją chronić. Kardynał Richelieu, posługując się tym terminem po raz pierwszy podczas trwania wojny trzydziestoletniej, wzywał króla Francji do ochrony interesów państwa francuskiego, rozumianych jako odrębne od interesów samego władcy czy kościoła. Król miał chronić tak rozumianą rację stanu poprzez znalezienie kompromisu pomiędzy tym, co nakazuje sumienie, a tym, czego wymaga polityka (fr. l'harmonie des maximes d'État avec celles de conscience $)^{79}$. Ta wyjątkowa rola władcy, utożsamianego z państwem identyfikowanym w oparciu o kryteria terytorialne, nie zaś plemienne czy religijne, przełożona została na zawężenie zakresu międzynarodowej odpowiedzialności państw. Dlatego też Grocjusz uznał winę za konieczną przesłankę odpowiedzialności międzynarodowej - państwo utożsamiane z jego władcą takiej personifikacji łatwo mogło sprostać ${ }^{80}$. Przywołując zasadę qui in culpa non est, natura ad nihil tenetur i wspomnianą już fikcje prawną współsprawstwa państwa w występku swojego obywatela, zwalniał od odpowiedzialności władcę bez winy ${ }^{81}$.

Inaczej przedmiotową kwestię interpretowali jego uczniowie. Wiek XVII przyniósł przełom w pojmowaniu odpowiedzialności międzynarodowej i odejście od odpowiedzialności zbiorowej na rzecz niezależnego postrzegania jednostki. Maine opisał ową ewolucję jako stopniowe osłabienie zależności rodzinnych na rzecz wzrostu znaczenia obowiązków jednostki. Jednostka zastępuje rodzinę jako podmiot prawa cywilnego, a rolę więzi rodzinnych przejmuje umowa społeczna $^{82}$. Zmiana ta nie nastapiła jednak od razu w pełni i pewne zapożyczenia z rzymskiego ius gentium wciąż były widoczne, choćby w pismach Wolffa. Ten urodzony we Wrocławiu, eklektyczny i wpływowy filozof wczesnego Oświecenia, w pracy z 1749 r. pt. Ius Gentium methodo scientifica pertractatum, odniósł się do pytania o zakres odpowiedzialności międzynarodowej państw ${ }^{83}$. Państwo nie powinno zezwalać sobie podległym, tj. nie tylko obywatelom, jak ujmował to Grocjusz, ale także cudzoziemcom, na wyrządzanie szkód innym suwerenom. Jeśli jednak szkoda taka nastąpiła, władca winien nakłonić sprawcę do naprawienia szkody lub ukarać go, choć działanie jednostki nie oznaczało zawsze odpowiedzialności całego państwa. Działanie jednostki przypisane mogło zostać państwu jedynie wówczas, gdy władca potwierdzi je lub uzna za swoje. Wolff pisał o ewentualnej odpowiedzialności „państwa” za „obywatela”" ${ }^{\text {, }}$, raczej niż

\footnotetext{
${ }^{78}$ Por. np.: Z. Wójcik, Historia powszechna XVI-XVII wieku, Warszawa 2001, s. 384-385.

${ }^{79}$ Por. np.: E. Thuau, Raison d'État et Pensée Politique à l'époque de Richelieu, Paryż 1966,

${ }^{80}$ Por.: J. A. Hessbruegge, op.cit., s. 286.

${ }^{81}$ Por.: H. Grocjusz, op.cit., s. 116-117.

${ }^{82}$ Por.: H. S. Maine, op.cit., s. 169.

${ }^{83}$ Ch. J. Wolff, Ius gentium methodo scientifica pertractatum, Buffalo, Nowy Jork 1995.

${ }^{84}$ Por. np.: ibidem, s. $160-162$.
} s. 213. 
„króla” za „podwładnego”85. Tym samym zastapił absolutystyczną koncepcję „współsprawstwa” władcy pierwowzorem współczesnej konstrukcji przypisania $^{86}$. Hessbruegge odnajduje w pracy Wolffa pierwowzór rozumowania MTS, wyrażonego $\mathrm{w}$ treści decyzji w sprawie zakładników amerykańskich w Teheranie. Filozof omówił przypisanie państwu tych czynów jednostek, które zostaną post factum przez państwo uznane ${ }^{87}$. Postuluje także przypisanie odpowiedzialności państwom za podmioty działające $\mathrm{z}$ ich polecenia albo na ich rozkaz ${ }^{88}$.

Rozważania Grocjusza, posiłkując się wnioskami Wollfa i Leibnitza, kontynuował de Vattel, choć jak pisał w przedmowie do tłumaczenia jego dzieła Winiarski, „zasadnicze koncepcje Vattela nie są jego własnością" ${ }^{89}$. W swoim „Prawie narodów” z 1758 r. definiuje tytułowe pojęcie jako „naukę o prawie, które wiąże wzajemnie narody, czyli państwa”, gdzie narody to „związki polityczne, społeczności ludzi złączonych razem celem zapewnienia sobie bezpieczeństwa i innych korzyści wspólnymi siłami" "90. Jednocześnie de Vattel, przytaczając idee swego mistrza Grocjusza, pozostaje pod wpływem rzymskiej doktryny ius gentium, odwołując się w opisie źródeł prawa międzynarodowego do prawa natury, które jest „prawem naturalnym w zastosowaniu do narodów" Opisując należytą staranność, Vatell powtarza, że „naród czy monarcha nie powinien dopuścić, by obywatele popełniali bezprawia względem poddanych innego państwa, a tym bardziej obrażali samo państwo"92. Przypisuje jednocześnie współodpowiedzialność władcy pozwalającemu wyrządzać krzywdę obcemu narodowi lub jego członkom za tak powstałe szkody. Powtarzając grocjańską zasadę patientia, zakazuje władcy tolerowania samowoli poddanych względem innych narodów, nakładając na niego obowiązek aktywnego przeciwdziałania takim szkodliwym zachowaniom. Nie każde więc zachowanie jednostki niosło jego zdaniem za sobą odpowiedzialność państwa jej obywatelstwa czy zamieszkania, bowiem „kiedy (...) jeden z członków narodu popełnił wobec nas bezprawie, nie można powiedzieć ogólnie, że popełnił je naród"93. Powtarza także formułowaną przez poprzedników ideę zasady aut dedere aut iudicare, nie upatrując jednak jej jedynej podstawy w traktacie, raczej w „węzłach przyjaźni i dobrego sąsiedztwa" ${ }^{4}$. Opierając się na tak sformułowanej, szerokiej, podstawie międzynarodowej współpracy, proponuje jeszcze jedną, nieopisaną wcześniej w doktrynie, podstawę odpowiedzialności międzynarodowej, wynikającą de

${ }^{85}$ Choć i tej terminologii używa; por. np.: ibid., s. 161-162.

${ }^{86}$ Por.: J. A. Hessbruegge, op.cit., s. 289.

${ }^{87}$ Ibidem, s. 289. Por.: Ch. J. Wolff, op.cit., § 314, s. 160. Sprawa zakładników w Teheranie została omówiona w rozdz. III.

${ }^{88}$ Por.: Ch. J. Wolff, op.cit., § 315, s. 160.

${ }^{89}$ E. de Vattel, op.cit., s. XVII.

${ }^{90}$ Ibidem, s. 53.

${ }^{91}$ Ibid., par. 74, s. 55.

92 Ibid., par. 72 , s. 369

${ }^{93}$ Ibid., par. 73, s. 369-70.

${ }^{94}$ Ibid., par. 75-6, s. 370. 
facto z niedołożenia przez suwerena należytej staranności (choć nie używa tego terminu). Jeśli wskutek trwałej praktyki władcy mieszkańcy uczynią sobie zwyczaj z łupienia cudzoziemców i napadania państw ościennych, ponosił on będzie odpowiedzialność za ich przewinienia ${ }^{95}$. De Vattel formułuje tezę o prawie do zbiorowej samoobrony przeciwko takim atakom, argumentując, że „wszystkie narody mają prawo połączyć się przeciwko niemu, unieszkodliwić go, postapić z nim tak, jak ze wspólnym nieprzyjacielem rodzaju ludzkiego" ${ }^{96}$. Ponad 240 lat później analogiczną konstrukcję zawarła KPM w Projekcie artykułów o odpowiedzialności państw z $2001 \mathrm{r}^{97}$ Bilateralna koncepcja de Vattela oparta była o zasadę pacta sunt servanda. Dowodził on, iż podstawą odpowiedzialności może być jedynie naruszenie wzajemnego zobowiązania między państwami, nie zaś np. interesów ogólnie rozumianej społeczności międzynarodowej ${ }^{98}$. Takie podejście zostało przyjęte przez większość współczesnych mu dogmatyków prawa międzynarodowego.

Choć koncepcje Wolffa i de Vattela były przełomowe, nie oderwały prawa międzynarodowego od pierwotnej idei plemiennej odpowiedzialności zbiorowej. De Vattel przypisywał monarsze odpowiedzialność za niektóre czyny obywateli państwa, na czele którego stał. Wolff ograniczał tą odpowiedzialność monarchy wyłącznie do czynów obywateli państwa, nie zaś wszystkich jego mieszkańców ${ }^{99}$.

W XIX w. Phillimore przywołał grocjański podział na receptus i patientia oraz cytował za Burlemaquim przypadki tolerowania (ang. sufferance) i uznania (ang. reception) szkodliwego czynu jako podstawy odpowiedzialności suwerena za działania osób prywatnych ${ }^{100}$. Słusznym powodem wypowiedzenia mu wojny była więc sytuacja, w której suweren wiedział o występkach swoich podwładnych i - mając obowiązek i sposobność - nie zapobiegł im, godząc się na bezprawne działanie, popełnienie którego dopuszczał ${ }^{101}$. Tak rozumiany obowiązek poszanowania suwerenności innych państw Phillimore uzupełnił domniemaniem odpowiedzialności władcy, którego podwładny dopuścił się występku, przenosząc na suwerena ciężar dowodu dołożenia należytej staranności przy zapobieganiu szkodzie ${ }^{102}$. Podobną tezę odnaleźć można także we wcześniejszych pra-

${ }^{95}$ Ibid., par. 78 , s. 372-3.

${ }^{96}$ Ibid., par. 78 , s. 372

${ }^{97}$ Por.: rozdz. III; Projekt artykułów o odpowiedzialności państw z 2001 r., art. 9, s. 49, dotyczący odpowiedzialności państwa za działania realizowane pod nieobecność lub wobec bezczynności jego organów.

${ }^{98}$ Por.: G. Nolte, From Dionisio Anzilotti to Roberto Ago: The Classical International Law of State Responsibility and the Traditional Primacy of a of a Bilateral Conception of Inter-state Relations, European Journal of International Law 2002, nr 13(5), s. 1085.

${ }^{99}$ Por.: Ch. J. Wolff, op.cit., § 317, s. 161.

${ }^{100}$ Por. J. J. Burlamaqui, Burlemaqui's principles of natural law, Londyn 1763, s. 255.

${ }^{101}$ R. Phillimore, Commentaries upon international law, tom I, Londyn 1871, s. 258.

${ }^{102}$ Ibidem, s. 258, gdzie cytowany autor pisze: ,przyjmuje się (ang. it is presumed), że suweren wie, jakiego rodzaju występków dopuszczają się zazwyczaj jego podwładni oraz zna swoje możliwości zapobiegania im, o ile sytuacja przeciwna nie została sbez wątpliwości udowodniona”. 
cach de Vattela ${ }^{103}$. Phillimore różnicował jednak odpowiedzialność suwerena za pojedyncze akty indywidualne i działania licznych grup podwładnych, zwłaszcza jeśli te zdobyły dostęp do broni ${ }^{104}$.

$\mathrm{Z}$ tak rozumianą koncepcją odpowiedzialności międzynarodowej zgadzał się współczesny Phillimore'owi Hall, pisząc, iż państwo ,jest oczywiście odpowiedzialne za działania i zaniechania mające miejsce w jego terytorium, skutkiem których inne państwo lub jego obywatele (ang. subjects) ponoszą szkodę"105. Odpowiedzialność ponosiło ono jednak jedynie wtedy, gdy nie zapobiegło, nie spenalizowało lub nie ukarało szkodliwych działań jednostek na swoim terytorium. Hall wskazał tu po raz pierwszy na łącznik terytorialny jako kluczowy dla ustalenia zakresu odpowiedzialności suwerena. Jednocześnie więź państwa z osobami jedynie zamieszkującymi jego terytorium była bez porównania mniej ścisła niż z jego urzędnikami, co skutkowało innym charakterem odpowiedzialności państwa za działania tych pierwszych. Obowiązkiem państwa względem działań osób prywatnych była więc jedynie ich ogólna kontrola, sprawowana jednocześnie nad wszystkimi zdarzeniami na terytorium państwa. Kontrola taka stanowiła część wypełniania funkcji władczych. Państwo ponosi więc odpowiedzialność jedynie za takie działania osób prywatnych, co do których można racjonalnie zakładać, że o nich wiedziało i mogło im zapobiec ${ }^{106}$. Hall jako pierwszy, przywołał w tym kontekście termin „staranność” (ang. diligence) dla opisania kryterium owego racjonalnego założenia ${ }^{107}$. Państwo mogło więc zwolnić się od odpowiedzialności, jeśli wykazało, że mimo iż nie zapobiegło szkodliwemu działaniu realizowanemu na jego terytorium, spełniło jedną z trzech przesłanek. Mogło więc dowodzić, że pozostawało w uzasadnionym okolicznościami błędnym przekonaniu, powodującym niepodejmowanie działań zmierzających do zapobieżenia szkodzie. Jeśli jednak państwo podjęło działania zmierzające do zapobieżenia szkodzie, a mimo tego jej nie zapobiegło, winno wykazać, że szkodzie nie można było zapobiec mimo wykazania ostrożności (ang. watchfulness) proporcjonalnej do znanej natury szkodliwych okoliczności lub przy wykorzystaniu środków mu dostępnych. Jeśli nie było w stanie przywołać dwóch powyższych okoliczności, państwo chcące zwolnić się z odpowiedzialności powinno było wykazać, że szkoda wynikająca $z$ danych działań lub zaniechań była przypadkowa albo niezależna od jakiegokolwiek czynu podejmowanego na jego terytorium, któremu mogło było zapobiec ${ }^{108}$. Ocena racjonalności działania państwa dokonywana winna być $\mathrm{w}$ oparciu o stan wiedzy sprzed powstania szkody, nie zaś po jej powstaniu ${ }^{109}$. Według Halla, jedyną miarą staranności

\footnotetext{
${ }^{103}$ Por.: E. de Vattel, op.cit., s. 369-70.

${ }^{104}$ R. Phillimore, op.cit., s. 259.

${ }^{105}$ W. E. Hall, A Treatise on International Law, Oksford 1895, par. 65, s. 226.

${ }^{106}$ Ibidem, s. 227.

107 Ibid., s. 229.

${ }^{108}$ Ibid., s. 226.

${ }^{109}$ Ibid., s. 229. Jak pisze, niezapobieżenie ucieczce internowanego oficera może doprowadzić do upadku imperium.
} 
w danej sytuacji winna więc być ta wynikająca z samych okoliczności sprawy, nie zaś oceniana względem jej konsekwencji. Hall identyfikuje poziom należytej staranności według standardów wewnętrznych państwa mającego ponosić ewentualną odpowiedzialność. Jeśli państwo poświęciło danej sprawie tyle uwagi, ile wydaje się odpowiednie w danych okolicznościach średnio inteligentnemu człowiekowi, to dopełniło swoich obowiązków i nie mogło być pociagnięte do odpowiedzialności ${ }^{110}$. Formułując treść pierwowzoru należytej staranności jako kryterium oceny wypełnienia przez państwo jego międzynarodowych zobowiązań, Hall pisał o obowiązku wprowadzenia przez państwo takich regulacji i takiej ich egzekucji, aby uznać można było to państwo za „dobrze zorganizowane na umiarkowanym poziomie" ${ }^{111}$. Sposoby osiagnięcia tego skutku pozostają w swobodnej dyspozycji państwa ${ }^{112}$, lecz nie może ono skutecznie bronić się przed odpowiedzialnością międzynarodową, deklarując anarchię jako świadomie wybrany porządek wewnętrzny ${ }^{113}$.

\subsection{Odpowiedzialność pośrednia (zastępcza) państwa według Oppenheima}

Oppenheim, XX-wieczny niemiecki internacjonalista, uznawany za ojca współczesnej myśli prawa międzynarodowego potwierdzał, że ,przestępstwem międzynarodowym” (ang. international delinquency), za które państwa ponosić winny odpowiedzialność, jest jakakolwiek szkoda wyrządzona innemu państwu poprzez naruszenie zobowiązania międzynarodowego wskutek działania głowy państwa lub członków jego rządu ${ }^{114}$. Opisując zagadnienie odpowiedzialności państwa za działania jednostek niepełniących funkcji państwowych i niedziałających na polecenie lub z upoważnienia rządu, zaproponował nowatorski podział na odpowiedzialność pierwotną (ang. original) i zastępczą (ang. vicarious) państwa $^{115}$.

Pierwotna odpowiedzialność państwa wynikała z niedopełnienia międzynarodowo prawnego obowiązku zapobiegania, w granicach własnych możliwości, szkodom wyrządzanym innym państwom przez obywateli i mieszkańców terytorium $^{116}$. Państwo, które celowo (ang. intentionally), w złej wierze (ang. malicious) albo choćby w świadomej nieumyślności (dosł. wskutek zawinionego niedbalstwa, ang. culpable negligence) nie dopełniło rzeczonego obowiązku,

\footnotetext{
${ }^{110}$ Ibid., s. 229.

111 Ibid., s. 230.

112 Ibid., s. $230-231$.

${ }^{113}$ Ibid., s. 230-231.

${ }^{114}$ L. Oppenheim, International law: a treatise, tom 1, Londyn-Nowy Jork-Bombaj-Kalkuta-Madras 1920, § 151, s. 245.

${ }^{115}$ Ibidem, § 164, s. 258. Por. też: I. Brownlie, System..., s. 36, gdzie autor poddaje koncepcję Oppenheima zdecydowanej krytyce, nazywając ją „oczywiście błędną”.

${ }^{116}$ L. Oppenheim, op.cit., § 164, s. 258.
} 
ponosiło pierwotną odpowiedzialność za swoje działanie albo zaniechanie ${ }^{117}$. Skoro jednak zapobieganie wszelkim szkodliwym działaniom na własnym terytorium jest niemożliwe, Oppenheim sugerował, że także jeśli państwo nie wykazało złej woli czy choćby braku staranności przy zapobieganiu szkodliwym czynom, zaś szkoda w interesach lub dobrach innego suwerena powstała, winno ono ponosić odpowiedzialność nazywaną przez cytowanego autora pośrednią. Odpowiedzialność pośrednia przywołana mogła być wtedy, gdy państwo nie było w stanie zapobiec powstaniu szkody ${ }^{118}$. Państwa odpowiedzialne były więc pośrednio także za działania inne niż własne, takie jak działania swoich przedstawicieli (ang. agents) wykraczające poza zakres otrzymanego upoważnienia lub mandatu, obywateli (ang. subjects), a nawet obcokrajowców (ang. aliens), przebywających $w$ ich granicach ${ }^{119}$. Oppenheim dowodził, że państwo ponosi odpowiedzialność za wybiegające poza zakres upoważnienia działania wojska czy administracji, bowiem zobowiązane jest sprawować nad nimi „dyscyplinarna kontrolę" ${ }^{120}$. Państwo zobowiązane było więc przede wszystkim zdystansować się od takich działań poprzez stosowną deklarację i je potępić, przekazując wyrazy ubolewania lub ,nawet” przeprosiny poszkodowanym. Spoczywa na nim także obowiązek kompensacji powstałych strat oraz należytego, tj. zależnego od okoliczności sprawy, ukarania sprawców ${ }^{121}$.

Tak szerokie ujęcie bezpośredniej odpowiedzialności państwa Oppenheim tłumaczył brakiem bezpośredniej skuteczności prawa międzynarodowego względem jednostek. Jedynie bowiem państwa mogły skutecznie zobligować jednostki do przestrzegania dyspozycji prawa narodów. Dlatego też w systemie prawa międzynarodowego musiała istnieć norma zobowiązująca państwa do wykonywania swojej władzy wobec podległych im osób i skutecznego przekładania ustaleń międzynarodowych na przepisy prawa krajowego oraz praktykę ich stosowania na terytorium państwa. Egzemplifikując wprowadzony podział, Oppenheim pisał, że tak jak za czyny rządu czy osób przez niego upoważnionych lub działających na jego zlecenie, państwo ponosić powinno pierwotną odpowiedzialność za szkodliwe dla innych państw działania jednostek pozostających na jego terytorium. Reguła ta dotyczyła zarówno obywateli, jak i cudzoziemców, jeśli umyślnie lub wskutek ,zawinionego niedbalstwa”, w granicach swoich możliwości (ang. as far as possible) państwo nie starało się zapobiec szkodom przez nich powodowanym ${ }^{122}$. Autorską koncepcją Oppenheima była kategoria odpowiedzialności zastępczej, uzupełniająca odpowiedzialność pierwotną jako substytut grocjańskich patientia i receptus. Wskazywał ogólny, ciążący na państwie obowiązek „zmuszenia sądów” nadmiernie lub niezasadnie opóźniających wykonywanie wymiaru sprawiedliwości, odmawiających go czy

\footnotetext{
${ }^{117}$ Ibidem, § 164, s. 258.

${ }^{118}$ Ibid., s. 258-259.

119 Ibid., s. 244.

${ }^{120}$ Ibid., s. 251-252.

${ }^{121}$ Ibid., s. 255.

${ }^{122}$ Ibid., s. 244-245.
} 
też „w sposób oczywisty i umyślny niewłaściwie stosujących prawo”, wywołujących szkodę innego państwa do właściwego pełnienia swojej funkcji ${ }^{123}$. O ile jednak odpowiedzialność pośrednia państwa za działania jego organów administracyjnych i wojska była nieograniczona, o tyle odpowiedzialność pośrednia za działania osób prywatnych była jego zdaniem „względna” (ang. relative). Jedynym obowiązkiem państwa wobec tych osób było bowiem wykazanie należytej staranności w zapobieganiu wyrządzanym przez nie szkodom w interesach innych suwerenów. Jeśli jednak taki szkodliwy czyn został przez osobę prywatną popełniony, zadanie państwa ograniczone było do przekazania odszkodowania i satysfakcji poszkodowanemu. Obowiązkowi temu państwo winno uczynić zadość w granicach swoich możliwości, poprzez ukaranie sprawców i zobowiązanie ich do uiszczenia stosowego odszkodowania. Odpowiedzialność państwa za działania osób prywatnych nie sięgała dalej. Nie ciążył na nim obowiązek samodzielnego wynagradzania powstałych szkód, nawet jeśli sprawcy sami nie byli w stanie ich pokryć. Jedynie w sytuacji, w której państwo nie wykazało należytej staranności, czy to w zapobieganiu szkodom, czy ukaraniu sprawców, mogło samo zostać obciążone obowiązkiem uiszczenia odszkodowania ${ }^{124}$. Współczesna krytyka koncepcji odpowiedzialności pośredniej omówiona została w dalszej części opracowania ${ }^{125}$.

\subsection{Odpowiedzialność obiektywna według Anzilottiego}

Anzillotti zawęził zakres odpowiedzialności państwa do zachowań niezgodnych z prawem międzynarodowym ${ }^{126}$. Nieświadomie nadał $\mathrm{w}$ ten sposób kierunek pracom XX-wiecznej Komisji Prawa Międzynarodowego, bowiem zweryfikowana doktryna Anzilottiego stała się podstawą koncepcji Ago, pierwszego Specjalnego Sprawozdawcy grupy roboczej badającej kwestię odpowiedzialności międzynarodowej państw z ramienia Komisji ${ }^{127}$. Anzillotti wskazywał, że państwo ponosić powinno odpowiedzialność tylko wtedy, gdy przypisany mu czyn był sprzeczny $\mathrm{z}$ istniejącą normą prawa międzynarodowego ${ }^{128}$, a normy te pojmował pozytywistycznie, widząc ich źródło w zasadzie pacta sunt servanda ${ }^{129}$. Według niego, naruszenie normy prawa międzynarodowego dawało podstawy jedynie do roszczeń reparacyjnych, bowiem tylko te wynikały z treści reguł od-

${ }^{123}$ Ibid., s. 253-254.

${ }^{124}$ Ibid., s. 259.

${ }^{125}$ Por. rozdz. IV.

${ }^{126}$ Por.: D. Anzilotti, op.cit., s. 360. Por. też: P. M. Dupuy, Dionisio Anzillotti and the Law of International Responsibility of States, European Journal of International Law 1992, nr 3, s. 139-148.

${ }^{127}$ Por.: P. M. Dupuy, op.cit., s. 139-148. Zob. też: rozdz. III, gdzie opisano ewolucje prac KPM nad odpowiedzialnością państw w kontekście kształtowania się zasady należytej staranności.

${ }^{128}$ Por.: D. Anzilotti, op.cit., s. 360, 365-366. Por. też: G. Nolte, op.cit., s. 1087. M. Lachs, Rzecz o nauce prawa międzynarodowego, Wrocław 1986, s. 120.

${ }^{129}$ Por. M. Lachs, op.cit., s. 120-121. 
powiedzialności państwa ${ }^{130}$. Zdaniem Lachsa, podejście Anzilottiego uznać można za wczesną próbę wyróżnienia odpowiedzialności obiektywnej w prawie międzynarodowym ${ }^{131}$. Roszczenia te odróżniał od środków odwetowych czy podstaw do zbrojnej interwencji ${ }^{132}$. Do sekwencji przesłanek międzynarodowej odpowiedzialności Anzillotti dodawał naruszenie żywotnych interesów innego państwa, wykluczając jako jej podstawę naruszenie o charakterze ogólnym czy dotyczące jedynie niektórych, szczególnych interesów. Jedynie naruszenie międzynarodowej normy uznane mogło zostać za podstawę użycia siły przez poszkodowanego $^{133}$.

Naruszenia prawa międzynarodowego, stanowiącego podstawę odpowiedzialności, państwo dopuścić się mogło zarówno poprzez działania, jak i zaniechania jego organów. Ocena takiego naruszenia dokonywana być powinna jedynie $\mathrm{w}$ oparciu o treść norm prawa międzynarodowego, nie zaś $\mathrm{w}$ odniesieniu do przepisów wewnętrznych i charakteru organu państwa, którego działanie lub zaniechanie wywołało naruszenie prawa międzynarodowego ${ }^{134}$. Jako przykład zaniechania mogącego stanowić podstawę odpowiedzialności państwa wskazywał odmowę wymiaru sprawiedliwości ${ }^{135}$. Jednocześnie dla uznania odpowiedzialności międzynarodowej państwa nie miało znaczenia nastawienia psychiczne osób pełniących funkcje jego organów. Nie znajdowała tu także zastosowania jakakolwiek teoria winy, czy to w wyborze, czy w nadzorze nad funkcjonariuszami państwa. Podstawą odpowiedzialności był więc fakt naruszenia wiążącego państwo zobowiązania międzynarodowego, czy to przez działanie, czy zaniechanie jego organu. Odpowiedzialność za zaniechanie Anzilotti utożsamiał z dołożeniem należytej staranności w zapobieganiu szkodom innych suwerenów ${ }^{136}$.

Naruszenie prawa międzynarodowego, wywołane przez działania osób prywatnych, wynikać mogło zarówno z działań jednostek czy grup, jak i być efektem „masowej psychozy” czy ruchów społecznych ${ }^{137}$. Nie budziło wątpliwości Anzilottiego zobowiązanie państwa, na terytorium którego miało miejsce szkodliwe działanie lub zaniechanie, względem państwa poszkodowanego. W konsekwencji owego niedopełnienia obowiązku, państwo zobligowane było ukarać sprawców oraz zadośćuczynić państwu poszkodowanemu. Tak rozumiane zobowiązanie utożsamiane było przez Anzilottiego z odpowiedzialnością państwa za działania osób prywatnych. Bez znaczenia dla tak postrzeganej odpowiedzialności państwa był brak bezpośredniej skuteczności norm międzynarodowych

${ }^{130}$ D. Anzilotti, op.cit., s. 366. Por.: M. M. Kenig-Witkowska, która wskazuje, że roszczenie reparacyjne niekiedy uważane jest za zobowiązanie wynikające z zasad odpowiedzialności cywilnej. M. M. Kenig-Witkowska, op.cit., s. 140.

${ }^{131}$ Por. M. Lachs, op.cit., s. 120.

${ }^{132}$ Por.: G. Nolte, op.cit., s. 1087.

${ }^{133}$ Ibidem.

${ }^{134}$ D. Anzilotti, op.cit., s. 368.

${ }^{135}$ Ibidem, s. 374.

${ }^{136}$ Ibid., s. 390-391.

${ }^{137}$ Ibid., s. 378. 
względem jednostki, tak jak dla odpowiedzialności właściciela w prawie prywatnym nie ma znaczenia brak podmiotowości prawnej zwierząt wyrządzających szkody ${ }^{138}$.

Lauterpacht krytykował pozytywistyczną koncepcję Anzilottiego jako zbyt wąska, przywołując w swoich rozważaniach z 1927 r. idee prawa natury ${ }^{139}$. Podkreślał jednak, że jest to nowe ujęcie praw przyrodzonych człowiekowi, nienawiązujące do koncepcji Grocjusza i epoki rzymskiej ${ }^{140}$. Wskazać należy, iż Lauterpacht oparł swoją koncepcję reguł międzynarodowej odpowiedzialności państw na równowadze pomiędzy prawem stanowionym a zwyczajowym. W jego ujęciu prawa narodów większą rolę niż w koncepcjach poprzedników odgrywali sędziowie i doktryna, którym powierzał zadanie zapewnienia praktycznej stosowalności koncepcji dogmatycznych i zapisów traktatów ${ }^{141}$.

\subsection{Spuścizna Anzilottiego w pracach Ago}

Jak wspomniano, w oparciu o koncepcję odpowiedzialności państwa autorstwa Anzilottiego, jego rodak Ago, któremu powierzono funkcję Specjalnego Sprawozdawcy KPM, opracował w 1976 r. raport o zasadach odpowiedzialności państw. Raport ten stanowił podsumowanie wieloletnich badań Ago nad międzynarodową odpowiedzialnością państw. Choć przyjął on pozytywistyczną konstrukcję odpowiedzialności państwa, opisaną w 1906 r. przez Anzilottiego, jego ujęcie koncepcji poprzednika oparte było o diametralnie inne podstawy dogmatyczne, określane jako początek renesansu prawa natury w nauce prawa międzynarodowego ${ }^{142}$. Pozytywista Anzilotti był apologetą suwerenności i w niej upatrywał podstawy ograniczania odpowiedzialności państw - ponosić ją mogło jedynie to państwo, które naruszyło pozytywne, wynikające z traktatu lub zwyczaju, zobowiązanie międzypaństwowe ${ }^{143}$. Swoją obecność w debacie nad kształtem odpowiedzialności państwa Ago zaznaczył po raz pierwszy wykładem na temat deliktu międzynarodowego, wygłoszonym na zaproszenie Akademii Haskiej w 1939 r. ${ }^{144} \mathrm{~W}$ jego treści połączył pozytywizm Anzilottiego z krytykowaną naturalno-prawna, grocjańską koncepcją winy, nadając tej ostatniej nowy charakter. Jakiekolwiek formy prowokacji, pomocnictwa czy udziału państwa przy popełnianiu deliktów międzynarodowych przez osoby prywatne zdawały mu się

${ }^{138}$ Ibid., s. 380. Por. też: B. Sabahi, Compensation and Restitution in Investor-State Arbitration: Principles and Practice, Oksford 2011, s. 42, który opisuje wpływ Anzilottiego na współczesną dogmatykę odpowiedzialności państw.

${ }^{139}$ Por.: G. Nolte, op.cit., s. 1092.

${ }^{140}$ H. Lauterpacht, Regles générales du droit de la paix, RdC 1937, nr 62 (IV), s. 353 i n., podaję za: G. Nolte, op.cit., s. 1092.

${ }^{141}$ G. Nolte, op.cit., s. 1093.

142 Ibidem, s. 1084.

${ }^{143}$ Por.: D. D. Anzilotti, op.cit., s. 365-366.

${ }^{144}$ R. Ago, Le delit international, RdC 1939, nr 68, s. 419-554. 
we współczesnym prawie międzynarodowym niewyobrażalne, odrzucał więc koncepcje współsprawstwa znane krajowym porządkom prawa karnego ${ }^{145}$.

W konsekwencji, Ago przywołał w treści swojego wywodu winę państwa jako element konieczny jego odpowiedzialności, jednak nie utożsamił jej z psychicznym nastawieniem sprawcy, jak czynili to protagoniści Grocjusza, ale z brakiem należytej staranności państwa wobec osób fizycznych, pozostających w jego władzy ${ }^{146}$. Brak należytej staranności, pojmowany jako „subiektywny element winy" był według niego koniecznym elementem odpowiedzialności państwa $^{147}$. Ago ograniczył konieczność wykazania wystapienia owej okoliczności wyłącznie do przypadków zaniechania państwa, tj. niezapobieżenia szkodliwej aktywności osób fizycznych, realizowanych w jego jurysdykcji ${ }^{148}$. Zdaniem Ago, praktyka międzynarodowa wymagała jednoczesnego, choćby pośredniego, wykazania winy państwa w sprawach dotyczących odpowiedzialności za działanie jego organów lub przedstawicieli ${ }^{149}$. W sprawach ich dotyczących konieczne było przeprowadzenie odwróconego dowodu winy tj. wykazanie, że jeśli nie było winy po stronie państwa, to nie ma czynu stanowiącego naruszenie prawa międzynarodowego. Potwierdzeniem obowiązywania tak rozumianej przesłanki winy miała być praktyka międzynarodowa, zwalniająca $\mathrm{z}$ odpowiedzialności państwa dopuszczające się naruszenia normy międzynarodowej w okolicznościach wystapienia siły wyższej, błędu czy zdarzenia losowego. Ago kwalifikował te okoliczności jako „brak winy” ${ }^{\text {"150 }}$. Jego wnioski wynikały z ponownej analizy organizacji wewnętrznej państw, dokonanej z perspektywy prawa międzynarodowego. W jej wyniku postulował przypisanie państwu, jako osobie prawnej, odpowiedzialności za działania osób fizycznych, działających jako jego organy. Inaczej niż Anzilotti, nie uważał, iż o międzynarodowej odpowiedzialności państwa mogą przesądzić jego przepisy wewnętrzne. Ago uważał, że wina państwa to zawsze wina jego organów, a wina osób działających jako organy państwa może być państwu przypisana, jako konieczny, subiektywny warunek jego odpowiedzialności. W konsekwencji, dostrzegał w praktyce międzynarodowej wymóg odwróconego dowodu winy zawsze wtedy, gdy rozważana była kwestia odpowiedzialności państwa za działania jego organów i przedstawicieli. Wtedy to odwrócony dowód winy jest niezbędny, aby wykazać, że naruszenie prawa międzynarodowego nie powstało, bo nie było winy państwa ${ }^{151}$. Koncepcja subiektywnej winy jako elementu koniecznego odpowiedzialności międzynarodowej państwa znajdowała swoich zwolenników jeszcze w drugiej połowie XX w., głównie w doktrynie włoskiej ${ }^{152}$. Subiektywna teoria odpowie-

${ }^{145}$ Por.: H. P. Aust, Complicity and the Law of State Responsibility, Cambridge 2011, s. 12.

${ }^{146}$ Por. np.: R. Ago, op.cit., s. 476; Por. też: R. Pisillo Mazzeschi, op.cit., s. 11.

${ }^{147}$ R. Ago, op.cit., s. 491 i 492.

${ }^{148}$ Ibidem, s. 473-476.

${ }^{149}$ Ibid., s. 475; por.: R. Pisillo Mazzeschi, op.cit., s. 11.

${ }^{150}$ Ibidem, s. 11.

${ }^{151}$ Por.: ibid.

${ }^{152}$ Ibid., s. 12. Obszerna analiza roli winy w odpowiedzilaności państw zawarta została w pracy Ago, poświęconej „deliktom międzynarodowym”, por. R. Ago, op.cit., s. 476-498. 
dzialności międzynarodowej była jednak koncepcją przyjmowaną przez niewielu. Zmuszony był więc odstapić od niej także sam jej twórca, opisując w 1976 r. praktykę międzynarodową w treści Raportu KPM. Ago postulował konieczność ochrony interesów ogólnie rozumianej społeczności międzynarodowej ${ }^{153}$. Czerpiąc z doświadczeń II wojny światowej wywodził, że istnieje społeczność międzynarodowa, której wspólne interesy można zidentyfikować odwołując się do prawa natury i które należy chronić, zaś państwa je naruszające ponosić winny międzynarodową odpowiedzialność ${ }^{154}$.

Według zrewidowanej koncepcji Anzilottiego, stanowiącej współcześnie podstawę reguł odpowiedzialności za czyny międzynarodowo bezprawne, odpowiedzialność państwa zawsze pojmowana winna być w kategoriach obiektywnych i stanowić konsekwencję naruszenia chronionego prawem interesu innego państwa oraz jego przypisania, rozumianego jako związek przyczynowo-skutkowy pomiędzy czynem bezprawnym a państwem, niezależnie od winy działającego podmiotu ${ }^{155}$. Przesłankę winy odrzucono $\mathrm{z}$ trzech powodów: po pierwsze, z powodu niemożności ustalenia stanu psychicznego, stanowiącego treść winy osoby prawnej, jaką jest państwo. Po drugie, nie można mówić o winie organu państwa czy jego pełnomocnika, bowiem ich działanie jest zdeterminowane treścią prawa krajowego. Trzeci argument przeciwko teorii winy wynikał z praktycznej niemożności przypisania jej państwu w przypadku działania osoby fizycznej, przez nie nieupoważnionej ${ }^{156}$. Praktyka międzynarodowa pokazała, że kluczowy dla uznania odpowiedzialności państwa za działania osób fizycznych nie jest sam brak należytej staranności władz państwa, ale istnienie międzynarodowego zobowiązania, obligującego państwo do podjęcia określonych działań. Jak pisze Pisillo Mazzeschi, obowiązek dołożenia należytej staranności nie powinien być postrzegany jako „absolutny”, ale jako obowiązek „względny” podjęcia szczególnych działań prewencyjnych i kontrolnych, określonych $\mathrm{w}$ treści normy międzynarodowej względem danej aktywności. Jego zdaniem, należyta staranność jest więc treścią istniejącego obowiązku międzynarodowego, nie subiektywnym elementem odpowiedzialności państwa ${ }^{157}$. Interpretacja należytej staranności przez współczesnych dogmatyków prawa międzynarodowego często zbliża przesłankę opisaną przez Anzilottiego do „zobiektywizowanej” winy - niedbalstwo, postrzegane nie jako czynnik psychologiczny, ale naruszenie standardów wymaganego zachowania, przypisywane jest państwu na podstawie obiektywnych kryteriów ${ }^{158}$. To swoiste połączenie

${ }^{153}$ Raport KPM, 1976 r., U. N. Doc. A/31/10, s. 18-19.

${ }^{154}$ G. Nolte, op.cit., s. 1084.

${ }^{155}$ Por.: R. Pisillo Mazzeschi, op.cit., s. 15, gdzie autor wskazuje licznych zwolenników tak rozumianej doktryny Anzilottiego. Rewizja poglądów Anzilottiego, dokonana przez Ago, dotyczyła przede wszystkim wyłączenia możliwości determinowania międzynarodowej odpowiedzialności państwa wyłącznie w oparciu o jego przepisy wewnętrzne.

\footnotetext{
${ }^{156}$ R. Pisillo Mazzeschi, op.cit., s. 15-16.

${ }^{157}$ Ibidem, s. 15.

${ }^{158}$ Ibid., s. 17 i podana tam literatura.
} 
obiektywizmu Anzilottiego z koncepcją winy Ago spowodowało, że aktualny pogląd większości doktryny na kwestie należytej staranności określany bywa mianem eklektycznego. Eklektyczne ujęcie odpowiedzialności państwa uwzględnia subiektywną koncepcję winy w kilku kategoriach stanów faktycznych. Według niektórych autorów, przesłanka winy spełniona powinna być jedynie wtedy, gdyby państwo miało ponosić odpowiedzialność za działania swoich organów ${ }^{159}$. Druga grupa zwolenników podejścia eklektycznego postuluje natomiast, aby weryfikować subiektywnie występującą po stronie państwa winę jedynie wtedy, gdy mamy do czynienia z jego odpowiedzialnością za czyny jednostek ${ }^{160}$. Wśród przedstawicieli doktryny są także ci, którzy przywołują winę państwa zawsze wtedy, gdy ma ono ponosić odpowiedzialność za zaniechania stanowiące naruszenie prawa międzynarodowego. Postulując włączenie przesłanki winy do koncepcji odpowiedzialności państwa, niektórzy autorzy mają świadomość jej relatywizmu, wskazując, że zarówno jej uwzględnienie, jak i interpretacja leżeć będą $\mathrm{w}$ gestii sędziego, rozstrzygającego konkretną sprawę ${ }^{161}$. Chcąc uniknąć niepewności prawnej, jaką niosłaby za sobą tak rozumiana swoboda orzecznicza, próbują wskazać konkretne stany faktyczne, w których wina powinna być brana pod uwage przez sąd obligatoryjnie ${ }^{162}$.

Wina państwa, rozumiana jako nastawienie psychiczne jego przedstawicieli do naruszenia prawa co do zasady nie jest jednak odzwierciedlana we współczesnej koncepcji odpowiedzialności międzynarodowej państw. Kres epoki w nauce prawa międzynarodowego, która wywodziła odpowiedzialność państwa z winy jego przedstawicieli, przyniosły prace Komisji Prawa Międzynarodowego pod kierownictwem $\mathrm{Ago}^{163}$. Należy uznać, że współczesna koncepcja odpowiedzialności państwa oparta jest o kryterium obiektywnego naruszenia normy międzynarodowo prawnej oraz możliwość przypisania odpowiedzialności za to naruszenie państwu. Owe dwa elementy powinny pozostawać w obiektywnym związku przyczynowo-skutkowym. Wina przywoływana bywa przez niektórych autorów jako uzasadnienie szczególnego obowiązku dołożenia przez państwa należytej staranności celem zapewnienia przestrzegania norm o szczególnym znaczeniu dla społeczności międzynarodowej ${ }^{164}$. Tak rozumiana koncepcja winy oparta jest o zobiektywizowane kryteria przypisania ${ }^{165}$. Jak już wspomniano, próżno szukać odwołań do winy państwa lub jego organów w pracach KPM. W konsekwencji,

\footnotetext{
${ }^{159}$ Ibid., s. 18 i podana tam literatura.

${ }^{160}$ K. Strupp, Das völkerrechtliche delikt, Berlin 1920, s. 48.

${ }^{161}$ R. Pisillo Mazzeschi, op.cit., s. 18 i podana tam literatura.

${ }^{162}$ Ibidem, s. 19.

${ }^{163}$ Por.: rozdz. III.

${ }^{164}$ Por.: A. Verdross, B. Simma, Universales Völkerrecht, Berlin 1984, s. 850, 855; Ch. Rousseau, Chronique des faits internationaux, RDGIP 1969, nr 73, tom V, s. 16 i n., podaję za: J. Delbrück, R. Wolfrum, Völkerrecht, tom 1, Berlin 2002, par. 183, s. 948; R. Pisillo Mazzeschi, op.cit., s. 13-14; P. Birnie, A. Boyle, C. Redgwell, op.cit., s. 215-216.

${ }^{165}$ R. Pisillo Mazzeschi, op.cit., s.19.
} 
doktryna XX w. przywołuje zamiast winy obiektywny standard należytej staranności, mocą prawa zwyczajowego towarzyszący zasadzie pacta sunt servanda. Szczegółowy opis elementów należytej staranności w pracach dogmatyków oraz ewolucja dotyczącego jej orzecznictwa opisane zostały szczegółowo w rozdziałach następnych. 


\section{Rozdzial II}

\section{NALEŻYTA STARANNOŚĆ W ORZECZNICTWIE MIĘDZYNARODOWYM}

\subsection{Sprawa statku Caroline (1837)}

Zasadzie należytej staranności kształt nadało przede wszystkim bogate orzecznictwo. Wskazać należy w pierwszej kolejności te orzeczenia, w których sądy rozstrzygając o odpowiedzialności międzynarodowej państwa, uzależniały ją od dołożenia przez państwo należytej staranności.

Sprawa statku Caroline przywoływana jest współcześnie nader często w toku debaty dotyczącej walki z terroryzmem, jako rzekome uzasadnienie prawa do samoobrony wyprzedzającej ${ }^{1}$. Odwołująca się do niej współczesna dyskusja koncentrowała się na konieczności stosowania samoobrony wyprzedzającej, także w czasach bezwzględnego zakazu użycia siły, wynikającego z art. 2 ust. 4 Karty Narodów Zjednoczonych ${ }^{2}$. Przeciwnicy tezy o istnieniu owej konieczności wkazywali, że nie można skutecznie przywołać kazusu statku Caroline jako uzasadnienia owej obrony wyprzedzającej w XXI w., bowiem uznanie jego aktualności oznaczałoby zanegowanie ponad stuletniego dorobku społeczności międzynarodowej, zwieńczonego bezwzględnym zakazem użycia siły, zapisanym w 1945 r. w KNZ ${ }^{3}$. Uznanie samoobrony wyprzedzającej podawałoby w wątpliwość celowość wskazania w treści KNZ okoliczności uzasadniających użycie siły bez autoryzacji Rady Bezpieczeństwa ${ }^{4}$. W doktrynie pojawiają się jednak także głosy uznające możliwość stosowania tezy przewodniej w tej spra-

${ }^{1}$ Por.: The National Security Strategy of the United States of America, Waszyngton 2002, s. 15; por.: także I. Brownlie, Principles..., s. 734.

${ }^{2}$ Por. np.: N. Tsaogurias, Necessity and the Use of Force: a Special Regime, Netherlands Yearbook of International Law 2010, nr 4, s. 19; K. T. Szabó, Anticipatory Action in Self-Defence: Essence and Limits under International Law, Berlin 2011, s. 74; I. Brownlie, Principles..., s. 734.

${ }^{3}$ Por. np.: I. Brownlie, Principles..., s. 734; Por. też A. Cassesse, International law, Oksford 2005, s. 298, który pisze o licznych nadużyciach wynikających z przywoływania sprawy Caroline dla uzasadnienia zbrojnych interwencji na obcym terytorium, przede wszystkim na przełomie XIX i XXw.

${ }^{4}$ P. Malanczuk, Akehurst's Modern Introduction to International Law, Londyn, Nowy Jork 2007, s. 312; zob też: idem, Akehurst's Modern Introduction to International Law, Londyn, Nowy Jork 1987, s. 246-251, gdzie autor omawia poglądy zwolenników koncepcji samoobrony wyprzedzającej. O wąskiej i szerokiej interpretacji art. 2 ust. $4 \mathrm{KNZ}$ pisze W. Czapliński, wskazując niebezpieczeństwa dla międzynarodowego pokoju i bezpieczeństwa, jakie niesie za sobą szeroka wykładnia zakazu użycia siły; por.: W. Czapliński, op.cit., s. 20-23. 
wie do ograniczonej kategorii stanów faktycznych, dotyczących działań osób prywatnych $^{5}$. Czapliński, przyłączając się do krytyków samoobrony prewencyjnej, odnotowywał znaczący wpływ orzeczenia w sprawie statku Caroline na współczesną praktykę i orzecznictwo międzynarodowe ${ }^{6}$.

Okoliczności sprawy z 1837 r., kiedy to podczas powstania mieszkańców Kanady przeciwko władzom brytyjskim Stany Zjednoczone tolerowały dostarczanie broni powstańcom z terytorium USA na pokładzie statku Caroline, dając mu schronienie w porcie w Fort Schlosser, przywołane w kontekście niniejszych rozważań prowokuja pytanie nie o konstrukcję samoobrony prewencyjnej, ale o zakres odpowiedzialności państwa za działania osób prywatnych, pozostających w jego jurysdykcji, jeśli działania te stanowią zagrożenie dla bezpieczeństwa wewnętrznego innych państw ${ }^{7}$.

Lubell, autor monografii poświęconej użyciu siły zbrojnej wobec podmiotów niepaństwowych bez wątpliwości konstatował, że działania osób prywatnych mogą stanowić podstawę do zbrojonej interwencji na terytorium państwa ich pobytu ${ }^{8}$. Nie uczynił przy tym odwołania do zachowania organów owego państwa ani ich obowiązku wykazania należytej staranności przy zapobieganiu szkodliwym działaniom osób prywatnych. Odwołania takie pojawiają się jednak w większości opracowań dotyczących prawa do samoobrony, realizowanego w odpowiedzi na działania podmiotów innych niż organy państwa, osoby działające $\mathrm{z}$ jego upoważnienia lub na jego zlecenie ${ }^{9}$. Przede wszystkim, w kontekście działań terrorystycznych wskazuje się, że państwa związane są mocą normy peremptoryjnej, obligującej je do nieudostępniania swojego terytorium do działań o charakterze terrorystycznym ${ }^{10}$. Niedopełnienie tego zobowiązania, poprzez

${ }^{5}$ Por. np.: N. Lubell, Extraterritorial Use of Force Against Non-State Actors, Oksford 2010, s. 56, 73-74 i wskazana tam literatura.

${ }^{6}$ Por. W Czapliński, op.cit., s. 37; por. także ibidem, s. 49-52, gdzie autor omawia szczegółowo kwestię samoobrony wyprzedzającej.

${ }^{7}$ Por.: np.: A. Cassesse, op.cit., s. 298; R. Y. Jennings, The Caroline and McLeod Cases, American Journal of International Law 1938, nr 32, s. 82-99; J. B. Moore, A Digest of International Law, Waszyngton 1906, tom II, s. 24-27; par. 217, 409-413.

${ }^{8}$ N. Lubell, op.cit., s. 35. Por. też: T. H. Franck, Terrorism and the Right of Self Defense, American Journal of International Law 2001, nr 95, s. 840; J. Paust, Use of Armed Force against Terrorist in Afghanistan, Iran and Beyond, Cornell International Law Journal 2002, nr 35, s. 534-535; idem, Self-Defense Targetings of Non-State Actors and Permissibility of U.S. Use of Drones in Pakistan, Journal of Transnational Law \& Policy 2010, nr 19(2), s. 238-258.

${ }^{9}$ Por.: np.: H. Duffy, The 'War on Terror' and the Framework of International Law, Cambridge 2005, s. 57, 302; T. Tsagourias, International Peace and Security, (w:) Participants in the International Legal System, red. J. D’Aspremont, Londyn, Nowy Jork 2011, s. 330; T. Ruys, 'Armed Attack' and Article 51 of the UN Charter: Evolutions in Customary Law and Practice, Cambridge 2010, s. 382; D. W. Bowett, op.cit., s. 49.

${ }^{10}$ Por.: K. N. Trapp, op.cit., s. 85, 110; J. Somer, Acts of Non-State Armed Groups and the Law Governing Armed Conflict [online]. American Society of International Law Insight z 24 sierpnia 2006 [dostęp: 2013-01-20]. Dostępny w Internecie: <http://dspace.cigilibrary.org/jspui/bitstream/ 123456789/13168/1/Acts\%20of\%20Non\%20State\%20Armed\%20Groups\%20and\%20the\%20Law \%20Governing\%20Armed\%20Conflict.pdf?1>; D. W. Bowett, op.cit., s. 49; R. Lillich, J. Paxman, State Responsibility for Injuries to Aliens Occasioned by Terrorist Activities, American University Law Review 1977, nr 26, s. 309-310. 
wykazanie braku należnej staranności w zapobieganiu takim działaniom, może stać się podstawą odpowiedzialności międzynarodowej państwa. Kazus statku Caroline uznać więc można za początek ewolucji prawa do samoobrony, które mocą normy peremptoryjnej, zawartej w 1945 r. w art. 2 ust. $4 \mathrm{KNZ}$, obliguje państwa do nieudostępniania swojego terytorium w sposób niosący szkody innym państwom. Celem realizacji owego zobowiązania państwa winny wykazać należytą staranność, tj. podjąć wszelkie niezbędne działania zmierzające do udaremnienia owej szkodliwej działalności podmiotów prywatnych na ich terytorium. Odmowa podjęcia jakichkolwiek działań, podejmowanie działań pozornych lub ewidentnie poniżej faktycznych możliwości państwa naraża je na odpowiedzialność międzynarodową ${ }^{11}$. W tym też zakresie kazus statku Caroline leży u podstaw zasady dobrosąsiedztwa, z której wywodzony jest obowiązek dokładania należytej staranności przy realizacji zobowiązań międzynarodowych, a przede wszystkim przy zapobieganiu szkodom transgranicznym.

\subsection{Należyta staranność a odmowa wymiaru sprawiedliwości}

Historycznie najwcześniejszą sprawą, przywoływaną w kontekście przedmiotowego zagadnienia, jest sprawa rozpatrywana przez Komisję Mieszaną Stanów Zjednoczonych i Peru w 1868 r. na mocy podpisanej w tym samym roku umowy pomiędzy stronami sporu. Dotyczyła ona roszczenia odszkodowawczego, które obywatel Stanów Zjednoczonych Ruden skierował przeciwko Peru w związku ze spaleniem zabudowań i zniszczeniem ogrodzeń jego peruwiańskiej plantacji. Nie było pewne, czy czynu tego dopuścili się cywile, korzystający z nieuwagi właściciela, czy członkowie sił zbrojnych. Peruwiański wymiar sprawiedliwości nie uwzględnił roszczenia odszkodowawczego Rudena. Pełniąca funkcję arbitra w powstałym sporze Wenezuela uznała, że Peru winno ponieść międzynarodową odpowiedzialność za odmowę wymiaru sprawiedliwości, uniemożliwiającą wyegzekwowanie odszkodowania oraz za bezpośredni udział w ataku na plantację. Dowody na przyczynienie się władz do dokonania zniszczeń przedstawił personel konsularny, wskazując na aktywny udział wojska w roznieceniu pożaru ${ }^{12}$. Decyzja ta potwierdza, że państwo ponosi odpowiedzialność za działania i zaniechania swoich organów, zaś w tym przypadku za zaniechanie wymiaru sprawiedliwości oraz działania wojska. Peru ponosiło odpowiedzialność za szkody dlatego, że wykazano bezpośredni udział przedstawicieli jego organów w dokonaniu zniszczeń i udaremnieniu dochodzenia roszczeń odszkodowawczych.

W tym samym roku zapadła decyzja sądu arbitrażowego, badającego odpowiedzialność Meksyku za szkody obywatela Stanów Zjednoczonych wyrządzone

\footnotetext{
${ }^{11}$ Por. np.: J. Sutor, op.cit., s. 234. Szczegółowy opis treści zobowiązania państw do zapobiegania przestępstwom o charakterze terrorystycznym opisany został w rozdz. V.

12 Por.: Czwarty raport Ago, U.N. Doc. A/CN.4/264, pkt 75, s. 100-101.
} 
na meksykańskim terytorium. Ta sprawa także dotyczyła odmowy wymiaru sprawiedliwości, której dopuścił się Meksyk względem Amerykanki nazwiskiem Glenn. Meksyk nie postawił przed krajowym wymiarem sprawiedliwości sprawców śmierci jej męża i syna, pozbawionych życia przez członków meksykańskich sił zbrojnych, działających, zdaniem wdowy, na bezpośredni rozkaz Kongresu Narodowego Meksyku. Choć nie udało się jej wykazać owego bezpośredniego związku zabójców z Kongresem, arbiter uznał Meksyk winnym odmowy wymiaru sprawiedliwości wobec faktu niepostawienia sprawców zabójstwa przed krajowym wymiarem sprawiedliwości. Ta decyzja potwierdza brak odpowiedzialności państwa za działania osób prywatnych, za jakich uznani zostali w opisywanym stanie faktycznym członkowie sił zbrojnych, niedziałający na podstawie rozkazu. Oznacza jednak także, że państwo ponosi odpowiedzialność za zaniechania swoich organów, również jeśli wiążą się one z naruszeniem prawa przez osoby prywatne ${ }^{13}$.

Sprawa Coteswortha i Powella z 1872 r. dotyczyła dwóch amerykańskich przedsiębiorców, którzy domagali się odszkodowania za skutki spowodowane bezczynnością wymiaru sprawiedliwości w Kolumbii oraz „notoryczną i jawną niesprawiedliwością" (ang. notoriuous injustice), panującą w tym kraju w latach $1858-1860^{14}$. Kolumbijskie oddziały brytyjskich firm, prowadzone przez poszkodowanych, podpisały z lokalnym przedsiębiorstwem umowy na dostawy tytoniu. W 1859 r., tj. podczas postępowania upadłościowego dostawcy, w Kolumbii wybuchła rewolucja. Wówczas sędzia Salazar z prowincji Bogota, gdzie mieściła się siedziba dostawcy, prowadząc sprawę o jego upadłość, dokonał zaboru i sprzedaży spornych towarów, stanowiących masę upadłościową, natomiast akta sprawy częściowo zaginęły. Sąd cywilny oddalił roszczenie przeciwko sędziemu, a organy ścigania odmówiły wszczęcia postępowania karnego w sprawie. W 1863 r. naruszenia prawa, których według poszkodowanych dopuścił się sędzia, objęte zostały amnestią ${ }^{15}$. Na ten czas przypadały także liczne zmiany prawa, wynikające $\mathrm{z}$ niestabilnej sytuacji politycznej w regionie ${ }^{16}$. W odpowiedzi na liczne zapytania powodów, w 1865 r. władze Kolumbii oświadczyły, że nie ponosi ona żadnej odpowiedzialności za działania sędziego Salazara, zaś poszkodowanym nie przysługuje prawo do odszkodowania.

Rozpatrująca spór brytyjsko-kolumbijska komisja mieszana, powołana w tym samym roku mocą traktatu arbitrażowego, wskazała, że „,naród nie ponosi odpowiedzialności za działania pojedynczych obywateli, jeśli tych działań nie potwierdzi lub nie uzna (ang. approves or ratifies)" ${ }^{\text {"17. }}$. Jeśli jednak władze państwa uznają lub potwierdzą działania obywateli, także w sposób domniemany,

\footnotetext{
${ }^{13}$ Por.: R.I.A.A. 1925, Nowy Jork 2006, nr 4, s. 96-97. Por.: C. Eagleton, Denial of Justice in International Law, American Journal of International Law 1928, nr 22(3), s. 538, 542.

${ }^{14} \mathrm{H}$. La Fontaine, Pasicrisie internationale historie documentaire des arbitrages internationaux, Haga 1902, s. 173.

${ }^{15}$ Ibidem, s. 174.

${ }^{16}$ Por.: ibid., s. 174.

${ }^{17}$ J. B. Moore, op.cit., tom II, s. 2082; H. La Fontaine, op.cit., s. 187.
} 
stają się one sprawą publiczną (ang. a public concern), zaś poszkodowany w wyniku takich działań może uznać sam naród za sprawcę szkody ${ }^{18}$. Owo uznanie może być domniemane w oparciu o odmowę wymiaru sprawiedliwości, jeśli ta pozostaje w gestii państwa albo w oparciu o fakt ułaskawienia sprawcy, jeśli pozbawia ono poszkodowanego możliwości dochodzenia odszkodowania lub zadośćuczynienia. Komisja dowodziła, iż jest uznaną zasadą stosunków międzynarodowych, jakoby poprzez ułaskawienia sprawcy państwo przejmowało na siebie odpowiedzialność za jego dawne uczynki ${ }^{19}$. Państwa ponoszą odpowiedzialność względem tych cudzoziemców, którym odmówiły wymiaru sprawiedliwości albo względem których dopuściły się aktów „oczywistej i jawnej bezprawności”" ${ }^{20}$. Pierwsza $z$ tych sytuacji ma miejsce, gdy sądy odmawiają rozpatrzenia sprawy albo uwzględnienia skargi, postępując zgodnie z krajowymi przepisami proceduralnymi. Odmowa wymiaru sprawiedliwości ma także miejsce, gdy czas rozpatrywania sprawy jest nieuzasadnienie długi. $Z$ bezprawnością mamy do czynienia, gdy wyroki ferowane są z wyraźnym naruszeniem obowiązującego prawa albo gdy są one ewidentnie niesprawiedliwe ${ }^{21}$.

W XIX w. państwo nie ponosiło więc odpowiedzialności za działania jednostki, także gdy działająca jednostką był przekraczający swoje uprawnienia urzędnik $^{22}$. Jego zachowania mogły więc skutkować odpowiedzialnością państwa jedynie, jeśli towarzyszyło im działanie lub zaniechanie po stronie organów państwa, odmawiających wymiaru sprawiedliwości. Potwierdzenie takie mogło nastąpić w sposób domniemany.

W pierwszej połowie XX w. zapadły liczne orzeczenia arbitrażowe, dotyczace odpowiedzialności odszkodowawczej Peru wobec obywateli Włoch, mieszkających w peruwiańskich granicach. Decyzje w tych sprawach, w których sprawozdawcą był włoski arbiter de Urbarri, zapadały na podstawie umowy bilateralnej pomiędzy Włochami a Peru z 1899 r. Przyczyniły się one do utrwalenia treści obowiązku wykazywania należytej staranności przy realizacji międzynarodowych zobowiązań.

W reprezentatywnym dla tej linii orzeczniczej wyroku w sprawie Capalleti sędzia-arbiter odmówił uznania odszkodowania na rzecz poszkodowanego Włocha. Tenże Capalleti domagał się uznania odpowiedzialności Peru za skradzione $\mathrm{z}$ jego domu ruchomości i szkody poniesione w związku z uprowadzeniem go z miejsca zamieszkania i bezprawnym pozbawieniem wolności przez pułkownika La Torre, dowodzącego oddziałem rebeliantów podczas wojny domowej w latach 1894-1895. Sędzia de Urbarri uznał, że „kradzież mebli i drobnych przedmiotów należących do powoda nie może zostać przypisana organom państwa

\footnotetext{
${ }^{18}$ J. B. Moore, op.cit., tom II, s. 2082; H. La Fontaine, op.cit., s. 187.

19 J. B. Moore, op.cit., tom II, s. 2085. Por. też: H. La Fontaine, op.cit., s. 189.

${ }^{20}$ H. La Fontaine, op.cit., s. 188.

${ }^{21}$ Ibidem.

${ }^{22}$ Art. 7 Projektu artykułów o odpowiedzialności państw z 2001 r. przewiduje możliwość przypisania państwu odpowiedzialności za czyny urzędników przekraczających przyznane im kompetencje, por. s. 45-47.
} 
(...) i jako taka nie może zostać uznana za podstawę jego odpowiedzialności."23 Jako że sprawa dotyczyła przestępstwa kradzieży, opisanego w peruwiańskim prawie wewnętrznym, to jego ramy stanowiły zdaniem Komisji właściwe odniesienie dla rozpatrywanej sprawy, nie zaś normy prawa międzynarodowego ${ }^{24}$. W badanym stanie faktycznym nie bez znaczenia pozostawał fakt, iż poszkodowany sam przekazał klucze do swojego domu przedstawicielowi konsularnemu Włoch, czyniąc go odpowiedzialnym za bezpieczeństwo znajdujących się tam ruchomości ${ }^{25}$. Nie dopatrując się zaniechań po stronie organów państwa, sędzia uznał brak jego odpowiedzialności.

W 1905 r. pełniąca analogiczną funkcję do komisji włosko-peruwiańskiej komisja włosko-wenezuelska rozpatrywała sprawę Włocha Poggioliego, którego w 1891 r. czterej mieszkańcy Wenezueli okaleczając doprowadzili do niepełnosprawności. W 1899 r. ci sami sprawcy pozbawili życia jego brata, którego śmierć stanowiła tragiczną kulminację serii represji, jakiej dwaj włoscy przedsiębiorcy doświadczali ze strony władz wenezuelskiej prowincji Los Andes od blisko dekady ${ }^{26}$. Wśród zarzutów formułowanych wobec władz znalazły się oskarżenia o podpalenia przez urzędników domów, sklepów, młynów, plantacji cukru, kawy i bananów należących do braci Poggioli, zamknięcie należącego do nich portu, pozbawienie ich prawa własności licznego stada bydła, nieposiadające podstawy prawnej pozbawienie ich wolności, jak również obelgi i groźby formułowane pod ich adresem. Wszystko to doprowadziło do bankructwa firmy, utraty majątku rodzinnego, a w konsekwencji także środków do życia ${ }^{27}$. Ponadto domniemani sprawcy zabójstwa brata powoda zostali uwolnieni przez generała armii wenezuelskiej i przyjęci w jej szeregi, unikając odpowiedzialności za swoje czyny. Ich wojskowi zwierzchnicy pozostawali bezczynni pomimo wielokrotnych interwencji Poggioliego. Sprawcy dopuścili się w czasie swojej służby innych naruszeń prawa względem poszkodowanego i wdowy oraz dzieci ofiary, wciąż uchodząc wenezuelskiemu wymiarowi sprawiedliwości. Co więcej, lokalne władze w Los Andes ostrzegały ich przed ewentualnymi próbami aresztowania, tym samym je udaremniając. Ten stan utrzymywał się przez ponad dwa lata, w którym to czasie, pomimo bezpośrednich rozkazów władzy centralnej w Caracas, odpowiedzialni za śmierć Poggioliego nie stanęli przed obliczem sprawiedliwości $^{28}$.

Komisja wskazała, że Wenezuela ponosiła odpowiedzialność za szkody materialne poniesione przez cudzoziemca, bowiem tolerowała wyrządzanie mu

${ }^{23}$ Sentence arbitrale sur la réclamation numéro 54, présentée par Don Aquilino Capalleti, R.I.A.A. 1901, nr XV, s. 439. Por.: Czwarty raport Ago, U.N. Doc. A/CN.4/264, pkt 79, s. 102.

${ }^{24}$ Odmienny wniosek w podobnych okolicznościach faktycznych, badanych 30 lat wcześniej, stał się podstawą rozwiązania sporu w omawianej poniżej sprawie statku Alabama.

${ }_{25}$ Sentence arbitrale sur la réclamation numéro 54, présentée par Don Aquilino Capalleti, R.I.A.A. 1901, nr XV, s. 439. Por.: Czwarty raport Ago, U.N. Doc. A/CN.4/264, pkt 79, s. 102.

${ }^{26}$ Poggioli Case, R.I.A.A. 1903, nr X (dalej: sprawa Poggioli), s. 669-692.

${ }^{27}$ Sprawa Poggioli, s. 672-675.

${ }^{28}$ Sprawa Poggioli, s. 673. 
poważnych szkód przez osoby prywatne, zaś sprawcy, których tożsamość nie budziła wątpliwości, uniknęli kary. Ponosiła ją także dlatego, że jej urzędnicy, działając wspólnie ze sprawcami, przyczynili się do utraty mienia i bankructwa przedsiębiorstwa poszkodowanego, nie zapewniając mu żadnego odszkodowania $^{29}$. Odpowiedzialność państwa przywołana być więc może także, jeśli jedynie część szkód powstała wskutek działania urzędników, zaś pozostałe wynikały $\mathrm{z}$ ich sugestii lub były efektem pobłażliwości władz ${ }^{30}$. Wenezuela dopuściła się tym samym naruszenia ciążących na niej obowiązków i komisja uznała ją za odpowiedzialną z tytułu odmowy wymiaru sprawiedliwości, którego dopuścić się mogą także organy władzy administracyjnej. Ponadto, skoro władze prowincji Los Andes działały w porozumieniu z przestępcami, przypisać im można odpowiedzialność za szkody wyrządzone osobom prywatnym, zaś szkodliwy czyn uznać za czyn państwa. Konkluzję te potwierdzał fakt niepostawienia sprawców przed obliczem wymiaru sprawiedliwości. Takie działanie nie mogło zostać uznane za reakcję dobrze zorganizowanego państwa (ang. acts of a well-ordered state), ale raczej za bezczynność niektórych jego organów, za którą odpowiedzialność ponosi państwo ${ }^{31}$. Orzeczenie w sprawie Poggioli potwierdza tezę wcześniejszych judykatów, dotyczących odmowy wymiaru sprawiedliwości. Źródłem odpowiedzialności państw za działania jednostek może być zaniechanie po stronie wymiaru sprawiedliwości lub organów administracyjnych, polegające na ograniczeniu dostępu do sądu lub odmowie wymiaru sprawiedliwości, uniemożliwiające skuteczne dochodzenie odszkodowania. Odpowiedzialność państwa $\mathrm{w}$ omawianej sprawie wynikała także $\mathrm{z}$ innych rodzajów czynów, których dopuściły się organy władzy państwowej. Po pierwsze, o odpowiedzialności państwa zdecydowało współsprawstwo władz lokalnych w działaniach osób prywatnych ${ }^{32}$. Komisja, przywołując opinie doktryny, wskazała, że niezależnie od tego, czy urzędnicy własnym działaniem wyrządzili szkodę w interesach cudzoziemców, realizując obowiązki służbowe, czy to rząd zaniedbał podjęcia natychmiastowych kroków w celu udaremnienia pewnych ich działań, albo czy bezpośrednio lub pośrednio zatwierdził poczynania swoich funkcjonariuszy, „sprawiedliwość i słuszność” wymagają pociagnięcia owego państwa do „dyplomatycznej odpowiedzialności” i naprawienia powstałej szkody $^{33}$. Prowincja Los Andes na przestrzeni lat działała „notorycznie i rażąco niedbale oraz nieporządnie w zarządzaniu własnymi sprawami”, zaś poprzez zaniechanie ukarania winnych, Wenezuela stała się tym samym „w jakiejś mierze współsprawcą szkody" i ponosiła odpowiedzialność za czyny władz lokalnych. Szkodliwe działania były powszechnie znane i realizowane demonstracyjnie. Państwo było więc „oczywiście odpowiedzialne” za zaniechanie użycia

\footnotetext{
${ }^{29}$ Sprawa Poggioli, s. 669.

${ }^{30}$ Sprawa Poggioli, s. 673.

${ }^{31}$ Sprawa Poggioli, s. 689.

${ }^{32}$ Sprawa Poggioli, s. 690

${ }^{33}$ Sprawa Poggioli, s. 670
} 
odpowiednich środków w celu ich powstrzymania i za nieukaranie sprawców z wykorzystaniem przysługujących mu ,kompetencji prawnych”34.

$\mathrm{W}$ pierwszej połowie XX w. odpowiedzialność państwa za odmowę wymiaru sprawiedliwości wyniknęła przy rozpatrywaniu sporu brytyjsko-hiszpańskiego. Jedna z pierwszych nowożytnych definicji należytej staranności przedstawiona została przez sędziego STMS Hubera w rozstrzygnięciu sporu pomiędzy Wielką Brytanią i Hiszpanią, dotyczącego brytyjskich roszczeń do udziałów w nadzorowanej przez Hiszpanię strefie międzynarodowej w Maroku ${ }^{35}$.

Mocą umowy z 19 maja 1923 r., Wielka Brytania i Hiszpania przekazały STMS 53 roszczenia odszkodowawcze osób pozostających w brytyjskiej jurysdykcji, przede wszystkim obywateli Korony. Roszczenia dotyczyły poniesionych przez nich uszczerbków na zdrowiu lub mieniu w strefie Maroka zarządzanej przez Hiszpanię. Szkody obywateli brytyjskich w hiszpańskiej strefie Maroka powstały w wyniku działań wojskowych, powstań i rozbojów. Wielka Brytania nie zgłaszała jednak roszczeń odszkodowawczych wynikających bezpośrednio z owych szkód. Wskazywała, że rząd Hiszpanii mógłby ponosić za nie odpowiedzialność jedynie wówczas, gdyby wykazał ewentualnie niedbalstwo w sytuacji, w której mógł był zapobiec szkodom, gdyby wypłacił odszkodowania swoim obywatelom, pomijając cudzoziemców, albo gdyby powstanie zakończyło się przejęciem władzy przez siły powstańcze. Londyn postulował natomiast przypisanie Hiszpanii odpowiedzialności za działania jej urzędników oraz żołnierzy, choć te nie były bezpośrednio związane $\mathrm{z}$ zapobieganiem szkodliwym aktom powstańców. Zdaniem przedstawicieli Korony, Hiszpania ponosiła odpowiedzialność za przedłużającą się zwłokę w przeprowadzeniu postępowań odszkodowawczych, przybierającą postać faktycznej odmowy wymiaru sprawiedliwości ofiarom. Nie sposób stosowania prawa wewnętrznego stał się podstawą roszczeń, a raczej norma prawa międzynarodowego, zakazująca faktycznej odmowy wymiaru sprawiedliwości cudzoziemcom. Pełnomocnicy Hiszpanii odpierali zarzuty wskazując, iż odpowiedzialność państwa za odmowę wymiaru sprawiedliwości przywołana może być jedynie wówczas, gdy państwo zaniechało zastosowania krajowych procedur karnych, wymaganych w jego prawie wewnętrznym, a sytuacja taka nie miała tu miejsca ${ }^{36}$.

Przed rozpatrzeniem indywidualnych roszczeń arbiter Huber przedstawił kilka reguł odpowiedzialności państw celem opisu należytej staranności, wymaganej w stosunkach międzynarodowych. Fundamentem prawa międzynarodowego jest terytorialny charakter wykonywania suwerenności przez państwa. Dlatego prawo do interwencji dyplomatycznej w relacje pomiędzy państwem a osobami pozostającymi w jego terytorialnej jurysdykcji może mieć wyłącznie charakter wyjątkowy. Przywołane być może jedynie w sytuacjach, gdy jakiś szczególny

\footnotetext{
${ }^{34}$ Sprawa Poggioli, s. 690; Por.: Czwarty raport Ago, U.N. Doc. A/CN.4/264, pkt 80, s. 102.

${ }^{35}$ Sprawa roszczeń brytyjskich w Maroku, R.I.A.A. 1924, nr 2, (dalej: Sprawa roszczeń brytyjskich w Maroku), s. 615.

${ }^{36}$ Sprawa roszczeń brytyjskich w Maroku, s. 635.
} 
element powoduje powstanie odpowiedzialności międzynarodowej państwa lub gdy ogólny stan bezpieczeństwa w państwie sprawującym kompetencję terytorialną spada poniżej określonego poziomu albo faktyczna ochrona sądowa jest iluzoryczna ${ }^{37}$. O ile więc państwo nie może być uznane za odpowiedzialne za konsekwencje wojny lub niepokojów wewnętrznych, o tyle może być pociagnięte do odpowiedzialności za działania lub zaniechania jego władz, popełnione w tym czasie. Państwo ponosi międzynarodową odpowiedzialność, gdy jego władze zaniechały działania, mimo iż w danych okolicznościach powinny były zapobiegać szkodliwym czynom mieszkańców lub doprowadzić do ich zakończenia z dołożeniem możliwej, należytej staranności przy udzielaniu pomocy cudzoziemcom lub podejmowaniu działań zapobiegawczych lub ochronnych względem nich i ich prawnie chronionych dóbr ${ }^{38}$. W odniesieniu do pojedynczych aktów przestępnych, niemających charakteru zamieszek, państwo ponosi odpowiedzialność, jeśli staranność wykazywana przy zapobieganiu szkodom w interesach cudzoziemców dalece odbiega od staranności wykazywanej w prowadzeniu własnych spraw (diligentia quam in suis) ${ }^{39}$. Państwo ponosi odpowiedzialność także wówczas, gdy nie podejmie działań zmierzajacych do ukarania sprawców, którzy dopuścili przestępstw przeciwko cudzoziemcom lub nie zastosuje względem nich przewidzianych prawem sankcji. Ten wymóg nie ma jednak charakteru absolutnego, bowiem przy badaniu okoliczności sprawy brane muszą być pod uwage środki pozostające $\mathrm{w}$ dyspozycji państwa i jego organu. Odpowiedzialność za działania lub zaniechania władz publicznych jest czymś innym niż odpowiedzialność za działania osób pozostających w terytorialnej władzy państwa i otwarcie niechętnych jego urzędnikom. Huber wskazał, jako naturalne atrybuty każdego rządu, minimalny stopień wykazywanej przez niego ostrożności i wykorzystanie dostępnej mu infrastruktury, jak również monitorowanie działań realizowanych na terytorium państwa celem zapobiegania szkodom wyrządzanym cudzoziemcom ${ }^{40}$.

Wskazał jednocześnie, że nie można wymagać, aby państwo, którego obywatele ponieśli szkody lub są pozbawieni ochrony bez uzasadnionej przyczyny pozostało bierne ${ }^{41}$. Jego przywilejem jest dochodzenie odszkodowania za naruszenia prawa, których ofiarami są osoby w ich jurysdykcji personalnej. Państwo wykonujące jurysdykcję terytorialną może ponosić odpowiedzialność nie tylko ze względu na brak ostrożności w zapobieganiu szkodliwym czynom, ale także z powodu braku staranności w ściganiu sprawców przestępstw i niedostępności lub nieskuteczności roszczeń cywilnych. Właściwym odniesieniem dla oceny owej należytej staranności jest nie standard opisany w treści przepisów prawa wewnętrznego, jak podnosili przedstawiciele Hiszpanii, a raczej staranność

\footnotetext{
${ }^{37}$ Sprawa roszczeń brytyjskich w Maroku, s. 615.

38 Sprawa roszczeń brytyjskich w Maroku, s. 636.

${ }^{39}$ Sprawa roszczeń brytyjskich w Maroku, s. 644. Por. R. Pisillo Mazzeschi, op.cit., s. 40.

${ }^{40}$ Sprawa roszczeń brytyjskich w Maroku, s. 644.

${ }^{41}$ Sprawa roszczeń brytyjskich w Maroku, s. 642.
} 
wykazywana przez państwo we własnych sprawach, niezależnie od dyspozycji karnych prawa wewnętrznego ${ }^{42}$. Odpowiedzialność za odmowę wymiaru sprawiedliwości zależy więc od natury konkretnego naruszenia prawa. Jedynie analizując konkretne roszczenie można zdecydować, czy miała miejsce odmowa wymiaru sprawiedliwości ${ }^{43}$. Ów praktyczny test zastosowany został w sprawie jednego z poszkodowanych obywateli Korony, Menebhiego (sprawa Si-el-Haj-el-Mehdi-el-Menebhiego). Sprawa ta dotyczyła odszkodowania za skradzione bydło $^{44}$. 30-osobowa grupa sprawców wtargnęła do nadzorowanej przez Hiszpanię międzynarodowej strefy Maroka ze strefy hiszpańskiej. Sędzia Huber uznał, że stopień staranności, wymagany w danych okolicznościach, warunkowany jest przez dostępne władzom środki, zaś ocenę ich wykorzystania uzależnił od okoliczności sprawy i przedmiotu ochrony ${ }^{45}$. Obowiązek prewencji w tej konkretnej sytuacji spoczywał na hiszpańskich władzach strefy międzynarodowej w Maroku. Władze brytyjskie pominęly jednak roszczenia wobec władz lokalnych, te zaś nie wszczęły żadnego postępowania z urzędu. Pierwsze zawiadomienie o popełnieniu przestępstwa nastapiło ze strony brytyjskiej osiem dni po zdarzeniu, gdy sprawcy wrócili już do strefy hiszpańskiej. W tej sytuacji strażnicy graniczni nie mieli podstaw przypuszczać, że przepędzanie bydła było nielegalne. Odpowiedzialność władz hiszpańskich może więc dotyczyć jedynie ich postawy wobec konieczności ukarania sprawców przestępstwa, nie dotyczy jednak z pewnością samego zdarzenia, będącego bezpośrednim źródłem szkody. Co do zasady bowiem, państwo nie jest zobligowane uiszczać odszkodowania za wszelkie szkody powstałe na jego terytorium ${ }^{46}$. Wielka Brytania podnosiła, że po złożeniu zawiadomienia żadne działania zmierzające do ukarania sprawców nie zostały podjęte. Co więcej, biorąc pod uwagę poziom niesubordynacji i nieskuteczność interwencji władz lokalnych, było mało prawdopodobne, aby wyniki dochodzenia policji znacząco wpłynęły na rozwiązanie sprawy. Ten stan rzeczy nie stanowił jeszcze jednak naruszenia prawa międzynarodowego. Hiszpania nie ponosiła więc odpowiedzialności za powstanie szkody, ani za niezapobieżenie jej. Jedyna odpowiedzialność, jaka mogła zostać jej przypisana, to odpowiedzialność za brak współpracy śledczej pomiędzy urzędnikami dwóch obszarów administracyjnych, pozostających $\mathrm{w}$ jej władzy ${ }^{47}$. Formułując treść obowiązku prewencji sędzia Huber wskazał, że władze państwa mogą realizować go jedynie w kontekście obrony swoich granic, nie zaś odnośnie do porządku wewnętrznego. Dlatego też obowiązek państwa ogranicza się jedynie do ścigania i ewentualnego ukarania sprawców wykroczeń, nie obejmuje natomiast obowiązku bezwzględnej prewencji wszelkich naruszeń, popełnianych $\mathrm{w}$ jego granicach ${ }^{48}$.

\footnotetext{
${ }^{42}$ Sprawa roszczeń brytyjskich w Maroku, s. 645.

${ }^{43}$ Sprawa roszczeń brytyjskich w Maroku, s. 645.

44 Sprawa roszczeń brytyjskich w Maroku, s. 624, 790-791.

${ }^{45}$ Sprawa roszczeń brytyjskich w Maroku, s. 636.

${ }^{46}$ Sprawa roszczeń brytyjskich w Maroku, s. 790.

47 Sprawa roszczeń brytyjskich w Maroku, s. 791.

${ }^{48}$ Sprawa roszczeń brytyjskich w Maroku, s. 710.
} 
Władze Hiszpanii nie dopełniły tak rozumianego obowiązku prewencji, nie wszczynając postępowania mającego na celu ustalenie i ukaranie sprawców. Takie zaniechanie stanowiło naruszenie międzynarodowego zobowiązania ${ }^{49}$. Odpowiedzialność Hiszpanii wynikała nie bezpośrednio z napaści jej obywateli na mieszkańca brytyjskiej strefy, ale ze sposobu wykonywania przez nią wymiaru sprawiedliwości ${ }^{50}$.

Odpowiedzialność państwa za zaniechanie zależna jest więc od spełnienia czterech przesłanek. Po pierwsze, jeśli źródłem szkody cudzoziemca jest działanie osoby prywatnej, odpowiedzialność państwa może wynikać jedynie z niedopełnienia obowiązków przez władzę wykonawczą tj. zapobiegania szkodom i sądową, poprzez ściganie i karanie sprawców. Po drugie, Huber odrzucił możliwość przypisania państwu odpowiedzialności za działania osób prywatnych państwo więc, co do zasady, za ich czyny nie odpowiadało. Po trzecie wskazał, że szkodliwe działanie osoby prywatnej pojmowane być winno jako odrębne od działania czy zaniechania przypisywanego państwu. Wreszcie, przy szacowaniu wysokości odszkodowania za kryterium powinien służyć charakter i skala zaniechania władz państwa, nie zaś rozmiar faktycznej szkody, wywołanej przez osoby prywatne ${ }^{51}$.

Orzeczenie w sprawie Menebhego, przywoływane w późniejszych rozstrzygnięciach komisji ds. roszczeń amerykańsko-meksykańskich, potwierdziło zasadę, zgodnie z która państwo nie ponosi odpowiedzialności za szkodliwe działania osób prywatnych, o ile dołoży należytej staranności przy zapobieganiu im oraz podejmie należne działania zmierzające do ustalenia i ukarania sprawców. Ta teza znalazła odzwierciedlenie w treści rozstrzygnięcia z $1925 \mathrm{r}$. w sprawie dotyczącej morderstwa obywatela Stanów Zjednoczonych Janesa na terytorium Meksyku przez obywatela Meksyku, górnika, zwolnionego z pracy w kopalni, którą Amerykanin kierowal ${ }^{52}$. Roszczenie odszkodowawcze wdowy, Laury Janes, oparte było na tezie o niedołożeniu przez władze Meksyku należytej staranności w ściganiu sprawcy, którego nie spotkała żadna kara ${ }^{53}$. Pełnomocnik Stanów Zjednoczonych wskazywał na „współsprawstwo” władz Meksyku w dokonaniu zabójstwa, bowiem państwo, nie doprowadzając do pojmania i skazania sprawcy, „darowało i potwierdziło" przestępstwo, czyniąc je własnym ${ }^{54}$.

Przewodniczący Komisji, holenderski sędzia Vollenhoven, uzasadniając odpowiedzialność Meksyku za niedbalstwo, przywołał dorobek orzecznictwa sądów arbitrażowych i wskazał, że państwo wykazujące istotny brak staranności w ściganiu lub karaniu sprawców ponosi odpowiedzialność „pochodną” (ang.

\footnotetext{
${ }^{49}$ Por.: Czwarty raport Ago, U.N. Doc. A/CN.4/264, pkt 81, s. 102.

${ }^{50}$ Por.: Czwarty raport Ago, U.N. Doc. A/CN.4/264, pkt 82, s. 103.

${ }^{51}$ Por.: Czwarty raport Ago, U.N. Doc. A/CN.4/264, pkt 82, s. 103.

${ }^{52}$ Laura M. B. Janes i in. przeciwko Stanom Zjednoczonym Meksyku, R.I.A.A. 1925, nr 4 (dalej: sprawa Janes), s. 82-98.

${ }^{53}$ Sprawa Janes, s. 83.

${ }^{54}$ Sprawa Janes, s. 90.
} 
a derivative liability) za „współudział” w ich przestępstwie ${ }^{55}$. Powodem uznania takiej odpowiedzialności w sytuacji, w której władze nie były w stanie zapobiec powstaniu szkody, jest założenie, że brak kary stanowi przejaw pochwały dla szkodliwego zachowania, zwłaszcza w sytuacji, gdy władze pozwoliły sprawcom opuścić terytorium państwa, stosując prawo łaski albo amnestię. Państwo ponosi odpowiedzialność także wówczas, gdy władze wiedziały o zamiarze popełnienia przestępstwa, mogły były mu zapobiec, ale tego nie uczyniły ${ }^{56}$.

W badanej sytuacji władze dopuściły się nieukarania sprawców, lecz nie miały faktycznej możliwości zapobieżenia przestępstwu, nie brały także aktywnego udziału w jego popełnieniu. Ponosiły więc odpowiedzialność za niedopełnienie obowiązku starannego ścigania i właściwego ukarania sprawców. O ile dopuścili się oni naruszenia krajowych przepisów karnych, o tyle państwo dopuściło się naruszenia normy prawa międzynarodowego, opisującej obowiązki państw przy zapobieganiu szkodom cudzoziemców ${ }^{57}$. Nieprzedsięwzięcie przez organy państwa kroków zmierzających do ukarania sprawców nie jest tożsame z uznaniem lub potwierdzeniem naruszenia prawa, którego oni się dopuścili. Ich działania mogą więc być przypisane jedynie im, państwu zaś - wyłącznie działania lub zaniechania jego organów. Te dwie kategorie działań rozpatrywane być winny w odniesieniu do odrębnych, właściwych sobie reżimów odpowiedzialności ${ }^{58}$. Dlatego też naruszenia stanowiące elementy badanego stanu faktycznego uznane zostały za odmienne $\mathrm{w}$ genezie, charakterze i skutku ${ }^{59}$. Państwo zobowiązane było jedynie naprawić szkodę powstałą w wyniku własnego zaniechania.

W zdaniu odrębnym, które nie zostało uwzględnione w decyzji arbitrażowej, sędzia reprezentujący Stany Zjednoczone podkreślał, że przy określaniu wysokości odszkodowania państwo powinno ponosić pełną odpowiedzialność za powstałe szkody, niezależnie od charakteru i skali jego szkodliwego zaniechania ${ }^{60}$.

Sformułowana $\mathrm{w}$ treści omawianej decyzji zasada braku odpowiedzialności państwa za działania osób prywatnych znalazła potwierdzenie w szeregu późniejszych rozstrzygnięć arbitrażowych tej samej amerykańsko-meksykańskiej komisji w latach 1927-1928, w szczególności w sprawach: Kennedy'ego ${ }^{61}$, Venabiego $^{62}$ i Canahla $^{63}$. W tej ostatniej sprawie Komisja jednomyślnie obniżyła wysokość odszkodowania, ponieważ za sprawą trwających wówczas w Meksyku

\footnotetext{
${ }^{55}$ Sprawa Janes, s. 86.

${ }^{56}$ Sprawa Janes, s. 86.

${ }^{57}$ Sprawa Janes, s. 86.

${ }^{58}$ Sprawa Janes, s. 88.

${ }^{59}$ Sprawa Janes, s. 89.
}

${ }^{60}$ Por.: Czwarty raport Ago, U.N. Doc. A/CN.4/264, pkt 85, s. 103. Obecnie odpowiedzialność absolutna jest przedmiotem wąskiego konsensusu, wyrażonego w treści traktatów dotyczących szkód kosmicznych, por. rozdz. V.

${ }^{61}$ George Adams Kennedy przeciwko Stanom Zjednoczonym Meksyku, R.I.A.A. 1927, nr IV, s. 194-203.

${ }^{62}$ H. G. Venable przeciwko Stanom Zjednoczonym Meksyku, R.I.A.A. 1927, nr IV, s. 219-261.

${ }^{63}$ Louise O. Canahl przeciwko Stanom Zjednoczonym Meksyku, R.I.A.A. 1928, nr IV, s. 389-391. 
zamieszek władze nie były w stanie sprawnie wykonywać wymiaru sprawiedliwości. W omawianych sprawach odpowiedzialność państwa wynikała jedynie z jego zaniechania, jeśli wcześniej udało się ustalić, że leżał po stronie panstwa obowiązek prewencji i ukarania sprawców ${ }^{64}$.

\subsection{Sprawa statku Alabama (1872)}

Sprawa statku Alabama, przedłożona trybunałowi arbitrażowemu, dotyczyła sporu pomiędzy Stanami Zjednoczonymi a Wielką Brytanią ${ }^{65}$. Sporna była kwestia odpowiedzialności Wielkiej Brytanii za niezachowanie neutralności w sporze pomiędzy Konfederatami a Unionistami. Dopuściła się ona naruszenia prawa poprzez okazanie wsparcia Konfederatom, tj. wybudowanie i udostępnienie im statku Alabama, wbrew protestom przedstawicieli Stanów Zjednoczonych. Wielka Brytania wiedziała, że statek miał służyć do zbrojnych wypraw handlowych przeciwko Unionistom ${ }^{66}$.

Stany Zjednoczone wstapiły w spór dowodząc odpowiedzialności Wielkiej Brytanii za naruszenie wzajemnego zobowiązania stron do zachowania neutralności, potwierdzonego treścią traktatu waszyngtońskiego o wzajemności z $1854^{67}$. Owego naruszenia prawa Wielka Brytania miała była dopuścić się poprzez niedołożenie należytej staranności przy zapobieganiu wykorzystania jej terytorium w sposób sprzeczny z treścią przyjętego zobowiązania ${ }^{68}$.

Strony przedstawily $\mathrm{w}$ trakcie trwania sporu odmienne definicje należytej staranności, które nadały kierunek późniejszym dyskusjom dotyczącym treści tego sformułowania. Stany Zjednoczone określiły należytą staranność jako „staranność proporcjonalną do wielkości przedmiotu, względem którego ma być

\footnotetext{
${ }^{64}$ Dlatego też w sprawie w sprawie Kidd rozpatrywanej przez komisję brytyjsko-meksykańską w 1931 r., arbitrzy stwierdzili brak spełnienia owych przesłanek, prowadzący do niemożności pociagnnięcia Meksyku do odpowiedzialności. Organy państwa podjęły niezwłoczne i zdecydowane działania, prowadzące do ustalenia i aresztowania sprawców zabójstwa męża poszkodowanej. Por.: Annie Bella Graham Kidd przeciwko Stanom Zjednoczonym Meksyku, R.I.A.A. 1931, nr V, s. $142-144$.

${ }^{65}$ Projekt Barbozy, U.N. Doc. A/51/10, s. 111. Por.: C. C. Beaman, The national and private „Alabama claims" and their ,final and amicable settlement”, Waszyngton 1871, s. 171-286; J. B. Moore, History and Digest of the International Arbitrations to which the United States Has Been a Party, Together with Appendices Containing the Treaties Relating to Such Arbitrations, and Historical and Legal Notes on Other International Arbitrations Ancient and Modern, and on The Domestic Commissions of the United States for the Adjustment of International Claims, tom III, Waszyngton 1898, s. 2208-2210.

${ }^{66}$ Oddziały mające korzystać ze statku określane były terminem: Confederate Commerce Raiders. Por.: C. C. Beaman, op.cit., s. 4; G. T. Fullam, The journal of George Townley Fullam, boarding officer of the Confederate sea raider Alabama, Alabama 1973, s. vii; T. L. Jones, Historical Dictionary of the Civil War, tom 1, Lanham 2011, s. 81.

${ }^{67}$ Por.: J. Hatschek, K. Strupp, Woerterbuch des Voelkerrechts und der Diplomatie, Berlin 1925, tom II, s. 133-134, gdzie autorzy opisują genezę powstania oraz treść owego zobowiązania. Por. też: J. B. Moore, History ..., tom VII, s. 1010.

${ }^{68}$ J. B. Moore, History ..., tom VII, s. 496.
} 
wykazana oraz do godności i siły władzy, która ma ją wykazać" ${ }^{69}$. Należyta staranność wedle tej definicji miała oznaczać także wykazaną przez państwo „czujność” (ang. vigilance) oraz przedsięwzięcie wszelkich środków, pozostających w jego dyspozycji, celem zapobiegania naruszaniu integralności terytorium innego państwa. Działania te miałyby obejmować także powstrzymywanie jednostek znajdujących się na terytorium państwa od przygotowywania i dopuszczania się aktów wojny wbrew woli organów państwa. Należyta staranność oznaczała podejmowanie energicznych działań celem zidentyfikowania zdarzeń na terytorium państwa, które mogłyby zagrozić bezpieczeństwu innych stron. Niosła za sobą także zobowiązanie do użycia wszelkich środków, pozostających w dyspozycji państwa, celem zapobieżenia owemu szkodliwemu czynowi, niezwłocznie po uzyskaniu informacji o podejmowanych do niego przygotowaniach. Jakiekolwiek starania, inne od opisanych powyżej, nie moga zostać uznane za należyte. Poziom należytej staranności winien więc być określany w odniesieniu do powstałego zagrożenia lub ewentualnej szkody ${ }^{70}$.

W tym samym sporze Wielka Brytania definiowała należytą staranność jako taką, „którą wykazują zazwyczaj rządy względem spraw wewnętrznych”"71. Treść obowiązku wykazania należytej staranności była, zdaniem przedstawicieli Jej Królewskiej Mości, opisana w treści norm prawa wewnętrznego, niezależnie od treści i charakteru zobowiązań międzynarodowych państwa ${ }^{72}$.

Tę definicję Trybunał uznał za zbyt wąską, przedkładając bardziej precyzyjny i wymagający wzorzec, zaproponowany przez Amerykanów. Trybunał wskazał, że Brytyjczycy nadmiernie zawęzili definicję należytej staranności, ograniczając ją jedynie do władzy wykonywanej na mocy przepisów krajowych, niezasadnie abstrahując od zobowiązań międzynarodowych, które wymagać mogą dostosowania do nich przepisów prawa krajowego, potwierdzając tym samym zasadę prymatu prawa międzynarodowego nad normami wewnętrznymi ${ }^{73}$. Trybunał zidentyfikował standard należytej staranności wprost proporcjonalny do zagrożenia interesów którejkolwiek $\mathrm{z}$ walczących stron $\mathrm{w}$ wyniku niedopełnienia obowiązku zachowania neutralności przez Wielką Brytanię ${ }^{74}$. Spór zakończył się ugoda - Wielka Brytania zgodziła się zapłacić ponad 14 milionów dolarów odszkodowania na rzecz Stanów Zjednoczonych ${ }^{75}$.

Niezależnie od faktu zawarcia ugody Barboza podnosi, iż w tej sprawie mamy do czynienia z odpowiedzialnością Wielkiej Brytanii za niedbalstwo w wykonywaniu spoczywających na niej obowiązków, nie zaś z jej odpowiedzialnością deliktową. Jego zdaniem, Brytyjczycy nie wypełnili własnej definicji należytej

\footnotetext{
${ }^{69}$ Ibidem, s. 572-573.

70 Ibid.

${ }^{71}$ Ibid., s. 612. Tej samej argumentacji Wielka Brytania używała w sporach z Hiszpanią dotyczących roszczeń w Maroku, opisanych powyżej, por. sprawa sprawa Menebhiego.

72 Ibid., s. 613.

${ }^{73}$ Ibid., s. 616-617. Por. też: Projekt Barbozy, U.N. Doc. A/51/10, s. 111.

74 J. B. Moore, op.cit., tom VII, s. 654.

${ }^{75}$ Ibidem, s. 630.
} 
stranności. Tym samym krytykuje komentatorów, którzy wskazują, jakoby trybunał wytyczył w sprawie statku Alabama kryterium proporcjonalności dla należytej staranności, gdyż nie było potrzeby, aby odwołanie takie w ogóle czynił. Wprowadzenie standardu staranności proporcjonalnego do prawdopodobieństwa wywołania szkody przez daną aktywność oznaczałoby faktyczne wyłączenie możliwośći uniknięcia odpowiedzialności ${ }^{76}$. Jest to opinia uzasadniona w kontekście faktycznych okoliczności sprawy, choć odniesienie do proporcjonalności wysiłków podejmowanych celem wykazania należytej staranności ocenić należy jako przydatne. Nie pozostało ono także bez wpływu na dalszy kierunek badań nad należytą starannością ${ }^{77}$.

Co istotne dla czynionych tu rozważań, w toku badania sprawy statku Alabama zidentyfikowane zostały dwa odmienne stanowiska, reprezentatywne dla późniejszych dyskusji dotyczących granic należytej staranności. Wielka Brytania podnosiła, że obowiązek należytej staranności interpretowany być winien wąsko, aby jej brak dotyczył wyłącznie sytuacji, w których rząd nie podjął dostatecznych wysiłków celem zapobieżenia działaniu, do zapobiegania któremu był zobowiązany moca przepisów prawa wewnętrznego. Ocena stopnia staranności wykazanej przez rząd czyniona być więc powinna w odniesieniu do starań zazwyczaj czynionych przez rządy w sprawach wewnętrznych i jako taka mogłaby być racjonalnie oczekiwana przy realizacji zobowiązań międzynarodowych. Treść ugody w sprawie Alabama wskazuje jednak, że należyta staranność oznaczała zobowiązanie państwa do podjęcia wszelkich możliwych działań celem zapobiegania szkodliwym zachowaniom, realizowanym w jego jurysdykcji, zaś ocena owych wysiłków czyniona być powinna w odniesieniu zarówno do zachowań innych rządów w podobnej sytuacji, jak i do rozmiarów szkód powstałych w wyniku jej niedołożenia lub skali zagrożenia interesów obcego suwerena, tj. zaniechania dołożenia należytej staranności w dopełnianiu zobowiązania międzynarodowego ${ }^{78}$. Warto zaznaczyć, że obecnie punktem odniesienia dla oceny staranności wykazywanej przez państwa nie jest rozmiar powstałej lub grożącej szkody, ale sama treść zobowiązania do zapobiegania określonym skutkom i praktyka innych państw.

\subsection{Sprawa De Brissot $\mathrm{i}$ innych (1885)}

W sprawie roszczeń skierowanych przez: de Brissot, Rawdon, Stakpole i de Hammer w 1885 r. Komisja ds. roszczeń pomiędzy Stanami Zjednoczonymi a Wenezuelą, powołana mocą konwencji z tego samego roku, opisała treść nale-

\footnotetext{
${ }^{76}$ J. Barboza, The Environment, Risk and Liability in International Law, Haga 2011, s. 50.

${ }^{77}$ Por.: rozdział III i IV poniżej, gdzie omówiono spory dotyczące roli szkody w ocenie staranności wykazywanej przez państwo i wpływ tej oceny na kształt jego odpowiedzialności. Przyjąć można, iż dla tej oceny znaczenie ma skala naruszenia ciążącego na państwie obowiązku, nie zaś rozmiar szkód wywołanych owym naruszeniem.

${ }^{78}$ Por. X. Hanquin, Transboundary Damage in International Law, Cambridge 2009, s. 162-164.
} 
żytej staranności w prawie międzynarodowym, odnosząc się pośrednio do koncepcji przypisania państwu odpowiedzialności za zaniechanie jego organów ${ }^{79}$. Sprawa dotyczyła napaści na statek przewożący prezydenta Wenezueli Garcię, dokonanej przez przeciwników jego rządów podczas postoju statku w porcie Apurito w Weneueli. Generał Garcia wyszedł z tego incydentu bez szwanku, jednak śmierć w jego obronie ponieśli dwaj członkowie załogi: kapitan John W. Hammer oraz główny mechanik Julius de Brissot, zaś trzeci z marynarzy, Joseph Stackpole, został ranny ${ }^{80}$. Wszyscy poszkodowani mieli amerykańskie obywatelstwo. Z roszczeniem odszkodowawczym do władz Wenezueli zwróciły się wdowy po zmarłych marynarzach oraz poszkodowany Stackpole. Odpowiedzialność Wenezueli miała zostać zweryfikowana względem podjętych działan, zmierzających do pojmania i ukarania sprawców napaści ${ }^{81}$. Badając sprawę, komisja potwierdziła, że obowiązek podjęcia działań zmierzających do ustalenia tożsamości sprawców i zapewnienia im uczciwego procesu spoczywa na każdym państwie. Obowiązek ten wynika z faktu iż państwo, jako „osoba moralna”, zobowiązane jest do ponoszenia odpowiedzialności za konsekwencje swoich czynów, tak samo jak ponoszą je członkowie tworzącej owo państwo społecznoś$\mathrm{ci}^{82} . \mathrm{Z}$ tego samego powodu zobowiązane jest ono do uiszczenia odszkodowania za działania osób „od niego zależnych” oraz tych, za które ponosi odpowiedzialność (ang. accountable) ${ }^{83}$. Przewodniczący komisji sędzia Little zaznaczył, że tylko o ile organy państwa zrobiły wszystko, czego można było od nich racjonalnie wymagać w konkretnej sytuacji, należałoby uznać Wenezuelę za wolną od odpowiedzialności ${ }^{84}$. Aplikując tak sformułowany test staranności, w treści orzeczenia wskazano niedociagnięcia, jakich dopuściła się Wenezuela. Organy państwa nie podjęły żadnych działań zmierzających do ustalenia tożsamości choćby przywódców grupy, która dopuściła się napaści. Gdyby prowadzone były skoordynowane działania zmierzające do postawienia sprawców przed sądem, albo przeprowadzone postępowanie, dowodzące ich niewinności, uznać by można, że Wenezuela spełniła spoczywające na niej obowiązki. W związku z powyższym uznać należy, że państwo ponosi odpowiedzialność za niedopełnienie obowiązku zidentyfikowania i osądzenia sprawców naruszenia. Jednocześnie wysokość odszkodowania odzwierciedlać miała fakt, że zaniechanie nie było ,skandaliczne" ${ }^{\text {, }}$.

$\mathrm{Z}$ omawianego orzeczenia wynika potwierdzenie odpowiedzialności państwa za działania i zaniechania jego organów. Wysokość odszkodowania w konkretnej

${ }^{79}$ J. B. Moore, History ..., tom VII, s. 2457; por.: Amelia de Brissot, Ralph Rawdon, Joseph Stackpole i Narcisa de Hammer przeciwko Wenezueli, R.I.A.A. 1903, tom IX, s. 503 i n.; B. Cheng, op.cit., s. 181 i n.

${ }^{80}$ J. B. Moore, op.cit., tom III, s. 2457.

${ }^{81}$ Ibidem, s. 2968.

${ }^{82}$ Ibid., s. 2952.

${ }^{83}$ Ibid.

${ }^{84}$ Ibid., s. 2953.

${ }^{85}$ Ibid. 
sprawie odzwierciedlać powinna jej specyfikę i rodzaj naruszenia prawa, jakiego dopuściły się organy państwa. Komisja wskazała, że państwo postrzegane powinno być ponadto jako „podwójna osoba prawna”. Tak jak „osoba cywilna” (ang. civil person), wykonuje władzę zwierzchnią nad powierzoną mu ziemią, na wzór prywatnoprawnego patrymonium. Państwo jest jednocześnie „osobą polityczną", jednostką polityczna, niezależną i suwerenna, zobowiązaną do dbałości o porządek publiczny i interesy swoich obywateli ${ }^{86}$. Odpowiedzialność za szkody wyrządzone cudzoziemcom przez urzędników państwowych ma więc aspekt moralny, wynikający z podobieństwa roli państwa do funkcji patrona, odpowiedzialnego za sposób zarządzania powierzonym mu majątkiem. Ponosić ono ją będzie jednak tylko wówczas, gdy szkoda powstała z jego współudziałem, np. za sprawą oczywistej odmowy wymiaru sprawiedliwości. Osobowość „polityczna” państwa powoduje jego odpowiedzialność za działania jego organów jedynie wówczas, gdy z okoliczności danej sprawy wynika, iż fakt który spowodował powstanie szkody „może zostać moralnie przypisany” państwu ${ }^{87}$. Przypisanie takie może mieć miejsce po spełnieniu czterech warunków. Po pierwsze, władze państwa musiały były wiedzieć o bezprawnym zachowaniu osoby pełniącej funkcję jej organu dostatecznie wcześnie, aby móc temu zapobiec i tego nie uczyniły. Po drugie, posiadając możliwość cofnięcia aktu swojego organu, władze państwa nie cofnęły go. Po trzecie, niewiedza władz państwowych o zaistniałym naruszeniu uznana może być za przejaw złej wiary albo element przestępstwa, jeśli nie podjęło ono stosownych kroków celem jej pozyskania. Po czwarte wreszcie, państwo ponosi odpowiedzialność, jeśli będąc uprzedzonym o owych szkodliwych czynach, nie podjęło działań celem przedstawienia zarzutów dopuszczającemu się naruszenia prawa urzędnikowi ani nie podjęło właściwych (ang. proper) kroków celem zapobieżenia przyszłym występkom podobnego rodzaju ${ }^{88}$.

\subsection{Sprawa Lovetta i innych (1892)}

Zasada braku odpowiedzialności państwa za działania osób prywatnych potwierdzona została także względem szkód powstałych podczas niepokojów wewnętrznych, zamieszek czy rebelii. Także w tak niespokojnym czasie państwo nie ponosi, co do zasady, odpowiedzialności za działania członków grup burzących porządek wewnętrzny. Zasadę tę potwierdziła Komisja ds. roszczeń amerykańsko-chilijskich, powołana mocą umowy z 1892 r. w sprawie gubernatora kolonii karnej w Sandy Point w Chile, Lovetta, pozbawionego życia wraz $\mathrm{z}$ całym podległym mu garnizonem przez zbuntowanych osadzonych ${ }^{89}$. Zdarzenie

\footnotetext{
${ }^{86}$ Ibid.

${ }^{87}$ Ibid.

${ }^{88}$ Ibid.

${ }^{89}$ Por.: Czwarty raport Ago, U.N. Doc. A/CN.4/264, pkt 90, s. 106.
} 
to miało miejsce podczas przyjmowania transportu nowych więźniów, realizowanego na zlecenie władz Chile przez obywateli Stanów Zjednoczonych, kapitana Browna i właściciela prywatnego statku Floryda, nazwiskiem Shaw. Ten ostatni i kilku innych członków załogi także straciło życie ${ }^{90}$.

Komisja uznała, iż naruszenie prawa dokonane przez mieszkańca państwa nie może być uznane za dokonane przez samo państwo ${ }^{91}$. Rząd odpowiada za przestępstwo popełnione na jego terytorium tylko wtedy, gdy istnieje dowód, iż był w stanie zapobiec szkodliwym aktom, ale nie zrobił tego, celowo lub w skutek lekkomyślności. W tej sprawie Komisja uznała, że rząd nie ponosił odpowiedzialności za buntowników i nie był w stanie zapobiec szkodom ${ }^{92}$.

\subsection{Sprawa Davis (1903)}

Brytyjsko-wenezuelska komisja mieszana w 1903 r. zajmowała się skargą angielskiej firmy John Davis \& Son, której właściciele twierdzili, iż wskutek niedbalstwa wenezuelskiego celnika nie byli w stanie na czas zrealizować zamówienia towarów dla działającej w Wenezueli włoskiej firmy Lanzoni, Martini \& Co. Przesyłka została odebrana ze składu celnego po dwóch latach, zamiast przewidzianych krajową ustawą piętnastu dni ${ }^{93}$. Niedbalstwo celnika miało zdaniem poszkodowanych polegać na nieprzekazaniu listów podróżnych do adresatów przesyłki, uniemożliwiając tym samym jej odbiór. Komisja ustaliła, że roszczenie było oczywiście bezzasadne, obarczając winą za nieterminowe doręczenie poszkodowanego, który nie dołączył do przesyłki listów przewozowych, a przekazal je dopiero trzy miesiące po wysłaniu towarów ${ }^{94}$.

Przy okazji czynionych rozważań komisja określiła treść obowiązków państwa, dotyczących ochrony cudzoziemców przed skutkami niedbalstwa jego urzędników. Roszczenie odszkodowawcze za brak należytej staranności urzędnika państwowego powinno wiązać się z uprzednim powiadomieniem państwa o zaistniałym zagrożeniu dobra chronionego prawem, dając władzom możliwość usunięcia przyczyny powstałego zagrożenia. Niedbalstwem byłoby uchybienie wymogom ostrożności, zapobiegliwości i czujności (ang. care, precaution, and vigilance), wymaganym $\mathrm{w}$ danych okolicznościach dla zapewnienia ochrony interesom innej osoby, wskutek którego to uchybienia ponosi ona szkodę ${ }^{95}$. Świadoma nieumyślność (dosł. zawinione niedbalstwo, ang. culpable negligence)

${ }^{90}$ Lovett $\mathrm{i}$ in. v. Chile, Commission for the Settlement of Claims under the Convention of 7 August 1892 concluded between the United States of America and the Republic of Chile Case Frederick H. No. 43, decision of 10 April 1894, R.I.A.A. 1894, tom XXIX, s. 319-321.

${ }^{91}$ Por.: J. B. Moore, op.cit., tom III, s. 2991.

${ }^{92}$ Lovett $\mathrm{i}$ in. v. Chile, Commission for the Settlement of Claims under the Convention of 7 August 1892 concluded between the United States of America and the Republic of Chile Case Frederick H. No. 43, decision of 10 April 1894, R.I.A.A. 1894, tom XXIX, s. 320-321.

${ }^{93}$ Davis Case, R.I.A.A. 1903, nr IX, (dalej: sprawa Davis), s. 462.

${ }^{94}$ Sprawa Davis, s. 463.

${ }^{95}$ Sprawa Davis, s. 463. 
jest zatem zaniechaniem dopełnienia obowiązku prawnego, tj. wcześniej istniejącego zobowiązania do wykazania określonego poziomu staranności ${ }^{96}$. Komisja odróżniła od niedbalstwa „brak ostrożności wymaganej w danych okolicznościach”, opisując tym mianem zaniechanie „rozsądnej” osoby, przejawiające się niedołożeniem staranności, umiejętności czy niewykazaniem ostrożności, prawnie wymaganych w danych okolicznościach, celem ochrony innej osoby przed szkoda, przez co szkoda powstaje ${ }^{97}$. Termin ten opisuje więc zaniechanie w wykonaniu tego, co rozsądna i ostrożna osoba zazwyczaj zrobiłaby w danych okolicznościach albo zrobienie tego, czego taka osoba by zaniechała. Komisja wprowadziła również kategorię „opieszałości” (ang. laches). Oznaczała ona zaniedbanie wykonania obowiązku albo dochodzenia egzekucji prawa we właściwym czasie. Innymi słowy jest to zaniedbanie prawnego obowiązku działania lub zaniechania. „Właściwy” czas nie odnosił się jedynie do obiektywnej długości jego trwania, ale przede wszystkim do możliwości skutecznej egzekucji praw, ze szczególnym uwzględnieniem równego traktowania wszystkich podmiotów przy rozpatrywaniu ich roszczeń ${ }^{98}$. Należyta staranność to więc także zakaz dyskryminacji.

\subsection{Sprawa Tellini (1923)}

Odpowiedzialność państwa za działania osób prywatnych znalazła interesujące odzwierciedlenie $\mathrm{w}$ treści orzeczenia w sprawie śmierci generała Telliniego i członków kierowanej przez niego komisji z 1923 r. Rada Ligi Narodów powołała Specjalną Komisję Prawników celem rozstrzygnięcia watpliwości prawnych związanych z incydentem pomiędzy Włochami i Grecją, dotyczącym zamachu dokonanego $\mathrm{w}$ greckiej miejscowości Janina, nieopodal granicy z Albanią ${ }^{99}$. Przewodniczący Tellini i członkowie komisji powołanej dla określenia przebiegu spornej granicy grecko-albańskiej zostali pozbawieni życia rankiem 27 sierpnia 1923 r., znajdując się na terytorium Grecji. Brakowało dowodów na bezpośrednie zaangażowanie greckich sił zbrojnych czy porządkowych w pozbawienie ich życia, choć jako prawdopodobne uzasadnienie zbrodni wskazywano włoskie obywatelstwo generała Telliniego i fakt, iż cele polityczne Rzymu i Tirany były wówczas zbieżne, sprzeczne natomiast $\mathrm{z}$ priorytetami polityki Greków. W odpowiedzi na zamach, stojący na czele państwa włoskiego Mussolini, wystosowawszy listę żądań wobec Aten, doprowadził do wojskowej okupacji greckiej wyspy Korfu ${ }^{100}$. Nie sformułował jednak żadnego zarzutu, dotyczącego podstaw

\footnotetext{
${ }^{96}$ Por.: B. B. Cheng, op.cit., s. 226.

${ }^{97}$ Sprawa Davis, s. 463.

${ }^{98}$ Sprawa Davis, s. 463.

${ }^{99}$ Por.: J. Crawford, A. Pellet, S. Olleson, K. Parlett, op.cit, s. 1075.

${ }^{100}$ List z 27 września 1923 r. wystosowany przez Mussoliniego do rządu Grecji zawierał żądania: ukarania sprawców oraz uiszczenia odszkodowania i zadośćuczynienia za szkody moralne. Por.: F. Przetacznik, Protection of Officials of Foreign States According to International Law, Haga 1983, s. 202.
} 
odpowiedzialności Grecji za zamach dokonany przez osoby prywatne, czy to poprzez zaniechanie czy niewłaściwe działanie organów państwa, suponując odpowiedzialność absolutną za naruszenie prawa dyplomatycznego ${ }^{101}$. Zważywszy na szczególny status ofiar, Mussolini wskazywał, że odpowiedzialność państwa greckiego wynikała bezpośrednio $\mathrm{z}$ faktu popełnienia przestępstwa na greckim terytorium, nie zaś z konkretnego działania lub zaniechania organów państwa ${ }^{102}$. Co ciekawe, stanowisko to znalazło potwierdzenie w rezolucji Konferencji Ambasadorów z 5 września 1923 r., w treści której ów organ LN potwierdził ,automatyczną” odpowiedzialność państw za „przestępstwa polityczne" popełnione na ich terytorium ${ }^{103}$. Włoska okupacja Korfu przyniosła Grecji poważne straty w ludziach i mieniu ${ }^{104}$. Osamotnieni politycznie Grecy zwrócili się do Ligii Narodów z prośbą o zbadanie sytuacji, leżącej u podstaw narastającego konfliktu i ocenę ewentualnej odpowiedzialności ich państwa za ów sierpniowy incydent. Specjalna Komisja stwierdziła, że państwo może ponosić odpowiedzialność za popełnione na jego terytorium przestępstwa polityczne popełnione na szkodę cudzoziemców, jeżeli zaniechało podjęcia wszelkich uzasadnionych kroków, zmierzających do zapobiegania przestępstwom, ścigania ich, aresztowania sprawców i postawienia przed sądem karnym ${ }^{105}$. Sam fakt obecności cudzoziemca na terytorium państwa oraz okoliczności jego wizyty nakładają na państwo stosowne obowiązki szczególnej troski o jego bezpieczeństwo. Odpowiedzialność państwa powstaje więc wówczas, gdy jego organy zaniechały działań, do których były w danych okolicznościach faktycznych zobowiązane $^{106}$. Co ciekawe jednak, niezależnie od owego merytorycznego wsparcia otrzymanego od wspólnoty międzynarodowej, Grecja mocą zawartej ugody została zobowiązana do uiszczenia na rzecz Włoch wysokiego odszkodowania. Był to jedyny politycznie możliwy sposób wycofania włoskich wojsk z Korfu. Jak opisywał ową ugodę Nicolson, ówczesny pierwszy sekretarz brytyjskiego Foreign Office, Wielka Brytania, architekt tego porozumienia, w reakcji na kolejne występki Mussoliniego „okiełznała Ligę i nałożyła na Grecję wysoką karę bez dowodów jej winy, bez odwołania do trybunału w Hadze, rozwiązując komisję śledczą" ${ }^{107}$. Rozwiązanie to potwierdza tym samym obecną także dziś w treści dogmatycznych sporów silną zależność treści prawa międzynarodowego od politycznego rozkładu sił.

${ }^{101}$ F. Przetacznik nazywa to działanie wyrazem arogancji. Por.: F. Przetacznik, op.cit., s. 202.

102 Por.: Ibidem.

${ }^{103}$ League of Nations Official Journal 1924, nr 4, s. 524; podaję za: F. Przetacznik, op.cit., s. 202.

104 Szczegółowy opis sytuacji politycznej w czasie konfliktu: P. J. Yearwood, 'Consistently with Honour': Great Britain, the League of Nations and the Corfu Crisis of 1923, Journal of Contemporary History 1986, nr 21(4), s. 559-579.

${ }^{105}$ League of Nations Official Journal 1924, nr 4; s. 524; podaję za: F. Przetacznik, op.cit., s. 202. Por.: S. Rosenne, The International Law Commission's Draft Articles on State Responsibility: Part 1, Articles 1-35, Haga 1991, s. 122; J. Crawford, The International Law Commission's Articles on State Responsibility: Introduction, Text and Commentaries, Cambridge 2002, s. 91.

${ }^{106}$ Por.: S. Rosenne, The International Law Commission's Draft Articles on State Responsibility: Part 1, Articles 1-35, Haga 1991, s. 122.

${ }^{107}$ P. J. Yearwood, op.cit., s. 559. 


\subsection{Sprawa Noyes (1933)}

Komisja ds. roszczeń amerykańsko-panamskich powstała na mocy umowy dwustronnej z 1926 r. W 1933 r. badała sprawę dotyczącą odpowiedzialności państwa za szkody cudzoziemców wywołane podczas rozruchów, które towarzyszyły podpisaniu rzeczonej konwencji w położonym nieopodal stolicy mieście Juan Diaz ${ }^{108}$. Przebiegu spotkania nie zabezpieczono wzmożoną ochroną policyjną, ograniczając ją do trzech stale stacjonujących w mieście policjantów. Ponadto poszkodowany obywatel Stanów Zjednoczonych, w którego imieniu Stany Zjednoczone wystapiły przeciwko Panamie, wskazywał na brak czynnej ochrony policji, gdy został zaatakowany i pobity podczas zamieszek. Z treści zarzutów wynikało także, że Panama nie dołożyła należytej staranności przy utrzymywaniu porządku, jak też nie podjęła odpowiednich kroków, zmierzających do ujęcia i ukarania napastników, co miało czynić ją odpowiedzialną za powstałe szkody ${ }^{109}$.

Komisja oddaliła roszczenie wskazując, że w świetle prawa międzynarodowego państwo nie ponosi odpowiedzialności za „Zwykłe przejawy przemocy” (ang. ,mere facts of agression"), które mogły zostać łatwo opanowane przez wystarczające siły policyjne. Nie uznała za przejaw braku należytej staranności samego faktu niezabezpieczenia podpisania konwencji dodatkowymi siłami porządkowymi ${ }^{110}$. Przedstawiciele sił porządkowych, obecni na miejscu zdarzenia, dopełnili swoich obowiązków, aktywnie chroniąc poszkodowanego, zaś w ślad za informacją o wzmagających na sile zamieszkach, oddziały policji ze stolicy zostały niezwłocznie wysłane do Juan Diaz. Okoliczności sprawy nie pozwalały także uznać państwa za odpowiedzialne za brak wszczęcia postępowania przeciwko napastnikom ${ }^{111}$. Sam fakt wywołania szkód u cudzoziemca przez osoby prywatne, którym to szkodom można było zapobiec poprzez zorganizowanie liczniejszych sił porządkowych, nie niesie za sobą odpowiedzialności państwa ${ }^{112}$. Dla powstania odpowiedzialności niezbędne jest wykazanie zaistnienia szczególnych okoliczności ją uzasadniających. Odpowiedzialność państwa mogłaby zostać skutecznie przywołana jedynie w jednej z dwóch możliwych sytuacji, wówczas, gdyby władze bezpośrednio uczestniczyły w szkodliwych działaniach osób prywatnych albo gdyby nie dopełniły ogólnego obowiązku utrzymywania porządku wewnętrznego, zapobiegania przestępstwom lub karania sprawców. Komisja uznała, że żadna z powyższych sytuacji nie miała miejsca w przedmiotowym stanie faktycznym ${ }^{113}$.

\footnotetext{
${ }^{108}$ Walter A. Noyes przeciwko Panamie, R.I.A.A. 1933, nr VI, (dalej: sprawa Noyes), s. 308-

${ }^{109}$ Sprawa Noyes, s. 309.

${ }^{110}$ Sprawa Noyes, s. 311.

${ }^{111}$ Sprawa Noyes, s. 309-301.

${ }^{112}$ Sprawa Noyes, s. 311.

${ }^{113}$ Sprawa Noyes, s. 311.
} -312 . 


\subsection{Sprawa Denham (1933)}

Ta sama komisja rozpatrywała w 1933 r. sprawę obywatelki USA, Lettie Charlotte Denham, której mąż, także obywatel Stanów Zjednoczonych, został pozbawiony życia w Panamie ${ }^{114}$. Zabójstwa Jamesa Denhama dopuścił się były pracownik kierowanej przez niego fabryki. Sprawca został pojmany, osądzony i skazany na 18 lat i cztery miesiące pozbawienia wolności, jednak po 37 miesiącach pozbawienia wolności objęła go amnestia. Poszkodowani, wdowa i syn Denhama, wnosili o uznanie odpowiedzialności Panamy zarówno za brak należytej staranności przy ochronie cudzoziemców, jak i za skrócenie czasu odbywania kary, co stanowiło pogwałcenie prawa do sprawiedliwego ukarania sprawcy.

Komisja nie dopatrzyła się naruszenia obowiązku ochrony cudzoziemców po stronie Panamy. Jednak o ile orzeczona kara nie była nieadekwatna wedle standardów międzynarodowych, o tyle była taką kara wykonana. Skrócenie czasu jej wykonania przesądziło o jej nieadekwatności i o odpowiedzialności władz za działania Zgromadzenia Narodowego, wprowadzającego nadmiernie skrócenie wyroku. Komisja orzekła odszkodowanie na rzecz powodów. Państwo pociągnięte zostało więc do odpowiedzialności za działania swoich organów, które ogłosiły amnestię, od której to decyzji poszkodowanym nie przysługiwał żaden środek odwoławczy. Oceniając wysokość odszkodowania Komisja nie brała pod uwagę rozmiaru szkody wywołanej działaniem sprawcy, a jedynie skalę naruszenia prawa, którego dopuściły się władze. Jak dowodziła Komisja, mimo iż działanie Zgromadzenia Narodowego nie dotyczyło jedynie tej sprawy, a skrócenie kary nie wynikało z pojedynczego, konkretnego działania organu państwa, dotyczącego jednego skazanego, Panama ponosiła międzynarodowa odpowiedzialność, bowiem odpowiedzialność za niedopełnienie obowiązku odpowiedniego ukarania sprawców przestępstw przeciwko cudzoziemcom nie jest oparta na szczególnym traktowaniu sprawcy ${ }^{115}$. Treść owego zobowiązania nie budzi wątpliwości i każde państwo winno tak dostosować treść swoich wewnętrznych regulacji, aby uczynić mu zadość. Brak wykonania odpowiedniej kary wobec sprawcy naruszenia prawa może stanowić podstawę odpowiedzialności międzynarodowej państwa ${ }^{116}$. Międzynarodowy obowiązek ukarania

${ }^{114}$ Lettie Charlotte Denham i Frank Parlin Denham przeciwko Panamie, R.I.A.A. 1933, nr VI, (dalej: sprawa Denham), s. 312-313.

${ }^{115}$ Sprawa Denham, s. 313.

${ }^{116}$ Sprawa Denham, s. 313. Por.: także: Ida Robinson Smith Putnam przeciwko Stanom Zjednoczonym Meksyku, R.I.A.A. 1927, nr IV, s. 151-155, gdzie Komisja uznała odpowiedzialność Meksyku za zamianę przez sąd apelacyjny kary śmierci na osiem lat pozbawienia wolności dla policjanta, który po służbie dopuścił się zabójstwa obywatela Stanów Zjednoczonych. W tej sprawie o odpowiedzialności za niewydolność systemu państwowego, wynikającą z braku należytej staranności, świadczyła także ucieczka sprawcy po 36 miesiącach odbywania kary pozbawienia wolności, którego organy państwa nie były w stanie ponownie pojmać i ukarać. 
sprawcy nie wygasa $\mathrm{w}$ przypadku ogłoszenia amnestii ${ }^{117}$, co wynika $\mathrm{z}$ uznanej zasady pierwszeństwa zobowiązań międzynarodowych nad treścią aktów prawa krajowego ${ }^{118}$.

\subsection{Sprawa Adams (1933)}

Komisja uzupełniła treść poczynionych wcześniej ustaleń rozpatrując sprawę dotycząca poszkodowanego obywatela Stanów Zjednoczonych Adamsa, który padł ofiarą rozboju i pobicia, dokonanych przez policjanta na służbie ${ }^{119}$. Policjant został ukarany przez sąd dyscyplinarny wydaleniem ze służby i trzydziestoma dniami pozbawienia wolności za naruszenie obowiązków służbowych. Wyrok został opatrzony klauzulą wykonalności przez sąd powszechny i odbywany był przez 13 dni na posterunku policji i w jego pobliżu. Postępowanie karne zostało wszczęte i tymczasowo zawieszone 27 września 1921 r. Tymczasowe zawieszenie wciąż trwało w czasie rozpatrywania sprawy przez Komisję, tj. blisko 12 lat później. Po wszczęciu postępowania karnego oskarżony był przetrzymywany w siedzibie sądu przez 10 tygodni. Mimo sprzecznych zeznań poszkodowanego, dotyczących kwoty będącej przedmiotem rozboju, Komisja uznała, że Panama nieodpowiednio ukarała policjanta i uznała jej odpowiedzialność, przyznając Adamsowi odszkodowanie ${ }^{120}$.

Komisja uznała za zbyteczne identyfikowanie ogólnej normy, dotyczącej działania funkcjonariuszy państwa poza zakresem ich upoważnienia lub otrzymanego rozkazu, bowiem $\mathrm{w}$ przedmiotowej sprawie bez watpienia policjant działał jako osoba prywatna, tj. nie w granicach obowiązku służbowego. Nie miało znaczenia, że sprawca był umundurowanym policjantem na służbie, przekraczającym zakres swoich obowiązków, państwo nie ponosiło bowiem odpowiedzialności za jego działania ${ }^{121}$. Ponosiło ją jednak za czyny organów sądowych, które nie przeprowadziły rzetelnego postępowania wyjaśniającego i nie ukarały sprawcy odpowiednio do przewinienia. Potwierdzając konkluzję sprawy Denham, Komisja uznała, że nie ma znaczenia dla odpowiedzialności państwa, czy decyzja będąca podstawą braku odpowiedniej kary dotyczyła jednostkowej sprawy, czy grupy spraw lub sprawców.

${ }^{117}$ Sprawa Denham, s. 313. Por. także: F. R. West przeciwko Stanom Zjednoczonym Meksyku, R.I.A.A. 1927, nr IV, s. 270-272. L. Ehrlich potwierdza odpowiedzialność państwa za skutkujące naruszeniem prawa międzynarodowego decyzje o amnestii, por.: L. Ehrlich, Prawo międzynarodowe..., s. 643. Jak pisze, cytując orzeczenie w sprawie West, „udzielenie amnestii za przestępstwo ma ten sam skutek w prawie międzynarodowym, co nieukaranie tego przestępstwa, niewykonanie kary, albo darowanie przestępstwa (...), wynika z niego (...) pośrednia odpowiedzialność (państwa - uzupełnienie moje, JK).” Ibidem.

${ }_{118}$ Por.: np., art. 34 Konwencji wiedeńskiej o prawie traktatów, Dz.U. z 1990, nr 74, poz. 439 (dalej: KWPT).

${ }^{119}$ Gust Adams przeciwko Panamie, R.I.A.A. 1933, nr VI (dalej: sprawa Adams), s. 321-324.

${ }^{120}$ Sprawa Adams, s. 321.

${ }^{121}$ Sprawa Adams, s. 323. 


\subsection{Sprawa Terytorium Saary (1933)}

W konsekwencji decyzji komisji zarządzającej Terytorium Saary z 1933 r. państwo niemieckie zostało uznane za wolne od odpowiedzialności za porwanie przez obywateli Niemiec trzech mieszkańców Terytorium Saary, legitymujących się francuskim obywatelstwem ${ }^{122}$. Porwani zostali uprowadzeni do niemieckiego Kaiserslautern i tam bezprawnie pozbawieni wolności. Pełnomocnik Rzeszy podczas rozprawy podnosił, że sprawcy działali z prywatnych pobudek, z pomocą kilku znajomych, bez wiedzy i woli policji czy innych organów państwowych. W związku z powyższym państwo niemieckie nie ponosiło odpowiedzialności za te samodzielne działania osób prywatnych ${ }^{123}$. Niemieccy policjanci uwolnili porwanych i oddali ich w ręce strażnika granicznego Terytorium Saary ${ }^{124}$. Co więcej, władze Niemiec niezwłocznie po otrzymaniu informacji o tym incydencie wszczęły postępowanie wyjaśniające ${ }^{125}$. Ten stan rzeczy pozwolił Komisji uznać, że Niemcy dołożyły należytej staranności w ochronie cudzoziemców poszkodowanych przez ich obywateli i przetrzymywanych na ich terytorium, zwalniając się tym samym od międzynarodowej odpowiedzialności.

\subsection{Sprawa huty w Trail (1941)}

Trwający 15 lat spór pomiędzy Kanadą a Stanami Zjednoczonymi, dotyczący huty cynku w kanadyjskim miasteczku Trail, zakończony został orzeczeniem, które przyczyniło się do powstania międzynarodowego prawa środowiska ${ }^{126}$. Spór dotyczył możliwości nałożenia na kanadyjską hutę cynku ograniczeń emisji substancji, które powodowały szkody w środowisku naturalnym przygranicznych terenów Stanów Zjednoczonych, obniżając plony z upraw rolników w stanie Waszyngton. Huta ołowiu i cynku w kanadyjskim Trail wydzielała do atmosfery duże ilości zanieczyszczeń, te zaś przenoszone przez wiatr wywoływały szkody w środowisku naturalnym Stanów Zjednoczonych. Szkody przejawiały się zarówno obniżeniem plonów, jak i wartości nieruchomości. Przedsiębiorstwo zarządzające hutą, Consolidated Mining and Smelting Company of Canada in Trail, British Columbia, przystawało na ugodowe rozwiązania wcześniejszych sporów podobnej natury z mieszkańcami Kanady, wypłacając im odszkodowania za utracone uprawy, zdecydowanie odmawiając jednak zgody na nałożenie jakichkolwiek ograniczeń emisji szkodliwych substancji, bowiem oznaczałyby

${ }^{122}$ Sprawa Terytorium Saary, League of Nations Official Journal 1933, nr 14 (dalej: sprawa Terytorium Saary), s. 1046.

${ }^{123}$ Sprawa Terytorium Saary, s. 1050.

${ }^{124}$ Sprawa Terytorium Saary, s. 1046.

${ }^{125}$ Sprawa Terytorium Saary, s. 1046.

${ }^{126}$ Trail Smelter Arbitral Decision, American Journal of International Law 1939, nr 33, s. $182-$ -212 oraz Trail Smelter Arbitral Tribunal Decision, American Journal of International Law 1941, nr 35, s. 684-736. 
one konieczność ograniczenia wysoce dochodowej produkcji ${ }^{127}$. Na przyjęcie odszkodowania nie zgodzili się amerykańscy farmerzy i w 1927 r. sprawa szkodliwych substancji emitowanych przez hutę $\mathrm{w}$ Trail stała się przedmiotem zabiegów dyplomatycznych i prawnych obu rządów, najpierw przed Międzynarodową Komisją Wspólną (ang. International Joint Commision), zaś po 1935 r. - przed trybunałem arbitrażowym, powołanym do życia mocą konwencji z tegoż roku, celem rozwiązania problemu szkodliwych emisji kanadyjskiej firmy ${ }^{128}$.

Trybunał arbitrażowy sformułował wiążący państwa zakaz zezwalania na wykorzystanie ich terytorium celem spowodowania szkód poza ich granicami, który, jak wskazuje Kenig-Witkowska, stał się z biegiem czasu treścią nowożytnej zasady dobrosąsiedztwa ${ }^{129}$. Za taki stan rzeczy, niezgodny z prawem międzynarodowym, państwo ponosi odpowiedzialność, choćby szkodliwa działalność nie była przedmiotem aktywności jego organów. Przywołując Eagletona, Trybunał sformułował tezę fundamentalną dla międzynarodowego prawa środowiska: „państwo zawsze zobowiązane jest chronić inne państwa przed szkodliwymi działaniami jednostek w jego jurysdykcji" ${ }^{\prime 30}$. Aplikując tezę Eagletona, przy braku wcześniejszej praktyki międzynarodowych sądów i trybunałów, dotyczącej szkód transgranicznych, przywołał praktykę Stanów Zjednoczonych, dotyczącą sporów międzystanowych ${ }^{131}$. Cytując jedno $\mathrm{z}$ orzeczeń w sprawie międzystanowej dotyczącej odpowiedzialności za zanieczyszczenia powietrza wskazał, że po stronie państwa istnieje „sprawiedliwe i uzasadnione oczekiwanie”, aby jego środowisko naturalne nie było zanieczyszczane w znacznym stopniu ${ }^{132}$. Na tej podstawie Trybunał uznał, iż ,zgodnie z zasadami prawa międzynarodowego, podobnie jak prawa amerykańskiego, żadne państwo nie ma prawa wykorzystywać ani zezwalać na wykorzystanie swojego terytorium w sposób, który powoduje szkody (...) na terytorium innego państwa lub w mieniu osób na nim przebywających, jeżeli szkoda ma poważne konsekwencje i udowodniona została

${ }^{127}$ Por.: J. R. Allum, „An Outcrop of Hell”: History, Environment and the Poltics of the Trail Smelter Dispute, (w:) Transboundary Harm in International Law, Lessons from the Trail Smelter Arbitration, red. R. M. Bratspies, R. A. Miller, Cambridge 2006, s. 15.

${ }^{128}$ Por. M. M. Kenig-Witkowska, Prawnomiędzynarodowa ..., s. 311-312.

${ }^{129}$ Por. ibidem, s. 311.

${ }^{130}$ Trail Smelter Arbitral Tribunal Decision, American Journal of International Law 1941, nr 35, s. 713.

${ }^{131}$ Trail Smelter Arbitral Tribunal Decision, American Journal of International Law 1941, nr 35, s. 714. Jak podkreślają Birnie, Boyle i Redgwell, zasady międzynarodowego prawa środowiska jedynie w niewielkim stopniu wywodzą się ze wspólnej praktyki krajowej państw; P. W. Birnie, A. E. Boyle, C. Redgwell, International Law and the Environment, Oksford 2009, s. 27.

${ }^{132}$ Trail Smelter Arbitral Tribunal Decision, American Journal of International Law 1941, nr 35, s. 716, gdzie trybunał cytuje sprawę Georgia p. Tennessee Copper Co. z 1907 r. Jak wskazuje Ellis, rozstrzygnięcie tej sprawy, zapadłe w analogicznych okolicznościach faktycznych, nie opierało się o odpowiedzialność stanu Tennessee, z terytorium którego pochodziły szkodliwe substancje. To powodująca szkody firma została zobowiązana do uiszczenia odszkodowania. Por.: J. Ellis, Has International Laws Outgrown Trail Smelter?, (w:) Transboundary Harm in International Law, Lessons from the Trail Smelter Arbitration, red. R. M. Bratspies, R. A. Miller, Cambridge 2006, s. 58. 
w sposób wyraźny i przekonujący"133. Z treści omawianego judykatu wynika, iż państwo ponosi odpowiedzialność międzynarodową za negatywne immisje, powstające na jego terytorium i przedostające się na terytorium innego państwa. Takie ujęcie odpowiedzialności państwa, z pomięciem kryterium przypisania mu działań jego organów, trudno jest ująć w tradycyjnych ramach odpowiedzialności międzynarodowej państw ${ }^{134}$. Jak trafnie wskazuje Ellis, cytat z Eagletona, przywołanego jako eksperta $\mathrm{w}$ dziedzinie odpowiedzialności międzynarodowej państw, wyjęty z kontekstu, użyty został wbrew zamysłowi autora, który w kolejnych zdaniach dowodzi, że tak rozumiany obowiązek nie może być postrzegany jako podstawa absolutnej odpowiedzialności państw za działania podmiotów prywatnych, bowiem za takie działania państwo nie ponosi żadnej odpowiedzialności, co jest powszechnie przyjętą normą prawa międzynarodowego ${ }^{135}$. Działania jednostek mogą dać podstawę odpowiedzialności państwa za ich własne zaniechania $\mathrm{w}$ zapobieganiu lub poinformowaniu o szkodliwej działalności albo za aktywne jej wspieranie ${ }^{136}$. Ten pogląd Eageltona nie stracił na aktualności także w 1941 r., kiedy trybunał rozpatrywał skargę międzypaństwową oparta o roszczenie grupy amerykańskich rolników w związku z działalnością prywatnej kanadyjskiej firmy ${ }^{137}$.

To rozstrzygnięcie trudno kwalifikować w kategoriach odpowiedzialności międzynarodowej państwa, ponieważ trybunał nie opiera swojej decyzji na szczegółowym opisie dokonanej subsumcji zaniechań Kanady względem treści norm prawa międzynarodowego. Pominął milczeniem opis treści międzynarodowego zobowiązania, którego naruszenia miała dopuścić się Kanada. Subsumcja mogłaby zostać dokonana z uwzględnieniem przynajmniej jednej z trzech podstaw odpowiedzialności państwa, znanych prawu międzynarodowemu: odpowiedzialności na zasadzie ryzyka, naruszenia relacji dobrosąsiedzkich (ang. nuisance) albo braku należytej staranności ${ }^{138}$. Trybunał przywołuje jedynie „poważne konsekwencje" i ,jasne i przekonujące dowody" jako podstawy owej odpowiedzialności ${ }^{139}$. Sformułowanie to identyfikowane bywa w doktrynie $\mathrm{z}$ wyrazem obowiązku wykazywania należytej staranności w stosunkach międzynarodowych $^{140}$. Interpretacja taka byłaby zgodna $\mathrm{z}$ deklarowanym przez trybunał

${ }^{133}$ Trail Smelter Arbitral Tribunal Decision, American Journal of International Law 1941, nr 35, s. 716.

${ }^{134}$ Por.: J. Ellis, op.cit., s. 59.

${ }^{135}$ Por.: C. Eagleton, The Responsibility of States in International Law, Nowy Jork 1928, s. 8-9, por.: J. Ellis, op.cit., s. 59-60.

${ }^{136}$ J. Ellis, op.cit., s. 60.

${ }^{137}$ Por. np.: P. Okowa, State Responsibility For Transboundary Air Pollution In International Law, Oksford 2000, s. 67-68.

${ }^{138}$ Por.: J. Ellis, op.cit., s. 60.

${ }^{139}$ Trail Smelter Arbitral Tribunal Decision, American Journal of International Law 1941, nr 35, s. 716.

${ }^{140}$ Por.: J. Ellis, op.cit., s. 60-61. Ale por.: P. Daranowski, J. Połatyńska, Prawo międzynarodowe publiczne, Warszawa 2011, s. 69, gdzie autorzy wskazują, że podstawą rozstrzygnięcia była zasada słuszności. 
obowiązkiem zapobiegania szkodom innych państw, powodowanym z ich terytorium, jednak niesie za sobą liczne wątpliwości dotyczące współzależności pomiędzy odpowiedzialnością międzynarodową państw a odpowiedzialnością międzynarodową za czyny niezakazane prawem międzynarodowym. Jak już wspomniano, reguła sformułowana w orzeczeniu dotyczącym huty $\mathrm{z}$ Trail jest ściśle powiązana z zasadą dobrego sąsiedztwa, zapisaną w art. 21 Deklaracji sztokholmskiej ${ }^{141}$. Obowiązek ten Barboza wywodzi z rzeczywistości prawnej, w której nie ma miejsca na pełną i bezwzględną suwerenność państw ${ }^{142}$. Konsekwencje orzeczenia $\mathrm{w}$ sprawie huty $\mathrm{w}$ Trail dla prawa odpowiedzialności międzynarodowej najlepiej widoczne są na przykładzie trwających od $1978 \mathrm{r}$. burzliwych prac KPM nad Projektem artykułów o prewencji z 2001 r. Niemożność ustalenia reguł podziału pomiędzy obszarem aktywności państw, opisanych $\mathrm{w}$ treści tego projektu, a zasadami odpowiedzialności państw spowodowała przede wszystkim dynamiczny wzrost dorobku traktatowego społeczności międzynarodowej w obszarze międzynarodowego prawa środowiska. Wobec praktycznych trudności z identyfikacją reguł odpowiedzialności za brak należytej staranności powstały liczne, szczegółowe reżimy traktatowe, opisujące przede wszystkim treść obowiązku prewencji, ale także mechanizmy kompensacji powstałych szkód ${ }^{143}$. Na podstawie zapisów owych konwencji możliwe jest zidentyfikowanie treści działań, które winno podjąć państwo wykazujące należytą

${ }^{141}$ Deklaracja Konferencji Narodów Zjednoczonych w sprawie Naturalnego Środowiska Człowieka, podpisana w Sztokholmie w 1972 r., U.N. Doc. A/CONF.48/14/Rev. 1, dalej: Deklaracja sztokholmska. Konferencja Narodów Zjednoczonych w sprawie środowiska człowieka, zwołana w następstwie przyjęcia przez Zgromadzenie Ogólne ONZ Rezolucji G.A. Res. nr 2398 (XXIII), odbyła się pomiędzy 5 a 16.VI.1972 r. Na konferencji reprezentowanych było 116 państw za pośrednictwem ok. 6000 uczestników. Konferencja zakończyła się przyjęciem tzw. Deklaracji sztokholmskiej w sprawie środowiska człowieka oraz Planu działania, który obejmował 109 zaleceń i rezolucji, dotyczących zobowiązań ONZ zmierzających do skutecznej ochrony środowiska naturalnego. Por.: M. M. Kenig-Witkowska, Międzynarodowe prawo..., s. 20-22; zob. też: M. Górski, Prawo ochrony środowiska, Warszawa 2009, s. 77. Birnie, Boyle i Redgwell utożsamiają decyzję $\mathrm{w}$ sprawie huty $\mathrm{w}$ Trail z potwierdzeniem obowiązku prewencji; P. W. Birnie, A. E. Boyle, C. Redgwell, op.cit., s. 145. M. M. Kenig-Witkowska utożsamia sentencję orzeczenia w sprawie huty z Trail z treścią owej zasady; por.: M. M. Kenig-Witkowska, Międzynarodowe prawo..., s. 19; choć, jak wskazuje J. Ellis, wielu autorów przywołuje praktyczne różnice pomiędzy sentencją wyroku a treścią owej zasady; por.: J. Ellis, op.cit., s. 62. Zasada dobrosąsiedztwa jako podstawa obowiązku prewencji omówiona została w rozdziale IV.

${ }^{142}$ Por. Drugi raport Barbozy, U.N. Doc. A/CN.4/402, s. 157.

${ }^{143}$ Wśród dorobku traktatowego wskazać można Konwencję genewską w sprawie transgranicznego zanieczyszczania powietrza na dalekie odległości dotyczącego kontroli emisji tlenków azotu oraz ich przepływu o charakterze transgranicznym z 1979 r., Dz.U. 1985, nr 60, poz. 311. oraz osiem towarzyszących jej protokołów dodatkowych, Konwencję wiedeńską o ochronie warstwy ozonowej z 1985 r., Dz.U. 1992, nr 98, poz. 488, wraz z protokołem montrealskim w sprawie substancji zubożających warstwę ozonową z 1987 r., Dz.U. 1992, nr 98, poz. 490; Konwencję o ochronie środowiska morskiego obszaru Morza Bałtyckiego, sporządzona w Helsinkach dnia 9 kwietnia 1992 r., Dz.U. 2000, nr 28, poz. 346; Ramową Konwencję Narodów Zjednoczonych w sprawie zmian klimatu z 1992 r., Dz.U. 1996, nr 53, poz. 238 wraz z towarzyszącym jej protokołem z Kyoto z 1998 r., Dz.U. 2002, nr 144, poz. 1207. Por.: M. Górski, op.cit., Warszawa 2009, s. $241 \mathrm{i} \mathrm{n}$. 
staranność. Niektóre z owych dokumentów wprowadzają procedury stosowane w przypadku niezgodności praktyki z przepisami traktatu (tzw. procedury noncompliance) i towarzyszące im środki, zastępujące w praktyce mechanizmy odpowiedzialności międzynarodowej ${ }^{144}$. Sands wskazuje, iż procedury te to instrument pośredni pomiędzy koncyliacją a sądowym rozwiązywaniem sporów międzynarodowych, Kenig-Witkowska twierdzi jednak, że procedury są emanacją prawa traktatów, upatrując ich mocy wiążącej $\mathrm{w}$ treści zasady pacta sunt servanda ${ }^{145}$. Inni autorzy uznają że niektóre $\mathrm{z}$ tych procedur zaliczyć można do instrumentów miękkiego prawa międzynarodowego ${ }^{146}$.

\subsection{Sprawa cieśniny Korfu (1949)}

Zakaz wykorzystania terytorium państwowego w sposób powodujący powstanie szkód innych, zapisany po raz pierwszy $w$ treści orzeczenia $\mathrm{w}$ sprawie huty w Trail, potwierdził w 1949 r. MTS, rozstrzygając spór pomiędzy Wielką Brytanią a Albanią dotyczący cieśniny Korfu. Trybunał opisał wówczas ogólną regułę braku odpowiedzialności państwa za działania osób prywatnych realizowane na jego terytorium.

Pytanie postawione MTS dotyczyło odpowiedzialności Albanii za szkody, które poniosła flota brytyjska, gdy należące do niej dwa statki wojenne przepływały przez zaminowane wody terytorialne Albanii. Albania nie była odpowiedzialna za umieszczenie ładunków, jednak mając o nich wiedzę nie ostrzegła kapitanów brytyjskich jednostek o grożącym niebezpieczeństwie ${ }^{147}$.

MTS uznał, że sam fakt powstania szkód w wyniku eksplozji min na terytorium Albanii nie czyni jej odpowiedzialną. Obowiązki Albanii, wynikające z uznanych zasad prawa międzynarodowego, ograniczone były do przedstawienia wyjaśnień dotyczących okoliczności szkodliwego incydentu ${ }^{148}$. Państwo nie może odmówić takich wyjaśnień, przywołując jako powód odmowy jedynie brak wiedzy lub troski o poczynania osób prywatnych na jego terytorium. W ograniczonym zakresie państwo jest zobowiązane do poinformowania o sposobach zdobywania wiedzy i pozyskiwania wyjaśnień dotyczących szkodliwych zajść. $Z$ faktu sprawowania kontroli nad terytorium państwowym nie wynika domniemanie wiedzy władz o bezprawnych czynach na nim dokonanych czy o ich sprawcach ani obowiązek posiadania takiej wiedzy. Obowiązek przed-

${ }^{144}$ Por.: M. M. Kenig-Witkowska, Międzynarodowe prawo..., s. 133-138, która szczegółowo opisuje procedury non-compliance. Zob. też: J. Ellis, op.cit., s. 64; R. Wolfrum, Means of Ensuring Compliance and Enforcement in International Environmental Law, RdC 1998, nr 272, s. 9-154.

${ }^{145}$ Por. M. M. Kenig-Witkowska, op.cit, s. 133.

${ }^{146}$ P. W. Birnie, A. E. Boyle, C. Redgwell, op.cit., Oksford 2009, s. 245.

147 Por.: Wyrok w sprawie cieśniny Korfu, STSM, International Court of Justice Reports 1949 (dalej: sprawa cieśniny Korfu), s. 21-22. Trybunał zlecił przeprowadzenie eksperymentów dowodowych, z których bez wątpliwości wynikało, że obsługa albańskiego portu musiała była zauważyć obcy statek instalujący miny.

${ }^{148}$ Sprawa cieśniny Korfu, s. 18. 
stawienia informacji nie wynika także $\mathrm{z}$ domniemania odpowiedzialności państwa, a jedynie z jego wyjątkowej, często wyłącznej możliwości uzyskania informacji na podległym mu terytorium o przyczynach powstania szkody, której to możliwości nie posiada poszkodowany ${ }^{149}$. MTS uznał, że na władzach Albanii spoczywał obowiązek poinformowania kapitanów statków brytyjskich o istnieniu pola minowego na wodach terytorialnych kraju celem ochrony bezpieczeństwa żeglugi. Obowiązek ów wynikał z ogólnych i przyjętych bez sprzeciwu zasad, tj. elementarnych względów człowieczeństwa (ang. elementary considerations of humanity), bardziej wymagających w czasie pokoju niż wojny, z zasady wolności mórz oraz obowiązku każdego państwa, aby nie dopuścić do świadomego wykorzystywania jego terytorium do czynów godzących w chronione prawem interesy innych państw ${ }^{150}$. Ponadto, władze winny podjąć wszelkie niezbędne kroki w celu zapobieżenia szkodom innych suwerenów. Jak wskazał Trybunał, ,jest zobowiązaniem każdego państwa, aby nie udostępniać świadomie swojego terytorium do czynów naruszających prawa innych państw" $" 151$. Albania nie podjęła żadnych działań, aby zapobiec katastrofie: nie poinformowała o istnieniu pola minowego ani nie ostrzegła Brytyjczyków o grożącym niebezpieczeństwie, mimo iż posiadała o nim wiedzę i dysponowała czasem niezbędnym do przekazania ostrzeżenia. Pozyskawszy wiedzę o rozmieszczeniu ładunków na wodach terytorialnych, pracownicy albańskiego portu powinni byli poinformować przepływające statki o położeniu pola minowego. Wobec zaniechania podjęcia jakichkolwiek działań zmierzających do zapobieżenia katastrofie, w tym przekazania stosownej informacji, Albania uznana została za międzynarodowo odpowiedzialną za szkody poniesione przez statki Jej Królewskiej Mości i zobowiązana do wypłaty odszkodowania ${ }^{152}$.

\subsection{Sprawa zatrucia Renu przez firmę Sandoz (1986)}

Opisując należytą staranność w porządku traktowym międzynarodowego prawa środowiska, przywołać należy sprawę z 1986 r., dotyczącą zatrucia rzeki Ren. Do zanieczyszczenia jej wód doszło wskutek pożaru w magazynie agrochemicznym szwajcarskiej firmy farmaceutycznej Sandoz, obecnie Novartis, i przedostania się do rzeki substancji przechowywanych w magazynie oraz

${ }^{149}$ Sprawa cieśniny Korfu, s. 18.

${ }^{150}$ Sprawa cieśniny Korfu, s. 22. Por. P. Daranowski, J. Połatyńska, op.cit., s. 71.

${ }^{151}$ Sprawa cieśniny Korfu, s. 22. Por.: także sprawa młynów rzecznych na rzece Urugwaj (Argentyna p. Urugwajowi), ICJ Reports 2010, s. 38; orzeczenie omówione w dalszej części rozdziału.

${ }^{152}$ Sprawa cieśniny Korfu, s. 22-23. Zob. także: P. Okowa, op.cit., s. 67-68, która podkreśla, że decyzja Trybunała wywiedziona została z treści zasad prawa międzynarodowego. Szczegóły postępowania w sprawie huty w Trail opisał J. E. Read, The Trail Smelter Dispute, (w:) Transboundary Harm in International Law, Lessons Learned from the Trail Smelter Arbitration, red. R. M. Bratspies, R. A. Miller, Cambridge 2006, s. 27-33. 
środków użytych do gaszenia ognia. W następstwie pożaru i akcji gaśniczej także do atmosfery dostało się kilka ton szkodliwych substancji. Spowodowały one zanieczyszczenie okolicy rzeki i jej wód, które przybrały czerwoną barwę ę3 $^{153}$. Zatrucie spowodowało znaczące straty w ekosystemie rzeki i jej okolic. Przyczyna pożaru nigdy nie została ustalona. Postępowania karne w sprawie zabójstwa i 21 przypadków nieumyślnego spowodowania uszczerbku na zdrowiu zakończyły się uniewinnieniem siedmiu podejrzanych pracowników Sandoz. Nikomu nie przypisano winy za naruszenie przepisów porządkowych. Na niewysokie kary grzywny za naruszenie ustawy o ochronie zasobów wodnych przed zanieczyszczeniami skazani zostali w 1992 r. dwaj pracownicy przedsiębiorstwa, którzy spowodowali dodatkowe zatrucie wód rzeki poprzez spłukanie zgliszczy wodą po zakończeniu akcji gaśniczej. Firma Sandoz zawarła ponad 1100 umów ugodowych na łączną kwotę 42 milionów franków szwajcarskich z poszkodowanymi ze Szwajcarii, Francji, Niemiec i Holandii bez postępowań sądowych. Pozostałe roszczenia, o łącznej wartości blisko 14 milionów franków, pokryły firmy ubezpieczeniowe. Sandoz wyłożyła także 10 milionów franków na zasilenie Funduszu reńskiego, finansującego badania nad ekosystemem rzeki ${ }^{154}$.

Odpowiedzialność Szwajcarii za szkody powstałe wskutek awarii w magazynach firmy Sandoz rozpatrywana mogła była być w oparciu o przepisy prawa zwyczajowego, przede wszystkim jednak o zapisy traktatów wielostronnych dotyczących Renu ${ }^{155}$. Spośród nich najważniejsze to: konwencja w sprawie powołania międzynarodowej komisji ds. ochrony Renu przed zanieczyszczeniami (tzw. konwencja berneńska) z $1963 \mathrm{r}^{156}$ oraz konwencja dotycząca ochrony Renu przed zanieczyszczeniami chemicznymi (tzw. reńska konwencja chemiczna) z 1976 r. ${ }^{157}$ Szwajcaria była stroną obu umów. Mocą pierwszej z nich powołana została międzynarodowa komisja ds. ochrony Renu przed zanieczyszczeniami. Jej zadaniem było rozwiązywanie problemów związanych z rosnąca ilością szkodliwych substancji w wodach rzeki. Wobec niesatysfakcjonujących postępów prac komisji po 13 latach państwa-strony podpisały reńską konwencję chemiczna, przyznająca jej więcej uprawnień ${ }^{158}$. Państwa ustanowiły możliwość podjęcia arbitrażu w przypadkach sporów co do zakresu obowiązków wynikają-

${ }^{153} \mathrm{~W}$ ciagu kolejnych kilku lat Ren uległ całkowitemu, naturalnemu oczyszczeniu. Por.: A. Boos-Hersberger, Transboundary Water Pollution and State Responsibility: The Sandoz Spill, Annual Survey of International and Comparative Law 1997, nr 4(1), s. 107.

${ }^{154}$ Ibidem, s. 107-109. Por.: I. Leybold-Johnson, Kontroverse um Brandplatz Schweizerhalle dauert an [online] swissinfo.ch, z 31.10.2011 [dostęp: 2013-01-20]. Dostępny w Internecie: $<\mathrm{http}$ ://www.swissinfo.ch/ger/politik_schweiz/Kontroverse_um_Brandplatz_Schweizerhalle_dauert an_html? cid $=31466146>$.

${ }^{155}$ Por.: A. Boos-Hersberger, op.cit., s. 114.

156994 UNTS 3, 1963 r. (dalej: konwencja berneńska).

${ }^{157} 16$ ILM 242, 1977 r. (dalej: reńska konwencja chemiczna). Obecnie miejsce obu dokumentów zajmuje Porozumienie berneńskie o ochronie Renu (niem. Übereinkommen zum Schutz des Rheins) z 12 kwietnia 1999 r., z sekretariatem Komisji rezydującym w Koblencji [online]. IKSR [dostęp: 2013-01-20]. Dostępny w Internecie: <http://www.iksr.org/index.php?id=33>.

${ }^{158}$ Por.: A. Boos-Hersberger, op.cit., s. 115. 
cych z celu i przedmiotu umowy ${ }^{159}$. Oś regulacji obu konwencji stanowiło zapobieganie szkodom, raczej niż określenie mechanizmów odszkodowawczych, uruchamianych po ich powstaniu. W treści umowy nie został określony obowiązek odszkodowawczy państwa, nawet w sytuacji, gdy podmiot prywatny, który bezpośrednio przyczynił się do powstania szkody, odmówi jej kompensacji.

Określenie udziału Szwajcarii w powstaniu katastrofy było więc szczególnie trudne. Nie istniał konwencyjny mechanizm reparacji - traktaty przewidywały jedynie arbitraż. Nie były także znane faktyczne przyczyny pożaru - możliwe było zarówno naruszenie prawa administracyjnego, jak i podpalenie. $Z$ trudności $\mathrm{z}$ ustaleniem roli władz w owej katastrofie sprawę zdawali sobie zarówno przedstawiciele federacji, jak i państwa, na terytorium których znajdowali się poszkodowali przez eksplozję.

Z roszczeniem odszkodowawczym wobec Szwajcarii jako pierwsza wystąpiła Francja ${ }^{160}$. Nigdy jednak nie doszło do arbitrażu, bowiem władze Szwajcarii i zarząd firmy zgodnie przyjęły na siebie obowiązek odszkodowawczy. $\mathrm{Z}$ treści oświadczenia nie wynikało, w jakiej mierze i w jaki sposób Szwajcaria ponosiłaby ewentualną odpowiedzialność za powstała szkodę ${ }^{161}$. Kwestia ta nie stała się więc przedmiotem rozważań komisji arbitrażowej.

Roszczenia odszkodowawcze wobec Szwajcarii, oparte o supozycję naruszenia przez nią zobowiązań międzynarodowych, implikowałyby związek przyczynowy pomiędzy szkodą a działaniem lub zaniechaniem organu państwa. Taki związek przyczynowy byłby trudny do wykazania, zwłaszcza wobec braku informacji co do faktycznych przyczyn powstania ognia. Jednocześnie analiza stanu faktycznego sprawy pozwala wskazać na niedopełnienie pewnych obowiązków przez organy federacji, wynikających z zasady prewencji zawartej w obu konwencjach.

Przechowywanie substancji chemicznych w magazynie firmy Sandoz odbywało się w zgodzie z prawem szwajcarskim, tj. mocą decyzji administracyjnej magazyn został uznany za przystosowany do przechowywania chemikaliów ${ }^{162}$. Jednocześnie owe regulacje krajowe nie wypełniały dyspozycji wspominanych wyżej traktatów. Magazyn, w którym doszło do pożaru, pierwotnie pełnił funkcję magazynu maszyn i uznany został za odpowiedni do przechowywania substancji chemicznych mocą decyzji administracyjnej. Jednak raport firmy ubezpieczeniowej z $1981 \mathrm{r}$. wskazywał, że to pomieszczenie nie spełnia wymagań stawianych magazynom substancji chemicznych, a decyzja mogła stanowić naruszenie szwajcarskiego prawa administracyjnego ${ }^{163}$. O treści raportu ubezpieczyciela władze wiedziały i nie podjęły żadnych kroków celem uchylenia wydanej

\footnotetext{
${ }^{159}$ Art. 15 reńskiej konwencji chemicznej.

${ }^{160}$ X. Hanqin, op.cit., s. 91 .

${ }^{161}$ Ibidem.

162 Por.: Wir sollten aufwachen und überlegen [online]. DER SPIEGEL 1986, nr 47, s. 138-147 [dostęp: 2013-01-20]. Dostępny w Internecie: <http://www.spiegel.de/spiegel/print/d-13521501.html>.

${ }^{163}$ Por.: Ibidem.
} 
decyzji czy modyfikacji przepisów administracyjnych. Takie zaniechanie mogłoby zostać uznane za sprzeczne z dyspozycją art. 7 reńskiej konwencji chemicznej, obligującej do skutecznej implementacji jej postanowień do prawa krajowego. Ponadto 24-godzinna zwłoka w przekazaniu informacji o katastrofie do wiadomości publicznej, w tym do władz i mieszkańców poszkodowanych państw, także mogła być postrzegana jako naruszenie art. 11 reńskiej konwencji chemicznej, obligującego do niezwłocznego dopełnienia obowiązku informacyjnego. Owo naruszenie pozwalałoby pociągnać Szwajcarię do międzynarodowej odpowiedzialności, niezależnie od jej obowiązku uczestnictwa w postępowaniu arbitrażowym przewidzianym treścią konwencji. Sądowe rozstrzygnięcie o odpowiedzialności władz Szwajcarii nie leżało jednak $\mathrm{w}$ interesie żadnej ze stron. Wstapienie w spór mogło było bowiem skutkować zidentyfikowaniem dodatkowych elementów obowiązku prewencji, wiążącego wszystkie państwa-strony konwencji. Tego ryzyka żadne z państw nie chciało podejmować, zwłaszcza że ocena obowiązujących regulacji prawa szwajcarskiego była najwyższa spośród wszystkich obowiązujących w państwach związanych traktatem ${ }^{164}$.

Rząd Szwajcarii uznał swoją odpowiedzialność za brak należytej staranności przy zapobieganiu wypadkowi poprzez niewystarczającą regulację sposobu działania przemysłu farmaceutycznego ${ }^{165}$. Paradoksalnie, uznanie roszczenia świadczy o słabości, nie o sile, zapisów konwencyjnych międzynarodowego prawa środowiska. Niejasna jest dystynkcja pomiędzy zapisami tych konwencji, a zasadami odpowiedzialności międzynarodowej państw. Trudna do ustalenia jest także konieczna zależność pomiędzy przypisaniem państwu odpowiedzialności za zaniechanie jego organów a oceną ekspertów, dotyczącą technologicznych czy biologicznych związków przyczynowo-skutkowych. Te trudności wpływają na ograniczenie zakresu aplikacji zasady prewencj ${ }^{166}$. Jak pokazuje sprawa Sandoz, doprecyzowanie treści owych standardów często nie leży w interesie ani szkodzących, ani poszkodowanych.

\subsection{Sprawa zakładników amerykańskich w Teheranie (1980)}

Odpowiedzialność państwa za zaniechanie stała się przedmiotem orzeczenia Międzynarodowego Trybunału Sprawiedliwości, opisującego zakres obowiązków państwa wobec goszczących na jego terytorium predstawicieli dyplomatycznych.

\footnotetext{
${ }^{164}$ Por.: A. Boos-Hersberger, op.cit., s. 118-119.

${ }^{165}$ Projekt Barbozy, U.N. Doc. A/51/10, Komentarz (5) s. 110, Projekt artykułów o prewencji z 2001 r., pkt (8), s. 154; Por. też: A. Boos-Hersberger, która podkreśla, że Szwajcaria nie została uznana przez żaden trybunał odpowiedzialną za brak należytej staranności, zaś zakres jej ewentualnej odpowiedzialności pozostaje niejasny; por.: A. Boos-Hersberger, op.cit., s. 104.

${ }^{166}$ Wzajemna zależność obu zaproponowanych przez KPM reżimów odpowiedzialności oraz należytej staranności omówiona zostanie w rozdziale IV.
} 
Antyamerykańskie nastroje w Iranie wzmogły się po przejęciu władzy w $1979 \mathrm{r}$. przez ajatollaha Chomeiniego, tj. z początkiem irańskiej rewolucji islamskiej. Formalnie sprawujący władzę rząd Bazargana nie był w stanie powstrzymać antyamerykańskich protestów towarzyszących obaleniu proamerykańskiego szacha Pahlaviego, który opuścił kraj i udał się na emigrację do Stanów Zjednoczonych. 4 listopada 1979 r. w Teheranie, podczas antyamerykańskiej demonstracji, w której uczestniczyło około trzech tysięcy osób, kilkaset z nich, przełamując zabezpieczenia na oknach piwnicy budynku kancelarii, wdarło się na teren ambasady Stanów Zjednoczonych i przejęło nad nim kontrolę. Pracownicy ochrony ambasady, działający na zlecenie rządu irańskiego, nie podjęli żadnych działań zmierzających do powstrzymania demonstrantów lub zniechęcenia ich do ataku. Napastnicy pojmali jako zakładników 52 pracowników ambasady. Kiedy przez dwie godziny demonstranci usiłowali podpalić budynek ambasady i sforsować metalowe drzwi do pomieszczenia, w którym schronili się jej pracownicy, przedstawiciele irańskich sił bezpieczeństwa nie otrzymali rozkazów udzielenia wsparcia pracownikom ambasady, mimo ich wielokrotnych apeli o pomoc kierowanych do irańskiego ministerstwa spraw zagranicznych i próśb dyplomaty ONZ, który skontaktował się z biurem premiera i ministerstwem spraw zagranicznych w czasie trwania ataku ${ }^{167}$. Rząd nie podjął żadnych działań zmierzających do oczyszczenia terenu ambasady z napastników, uratowania zakładników ani negocjacji z protestującymi. Rząd nie podjął działań także wówczas, gdy dwie kolejne ambasady Stanów Zjednoczonych w miastach Tabriz i Shiraz padły ofiarami podobnych ataków. Zakładnicy byli przetrzymywani przez 444 dni w warunkach uwłaczających ich godności i zagrażających zdrowiu ${ }^{168}$.

Brak działania po stronie władz Iranu był tym bardziej wyraźny, że w analogicznej sytuacji z lutego tego samego roku podjęta została skuteczna interwencja przeciwko napastnikom i 40 zakładników przetrzymywanych w budynku ambasady zostało uwolnionych, zaś władze Iranu przeprosiły Stany Zjednoczone za zajście $^{169}$.

Przedstawiciele Stanów Zjednoczonych domagali się uznania odpowiedzialności władz Iranu za przetrzymywanie zakładników, jako za akt sprzeczny $\mathrm{z}$ treścią międzynarodowych zobowiązań tego państwa wynikających z prawa dyplomatycznego, a także zaprzestania dalszego naruszania prawa, tj. doprowa-

${ }^{167}$ Stany Zjednoczone przeciwko Iranowi, sprawa amerykańskiego personelu dyplomatycznego i konsularnego w Teheranie, ICJ Pleadings 1982, (dalej: sprawa zakładników w Teheranie), s. 3. Por. także: nakaz zastosowania środków tymczasowych z 15 grudnia 1979 r., sprawa amerykańskiego personelu dyplomatycznego i konsularnego w Teheranie, ICJ Reports 1979, s. 7; wyrok z 24 maja 1980 r. w sprawie amerykańskiego personelu dyplomatycznego i konsularnego w Teheranie, 1980 r., (dalej: wyrok w sprawie zakładników w Teheranie), s. 3; nakaz z 12 maja 1980 r., w sprawie amerykańskiego personelu dyplomatycznego i konsularnego w Teheranie, ICJ Reports, 1981 r., s. 45.

${ }^{168}$ Sprawa zakładników amerykańskich w Teheranie, s. 3-8.

${ }^{169}$ Wyrok w sprawie zakładników w Teheranie, s. 31.; J. C. Barker, The Protection of Diplomatic Personnel, Aldershot 2006, s. 77. 
dzenia do uwolnienia zakładników, wypłaty odszkodowania i wszczęcia postępowania karnego względem sprawców zamachu ${ }^{170}$.

W treści rozstrzygnięcia MTS doprecyzował treść zasady odpowiedzialności państw w przypadku szkodliwych działań osób prywatnych. Zidentyfikował ciążący na Iranie obowiązek ochrony wszystkich przedstawicieli personelu dyplomatycznego pozostających $\mathrm{w}$ jego granicach przed zagrożeniami wewnętrznymi, zgodnie z treścią art. 22 ust. 2 KWSD. Ów zapis wymaga od państwa przedsiębrania „wszelkich niezbędnych kroków celem ochrony siedziby misji”, czyniąc owo zobowiązanie zobowiązaniem „szczególnym”"171. Iran nie dopełnił owego obowiązku, nie wykazując należytej staranności przy ochronie amerykańskich dyplomatów. Ów brak staranności doprowadził do trwającego ponad rok przetrzymywania zakładników w siedzibie teherańskiej ambasady przez przeciwników interwencyjnej polityki USA w Iranie. MTS bez wątpienia uznał, że rząd Iranu nie podjął „niezbędnych kroków” celem ochrony pomieszczeń misji, jej personelu i archiwów ${ }^{172}$. Nie podjął żadnych kroków zmierzających do zapobieżenia atakowi lub udaremnienia go, ani w Teheranie, ani podczas ataków na konsulaty w Tabiz i Shiraz ${ }^{173}$. Owo zaniechanie nie wynikało jednak z niedbalstwa czy braku możliwości działania. Taka możliwość istniała, co władze udowodniły przeprowadzając skuteczną akcję przeciwko napastnikom w lutym tego samego roku ${ }^{174}$.

Przytaczając liczne wypowiedzi przywódców irańskiej rewolucji ${ }^{175}$, w tym samego Chomeiniego, MTS dowodził, że: „zgoda na te zdarzenia udzielona została przez ajatollaha Chomeiniego i inne organy państwa irańskiego, a decyzja o utrzymywaniu stanu naruszenia umożliwiała uznanie zajęcia terenu ambasady i przetrzymywanie zakładników za akty rzeczonego państwa. Bojownicy, sprawcy napaści i strażnicy zakładników stali się funkcjonariuszami irańskiego państwa, których akty pociagają odpowiedzialność międzynarodową" ${ }^{, 176}$. Trybunał uznaje więc zgodę na utrzymujący się stan naruszania prawa za równoznaczną z przyjęciem na siebie odpowiedzialności za nie przez Iran. Konstatacja

${ }^{170}$ Konwencja wiedeńska o stosunkach dyplomatycznych, sporządzona w Wiedniu dnia 18 kwietnia 1961 r. Dz.U. 1965, nr 37, poz. 233 (dalej: KWSD). Stany Zjednoczone zarzucały naruszenia art. 22, 24, 25, 27, 29, 31, 37 i 47 tegoż traktatu oraz art. 28, 31, 33, 34, 36 i 40 Konwencji wiedeńskiej o stosunkach konsularnych z 24 kwietnia 1963 r. (Dz.U. 1982, nr 13, poz. 98). Ponadto władze Iranu nie uczyniły zadość dyspozycjom art. 4 i 7 Konwencji o zapobieganiu przestępstwom i karaniu sprawców przestępstw przeciwko osobom korzystającym z ochrony międzynarodowej, w tym przeciwko dyplomatom (Dz.U. 1983, nr 37, poz. 168), art. II (4), XIII, XVIII i XIX umowy bilateralnej o przyjaźni, stosunkach gospodarczych i prawach konsularnych pomie-dzy USA i Iranem oraz art. 2 ust. 3 i ust. 4 oraz 33 Karty Narodów Zjednoczonych (Dz.U. 1947, nr 23, poz. 90); Por.: wyrok w sprawie zakładników w Teheranie, s. 7 i 31.

${ }_{171}$ Art. 22 KWSD.

${ }^{172}$ Wyrok w sprawie zakładników w Teheranie, pkt 74, pkt 63, s. 31.

${ }^{173}$ Wyrok w sprawie zakładników w Teheranie, pkt 74, pkt 63, s. 31.

${ }^{174}$ Wyrok w sprawie zakładników w Teheranie, pkt 74, pkt 64, s. 31.

${ }^{175}$ Wyrok w sprawie zakładników w Teheranie, s. 33.

${ }^{176}$ Wyrok w sprawie zakładników w Teheranie, pkt 74, s. 35. 
ta nie oznaczała jednak, jak wyjaśniał Trybunał, że działania uczestników zamieszek uznać można za działania przedstawicieli państwa, ani że działania te mogły zostać przypisane państwu irańskiemu ${ }^{177}$. Przypisanie takie mogłoby nastapić jedynie wówczas, gdyby zostało wykazane, że bojownicy działali w imieniu państwa, otrzymawszy pełnomocnictwo od uprawnionego organu irańskiego państwa do przeprowadzenia konkretnych operacji ${ }^{178}$. Za takie pełnomocnictwo nie można było uznać oświadczenia ajatollaha Chomeiniego z 1 listopada $1979 \mathrm{r}$. W jego treści uzależniał „od wykorzystania przez drogich uczniów i studentów całej ich siły w atakach przeciwko Stanom Zjednoczonym i Izraelowi" wymuszenie na Stanach Zjednoczonych przekazania do Iranu „zdetronizowanego szacha-przestępcy i wyrażenie potępienia dla amerykańskiego spisku"179. Za pełnomocnictwo nie może być uznana pochwała, jaką Chomeini przekazał bojownikom telefonicznie $\mathrm{w}$ noc zamachu na ambasadę ${ }^{180}$, tak jak i nie były nim jego liczne wypowiedzi pochwalające atak i jego wykonawców i odmawiające interwencji zmierzającej do usunięcia utrzymującego się naruszania prawa międzynarodowego ${ }^{181}$. Uznanie dla ataków znalazło się także w treści dekretu rządowego z 17 listopada 1979 r., autorstwa Chomeiniego ${ }^{182}$. Pomimo wcześniejszych deklaracji przedstawicieli rządu irańskiego o świadomości ciążącego na nich obowiązku udzielenia pomocy ofiarom ataku, żadne działania nie zostały przedsięwzięte ${ }^{183}$. W treści dekretu z 17 listopada zaznaczono, że teren ambasady i zakładnicy pozostaną w rękach bojowników dopóki Stany Zjednoczone nie ekstradują szacha do Iranu i nie zwrócą jego osobistego majątku ${ }^{184}$.

Wbrew jednoznacznej deklaracji Trybunału, jakoby bojownicy nie reprezentowali rządu, według Cassese dzień wydania oświadczenia przez Chomeiniego wskazać można jako cezurę, po której bojownicy stali się przedstawicielami państwa $^{185}$. O ile przed oficjalnym uznaniem działań bojowników władze Iranu mogłyby ponosić odpowiedzialność jedynie za niedołożenie należytej staranności do udaremnienia ataku, o tyle owo uznanie ich działań uczyniło Iran bezpośrednio odpowiedzialnym za szkody przez nich wywołane. Przypisanie władzom odpowiedzialności nie wynikało z samych czynów osób prywatnych, które - jak wykazano - nie działały z upoważnienia rządu, ale z poparcia ich przez władze.

${ }^{177}$ Wyrok w sprawie zakładników w Teheranie, pkt 58, s. 29. Ale por. np. J. Sutor, który cytując Shawa, w ten właśnie sposób odczytuje decyzję MTS; J. Sutor, op.cit., s. 226, choć pisze także, iż „MTS zarzucił władzom Iranu m.in., iż ponoszą odpowiedzialność z tytułu niepodjęcia kroków i zaniechania"; Ibidem, s. 225. O odmiennych interpretacjach tego orzeczenia zob. P. Dupuy, The International Law of State Responsibility: Revolution or Evolution, Michigan Journal of International Law 1989, nr 11, s. 121-122.

${ }^{178}$ Wyrok w sprawie zakładników w Teheranie, pkt 58, s. 29.

${ }^{179}$ Wyrok w sprawie zakładników w Teheranie, pkt 59, s. 29.

${ }^{180}$ Wyrok w sprawie zakładników w Teheranie, pkt 59, s. 29-30.

${ }^{181}$ Wyrok w sprawie zakładników w Teheranie, pkt 71, s. 34-35.

${ }^{182}$ Wyrok w sprawie zakładników w Teheranie, pkt 73, s. 35.

${ }^{183}$ Wyrok w sprawie zakładników w Teheranie, pkt 70-73, s. 33-36.

${ }^{184}$ Wyrok w sprawie zakładników w Teheranie, pkt 73, s. 35.

${ }^{185}$ A. Cassese, op.cit., s. 250-251. 
Owo poparcie spowodowało zmianę prawnej oceny ataku i pozwoliło uznać atakujących za przedstawicieli (ang. agents) państwa, za których naruszenia ponosiło ono odpowiedzialność ${ }^{186}$. Analizując treść orzeczenia i towarzyszących mu komentarzy uznać należy, że Iran przyjął na siebie odpowiedzialność za działania buntowników przez zaniechanie: nie interweniując podczas dokonywanego przez nich zamachu na placówkę dyplomatyczną USA.

\subsection{Sprawa oddzialów contras w Nikaragui (1986)}

Rodzaj kontroli, jaką państwo musi wykonywać nad jednostkami, aby przypisana mu mogła zostać odpowiedzialność za ich działania, MTS opisał w orzeczeniu dotyczącym wspieranych przez USA oddziałów contras w Nikaragui ${ }^{187}$. 9 kwietnia 1984 r. ambasador Nikaragui wystapił do MTS z prośbą o rozstrzygnięcie sporu ze Stanami Zjednoczonymi, dotyczącego odpowiedzialności za działania wojskowe i paramilitarne w i przeciwko Nikaragui ${ }^{188}$. Trybunał, nie bez wątpliwości, uznał, że Stany Zjednoczone czynnie wspierały działania Jednostronnie Kontrolowanych Zasobów Latynoskich (ang. Unilaterally Controlled Latino Assets, dalej UCLAs) ${ }^{189}$, przy pomocy urzędników państwowych finansujących, organizujących i wspierających logistycznie działania UCLAs spoza terytorium kraju ${ }^{190}$. Udzielone przez Stany Zjednoczone wsparcie dotyczyło umieszczania min w portach morskich Nikaragui na przełomie lat 1983/1984, wykonane z upoważnienia Prezydenta USA przez osoby opłacone, poinstruowane i upoważnione przez urzędników Stanów Zjednoczonych, jak też dziesięciu innych ataków lotniczych, naziemnych i morskich, dokonanych w tym samym czasie $^{191}$. Upoważniając UCLAs do zaminowania nikaraguańskich portów, rząd Stanów Zjednoczonych nie wystosował żadnego ostrzeżenia dla statków przepływających wodami terytorialnymi Nikaragui, powodując liczne szkody materialne, ofiary w ludziach i spowodowany nimi wzrost stawek ubezpieczeń morskich ${ }^{192}$.

${ }^{186}$ Wyrok w sprawie zakładników w Teheranie, pkt 74, s. 36.

${ }^{187}$ Nikaragua przeciwko Stanom Zjednoczonym, ICJ Reports 1986, (dalej: sprawa operacji militarnych w Nikaragui), s. 24.

${ }^{188}$ Sprawa operacji militarnych w Nikaragui, s. 24.

${ }^{189}$ CIA używało tego akronimu dla nazwania członków contras, z którymi współpracowało. Por.: Sprawa operacji militarnych w Nikaragui, s. 35.

${ }^{190}$ Por.: sprawa operacji militarnych w Nikaragui, s. 45.

${ }^{191}$ Por.: sprawa operacji militarnych w Nikaragui, s. 48-49. Atak lotniczy na lotnisko w Managua z 8 września 1983 r., eksplozja ropociagu podwodnego z 13 września 1983 r., atak na magazyn z ropą w Benjamin Zeledon z 2 października 1983 r., atak powietrzny i morski na port w Corinto i zniszczenie pełnych zbiorników z ropa, wymagające ewakuacji ludności z 10 października 1983 r., wybuch ropociagu podwodnego z 14 października 1983 r., rakietowy atak morski i powietrzny na baze morska w Potosi z 4-5 stycznia 1984 r., wybuch miny w El Buff z 24 lutego 1984 r., atak morski i powietrzny na zbiorniki z ropą w San Juan del Sur 7 marca 1984 r., zderzenie motorówek minujących port w Puerto Sandino z łodziami patrolowymi straży przybrzeżnej z 30 marca 1984 r., powietrzne wsparcie ataku na San Juan del Norte z 9 kwietnia 1984 r.

192 Por.: sprawa operacji militarnych w Nikaragui, s. 48-49. 
Kiedy ataki miały miejsce, władze przyjęły, że byli za nie odpowiedzialni wyłącznie antyrządowi partyzanci z contras. Początkowo rząd USA utajniał informacje o udzielanym contras wsparciu, jednak po serii artykułów prasowych, oświadczeń przedstawicieli władz i ostatecznie decyzji Kongresu, który oficjalnie przekazał znaczące środki finansowe na „bezpośrednie lub pośrednie wojskowe lub paramilitarne operacje w Nikaragui" w 1983 r. amerykańskie wsparcie dla contras stało się elementem polityki zagranicznej Białego Domu ${ }^{193}$. Przeprowadzanie tajnych operacji w Nikaragui potwierdził także prezydent Reagan podczas konferencji, kilka dni po kolejnym ataku na nikaraguański port $^{194}$. Korzystając $\mathrm{z}$ owego wsparcia contras powodowali znaczące szkody materialne, dopuszczali się zabójstw, morderstw, porwań, tortur i gwałtów, także wobec ludności cywilnej. Nikaragua wnosiła, że Stany Zjednoczone sprawuja „efektywną kontrolę" nad contras, pomagając im strategicznie i taktycznie, celem obalenia rządu nikaraguańskiego ${ }^{195}$. Protesty władz Nikaragui nie spowodowały żadnych zmian w polityce Waszyngtonu. Oświadczenie Reagana Nikaragua interpretowała jako potwierdzenie, iż „Stany Zjednoczone stale i systematycznie udzielały pomocy najemnikom, przeprowadzającym operacje wojskowe przeciwko rządowi Nikaragui" 196 . Trybunał uznał to oświadczenie jedynie za potwierdzenie pewnego udziału USA w incydencie, nie zaś za przyjęcie odpowiedzialności czy potwierdzenie udziału w nim funkcjonariuszy służb państwowych ${ }^{197}$.

W treści omawianego orzeczenia MTS określił zasady odpowiedzialności państwa za osoby prywatne, działające $\mathrm{z}$ upoważnienia lub pod kontrolą jego organów. Uzasadniając brak odpowiedzialności Stanów Zjednoczonych za działania członków bojówki opisał zastosowany w tej sprawie po raz pierwszy test „skutecznej kontroli” (ang. effective control). Opierał go na przesłance przypisania państwu „skutecznej kontroli” nad działaniami grupy wojskowej, która dopuściła się naruszenia prawa międzynarodowego i od jej spełnienia uzależniał odpowiedzialność państwa za czyny międzynarodowo bezprawne przez ową grupę popełnione ${ }^{198}$. Uwzględniając jedynie część roszczeń Nikaragui, domagającej się przypisania Stanom Zjednoczonym odpowiedzialności za działania contras, MTS uznał, że Stany Zjednoczone były odpowiedzialne za „planowanie, kierowanie i wsparcie" działań oddziałów nikaraguańskich partyzantów ${ }^{199}$, ale, co do zasady, odpowiadały jedynie za własne działania, tj. wsparcie contras, nie za działania samej grupy wojskowej ${ }^{200}$. Stany Zjednoczone ponosiłoby odpowiedzialność bezpośrednio za działania contras, gdyby te działania były realizowane w oparciu o wskazówki z Waszyngtonu czy z czynnym udziałem amery-

\footnotetext{
${ }^{193}$ Por.: sprawa operacji militarnych w Nikaragui, s. 21-22.

194 Por.: sprawa operacji militarnych w Nikaragui, s. 49.

195 Por.: sprawa operacji militarnych w Nikaragui, s. 21.

196 Por.: sprawa operacji militarnych w Nikaragui, s. 49.

197 Por.: sprawa operacji militarnych w Nikaragui, s. 49.

198 Por.: sprawa operacji militarnych w Nikaragui, s. 64-65.

199 Por.: sprawa operacji militarnych w Nikaragui, s. 50.

200 Por.: J. Crawford, S. Olleson, op.cit., s. 455.
} 
kańskich sił zbrojnych lub przedstawicieli państwa. Ogólna zależność i wsparcie udzielanie UCLAs nie wystarczyły do przypisania Amerykanom odpowiedzialności. Trybunał uznał, iż te wszystkie formy uczestnictwa Stanów Zjednoczonych, a nawet sprawowana ogólna kontrola nad związanymi poleceniami Białego Domu UCLAs, bez innych dowodów nie przesądzają o odpowiedzialności Stanów Zjednoczonych za kierowanie popełnianiem lub popełnianie naruszeń praw człowieka czy prawa humanitarnego. Czyny te mogły zostać popełnione przez członków contras bez kontroli Stanów Zjednoczonych: „Aby owe czyny niosły ze sobą odpowiedzialność prawną Stanów Zjednoczonych, co do zasady musi zostać udowodnione, że państwo sprawowało skuteczną kontrolę nad operacjami wojskowymi lub paramilitarnymi, w trakcie których rzekome naruszenia zostały popelnione" 201 .

$Z$ rozstrzygnięcia w tej sprawie wynika, iż państwo nie ponosi odpowiedzialności za szkodliwe działania osób prywatnych niebędących jego obywatelami, także jeśli wspiera ich działania, o ile działania te nie stanowią wykonania konkretnych poleceń organów państwa. Konstatacja ta powinna jednak zostać uzupełniona zobowiązaniem do wykazania przez państwo wspierające takie działania należytej staranności w zapobieganiu sytuacji, w której ich działania stanowią naruszenie prawa. Ten dodatkowy element teorii kontroli pojawił się $\mathrm{w}$ opisanym poniżej orzeczeniu w sprawie Tadiča ${ }^{202}$.

\subsection{Sprawa Tadiča (1999)}

To samo zagadnienie - odpowiedzialności państwa za działania osób prywatnych - stało się przedmiotem rozstrzygnięcia Międzynarodowego Trybunału Karnego ds. Zbrodni w b. Jugosławii (dalej: MTKJ) w sprawie Tadiča z 1999 r. $^{203}$ Jak wskazuje Cassese, w tej sprawie zadanie Trybunału było ograniczone do ustalenia, czy konflikt, w trakcie trwania którego miały miejsce zbrodnie ludobójstwa, miał charakter międzynarodowy, czy wewnętrzny. Ustalenia tego nie można było dokonać w oparciu o normy prawa humanitarnego, dlatego też Trybunał odwołał się do norm odpowiedzialności międzynarodowej państw. Uznał tym samym test całkowitej kontroli, oparty o orzecznictwo i praktykę państw, jako możliwy do zastosowania w celu przypisania państwu działań grup osób prywatnych. Test „kontroli efektywnej”, opisany w uzasadnieniu decyzji

${ }^{201}$ Por.: sprawa operacji militarnych w Nikaragui, s. 64-65.

${ }^{202}$ Por.: wyrok Izby Orzekającej Międzynarodowego Trybunału Karnego ds. Zbrodni w b. Jugosławii (dalej: MTKJ) z 7 maja 1997 w sprawie Prokurator przeciwko D. Tadić, IT-94-1-T; s. 156. Ale por. Projekt artykułów o odpowiedzialności państw z 2001 r., s. 47, gdzie KPM podkreśliła, że sprawy dotyczyły znacząco różniących się stanów faktycznych, zaś orzekające trybunały różnił zakres ich kompetencji. O ile MTS rozstrzygał o odpowiedzialności państwa, to MTKJ decydował wyłącznie o odpowiedzialności jednostki za zbrodnie międzynarodowe.

${ }^{203}$ Wyrok Izby Orzekającej MTKJ z 7 maja 1997 w sprawie Prokurator przeciwko D. Tadić, IT-94-1-T; wyrok Izby Apelacyjnej MTKJ z 15 lipca 1999 w sprawie Prokurator przeciwko D. Tadić, IT-94-1-A. 
w sprawie Tadiča, dotyczyć miał w zamierzeniu Trybunału odpowiedzialności państw za indywidualne działania osób prywatnych ${ }^{204}$.

Faktycznie jednak w treści orzeczenia Trybunał sformułował tezę sprzeczną z przedstawioną przez MTS w 1986 r. teorią efektywnej kontroli. Dokonał dalszego ograniczenia katalogu sytuacji, w których państwa mogą zostać pociągnięte do odpowiedzialności za działania osób prywatnych, które wspierają lub akceptują. Tę konstrukcję dogmatyczną przedstawił jednak nie celem ustalenia międzynarodowej odpowiedzialności państwa, ale, zgodnie z przyznanym mu mandatem, odnosił się do możliwości stosowania międzynarodowego prawa humanitarnego w badanym stanie faktycznym, tj. weryfikując odpowiedzialność jednostki za zbrodnie międzynarodowe. Rozważania Trybunału czynione były więc $\mathrm{w}$ odniesieniu do innego zbioru norm prawa międzynarodowego niż ten stosowany w sprawie contras.

Trybunał badał kwestię odpowiedzialności Tadiča, członka sił paramilitarnych, który dopuścił się aktów nieludzkiego i okrutnego traktowania, gwałtów, zabójstw, morderstw i tortur wobec Muzułmanów osadzonych w obozach dla internowanych w Omarska, Trnopolje i Keraterm w okręgu Prijedor w Republice Serbskiej, tj. na obszarze obecnej Bośni i Hercegowiny ${ }^{205}$. Został on skazany za zbrodnie przeciwko ludzkości, naruszenia Konwencji genewskich i zwyczajowego prawa wojny ${ }^{206}$. Trybunał oparł swoją decyzję o sporządzony na potrzeby tego orzeczenia tekst „całkowitej kontroli” (ang. overall control) ${ }^{207}$. Wskazał, że zgodnie $\mathrm{z}$ treścią norm prawa międzynarodowego przypisanie państwu odpowiedzialności za czyny osób prywatnych wymaga, aby państwo sprawowało nad tymi osobami szczególny rodzaj kontroli. Poziom owej kontroli może różnić się w zależności od okoliczności sprawy i nie zawsze musi być wysoki ${ }^{208}$. Poziom kontroli, który pozwoliłby na przypisanie odpowiedzialności za działania sił zbrojnych władzom Jugosławii, to poziom „całkowitej kontroli”, wymagający od władz nie tylko ich finansowania i wyposażenia, ale także udziału w planowaniu i nadzorowaniu ich działan ${ }^{209}$. Trybunał ograniczył tym samym krąg podmiotów, za których działania państwo może ponieść odpowiedzialność wyłącznie do grup, których wszyscy członkowie dopuszczający się szkodliwego działania są kontrolowani przez państwo ${ }^{210}$. Ewolucja orzecznictwa międzyna-

${ }^{204}$ Por.: A. Cassese, The Nicaragua and Tadič Tests Revisited in Light of the ICJ Judgment on Genocide in Bosnia, European Journal of International Law 2007, nr 18(4), s. 649.

${ }^{205}$ Wyrok Izby Orzekającej MTKJ z 7 maja 1997 w sprawie Prokurator przeciwko D. Tadič, sygn. IT-94-1-T, s. 3-4.

${ }^{206}$ Wyrok Izby Apelacyjnej MTKJ z 15 lipca 1999 w sprawie Prokurator przeciwko D. Tadič, IT-94-1-A, s. 74-75.

${ }^{207}$ Por.: wyrok Izby Apelacyjnej MTKJ z 15 lipca 1999 w sprawie Prokurator przeciwko D. Tadič, IT-94-1-A, s. 48-49.

${ }^{208}$ Por.: wyrok Izby Apelacyjnej MTKJ z 15 lipca 1999 w sprawie Prokurator przeciwko D. Tadič, IT-94-1-A, s. 48.

${ }^{209}$ Wyrok Izby Apelacyjnej MTKJ z 15 lipca 1999 w sprawie Prokurator przeciwko D. Tadič, IT-94-1-A, s. 48.

${ }^{210}$ Wyrok Izby Apelacyjnej MTKJ z 15 lipca 1999 w sprawie Prokurator przeciwko D. Tadič, IT-94-1-A, s. 49. 
rodowego ograniczyła kragg osób, za które państwo może ponosić odpowiedzialność i działań, które mogą być państwu przypisane, w konsekwencji wzmacniając znaczenie odpowiedzialności państwa za zaniechania ich organów, w tym za brak po ich stronie należytej staranności.

\subsection{Sprawa ludobójstwa w Srebrenicy (2007)}

Test całkowitej kontroli ze sprawy Tadiča znalazł potwierdzenie w rozstrzygnięciu Międzynarodowego Trybunału Karnego (dalej: MTK) z 2007 r. w sprawie masakry w Srebrenicy ${ }^{211}$. Zadaniem Trybunału było ustalić, czy dopuszczalne jest stosowanie adresowanej do państw konwencji o zapobieganiu i karaniu zbrodni ludobójstwa ${ }^{212}$ przy ocenie zbrodni popełnionych przez Serbów przeciwko bośniackim Muzułmanom podczas wojny w byłej Jugosławii. Bośnia i Hercegowina zwróciła się do Trybunału z pytaniem o możliwość stosowania wobec Serbii umowy międzynarodowej w tej sprawie. MTK uznał, że masakra w Srebrenicy stanowiła zbrodnię ludobójstwa opisaną w konwencji i dlatego umowa może być aplikowana celem rozstrzygnięcia przedmiotowego sporu. Wskazał jednak także, choć uczynił to niejednomyślnie, że młode państwo serbskie nie może być pociągnięte do międzynarodowej odpowiedzialności za naruszenie postanowień owej konwencji, bowiem Serbia nie była ani bezpośrednio odpowiedzialna za ludobójstwo w Srebrenicy, ani za współudział w nim, w rozumieniu art. III wspomnianego traktatu ${ }^{213}$. Potwierdził tym samym koncepcje całkowitej kontroli ze sprawy Tadiča, zgodnie z którą Serbia ponosiłaby odpowiedzialność międzynarodową za sprawców zbrodni jedynie wówczas, gdyby przedstawiciele organów państwa udzielali przestępcom bezpośrednich instrukcji do popełniania zbrodni lub $\mathrm{w}$ zbrodniach uczestniczyli, co nie miało miejsca w przedmiotowej sprawie ${ }^{214}$.

Trybunał uznał jednak, że Serbia dopuściła się naruszenia konwencji poprzez niepodjęcie działań zmierzających do zapobieżenia masakrze oraz zaniechanie współpracy z MTKJ przy karaniu sprawców ludobójstwa, w szczególności generała Mladicia, narażając się tym samym na odpowiedzialność międzynarodową ${ }^{215}$.

Przywołując należytą staranność jako termin kluczowy dla rozstrzygnięcia zaistniałego sporu, Trybunał wskazał, że zobowiązanie, o którym mowa dotyczy konieczności podjęcia określonych działań przez państwo, nie zaś osiagnięcia przez nie określonego rezultatu. Nie można więc zasadnie oczekiwać od władz

${ }^{211}$ Orzeczenie MTK z 26 lutego 2007 w sprawie: Bośnia i Hercegowina przeciwko Serbii i Czarnogórze, stosowanie konwencji o zapobieganiu i karaniu zbrodni ludobójstwa, ICJ Reports, 2007 r., (dalej: sprawa ludobójstwa), s. 43 i n.

${ }^{212}$ Konwencja ONZ w sprawie zapobiegania i karania zbrodni ludobójstwa z dnia 9 grudnia 1948 r., Dz.U. 1950, nr 36, poz. 325.

${ }^{213}$ Por.: sprawa ludobójstwa, s. 127-128.

${ }^{214}$ Por.: sprawa ludobójstwa, s. 230-231, 240.

${ }^{215}$ Por.: sprawa ludobójstwa, s. 229-230. 
państwa, że zapobiegną popełnieniu zbrodni ludobójstwa, niezależnie od okoliczności. Ich obowiązkiem jest natomiast podjęcie wszelkich rozsądnych, możliwych do zrealizowana działań, zmierzających do zapobieżenia ludobójstwu, na ile to tylko możliwe. Państwo nie będzie więc ponosić odpowiedzialności jedynie dlatego, że nie osiagnęło oczekiwanego przez inne państwa skutku, ale będzie ją ponosić, jeśli demonstracyjnie zaniechało podjęcia jakichkolwiek działań zmierzających do zapobieżenia mu, mimo iż działania takie mogło było podjąć, a ich podjęcie przyczyniłoby się do zapobiegnięcia zbrodni. Weryfikacja stopnia staranności wykazanego przez państwo prowadzona więc być musi in concreto. Analiza taka oparta być powinna o trzy kryteria. Po pierwsze, weryfikacji podlega faktyczna możliwość skutecznego wpływania na zachowania osób zdolnych do popełnienia lub popełniających już owe zbrodnie ${ }^{216}$. Ocena ta będzie się znacząco różnić w zależności od państwa, w którym zostanie przeprowadzona. Jej wynik zależy w znacznej mierze od fizycznej odległości siedziby władz od miejsca popełniania zbrodni oraz od siły więzi politycznych i innych, jakie łączą władze i uczestników zdarzeń ${ }^{217}$. Drugim kryterium oceny należytej staranności jest analiza właściwych w danej sytuacji faktycznej norm prawa międzynarodowego, bowiem tylko w oparciu o ich treść władze mogą realizować zobowiązania spoczywające na państwie. Zdolność do wpływania na przebieg zdarzeń zależy więc od szczególnej sytuacji prawnej, z uwzględnieniem zdarzeń i osób stwarzających zagrożenie dla dóbr chronionych prawem międzynarodowym. Jednocześnie pozostaje bez znaczenia, czy władze państwa twierdzą czy wręcz udowodnią, że nawet w przypadku, gdyby zastosowały wszystkie racjonalne środki w ich dyspozycji, nie wystarczyłoby to, aby zapobiec popełnieniu ludobójstwa. Niezależnie od trudności dowodowych, nie ma to znaczenia w przypadku naruszenia zobowiązania, o którym mowa, tym bardziej, że nie można wykluczyć, że połączone wysiłki kilku państw, z których każde spełniłoby własne zobowiązanie do zapobiegania zbrodniom, mogłyby pozwolić na uniknięcie ludobójstwa, choć cel ten byłby niemożliwy do osiagnięcia przez tylko jedno państwo. Po trzecie wreszcie, państwo może zostać pociagnięte do odpowiedzialności międzynarodowej jedynie wówczas, gdy zbrodnia ludobójstwa została faktycznie popełniona ${ }^{218}$. Naruszenie zobowiązania ma miejsce dopiero wtedy, gdy rozpoczyna się popełnianie przestępstwa, co nie oznacza, że samo zobowiązanie powstaje dopiero $\mathrm{z}$ chwila podjęcia przygotowań do jego popełnienia. Obowiązek zapobiegania zbrodniom, i odpowiadający mu obowiązek działania pojawiają się w chwili, gdy państwo dowiaduje się lub powinno było w normalnych okolicznościach się dowiedzieć o istnieniu poważnego ryzyka ich popełnienia. Od tego momentu, jeśli państwo dysponuje dostępnymi mu środkami, które mogą przyczynić się do powstrzymania osób podejrzanych o przygotowywanie ludobójstwa lub istnieje uzasadnione podejrzenie, że zamie-

\footnotetext{
${ }^{216}$ Por.: sprawa ludobójstwa, s. 221.

${ }^{217}$ Por.: sprawa ludobójstwa, s. 221.

${ }^{218}$ Por.: sprawa ludobójstwa, s. 221.
} 
rzają ją popełnić, państwo zobowiązane jest wykorzystać pozostające w jego dyspozycji środki tak, jak pozwalają na to okoliczności. Jednakże, jeśli zbrodnia nie zostanie popełniona, państwo, które zaniechało działania nie może być pociągnięte do odpowiedzialności, ponieważ zgodnie z regułą określoną powyżej, muszą mieć miejsce przestępne zachowania osób prywatnych, aby uznać naruszenie obowiązku prewencji ${ }^{219}$.

Omówione powyżej sprawy oddziałów contras, Tadiča i masakry w Srebrenicy pokazuja, że spoczywający na państwach powszechny obowiązek zapobiegania naruszaniu prawa międzynarodowego, realizowanego $\mathrm{w}$ ich jurysdykcji oraz opisująca jego treść zasada należytej staranności odgrywają istotną rolę nie tylko w porządku międzynarodowego prawa środowiska, gdzie odnalazły już swoje uznane miejsce, ale także w prawie praw człowieka czy przy realizacji zasady suwerennej równości. Wymóg dokładania należytej staranności, spoczywający na organach państwa przy realizacji jego międzynarodowych zobowiązań, $\mathrm{w}$ tym przy zapobieganiu szkodliwym działaniom osób prywatnych realizowanym na jego terytorium lub pod jego kontrolą, uzupełnia wąsko określone w orzecznictwie MTS możliwości przypisania państwu odpowiedzialności za czyny osób prywatnych. O ile więc państwa nie ponoszą odpowiedzialności za ich działania, jeśli nie sprawują nad nimi „efektywnej kontroli”, o tyle państwa ponosić mogą odpowiedzialność za szkodliwe skutki owych działań, stanowiące naruszenie prawa międzynarodowego, jeśli nie dołożyły należytej staranności przy zapobieganiu im.

\subsection{Kwestia legalności użycia broni nuklearnej (1996)}

Odpowiedzialność państw za szkody wyrządzone wskutek wykorzystania broni nuklearnej kilkakrotnie była przedmiotem badań międzynarodowych sądów i trybunałów ${ }^{220}$. Dla czynionych rozważań szczególnie istotne są dwa wywody MTS.

Trybunał wypowiadał się o konsekwencjach użycia broni nuklearnej w kontekście odpowiedzialności państw w kilku sprawach przeciwko Francji, która na wodach Oceanu Spokojnego przeprowadzała próby jądrowe do połowy lat 90 . XX w. W 1995 r. Nowa Zelandia prosiła Trybunał o opinię dotyczącą wykony-

${ }^{219}$ Por.: sprawa ludobójstwa, s. 222.

${ }^{220}$ Por. np. sprawa The People of Bikini, by and through the Kili/BikiniEjit, Local Government Council Plaintiffs przeciwko Stanom Zjednoczonym Ameryki [online]. United States Court of Federal Claims 1996 [dostęp: 2013-04-20]. Dostępny w Internecie: <http://www.bikiniatoll .com/7-18-06\%20Amended\%20complaint.pdf $>$. Stany Zjednoczone nie uznały roszczenia Bikinii, przywołując brak jurysdykcji; por.: M. Fitzmaurice, Contemporary Issues in International Environmental Law, Cheltenham, Northampton 2009, s. 165. Inne sprawy dotyczące testów nuklearnych to np. połączone sprawy: Australii przeciwko Francji i Nowej Zelandii przeciwko Francji, wyrok MTS z 20 grudnia 1974, ICJ Rep. 1975, nr 253, s. 253-74; sprawa Nowej Zelandii przeciwko Francji, dotycząca stosowania środków tymczasowych, wyrok MTS z 22 września 1995, I. C. J. Reports 1995, s. 288-308. 
wania przez Francję jego wcześniejszego wyroku, postulując istnienie obowiąz$\mathrm{ku}$ dokonania oceny oddziaływania na środowisko (ang. environmental impact assesment, dalej: EIA) jako elementu zasady przezorności (ang. precautionary principle), znanej prawu międzynarodowemu ${ }^{221}$. Francja ogłosiła plany podjęcia podziemnych prób nuklearnych, których szkodliwe skutki mogły były wystapić także w granicach Nowej Zelandii. Ta argumentowała, iż planowane podziemne próby atomowe uznać należy za sprzeczne z prawem międzynarodowym, jeśli Francja nie przeprowadzi oceny oddziaływania na środowisko albo jeśli ocena ta wykaże niebezpieczeństwo powstania szkód w środowisku morskim ${ }^{222}$. Choć $\mathrm{w}$ tej sprawie Trybunał uznał się za pozbawiony jurysdykcji, zdania odrębne sędziów MTS potwierdziły istnienie postulowanego przez Nową Zelandię obowiązku i znalazły swoje odzwierciedlenie w późniejszych opiniach doradczych MTS. Sędzia Weeramantry w obszernej opinii dowodził istnienia pierwotnego obowiązku państw przeprowadzania ocen oddziaływania na środowisko przedsiębranych przez nich działań. W jego treść wpisywał konieczność przedstawienia dowodów, iż planowane działania nie przyniosą szkód transgranicznych ${ }^{223}$. Zdanie odrębne sędziego Weeramantry oraz korespondujące $\mathrm{z}$ nim zdanie odrębne sędziego Palmera potwierdziały zwyczajową moc Zasady 21 Deklaracji sztokholmskiej, która zakazuje wykorzystywania lub pozwalania na wykorzystanie terytorium państwowego $\mathrm{w}$ sposób powodujący znaczące szkody poza jego granicami ${ }^{224}$.

To zdanie mniejszości składu Trybunału znalazło swoje odzwierciedlenie w treści opinii doradczej sformułowanej rok później, tj. w 1996 r., w odpowiedzi na pytanie o legalność użycia broni nuklearnej ${ }^{225}$. Choć Trybunał odmówił jednoznacznej kwalifikacji użycia broni atomowej względem treści norm prawa międzynarodowego, to potwierdził istnienie „ogólnego zobowiązania państw do zapewnienia, aby działania realizowane $\mathrm{w}$ ich jurysdykcji i pod ich kontrola realizowane były z poszanowaniem środowiska innych państw oraz przestrzeni znajdujących się poza jurysdykcją państwową"226. Zobowiązanie takie MTS uznał za część współczesnego prawa międzynarodowego dotyczącego środowi-

${ }^{221}$ Por. Nowa Zelandia p. Francji, Request for an Examination of the Situation in Accordance with the Court's Judgment in the Nuclear Tests Case, ICJ Reports 1995, s 288-308 (dalej: sprawa prób atomowych na Pacyfiku). Zasada przezorności w pracach KPM omówiona została w kolejnym rozdziale.

${ }^{222}$ Sprawa prób atomowych na Pacyfiku, s. 290; por. P. W. Birnie, A. E. Boyle, C. Redgwell, op.cit., s. 138-139.

${ }^{223}$ Zdanie odrębne sędziego Weeramantry, sprawa prób atomowych na Pacyfiku, s. 317-362; por. P. W. Birnie, A. E. Boyle, C. Redgwell, op.cit., s. 138-139; M. Fitzmaurice, op.cit., s. 21-22.

${ }^{224}$ Zdanie odrębne sędziego Weeramantry, sprawa prób atomowych na Pacyfiku, s. 347; P. W. Birnie, A. E. Boyle, C. Redgwell, op.cit., s. 139; M. Fitzmaurice, op.cit., s. 21-22.

${ }^{225}$ Por.: opinia doradcza MTS w sprawie legalności użycia broni nuklearnej, ICJ Reports 1996, vol. 1, s. 226 i n.

${ }_{226}$ Por.: opinia doradcza MTS w sprawie legalności użycia broni nuklearnej, ICJ Reports 1996, vol. 1, s. 241-242. 
$\mathrm{ska}^{227}$. W doktrynie jest ono interpretowane jako potwierdzenie zasady nieszkodzenia (ang. no harm principle), tj. pierwotnego obowiązku takiego korzystania z terytorium i zasobów dostępnych państwu, aby nie wyrządzać znaczących szkód transgranicznych ${ }^{228}$. Jego naruszenie skutkuje powstaniem obowiązku kompensacyjnego. Państwa powinny uwzględniać stan środowiska oraz interesy innych przy wykonywaniu swojego prawa do zbrojnej samoobrony, realizowanego także przy wykorzystaniu nowych technologii. W kontekście czynionego wywodu przyjąć należy, iż ocena działań przedsiębranych przez państwo celem realizacji owego zobowiązania, czyniona będzie w odniesieniu do właściwego w danym stanie faktycznym standardu należytej staranności.

\subsection{Sprawa zapory Gabcikovo-Nagymaros na Dunaju (1997)}

Odpowiedzialność państwa za zaniechanie jego organów przywoływana była w szeregu spraw dotyczących międzynarodowego prawa środowiska. Należyta staranność jest postrzegana jako element zasady prewencji, konstytuującej obowiązek państw przeprowadzenia oceny oddziaływania na środowisko naturalne przed podjęciem działań, mogących w znaczącym stopniu wpłynąć na jego $\operatorname{stan}^{229}$. Obowiązek podejmowania racjonalnych wysiłków przez organy państwa celem zapobiegania szkodom $\mathrm{w}$ środowisku naturalnym został potwierdzony m.in. w treści orzeczenia z 1997 r. w sprawie szkód grożących po regulacji koryta Dunaju przez Słowację, wbrew treści umowy dwustronnej z Węgrami ${ }^{230}$.

Na podstawie umowy pomiędzy Węgrami i Czechosłowacją z 1977 r. miała zostać wzniesiona tama na Dunaju, umożliwiająca budowę elektrowni wodnych, chroniąca przed powodziami i zapewniająca poprawę żeglowności rzeki. Jej projekt i budowa, będące przedmiotem owej umowy, miały zostać opracowane i wykonane wspólnie przez oba państwa. Pierwotnie, z powodu kłopotów ekonomicznych Węgier, później zaś ze względu na obawy o stan środowiska naturalnego wyrażane przez węgierskich ekspertów, Budapeszt opóźniał realizację projektu. W 1983 r. w Pradze państwa zgodziły się przesunąć w czasie budowę tamy. Po stronie węgierskiej narastała krytyka projektu, wynikająca z niebezpieczeństwa powstania szkód w środowisku naturalnym ${ }^{231}$. Wobec braku woli

${ }^{227}$ Ibidem. Por. także: P. Okowa, op. cit., s. 70-71, gdzie autorka przypomina rozumowanie Trybunału w sprawie testów nuklearnych z 1978 r.; Sprawa testów nuklearnych, ICJ Pleadings 1978, tom I, s. 304.

${ }^{228}$ Por. np.: R. Verheyen, op.cit., Haga 2005, s. 147; P. W. Birnie, A. E. Boyle, C. Redgwell, op.cit., s. 139.

${ }^{229}$ Obowiązek przeprowadzania EIA jako element zasady należytej staranności w międzynarodowym prawie środowiska omówiony został w rozdziale IV.

${ }^{230}$ Wyrok MTS z 25 września 1997 r. w sprawie projektu Gabcikovo-Nagymaros (Węry przeciwko Słowacji), ICJ Reports, 1997, nr 92, (dalej: Sprawa Gabcikovo-Nagymaros), Część B.a., par. 140, s. 39.

${ }^{231} \mathrm{Na}$ początku 1984 powstał na Węgrzech „Krąg dunajski”, ruch społecznego oporu przeciwko budowie tamy. To przede wszystkim jego działania doprowadziły do ogłoszenia przez 
realizacji projektu po stronie władz Węgier Słowacja przystapiła samodzielnie do uregulowania rzeki według jednego $\mathrm{z}$ wariantów, stanowiących przedmiot dwustronnych negocjacji, co spowodowało, że w 1992 r. Węgry wypowiedziały umowę z 1977 r. W tym samym roku działania Słowacji doprowadziły do uszczuplenia zasobów wodnych w starym korycie rzeki o $90 \%$, zagrażając jej ekosystemowi ${ }^{232}$. Meritum sporu stanowily zagadnienia $\mathrm{z}$ zakresu prawa traktatów, dotyczące odpowiedzialności Słowacji za działania sprzeczne z celem i przedmiotem umowy z $1977 \mathrm{r}$. Na marginesie tych rozważań MTS odnotował po raz pierwszy obecność zasady ciagłego rozwoju w katalogu zasad prawa międzynarodowego ${ }^{233}$. Zasygnalizował konieczność wykazywania należytej staranności przy realizacji owej zasady, w treści której zawarte jest zobowiązanie do dokonywania analizy oddziaływania na środowisko i monitorowania skutków planowanych przedsięwzięć dla środowiska naturalnego.

MTS uznał, że oba państwa naruszyły prawo międzynarodowe, łamiąc normy traktatowe. O ile Węgry uczyniły to jednostronnie decydując o zawieszeniu realizacji projektu, o tyle Słowacja dopuściła się naruszenia traktatu samodzielnie przystępując do realizacji zaplanowanego wspólnie działania ${ }^{234}$. Trybunał odmówił rozstrzygnięcia sporu co do meritum, zobowiązując strony do zintensyfikowania negocjacji i przywołując zasadę ciagłego rozwoju jako ich wytyczną ${ }^{235}$.

Choć w treści orzeczenia z 1997 r. MTS nie przywołał explicite należytej staranności, decyzja ta nawiązuje do odpowiedzialności państwa za brak działania jego organów. Zgodnie z rozumowaniem MTS przeprowadzonym w tej sprawie, Słowacja pozostawała zobowiązana do oceny skutków planowanych działań przed ich realizacją oraz do następczego monitorowania ich konsekwencji. To zobowiązanie wynikało z zasady ciagłego rozwoju i przejawiało się w konieczności wykazania należytej staranności ${ }^{236}$.

Trybunał zaznaczył, że wpływ projektu na stan środowiska naturalnego stanowił kluczowy element jego realizacji, o czym świadczy sama liczba opinii biegłych, przedstawionych przez strony, choć treści owych ekspertyz często były sprzeczne $^{237}$. Ocena ryzyka, jakie wiązało się z realizacją projektu, dokonywana być powinna w oparciu o ,aktualne standardy”. Obowiązek ten był konsekwencją zapisu wiążącego strony traktatu, który nakazywał im utrzymywać jakość

władze w Budapeszcie zawieszenia realizacji projektu w 1989 r. Por.: S. Krech, J. R. McNeill, C. Merchant, Encyclopedia of World Environmental History, Nowy Jork 2004, t. II, s. 654.

${ }^{232}$ Por.: H. Fürst, The Hungarian-Slovakian Conflict over the Gabcikovo-Nagymaros Dams: An Analysis, Intermarium 2003, vol. 6, nr 2, s. 2.

${ }^{233}$ Por. M. M. Kenig-Witkowska, Koncepcja ..., s. 57-58, która podkreśla rolę orzecznictwa w identyfikowaniu katalogu i treści zasad prawa międzynarodowego. Wskazuje, iż przywołanie zasady ciagłego rozwoju w orzeczeniu w sporze słowacko-węgierskim oraz w późniejszym rozstrzygnięciu GATT, dotyczącym meksykańsko-amerykańskiej „wojny tuńczykowej” potwierdzają jej obecność w katalogu zasad prawa międzynarodowego.

${ }^{234}$ Sprawa Gabcikovo-Nagymaros, s. 53-54.

${ }^{235}$ Sprawa Gabcikovo-Nagymaros, s. 78.

${ }^{236}$ L. Viikari, op.cit., s. 272. Por.: sprawa Gabcikovo-Nagymaros, s. 77-78.

${ }^{237}$ Sprawa Gabcikovo-Nagymaros, s. 77. 
wody w Dunaju i chronić jej żywe zasoby. W obszarze ochrony środowiska czujność i prewencja (ang. vigilance and prevention) są niezbędne w związku z nieodwracalnymi konsekwencjami, jakie może przynieść ich brak. Rozwój technologii umożliwia przewidywanie i kontrolowanie skutków, jakie niesie za sobą korzystanie z naturalnych zasobów. Nowe technologie doprowadziły do powstania nowych norm i standardów w treści licznych źródeł prawa międzynarodowego. Owe normy i standardy muszą być brane pod uwagę nie tylko przy realizacji nowych przedsięwzięć, ale także przy podejmowaniu działań je poprzedzających. Rozwój ekonomiczny musi pozostawać w zgodzie z ochroną środowiska, która to współzależność znajduje swój wyraz w koncepcji ciągłego rozwoju ${ }^{238}$.

W opinii odrębnej wiceprzewodniczący MTS sędzia Weeramantry wskazał na istnienie zasady stałej oceny wpływu oddziaływania na środowisko (ang. principle of continuing environmental impact assessment) ${ }^{239}$. Jego zdaniem, zobowiązanie to oznacza nie tylko konieczność dokonania oceny skutków danego działania przed rozpoczęciem jego realizacji, ale zobowiązuje państwa do stałego ponawiania tej oceny przez cały czas trwania niebezpiecznego przedsięwzięcia. Dlatego też zasada oceny oddziaływania na środowisko ma charakter dynamiczny. Tak długo, jak realizowane jest przedsięwzięcie dużych rozmiarów, tak długo obowiązek przeprowadzania oceny pozostaje aktualny. Im większy projekt, tym większa jest potrzeba ciagłego monitorowania jego skutków ${ }^{240}$. Zasada opisywana przez sędziego Weeramantry jest praktycznym przełożeniem treści ogólnej zasady ostrożności (ang. principle of caution), która ustanawia obowiązek ciagłego „wykazywania czujności i przewidywania” (ang. watchfulness and anticipation). Weeramantry wskazuje, że treścią zasady podstawowej dla systemu międzynarodowego prawa środowiska - zasady „powiernictwa zasobów ziemi" (ang. principle of trusteeship of earth resources) - jest zobowiazanie do „mądrego" zarządzania zasobami naturalnymi z należytą uwagą czy starannością (ang. due care, fr. diligence) i troską o przyszłe pokolenia ${ }^{241}$. W treści orzeczenia w sprawie Gabcikovo-Nagymaros MTS skorzystał z możliwości potwierdzenia aktualności zobowiązania państw do zapewnienia, aby działania realizowane $\mathrm{w}$ ich jurysdykcji i pod ich kontrolą realizowane były z poszanowaniem środowiska innych państw oraz przestrzeni znajdujących się poza jurysdykcją państwową, zapisanego w treści opinii doradczej MTS w sprawie użycia broni nuklearnej z $1996 \mathrm{r}^{242} \mathrm{~W}$ treść tego obowiązku wpisał konieczność wykazywania należytej staranności przy realizacji zobowiązań międzynarodowych.

${ }^{238}$ Sprawa Gabcikovo-Nagymaros, s. 78.

${ }^{239}$ Sprawa Gabcikovo-Nagymaros, zdanie odrębne sędziego Weeramantry, s. 88.

${ }^{240}$ Sprawa Gabcikovo-Nagymaros, zdanie odrębne sędziego Weeramantry, s. 111.

${ }^{241}$ Sprawa Gabcikovo-Nagymaros, zdanie odrębne sędziego Weeramantry, s. 108.

242 Por.: opinia doradcza MTS w sprawie legalności użycia broni nuklearnej, ICJ Reports 1996, vol. 1, s. 241-242. 


\subsection{Sprawa młynów rzecznych (Argentyna p. Urugwajowi, 2010)}

W latach 2006-2010 MTS rozstrzygał sprawę, której stan faktyczny przypominał okoliczności sporu słowacko-węgierskiego. Argentyna wnosiła o ustanowienie środka tymczasowego wobec Urugwaju, obligującego go do powstrzymania budowy młynów rzecznych na jego terytorium. Budowa młynów wpłynęłaby niekorzystnie na stan środowiska naturalnego sąsiedniej Argentyny poprzez zanieczyszczenie wód rzeki Urugwaj. Argentyna zarzucała władzom Urugwaju naruszenie obowiązku należytej staranności przy ustanawianiu i implementowaniu środków niezbędnych dla ochrony równowagi ekologicznej rzeki ${ }^{243}$. Obowiązek taki wynikał z treści traktatu wiążącego strony sporu ${ }^{244}$. Weryfikacja zasadności roszczenia Argentyny oparta była o szczegółową analizę stanu faktycznego i liczne opinie ekspertów, korzystających z najnowszych technologii celem ustalenia wpływu na środowisko kwestionowanych budowli.

MTS przywołując rozważania zawarte w decyzji w sprawie zapory w Gabcikovo-Nagymaros wskazał, że państwa odpowiedzialne są nie tylko za swoje własne działania, ale pozostają związane także „obowiązkiem należytej staranności" dotyczącym czynności, nad którymi sprawują kontrolę ${ }^{245}$. Łączące strony zobowiązanie traktatowe do „ochrony środowiska wodnego” obejmowało obowiązek zapobiegania jego zanieczyszczeniu poprzez wprowadzenie odpowiednich zasad i środków. Trybunał odczytał je jako ,zobowiązanie do działania z należytą starannością we wszystkich przedsięwzięciach realizowanych w jurysdykcji lub pod kontrolą każdej ze stron"246. Należyta staranność obejmuje więc zobowiązanie do działania racjonalnego i w dobrej wierze oraz stosowania „najlepszych dostępnych technologii” i „najlepszych praktyk środowiskowych" ${ }^{247}$. Jest to obowiązek, który wymaga nie tylko przyjęcia odpowiednich przepisów, ale także pewnego poziomu czujności w ich egzekwowaniu i wykonywaniu kontroli administracyjnej względem podmiotów publicznych i prywatnych, takich jak monitorowanie działań przez nich podejmowanych, celem

${ }^{243}$ Argentyna przeciwko Urugwajowi, ICJ Reports, 2010 (dalej: sprawa młynów rzecznych na rzece Urugwaj), s. 3-4.

${ }^{244}$ Sprawa młynów rzecznych na rzece Urugwaj, s. 55-56.

${ }^{245}$ Nakaz tymczasowy w sprawie młynów rzecznych na rzece Urugwaj (Argentyna przeciwko Urugwajowi), MTS 2006, ICJ Reports 113, par. 72, s. 132, odnosząc się m.in. do decyzji w sprawie zapory w zapory w Gabcikovo-Nagymaros. Por.: M. Grosz, Sustainable Waste Trade under WTO Law: Chances and Risks of the Legal Frameworks' Regulation of Transboundary Movements of Wastes, Haga 2011, s. 121.

${ }^{246}$ Sprawa młynów rzecznych na rzece Urugwaj, s. 58.

${ }^{247}$ Sprawa młynów rzecznych na rzece Urugwaj, pkt 101, s. 38; Por.: M. Grosz, op.cit., s. 121; Por. też P. W. Birnie, A. E. Boyle, C. Redgwell, op.cit., s. 148-149 wskazują że takie podejście pozwala na zmiany standardu należytej staranności i dostosowanie go do danych okoliczności faktycznych. 
ochrony praw drugiej strony ${ }^{248}$. Na mocy łączącej strony umowy międzynarodowej odpowiedzialność ponosić będzie jedynie to państwo, które nie działało z należytą starannością, tj. nie podejmowało wszelkich niezbędnych działań zmierzających do egzekwowania odpowiednich przepisów względem podmiotów publicznych lub prywatnych $w$ jego jurysdykcji ${ }^{249}$. Na mocy umowy pomiędzy stronami zobowiązanie do wykazywania należytej staranności w ustanawianiu i egzekwowaniu przepisów prawa wzmocnione zostało poprzez wymóg, aby takie przepisy i środki były „zgodne z umowami międzynarodowymi” i ,o ile to zasadne, zgodne $\mathrm{z}$ wytycznymi i zaleceniami międzynarodowych organów technicznych" ${ }^{250}$. Należyta staranność oznacza więc zarówno przestrzeganie umów międzynarodowych, jak i uzgodnionych na poziomie międzynarodowym standardów technicznych ${ }^{251}$. W tym kontekście obowiązek ochrony i poszanowania środowiska naturalnego Trybunał interpretował zgodnie z praktyką państw. Uznały one za zasadę prawa międzynarodowego konieczność przeprowadzania oceny oddziaływania na środowisko w przypadku, gdy istnieje ryzyko, że ,proponowana działalność przemysłowa może wywołać istotne niekorzystne skutki transgraniczne, w szczególności, we wspólnym zasobie naturalnym"252. MTS wskazał, że ,zwyczajowa norma prawa międzynarodowego inkorporująca zasadę prewencji wywodzi się z należytej staranności” wymaganej od państw na ich własnym terytorium. Przywołując sentencję orzeczenia w sprawie cieśniny Korfu MTS wskazał, że ,jest zobowiązaniem każdego państwa, aby nie udostępniać świadomie swojego terytorium do czynów naruszających prawa innych państw" ${ }^{253}$. Nie uważa się więc za przejaw należytej staranności oraz dopełnienie implikowanego przez nią obowiązku czujności i prewencji sytuacji, w której państwo planujące realizację przedsięwzięcia, które ze swej natury wpływa na system rzeczny lub jakość wód, zaniecha zlecenia oceny oddziaływania owego przedsięwzięcia na środowisko ${ }^{254}$. Trybunał uznał tym samym ocenę oddziaływania na środowisko za konieczny element dopełnienia obowiązku należytej staranności ${ }^{255}$. Wskazał także, że kiedy potencjalnie szkodliwe działania zostały rozpoczęte, wymagane jest ciagłe monitorowanie ich przebiegu ${ }^{256}$. Każde państwo zobowiązane jest tym samym do określenia w ustawodawstwie krajowym lub w toku procedury koncesyjnej szczegółowej treści oceny oddziaływania na środowisko wymaganej $\mathrm{w}$ danym przypadku. Regulacje te powinny uwzględniać charakter i skalę przedsięwzięcia, jego prawdopodobny negatywny wpływ

\footnotetext{
${ }^{248}$ Sprawa młynów rzecznych na rzece Urugwaj, s. 58.

${ }^{249}$ Sprawa młynów rzecznych na rzece Urugwaj, s. 58.

${ }^{250}$ Sprawa młynów rzecznych na rzece Urugwaj, s. 58.

${ }^{251}$ Sprawa młynów rzecznych na rzece Urugwaj, s. 58.

${ }^{252}$ Sprawa młynów rzecznych na rzece Urugwaj, s. 58.

${ }^{253}$ Sprawa młynów rzecznych na rzece Urugwaj, s. 38.

${ }^{254}$ Sprawa młynów rzecznych na rzece Urugwaj, s. 58.

${ }^{255}$ Sprawa młynów rzecznych na rzece Urugwaj, s. 61.

${ }^{256}$ Sprawa młynów rzecznych na rzece Urugwaj, s. 61.
} 
na środowisko, jak również konieczność zachowania należytej staranności w przeprowadzaniu takiej oceny ${ }^{257}$.

Osądzając działania Urugwaju, przy ocenie wpływu na środowisko spornych przedsięwzięć, Trybunał wziął pod uwagę wybór lokalizacji przewidzianej na ich realizację, w szczególności zaś, czy lokalizacja ta w ogóle nadawała się dla tego rodzaju działań, których immanentną cechą było zanieczyszczanie środowiska naturalnego i szkodliwy wpływ na ekosystem rzeki ${ }^{258}$. Zobowiązanie do zapobiegania zatruciu środowiska naturalnego i wynikający z niego obowiązek należytej staranności niosą ze sobą konieczność dokonania wnikliwej analizy wykorzystywanych technologii pod kątem konsekwencji ich stosowania dla środowiska naturalnego. Owa ocena powinna zostać dokonana $\mathrm{z}$ uwzględnieniem wytycznych i zaleceń międzynarodowych organizacji technicznych ${ }^{259}$. Państwo zobowiązane jest więc do użycia wszystkich środków pozostających w jego dyspozycji celem zapobieżenia działaniom, które mogłyby zostać zrealizowane na jego terytorium lub $\mathrm{w}$ jakiejkolwiek przestrzeni pozostającej $\mathrm{w}$ jego jurysdykcji, jeśli działania te wywołałyby znaczącą szkodę w środowisku naturalnym innego państwa. Trybunał wskazał, że zobowiązanie tej treści ,jest współcześnie częścią kanonu prawa międzynarodowego w zakresie ochrony środowiska" ${ }^{260}$.

\subsection{Podsumowanie}

Opisana ewolucja orzecznictwa międzynarodowego wskazuje, że przyjętą zasadą prawa międzynarodowego jest brak odpowiedzialności państwa za działania osób prywatnych znajdujących się na jego terytorium lub w jego jurysdykcji. Jednocześnie praktyczne stosowanie tej zasady ulega znaczącym ograniczeniom, wynikającym z odpowiedzialności państwa za zaniechania jego organów lub osób działających z jego upoważnienia. Szczególną rolę odgrywają tu organy sądownicze i ścigania. Jeśli $w$ danych okolicznościach faktycznych nie zapewnią one racjonalnej ochrony interesom obcego suwerena lub cudzoziemcom, państwo pociagnięte może zostać do międzynarodowej odpowiedzialności za niedopełnienie ciążącego na nim zobowiązania ochrony suwerenności innych państw czy interesów goszczonych obcokrajowców. O ile pierwotnie odpowiedzialność państwa dotyczyła przede wszystkim odmowy wymiaru sprawiedliwości poszkodowanym cudzoziemcom, o tyle sprawa cieśniny Korfu pozwoliła zidentyfikować także pozytywne obowiązki po stronie organów państwa, wymagające

${ }^{257}$ Sprawa młynów rzecznych na rzece Urugwaj, s. 61.

${ }^{258}$ Sprawa młynów rzecznych na rzece Urugwaj, s. 62.

259 Sprawa młynów rzecznych na rzece Urugwaj, s. 65.

${ }^{260}$ Sprawa młynów rzecznych na rzece Urugwaj, pkt 101, s. 38; cytując opinię doradczą MTS w sprawie legalności użycia broni nuklearnej, ICJ Reports 1996, vol. I, s. 242. Por. też Irlandia przeciwko Wielkiej Brytanii (sprawa elektrowni MOX), Międzynarodowy Trybunał Prawa Morza, 2001, s. 33. 
od nich podejmowania aktywnych starań celem ochrony państw, których interesy i bezpieczeństwo narażone są na uszczerbek, w związku z przedsięwzięciami realizowanymi na jego terytorium. Zakres owego pozytywnego obowiązku ochrony ulegał poszerzeniu i doprecyzowaniu, choćby o szczególną troskę wykazywaną celem zapewnienia bezpieczeństwa członkom międzynarodowych komisji śledczych $\mathrm{w}$ sprawie Tellini czy przedstawicieli dyplomatycznych w sprawie zakładników amerykańskich w Teheranie. Mimo iż zakres odpowiedzialności państwa za działania jego organów czy osób działających na jego polecenie uległ ograniczeniu w sprawach contras i Tadiča, to treść pozytywnego obowiązku prewencji ulegała poszerzeniu wraz z rozwojem międzynarodowego prawa ochrony środowiska, którego fundamenty stanowią orzeczenia $\mathrm{w}$ sprawach huty w Trail czy doliny Dunaju. Należyta staranność ma więc utrwalone miejsce w orzecznictwie dotyczącym odpowiedzialności państw. 


\section{Rozdzial III}

\section{ODPOWIEDZIALNOŚĆ PAŃSTWA (STATE RESPONSIBILITY) ZA BRAK NALEŻYTEJ STARANNOŚCI}

\subsection{Uwagi wstępne}

Należyta staranność musi być omawiana w kontekście reguł odpowiedzialności znanych prawu międzynarodowemu. Szczegółowe omówienie tych reguł znacznie wybiega poza ramy niniejszego opracowania, dlatego też ich analiza przeprowadzona została jedynie celem zidentyfikowania i opisania miejsca należytej staranności w tworzonym przez nie reżimie. Nie jest zamierzeniem autorki wyjaśnienie wszystkich wątpliwości, jakie pojawiają się zarówno w dogmatyce prawa międzynarodowego, jak i w praktyce stosowania opisanych reguł. Jednak uwzględnienie norm międzynarodowej odpowiedzialności państw za czyny niezakazane jest niezbędne dla zidentyfikowania treści zasady należytej staranności. Dlatego też reżim odpowiedzialności państw zostanie opisany jedynie w zakresie koniecznym dla realizacji owego celu. Poza zakresem analizy pozostaje tym samym wiele kluczowych zagadnień odpowiedzialności państw, dotyczących m.in. pojęcia i działań organów państwa, teorii kontroli czy środków odwetowych. Nie uwzględniono jako osobnego przedmiotu rozważań przypadków niepokojów wewnętrznych i zamieszek jako podstaw odpowiedzialności międzynarodowej państwa za działania osób prywatnych. Kategoria ta została omówiona jedynie w zakresie, w jakim państwo ponosi odpowiedzialność za brak należytej staranności przy zapobieganiu skutkom takich wydarzeń.

Poniższa analiza dorobku doktryny i praktyki, opisujących reguły międzynarodowej odpowiedzialności, bazuje na chronologicznej analizie prac Ligi Narodów i kontynuującej jej rozważania Komisji Prawa Międzynarodowego ONZ. Punktem wyjścia prac obu organizacji była odpowiedzialność państwa za czyny, tj. działania i zaniechania, zakazane $\mathrm{w}$ treści norm prawa międzynarodowego, dlatego też temu zagadnieniu poświęcony został niniejszy rozdział. W toku późniejszych prac prowadzonych przez Komisję wyłoniony został drugi obszar rozważań, jakim jest odpowiedzialność międzynarodowa za szkodliwe skutki działań niezakazanych $\mathrm{w}$ treści norm prawa międzynarodowego, opisany w rozdziale kolejnym. Wśród reguł tego drugiego, późniejszego, reżimu odpowiedzialności Komisja zidentyfikowała spoczywający na państwach obowiązek 
prewencji, którego treść stanowi zobowiązanie państw do wykazywania należytej staranności względem realizowanych na ich terytorium, w ich jurysdykcji lub pod ich kontrolą działań potencjalnie niosących transgraniczne szkody. Oba reżimy odpowiedzialności pozostają ze sobą ściśle związane historycznie i merytorycznie, którą to zależność opisano w podsumowaniu kolejnego rozdziału. W pierwszej części rozdziału omówiono genezę prac nad odpowiedzialnością międzynarodową celem zarysowania kontekstu ewolucji zasady należytej staranności. Następnie przedstawiono szczegółową analizę roli i ewolucję treści owej zasady, z uwzględnieniem wpływu propozycji doktryny na kształt dotyczących jej prac KPM.

\subsection{Prace Ligi Narodów nad zasadami odpowiedzialności państw}

Zagadnienie odpowiedzialności międzynarodowej państwa do XIX w. nie cieszyło się zainteresowaniem dogmatyków ${ }^{1}$. Jak już wpominano, pisarze rodzącego się prawa międzynarodowego koncentrowali uwagę na odpowiedzialności suwerenów albo społeczności, którym ci przewodzili, nie konstruując koncepcji dogmatycznych dotyczących odpowiedzialności państwa jako podmiotu prawa międzynarodowego. Piszący w XX w. Brierly także nie uznawał tego zagadnienia za konieczny, odrębny element swojej rozprawy o prawie międzynarodo$w_{y m}{ }^{2}$. Porządek westfalski skoncentrowany wokół pojęcia racji stanu, odrębnej od interesów suwerena czy sumy interesów jednostek, spowodował, że Liga Narodów w 1924 r. uwzględniła w swoich pracach problem odpowiedzialności państwa jako podmiotu prawa międzynarodowego, ale jedynie w zakresie odpowiedzialności za szkody wyrządzone na jego terytorium cudzoziemcom ${ }^{3}$.

W 1924 r. Liga Narodów powołała komitet ekspertów, którego zadaniem była koordynacja prac nad kodyfikacją prawa międzynarodowego. Konferencja haska planowana na 1930 r. miała zostać poświęcona kodyfikacji prawa międzynarodowego i stała się pierwszym w historii spotkaniem przedstawicieli rządów poświęconym tej tematyce ${ }^{4}$. Dokonano wyboru tematów, które miały stać się przedmiotem dyskusji podczas konferencji. Wśród zagadnień pierwotnie wskazanych jako nadające się do kodyfikacji, znalazły się kwestie obywatelstwa, wód terytorialnych oraz, jak wspomniano, odpowiedzialność państwa za

\footnotetext{
${ }^{1}$ I. Brownlie, System ..., s. 2.

${ }^{2}$ Por.: ibidem, część I, s. 7.

${ }^{3}$ League of Nations, Official Journal, Special Supplement 1924, s. 10; podaję za: Pierwszy raport Specjalnego Sprawozdawcy Roberta Ago o odpowiedzialności państw, 1967 r., U.N. Doc. A/CN.4/217, zał. 6 (dalej: Pierwszy raport Ago), pkt 32, s. 142; por. też: D. M. Bodansky, J. R. Crook, Symposium on the ILC's State Responsibility Articles: Introduction and Overview, American Journal of International Law 2002, nr 96, s. 776-7.

${ }^{4}$ H. Miller, The Hague Codification Conference, American Journal of International Law 1930, nr 24, s. 674.
} 
szkody wyrządzone cudzoziemcom lub ich własności na terytorium państwa 5 . Podczas drugiej sesji w Genewie w 1926 r. komitet ekspertów wskazał siedem tematów, zaproponowanych państwom członkowskim jako ewentualne części raportu końcowego. Wśród nich znalazło się także zagadnienie „odpowiedzialności państwa za szkody wyrządzone w jego terytorium osobom i własności cudzoziemców", które zyskało poparcie 30 przedstawicieli rządów, podczas gdy jedynie cztery państwa uznały za zbędne opracowanie traktatu w przedmiotowej materii ${ }^{6}$. Materiałem pomocniczym dla uczestników konferencji był raport podkomitetu ekspertów ds. postępowej kodyfikacji prawa międzynarodowego z 1926 r. nazywany od nazwiska przewodniczącego podkomitetu Raportem Guerrero $^{7}$. W jego treści zaproponowano domniemanie braku odpowiedzialności państwa za szkody wyrządzone cudzoziemcowi przez jego przedstawiciela przekraczającego kompetencje określone w prawie krajowym. ${ }^{8}$. Domniemanie to nie obejmowało trzech wyjątkowych sytuacji. Do nich komitet zaliczył niepodjęcie lub zwłokę przy podejmowaniu przez władze państwa kroków zmierzających do zapobieżenia szkodzie, o zamiarze wyrządzenia której państwo zostało poinformowane. Nieobjęte domniemaniem były także szkodliwe działania przedstawicieli państwa, które nie stały się niezwłocznie przedmiotem postępowania sądowego, zgodnie z prawem krajowym. Projekt przewidywał także, że domniemanie nie jest skuteczne, jeśli nie istnieją w systemie krajowym dostępne dla cudzoziemców instrumenty prawne, służące ich obronie przed szkodą lub bezczynnością organu państwowego ${ }^{9}$. Ostatecznie komitet ekspertów wysłał do rządów państw pomiędzy 1925 a 1929 r. trzy dokumenty. Pierwszym z nich był wspomniany Raport Guerrero. Drugi to Plan punktów dyskusji (ang. Schedule of Points), przygotowany przez komitet ekspertów, zaś trzeci to Podstawy dyskusji (ang. Bases of Discussion), składające się z odpowiedzi 30 państw na rozesłany wcześniej Plan punktów dyskusji $1^{10}$.

VII Punkt planu dyskusji zawierał pytanie o odpowiedzialność państwa za działania osób prywatnych, naruszających dobra osobiste lub materialne cudzoziemca na terytorium państwa. Komitet wskazywał, że odpowiedzialność państwa w takiej sytuacji ograniczona być powinna do okoliczności, w których władze państwa nie ,zrobiły co w ich mocy” celem zachowania porządku i zapobiegania popełnieniu przestępstwa lub udzielenia „rozsądnej” ochrony osobie i mieniu cudzoziemca. Odpowiedzialność państwa pojawiała się także

\footnotetext{
${ }^{5}$ Ibidem, s. 674; E. M. Borchard, „Responsibility of States”, at the Hague Codification Conference, American Journal of International Law 1930, nr 3(24), s. 517-540.

${ }^{6}$ Por.: Czwarty raport Ago, U.N. Doc. A/CN.4/264, pkt 33; zob. także: J. Symonides, op.cit., s. $34-35$.

${ }^{7}$ Raport podkomitetu ekspertów ds. postępowej kodyfikacji prawa międzynarodowego Ligii Narodów (dalej: Raport Guerrero), U.N. Doc A/CN.4/96, zał. 1. Por.: H. Miller, op.cit., s. 674; E. M. Borchard, op.cit., s. 517-540.

${ }^{8}$ Raport Guerrero, par. 4, s. 174 i 221; por. też: E. M. Borchard, Theoretical Aspects of the International Responsibility of States, Heidelberg Journal of International Law 1929, nr 1, s. 223-250.

${ }^{9}$ Raport Guerrero, par. 4, s. 174.

${ }^{10}$ E. M. Borchard, Responsibility of States..., s. 517.
} 
wówczas, gdy zaniechało ono dołożenia „rozsądnej staranności” (ang. reasonable diligence) przy osądzeniu i karaniu osób dopuszczających się wykroczeń względem cudzoziemca ${ }^{11}$. Komitet oczekiwał od państw także odpowiedzi na pytanie, czy na rozstrzygnięcie co do odpowiedzialności państwa powinien wpływać fakt skierowania działań przeciwko cudzoziemcowi, raczej niż jedynie wywołanie szkód przez zaniechanie.

Sformułowanie pytań świadczyło o przekonaniu komitetu, iż podstawą odpowiedzialności państwa nie może być jedynie zachowanie jego obywatela. Skuteczne jej przywołanie możliwe byłoby dopiero wówczas, gdyby organy państwa dopuściły się zaniechania, skutkującego powstaniem szkody obcokrajowca. Ta koncepcja została potwierdzona $\mathrm{w}$ treści odpowiedzi skierowanych do komitetu przez 23 państwa, choć jedynie dziesięć spośród nich wyraźnie wskazało, że państwo pozostawało w szczególnym obowiązku zapewnienia obcokrajowcom ochrony. Wskazały tym samym, że odpowiedzialność międzynarodowa może pojawić się jedynie w sytuacji naruszenia zobowiązania międzynarodowego do jej zapewnienia przez organy państwa. Jedynie dwa państwa wskazały wprost, że bezpośrednie zastosowanie powinny mieć okoliczności sformułowane w treści pytania. Jednoznacznej odpowiedzi udzieliły Niemcy, których przedstawiciele w przekazanym komitetowi oświadczeniu wskazali, że, zgodnie z zasada odpowiedzialności międzynarodowej państw, ponoszą one odpowiedzialność wskutek własnego lekceważenia prawa międzynarodowego. W konsekwencji odpowiedzialność państwa pojawiała się jedynie wskutek działań lub zaniechań jego przedstawicieli, nigdy zaś w następstwie działań osób prywatnych. Szkody wyrządzone cudzoziemcom przez osoby prywatne mogły nieść za sobą odpowiedzialność państwa jedynie wówczas, gdy jego organy w danej sytuacji niesłusznie zlekceważyły ciążący na nich obowiązek. Nawet w takiej sytuacji jednak to nie działanie osoby prywatnej dawało podstawę odpowiedzialności państwa, a jedynie zaniechanie jego organów. W podobnym tonie wypowiadali się przedstawiciele Finlandii wskazując, iż państwo ponosi odpowiedzialność jedynie wówczas, gdy szkoda wynika z faktu, że jego właściwie umocowani przedstawiciele zaniechali podjęcia kroków, które powinni byli podjąć $\mathrm{z}$ całą należytą starannością, celem zaniechania i ukarania szkodliwych działań ${ }^{12}$. Także stanowisko Stanów Zjednoczonych wskazywało, iż państwo nie ponosi odpowiedzialności za bezprawne działania jednostek skierowane przeciwko cudzoziemcom, bowiem dopiero przewinienie po stronie państwa stanie się podstawą jego odpowiedzialności, niezależnie od działania osoby fizycznej ${ }^{13}$. Również reprezentujący Polskę Lachs podkreślał, iż z punktu widzenia prawa międzynarodowego państwo nigdy nie może być uznane za odpowiedzialne za działania osób prywatnych ${ }^{14}$.

\footnotetext{
${ }^{11}$ Por.: Czwarty raport Ago, U.N. Doc. A/CN.4/264, pkt 92, s. 107. Por. M. N. Shaw, Prawo..., s. 435.

${ }^{12}$ Por.: Czwarty raport Ago, U.N. Doc. A/CN.4/264, pkt 93, s. 107.

${ }^{13}$ Por.: Czwarty raport Ago, U.N. Doc. A/CN.4/264, pkt 93, s. 107.

${ }^{14}$ Por.: Czwarty raport Ago, U.N. Doc. A/CN.4/264, pkt 93, s. 107.
} 
Przedstawiciele państw udzielili obszernych odpowiedzi na postawione im $\mathrm{w}$ treści raportu pytania dotyczące każdego z wybranych zagadnień. Na szczególną uwagę zasługuje obszernie uzasadnione stanowisko Stanów Zjednoczonych w sprawie odpowiedzialności państw, przygotowane przez profesora prawa Hudsona z Uniwersytetu Harvarda, które znacząco wpłynęło na przebieg haskich negocjacji ${ }^{15}$. Inicjatywa Ligii Narodów przyczyniła się jednocześnie do zintensyfikowania prac badaczy prawa międzynarodowego nad zagadnieniem odpowiedzialności państw, co zaowocowało szeregiem opracowań i projektów konwencji, przygotowanych przez krajowe instytucje badawcze i organy państwowe.

W oparciu o stanowisko Hudsona pracownicy wydziału prawa Uniwersytetu Harvarda pod kierownictwem Borcharda przygotowali w 1929 r. projekt konwencji o odpowiedzialności państw za szkody wyrządzone $\mathrm{w}$ ich terytorium cudzoziemcom i ich własności ${ }^{16}$. W treści tego projektu uwzględniono także zagadnienie ochrony dyplomatycznej i odmowy wymiaru sprawiedliwości jednego spośród trzydziestu zagadnień opracowanych przez Amerykański Instytut Prawa Międzynarodowego (ang. American Institute of International Law) na zlecenie Rady Zarządzającej Związku Panamerykańskiego (ang. Governing Board of the Pan American Union) ${ }^{17}$. Projekt harwardzki był dość zachowawczy, nie obejmował bowiem szeregu ustalen, dokonanych podczas poprzedzających go spotkań dyplomatycznych ${ }^{18}$. Każdy z artykułów projektu przygotowanego przez Borcharda opatrzony został komentarzem, w treści którego znalazły się odniesienia do postanowień traktatowych, rozstrzygnięć sądowych i praktyki międzynarodowej ${ }^{19}$. Na polecenie KPM projekt Borcharda został zaktualizowany i znacząco zmodyfikowany, a następnie opublikowany w $1961 \mathrm{r}$. jako projekt konwencji o międzynarodowej odpowiedzialności państw za szkody poniesione przez cudzoziemców ${ }^{20}$.

Tym samym zagadnieniom poświęcony był projekt Instytutu Prawa Międzynarodowego. Poprzedzając konferencję Ligii Narodów w Hadze w 1927 r. podczas sesji w Lozannie, Instytut przyjął projekt artykułów poświęconych „odpowiedzialności międzynarodowej państw za szkody powstałe na ich terytorium

${ }^{15}$ H. Miller, op.cit., s. 674. Por. także J. Symonides, op.cit., s. 37. Autor wspomina o jeszcze jednym, składającym się jedynie z dwóch artykułów projekcie amerykańskim, dotyczącym odpowiedzialności państw, przygotowanym przez Instytut Prawa Międzynarodowego w $1925 \mathrm{r}$. W jego treści zawarto zobowiązanie państw do utrzymywania na swym terytorium porządku wewnętrznego i stabilności, niezbędnych do wypełniania zobowiązań międzynarodowych, przesądzając o odpowiedzialności państw za szkody poniesione przez cudzoziemców w sytuacji, gdy te były następstwem zaniechań organów państwowych. Zaniechania te mogły polegać na nieutrzymywaniu porządku wewnątrz państwa, niepodejmowaniu działań zmierzających do powstrzymania zakłoceń porządku wewnętrznego lub nie zapobieganiu powstaniu takich szkód. Ibidem.

${ }^{16}$ Pierwszy raport Ago, s. 142.

${ }^{17}$ Pierwszy raport Ago, s. 128.

${ }^{18}$ Por. J. Symonides, op.cit., s. 35.

${ }^{19}$ Pierwszy raport Ago, s. 128.

${ }^{20}$ Harvard Law School, Draft Convention on the International Responsibility of States for Injuries to Aliens, (w:) Pierwszy raport Ago, s. 128 i zał. VII, s. 548-584. 
względem cudzoziemców i ich mienia"21. Projekt dotyczył odpowiedzialności międzynarodowej, reguł jej przypisania państwom oraz przypisania im szkodliwych konsekwencji zachowań niezgodnych z prawem międzynarodowym. Choć instytut nie pochylał się nad zagadnieniem odpowiedzialności międzynarodowej po 1927 r., to w drugiej połowie XX w. przyjął dwie rezolucje poświęcone częściowo temu problemowi: w 1956 r. podjął rezolucję poświęconą zasadzie wyczerpania środków lokalnych, zaś w 1965 r. - narodowemu charakterowi roszczenia międzynarodowego państwa, wystosowanego $\mathrm{w}$ związku ze szkoda poniesioną przez jednostkę 2 .

W 1926 r. projekt kodeksu prawa międzynarodowego zgłosili także przedstawiciele Japonii pod kierownictwem Gakkwai. Jego rozdział drugi poświęcony był „zasadom dotyczącym odpowiedzialności państwa za życie, osobę i własność cudzoziemców" i zawierał opis reguł dotyczących odpowiedzialności państwa za naruszenia ich obowiązków względem cudzoziemców ${ }^{23}$.

$\mathrm{W}$ ramach przygotowań do konferencji haskiej własny projekt konwencji o odpowiedzialności państw za szkody wyrządzone na ich terytorium cudzoziemcom oraz ich mieniu został przygotowany przez Niemieckie Stowarzyszenie Prawa Międzynarodowego (niem. Deutsche Gesellschaft fur Völkerrecht) w $1930 \mathrm{r}^{24}{ }^{24}$ Ponadto dwóch przedstawicieli niemieckiej doktryny prawa międzynarodowego przygotowało własne propozycje kodyfikacji reguł odpowiedzialności międzynarodowej państw. Karl Strupp w 1927 r. przedstawił projekt konwencji o odpowiedzialności państw za akty międzynarodowo bezprawne ${ }^{25}$. Podobny projekt, kilka lat po zakończeniu konferencji haskiej, tj. w 1932 r., przedstawił inny niemiecki badacz prawa międzynarodowego, Roth ${ }^{26}$. Te dwie ostatnie propozycje są ciekawe dla czynionych tu rozważań, poświęconych badaniu zależności pomiędzy reżimami międzynarodowej odpowiedzialności, bowiem ich autorzy nie uwzględniają podziału na odpowiedzialność państwa i odpowiedzialność międzynarodową za czyny niezakazane prawem międzynarodowym, przyjętego w XX w. przez KPM. Wskazują na ogólne zasady odpowiedzialności państwa za czyn międzynarodowo bezprawny, abstrahując od charakteru jej źródła.

Jak wspomniano, w oparciu o otrzymane odpowiedzi komitet sformułował Podstawy dyskusji - dokument stanowiący punkt wyjścia haskich negocjacji.

${ }^{21}$ Pierwszy raport Ago, s. 128 i zał. III.

${ }^{22}$ Pierwszy raport Ago, s. 128 i zał. V.

${ }^{23}$ Pierwszy raport Ago, s. 128.

24 Institut für Internationalen Recht an der Universität Kiel, Zeitschrift für Völkerrecht (Breslau, 1930), vol. XV, s. 359-364, podaję za: Pierwszy raport Ago, s. 128. Pełen tekst dostępny ibidem, zał. VIII, s. 149.

${ }^{25}$ K. Strupp, Die völkerrechtliche Haftung des Staates insbesondere bei Handlungen Privater, Abhandlung zur fortschreitenden Kodifikation des internationalen Rechts, Heft 1 (Kiel, 1927), podaję za: Pierwszy raport Ago, s. 128. Pełen tekst dostępny ibidem, zał. IX, s. 150.

${ }^{26}$ A. Roth, Das volkerrechtliche Delikt vor und in der Verhandlungen auf der Haager Kodifications Konferenz 1930, Lipsk 1932, s. 177-178, podaję za: Pierwszy raport Ago, s. 128. Pełen tekst dostępny ibidem, zał. X, s. 151. 
W jego treści poruszona została kwestia odpowiedzialności państwa za szkody wyrządzone cudzoziemcom przez osoby prywatne w sytuacji, gdy państwo nie zapewniło należycie starannej ochrony jemu lub przedmiotowi jego własności, wymaganej od cywilizowanego państwa $w$ danych okolicznościach lub ze względu na przysługujący mu wyjątkowy status, np. dyplomatyczny ${ }^{27}$. Zwrócono także uwagę negocjujących na zagadnienie odpowiedzialności państwa za szkody cudzoziemców wywołane przez osoby prywatne w sytuacji, gdy nie wykazało ono należytej staranności, której można oczekiwać od cywilizowanego państwa przy wykrywaniu i karaniu sprawcy szkody ${ }^{28}$. Komitet poczynił także sugestię odnośnie do zamiaru sprawcy szkody i wskazał, iż zakres odpowiedzialności państwa zależał będzie w szczególności od tego, czy szkodliwe działanie było skierowane przeciwko cudzoziemcowi czy też szkoda powstała od owego zamiaru niezależnie. 18 państw potwierdziło także, że na zakres odpowiedzialności wpływa publiczno-prawny status poszkodowanego cudzoziemca, tj. na organach władzy spoczywa szczególny obowiązek ochrony cudzoziemców będących oficjalnymi przedstawicielami państwa. Państwo ponosić więc będzie odpowiedzialność jedynie wtedy, gdy owego szczególnego obowiązku nie dopełni ${ }^{29}$. W toku dyskusji pojawiały się jednak także głosy podnoszące, że sam atak na przedstawiciela państwa wysyłającego nie może przesądzać o odpowiedzialności państwa goszczącego. Tak dowodziła np. Szwajcaria, wskazując, iż o ile można uznać, że odpowiedzialność państwa względem innych państw za czyny osób prywatnych popełnione na jego terytorium wynika z braku podjęcia $\mathrm{w}$ dobrej wierze odpowiednich kroków zmierzających do zapobiegania powstaniu szkody i udaremnienia usiłowań sprawców, jeśli zostało o takich usiłowaniach poinformowane, o tyle delegacja szwajcarska nie podzielała poglądów tej części doktryny, która uznawała za współsprawcę (ang. accomplice) państwo niewykazujące „wszelkiej właściwej staranności”30. Państwo faktycznie bowiem odpowiedzialne jest nie za działania jednostek, ale za własne zaniechania, niedbalstwo, które w danej sytuacji poczytane może zostać za sprzeczne $\mathrm{z}$ treścią jego międzynarodowego zobowiązania.

Podsumowując stanowiska stron, komitet wskazał w treści Podstaw dyskusji, iż państwo ponosi odpowiedzialność za szkody poniesione przez cudzoziemca w wyniku zaniechania organów jego władzy wykonawczej, które nie wykazały takiej staranności przy ochronie cudzoziemców, jakiej w danych okolicznościach i z uwzględnieniem statusu chronionych osób oczekiwać można od cywilizowanego państwa. Szczególny obowiązek „czujności” wynika z przysługującemu

${ }^{27}$ Por.: Czwarty raport Ago, U.N. Doc. A/CN.4/264, pkt 94, s. 107; zob. też: Pierwszy raport Specjalnego Sprawozdawcy F.V. García-Amadora, 1956 r., U.N. Doc. A/CN.4/96, zał. 2 (dalej: Pierwszy raport Garcíi-Amadora, U.N. Doc. A/CN.4/96).

${ }^{28}$ Por.: Czwarty raport Ago, U.N. Doc. A/CN.4/264, pkt 94, s. 107; zob. też: Pierwszy raport Garcíi-Amadora, U.N. Doc. A/CN.4/96.

${ }^{29}$ Por.: Czwarty raport Ago, U.N. Doc. A/CN.4/264, pkt 95, s. 108.

${ }^{30}$ Por.: Czwarty raport Ago, U.N. Doc. A/CN.4/264, pkt 95, s. 108. 
cudzoziemcowi uznanego statusu publicznego jako przedstawicielowi swojego państwa ${ }^{31}$.

Sześć państw poparło propozycje uwzględnienia odwróconego ciężaru dowodu, gdy osobami prywatnymi, za które odpowiedzialność może ponosić państwo, są członkowie ruchu rewolucyjnego lub gdy do powstania szkody dochodzi podczas zamieszek. Wówczas po stronie rządu spoczywał obowiązek wykazania, że jego organy nie dopuściły się braku należytej staranności w zapobieganiu szkodom. Sześć innych państw, które także pochyliły się nad owym szczególnym stanem faktycznym wskazało, że odwrócony dowód winy nie jest potrzebny i także w tych okolicznościach mogą być stosowane ogólne zasady odpowiedzialności za działania osób prywatnych. Japonia zaproponowała, aby w takiej sytuacji państwo ponosiło odpowiedzialność niezależnie od rodzaju działań podjętych przez jego organy ${ }^{32}$. Na podstawie otrzymanych uwag komitet ustalił, iż państwo ponosi odpowiedzialność za szkody wyrządzone cudzoziemcom lub ich mieniu przez uczestników zamieszek, jeśli te wymierzone były przeciwko cudzoziemcom lub osobom określonej narodowości, chyba że władze państwa udowodnią, iż ich organy nie działały niedbale ${ }^{33}$. Podsumowanie dyskusji komisji zawierało konstatację, iż państwo winno ponosić odpowiedzialność za szkody wyrządzone cudzoziemcom i ich mieniu przez osoby prywatne, jeśli zaniechało podjęcia środków prewencyjnych lub karnych, jakie w danych okolicznościach mogłyby być od niego wymagane ${ }^{34}$. Stanowiska uczestników debaty nad dokumentami przygotowanymi przez komisję wykrystalizowały dwa rozbieżne podejścia do odpowiedzialności państwa. Jedno z nich, oparte na wnioskach komisji, wyrażało przekonanie, iż w pewnych okolicznościach państwa zobowiązane były zapewnić cudzoziemcom ochronę skuteczniejszą niż własnym obywatelom. Stanowisko przeciwne koncentrowało się wokół przyzwolenia na przyznanie cudzoziemcom ochrony równej własnym obywatelom, zaś jego zwolennicy odżegnali się tym samym od ustaleń dokonanych przez komisję. Zwolennicy tej pierwszej koncepcji stali się apologetami tzw. standardu minimum, który wciąż stanowi przedmiot ożywionej dyskusji na arenie stosunków międzynarodowych, zaś w Hadze stał się głównym powodem silnej polaryzacji stanowisk, czyniącej kompromis nieosiagalnym. Propozycja takiego kompromisu autorstwa przedstawiciela Włoch, określana od jego nazwiska mianem propozycji Gianniniego, oparta została o przyjęcie negatywnej formuły, stanowiącej o braku odpowiedzialności państwa za działania osób prywatnych, zawierającej jednak podkreślenie wyjątkowego charakteru odpowiedzialności państwa w okolicznościach stanowiących przedmiot sporu. Giannini sugerował, iż państwo ponosić winno odpowiedzialność jedynie za szkody cudzoziemców

${ }^{31}$ Por.: Czwarty raport Ago, U.N. Doc. A/CN.4/264, pkt 96, s. 108; por.: Pierwszy raport Garcíi-Amadora, U.N. Doc. A/CN.4/96.

${ }^{32}$ Por.: Czwarty raport Ago, U.N. Doc. A/CN.4/264, pkt 98, s. 108.

${ }^{33}$ Por.: Czwarty raport Ago, U.N. Doc. A/CN.4/264, pkt 98, s. 108. Por.: Pierwszy raport Garcíi-Amadora, U.N. Doc. A/CN.4/96, s. 124, 126.

${ }^{34}$ Por.: Czwarty raport Ago, U.N. Doc. A/CN.4/264, pkt 99, s. 108. 
i ich mienia wywołane przez osoby prywatne, jeśli w sposób oczywisty zaniechało (ang. manifestly failed) podjęcia takich środków prewencyjnych i karnych, których w danych okolicznościach można by od niego wymagać ${ }^{35}$. Kompromisowej propozycji sprzeciwiły się jednak państwa Ameryki Łacińskiej, w imieniu których wypowiadał się przewodniczący Guerrero i, podobnie jak wcześniejsze propozycje komisji, została ona wycofana. Alternatywne sformułowanie spornej zasady zgłosili przedstawiciele Grecji, Włoch, Wielkiej Brytanii, Francji i Stanów Zjednoczonych. Według nich państwa ponosiłyby odpowiedzialność za szkody wyrządzone cudzoziemcom $\mathrm{i}$ ich mieniu przez osoby prywatne jedynie wówczas, gdyby szkoda wynikała $\mathrm{z}$ faktu zaniechania przez państwo podjęcia takich kroków, jakie w danych okolicznościach powinny zostać normalnie podjęte celem zapobieżenia szkodzie, odszkodowania za nią lub ukarania sprawców za ich szkodliwe działania ${ }^{36}$. Także ta propozycja nie uratowała konferencji przed niepowodzeniem.

Prace konferencji haskiej ograniczały się do zbadania charakteru i treści obowiązków państw względem cudzoziemców i ich mienia ${ }^{37}$. Być może także z tego względu zakończyły się fiaskiem, gdyż podjęte zadanie było zbyt precyzyjnie określone i przez to zbyt trudne do realizacji. Do niepowodzenia konferencji mógł przyczynić się również fakt, że stanowiący jeden z dokumentów do dyskusji raport Guerrero znacząco odbiegał od reprezentatywnych dla stanowiska uczestników konferencji Punktów dyskusji, przedstawiając opinie mniejszości ${ }^{38}$. Powołana w wyniku konferencji haskiej komisja ds. odpowiedzialności państw spotkała się w Hadze 17 razy pomiędzy marcem a kwietniem 1930 r. Pomimo wsparcia udzielanego przedstawicielom 42 państw przez komitet traktatowy i trzy podkomitety, spotkania zakończyły się deklaracją o niemożności osiągnięcia konwencyjnego konsensusu, choć obrady zakończono przyjęciem w drodze głosowania uchwały zawierającej projekt dziesięciu artykułów, które zyskały poparcie większości i ${ }^{39}$. Jak zaznacza Symonides, znaczenie konferencji polegało na tym, iż była pierwszą uniwersalną próbą kodyfikacji reguł odpowiedzialności międzynarodowej ${ }^{40}$. W kontekście analizy przedstawionej w rozdziale poprzednim odnotować należy, iż w przedmiotowym dla konferencji obszarze odpowiedzialności za szkody cudzoziemców istotną, choć sporną rolę odgrywała należyta staranność.

${ }^{35}$ Por.: Czwarty raport Ago, U.N. Doc. A/CN.4/264, pkt 99, s. 109.

${ }^{36}$ Por.: Czwarty raport Ago, U.N. Doc. A/CN.4/264, pkt 99, s. 109.

${ }^{37} \mathrm{~W}$ latach 70. minionego wieku, J. Symonides odnotowywał ograniczenie rozumienia odpowiedzialności państwa do odpowiedzialności za szkody poniesione na jego terytorium przez cudzoziemców jako jedną z dwóch konkurujących tendencji w badaniach omawianego obszaru („tendcję konserwatywną”). W opozycji do niej pozostawała koncepcja „postępowa”, opisująca odpowiedzialność za naruszenie przez państwa zakazu uciekania się do wojny oraz za akty agresji, która to koncepcja stała się dominującą „po Rewolucji Październikowej”. Por. J. Symonides, op.cit., s. 33-34.

${ }^{38}$ E. M. Borchard, Responsibility of States..., s. 517.

${ }^{39}$ Ibidem.

${ }^{40}$ J. Symonides, op.cit., s. 36. 
Nieudana próba kodyfikacji z 1930 r. odzwierciedlała ówczesne podejście państw do kwestii odpowiedzialności międzynarodowej. Miała ona stanowić opis reguł odpowiedzialności za szkody wyrządzone cudzoziemcom, dotyczyła więc dobrze udokumentowanego $\mathrm{w}$ praktyce i orzecznictwie obszaru prawa międzynarodowego. To wąskie ujęcie odpowiedzialności państw przyczyniło się do jej fiaska, bowiem uczestnicy konferencji usiłowali rozstrzygnąć ogólne kwestie odpowiedzialności państw odwołując się do szczegółowych reguł odpowiedzialności za szkody wyrządzone cudzoziemcom, który to zabieg skazany był z góry na niepowodzenie ${ }^{41}$. Odnotować jednak należy, iż w tym kontekście przedmiotem badań komisji było także pytanie o działania, jakie powinno przedsięwziąć państwo chcące uniknąć odpowiedzialności międzynarodowej za brak należytej staranności przy ochronie interesów cudzoziemców obecnych na jego terytorium.

Analizując niepowodzenie prac konferencji haskiej w 1969 r. Ago wskazywał, że architekci porozumienia popełnili kluczowy błąd. Nadmiernie skoncentrowali się na kwestiach drugoplanowych względem przedmiotu debaty - zagadnienie odpowiedzialności za szkody wyrządzone cudzoziemcom uniemożliwiło zidentyfikowanie ogólnych reguł odpowiedzialności państw. Ago przewidywał, że gdyby uczestnicy konferencji pominęli sporne zagadnienie szczegółowe, kompromis dotyczący zasad ogólnych okazałby się łatwiejszy do osiagnięcia. Istotnym sukcesem konferencji, choć nieujętym w treści aktu twardego prawa międzynarodowego, było wypracowanie konsensusu dotyczącego niemożności przypisania państwu odpowiedzialności międzynarodowej za działania osób prywatnych, wyrządzających szkody cudzoziemcom, niezależnie od statusu tych ostatnich. Względem owych szkodliwych zachowań państwo ponosić mogło odpowiedzialność jedynie wówczas, gdy działania lub zaniechania jego organów pozostawały w sprzeczności z treścią jego międzynarodowych zobowiązań ${ }^{42}$.

\subsection{Prace Komisji Prawa Międzynarodowego nad zasadami odpowiedzialności państw}

ONZ przejęła po LN zadanie zidentyfikowania i skodyfikowania reguł międzynarodowej odpowiedzialności. Już podczas pierwszego posiedzenia Komisji Prawa Międzynarodowego w 1949 r. zagadnienie odpowiedzialności zapisane zostało wśród jej priorytetów. KPM otrzymała od LN bogaty dorobek badawczy powstały podczas prób zidentyfikowania reguł rządzących tym kluczowym dla nauki prawa międzynarodowego obszarem praktyki. KPM nie popełniła jednak błędów swojej poprzedniczki działającej przy LN i już podczas formułowania tematu badawczego wyraźnie oddzieliła problem odpowiedzialności państw za naruszenie prawa międzynarodowego od zagadnienia odpowiedzialności państw

\footnotetext{
${ }^{41}$ Por.: Czwarty raport Ago, U.N. Doc. A/CN.4/264, s. 100.

${ }^{42}$ Por.: Czwarty raport Ago, U.N. Doc. A/CN.4/264, pkt 100, s. 109.
} 
za szkody wyrządzone cudzoziemcom, określając ten ostatni jako jeden z wielu elementów analizowanej praktyki państw ${ }^{43}$.

W 1953 r. potrzebę zbadania i ewentualnego późniejszego skodyfikowania zasad międzynarodowej odpowiedzialności państw przedstawił Komisji delegat Kuby, García-Amador. Wówczas Komisja została upoważniona do zbadania przedmiotowego zagadnienia na mocy Rezolucji Zgromadzenia Ogólnego 799 (VIII). Nie było to zadanie łatwe - wypracowanie treści projektu reguł międzynarodowej odpowiedzialności, który spotkałby się z akceptacją większości państw reprezentowanych w Szóstym Komitecie ZO ONZ wymagało opracowania 30-tu raportów przez sześciu Specjalnych Sprawozdawców na przestrzeni $48 \mathrm{lat}^{44}$. Otrzymawszy mandat, Komisja odsunęła w czasie badanie zaproponowanego przez Garcíę-Amadora zagadnienia, powołując się na nadmiar innych, pilnych kwestii, wymagających zbadania. Dopiero dwa lata później powierzyła mu funkcję Specjalnego Sprawozdawcy ds. odpowiedzialności państw.

García-Amador podczas kolejnych sześciu posiedzeń Komisji, w latach 1956-1961, przedstawił sześć raportów, dotyczących przede wszystkim zasad odpowiedzialności państwa za szkody wyrządzone cudzoziemcom ${ }^{45}$. Było to, jego zdaniem, zagadnienie obszernie udokumentowane w nauce prawa międzynarodowego, stanowiące dobry początek dalszych badań ${ }^{46}$. Jednak połączenie reguł odpowiedzialności państwa za szkody wyrządzone cudzoziemcom z powstającymi regulacjami dotyczącymi praw człowieka oraz silna inspiracja grocjańską zasadą winy nie przyniosły oczekiwanego sukcesu. Szczegółowe opisy reguł odpowiedzialności państw, z uwzględnieniem specyfiki poszczególnych reżimów, zawarte w raportach autorstwa Kubańczyka w znikomej części odnaleźć można w treści ostatecznego projektu. Ponadto nacisk kładziony przez Garcíę-Amadora na reguły odpowiedzialności wynikające z prawa dyplomatycznego stał się przyczyną sporów na forum Komisji w $1957 \mathrm{r} .{ }^{47} \mathrm{~W}$ tym roku przedstawił on swój drugi raport, który zawierał autorski projekt artykułów

${ }^{43}$ Por. Podsumowanie obrad pierwszej sesji ONZ, Summary Records and Documents of the First Session, 1949 r., U.N. Doc. A/CN.4/Ser.A/194, s. 49-50.

${ }^{44}$ Por.: D. M. Bodansky, J. R. Crook, op.cit., s. 777.

45 Por.: Pierwszy raport García-Amadora, U.N. Doc. A/CN.4/96, Drugi raport GarcíaAmadora, U.N. Doc. A/CN.4/106; Trzeci raport García-Amadora, U.N. Doc. A/CN.4/111; Czwarty raport García-Amadora, U.N. Doc. A/CN.4/119; Piąty raport García-Amadora, U.N. Doc. A/CN.4/125; Szósty Raport García-Amadora, U.N. Doc. A/CN.4/134.

${ }^{46}$ Ale por.: Raport R. Ago, przewodniczącego podkomitetu ds. odpowiedzialności państwa (dalej: raport podkomitetu Ago), U.N. Doc. A/CN.4/152, s. 228, który odnotował, iż przyjęta przez García-Amadora metoda badawcza była przedmiotem krytyki. Podkomitet obradujący pod jego przewodnictwem zalecił Komisji w 1963 r. skoncentrowanie uwagi na identyfikacji ogólnych zasad odpowiedzialności państw, raczej niż zgłębienie jednego, szczegółowego reżimu, zawierającego reguły tej odpowiedzialności, choćby był on najlepiej rozwinięty. Nadmierna analiza szczegółów uniemożliwiała bowiem, zdaniem podkomitetu, identyfikację ogólnych, bardziej elastycznych, reguł, możliwych do aplikacji względem szerokiego katalogu przypadków. Por.: Raport KPM, 1963 r., U.N. Doc. A/CN.4/163, pkt 5, s. 228. Zalecenia Ago wcielił w życie James Crawford w drugiej połowie XX w.; por. dalej.

${ }^{47}$ Por.: D. M. Bodansky, J. R. Crook, op.cit., s. 777. 
o odpowiedzialności państwa za szkody wyrządzone na jego terytorium osobom i własności cudzoziemców. Najistotniejszy dla czynionych tu rozważań był art. 10 projektu, w myśl którego państwo odpowiedzialne było za szkody wyrządzone cudzoziemcom przez „zwykłe osoby prywatne”, jeśli jego przedstawiciele wykazali ,jawne niedbalstwo" przy przedsiębraniu środków normalnie podejmowanych celem zapobieżenia takim szkodliwym czynom lub ukarania $\mathrm{ich}^{48}$. Artykuł 10 umieszczony został $\mathrm{w}$ treści rozdziału $\mathrm{V}$, poświęconego w całości odpowiedzialności państwa za czyny osób prywatnych i niepokoje wewnętrzne $^{49}$. Choć zasada ta wywodzona była $\mathrm{z}$ wciąż aktualnej zasady odpowiedzialności państwa za zaniechanie jego organu, który nie zapobiegał powstaniu szkody, o tyle zbyt precyzyjne sformułowanie zaproponowane przez Garcíę-Amadora spowodowało, że KPM nigdy już nie pochyliła się nad jego propozycjami. Mimo iż w 1961 r. Zgromadzenie Ogólne mocą Rezolucji 1686 (XVI) z 18 grudnia podtrzymało upoważnienie Komisji do badania reguł odpowiedzialności państwa, w toku dyskusji podczas XIV sesji w 1962 r. narzuciło jej pracom inny kierunek. Nowe rozwiązania miał zaproponować powołany w tym celu Podkomitet ds. odpowiedzialności państw, na czele którego stanął Włoch Roberto Ago, następca Garcíi-Amadora w funkcji Specjalnego Sprawozdawcy. Jego zadaniem było przedstawienie Komisji sugestii co do zakresu i sposobu prowadzenia dalszych badań nad odpowiedzialnością państw. Ago sugerował odstapienie od szczegółowej analizy reżimu odpowiedzialności za szkody wyrządzone cudzoziemcom i skoncentrowanie wysiłków na identyfikacji ogólnych reguł odpowiedzialności państw, stosowalnych w każdych okolicznościach. Ten pogląd udało mu się przeforsować w treści raportu z zakończonych w $1963 \mathrm{r}$. prac podkomitetu. Potwierdzono tam, iż zidentyfikowane muszą zostać ogólne zasady odpowiedzialności państw, w odróżnieniu od wskazania reguł poszczególnych reżimów. W tym celu uwzględniono przykłady $\mathrm{z}$ różnych obszarów prawa międzynarodowego, podsumowane w postaci wszechstronnych, ogólnie sformułowanych regut ${ }^{50}$. Uznano, że szczególną uwagę należy poświęcić skutkom, jakie rozwój poszczególnych obszarów prawa międzynarodowego wywiera na zagadnienie odpowiedzialności państwa ${ }^{51}$. Jednocześnie zdecydowano wyłączyć z toku prowadzonych badań zagadnienie odpowiedzialności międzynarodowej podmiotów innych niż państwa. Podczas tej samej sesji, w 1963 r., funkcję Specjalnego Sprawozdawcy powierzono Ago. Zgromadzenie Ogólne zleciło Komisji kontynuację prac w oparciu o raport podkomitetu, ze szczególnym uwzględnieniem celów i zasad zapisanych w Karcie Narodów Zjednoczonych $^{52}$. Wobec braku postępów prac Komisji, w treści Rezolucji 2272 (XXII) z 1967 r. Zgromadzenie Ogólne zaleciło jej przyspieszenie prac, zaś mocą Rezolu-

\footnotetext{
${ }^{48}$ Por.: Drugi raport García-Amadora, U.N. Doc. A/CN.4/106) 1957, art. 10, s. 121.

${ }^{49}$ Towarzyszyło mu obszerne wyjaśnienie „zasady należytej stranności”, opisane szczegółowo dalej. Por.: Drugi raport García-Amadora, U.N. Doc. A/CN.4/106, s. 121-123.

${ }^{50}$ Por.: Raport podkomitetu Ago, U.N. Doc. A/CN.4/152, s. 227-228.

${ }^{51}$ Por.: Raport podkomitetu Ago, U.N. Doc. A/CN.4/152, s. 234.

${ }^{52}$ Por. Rezolucja 1902 (XVIII) z 18 listopada 1963 r., Raport KPM, s. 69.
} 
cji 2400 (XXIII) z 11 grudnia 1968 r. poczyniło sugestię dołożenia przez Komisję „najwyższych starań celem rozpoczęcia merytorycznych prac” z początkiem kolejnej jej sesji ${ }^{53}$.

Pod przewodnictwem Ago Komisja kontynuowała prace podczas kolejnych sesji, lecz nadrzędne założenie identyfikacji ogólnych reguł odpowiedzialności państw prowadziło do nawiązania do XIX-wiecznej koncepcji Oppenheima ${ }^{54}$. W oparciu o jego prace Ago zaproponował podział reguł odpowiedzialności państw na normy pierwotne (czyli te, w treści których opisane są szczegółowe zobowiązania państw, np. dotyczące ochrony cudzoziemców) i normy wtórne (tj. ogólne reguły odpowiedzialności państw za naruszenie norm pierwotnych, na których, jako jedynych, od teraz miały koncentrować się prace Komisji) ${ }^{55}$. Zaproponował także podzielenie wypracowywanego dokumentu na dwie części. Pierwsza miała być poświęcona źródłom naruszeń prawa międzynarodowego i definiować terminy: „zobowiązanie międzynarodowe państwa” i „przypisanie odpowiedzialności”. Druga część zawierałaby opis konsekwencji takiego naruszenia, tj. zobowiązania odszkodowawcze i środki odwetowe ${ }^{56}$. Propozycje Ago wywarły zasadniczy wpływ na ostateczny kształt projektu Komisji z 2001 r., choć względy polityczne i pragmatyczne, raczej niż dogmatyczne, przesądziły o niektórych jego szczegółowych zapisach ${ }^{57}$.

W 1969 r. Komisja poprosiła Ago o przygotowanie podstaw do projektu artykułów o odpowiedzialności państw ${ }^{58}$. Projekt taki powinien był zawierać wstępne ustalenia dotyczące badanej materii, pozwalające w efekcie opracować projekt traktatu oraz zidentyfikować okoliczności niezbędne do powstania takiego dokumentu $^{59}$. Kolejny Raport Ago dotyczył jedynie opisu reguł odpowiedzialności państw, począwszy od konsekwencji naruszenia przez państwo norm prawa międzynarodowego. Późniejsze prace miały objąć reguły odpowiedzialności za działania niezakazane $\mathrm{w}$ treści tych norm ${ }^{60} . \mathrm{Z}$ zakresu badań wyłączone zostały rozważania nad mechanizmami rządzącymi powstawaniem owych zasad. Skupiono się na genezie, ewolucji i aktualnej treści reguł odpowiedzialności ${ }^{61}$.

Komisja zidentyfikowała kryteria, jakie musi spełnić państwo, aby móc przypisać mu naruszenie prawa międzynarodowego, stanowiące podstawę jego

\footnotetext{
${ }^{53}$ Por. Rezolucja 2400 (XXIII) z 11 grudnia 1968 r., Raport KPM, s. 87.

${ }^{54}$ Por.: roz. I; Drugi raport Ago, U.N. Doc. A/CN.4/233, przypis 67, s. 191; por. też: podsumowanie prac Komisji, Ósmy raport Ago, zał. 5, U.N. Doc. A/CN.4/318, s. 44.

${ }^{55}$ Por.: Drugi raport Ago, U.N. Doc. A/CN.4/233, s. 179. Por. też: D. M. Bodansky, J. R. Crook, op.cit., s. 777.

${ }^{56}$ Por. też: ibidem, s. 778.

${ }^{57}$ Por.: ibid., s. 778. Większość z 35 artykułów, przyjętych podczas jego dziesięcioletniej kadencji (pracował w Komisji do 1980 r., tj. do czasu wyboru na stanowisko sędziego MTS) zawartych zostało w ostatecznej wersji projektu.

${ }^{58}$ Por.: Pierwszy raport Ago, U.N. Doc. A/CN.4/217, s. 136-137. Drugi raport Ago zawierał projekt trzech pierwszych artykułów, por. Drugi raport Ago, U.N. Doc. A/CN.4/233, s. 179-197.

${ }^{59}$ Por.: Raport KPM, 1969 r., U.N. Doc. A/7610/Rev.l, par. 80, s. 233.

${ }^{60}$ Por.: Raport KPM, 1969 r., U.N. Doc. A/7610/Rev.1, s. 233, 235.

${ }^{61}$ Por.: Raport KPM, 1969 r., U.N. Doc. A/7610/Rev.1, s. 235.
} 
odpowiedzialności. Poprosiła Specjalnego Sprawozdawcę o opisanie wynikających z treści norm prawa międzynarodowego konsekwencji aktu międzynarodowo bezprawnego w różnych sytuacjach faktycznych, aby móc przedstawić także treść, formy i stopnie odpowiedzialności państw ${ }^{62}$. Wreszcie zamierzała zidentyfikować problemy, na jakie napotyka implementacja reguł odpowiedzialności państw, aby zająć się zasadami rozwiązywania sporów międzynarodowych, powstających wokół ich implementacji. Podczas sesji Komisji w 1970 r. Ago przedstawił drugi raport, dotyczący genezy reguł odpowiedzialności państwa $^{63}$. W treści raportu wskazał kilka podstawowych norm analizowanego reżimu. Za źródło odpowiedzialności uznał czyn międzynarodowo bezprawny. Określił także konieczne warunki uznania działania lub zaniechania państwa za konstytuujący taki czyn, jak też kryteria, jakie musi spełnić podmiot prawa międzynarodowego, aby takiego czynu się dopuścić. W oparciu o tak sformułowane podstawowe zasady, Ago zaproponował pierwszy projekt artykułów o odpowiedzialności państw.

Opisując reguły przypisania państwu czynu stanowiącego naruszenie jego międzynarodowego zobowiązania Ago wskazywał, że, historycznie, częściej państwa pociagane były do odpowiedzialności za zaniechania swoich organów, niż za ich działania. Liczne były także przypadki, gdy państwo ponosiło odpowiedzialność za działania osób prywatnych, które zaliczyć można do tej samej kategorii, bowiem to zaniechanie organów, skutkujące szkodliwym działaniem jednostki, uznawane było za podstawę odpowiedzialności państwa. Identyfikował odpowiedzialność państwa za zaniechania jego organów jako uznaną zasadę prawa międzynarodowego, potwierdzoną $\mathrm{w}$ treści odpowiedzi państw na skierowany do nich raport komitetu ekspertów Ligi Narodów z 1924 r., o którym była tu już mowa ${ }^{64}$. Jednak aby przypisać państwu odpowiedzialność za naruszenie obowiązku zapewnienia skutecznej ochrony np. lokalowi placówki dyplomatycznej czy cudzoziemcom znajdującym się w jego granicach podczas zamieszek, nie wystarczy wykazanie zaniedbania państwa przy zapewnianiu owej ochrony. Takiemu zaniedbaniu musiało towarzyszyć jakieś „zewnętrzne wydarzenie", np. atak osób prywatnych na budynek ambasady czy pozbawienie cudzoziemców życia przez członków sił powstańczych ${ }^{65}$. Jedynie wówczas, gdy zaniedbaniu za strony organów państwa towarzyszyło takie wydarzenie, państwo będzie mogło zostać pociagnięte do odpowiedzialności, zaś oba te zdarzenia muszą pozostawać w związku przyczynowo-skutkowym. Państwo ponosiło więc będzie odpowiedzialność jedynie, jeśli zaniechanie jego organów uznać można za bezpośrednią lub pośrednią przyczynę innego, zewnętrznego wydarzenia, sprzecznego z treścią międzynarodowego zobowiązania państwa. Owa zależ-

\footnotetext{
${ }^{62}$ Por.: Raport KPM, 1969 r., U.N. Doc. A/7610/Rev.l, s. 233.

${ }^{63}$ Raport nosił tytuł: „Źródło odpowiedzialności międzynarodowej”; por.: Drugi raport Ago, U.N. Doc. A/CN.4/233.

${ }^{64}$ Drugi raport Ago, U.N. Doc. A/CN.4/233, s. 188.

${ }^{65}$ Drugi raport Ago, U.N. Doc. A/CN.4/233, s. 194.
} 
ność mogła być zależnością kauzalną lub normatywną, kiedy to powiązanie obu zdarzeń wynikało nie $\mathrm{z}$ ich charakteru, ale $\mathrm{z}$ właściwości systemu prawnego. Dzieje się tak na przykład wówczas, gdy państwo zaniechało podjęcia działań prewencyjnych, które mogły były zapobiec owemu zewnętrznemu wydarzeniu. Poszczególne sytuacje, w których zachodzi ów związek przyczynowo-skutkowy wymagają analizy z uwzględnieniem specyficznych dla nich, dodatkowych kryteriów. Odpowiedzialność państwa może jednak wynikać w równej mierze zarówno z działania państwa, jak i z zachowań innych podmiotów, jeśli towarzyszą zaniechaniu jego organów i są z nim przyczynowo powiązane ${ }^{66}$. Owo zewnętrzne zdarzenie Ago odróżniał od przesłanki szkody, przywoływanej przez niektórych autorów jako konieczny warunek międzynarodowej odpowiedzialności państwa. Wskazywał, że zwolennicy uznania szkody jako przesłanki międzynarodowej odpowiedzialności państwa nadmiernie i niepotrzebnie wykorzystywali analogię do reguł prawa krajowego, gdzie podstawą odpowiedzialności była szkoda majątkowa jednostki. W prawie międzynarodowym natomiast odpowiedzialność państwa względem innego suwerena powstawała także, gdy miało miejsce naruszenie jego interesów niepowiązane bezpośrednio $\mathrm{z}$ materialną szkodą. Wystarczające jest więc wystapienie owego „zewnętrznego zdarzenia”. Może to być na przykład przejaw dyskryminacji, także jeśli nie oznacza ono powstania materialnej szkody jednostki. $Z$ charakteru pierwotnego zobowiązania państwa do poszanowania statusu cudzoziemców dla jego organów wynika nakaz powstrzymywania się przed czynieniem im szkody. $Z$ treści tak sformułowanego zobowiązania wynika, że jego naruszenie nierozłącznie wiąże się z wystapieniem uszczerbku po stronie cudzoziemca. Uszczerbek ów jednak nie powinien być utożsamiany ze szkodą uznaną w systemach prawa krajowego. Aby stanowić podstawę odpowiedzialności międzynarodowej państwa, naruszenie musi dotyczyć interesów państwa i to uszczerbek na jego majątku lub chronionych prawem interesach stanowić może przesłankę odpowiedzialności państwa-sprawcy naruszenia ${ }^{67}$. Błędem było więc bezpośrednie stosowanie $\mathrm{w}$ prawie międzynarodowym koncepcji zapożyczonych z prawa krajowego ${ }^{68}$. Każde bowiem naruszenie porozumienia pomiędzy państwami i każde ograniczenie wynikającego z owego porozumienia praw państwa-strony stanowi uszczerbek, materialny czy moralny. Odpowiedzialność państwa wynikała z samego faktu naruszenia zobowiązania międzynarodowego i samo naruszenie owego zobowiązania stanowiło uszczerbek w prawnie chronionych interesach poszkodowanego. Rozmiar ewentualnej fizycznej szkody wywołanej naruszeniem zobowiązania mógł mieć znaczenie jedynie i dopiero przy szacowaniu kwoty odszkodowania, nie przesądzał natomiast o odpowiedzialności międzynarodowej ${ }^{69}$.

\footnotetext{
${ }^{66}$ Drugi raport Ago, U.N. Doc. A/CN.4/233, s. 194.

${ }^{67}$ Drugi raport Ago, U.N. Doc. A/CN.4/233, s. 194.

${ }^{68}$ Drugi raport Ago, U.N. Doc. A/CN.4/233, s. 194.

${ }^{69}$ Drugi raport Ago, U.N. Doc. A/CN.4/233, s. 194.
} 
Uwzględniające stanowisko sprawozdawcy i komisji artykuły o odpowiedzialności państw opracowane zostały w formie pozwalającej na ich późniejsze przyjęcie $\mathrm{w}$ formie traktatu. Zawierały jedynie opis reguł odpowiedzialności państw za akty międzynarodowo bezprawne, w tym odpowiedzialność państwa za bezczynność jego organów $\mathrm{w}$ kształcie opisanym powyżej. W ich treści uwzględniono także kwestie bezpośrednio związane $\mathrm{z}$ tak określonym obszarem badań, takie jak reparacje czy restytucja. Te ostatnie spowodowały, że w kręgu zainteresowań Komisji znalazły się także zagadnienia pierwotnie dla niej nieprzewidziane, dotyczące konsekwencji działań prawem międzynarodowym niezakazanych, zwłaszcza generujących ryzyko szkody transgranicznej. Wydawały się one - przynajmniej na początku prac Komisji - nierozłącznie związane z badanym zagadnieniem. Pomimo iż Komisja po raz kolejny wskazała na konieczność odrębnej ich analizy, faktyczne trudności z dokonaniem stosownej dystynkcji uniemożliwiły jej dokonanie. W 1970 r. uznała, że odpowiedzialność za naruszenie prawa międzynarodowego, choć także związana $\mathrm{z}$ obowiązkiem naprawienia szkody, odróżniona być musi od sytuacji, gdy obowiązek odszkodowawczy wynika z realizacji działań niebezpiecznych, ale niezakazanych prawem międzynarodowym. Wspólna analiza tych dwóch okoliczności była niemożliwa, w związku z czym to ostatnie zagadnienie Komisja planowała uczynić przedmiotem odrębnych badań. Ago w treści drugiego raportu podkreślał, że sformułowanie „odpowiedzialność państwa” oznacza wyłącznie „odpowiedzialność państwa za czyn międzynarodowo bezprawny" ${ }^{70}$.

W treści dokumentu z 1970 r. Komisja opisała normy dotyczące odpowiedzialności w prawie międzynarodowym jako pierwotne albo wtórne. Celem opracowywanego dokumentu nie było bowiem zdefiniowanie zasad obligujących państwa do określonych działań czy zaniechań. Normy wskazujące treść wymaganego zachowania w poszczególnych dziedzinach prawa międzynarodowego, tj. normy pierwotne, nie stanowiły przedmiotu rozważań Komisji. Jej zadaniem było ustalenie treści norm wtórnych, a więc tych, które znajdą zastosowanie wtedy, gdy dojdzie do naruszenia norm pierwotnych. W treści norm wtórnych określone zostały konsekwencje niespełnienia dyspozycji norm pierwotnych. Komisja wskazywała, że tylko normy wtórne są przedmiotem jej zainteresowania, jako tworzące reguły międzynarodowej odpowiedzialności państw. Podkreślono także znaczenie norm pierwotnych dla implementacji norm wtórnych. Jedynie w oparciu o treść normy pierwotnej możliwe jest ustalenie zaistnienia naruszenia zobowiązania międzynarodowego i w konsekwencji zainicjowanie mechanizmów opisywanych w treści norm wtórnych. Ustalenie treści zobowiązania pierwotnego odróżnić należy od sposobu ustalenia wystapienia i konsekwencji jego naruszenia ${ }^{71}$. Reguły międzynarodowej odpowiedzialności państw stosowane są więc do osobnej, nowej relacji prawnej, powstałej wskutek naruszenia normy pierwotnej. Określają ogólne reguły

\footnotetext{
${ }^{70}$ Zagadnienie to zostało omówione w ostatnim akapicie niniejszego rozdziału.

${ }^{71}$ Raport KPM, 1980 r., U.N. Doc. A/35/10, s. 27-28.
} 
odpowiedzialności państw za naruszenie zobowiązań międzynarodowych, nie odnosząc się do specyfiki samego naruszenia. Niezależnie więc od treści norm regulujących dany obszar międzynarodowej aktywności państwa, zasady jego międzynarodowej odpowiedzialności za ich naruszenie pozostaną bez zmian ${ }^{72}$. Te reguły odzwierciedlone zostały w pierwszym projekcie artykułów, przedstawionym przez Komisję w 1973 r. $^{73}$ Zagadnienie odpowiedzialności państwa za brak należytej staranności po stronie jego organów, tj. za ich niedbalstwo, poruszone tu zostało w kontekście art. 3 projektu, opisującego elementy międzynarodowo bezprawnego czynu państwa ${ }^{74}$. Przesłanka przypisania państwu czynu międzynarodowo bezprawnego spełniona zostanie nie tylko wskutek działań, ale i zaniechań jego organów. Jeśli państwo nie dopełnia obowiązku ochrony np. siedziby placówki dyplomatycznej przed zamachami stron trzecich nie zapewniając wystarczającej ochrony policyjnej, aby przypisać mu odpowiedzialność za naruszenie międzynarodowego zobowiązania konieczne będzie dowiedzenie niedbalstwa po stronie jego organów, sprzecznego z prawnym obowiązkiem ochrony owej placówki oraz wynikającego $\mathrm{z}$ owego zaniechania uszczerbku po stronie personelu dyplomatycznego czy państwa wysyłającego. W przypadku zobowiązania obejmującego obowiązek ochrony, samo jego niedopełnienie nie wystarczy do przypisania państwu odpowiedzialności, jeśli zaniechaniu nie towarzyszy „element uzupełniajacy" (ang. supplementary element) - zdarzenie zewnętrzne z kategorii tych, którym państwo zobowiązane było zapobiegać ${ }^{75}$.

Zgromadzenie Ogólne przyjęło raport KPM w treści rezolucji 3071 $(X X V I I I)^{76} 30$ listopada 1973 r. i zleciło Komisji dalsze prace nad identyfikacja zasad odpowiedzialności państw. Wskazano jednocześnie, że Komisja powinna zając się odrębną kwestią odpowiedzialności międzynarodowej za działania niezakazane prawem międzynarodowym w innym czasie. Podczas dwóch sesji, odbywających się w latach: 1973 i 1978, Komisja przyjęła trzy pierwsze części projektu artykułów o odpowiedzialności państwa za działania niezgodne z prawem międzynarodowym, zaś w 1978 r. poprosiła państwa członkowskie o komentarze, którą to prośbę Zgromadzenie Ogólne potwierdziło mocą Rezolucji $33 / 139^{77}$.

Ago zrezygnował z przewodzenia pracom w 1978 r., zaś na jego następców Zgromadzenie Ogólne wybrało kolejno: Willema Riphagena w 1979 r., Gaetano Arangio-Ruiza w 1987 r. i Jamesa Crawforda w 1997 r.

${ }^{72}$ Por.: Raport KPM, 1973 r., U.N. Doc. A/9010/Rev.1, par. 42, s. 170. Opis wzajemnej zależności norm pierwotnych i wtórnych, por. par. 36-57, s. 169-173.

${ }^{73}$ Por. Raport KPM, 1973 r., U.N. Doc. A/9010/Rev.1, s. 173 i n.

${ }^{74}$ Por. Raport KPM, 1973 r., U.N. Doc. A/9010/Rev.1, s. 179.

${ }^{75}$ Raport KPM, 1973 r., U.N. Doc. A/9010/Rev.1, s. 182; Raport zawierał propozycje rozdziałów: I i II projektu artykułów o odpowiedzialności państwa, s. 173-198.

${ }^{76}$ Rezolucja Zgromadzenia Ogólnego ONZ z 30 listopada 1973 r., U.N. Doc. A/RES/3071 (XXVIII), s. 139-140.

${ }^{77}$ Por. Rezolucja Zgromadzenia Ogólnego z 19 grudnia 1978 r., U.N. Doc. A/RES/33/139, s. 1-2. Por. Raport KPM, 1978 r., U.N. Doc. A/33/10, Projekt 27 artykułów projektu z komentarzami, s. 78-106. 
Riphagen uzupełnił koncepcję Ago wskazując, że niektóre normy pierwotne mogą same w sobie zawierać określenie konsekwencji ich naruszenia. Środki takie traktować należy jako lex specialis w katalogu ogólnych zasad, opisanych przez KPM, a stosowanie reguł wtórnych uznać można za zbędne ${ }^{78}$. Jego zdaniem, różnorodność charakteru i treści norm pierwotnych nie może pozostawać bez wpływu na zakres stosowania i charakter norm wtórnych. Wskazał, że przedmiotem badań Komisji powinny być jedynie konsekwencje zachowań sprzecznych z prawem międzynarodowym, nie zaś te wynikające z działań lub zaniechań niezakazanych $\mathrm{w}$ treści normy prawa międzynarodowego ${ }^{79}$. Odnosząc się do podziału na normy pierwotne i wtórne, Riphagen poddał krytyce pojęcie suwerenności państw. Wskazał, że suwerenność pojmowana „prymitywnie” i „bez ograniczeń” jako całkowita swoboda działania nie była ,prawem” państw w świetle norm międzynarodowych ${ }^{80}$. Jej ograniczenia wynikały zarówno $\mathrm{z}$ faktu powstania nowego stosunku prawnego w wyniku naruszenia normy pierwotnej, jak i z samego faktu obowiązywania tej ostatniej. Podstawowym obowiązkiem państwa jest powstrzymanie naruszenia wiążącego je zobowiązania międzynarodowego. Bez znaczenia jest, czy uznać obowiązek ten za wynikający z treści zobowiązania pierwotnego, czy z faktu jego naruszania - są to

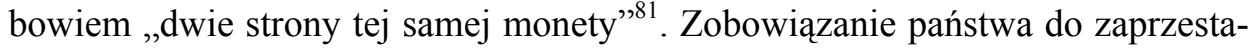
nia naruszania obejmowało obowiązek usunięcia ex nunc powstałych skutków działania niezgodnego $\mathrm{z}$ prawem, które w braku jego działania pozostałyby niezmienione. Zobowiązanie do przerwania stanu niezgodnego $\mathrm{z}$ treścią normy międzynarodowoprawnej byłoby jednak aktualne jedynie względem jego naruszeń „rozciagniętych w czasie" ${ }^{\text {} 82}$. Na ocenę zachowania państwa w sytuacji naruszenia jego międzynarodowych zobowiązań wpływ będą miały także czynniki jakościowe, takie jak jego stanowisko względem samego faktu naruszenia normy oraz dotkliwość jej naruszenia dla państwa poszkodowanego. Inaczej ocenione zostanie zamierzone naruszenie prawa dokonane przez organy państwa, inaczej zaś niefortunny przypadek, skutkujący jego naruszeniem. Podobnie na ocenę działania państwa wpływ będzie miała ilość występków danego rodzaju. Surowszej ocenie podlegały będą naruszenia układające się w politykę systematycznych szkód wymierzonych przeciwko cudzoziemcom czy obcym terytoriom. Na ustalenie treści nowopowstałego zobowiązania odszkodowawczego wpływ będzie miał także charakter zobowiązania pierwotnego. W zależności od tego, czy było ono zobowiązaniem do działania, zobowiązaniem do osiagnięcia określonego skutku czy zobowiązaniem do zapobiegania danym zdarzeniom, kluczowe dla oceny odpowiedzialności państwa będzie miejsce działania

${ }^{78}$ Drugi raport W. Riphagena o treści, formach i stopniach międzynarodowej odpowiedzialności państw, 1981 r., U.N. Doc. A/CN.4/344 (dalej: Drugi raport Riphagena, U.N. Doc. A/CN.4/344), rozdz. IV(C), paragrafy $145-160$, s. 82 , pkt 31 .

${ }^{79}$ Por.: D. M. Bodansky, J. R. Crook, op.cit., s. 778.

${ }^{80}$ Drugi raport Riphagena, U.N. Doc. A/CN.4/344, pkt 65, s. 85.

${ }^{81}$ Drugi raport Riphagena, U.N. Doc. A/CN.4/344, s. 85.

${ }^{82}$ Drugi raport Riphagena, U.N. Doc. A/CN.4/344, s. 89. 
sprawców szkód, zaś państwo ponosić będzie odpowiedzialność wówczas, jeśli ci działali w jego jurysdykcji. Wtórne zobowiązanie państwa, wynikające z faktu naruszenia jego międzynarodowego zobowiązania, zawiera także obowiązek satysfakcji, który Riphagen rozumiał jako konieczność ponownego potwierdzenia przyjęcia przez państwo naruszonego zobowiązania lub deklarację przedsięwzięcia środków zmierzających do zapobiegania podobnym naruszeniom prawa $\mathrm{w}$ przyszłości ${ }^{83}$.

Podczas kolejnej sesji w 1997 r. Komisja rozpoczęła drugie czytanie artykułów, uwzględniając treść sugestii zawartych w czterech raportach nowego Specjalnego Sprawozdawcy, Jamesa Crawforda oraz uwagi zgłoszone przez rządy państw członkowskich ${ }^{84}$. Crawford, naglony przez Komisję, zweryfikował treść artykułów pragmatycznie, kierując się przede wszystkim poszukiwaniem kompromisu wśród członków Szóstego Komitetu ZO ONZ ${ }^{85}$. Jak sam później przyznawał, zależało mu na osiągnięciu takiego poziomu ogólności zapisów dokumentu, aby możliwe było ich przyjecie przez wymaganą większość dwóch trzecich głosów państw członków Organizacji, reprezentowanych w Komitecie, co świadczy o skali zaistniałego sporu, zważywszy że uchwały Szóstego Komitetu zazwyczaj przyjmowane były jednogłośnie ${ }^{86}$.

Komisja zakończyła drugie czytanie projektu w 2001 r. Z projektu przekazanego Zgromadzeniu Ogólnemu z sugestią uwzględnienia w treści Rezolucji usunięto najbardziej kontrowersyjne postanowienia, jak te dotyczące „zbrodni państwowych". Komisja chciała, aby jej projekt stał się podstawą późniejszego traktatu o zasadach odpowiedzialności państw. Podkreśliła rozróżnienie między odpowiedzialnością państwa za działania sprzeczne z treścią norm prawa międzynarodowego a odpowiedzialnością międzynarodową za działania niezakazane prawem międzynarodowym, które to zagadnienie wybiegało poza zakres przyznanego jej mandatu. Ostateczna wersja projektu dotyczyła „odpowiedzialności państw za działania zakazane prawem międzynarodowym" i składała się z 59 artykułów, opatrzonych obszernymi komentarzami ${ }^{87}$.

Komisja podzieliła opis reguł międzynarodowej odpowiedzialności państw na cztery części. Pierwsza część projektu artykułów zawierała opis aktu międzynarodowo bezprawnego, tj. naruszenia normy „pierwotnej”, skutkiem którego było poddanie państwa opisanym w treści dokumentu normom „wtórnym”. W rozdziale I części pierwszej opisano trzy podstawowe zasady odpowiedzialności, z których wywodzona jest pozostała treść artykułów. W treści rozdziału II zdefiniowano okoliczności, w których czyn może być przypisany państwu. Rozdział III zawierał opis przesłanek, których spełnienie pozwala uznać czyn państwa za naruszenie prawa międzynarodowego, zaś rozdział IV - opis okoliczności,

${ }^{83}$ Drugi raport Riphagena, U.N. Doc. A/CN.4/344, s. 90-91.

${ }^{84}$ Por.: Raport Grupy Roboczej ds. odpowiedzialności państwa, przedstawiony podczas 49. sesji KPM, 1997 r., U.N. Doc. A/CN.4/L.538.

${ }^{85}$ Por.: D. M. Bodansky, J. R. Crook, op.cit., s. 779.

${ }^{86}$ Ibidem.

${ }^{87}$ Projekt artykułów o odpowiedzialności państw z 2001 r., U.N. Doc. A/56/10. 
w których jedno państwo może zostać uznane za odpowiedzialne za czyny innego. W treści rozdziału $\mathrm{V}$ opisano okoliczności wyłączające bezprawność czynu państwa niezgodnego $\mathrm{z}$ treścią jego międzynarodowych zobowiązan ${ }^{88}$. Konsekwencje naruszenia zobowiązania międzynarodowego, a więc treść norm wtórnych, opisane zostały w drugiej części projektu. W części trzeciej zawarto opis praw państw poszkodowanych wskutek naruszeń prawa, zaś w części czwartej, ogólne zasady stosowania dokumentu, w tym np. kwestii międzynarodowej odpowiedzialności organizacji międzynarodowych. Zapisy tego opracowania odzwierciedlają przyjęte $\mathrm{w}$ zwyczajowym prawie międzynarodowym reguły odpowiedzialności państw. Ich znaczenie dla reguł należytej staranności jest przedmiotem szczegółowej analizy w dalszej części niniejszego rozdziału.

Rezolucje Zgromadzenia Ogólnego z lat 2001-2007, zawierające prośby o komentarze i kierowane do państw członkowskich, nie przyniosły oczekiwanego konsensusu, stanowiącego ewentualną podstawę negocjacji traktatowych ${ }^{89}$. Ostatnia dyskusja dotycząca odpowiedzialności państwa odbyła się podczas 65. sesji ZO w 2010 r. W treści podsumowującej ją Rezolucji 65/19 z 10 stycznia 2011 r. Zgromadzenie Ogólne powtórzyło prośbę zawartą w treści wcześniejszych dokumentów, skierowaną do Sekretarza Generalnego o uaktualnienie posiadanych informacji o praktyce państw i sądów międzynarodowych, dotyczącej stosowania reguł opisanych w treści Projektu artykułów o odpowiedzialności państw z 2001 r. $^{90}$ Kwestię odpowiedzialności państw wpisano także do programu posiedzenia Zgromadzenia Ogólnego na rok $2013^{91}$.

Ta blisko dziesięcioletnia, pozorna inercja w pracach nad odpowiedzialnością państw nie jest wyrazem braku zainteresowania przedmiotowym obszarem. W dobie walki z międzynarodowym terroryzmem oraz prób prawnej kwalifikacji bezczynności państw, tolerujących działania organizacji czy jednostek dopuszczających się przestępstw o charakterze terrorystycznym, inicjowanych czy przygotowywanych na terytorium państwa, konstrukcja jego odpowiedzialności, opisana przez Garcíę-Amadora i jego następców, podlega ciągłym reinterpretacjom. Najistotniejszym elementem toczącej się dyskusji jest pytanie o odpo-

\footnotetext{
${ }^{88}$ Projekt artykułów o odpowiedzialności państw z 2001 r., uwagi ogólne, s. 32.

${ }^{89}$ Zgromadzenie Ogólne mocą Rezolucji z 56/83 z 12 grudnia 2001 r. poleciło projekt Komisji uwadze rządów, choć nie uznało badań nad przedmiotową kwestią za zakończone. Temat „międzynarodowa odpowiedzialności państw za czyny zakazane prawem międzynarodowym" został umieszczony w programie 59. sesji, tj. na rok 2004. W treści Rezolucji 59/35 z 2 grudnia 2004 r. Zgromadzenie Ogólne ponownie zwróciło się z prośbą o komentarze i uwagi dotyczącego treści projektu, perspektyw jego transpozycji na tekst traktatu oraz o przykłady praktyk krajowych w przedmiotowym obszarze. W programie 62. sesji w 2007 r. kwestia międzynarodowej odpowiedzialności państw znalazła się ponowie. Podsumowaniem debaty było ponownie wezwanie państw do przedstawienia uwag do treści dokumentu z 2001 r., sugestii jego ewentualnej implementacji oraz przykładów praktyki krajowej w treści Rezolucji 62/61 z 6 grudnia 2007 r.

${ }^{90}$ Zob. dokument ZO ONZ, GA Res. 56/83, U.N. Doc. A/RES/56/83. Projekt artykułów o odpowiedzialności państw z $2001 \mathrm{r}$.

${ }^{91}$ Por. Rezolucja Zgromadzenia Ogólnego ONZ, Odpowiedzialność państw za czyny międzynarodowo bezprawne, 6 grudnia 2010 r., U.N. Doc. A/65/463, pkt. 4, s. 2.
} 
wiedzialność państwa za zaniechanie, przypisanie której może nastąpić w oparciu o negatywną ocenę wykazanej przez państwo staranności.

\subsection{Należyta staranność w pracach KPM}

Zagadnienie należytej staranności pojawiało się pracach KPM w kontekście analizy kryteriów przypisania państwu odpowiedzialności za jego czyn międzynarodowo bezprawny. Należyta staranność omawiana była przy okazji opisywania pojęcia czynu organów państwa, mogącego polegać na działaniu lub zaniechaniu. Odwołania do niej czyniono także przy okazji opisu treści międzynarodowego zobowiązania do zapobiegania określonym zdarzeniom, którego naruszenie prowadzić mogło do międzynarodowej odpowiedzialności państwa. Poprzez owo rozróżnienie Komisja zmierzała do doprecyzowania pojęcia naruszenia prawa międzynarodowego ${ }^{92}$. Rozróżnienie pomiędzy zobowiązaniami do określonego postępowania (ang. obligations of conduct), a zobowiązaniami do osiagnięcia określonego skutku (ang. obligations of result) zaproponował w $1977 \mathrm{r}$. Ago w treści odpowiednio: art. 20 i 21 Projektu artykułów o odpowiedzialności państw $^{93}$. Zobowiązania skutkowe to takie, w treści których pozostawiono państwom całkowitą swobodę sposobu ich realizacji, czyniąc przedmiotem zobowiązania jedynie pożądany skutek. Jako przykład Ago przywołał tu m.in. postanowienia KWSD dotyczące konieczności podjęcia „wszelkich niezbędnych środków" dla zapewnienia bezpieczeństwa personelu i placówki dyplomatycz$n j^{94}$. Interpretując jego prace Quentin-Baxter, Specjalny Sprawozdawca ds. odpowiedzialności międzynarodowej za czyny niezakazane prawem międzynarodowym, powiązał zobowiązania skutkowe z należytą starannością wskazując, że w ich przypadku od państw wymagany jest wyższy od należycie starannego standard działania, ale odpowiedzialność za ich naruszenie nie jest odpowiedzialnością absolutną ${ }^{95}$. Druga grupa, wyróżniona przez Ago, obejmowała te zobowiązania, w treści których zawarte zostały choćby wskazówki co do sposobu ich realizacji i sugestie, dotyczące poszczególnych środków, uznawanych za najbardziej odpowiednie do osiagnięcia danego rezultatu, czyniąc ich użycie przedmiotem danego zobowiązania ${ }^{96}$. Przykłady takich zobowiązań Ago wskazywał w treści postanowień Międzynarodowego Paktu Praw Gospodarczych,

\footnotetext{
${ }^{92}$ Por. C. Tomuschat, Gegenwartsprobleme der Staatenverantwortlichkeit in der Arbeit der Völkerrechtskommission der Vereinten Nationen, Vortraege, Reden und Berichte aus dem EuropaInstitut 1994, nr 311, s. 6-7.

93 Por. Szósty raport Specjalnego Sprawozdawcy R. Ago, KPM, 1977 r., U.N. Doc. A/CN.4/302 (dalej: Szósty raport Ago), s. 4-20.

${ }^{94}$ Por.: Szósty raport Ago, s. 9. Zob. też: F. Przetacznik, op.cit., s. 166. Treść tego zobowiązania została szczegółowo omówiona dalej, por. rozdz. IV.

${ }^{95}$ Por. Raport wstępny Specjalnego Sprawozdawcy Roberta Quentina-Baxtera, 1980 r., U.N. Doc. A/CN.4/334 (dalej: Raport wstępny Quentina-Baxtera), s. 253-254.

${ }^{96}$ Por. Szósty raport Ago, U.N. Doc. A/CN.4/302, s. 8-9.
} 
Społecznych i Kulturalnych, dotyczących np. konieczności podjęcia przez państwa kroków zmierzających do zapewnienia praw, zapisanych w treści traktatu, $\mathrm{w}$ tym do przyjęcia stosownych przepisów prawa wewnętrznego ${ }^{97}$. W toku prac nad projektem Riphagen czynił odpowiedzialność za naruszenie zobowiązania z którejkolwiek kategorii zależną od jurysdykcji państw ${ }^{98}$. Zaproponowany przez Ago podział zobowiązań międzynarodowych został pośrednio odzwierciedlony w treści art. 12 Projektu artykułów o odpowiedzialności państw z 2001 r., który stanowi, iż państwo ponosi odpowiedzialność za naruszenie zobowiązania międzynarodowego, niezależnie od jego charakteru. Komisja zaznaczyła jednak, że podział zaproponowany przez Ago nie jest podziałem zupełnym $\mathrm{i}$ jako taki nie stanowi przedmiotu jej zainteresowania ${ }^{99}$. Choć opisując charakterystykę podziału zobowiązań skutkowych i do określonego postępowania Ago nie odniósł się do reguł prewencji czy należytej staranności, jego koncepcja znacząco wpłynęła na treść Projektu artykułów o prewencji z 2001 r.

Podczas prac KPM nad zasadami odpowiedzialności państw najszerzej ,zasadę" należytej staranności opisał w treści drugiego raportu z 1957 r. García-Amador, przy okazji opisu reguły odpowiedzialności państwa za szkody cudzoziemców powstałe na jego terytorium. Uwzględnił tam charakterystykę działań i zaniechań, w tym zaniechań organów państwowych oraz czynów mieszkańców, stanowiących podstawę odpowiedzialności państwa ${ }^{100}$. Rozdział V raportu poświęcił regułom odpowiedzialności państwa za szkody powstałe wskutek działań osób prywatnych oraz w czasie silnej destabilizacji politycznej państwa. Punkt wyjścia analizy ,zasady należytej staranności” (ang. rule of due diligence) stanowiło pytanie o możliwość pociagnięcia państwa do odpowiedzialności za zaniechanie, w braku normatywnego zobowiązania do działania ${ }^{101}$. Przywołując sprawy: atolu Bikini ${ }^{102}$ oraz huty w Trail García-Amador powtórzył za arbitrami,

${ }^{97}$ Międzynarodowy Pakt Praw Gospodarczych, Społecznych i Kulturalnych otwarty do podpisu w Nowym Jorku dnia 19 grudnia 1966 r., Dz.U. 1977, nr 38, poz. 169. Por. Szósty raport Ago, U.N. Doc. A/CN.4/302, s. 9.

${ }^{98}$ Drugi raport Riphagena, U.N. Doc. A/CN.4/344, s. 89.

${ }^{99}$ Por. Projekt artykułów o odpowiedzialności państw z 2001 r., U.N. Doc. A/56/10, s. 57.

${ }^{100}$ Opisał także charakter i zakres odpowiedzialności państwa w kontekście jego zobowiązań umownych oraz rolę zasad odpowiedzialności państwa przy gwarantowaniu przestrzegania praw człowieka. Por.: Drugi raport García-Amadora, U.N. Doc. A/CN.4/106, s. 107, 112-114, 115.

${ }^{101}$ Drugi raport García-Amadora, U.N. Doc. A/CN.4/106, s. 122-123.

${ }^{102}$ Mieszkańcy Bikini przeciwko Stanom Zjednoczonym Ameryki [online]. United States Court Of Federal Claims 1996 r. [dostęp: 2013-04.20]. Dostępny w Internecie: <http://www .bikiniatoll.com/7-18-06\%20Amended\%20complaint.pdf>. Sprawa dotyczyła roszczeń mieszkańców atolu Bikinii, obecnie części Republiki Wysp Marshala, przeciwko Stanom Zjednoczonym, dotyczących szkód powstałych w wyniku serii testów nuklearnych, przeprowadzonych przez Pentagon w czasie, gdy Wyspy Marshala stanowiły terytorium powiernicze ONZ pod jego Stanów Zjednoczonych. Pomiędzy 30 czerwca 1946 r. a 18 sierpnia 1958 r. Stany Zjednoczone przeprowadziły na obszarze atolu Bikinii 67 powietrznych testów nuklearnych. Całkowita moc bomb użytych do testów wynosiła równowartość 7 tysięcy ładunków zrzuconych na Hiroshimę. Prawo do przeprowadzenia prób wynikało z umów, zawieranych pomiędzy Stanami Zjednoczonymi a przedstawicielami terytorium powierniczego. Podstawą do ich zawarcia było Porozumienie Powiernicze. Spór dotyczący odszkodowań za skutki prób nuklearnych rozwiązany został po 
że zobowiązanie państwa do działania istnieje także, gdy nie wynika bezpośrednio z normy prawa międzynarodowego ${ }^{103}$. Przywołując argumentację amerykańsko-kanadyjskiego trybunału arbitrażowego wskazał, że w świetle zasad prawa międzynarodowego ,żadne państwo nie ma prawa wykorzystywać swojego terytorium lub pozwalać na jego wykorzystanie w taki sposób, aby spowodować szkodę na terytorium innego państwa". Zobowiązanie to staje się aktualne, gdy z okoliczności realizowanej działalności wynika, iż niesie ona za sobą poważne konsekwencje, zaś niebezpieczeństwo powstania szkody zdiagnozować można na podstawie ,jednoznacznych i przekonujących dowodów" ${ }^{104}$. Zdaniem Specjalnego Sprawozdawcy, w tego typu sytuacjach nie sposób zaprzeczyć odpowiedzialności państwa za powstałe szkody oraz jego obowiązkowi odszkodowawczemu, mimo iż nie można wskazać konkretnej, naruszanej normy. Jest to naruszenie prawa polegające na niedopełnieniu obowiązku działania, wynikającego z samego przymiotu państwowości. Zobowiązanie do stworzenia warunków gwarantujących bezpieczeństwo osób i rzeczy znajdujących się i działających w zasięgu władzy państwowej wynika zarówno z zasad prawa prywatnego, jak i publicznego. Zasada należytej staranności jest wyrazem tej właśnie idei i jako taka stanowi integralną część reguł międzynarodowej odpowiedzialności państwa. Opisując treść zasady tak szeroko, García-Amador dostrzegał niebezpieczeństwo, jakie kryje się w tej interpretacji obowiązku dołożenia należytej staranności przez państwo. Oznaczałaby ona możliwość pociagnięcia do odpowiedzialności państwa, które nie dopuściło się naruszenia żadnej normy prawa międzynarodowego, dając podstawę do nieuzasadnionych roszczeń oraz znacząco utrudniając zadanie międzynarodowych sądów. Zauważając te praktyczne trudności autor raportu sugeruje, aby Komisja na początku swych prac nie wykluczała możliwości pociaggnięcia do odpowiedzialności państw w przypadku braku naruszenia możliwego do zidentyfikowania obowiązku międzynarodowego. Wtedy zawsze możliwe będzie przywołanie odpowiedzialności państwa za niedbalstwo jego organów, wykonujących funkcje władcze ${ }^{105}$.

W tym samym projekcie normatywnego sformułowania zasad odpowiedzialności, art. 10 dotyczył odpowiedzialności państw za działania osób prywatnych znajdujących się w ich granicach. W jego treści zapisano, że państwo ponosiło odpowiedzialność za szkody wyrządzone cudzoziemcom wskutek zachowań „zwykłych osób prywatnych” (ang. ordinary private individuals), jeśli organy

blisko 50 latach przez Trybunał ds. roszczeń nuklearnych (ang. Nuclear Claims Tribunal), powstały na mocy sekcji 177 owego Porozumienia. Mocą tego samego postanowienia umowy utworzony został Fundusz Kompensacyjny zasilony przez Stany Zjednoczone kwotą $150 \mathrm{mln}$ USD w 1988 r., którego celem była realizacja przez Stany Zjednoczone obowiązku kompensacyjnego, wynikającego $\mathrm{z}$ wywołanych szkód. W rozstrzygnięciu nie była podnoszona kwestia zasady prewencji ani należytej staranności. Dotyczyła ona jedynie roszczeń kompensacyjnych mieszkańców Bikini. Por. M. Fitzmaurice, op.cit., s. 154.

${ }^{103}$ Por.: Drugi raport García-Amadora, U.N. Doc. A/CN.4/106, s. 106. Obie sprawy omówione zostały powyżej, por. rozdz. II.

${ }^{104}$ Por. Drugi raport García-Amadora, U.N. Doc. A/CN.4/106, s. 106.

${ }^{105}$ Por.: Drugi raport García-Amadora, U.N. Doc. A/CN.4/106, s. 106. 
państwa lub jego urzędnicy zachowali się „, sposób oczywiście niedbały” przy podejmowaniu działań normalnie podejmowanych celem zapobieżenia takim działaniom lub ukaraniu ich ${ }^{106}$. Chodziło tu o działania, które bezpośrednio powoduja powstanie szkody po stronie cudzoziemca, a wywoływane zostały nie przez organ państwa czy jego urzędnika, ale przez osobę czy grupę osób działających jako osoby prywatne. Taka konstrukcja przypisania odpowiedzialności ma w prawie międzynarodowym charakter wyjątkowy - co do zasady bowiem państwo odpowiada jedynie za „własne” działania ${ }^{107}$. Przywołując wnioski z pierwszego raportu, García-Amador wskazywał, że odpowiedzialność państwa nie jest bezpośrednią konsekwencją samego szkodliwego czynu, ale zachowania władz względem niego. Przypisanie odpowiedzialności państwu będzie więc koniecznie zależne od okoliczności zewnętrznych względem samego szkodliwego działania, które to okoliczności, obciążające czy egzoneracyjne, zawsze były przedmiotem sporów zarówno w doktrynie, jak i w praktyce prawa międzynarodowego. Przy takim ujęciu należytej staranności nieaktualne stało się pytanie o zasadność stosowania zasady odpowiedzialności obiektywnej, relatywizowanej względem winy państwa w nadzorze czy w wyborze, tj. względem podmiotu działającego w jego imieniu lub z jego upoważnienia, skutkującej szkodą. Nie chodzi bowiem o bezpośrednią zależność pomiędzy tymże przedstawicielem państwa a szkodliwym działaniem. Chodzi raczej o czyn samego podmiotu upoważnionego przez państwo, a dokładniej o jego zaniechanie. Jeśli owo zaniechanie było „zawinione”, to państwo ponosić winno odpowiedzialność za powstały szkodliwy skutek czynu osoby prywatnej ${ }^{108}$. Przypisanie odpowiedzialności państwu następuje więc pośrednio, poprzez przypisanie mu odpowiedzialności za niedopełnienie ciążącego na nim, trudnego do zdefiniowania, międzynarodowego obowiązku, wskutek którego to niedopełnienia osoba prywatna spowodowała szkodę u podmiotu zagranicznego ${ }^{109}$. Pogląd ten trudno obronić w świetle aktualnego dorobku prawa międzynarodowego.

Opisując dorobek doktryny w zakresie ustalania reguł międzynarodowej odpowiedzialności państw, García-Amador przywołał m.in. wspomniany już Projekt artykułów o odpowiedzialności państw, opracowany w 1929 r. przez naukowców $\mathrm{z}$ wydziału prawa Uniwersytetu Harvarda ${ }^{110}$. W art. 10 projektu zawarli oni regułe, odzwierciedloną w art. 10 pierwszego projektu KPM. W projekcie harwardzkim zapisano, że „odpowiedzialność państwa za szkody wyrządzone cudzoziemcowi jest następstwem braku należytej staranności przy zapobieganiu ich powstaniu", konstatując, iż oznacza ona wyczerpanie dostępnych w prawie krajowym roszczeń

${ }^{106}$ Drugi raport García-Amadora, U.N. Doc. A/CN.4/106, s. 121.

${ }^{107}$ Drugi raport García-Amadora, U.N. Doc. A/CN.4/106, s. 121.

${ }^{108}$ Drugi raport García-Amadora, U.N. Doc. A/CN.4/106, s. 121. Autor pisze: „For not only must there be a harmful act committed by an individual, but, in addition, it must be possible to attribute to the State some conduct with respect to the act that implies a specific attitude wilfully adopted by the organ or official (fault, culpa)."

${ }^{109}$ Treść tego obowiązku omówiona zostanie w dalszej części ksiązki; por.: rozdz. V i VI.

${ }^{110}$ Harvard Law School, Research in International Law: Responsibility of States, Cambridge 1929, s. 187; podaję za: Drugi raport García-Amadora, U.N. Doc. A/CN.4/106, s. 122. 
odszkodowawczych, bez adekwatnego odszkodowania. Treść obowiązku dołożenia „należytej staranności” winna być ustalana z uwzględnieniem okoliczności sprawy oraz statusu poszkodowanego cudzoziemca, skutkiem czego różni się ona $\mathrm{w}$ zależności od stanu faktycznego ${ }^{111}$. Takie sformułowanie zasady należytej staranności implikuje dwie domniemane kompetencje państwa. Aby uznać, że państwo nie dopełniło obowiązku należytej staranności, należy przyjąć, że państwo miało jurysdykcję oraz faktyczną możliwość działania ${ }^{112}$. Należyta staranność to kwestia standardu postępowania, a nie treści prawnej definicji ${ }^{113}$. Odróżnić ją trzeba od samej możliwości działania, chodzi tu bowiem raczej o skuteczność i sposób użycia środków pozostających w gestii państwa, niż o samą ich dostępność ${ }^{114}$. Jest ona także czymś innym niż wykonywanie wymiaru sprawiedliwości - $\mathrm{w}$ jej istocie chodzi bowiem nie o wykonywanie przez państwo funkcji zaradczej, a o obowiązek wykonywania funkcji ochronnej ${ }^{115}$. Takie rozumienie zasady należytej staranności odnaleźć można także w treści raportu LN z 1929 r., gdzie zapisano, że „państwo ponosi odpowiedzialność za szkodę wyrządzoną cudzoziemcowi w wyniku niewykazania przez władzę wykonawczą takiej staranności w zapewnianiu mu ochrony, jakiej z uwzględnieniem konkretnych okoliczności, oczekiwać można od cywilizowanego państwa" ${ }^{\text {"16. }}$. W treści komentarzy do sprawozdania, przygotowanych przez państwa członkowskie, zidentyfikowano kryteria pomocne przy ustalaniu takiego wzorca należytej staranności dla konkretnej sprawy. Wyższa staranność wymagana będzie przy zapewnianiu ochrony np. przedstawicielowi dyplomatycznemu czy głowie

${ }^{111}$ Podaję za: Drugi raport García-Amadora, U.N. Doc. A/CN.4/106, s. 122.

${ }^{112}$ Drugi raport García-Amadora, U.N. Doc. A/CN.4/106, s. 122. Wprowadzenie odwołania do należytej staranności oznacza, że istniały dostępne oraganom państwa środki prewencyjne oraz faktyczna możliwość ich zastosowania.

${ }^{113}$ Drugi raport García-Amadora, U.N. Doc. A/CN.4/106, s. 122.

${ }^{114}$ Drugi raport García-Amadora, U.N. Doc. A/CN.4/106, s. 122. Przeciwstawienie „należytej staranności” ,środkom będącym w (...) rozporządzeniu” rządu, tj. kryterium zawartemu w treści art. 8 Konwencji dotyczącej praw i obowiązków mocarstw neutralnych w razie wojny morskiej (XIII konwencja haska z 18 października 1907 r.) miało zdaniem Specjalnego Sprawozdawcy podkreslić znaczenie skuteczności troski wykazywanej przez organy państwa, w odróżnieniu od samego faktu jej wykazania. Tekst konwencji por.: Prawo międzynarodowe $i$ historia dyplomatyczna. Wybór dokumentów, wstęp i opracowanie L. Gelberg, Warszawa 1954, t. I, s. 287-291.

${ }^{115}$ Drugi raport García-Amadora, U.N. Doc. A/CN.4/106, s. 122, par. 17, pkt 4, przypis 51. Czym innym jest więc brak należytej staranności przy zapobieganiu szkodom cudzoziemców, czym innym zaś - zaniechanie skutkujące odmową wymiaru sprawiedliwości, przejawiające się niepodjęciem kroków zmierzających do pojmania i osądzenia sprawców. W tym ostatnim przypadku państwo ponosi odpowiedzialność za odmowę wymiaru sprawiedliwości, w tym pierwszym natomiast - za naruszenie obowiązku zapobiegania przestępstwom i wykonywania funkcji ochronnnej.

${ }^{116}$ League of Nations publication, V. Legal, 1929.V.3 (dokument C.75.M.69.1929.V), s. 67. $\mathrm{W}$ treści materiałów przygotowawczych dla uczestników konferencji haskiej LN zobowiązanie to sformułowane zostało $\mathrm{w}$ art. 10. Zgodnie $\mathrm{z}$ jego zapisem państwo miałoby ponosić odpowiedzialność za szkody wyrządzone cudzoziemcom wskutek braku po stronie organów władzy wykonawczej (ang. failure on the part of the executive power) takiej staranności przy zapewnianiu ochrony cudzoziemcom, jakiej można by w danych okolicznościach oczekiwać od cywilizowanego państwa. Podaję za: Drugi raport García-Amadora, U.N. Doc. A/CN.4/106, pkt 5, s. 122, przyp. 52. 
państwa. Różna będzie ona dla państw rozwiniętych i niedawno powstałych, inna względem terytoriów własnych i niedawno nabytych czy zależnych ${ }^{117}$. Komentarz rządu Rzeczpospolitej Polskiej do raportu wskazywał, że o ile jest obowiązkiem państwa chronić cudzoziemców i ich własność, o tyle odpowiedzialność międzynarodowa powstanie dopiero wtedy, gdy obowiązek ten został poważnie naruszony ${ }^{118}$.

Ze szczegółowych rozważań orzecznictwa i doktryny wynikało, że należyta staranność nie może być pojmowana jako jednoznaczna i precyzyjnie opisana definicja, służąca za obiektywnie istniejący wzorzec mechanicznej weryfikacji działań państwa jako „należycie starannych”"119. Jest zgoła odwrotnie - czyny władz państwa muszą być weryfikowane względem okoliczności każdej sprawy, celem ustalenia treści standardu należytej staranności. Jak dowodził GarcíaAmador, w efekcie należyta staranność odzwierciedlała teorię winy. Mimo iż należyta staranność była ze swej natury niejasna, niejednoznaczna i nieprecyzyjna, to na niej właśnie opierać się musi odpowiedzialność państw za zaniechanie, przynajmniej dopóki praktyka i doktryna nie wypracują lepszego rozwiązania. Poszukując wskazówek dla stosowania tej niejasnej reguły, opisywał w treści raportu dwie przesłanki, które powinny być uwzględnione przy ocenianiu braku należytej staranności po stronie państwa. Pierwsza miała stanowić uzupełnienie wspomnianego wyżej kryterium „cywilizowanego państwa”, stanowiącego punkt odniesienia przy ocenianiu należytego zachowania władz. García-Amador, za Eagletonem, przywoływał kryterium ,międzynarodowego standardu sprawiedliwości" (ang. international standard of justice) i dowodził, że działania państwa oceniać należy względem ogólnie rozumianego standardu międzynarodowego ${ }^{120}$. Eagleton twierdził, że uznanie danego poziomu należytej staranności względem obywateli suwerena nie musi oznaczać wypełnienia obowiązku jej dołożenia także względem cudzoziemców ${ }^{121}$. Drugim koniecznym kryterium weryfikacji dołożenia należytej staranności przez państwo winno więc być, zdaniem Specjalnego Sprawozdawcy, zbadanie realizacji przez państwo uznanej w prawie międzynarodowym zasady równości pomiędzy obywatelami i cudzoziemcami ${ }^{122}$. O ile więc standard należytej staranności państwa względem obcego obywatela może być wyższy niż względem własnego obywatela, na pewno nie może on być niższy - musi być co najmniej równy. Ustalenie treści owego standardu nie przesądza o odpowiedzialności państwa - García-Amador formułował domniemanie jej braku jako punkt wyjścia dla oceny poziomu staranności

${ }^{117}$ Drugi raport García-Amadora, U.N. Doc. A/CN.4/106, s. 122.

${ }^{118}$ League of Nations publication, V. Legal, 1929.V.3 (dokument C.75.M.69.1929.V), s. 65; podaję za: Drugi raport García-Amadora, U.N. Doc. A/CN.4/106, pkt 6, s. 122.

${ }_{119}$ Drugi raport García-Amadora, U.N. Doc. A/CN.4/106, pkt 7, s. 122,

${ }^{120}$ Drugi raport García-Amadora, U.N. Doc. A/CN.4/106, pkt 8, s. 122. Jego zdaniem „zasada należytej staranności” została połączona z „międzynarodowym strandardem sprawiedliwości”.

${ }^{121}$ C. Eagleton, The Responsibility of States in International Law, Nowy Jork 1928, s. 130-131; podaję za: Drugi raport García-Amadora, U.N. Doc. A/CN.4/106, s. 122.

${ }^{122}$ Drugi raport García-Amadora, U.N. Doc. A/CN.4/106, pkt 8, s. 122. 
władz $^{123}$. Państwo, co do zasady, nie ponosiło więc odpowiedzialności za szkody powstałe wskutek działań mieszkańców jego terytorium, o ile nie dopuściło się poprzez działanie swoich organów jawnego lub oczywistego niedbalstwa (ang. patent or manifest negligence) przy podejmowaniu ,środków normalnie przedsiębranych w danych okolicznościach" celem zapobieżenia szkodliwym działaniom lub ukarania ich ${ }^{124}$.

Tak ogólnie określone cechy należytej staranności odzwierciedlają przyjętą przez Komisję metodologię badań nad odpowiedzialnością państwa. Poszukiwano zasad jak najbardziej ogólnych, starając się uniknąć błędów poprzedników tworzących zbyt rozległe opisy reguł odpowiedzialności, obejmujące liczne wyjątki przewidziane dla poszczególnych reżimów traktatowych czy obszarów praktyki zwyczajowej. Takie ogólne reguły miały być możliwe do stosowania w przypadku naruszenia przez państwo zobowiązań międzynarodowych, o ile tylko można było przypisać mu odpowiedzialność ${ }^{125}$. Choć uznano, że odpowiedzialność państwa za zaniechanie przeciwdziałania szkodzie wywołanej przez osoby prywatne ma charakter pośredni, w kolejnym, trzecim, raporcie García-Amador sugerował rozważenie „umyślnego" "126 (dosłownie: obciążającego, ang. aggravating) niedołożenia należytej staranności, skutkującego bezpośrednią odpowiedzialnością państwa ${ }^{127}$. Nie precyzując szczegółów tej koncepcji, wspominał o konieczności uwzględnienia sytuacji, w których zaniechanie państwa jest tak ostentacyjne i rażące, że stanowi de facto zgodę na wyrządzanie czy wręcz współudział władz w wyrządzaniu szkód cudzoziemcom ${ }^{128}$. Wyrażając pełną świadomość niestosowności używania terminologii prawa karnego do rozważań o odpowiedzialności międzynarodowej państw, które zgodnie z wolą Komisji miały zostać oparte o reguły bliższe prawu cywilnemu, wskazywał na istotny problem tolerowania naruszania prawa popełnianego $\mathrm{w}$ jurysdykcji państwa, z którym społeczności międzynarodowej przyjdzie się jeszcze zmierzyć $\mathrm{w}$ dobie walki z międzynarodowym terroryzmem ${ }^{129}$.

${ }^{123}$ Drugi raport García-Amadora, U.N. Doc. A/CN.4/106, pkt 9, s. 122, gdzie autor pisze: „,there is a presumption against responsibility”. Podobnie L. Ehrlich, Prawo międzynarodowe..., s. 643.

${ }^{124}$ Drugi raport García-Amadora, U.N. Doc. A/CN.4/106, pkt 9, s. 122.

${ }^{125}$ Drugi raport García-Amadora, U.N. Doc. A/CN.4/106, pkt 9, s. 122

${ }^{126}$ Kryterium „okoliczności obciążających”, a więc np. motywacji sprawcy, zasługującej na szczególne potępienie czy działającego ze szczególnym okrucieństwem, dotyczące więc raczej sposobu popełniania naruszenia, nie zaś obiektywnej oceny jego skutku, znane porządkom krajowym, obce było prawu międzynarodowemu. García-Amador zaproponował użycie owej terminologii celem opisania okoliczności, które, podobnie jak w prawie krajowym, mogą prowadzić do „wyższego stopnia odpowiedzialności” (ang. a greater degree of responsibility) państwa. Por.: Drugi raport García-Amadora, U.N. Doc. A/CN.4/106, pkt 9, s. 122. Za przykład takiej okoliczności uznać można przedłużający się i nieuzasadniony okolicznościami brak reakcji ze strony państwa, na terytorium lub pod kontrolą którego doszło do zdarzenia, niosącego szkody transgraniczne.

${ }^{127}$ Trzeci Raport Specjalnego Sprawozdawcy F.V. García-Amadora, 1958 r. U.N. Doc. A/CN.4/111 (dalej: Trzeci raport García-Amadora, U.N. Doc. A/CN.4/111), roz. IV(I), par. 54, pkt 22.

${ }^{128}$ Trzeci raport García-Amadora, U.N. Doc. A/CN.4/111, roz. IV(I), par. 54, pkt 23.

${ }^{129}$ Trzeci raport García-Amadora, U.N. Doc. A/CN.4/111, roz. IV(I), par. 54, pkt 22. 
W treści piątego reportu z 1960 r. García-Amador ponownie zmierzył się z kłopotliwą kwestią winy jako przesłanką odpowiedzialności państwa za zaniechanie ${ }^{130}$. Podsumowując rozważania zawarte we wcześniejszych raportach konstatowal, że odpowiedzialność państwa za zaniechanie względem działań osób prywatnych powiązana była bezpośrednio $\mathrm{z}$ winą organu lub urzędnika państwa. W opinii Sprawozdawcy, brak należytej staranności po stronie państwa praktycznie mógł zostać uznany za tożsamy $\mathrm{z}$ winą jego urzędnika, czyniąc ją przesłanką przypisania odpowiedzialności państwu. Jak pisał „w przypadku odpowiedzialności wynikającej z zaniedbania organu lub urzędnika, to właśnie zaniedbanie, stanowiące przejaw jego woli, stanowi zachowanie sprzeczne z prawem międzynarodowym", stając się podstawą jego międzynarodowej odpowiedzialności ${ }^{131}$. Kontestując poczynione ustalenia García-Amador sformułował argumenty przeciwko uznawaniu winy jako elementu koniecznego przypisania międzynarodowej odpowiedzialności państwu. Wskazywał, że przecież wina czy nastawienie psychiczne organu (łac. animus) nie odgrywa żadnej roli w przypadku odpowiedzialności państwa wynikającej z jego działania, w odróżnieniu od, jak można by uznać w powyższym kontekście, odpowiedzialności za zaniechanie. Zależy ona wówczas jedynie od wystappienia szkody oraz obiektywnego związku przyczynowo-skutkowego pomiędzy nim a działaniem państwa. Wskazuje, że włączenie kryterium winy do przypisania odpowiedzialności za zaniechanie znacząco utrudniałoby praktyczne stosowanie tak skonstruowanej normy. Jednocześnie jednak przypisanie odpowiedzialności mogłoby zależeć od charakteru normy pierwotnej i jej interpretacji, dokonanej przez sąd. Na podstawie analizy jej celu i przedmiotu, sąd mógłby uznać, że przypisanie odpowiedzialności za jej naruszenie zależy od winy lub innego elementu subiektywnego ${ }^{132}$.

Odnosząc się m.in. do prac Instytutu Prawa Międzynarodowego trzeciego kongresu hiszpańsko-portugalsko-amerykańskiego z 1927 r. Sprawozdawca wykazywał niezasadność warunkowania odpowiedzialności państwa wykazaniem winy jego urzędnika ${ }^{133}$. Przywołując odosobniony wówczas głos członka kongresu nazwiskiem Le Fur, wskazywał na dogmatyczną możliwość skonstruowania reżimu odpowiedzialności państwa za zaniechanie bez odwołania do kłopotliwej przesłanki winy czy dyskusyjnego kryterium ryzyka ${ }^{134}$. Poparcia propozycji LeFura udzielił także de Visscher, przedstawiając teorię odpowiedzialności zbudowaną na „systemie dowodów” (fr. systeme des preuves). De Visscher zaproponował wskazanie tych sytuacji, w których państwo co do

${ }^{130}$ Piąty raport Specjalnego Sprawozdawcy García-Amadora, 1960 r., U.N. Doc. A/CN.4/125, tom II (dalej: Piąty raport García-Amadora, U.N. Doc. A/CN.4/125).

${ }^{131}$ Piąty raport García-Amadora, U.N. Doc. A/CN.4/125, s. 63. Por. też: F. V. García Amador, The changing law of international claims, New Jersey 1984, tom I, s. 120-121.

${ }_{132}^{13}$ Piąty raport García-Amadora, U.N. Doc. A/CN.4/125, s. 63.

${ }^{133}$ Hiszp. Congreso Hispano-Luso-Americano de Derecho International; por.: Piąty raport García-Amadora, U.N. Doc. A/CN.4/125, s. 64.

${ }^{134}$ Jego zdaniem spór towarzyszący tym dwu przesłankom był przesadzony, bowiem jedynie dogmatyczny. Por.: Piąty raport García-Amadora, U.N. Doc. A/CN.4/125, s. 64. 
zasady ponosi odpowiedzialność, z której zwolnić się może jedynie poprzez wywołanie określonych zdarzeń czy dowód podjęcia określonych działań ${ }^{135}$.

García-Amador, odnotowując propozycje kongresu jako godne uwagi, wskazał nowe obszary aktywności państw, związane z rozwojem technologicznym, które wymagają lub wymagać będą stosownej modyfikacji reguł odpowiedzialności państw. Odnosząc się do powstającej gałęzi prawa międzynarodowego, jaką za sprawą orzeczenia w sprawie huty w Trail stawało się międzynarodowe prawo środowiska, opisywał takie kategorie szkód, za które państwo powinno ponosić odpowiedzialność niezależnie od nastawienia psychicznego reprezentujących je urzędników. Jak pisał: „nowe kategorie obiektywnej odpowiedzialności będą musiały zostać skonstruowane, aby sprostać rosnącej liczbie działań niebezpiecznych, związanych z rozwojem technologicznym”. Państwa będą musiały ponosić odpowiedzialność za szkody wynikające z eksploatowania technologii, stanowiących nowe źródła ryzyka. Niebezpieczeństwo wywołania szkód w dobrach lub interesach cudzoziemców czy obcych suwerenów poprzez eksploatację owych technologii stawało się szczególnie aktualne w kontekście konsekwencji testów nuklearnych $\mathrm{z}$ lat $50 .{ }^{136}$

Ago, przedstawiając pierwszy raport podkomitetu w 1963 r., wymienił należytą staranność wśród najtrudniejszych zagadnień, z jakimi przyjdzie się zmierzyć Komisji podczas prac nad identyfikacją reguł międzynarodowej odpowiedzialności państw ${ }^{137}$. Jak ustalił kierowany przez niego podkomitet, pomimo kontrowersji co do zakresu takiego obowiązku, nie budziło wątpliwości istnienie zobowiązania państw do zapobiegania działaniom osób prywatnych, które moga powodować powstanie szkody po stronie cudzoziemców lub innych suwerenów. Państwo ponosi międzynarodową odpowiedzialność za szkodę wywołaną dzia-

${ }^{135}$ Resolution V - La Responsabilidad del Estado por Daiios Causados a los Extranjeros, Congreso Hispano-Luso-Americano de Derecho International, Boletin de Information, 15, s. 106; podaję za: Piąty raport García-Amadora, U.N. Doc. A/CN.4/125, s. 64. Por. też: F. V. García-Amador, Louis B. Sohn, R. R. Baxter, Recent codification of the law of state responsibility for injuries to aliens, Haga 1974, s. 17.

${ }^{136}$ Piąty raport García-Amadora, U.N. Doc. A/CN.4/125, s. 64. Problem szkód wynikających z wykorzystania energii atomowej zyskał zainteresowanie społeczności międzynarodowej w związku z próbami jądrowymi, podejmowanymi przez Stany Zjednoczone na morzu otwartym. Przedstawiciele Białego Domu i amerykańscy teoretycy prawa międzynarodowego podnosili, iż prawo do przeprowadzania owych testów jest bezpośrednią konsekwencję prawa do samoobrony i stanowi do niej ,środek przygotowawczy”, mieszcząc się w koncepcji racjonalnych kompetencji państwa (ang. State's reasonable competence), wykonywanych poza jego morzem terytorialnym. Wykonywanie tego prawa ograniczone jest czasowo i przestrzennie, bowiem nie morze stanowić utrudnień dla żeglugi i rybołówstwa na morzu otwartym. Komentatorzy spoza Stanów Zjednoczonych odpierali te argumenty podnosząc, iż z prawnego punktu widzenia testy nuklearne, wpływające na stan morza otwartego niewątpliwie stanowią czyn międzynarodowo bezprawny, stając się podstawą międzynarodowej odpowiedzialności państwa i powstania po jego stronie obowiązku kompensacyjnego, niezależnie od podjętych przez państwo środków ostrożności. Por.: ibidem.

${ }^{137}$ Raport KPM, 1963 r., U.N. Doc. A/CN.4/163, pkt 12-14, s. 249-250. Przedmiotem zainteresowania Specjalnego Sprawozdawcy były w szczególności trzy zagadnienia: prawny charakter odpowiedzialności państw, jej konstytutywne elementy, tj. status prawny państw ponoszących odpowiedzialność oraz rola winy w przypisaniu im odpowiedzialności. Por. ibidem. 
łaniem lub zaniechaniem osoby fizycznej, jeśli nie wykaże należytej staranności przy zapobieganiu takiemu czynowi. Sugerował, że racjonalnie oczekiwany od suwerena stopień należytej staranności to ten, jakiego można wymagać od „cywilizowanego państwa"138. Odnosząc się do konsekwencji naruszenia prawa, wskazywał bez wątpliwości, że odpowiedzialność za zaniechanie niesie za sobą przede wszystkim obowiązek reparacji, zgodnie z treścią zasad uznanych przez narody cywilizowane ${ }^{139}$. Odpowiednia aplikacja tej zasady do praktyki państw stanowić miała, zdaniem Ago, jedno z największych wyzwań dla Komisji, zważywszy na to, że w prawie prywatnym obowiązek odszkodowawczy zależny jest od winy, uznając za nieuzasadnione odwołania do niej czynione w dogmatyce i praktyce prawa międzynarodowego. Odpowiedzialność za niedołożenie należytej staranności nie jest uwarunkowana wykazaniem winy podmiotu ją ponoszącego, a raczej samym faktem powstania szkody. Ago sugerował, aby „W niektórych przypadkach” odpowiedzialność za naruszenie praw obcego suwerena była obiektywna, choć nie był gotów całkowicie zrezygnować z uwzględniania winy przy ustalaniu zakresu międzynarodowej odpowiedzialności państwa. Wskazanie tych sytuacji, w których odpowiedzialność państwa powinna być obiektywna, Ago pozostawił Komisji ${ }^{140}$.

W pierwszej połowie lat 60 . inne niż KPM gremia badaczy prawa międzynarodowego przedstawiły własne założenia systemu międzynarodowej odpowiedzialności państw. Ago zawarł ich podsumowanie w swoim pierwszym raporcie jako Specjalny Sprawozdawca w 1969 r., uzupełniając opis dotychczasowych prac Komisji ${ }^{141}$. Przywołał m.in. opracowany w 1961 r. raport prawników międzynarodowych z Uniwersytetu Harvarda, dotyczący zasad odpowiedzialności państw za szkody wyrządzone cudzoziemcom ${ }^{142}$. Uznając, iż także zaniechanie

${ }^{138}$ Raport KPM, 1963 r., U.N. Doc. A/CN.4/163, pkt 12, s. 249. Jak pisał Ago, nie ulega wątpliwości, że państwo zobowiązane jest „w pewnym stopniu” zapobiegać działaniom osób prywatnych, działających samodzielnie lub w grupie, które prawdopodobnie spowodują szkodę cudzoziemców znajdujących się na jego terytorium. W konsekwencji, państwo ponosi odpowiedzialność za szkody wyrządzone przez działanie osoby prywatnej, jeśli nie wykaże należytej staranności celem zapobieżenia mu. Poziom wymaganej staranności ustalany być winien względem tego, jakiego oczekiwać można od cywilizowanego państwa. Por. ibidem.

${ }^{139}$ Raport KPM, 1963 r., U.N. Doc. A/CN.4/163, s. 249-250. Naruszenie praw innego podmiotu poprzez działanie lub zaniechanie, wywołujące skutki międzynarodowe, niesie za sobą obowiązek naprawy powstałych szkód, zgodnie z zasadą prawa cywilnego, uznawaną na całym świecie. Transpozycja tej zasady na grunt prawa międzynarodowego winna, zadniem Specjalnego Sprawozdawcy, być oparta na winie, choć pojmowanej odmiennie niż w doktrynie porządków krajowych, bowiem w prawie międzynarodowym pojęcie należytej staranności nie jest koniecznie związane z niedbalstwem. Odpowiedzialność międzynarodowa państw może występować w prawie międzynarodowym także wówczas, gdy powstaniu szkody nie towarzyszy wina po stronie państwa. Dlatego też, dowodził Ago, odpowiedzialność państwa może mieć niekiedy charakter obiektywny.

${ }^{140}$ Raport KPM, 1963 r., U.N. Doc. A/CN.4/163, s. 249-250.

${ }^{141}$ Pierwszy raport Ago, U.N. Doc. A/CN.4/217.

142 Projekt konwencji o międzynarodowej odpowiedzialności państw za szkody cudzoziemców, przygotowany przez Wydział Prawa Uniwersytetu Harwarda, 1961 r.; podaję za: Pierwszy raport Ago, U.N. Doc. A/CN.4/217, s. 137. 
po stronie państwa może stanowić naruszenie prawa międzynarodowego, zrezygnowali oni z przesłanki winy jako koniecznego elementu jego odpowiedzialności $^{143}$. Za ewentualną podstawę odpowiedzialności za zaniechanie uznali brak dostosowania prawa krajowego do treści międzynarodowych standardów lub jego dostosowanie w sposób niewłaściwy. Standard należytej staranności zidentyfikowano w treści art. 13 owego projektu jako nieudzielenie ochrony cudzoziemcowi wskutek braku zastosowania środków prewencyjnych czy deterencyjnych wobec osób, które dopuściły się zachowań uznanych za przestępstwa w prawie krajowym lub powszechne uznanych za takie w najważniejszych systemach prawnych świata. Niedopełnieniem obowiązku międzynarodowego był więc także brak należytej staranności w zgodnym $\mathrm{z}$ prawem krajowym pojmaniu i zatrzymaniu sprawcy uszczerbku w dobrach cudzoziemca. Niedopełenie owego obowiązku skutkować miałoby przejęciem przez państwo odpowiedzialności odszkodowawczej względem ofiary. Projekt harwardzki z 1961 r. zawierał także w art. 22 pierwsze zapisy dotyczące odpowiedzialności państwa za działalność niosącą jedynie niebezpieczeństwo powstania szkody, nie za konsekwencje spełnienia takiego ryzyka. Odmówiono roszczenia odszkodowawczego względem państwa z tytułu konsekwencji działań niezakazanych jedynie tym podmiotom, które otrzymały od niego pozwolenie na prowadzenie wysoce ryzykownej działalności - owa zgoda udzielana być miała pod warunkiem zrzeczenia się ww. roszczeń. Podmioty te nie mogłyby dochodzić odszkodowania od państwa nawet wtedy, gdyby roszczenie faktycznie wynikało z jego działania lub zaniechania, chyba że państwo działałoby lub dopuściło się zaniechania ,z wolą” (ang. willful) wywołania szkody $^{144}$. Ago przytoczył także zapisy opracowania przygotowanego przez Międzyamerykański Komitet Prawniczy (ang. Inter-American Juridical Committee) z 1962 r. ${ }^{145}$ Tam element winy przedstawiciela państwa, skutkujący brakiem należytej staranności przy zapewnianiu ochrony cudzoziemcom, pojawił się jedynie w sytuacji zamachu stanu, zamieszek lub przestępczości zorganizowanej. Jeśli wskutek takich działań cudzoziemiec poniósłby szkodę, państwo ponosiłoby odpowiedzialność międzynarodową, o ile powstaniu szkody towarzyszyło niedbalstwo urzędnika lub jego godzenie się na powstanie szkody (dosł. pobłażanie, ang. convivance) ${ }^{146}$.

${ }^{143} \mathrm{~W}$ treści art. 3 projektu, opisującego kategorie bezprawnych działań i zaniechań wskazali, że działanie lub zaniechanie przypisane może zostać państwu, jeśli wywołując szkodę cudzoziemcowi jest „bezprawne” (ang. wrongful), tj. jeśli bez „należytego uzasadnienia” ma na celu wywołanie lub pomoc przy wywołaniu szkody; stwarza nieuzasadnione ryzyko szkody wskutek braku należytej staranności po stronie państwa lub jeśli stanowi naruszenie umowy międzynarodowej. Podaję za: Pierwszy raport Ago, U.N. Doc. A/CN.4/217, s. 137.

${ }^{144} \mathrm{Za}$ : Pierwszy raport Ago, U.N. Doc. A/CN.4/217, s. 137.

${ }^{145}$ Inter-American Juridical Committee, Contribution of the American Continent to the principles of international law that govern the responsibilitv of the State, 1962 r., (w:) Recent Codification of the Law of State Responsibility for Injuries to Aliens, red. F. V. Gancia-Amador, L. B. Sohn, R. R. Baxter, Haga 1974, s. 359 i n.

${ }^{146}$ Por. Recent Codification of the Law of State Responsibility for Injuries to Aliens, red. F. V. Gancia-Amador, L. B. Sohn, R. R. Baxter, Haga 1974, s. 365. 
Ago poświęca szczególną uwagę regułom odpowiedzialności państw za działania osób fizycznych. Odpowiedzialność za szkody powstałe wskutek działania osób pozostających w jurysdykcji państwa określa jako bezpośrednią. Wskazuje, że wbrew argumentacji García-Amadora, nie chodzi tu o przejęcie przez państwo odpowiedzialności za szkodliwe działanie osoby fizycznej, ale o własną odpowiedzialność państwa za niedostateczne wysiłki zmierzające do zapobieżenia im. Czynem państwa, za które ponosi ono międzynarodową odpowiedzialność jest działanie lub zaniechanie jego organu, w wyniku którego pozostający w jego jurysdykcji podmiot prywatny wyrządził szkodę cudzoziemcowi $^{147}$. Przyjęcie koncepcji odpowiedzialności pośredniej państwa sprzeczne było z ideą prawa międzynarodowego, które kształtuje relacje między państwami, a którego podmiotem, co do zasady, nie może być osoba fizyczna. Konstrukcja odpowiedzialności pośredniej, jako zapożyczona z prawa krajowego, opierała się na założeniu, że jeden podmiot może zastąpić w odpowiedzialności inny, równy mu statusem. Założenie, że państwo ponosiłoby odpowiedzialność za podległą mu jednostkę oznaczałoby zrównanie ich w podmiotowości międzynarodowo prawnej i jako takie sprzeczne byłoby z samą istotą prawa międzynarodowego ${ }^{148}$. Państwo ponosić więc mogło odpowiedzialność za własny czyn, jeśli jego zaniechanie było sprzeczne $\mathrm{z}$ ciążącym na nim międzynarodowym obowiązkiem dołożenia należytej staranności celem zapobieżenia uszczerbkowi. Zdaniem Ago, owo zaniechanie podlega obiektywnej weryfikacji, niezależnej od woli czy wiedzy organu działającego w imieniu państwa ${ }^{149}$.

Naturalną konsekwencją przyjęcia takiego założenia było odrzucenie koncepcji winy państwa jako determinanty jego odpowiedzialności, która to wina w pracach Garcíi-Amadora odgrywała istotną rolę. Odnotowując obszerny dorobek zwolenników koncepcji winy w dogmatyce międzynarodowej odpowiedzialności państw, począwszy od Grocjusza, aż po de Vattela, nazywał ją „teorią współudziału” (ang. theory of complicity) państwa w szkodliwym akcie jednostki i deklarował jej zmierzch. Odrzucał także bardziej zachowawczą „teorię pobłażliwości" (dosł. darowania, ang. condonation), zaproponowaną przez Brierly'ego i Hyde'a, uwzględniającą winę jedynie jako przesłankę wysokości odszkodowania $^{150}$.

W konsekwencji, Ago wypowiadał się także przeciwko uznaniu wystąpienia i rozmiaru szkody jako przesłanek odpowiedzialności państwa za zaniechanie. Wskazywał, że skoro państwo odpowiada bezpośrednio za własne zaniechanie, a nie pośrednio za czyn osoby prywatnej, ewentualna wielkość szkody nie ma znaczenia ani dla przypisania mu odpowiedzialności ani nawet dla oszacowania wysokości odszkodowania. Wysokość owa powinna bowiem być relatywizowana względem rozmiarów zaniechania państwa i skutkującego naruszenia prawa

\footnotetext{
${ }^{147}$ Czwarty raport Ago, U.N. Doc. A/CN.4/264, s. 97.

${ }^{148}$ Czwarty raport Ago, U.N. Doc. A/CN.4/264, s. 100.

${ }^{149}$ Czwarty raport Ago, U.N. Doc. A/CN.4/264, s. 97.

${ }^{150}$ Czwarty raport Ago, U.N. Doc. A/CN.4/264, s. 122.
} 
międzynarodowego, a nie względem rozmiarów powstałej szkody, skoro niewielkie niedopełnienie obowiązków może prowadzić do ogromnych strat i odwrotnie $^{151}$.

Ago odżegnywał się także od koncepcji odpowiedzialności absolutnej, identyfikując jej źródła w nieaktualnej zasadzie solidarnej odpowiedzialności członków średniowiecznych rodów ${ }^{152}$. Przychylał się do najpopularniejszego poglądu, powtarzanego za Anzilottim, zgodnie z którym państwo nie ponosi odpowiedzialności za działania podmiotów prywatnych, o ile samo nie dopuści się czynu sprzecznego z ciążącymi na nim międzynarodowymi zobowiązaniami ${ }^{153}$. Uczynić to może m.in. poprzez niezakazanie szkodliwego działania podmiotom prywatnym, odmowę wykonania wymiaru sprawiedliwości względem poszkodowanego cudzoziemca czy będąc niechętnym lub niezdolnym do podjęcia działań przeciwko sprawcom szkód ${ }^{154}$. Jak twierdził Anzilotti, ukaranie sprawców przez państwo nie czyni zadość jego odpowiedzialności międzynarodowej, a stanowi jedynie treść jego międzynarodowego zobowiązania ${ }^{155}$, choć niedopełnienie tego obowiązku może stać się podstawą międzynarodowej odpowiedzialności państwa. Co więcej, stan w którym państwo nie wykazuje należytej staranności w zapobieganiu szkodliwym zachowaniom osób prywatnych może okazać się ich faktyczną przyczyna, tj. ich swoistym katalizatorem ${ }^{156}$. Zdaniem cytowanej przez Ago większości dogmatyków prawa międzynarodowego, reguła ta znajduje zastosowanie także w przypadku szkód wyrządzonych przez osoby prywatne cudzoziemcom, w tym zagranicznym dyplomatom i rządom, podczas sytuacji nadzwyczajnych, takich jak zamieszki czy demonstracje ${ }^{157}$.

Kolejny Specjalny Sprawozdawca, Willem Riphagen, uzasadniał formułe przyjętą przez poprzednika, odpierając zarzuty Austrii i Czechosłowacji, dotyczące pominięcia w treści projektu odniesienia do „winy” państwa, które odpowiadać by miało za brak należytej staranności ${ }^{158}$. Winę postrzegać należało, zdaniem Riphagena, jako wskazane w treści przepisu „naruszenie zobowiązania

${ }^{151}$ Czwarty raport Ago, U.N. Doc. A/CN.4/264, s. 98.

${ }^{152}$ Czwarty raport Ago, U.N. Doc. A/CN.4/264, s. 120-121.

${ }^{153}$ Czwarty raport Ago, U.N. Doc. A/CN.4/264, s. 123.

${ }^{154} \mathrm{~W}$ takiej sytuacji ukaranie sprawców nie jest skutkiem międzynarodowej odpowiedzialności państwa, a raczej przyczyny, dla której ową odpowiedzialność ponosi. Por.: D. D. Anzilotti, La responsabilité internationale des États a raison des dommages soufferts par des etrangers, Revue générale de droit international public, Paris 1906, vol. II, t. I, s. 195. Podaję za: Czwarty raport Ago, U.N. Doc. A/CN.4/264, s. 122-123.

${ }^{155}$ D. D. Anzilotti, La responsabilite..., s. 195. Podaję za: Czwarty raport Ago, U.N. Doc. A/CN.4/264, s. 122- 3.

${ }^{156}$ Czwarty raport Ago, U.N. Doc. A/CN.4/264, s. 123-4; podobnie: Siódmy Raport Specjalnego Sprawozdawcy R. Ago o międzynarodowo bezprawnym czynie państwa i źródłach odpowiedzialności międzynarodowej, 1978 r., U.N. Doc. A/CN.4/307 (dalej: Siódmy Raport Ago, U.N. Doc. A/CN.4/307), s. 34, pkt 8.

${ }^{157}$ Czwarty raport Ago, U.N. Doc. A/CN.4/264, s. 124, pkt 143.

${ }^{158}$ Siódmy Raport Specjalnego Sprawozdawcy W. Riphagena, 1986 r., U.N. Doc. A/CN.4/397 (dalej: Siódmy raport Riphagena, U.N. Doc. A/CN.4/397), s. 8. 
międzynarodowego" ${ }^{\text {159. }}$. Utożsamienie tych dwóch pojęć jest szczególnie zasadne, dowodził Specjalny Sprawozdawca, gdy mowa o odpowiedzialności państwa za zaniechanie. Wina może być pojmowana jako naruszenie zobowiązania międzynarodowego, jeśli z treści normy pierwotnej wynika zobowiązanie państwa do działania w sposób, jakiego można od niego racjonalnie wymagać. Wówczas winę stanowi zaniechanie, zwłaszcza jeśli $\mathrm{z}$ treści zobowiązania wynikał obowiązek należytej stranności. Celem twórców projektu było bowiem, jak już wspomniano, spisanie norm na tyle ogólnych, aby ich stosowanie było możliwe względem wszystkich stanów faktycznych, wynikających z norm pierwotnych, określających treść obowiązków państw. Ten sam cel przyświecał ogólnemu sformułowaniu opisującemu elementy naruszenia prawa międzynarodowego ${ }^{160}$. Pozwalało ono na zidentyfikowanie przesłanki winy w treści obowiązku prewencji, a zwłaszcza $\mathrm{w}$ treści szczegółowego obowiązku dokładania należytej staranności, bez czynienia do niej bezpośredniego odniesienia w treści norm wtórnych $^{161}$.

Kolejnemu Specjalnemu Sprawozdawcy, Jamesowi Crawfordowi, przypadło wythumaczenie przedstawicielom państw zaproponowanej przez Ago rezygnacji z przesłanki szkody jako koniecznej do odpowiedzialności państwa ${ }^{162}$. Czynił to poprzez odwołanie do zamierzonego, ogólnego charakteru zapisów projektu, wskazując, że trudności definicyjne pojęcia szkody, dotyczące np. szkody ekonomicznej czy niematerialnej, zniweczyłyby ten cel $^{163}$. Rozważania te uzupełnił wskazaniem obowiązku dołożenia należytej staranności jako „negatywnego” zobowiązania do osiagnięcia określonego skutku (ang. a ,negative” obligation of result $)^{164}$. Celem tym jest udaremnianie naruszenia prawa, nie zaś kompensacja

${ }^{159}$ Siódmy raport Riphagena, U.N. Doc. A/CN.4/397, s. 8.

${ }^{160}$ Por.: Siódmy raport Riphagena, U.N. Doc. A/CN.4/397, roz. IV(B), s. 8 w odniesieniu do art. 2 Projektu artykułów o odpowiedzialności państw z $2001 \mathrm{r}$.

${ }^{161} \mathrm{~W}$ tym kontekście wina może być potrzegana jako „naruszenie zobowiązania międzynarodowego" w znaczeniu art. 15 Projektu artykułów o odpowiedzialności państw z 2001 r., gdy norma pierwotna nakłada na państwo zobowiązanie do postępowania w sposób, jakiego można od niego racjonalnie wymagać, tj. „zobowiązanie należytej staranności” (ang. ,, an obligation of due diligence”). Szczegółowa treść owego zobowiązania wynikać będzie z interpretacji normy pierwotnej, w kontekście jej celu i przedmiotu. Analogicznie element winy wywodzony może być z możliwości przypisania państwu działania osób fizycznych, pełniących funkcje jego organów, lecz przekraczających przyznane im kompetencje lub działających wbrew poleceniom, w tym osób działających de facto w imieniu państwa. Por.: Siódmy raport Riphagena, U.N. Doc. A/CN.4/397, s. 8.

${ }^{162}$ Pierwszy raport Crawforda, U.N. Doc. A/CN.4/490.

${ }^{163}$ Crawford wskazywał, że konieczne było opracowanie projektu tak, aby zawierał jak najbardziej elastyczną formułę odpowiedzialności państw, co pozwoliłoby na stosowanie go w różnorodnych stanach faktycznych, niezależnie od treści normy pierwotnej, której naruszenie daje podstawe jego stosowania. Por.: Pierwszy raport Crawforda, U.N. Doc. A/CN.4/490, s. 5, pkt 16.

${ }^{164} \mathrm{~W}$ treści drugiego raportu Crawford opisał treść obowiązku prewencji (pkt. 85), wskazując, iż powinien on być pojmowany jako zobowiązanie do osiagnnięcia negatywnego skutku. Celem owego obowiązku nie jest bowiem doprowadzenie do pewnego, określonego stanu rzeczy, a jego uniknięcie. Ocena zobowiązania jako należącego do jednej z tych dwóch kategorii zależeć będzie od interpretacji danej normy pierwotnej, konstytuującej szczegółowe zobowiązanie. Por. Drugi raport Specjalnego Sprawozdawcy J. Crawforda, 1998 r., U.N. Doc. A/CN.4/498 (dalej: Drugi raport Crawforda, U.N. Doc. A/CN.4/498), s. 37. 
powstałych szkód. Jak wskazywał, analogiczna analiza winna być zastosowana przy rozważaniu alternatywy pomiędzy odpowiedzialnością państwa opartą na winie, czy uwzględniającą szerzej pojmowany „element psychiczny”, a odpowiedzialnością na zasadzie ryzyka, zależną od wykazania „należytej staranności” 165 .

Tak skonstruowana teoretyczna koncepcja odpowiedzialności państwa dała podstawy wspomnianego już Projektu artykułów o odpowiedzialności państw, przedstawionego przez KPM w $2001 \mathrm{r}^{166}$ Choć pozbawiony mocy prawnej, uznawany jest za poprawnie identyfikujący obowiązujące reguły odpowiedzialności międzynarodowej i przywoływany jest często przez sądy międzynarodowe w wydawanych orzeczeniach. Poniżej opisano reguły rządzące odpowiedzialnością państw w myśl zapisów owego projektu.

\subsection{Zasady odpowiedzialności międzynarodowej państw}

Prace Komisji opierały się na dwóch podstawowych założeniach. Po pierwsze, zgodnie z sugestią Ago Komisja przyjęła, że naruszenie międzynarodowego zobowiązania, tj. normy pierwotnej, skutkowało poddaniem państwa normom wtórnym, określającym reguły jego odpowiedzialności, w zakresie, w jakim treści tych reguł nie określa reżim pierwotny ${ }^{167}$. Celem projektu nie było zidentyfikowanie treści norm pierwotnych, których naruszenia państwo może się dopuścić. Temu celowi służyć miały zapisy regulacji poświęconych poszczególnym obszarom prawa międzynarodowego, np. prawa traktów czy prawa środowiska. Jest nim jedynie określenie konsekwencji takiego naruszenia, niezależnie od charakteru naruszonej normy pierwotnej. Przyjęta w treści dokumentu idea Ago potwierdzała, że reguły odpowiedzialności międzynarodowej stanowią materię niezależną od norm pierwotnych i jako takie mogą być przedmiotem niezależnej analizy $\mathrm{i}$ ewentualnej kodyfikacji ${ }^{168}$. Drugim założeniem przyjętym w pracach Komisji, uwzględnionym przez Crawforda w treści poprawek do projektu, było sformułowanie treści artykułów na wysokim poziomie ogólności, tak aby możliwe było ich zastosowanie względem jak najszerszego zakresu stanów faktycznych ${ }^{169}$.

${ }^{165}$ Por.: Drugi raport Crawforda, U.N. Doc. A/CN.4/498, s. 37.

${ }^{166}$ Projekt artykułów o odpowiedzialności państw z $2001 \mathrm{r}$.

${ }^{167}$ Por. D. M. Bodansky, J. R. Crook, op.cit., s. 779. Mowa tu o tzw. reżimach zamkniętych (ang. self-contained regimes), wyłączonych z zakresu ewentualnego stosowania Projektu artykułów o odpowiedzialności państw z 2001 r. na mocy art. 55 tego projektu. Por. np.: W. Czapliński, A. Wyrozumska, op.cit., s. 589-590; B. Simma, D. Pulkowski, Of Planets and the Universe: Self-contained Regimes in International Law, European Journal of International Law 2006, nr 3(17), s. 483-529; B. Simma, Self-Contained Regimes, Netherlands Yearbook of International Law 1985, nr 16, s. 111-136.

${ }^{168}$ Por.: D. M. Bodansky, J. R. Crook, op.cit., s. 780. Choć porównaj rozdział III, gdzie praktyczne trudności z dokonaniem tej dystynkcji, opisano w szczególe. Obszerną analizę krytyczną podziału zaproponowanego przez KPM przedstawił Boyle, State Responsibility..., s. 1-26.

${ }^{169}$ D. M. Bodansky, J. R. Crook, op.cit., s. 779-80. Por.: Projekt artykułów o odpowiedzialności państw z 2001 r., komentarz do art. 12, s. 55. 
Podstawowa reguła odpowiedzialności międzynarodowej zapisana została w treści art. 1 projektu. W jej myśl każdy międzynarodowo bezprawny czyn państwa niesie za sobą jego międzynarodową odpowiedzialność ${ }^{170}$. Jak już wspomniano, przedmiotem Projektu artykułów o odpowiedzialności państw z 2001 r. jest więc wyłącznie odpowiedzialność państw, nie zaś innych uczestników stosunków międzynarodowych, takich jak np. organizacje międzynarodowe $^{171}$. Na międzynarodowo bezprawny czyn państwa składać się może kilka jego działań lub zaniechań ${ }^{172}$. Ustalenie, czy państwo dopuściło się czynu międzynarodowo bezprawnego wymaga zweryfikowania dwóch kryteriów. Po pierwsze, konieczne jest zbadanie treści samego zobowiązania, którego naruszenia miało dopuścić się państwo. Po wtóre, jego odpowiedzialność zależeć będzie od ogólnych okoliczności czynu, opisanych w pierwszej części projektu. Niektóre czyny państw naruszać bowiem mogą zobowiązania nie tylko względem jednego lub kilku partnerów umownych, ale całej społeczności międzynarodowej (zobowiązania erga omnes) ${ }^{173}$. Jeden czyn międzynarodowo bezprawny przypisany może zostać więcej niż jednemu państwu. Państwo odpowiadać może także za bezprawny czyn innego państwa, jeśli to działało pod jego kierownictwem i kontrolą, choć, co do zasady, państwa ponoszą międzynarodową odpowiedzialność za niewywiązanie się z własnych zobowiązań ${ }^{174}$.

Druga $\mathrm{z}$ trzech głównych zasad odpowiedzialności międzynarodowej państw, określająca elementy czynu, zapisana została $\mathrm{w}$ art. 2. Stanowi ona, że na międzynarodowo bezprawny czyn państwa składa się działanie lub zaniechanie, które można mu przypisać, o ile stanowi ono naruszenie zobowiązania międzynarodowego tego państwa. Przypisanie nazywane bywa nieraz w doktrynie elementem subiektywnym odpowiedzialności, podczas gdy naruszenie zobowiązania międzynarodowego określane jest jako kryterium obiektywne. Komisja odrzuca jednak tę nomenklaturę, wskazując, że także wystąpienie naruszenia można uznać za „subiektywne” jako stanowiące konsekwencję woli lub stanu wiedzy działającego w imieniu państwa organu ${ }^{175}$.

Czyn może być przypisany państwu, jeśli jest działaniem lub zaniechaniem jego organów. Komisja zrównuje znaczenie działania i zaniechania dla przypi-

${ }^{170}$ Projekt artykułów o odpowiedzialności państw z 2001 r., s. 32.

171 Projekt artykułów o odpowiedzialności państw z 2001 r., pkt (7), s. 34. Ale por. uwagi wstępne, gdzie mowa o pracach Specjalnego Sprawozdawcy ds. odpowiedzialności organizacji międzynarodowych (ang. responsibility of international organizations) Giorgio Gaji, powołanego przez KPM w 2003 r.

${ }^{172}$ Projekt artykułów o odpowiedzialności państw z 2001 r., s. 32.

${ }^{173}$ Komisja przywołuje tu orzeczenie w sprawie Barcelona Traction, w treści której MTS opisał podział zobowiązań międzynarodowych na skuteczne względem całej społeczności międzynarodowej i skuteczne jedynie względem określonych jej członków. Wymóg przestrzegania norm zawartych w owej pierwszej kategorii zobowiązań erga omnes nakłada na państwa obowiązek wprowadzenia regulacji czyniących bezprawnymi akty agresji, ludobójstwa czy naruszenia podstawowych praw człowieka. Por. Projekt artykułów o odpowiedzialności państw z 2001 r., pkt (1), s. 32.

${ }^{174}$ Projekt artykułów o odpowiedzialności państw z 2001 r., s. 33-34.

${ }^{175}$ Projekt artykułów o odpowiedzialności państw z 2001 r., s. 34-35. 
sania odpowiedzialności państwu. Dla dokonania przypisania niezbędne jest zdefiniowanie podmiotu odpowiedzialności. Komisja definiuje państwo jako istniejący, wewnętrznie zorganizowany podmiot (ang. real organized entity), osobę prawną z pełną kompetencją do działania w myśl norm prawa międzynarodowego ${ }^{176}$. Tak definiowane państwo może działać jedynie za pośrednictwem swoich organów. Jako „akt państwa” (ang. act of state) Komisja określa czyn obejmujący działanie lub zaniechanie człowieka lub grupy ludzi ${ }^{177}$. Do przypisania państwu czynu niezbędne jest więc ustalenie relacji pomiędzy działającym podmiotem a państwem, tj. wykazanie dostatecznego związku przyczynowo-skutkowego pomiędzy przypisywanym mu czynem a określonym zdarzeniem, stanowiącym naruszenie jego międzynarodowego zobowiązania ${ }^{178}$. Ponadto przesłanką naruszenia zobowiązania międzynarodowego przez państwo jest identyfikacja konkretnego zdarzenia jako sprzecznego z treścią owego zobowiązania. Komisja definiuje naruszenie zobowiązania międzynarodowego na podstawie bogatego orzecznictwa i dorobku doktryny i uznaje je za równoznaczne z postępowaniem państwa sprzecznym z prawami innych państw ${ }^{179}$. Ustalenie wystapienia naruszenia zobowiązania powstałego wskutek przypisanego państwu zaniechania zależy od normy pierwotnej, określającej treść naruszanego zobowiązania. To na podstawie analizy jego treści w konkretnych okolicznościach faktycznych ustalić można, czy dla powstania naruszenia prawa wystarczy samo zaniechanie po stronie państwa, czy towarzyszyć mu musi szkoda ${ }^{180}$. $\mathrm{W}$ ten sposób Komisja wyjaśnia rolę szkody dla uznania odpowiedzialności międzynarodowej państwa. Wystąpienie szkody może być warunkiem koniecznym przypisania państwu odpowiedzialności za międzynarodowo bezprawne zaniechanie, co wynikać może z treści normy pierwotnej. $Z$ jej treści wynikać może także, że samo zaniechanie stanowić będzie naruszenie zobowiązania państwa i stanie się podstawą jego odpowiedzialności, niezależnie od wystąpienia szkody, będącej skutkiem owego zaniechania ${ }^{181}$.

${ }^{176}$ Projekt artykułów o odpowiedzialności państw z 2001 r., str. 34-35.

${ }^{177}$ Projekt artykułów o odpowiedzialności państw z 2001 r., pkt 5, str. 35. przywołując opinię doradczą STSM w sprawie osadników niemieckich w Polsce, Advisory Opinion, P.C.I.J. 1923, seria B, nr 6, s. 22, gdzie Trybunał wskazał, iż państwa mogą działać jedynie za pośrednictwem swoich organów i przedstawicieli. Zob. także np. L. Ehrlich, op.cit., s. 640-641.

${ }^{178}$ Projekt artykułów o odpowiedzialności państw z 2001 r., pkt (6), s. 35. Czyn przypisywany państwu musi być „dostatecznie połączony” z państwem jako podmiotem prawa międzynarodowego, w myśl jednej lub kilku zasad odpowiedzialności państwa, opisanych w rozdz. II Projektu.

${ }^{179}$ Por.: Projekt artykułów o odpowiedzialności państw z 2001 r., s. 35. Państwo może dopuścić się naruszenia zobowiązania traktatowego lub zwyczajowego, co potwierdzone zostało bogatym orzecznictwem. Charakter naruszonego zobowiązania nie ma znaczenia dla odpowiedzialności państwa. W sprawie złóż fosforanów w Maroku STSM wspominał o działaniach „sprzecznych z wynikającymi z traktatu prawami innych państw". Por. orzeczenie z 14 czerwca 1938 r. w sprawie Włochy przeciwko Francji (sprawa fosforanów w Maroku), STSM, 1938 r., s. 28.

${ }^{180}$ Projekt artykułów o odpowiedzialności państw z 2001 r.; por.: pkt (9), s. 35.

${ }^{181}$ Odmienne konsekwencje zaniechania państwa wynikać będą $\mathrm{z}$ natury zobowiązania, por. rozróżnienie na zobowiązania skutkowe i zobowiązania do określonego działania, opisane powyżej. 
W analogiczny sposób Komisja rozwiązuje drugi trudny problem dotyczący przypisania odpowiedzialności i także negatywnie odpowiada na pytanie o konieczność wykazania winy po stronie odpowiedzialnego państwa. Przesłankę winy wskazuje jako ewentualny element normy pierwotnej. Jeśli z treści normy pierwotnej wynikać będzie, że jedynie zawinione zaniechanie państwa będzie tożsame $\mathrm{z}$ naruszeniem opisanego $\mathrm{w}$ treści normy obowiązku, wtedy wina stanie się przesłanką jego odpowiedzialności ${ }^{182}$. To poniekąd sofistyczne rozwiązanie zostało zaproponowane przez Crawforda $\mathrm{w}$ trakcie ostatnich prac nad treścią artykułów, ponieważ koncepcja odpowiedzialności bez winy była nie do zaakceptowania przez przedstawicieli niektórych państw.

Zagadnieniu uznania czynu państwa za niezgodny z treścią norm prawa międzynarodowego poświęcony został w całości art. 3 projektu. Podkreślono, że dokonanie kwalifikacji czynu państwa jako międzynarodowo bezprawnego nastąpić może jedynie w oparciu o normy prawa międzynarodowego, niezależnie od jego oceny w świetle przepisów krajowych ${ }^{183}$. Jest to rozwiązanie odzwierciedlające analogiczne postanowienia wielu norm pierwotnych, choćby art. 27 $\mathrm{KWPT}^{184}$. Ponadto, czyn państwa nie może być uznany za międzynarodowo bezprawny, jeśli nie stanowi naruszenia międzynarodowego zobowiązania, nawet jeśli jest niezgodny z przepisami prawa krajowego ${ }^{185}$.

\subsection{Przypisanie państwu czynu międzynarodowo bezprawnego}

Rozdział II części pierwszej Projektu artykułów o odpowiedzialności państwa z 2001 r. Komisja poświęciła omówieniu konstrukcji przypisania państwu odpowiedzialności za działania osób fizycznych. Jako ogólną zasadę przypisania Komisja wskazuje odpowiedzialność państwa za działania organów jego władzy rządowej lub innych podmiotów, działających pod ich kierownictwem, na ich zlecenie lub pod ich kontrola, np. jako przedstawiciele państwa (ang. agents of the State $)^{186}$. Jako drugą zasadę Komisja wskazuje brak odpowiedzialności państwa za działania osób prywatnych, przywołując np. orzeczenie w sprawie Tellini ${ }^{187}$.

${ }^{182}$ Projekt artykułów o odpowiedzialności państw z 2001 r., por, pkt (10) s. 35. Wina, pojmowana np. jako zamiar spowodowania szkody, nie jest koniecznym elementem odpowiedzialności państwa. Jeśli w treści zobowiązania pierwotnego nie można zidentyfikować odwołania do tak pojmowanego elementy psychicznego, znaczenie dla oceny odpowiedzialności państwa ma jedynie jego działanie, niezależnie od ewentualnych, towarzyszących mu zamiarów.

${ }_{183}$ Projekt artykułów o odpowiedzialności państw z 2001 r., art. 3, s. 36.

${ }^{184}$ Art. 27 KWPT stanowi, iż państwo-strona nie może powoływać się na postanowienia swojego prawa wewnętrznego dla usprawiedliwienia niewykonywania przez nią traktatu.

${ }^{185}$ Projekt artykułów o odpowiedzialności państw z 2001 r., s. 36, pkt (1).

${ }^{186}$ Projekt artykułów o odpowiedzialności państw z 2001 r., s. 36. Ale por.: C. Yeo, Agents of the State: When is an Official of the State an Agent of the State?, International Journal of Refugee Law, Vol. 14, Issue 4, s. 509-533, gdzie autor opisuje trudności ze stosowaniem terminu ,przedstawiciele państwa".

${ }^{187}$ Projekt artykułów o odpowiedzialności państw z 2001 r., s. 38. W sprawie Tellinii (por. rozdz. II), odpowiedzialność państwa wynikała z zaniedbania przy zapewnianiu stosownej ochrony przedstawicielowi dyplomatycznemu, znajdującemu się na jego terytorium. 
Możliwość przypisania państwu określonego zachowania jednostki nie oznacza bezprawności samego zachowania, może ono jednak ponosić odpowiedzialność za zachowania bezprawne, jeśli im nie zapobiegało, zaś ich przypisanie państwu jest możliwe w myśl reguł opisanych w treści projektu ${ }^{188}$. Choć przypisanie czynu państwu i uznanie naruszenia zobowiązania międzynarodowego stanowią odrębne przesłanki odpowiedzialności międzynarodowej, w tym kontekście są one ze sobą blisko powiązane.

Uznanie podmiotu za organ państwa dla potrzeb odpowiedzialności międzynarodowej tego ostatniego dokonywane być powinno wyłącznie w oparciu o reguły zidentyfikowane w projekcie, nie o inne zespoły norm traktatowych, np. normy dotyczące pełnomocnictwa $\mathrm{w}$ prawie traktatów, opisujące kryteria uznania podmiotu za uprawniony do podejmowania zobowiązań $\mathrm{w}$ imieniu państwa $^{189}$. Reguły odpowiedzialności państwa znajdują zastosowanie zawsze wtedy, gdy państwo dopuszcza się naruszenia swoich zobowiązań międzynarodowych, niezależnie od rangi i kategorii działającego w ich imieniu uprawnionego urzędnika ${ }^{190}$. Komisja szczegółowo omówiła zasady przypisania państwu czynów podmiotów równych kategorii począwszy od organów władzy państwowej (art. 5), także tych przekazanych do dyspozycji innych państw (art. 6), jak i tych przekraczających swoje kompetencje lub działających wbrew poleceniom (akty ultra vires, art. 7). W treści tej części mowa także o odpowiedzialności za działania podmiotów niebędących organami państwa, ale działających pod ich kontrolą lub kierownictwem (ang. under its direction or control, art. 8) lub korzystających z braku skutecznej władzy państwowej (art. 9), zwłaszcza ruchów powstańczych (ang. insurrectional movements, art. 10). Państwo może być także pociagnięte do odpowiedzialności za działania niemieszczące się w żadnej z powyższych kategorii, jeśli takie działania post factum uzna za swoje (art. 11). Poza okolicznościami opisanymi w treści rozdziału II, państwo nie ponosi odpowiedzialności za działania osób fizycznych, chyba że odpowiedzialność taka wynika z przepisów szczegółowych, właściwych dla poszczególnych reżimów, traktatowych lub zwyczajowych ${ }^{191}$.

Dla prowadzonych rozważań istotne będzie ustalenie kryteriów pozwalających odróżnić organy państwa od podmiotów prywatnych, za których działania państwa, co do zasady, odpowiedzialności nie ponoszą. Pozwoli to określić granice odpowiedzialności państwa za niedołożenie należytej staranności w wykonywaniu obowiązków wynikających z treści norm prawa międzynaro-

${ }^{188}$ Projekt artykułów o odpowiedzialności państw z 2001 r., s. 39. Wszystkie reguły przypisania stosowane winny być kumulatywnie, państwo ponosić więc może odpowiedzialność za skutki działań osób prywatnych, jeśli nie podjęło wszelkich niezbędnych działań celem zapobieżenia szkodzie.

${ }^{189}$ Projekt artykułów o odpowiedzialności państw z 2001 r., pkt (5), s. 39. O ile więc głowa państwa objęta jest domniemaniem kompetencji traktatowych, o tyle owo domniemanie pozostaje irrelewantne dla oceny jej działania w kontekście odpowiedzialności międzynarodowej państwa. Do dokonania takiej oceny niezbędna jest analiza stanu faktycznego, niezależna od roli i funkcji organu dopuszczającego się aktu międzynarodowo bezprawnego, przypisywalnego państwu.

${ }^{190}$ Projekt artykułów o odpowiedzialności państw z 2001 r., pkt (7), s. 39.

${ }^{191}$ Projekt artykułów o odpowiedzialności państw z 2001 r., pkt 9, s. 40. 
dowego, realizowanych czy to poprzez organy władzy, czy poprzez osoby działające pod ich kontrolą, z ich upoważnienia lub na ich zlecenie. Określenie kręgu tych podmiotów pozwoli także wskazać, kiedy państwo ponosi odpowiedzialność za niedołożenie należytej staranności przez jego organy przy zapobieganiu skutkom czynów osób prywatnych, pozostających w jego jurysdykcji.

\subsection{Odpowiedzialność państwa za działania jego organów}

Komisja wskazała jako ewentualną podstawę jego odpowiedzialności akt państwa, identyfikowany na podstawie norm prawa międzynarodowego jako działanie organu państwa, niezależnie od tego, czy działa organ prawodawczy, wykonawczy czy sądowniczy. Nie ma także znaczenia dla przypisania państwu odpowiedzialności fakt, czy jest to organ pełniący inną niż wyżej wskazana funkcję ani jego pozycja w strukturze państwowej - równe znaczenie będą miały akty organów centralnych i terytorialnych, niezależnie od wzajemnej czy wewnętrznej, służbowej relacji ${ }^{192}$. Za organ państwa uznana może być każda osoba lub jednostka prawna, która posiada taki status w myśl przepisów prawa wewnętrznego, choć za organ państwa uznany może zostać także podmiot niewskazany jako posiadający taki charakter w przepisach prawa wewnętrznego. Status organu państwa determinowany jest nieraz bowiem także poprzez praktykę administracyjną państwa, niekoniecznie opartą o konkretny przepis prawa pozytywnego. Co więcej, przepisy prawa pozytywnego mogą w ogóle nie określać kryteriów lub listy organów państwa. Wtedy kwalifikacja podmiotu jako organu państwa dokonana powinna zostać wyłącznie w oparciu o uprawnienia posiadane przez dany podmiot oraz jego stosunek do innych organów państwa, wskutek analizy praktyki krajowej. Przepisy prawa krajowego nie mają tu znaczenia decydującego ${ }^{193}$. Pojęcie organu państwa rozumiane jest przez Komisję szeroko i obejmuje wszystkie podmioty, jedno- lub wieloosobowe, stanowiące część aparatu państwowego i działające $\mathrm{w}$ imieniu państwa. Z zasady traktowania państwa jako całości przy realizacji jego międzynarodowych zobowiązań wynika konieczność postrzegania wszelkich działań lub zaniechań jego organów jako ewentualnych podstaw międzynarodowej odpowiedzialności, niezależnie od specyfiki czy miejsca w hierarchii organu faktycznie działającego lub powstrzymującego się od działania ${ }^{194}$.

Kwalifikcja podmiotu jako organu państwa jest pierwszym krokiem ku przypisaniu państwu odpowiedzialności za jego działania. Bez znaczenia dla rozstrzygnięcia tej kwestii są prywatne pobudki osoby pełniącej funkcje organu. Istotne jest, czy jej działanie lub zaniechanie mieściło się bez wattpliwości w przysługujacych jej, oficjalnych kompetencjach lub w granicach wykonywanej władzy (ang. under colour of authority) ${ }^{195}$, choć warto odnotować, że także za prze-

\footnotetext{
192 Projekt artykułów o odpowiedzialności państw z 2001 r., art. 4, s. 40.

${ }^{193}$ Projekt artykułów o odpowiedzialności państw z 2001 r., s. 42.

${ }^{194}$ Projekt artykułów o odpowiedzialności państw z 2001 r., s. 40; por. także J. Sutor, op.cit., s. 226.

${ }^{195}$ Projekt artykułów o odpowiedzialności państw z 2001 r., pkt (13), s. 40.
} 
kroczenie przez nią przyznanych jej prawem wewnętrznym kompetencji państwo może ponosić odpowiedzialność. Nie będzie jej jednak ponosić za czyny o charakterze jednoznacznie prywatnym. Pomocne przy ustalaniu tej, zdaniem Komisji wyraźnej, granicy pomiędzy czynem państwa a działaniem lub zaniechaniem osoby pełniącej funkcje organu o charakterze jednoznacznie prywatnym może być bogate orzecznictwo arbitrażowe. Państwo może ponosić więc odpowiedzialność za działania i zaniechania swoich organów sprzeczne z treścią jego międzynarodowych zobowiązań, niezależnie od miejsca owych organów w krajowej hierarchii władzy oraz cech osobowych jednostki pełniącej daną funkcję, także jeśli osoba ta przekracza przypisane jej prawem krajowym kompetencje ${ }^{196}$.

\subsection{Odpowiedzialność państwa za podmioty wykonujące elementy władzy państwowej}

Nie tylko czyny organów państwa mogą zostać mu przypisane, choć, co do zasady, to za ich działania lub zaniechania państwo ponosi odpowiedzialnośćc ${ }^{197}$. Wyjątek od tej zasady dotyczy czynów osób fizycznych lub podmiotów prawnych, niebędących organami państwa, wykonujących pewne elementy władzy państwowej, których działania mogą zostać przypisane państwu. Może on być przywołany, gdy owe osoby lub podmioty zostały przez państwo upoważnione do wykonywania pewnych funkcji państwowych na podstawie przepisów prawa wewnętrznego, o ile w danej sytuacji osoby te lub podmioty działają w takim właśnie charakterze ${ }^{198}$. Podmioty te nie są więc organami państwa, choć uprawnione są do wykonywania pewnych elementów władzy państwowej. Użyty przez Komisję termin ,podmiot” (ang. entity) obejmuje szerokie spektrum potencjalnych wykonawców funkcji państwowych, takich jak przedsiębiorstwa, podmioty nieposiadające osobowości prawnej, podmioty publiczne (ang. public agencies) czy nawet spółki prywatne, o ile otrzymają umocowanie od państwa o odpowiedniej treści i formie ${ }^{199}$. Nie mają znaczenia dla ustalenia charakteru podmiotu jako wykonującego funkcje państwowe takie jego cechy jak forma prawna, forma finansowania jego działalności czy udział państwa w sprawowaniu nad tą działalnością nadzoru, a klasyfikacja jako podmiotu prywatnego czy publicznego nastapi zgodnie z przepisami prawa wewnętrznego. Jedynym kryterium

${ }^{196}$ Por. Projekt artykułów o odpowiedzialności państw z 2001 r., art. 7, s. 45-46; zob. także W. Czapliński, Kodyfikacja prawa o odpowiedzialności międzynarodowej, Studia Prawnicze 2003, nr 4(154), s. 35, który przywołuje dla uzasadnienia owej zasady dorobek traktatowy prawa humanitarnego.

${ }^{197}$ Projekt artykułów o odpowiedzialności państw z 2001 r., pkt (2), s. 40.

${ }^{198}$ Projekt artykułów o odpowiedzialności państw z 2001 r., art. 5, s. 42.

199 Projekt artykułów o odpowiedzialności państw z 2001 r., s. 43. Ciekawy problem przy kwalifikacji czynów podmiotów prywatnych jako czynów organów państwa wiąże się z oceną działań realizowanych przez prywatne firmy wojskowe. Szerzej o tym problemie por. np.: C. Lehnard, op.cit., s. 154-163. 
przypisania państwu odpowiedzialności za takie działania lub zaniechania jest jego umocowanie do wykonywania elementów władzy państwowej, choćby w ograniczonym zakresie ${ }^{200}$.

Kłopotliwe dla przypisania państwu odpowiedzialności za działanie jego organów lub podmiotów wykonujących funkcje państwowe może okazać się także zdefiniowanie zakresu „władzy państwowej”, które stanowi podstawowe kryterium wyróżnienia obu grup. Zakres tego pojęcia nie jest w treści art. 5 sprecyzowany. Poza pewnymi oczywistymi sytuacjami, ustalenie tego, co uznawane może być za kompetencje władzy państwowej „zależy od specyfiki społeczeństwa, jego historii i tradycji." ${ }^{201}$ Znaczenie ma tu nie tylko sam charakter wykonywanych kompetencji, ale także sposób ich powierzenia, cel, dla którego zostały przekazane oraz sposób rozliczenia wykonującego je podmiotu z ich wykonania. Umocowanie do działania weryfikowane będzie w oparciu o specyfikę prawa krajowego, odmiennie od opisanego powyżej przypadku ustalania zakresu pojęcia „organu państwa”, dokonywanego na podstawie kryteriów obiektywnych, inaczej także niż w sytuacji działania na zlecenie i pod kontrolą państwa, czy przejęcia władzy w państwie przez siły rewolucyjne ${ }^{202}$. Sformułowanie zawarte $\mathrm{w}$ art. 5 wyraźnie ogranicza zakres stosowania zawartej w nim reguły do podmiotów umocowanych przepisami prawa wewnętrznego do wykonywania władzy rządowej. Jeśli jednak uda się ustalić, że podmiot został umocowany do działania, państwo ponosić będzie odpowiedzialność za jego działania lub zaniechania także wtedy, gdy w treści umocowania pozostawi mu władzę dyskrecjonalną czy w inny sposób pozwoli na samodzielność w wykonywaniu powierzonych kompetencji. Nie jest konieczne wykazanie, że działanie lub zaniechanie miało miejsce pod kontrolą państwa. Jednocześnie nie oznacza to oczywiście, że państwo ponosi odpowiedzialność za wszelkie działania o charakterze samoobrony lub samopomocy, dokonywane przez podmioty upoważnione mocą przepisów prawa wewnętrznego. Chodzi tu raczej o wąski zakres sytuacji, w których podmiot uprawniony jest do wykonywania konkretnych funkcji władczych państwa ${ }^{203}$.

\subsection{Odpowiedzialność państwa za osoby prywatne działające pod kierownictwem lub kontrolą państwa}

Odmienną kategorią podmiotów, których czyny mogą zostać państwu przypisane, są podmioty działające pod kierownictwem lub kontrolą państwa. W myśl postanowień art. 8 zachowania osób lub grup moga zostać uznane za czyny państwa, jeśli owa osoba lub grupa realizując dane zachowanie wykonuje jego

\footnotetext{
${ }^{200}$ Projekt artykułów o odpowiedzialności państw z 2001 r., s. 43.

${ }^{201}$ Projekt artykułów o odpowiedzialności państw z 2001 r., s. 43.

${ }^{202}$ Projekt artykułów o odpowiedzialności państw z 2001 r., art. 8 i 9, s. 43.

${ }^{203}$ Projekt artykułów o odpowiedzialności państw z 2001 r., s. 43.
} 
polecenia, działa pod jego kierownictwem lub kontrolą. Te trzy formy legitymizowania przez państwo działań podmiotów prywatnych powinny być pojmowane i badane rozłącznie, choć dopełnienie jednej z nich wystarczy do przypisania państwu odpowiedzialności za czyn podmiotu prywatnego. Jednocześnie wykonywanie kompetencji przez państwo w jeden $\mathrm{z}$ ww. sposób musi bezpośrednio przyczynić się do powstania naruszenia jego zobowiązania międzynarodowego ${ }^{204}$.

Działania osób wykonujących polecenia państwa mogą być przypisane państwu ponieważ, zdaniem Komisji przywołującej zasadę efektywności, istnieje „wyjątkowy, faktyczny związek” pomiędzy państwem a osobą lub jednostką biorącą udział w wykonywaniu przez państwo jego funkcji ${ }^{205}$. Dwie takie wyjątkowe sytuacje opisano treści art. 8 projektu. Pierwsza z nich dotyczy osób prywatnych, które na podstawie polecenia państwa dopuszczają się bezprawnego zachowania. Druga okoliczność opisana została w sposób bardziej ogólny dotyczy osób działających na polecenie lub pod kontrolą państwa ${ }^{206}$. Nie ma tu znaczenia, czy działanie osoby prywatnej, wykonywane na zlecenie lub pod kontrolą państwa, mieści się w granicach władzy państwowej. Zapis ten dotyczy przede wszystkim sytuacji, w których organy państwa przywołują do pomocy podmioty prywatne, działające jako ich pomocnicy (ang. auxiliaries), nie stając się elementami struktury państwowej. Nie ma tu także znaczenia forma prawna działania owej grupy osób - chodzi o faktyczne działania wspólne kilku podmiotów $^{207}$.

Kluczowe dla ustalenia zakresu odpowiedzialności państwa za tę kategorię działań jest zdefiniowanie pojęcia czynów realizowanych „pod kierownictwem lub kontrolą" państwa. W komentarzu do projektu Komisja nakazuje definiować ten termin wąsko. Zachowanie realizowane pod kontrolą lub kierownictwem państwa będzie można przypisać mu jedynie wtedy, jeśli kontrolowało konkretne czynności podmiotu lub kierowało nim (ang. if it directed or controlled the specific operations) oraz gdy czyn stanowiący istotę naruszenia stanowił integralną część takiego kontrolowanego przez państwo zachowania ${ }^{208}$. Zasada ta nie dotyczy zachowań, które jedynie przypadkowo lub pobocznie towarzyszyły czynnościom i które nie podlegały kontroli ani kierownictwu państwa. Omówiona w rozdziale poprzednim praktyka orzecznicza precyzuje ogólne reguły odpowie-

${ }^{204}$ Projekt artykułów o odpowiedzialności państw z 2001 r., s. 48

${ }^{205}$ Projekt artykułów o odpowiedzialności państw z 2001 r., s. 48. O zasadzie efektywności por. np.: H. Kelsen, Principles of International Law, New Jersey 1952, s. 215 i n.; H. Kelsen, General Theory of Law And State, New Jersey 2007, s. 121 i n.

${ }^{206}$ Projekt artykułów o odpowiedzialności państw z 2001 r., pkt (1), s. 48. Inaczej postrzegane być powinny działania realizowane przez państwo działające pod kontrolą lub z polecenia innego państwa. Por. Projekt artykułów o odpowiedzialności państw z 2001 r., art. 17.

${ }^{207}$ Projekt artykułów o odpowiedzialności państw z 2001 r., pkt (9), s. 48. Państwo ponosić więc może odpowiedzialność także za grupy niemające osobowości prawnej.

${ }^{208}$ Projekt artykułów o odpowiedzialności państw z 2001 r., pkt (3), s. 48. Por. Sprawa operacji militarnych w Nikaragui, opisane szczegółówo w rozdz. II powyżej. 
dzialności, opisane w treści projektu. Przydatne są tu przede wszystkim rozważania MTS na kanwie stanu faktycznego sprawy oddziałów contras w Nikaragui czy decyzja MTKJ w sprawie Tadiča z 1999 r. ${ }^{209}$

\subsection{Problem tzw. odpowiedzialności pośredniej (zastępczej) państwa za działania osób prywatnych}

Komisja nie poświęca odrębnego artykułu, czy choćby komentarza, kwestii odpowiedzialności państw za działania osób prywatnych niemieszczących się w żadnej z powyższych kategorii, a więc niepełniących funkcji organu państwa, niepełniących funkcji państwowych ani niedziałających pod kontrolą państwa. Odnosi się do niej jedynie pośrednio, omawiając opisane powyżej zasady przypisania odpowiedzialności za czyny podmiotów innych niż organy państwa. Ta kategoria jednak pozostaje kluczowa dla czynionych tu rozważań, bowiem niedołożenie przez państwo należytej staranności przywoływane jest najczęściej $\mathrm{w}$ związku $\mathrm{z}$ działaniami osób prywatnych, powodujących stan sprzeczny z treścią międzynarodowych zobowiązań państwa ${ }^{210}$.

Skoro czyny osób prywatnych nie stanowią samodzielnej przesłanki odpowiedzialności państwa, to powstać ona może jedynie, jeśli działanie osoby prywatnej jest przyczyną stanu sprzecznego $\mathrm{z}$ treścią międzynarodowego zobowiązania państwa i było możliwe w związku z zaniechaniem jego organów, tj. brakiem ich aktywności zmierzającej do zapobieżenia naruszeniu prawa ${ }^{211}$.

Z treści zapisów Projektu artykułów o odpowiedzialności państw z 2001 r. niektórzy przedstawiciele doktryny wywodzą uzasadnienie dla koncepcji „odpowiedzialności pośredniej” Oppenheima, tj. dla odpowiedzialności państwa za

${ }^{209}$ Por.: Projekt artykułów o odpowiedzialności państw z 2001 r., s. 47. Obie sprawy opisane zostały w rozdz. II. Przypomnijmy: w orzeczeniu w sprawie operacji militarnych w Nikaragui MTS wskazał, iż niezależnie od wsparcia udzielanego przez Stany Zjednoczone oddziałom sił antyrządowych, ich poszczególne działania nie mogą zostać przypisane władzom w Waszyngtonie, gdyż te nie sprawowały nad nimi bezpośredniej kontroli. Aby działania contras móc przypisać Stanom Zjednoczonym, te musiałyby sprawować „skuteczną konrolę nad działaniami militarnymi i paramilitarnymi w trakcie realizacji których dopuszczono się naruszeń”. Por.: Sprawa operacji militarnych w Nikaragui, s. 52-53. W komentarzach do Projektu KPM przypomniała, że rozumowanie MTS w sprawie Nikaragui nie znalazło potwierdzenia w sprawie Tadič, rozstrzyganej przez MTKJ. Komisja podkreśliła, że sprawy dotyczyły znacząco różniących się stanów faktycznych, zaś orzekające trybunały różnił diametralnie zakres ich kompetencji - MTS rozstrzygał o odpowiedzialności państwa, która to kwestia pozostawała poza jurysdykcją MTKJ, decydującego o odpowiedzialności jednostki za zbrodnie międzynarodowe.

${ }^{210}$ Zob. np.: J. Barcik, T. Srogosz, op.cit., s. 394; krytyka koncepcji odpowiedzialności pośredniej; por.: W. Góralczyk, S. Sawicki, Prawo międzynarodowe publiczne w zarysie, Warszawa 2001, s. 171.

${ }^{211}$ Por.: ibidem; zob. także W. Czapliński, Odpowiedzialność za naruszenie..., s. 78, gdzie autor wskazuje, iż uznanie odpowiedzialności państwa za zaniechanie jego organów jako dogmatycznej podstawy odpowiedzialności za czyny osób prywatnych krytykowane było przez niektórych autorów jako uwzględnienie winy urzędnika, warunkującej odpowiedzialność państwa. 
działanie jednostek jako osobnej kategorii odpowiedzialności państwa za działanie, omówionej w rozdziale I. Opisują ją mianem zastępczej (ang. vicarious) lub pośredniej (ang. indirect) odpowiedzialności państwa ${ }^{212}$. Ta koncepcja zyskuje na popularności w XXI w. za sprawą wzmożonej walki z międzynarodowym terroryzmem i dyskusji nad zakresem odpowiedzialności państwa za „sponsorowanie" terroryzmu czy milczące przyzwolenie na prowadzenie działalności terrorystycznej z własnego terytorium ${ }^{213}$.

W tym tonie wypowiada się Brown ${ }^{214}$. Wskazuje, co prawda, że opisane w decyzji MTS przypisanie odpowiedzialności Iranowi za działania napastników więziących amerykańskich dyplomatów nie wystarczy dla przypisania odpowiedzialności Afganistanowi za działania Al-Kaidy przeprowadzone 11 września 2001 r. w Stanach Zjednoczonych. Dopatruje się jednak podstaw międzynarodowej odpowiedzialności Kabulu za akty terrorystyczne w fakcie dopuszczenia przez afgańskie władze do dalszych działań tej terrorystycznej organizacji na swoim terytorium. Wywoływane przez nią stałe zagrożenie dla międzynarodowego bezpieczeństwa przypisać można, jego zdaniem, Afganistanowi. Niechęć władz do wyeliminowania Al-Kaidy z życia społecznego i politycznego kraju uznaje za analogiczną względem przetrzymywania zakładników na obszarze placówki dyplomatycznej w Teheranie za wiedzą i przyzwoleniem Chomeiniego. Brown dowodzi, że jeśli państwo wspiera ataki terrorystyczne i uznaje je za swoje, ponosi za nie odpowiedzialność względem państw poszkodowanych ${ }^{215}$. O ile jednak w przypadku teherańskiej ambasady MTS wskazał na wypowiedzi Chomieniego pochwalające działania rebeliantów, o tyle władze Afganistanu żadnym oficjalnym wystapieniem nie udzieliły wsparcia Al-Kaidzie. Brown wskazuje jednak, że państwo może ponosić odpowiedzialność za działania osób prywatnych także wówczas, gdy nie uzna ich działań za swoje. O ile więc odpowiedzialność wynikająca $\mathrm{z}$ uznania działań osób prywatnych wymaga deklaracji organów państwa, o tyle odpowiedzialność zastępcza (ang. vicariuos responsibility) może zostać skutecznie przywołana w przypadku działań osób prywatnych, które nie zyskały oficjalnego poparcia władz. Cytując Oppenheima wskazuje, że odpowiedzialność państwa wynika wówczas z zaniechania podjęcia przez państwo kroków zmierzających do zapobieżenia szkodliwemu działaniu lub ukarania $\mathrm{go}^{216}$. Zazwyczaj odpowiedzialność pośrednia oznacza odpowiedzialność za szkodliwe działania urzędników państwowych realizowane bez upoważnienia, ale, zdaniem Browna, posiada ona także szersze znaczenie. Przypisać ją

${ }^{212}$ Por.: V. J. Proulx, Babysitting Terrorists: Should States Be Strictly Liable for Failing to Prevent Transborder Attacks, Berkeley Journal of International Law 2005, nr 3(23), s. 624; D. Brown, Use of Force Against Terrorism After September 11th: State Responsibility, Self-Defense and Other Responses, Cardozo Journal of International and Comparative Law 2003-2004, nr 11, s. 13-15.

${ }^{213}$ Por.: V. J. Proulx, op.cit., s. 643-659.

${ }^{214}$ D. Brown, op.cit., s. 13-15.

${ }^{215}$ Ibidem, s. 12.

${ }^{216}$ Ibid., s. 13. 
można także państwu, które świadomie godzi się na naruszanie prawa przez osoby prywatne, znajdujące się pod jego władzą. Państwo ma obowiązek zapobiegania i karania takich naruszeń prawa, zaś gdy jego działania nie wypełniaja dyspozycji takiego zobowiązania, ponosi ono odpowiedzialność za te naruszenia. Przywołując orzeczenie w sprawie cieśniny Korfu wskazuje, że państwo, które wie o czynnościach prowadzących do powstania szkody innego suwerena, a które im nie zapobiega, ponosi odpowiedzialność za naruszenie międzynarodowego zobowiązania. Stosując sentencję owego wyroku do ataków terrorystycznych wskazuje, że państwo które wie lub powinno wiedzieć, zważywszy na okoliczności, o atakach terrorystycznych skierowanych przeciwko innemu państwu, którym może zapobiec, ale tego nie czyni, nie ostrzegając innego państwa o grożącym mu niebezpieczeństwie, ponosi odpowiedzialność za taki atak ${ }^{217}$. Dając schronienie Al-Kaidzie, Afganistan brał udział w działaniach, którym miał obowiązek zapobiegać, a których bezpośrednim skutkiem były zamachy z 11 września 2001 r. Dlatego też Afganistan ponosił pośrednią odpowiedzialność za owe ataki terrorystyczne.

Brown nie poddaje analizie treści poszczególnych obowiązków władz w Kabulu, wynikających z ogólnego zobowiązania do zapobiegania szkodom, ani nie analizuje treści standardu należytej staranności w omawianej sytuacji, choć odnotowuje, że państwo nie ponosi odpowiedzialności międzynarodowej za szkody wyrząazone przez osoby prywatne, którym to szkodom nie mogło zapobiec, mimo dołożenia należytej staranności ${ }^{218}$. Co więcej, obejmuje odpowiedzialnością pośrednią także działania państw wspierających czy finansujących akty terrorystyczne, niezależnie od ewentualnej bezpośredniej kontroli działań terrorystów przez państwo ${ }^{219}$. Wskazuje, że odpowiedzialność pośrednia to rozwijający się obszar prawa międzynarodowego, którego znaczenie będzie rosnąć.

Proux idzie o krok dalej, wskazując, że podstawą odpowiedzialności pośredniej nie jest zindywidualizowane zaniechanie państwa, a sam fakt wystapienia szkody. Przedstawiając swoją koncepcję odpowiedzialności „,pośredniej”, proponuje wykreślenie przesłanki przypisania $\mathrm{w}$ kształcie zdefiniowanym $\mathrm{w}$ art. 2 Projektu artykułów o odpowiedzialności państw z 2001 r., wskazując, iż w obecnym kształcie stosunków międzynarodowych konstrukcja przypisania jest zbędna. W zamian proponuje odpowiedzialność państwa na zasadzie ryzyka za zaniechanie udaremnienia zamachów terrorystycznych. Nie chodzi mu więc o weryfikację spełnienia kryterium należytej staranności, wynikającego z innych, pierwotnych zobowiązań państw, ale o odpowiedzialność państwa za niezapobieżenie (w odróżnieniu od „niezapobiegania”) szkodliwemu skutkowi ${ }^{220}$. Koncepcja Proux oparta jest o domniemanie odpowiedzialności państwa, które

\footnotetext{
${ }^{217}$ Ibid., s. 13-15.

${ }^{218}$ Ibid., s. 31.

${ }^{219}$ Ibid., s. 15-17.

${ }^{220}$ Proulx wskazuje na problem definicyjne, jakie niesie ze sobą termin „terroryzm”, V. J. Proulx, op.cit., s. 630-637. Zagadnienie to zostało omówione szerzej w rozdziale V.
} 
atakowi nie zapobiegło - to jego władze musiałyby wykazać, że zapobieżenie szkodzie było niemożliwe ${ }^{221}$.

Koncepcje odpowiedzialności „pośredniej” i „zastępczej” państwa stanowić mają w XXI w. przeciwwagę dla linii orzeczniczej sądów międzynarodowych, ograniczających zakres czynów osób prywatnych, które można w świetle prawa międzynarodowego przypisać państwu. Większość orzeczeń, przywoływanych dla poparcia koncepcji odpowiedzialności pośredniej, dotyczyła stanów faktycznych, w których państwom przypisywano odpowiedzialność za ataki terrorystyczne lub reakcje na takowe ${ }^{222}$, zaś koronnym argumentem na rzecz tezy o odpowiedzialności pośredniej jest milczące poparcie społeczności międzynarodowej dla kampanii wojskowej Stanów Zjednoczonych w Afganistanie w odpowiedzi na ataki Talibów z 11 września 2011 r., działających z afgańskiego terytorium. To milczące przyzwolenie wskazywane jest jako potwierdzenie uznania pośredniej odpowiedzialności Afganistanu za wspomaganie terrory$\mathrm{zmu}^{223}$. Choć autorzy nie dowodzą jeszcze powstania normy zwyczajowej, wskazują na kształtującą się międzynarodową praktykę, suponując kierunek jej dalszego rozwoju - inkorporacji do systemu prawa międzynarodowego koncepcji pośredniej odpowiedzialności państwa. Wskazują wręcz, że ten kierunek rozwoju będzie dominującym w dogmatycznej i politycznej debacie nad kształtem prawa międzynarodowego i spowoduje, że zawarta w treści projektu KPM przesłanka przypisania okaże się zbędna ${ }^{224}$. Koncepcja ta inspirowana jest prawdopodobnie przez idee Schmitta, twórcy amerykańskiej doktryny ,,bellum Americanum" - wojny obronnej w wieku terroryzmu, choć on sam nie nawiązuje do idei odpowiedzialności pośredniej państwa, wywodząc odpowiedzialność państwa za niedopełnienie obowiązku prewencji m.in. z orzeczeń w sprawie statku Lotus i Caroline ${ }^{225}$.

Koncepcję odpowiedzialności pośredniej ocenić należy negatywnie ${ }^{226}$. Jeśli miałaby zostać oparta, jak proponuje Proux, na domniemaniu odpowiedzialności państwa, byłaby sprzeczna z zasadą domniemania niewinności, powszechnie uznaną przez narody cywilizowane $\mathrm{w}$ ich porządkach wewnętrznych, a więc uznaną przez społeczność międzynarodową. Co więcej jednak, wydaje się, że

${ }^{221}$ V. J. Proulx, op.cit., s. 654-656. Por. J. Sutor, który w kontekście odpowiedzialności państwa za naruszenie immunitetów dyplomatycznych pisze, iż państwo „ponosi ogólną odpowiedzialność za wszystko, co dzieje się w granicach jego terytorialnego zwierzchnictwa", por. J. Sutor, op.cit. s. 235. Konstatację tę interpretować jednak należy, jak się zdaje, we właściwym jej kontekście norm prawa dyplomatycznego.

${ }^{222}$ Por.: V. J. Proulx, op.cit., s. 630-631, odnosząc się do wydarzeń z 1982 r. pomiędzy Izraelem a Libanem i do bombardowania amerykańskich ambasad w Afryce w $1998 \mathrm{r}$.

${ }^{223}$ Por.: V. J. Proulx, op.cit., s. 626-630.

${ }^{224}$ Ibidem, s. 643-659.

${ }^{225}$ Por.: M. N. Schmitt, Bellum Americanum Revisited: U.S. Security Strategy and the Jus Ad Bellum, Military Law Review 2003, nr 176, s. 391. Zob. także ogólnie: M. N. Schmitt, Bellum Americanum: The U.S. View of Twenty-First Century War and Its Possible Implications for the Law of Armed Conflict, Michigan Journal of International Law 1998, nr 19, s. 1051 i n.

${ }^{226}$ Por. surowa krytyka tej koncepcji autorstwa I. Brownliego: I. Brownlie, State..., s. 36. 
istnieje możliwość realizowania zamierzonych przez zwolenników owej koncepcji celów bez rewolucji w systemie odpowiedzialności międzynarodowej ${ }^{227}$. Taką samą funkcję spełnia bowiem uznana przez KPM konstrukcja odpowiedzialności państwa za zaniechanie jego organów. Dla zbudowania podstaw takiej szerszej koncepcji odpowiedzialności służyć mogą choćby tezy z orzeczenia $\mathrm{w}$ sprawie zakładników teherańskich. Treść i cel koncepcji przypisania odpowiedzialności za zaniechanie mogą służyć do skutecznego egzekwowania odpowiedzialności państwa za „sponsorowanie” terroryzmu.

Koncepcję odpowiedzialności pośredniej krytyce poddał także Specjalny Sprawozdawca Ago w treści przedstawionego KPM czwartego raportu ${ }^{228}$. Stwierdza, iż jedyną odpowiedzialnością, jaką państwo może ponosić za działania osób prywatnych, jest odpowiedzialność bezpośrednia. Krytykując Oppenheima wskazuje, że idea odpowiedzialności pośredniej czy za „cudze działania” (ang. responsibility for ,, acts other than their own”) nie wyjaśnia kwestii odpowiedzialności państw i nie przyczynia się do usystematyzowania jej zasad. Szczególnie nieuzasadnione jest przywoływanie jej w związku z działaniami osób prywatnych, bowiem może to prowadzić do niejasności i pomylenia reżimu odpowiedzialności międzynarodowej państw z regułami odpowiedzialności za działania niezakazane prawem międzynarodowym. W każdym porządku prawnym, a więc także $\mathrm{w}$ prawie międzynarodowym, odpowiedzialność podmiotu prawa za działania innych podmiotów, tj. odpowiedzialność pośrednia, stanowi wyjątek i jako taka przywoływana może być jedynie w szczególnych sytuacjach. W prawie międzynarodowym jednak, inaczej niż w porządkach krajowych, nie mamy do czynienia z ponoszeniem odpowiedzialności za jeden podmiot tego systemu prawa przez inny, bowiem osoby prywatne nie sa podmiotami prawa międzynarodowego, w odróżnieniu od państw. Użycie więc zarówno owego terminu, jak i konstrukcji postrzegane być winno krytycznie. W podobnym tonie wypowiadają się Góralczyk i Sawicki ${ }^{229}$. Jak wskazuje Sutor, państwo nie ponosi odpowiedzialności za szkodliwe lub sprzeczne z prawem czyny osób prywatnych, niebędących urzędnikami państwowymi, może jednak ponosić „własną" odpowiedzialność za brak kontroli niezbędnej do zapobieżenia wywołanym przez nie szkodom lub naruszeniom. Państwo ponosi wówczas odpowiedzialność za zaniechanie własnych organów. Odpowiedzialność za działania osób prywatnych przypisana może zostać państwu jedynie, jeśli osoby te działały według instrukcji lub pod kierownictwem albo kontrolą danego państwa ${ }^{230}$.

Niezależnie więc od tego, czy państwo uznało działanie osoby prywatnej, czy jego organ dopuścił się zaniechania, które doprowadziło do szkodliwego działania jednostki, ponosiło będzie ono odpowiedzialność. Koncepcja odpowiedzialności pośredniej nie wydaje się także właściwa, jeśli uwzględnić odpowiedzialność

\footnotetext{
${ }^{227}$ Por.: V. J. Proulx, op.cit., s. 625.

${ }^{228}$ Czwarty raport Ago, U.N. Doc. A/CN.4/264, s. 100, pkt 72.

${ }^{229}$ W. Góralczyk, S. Sawicki, op.cit, s. 171.

${ }^{230}$ Por. J. Sutor, op.cit., s. 226.
} 
państwa za działania ruchów rewolucyjnych czy nieformalnych organizacji, nawet jeśli te posiadałyby charakter międzynarodowy. Uznanie odpowiedzialności państwa za działania takiego podmiotu pojawiało się $\mathrm{w}$ doktrynie jako postulat zmian (de iure condendo) i jako takie nie może służyć interpretacji zasad odpowiedzialności międzynarodowej państw ${ }^{231}$. Zaniechanie własnego organu polegające na niezapobieżeniu szkodliwemu działaniu osoby prywatnej, ustalane jest zawsze w oparciu o analizę okoliczności sprawy, ale jednocześnie zależy od znanego prawu międzynarodowemu standardu należytej staranności.

Należyta staranność jest kluczowa dla ustalenia reguł odpowiedzialności państwa za zaniechanie. Od treści norm pierwotnych zależeć będzie kształt odpowiedzialności państwa za zaniechanie, polegające na niedołożeniu należytej staranności w kontrolowaniu działań podmiotów prywatnych. Należyta staranność stanowi wspólne kryterium oceny realizacji przez państwo pierwotnego zobowiązania prewencji, niezależnie od jego traktatowego czy zwyczajowego źródła. Nim więc zostanie zdefiniowana zasada należytej staranności, konieczne jest poczynienie odniesienia do roli, jaką odgrywa ona $\mathrm{w}$ drugim $\mathrm{z}$ wyróżnianych przez KPM reżimie, dotyczącym odpowiedzialności za działania niezakazane prawem międzynarodowym, konstytuującym powszechny obowiązek prewencji, tj. zapobiegania szkodliwym konsekwencjom działań realizowanych na terytorium lub w jurysdykcji państwa. Wcześniej jednak należy wspomnieć o tych okolicznościach, których wystąpienie czyni naruszenie prawa międzynarodowego wolnym od odpowiedzialności.

\subsection{Okoliczności wylączające bezprawność}

Rozdział V Projektu artykułów o odpowiedzialności państw z 2001 r. w całości poświęcony został opisowi sześciu okoliczności, w których pomimo naruszenia zobowiązania międzynarodowego, państwo nie ponosi odpowiedzialności. Wśród tych okoliczności KPM wymienia zgodę poszkodowanego (art. 20), działanie w samoobronie, zgodne z Kartą Narodów Zjednoczonych (dalej KNZ; art. 21), stosowanie zgodnych z prawem międzynarodowym oraz treścią rodziału III projektu środków odwetowych (art. 22), działanie siły wyższej (art. 23), skrajny przymus (art. 24) oraz stan wyższej konieczności (art. 25).

Tak więc udzielona w sposób wiążący zgoda państwa poszkodowanego stanowi okoliczność wyłączającą odpowiedzialność państwa naruszającego zobowiązanie międzynarodowe, ale jedynie względem państwa, które owej zgody udzieliło i jedynie w zakresie, którego dotyczyła udzielona zgoda.

Jako skrajny przymus KPM opisuje sytuację, w której podmiot naruszający normę prawa międzynarodowego nie ma innej racjonalnej możliwości ocalenia swojego życia lub życia osób pozostających pod jego opieką. Wyjątek ten nie dotyczy zagrożeń, które powstały lub które były powiązane ze zdarzeniami

\footnotetext{
${ }^{231}$ Czwarty raport Ago, U.N. Doc. A/CN.4/264, pkt 73, s. 100.
} 
powstałymi wskutek działania państwa, podnoszącego ową okoliczność ${ }^{232}$. Nie może być także skutecznie przywołany, gdy konsekwencja uniknięcia owego zagrożenia sama stanie się źródłem porównywanego albo większego zagrożenia $^{233}$.

Komisja opisuje siłę wyższą jako wystapienie nieprzemożonej siły lub nieprzewidzianego zdarzenia, znajdujących się poza kontrolą państwa, powodujących fizyczną niemożność realizacji ciążącego na państwie zobowiązania międzynarodowego ${ }^{234}$. Siła wyższa wynikać może z przyczyn naturalnych, fizycznych lub ich połączenia. W żadnej sytuacji jako siły wyższej nie można taktować niedbalstwa władz lub ich zaniechania ${ }^{235}$. Okoliczności tej państwo nie może jednak skutecznie przywołać, jeśli samo przyczyniło się do powstania owego zdarzenia czy wystapienia siły lub liczyło się z ryzykiem ich wystąpienia.

Stan wyższej konieczności skutecznie przywołany może być przez państwo jedynie, jeśli naruszenie prawa międzynarodowego było jedynym sposobem ochrony jego żywotnych interesów przed poważnym i nieuchronnym zagrożeniem, a owo naruszenie nie stanowiło poważnego naruszenia istotnych interesów innego państwa, względem którego naruszane zobowiązanie winno być respektowane lub interesów społeczności międzynarodowej jako całości. Okoliczność ta nie może być skutecznie przywołana względem zobowiązań, w treści których zawarto jej wyłączenie lub państwo samo przyczyniło się do postania stanu wyższej konieczności ${ }^{236}$.

Co więcej, zgodnie z treścią art. 26 projektu, żadna z tych okoliczności nie może zostać skutecznie przywołana dla zwolnienia się przez państwo od odpowiedzialności za naruszenie normy peremptoryjnej ${ }^{237}$.

${ }^{232}$ Por. W. Czapliński, A. Wyrozumska, op.cit., s. 602, którzy utożsamiają ową okoliczność z koniecznością ochrony życia ludzkiego.

${ }^{233}$ Por. Projekt artykułów o odpowiedzialności państw z 2001 r., art. 24, s. 78.

${ }^{234}$ Por. Projekt artykułów o odpowiedzialności państw z 2001 r., art. 23, s. 76; por. W. Czapliński, A. Wyrozumska, op.cit., s. 601.

${ }^{235}$ Por. Projekt artykułów o odpowiedzialności państw z 2001 r., s. 76-77.

${ }^{236}$ Por. N. L. J. T. Horbach, P. H. F. Bekker, State responsibility for injurious transboundary activity in retrospect, Netherland International Law Review 2003, s. 358-360, gdzie autorzy omawiają możliwość przywołania stanu wyższej konieczności przez Węgry w sprawie projektu Gabcikovo-Nagymaros.

${ }^{237}$ Por. Projekt artykułów o odpowiedzialności państw z 2001 r., art. 25, s. 80. Zob. także M. N. Shaw, Prawo..., s. 426-428; W. Czapliński, A. Wyrozumska, op.cit., s. 601-602; R. Pisillo Mazzeschi, op.cit., s. 45-46, który potwierdza, że odpowiedzialność za brak należytej staranności podlega takim samym ograniczeniom, jak odpowiedzialność z tytułu naruszenia jakiejkolwiek innej normy prawa międzynarodowego. 


\section{ODPOWIEDZIALNOŚĆ MIĘDZYNARODOWA (INTERNATIONAL LIABILITY) ZA BRAK NALEŻYTEJ STARANNOŚCI}

\subsection{Należyta staranność a zasada dobrosąsiedztwa - uwagi wstępne}

We współczesnej doktrynie prawa międzynarodowego należyta staranność często przywoływana jest jako jedna z konsekwencji uznania zasady dobrosąsiedztwa za podstawę pokojowej koegzystencji państw. Zasada ta wynika bezpośrednio omówionego $\mathrm{w}$ poprzednim rozdziale i potwierdzonego wskazanym orzecznictwem zobowiązania państw do zapobiegania wykorzystaniu terytorium na szkodę innych suwerenów lub ich obywateli. Zasada dobrosąsiedztwa, stanowiąca normę pierwotną w rozumieniu Projektu artykułów o odpowiedzialności państw z 2001 r., wymieniona została w szeregu traktatów składających się na dorobek międzynarodowego prawa środowiska. Jej genezę wywodzić można $\mathrm{z}$ czasów rzymskich, kiedy to obowiązek powstrzymywania się przed wykorzystaniem własnego terytorium na szkodę innych opisywany był paremią sic utere tuo, ut aluenum non laedus ${ }^{1}$.

Zasady eksploatacji wspólnych zasobów były przedmiotem dyskusji ONZ od lat 70. XX w. ${ }^{2}$ Granice suwerenności państw, w dyspozycji których znajdowały się zasoby naturalne, wytyczane były przez zasadę dobrosąsiedztwa i należytą staranność. Orzecznictwo międzynarodowe potwierdziło ich aktualność, zaś dorobek traktatowy odzwierciedlił ich treść przede wszystkim w Deklaracji

\footnotetext{
${ }^{1}$ Por.: K. Wolfke, Some Reflections on International Environmental Law-Making and Enforcement, Polish Yearbook of International Law 1976, nr VIII, s. 45; M. M. Kenig-Witkowska, Prawno-międzynarodowa odpowiedzialność..., s. 311. Choć Lammers twierdzi, że rzymska geneza tej zasady budzi wątpliwości. Wskazuje, że nie znajduje ona także swojego bezpośredniego odzwierciedlenia we współczesnych porządkach prawa krajowego, bowiem wymieniana jest jedynie w nielicznych orzeczeniach anglosaskich i opracowaniach doktryny autorstwa pisarzy wywodzących się z systemu common law. Por.: J. G. Lammers, Pollution of International Watercourses: Search for Substantive Rules and Principles of Law, Haga 1984, s. 570.

${ }^{2}$ Szeroko o koncepcji wspólnych zasobów: J. A. Khan, The International Law of Joint Resource Development: With Special Reference to Its Functional Role in the Management and Resolution of Boundary and Territorial Disputes Involving Natural Resources, Medford 1991. Zob. także: E. Benvenisti, Sharing Transboundary Resources: International Law and Optimal Resource Use, Cambridge 2002, s. 201-232, gdzie autor definiuje pojęcie i opisuje zakres międzynarodowego prawa zasobów wspólnych.
} 
sztokholmskiej, potwierdzającej praktykę zwyczajową ${ }^{3}$. Jak już wspominano, zasada 21 Deklaracji sztokholmskiej stanowi, iż na państwach ciąży wynikający z Karty Narodów Zjednoczonych i zasad prawa międzynarodowego obowiązek zapewnienia, aby działania realizowane w ich jurysdykcji lub pod ich kontrola nie powodowały szkód w środowisku innych państw lub na obszarach poza jurysdykcją państwową. Zasada ta została potwierdzona blisko 20 lat później w treści Deklaracji z Rio de Janeiro w sprawie środowiska i rozwoju ${ }^{4}$. Jej Zasada 2 zawiera obowiązek wykonywania suwerennego prawa państw do eksploatacji ich terytoriów z troską o interesy innych, poszerzając zakres owego zobowiązania o konieczność uwzględnienia zasady ciagłego rozwoju. Zasada dobrosąsiedztwa posłużyła także za podstawę szeregu traktatów międzynarodowego prawa środowiska, począwszy od Konwencji z 1979 r. w sprawie transgranicznego zanieczyszczania powietrza na dalekie odległości poprzez Konwencję o prawie morza z 1982 r. ${ }^{5}$, aż po wspominaną już Konwencję wiedeńską o ochronie warstwy ozonowej z 1985 r. Jednocześnie zobowiązanie do poszanowania relacji dobrosąsiedzkich postrzegane może być także jako element powszechnego prawa zwyczajowego ${ }^{6}$. Zasada dobrosąsiedztwa wymieniania jest przez niektórych autorów łącznie z zasadą należytej staranności, jako dwa elementy zasady 21 Deklaracji sztokholmskiej, wywodzone $\mathrm{z}$ orzeczeń: trybunału arbitrażowego w sprawie huty w Trail i MTS dotyczącego cieśniny Korfu' ${ }^{7}$ Zasada dobrosąsiedztwa spotkała się z pozytywnym przyjęciem ze strony państw przede wszystkim ze względu na jej immanentną elastyczność, która stała się jednocześnie przedmiotem krytyki części doktryny. Zasada obejmuje poszanowanie dla suwerennego prawa państw do wykorzystania pozostających w ich jurysdykcji zasobów naturalnych, jak również obowiązek takiego ich wykorzystania, aby nie niosło ono za sobą szkód dla innych. Ta korelacja prawa i obowiązku pozwala na szeroki margines interpretacji, czyniąc niezmiernie trudnym ustalenie faktycznej treści zasady dobrosąsiedztwa ${ }^{8}$. W 1963 r. Winfield i Jolowicz wskazy-

\footnotetext{
${ }^{3}$ Por.: L. Viikari, op.cit., s. 150 oraz Raport z 64. konferencji ILA, Queensland 1990 [online]. ILA [dostęp: 2013-04-20]. Dostępny w Internecie: <http://www.ila-hq.org/en/publications/orderreports.cfm>, s. 168 .

${ }^{4}$ Deklaracja z Rio de Janeiro z 1992 r. w sprawie środowiska i rozwoju, Raport Konferencji ONZ ds. środowiska i rozwoju, 1992 r., U.N. Doc A/CONF.151/26, tom I, zał. 1. (dalej: Deklaracja z Rio).

${ }^{5}$ Konwencja Narodów Zjednoczonych o prawie morza, sporządzona w Montego Bay dnia 10 grudnia 1982 r., Dz.U. 2002, nr 59 poz. 543 (dalej: KoPM).

${ }^{6}$ Por.: L. Viikari, op.cit., s. 152.

${ }^{7}$ Zob. np.: N. Schrijver, Development..., s. 50; N. Schrijver, Soveregnty..., s. 127, J. G. Lammers, op.cit., s. 286. Włączenie obowiązku należytej staranności do treści zasady dobrosąsiedztwa potwierdza np. krajowe orzeczenie Sądu Apelacyjnego Dziewiątego Okręgu w sprawie położonej w stanie Waszyngton platformy wiertniczej Cherry Point, której awaria wywołała szkody na terytorium Kanady; por.: sprawa Ocean Advocates przeciwko United States Army Corps of Engineers [online]. Orzeczenie sądu Dziewiątego Okręgu, 2005 r., 402 F.3d 846 [dostęp: 2013-01-20]. Dostępny w Internecie: <https://bulk.resource.org/courts. gov/c/F3/402/402.F3d.846.01-36144.0136133.html>.

${ }^{8}$ Por.: L. Viikari, op.cit., s. 152.
} 
wali, że z tego właśnie powodu jest to zasada „niepomocna i zwodnicza”, bowiem jeśli oznacza zakaz zgodnego z prawem wykorzystania własności, o ile tylko niesie ono szkodę innym, to nie sposób ustalić granicy dozwolonego wykorzystania owej własności ${ }^{9}$. Określana ona bywała także jako „puste sformułowanie”, „niepomocna przy podejmowaniu decyzji” czy „całkowicie nieużyteczna jako zasada prawa"10. Krytyka zasady sic utere tuo, ut alienum non laedas jako obcej systemowi prawa międzynarodowego pojawiała się jeszcze w latach $80 . X{ }^{11}$ wej ograniczenie wyłącznie do szkód „znaczących”, które wynikać mogą z wykorzystania własności, opisane przez KPM w latach 90. XX w., pozbawiło zasadności część uwag krytycznych formułowanych względem niej, doprecyzowując zakres jej stosowania ${ }^{12}$. Niezależnie od owego doprecyzowania, zasada dobrosąsiedztwa pociagga za sobą zobowiązanie do zapobiegania znaczącym szkodom trangranicznym, nie nakładając na państwa konkretnych obowiązków. Ich treść weryfikowana być musi w danych okolicznościach w oparciu o zasadę należytej staranności. Jako taka, zasada należytej staranności jest kluczem do ustalenia odpowiedzialności międzynarodowej państwa za szkodę transgraniczną, w tym za pogwałcenie zasady dobrosąsiedztwa.

\subsection{Geneza powstania i historia rozwoju obszaru badań nad odpowiedzialnością międzynarodową}

W drugiej połowie XX w., w miarę rozwoju badań nad przestrzenią kosmiczną i nowymi źródłami energii, zwłaszcza nad energią nuklearną, jak też w związku z rozwojem transportu morskiego, nagląca stała się kwestia odpowiedzialności za szkodę transgraniczną powstałą wskutek działań niezakazanych w treści norm prawa międzynarodowego, a realizowanych na terytorium lub z upoważnienia państwa. Odpowiedzialność za szkodliwe skutki takich działań nie zawsze udawało się przypisać państwom w oparciu o kryteria opracowywane przez KPM pod kierownictwem Ago i jego następców, bowiem nie zawsze związane one były z naruszeniem normy prawa międzynarodowego ${ }^{13}$. W $1970 \mathrm{r}$. Komisja zdecydowała więc ograniczyć zakres prowadzonych dotychczas badań

${ }^{9}$ P. H. Winfield, J. A. Jolowicz, T. E. Lewis, Winfield on tort, Londyn 1975, s. 318; podaję za: J. G. Lammers, op.cit., s. 571.

${ }^{10}$ J. G. Lammers, op.cit., s. 571.

${ }^{11}$ Ibidem.

${ }^{12}$ Por.: orzeczenie MTS w sprawie legalności broni nuklearnej, ICJ Reports 1996, s. 241, par. 29; por.: R. Verheyen, op.cit., s. 147; P. N. Okowa, op.cit., s. 69 i n.

${ }^{13}$ Uwagi o konieczności wydzielenia z zakresu realizowanych przez KPM prac nad odpowiedzialnością państw kwestii odpowiedzialności za szkody powstałe wskutek działań niezakazanych prawem międzynarodowym pojawiały się w kolejnych raportach KPM począwszy od roku 1973: Rezolucja Zgromadzenia Ogólnego nr 3071 (XXVIII) z 30 listopada 1973 r, Rezolucja Zgromadzenia Ogólnego nr 3315 (XXIX) z 14 grudnia 1974 r., Rezolucja Zgromadzenia Ogólnego 3495 $(X X X)$ z 15 grudnia 1975 r., Rezolucja Zgromadzenia Ogólnego 31/97 z 15 grudnia 1976 r., Rezolucja Zgromadzenia Ogólnego 32/151 z 19 grudnia 1977 r. 
nad odpowiedzialnością państw do konsekwencji czynów sprzecznych z dyspozycją norm prawa międzynarodowego, przyjmując jednak, że „przy definiowaniu ogólnych zasad odpowiedzialności państw za działania sprzeczne z prawem międzynarodowym niezbędne jest uwzględnienie formuły niewykluczającej odpowiedzialności za działania niezakazane prawem międzynarodowym"14. To ogólne zalecenie zostało doprecyzowane w treści pierwszego Projektu artykułów o odpowiedzialności państw w 1973 r., gdzie explicite wyrażono potrzebę podjęcia przez KPM prac nad tzw. odpowiedzialnością za ryzyko, kiedy zakończone zostaną badania nad odpowiedzialnością za działania zakazane prawem międzynarodowym lub równolegle $\mathrm{z}$ nimi. Jak podkreśla Boyle, zamierzonym przez Komisję kryterium czynionej dystynkcji był fakt, iż odpowiedzialność międzynarodowa za czyny nieakazane nie obejmuje przesłanki naruszenia zobowiązania międzynarodowego ${ }^{15}$. Podczas odbywającej się w tym samym roku 28. sesji Zgromadzenie Ogólne wskazało, że KPM powinna podjąć temat „odpowiedzialności za ryzyko” w „dogodnym czasie”, choć już w 1976 r. zalecenie Zgromadzenia wskazywało na potrzebę podjęcia stosownych badań „w możliwie

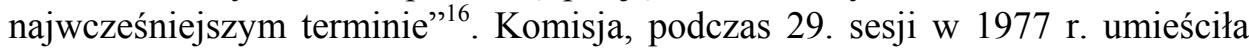
temat „odpowiedzialności za ryzyko” w swoim programie zadań, opierając się na istniejącym już dorobku w zakresie badań nad odpowiedzialnością państw. Zgromadzenie Ogólne, mocą Rezolucji 32/151 z 19 grudnia 1977 r., zainicjowało prace Komisji nad zagadnieniem odpowiedzialności międzynarodowej za szkodliwe konsekwencje czynów niezakazanych prawem międzynarodowym ${ }^{17}$. Dlatego też w 1978 r. KPM zleciła przygotowanie specjalnego raportu o zasadach „odpowiedzialności międzynarodowej za szkodliwe konsekwencje czynów niezakazanych prawem międzynarodowym" jako nowego obszaru potencjalnej kodyfikacji ${ }^{18}$. W skład powołanej $\mathrm{w}$ tym celu grupy roboczej wszedł w roli przewodniczącego Nowozelandczyk, Robert Q. Quentin-Baxter, późniejszy Specjalny Sprawozdawca Komisji w przedmiotowym obszarze ${ }^{19}$. Po trzech spotkaniach w czerwcu 1978 r. członkowie grupy roboczej ustalili treść wstępnego raportu, przedstawionego Komisji ${ }^{20}$. Badania nad odpowiedzialnością w prawie międzynarodowym prowadzone przez Komisję zostały podzielone tym samym pomiędzy grupę roboczą pod przewodnictwem Ago, której zadaniem było zbadanie konsekwencji działań zakazanych prawem mię-

${ }^{14}$ Raport KPM, 1978 r., U.N. Doc. A/33/10, s. 149.

${ }^{15}$ Por. A. E. Boyle, State Responsibility ..., s. 3.

${ }^{16}$ Raport KPM, 1978 r., U.N. Doc. A/33/10, s. 150.

${ }^{17}$ Raport KPM, 1978 r., U.N. Doc. A/33/10, s. 150.

${ }^{18}$ Raport KPM, 1978 r., U.N. Doc. A/33/10, roz. VIII(C), s. 176 i n. Skutkiem prac grupy był Projekt artykułów o odpowiedzialności międzynarodowej z 1998 r., U.N. Doc. A/53/10.

${ }^{19}$ Raport KPM, 1978 r., U.N. Doc. A/33/10, s. 150 pkt 171. W opracowaniu dokumentu wspierali go: prowadzący równolegle prace nad regułami odpowiedzialności państw Roberto Ago, Jorge Castaneda z Meksyku oraz Frank X.J.C. Njenga z Kenii.

${ }^{20}$ Raport KPM, 1978 r., U.N. Doc. A/33/10, s. 150 pkt 171. Por.: Raport Grupy Roboczej ds. międzynarodowej odpowiedzialności za szkodliwe konsekwencje czynów niezakazanych prawem międzynarodowym, U.N. Doc. A/CN.4/L.284. 
dzynarodowym, a grupę roboczą pod przewodnictwem Quentina-Baxtera, zajmującą się konsekwencjami działań niezakazanych w treści norm prawa międzynarodowego, acz niosących niebezpieczeństwo powstania szkody transgranicznej.

Dla opisania nowego przedmiotu badań używano różnych określeń. Pierwotnie używano sformułowania „odpowiedzialność za ryzyko wynikające z wykonywania pewnych dozwolonych przez prawo czynności, takich jak badania nad przestrzenią kosmiczną i energią nuklearną” lub „forma odpowiedzialności państwa, która stanowi w rzeczywistości zabezpieczenie przed ryzykiem konsekwencji niektórych czynności zgodnych z prawem międzynarodowym”. Jednocześnie używano określeń odróżniających przedmiot analizy od wcześniejszych ustaleń KPM, wpisując je jako „badania nad tą drugą formą odpowiedzialności, stanowiąca zabezpieczenie przed niebezpieczeństwem związanym z realizacją pewnych działań, niezakazanych w treści norm prawa międzynarodowego". W trakcie dyskusji na forum Szóstego Komitetu KPM pojawił się także nieuwzględniony $\mathrm{w}$ toku prac, mniejszościowy wniosek o wyróżnienie trzeciej kategorii czynów, „które z uwagi na stanowiące ich immanentną część niebezpieczeństwo (dosł. niebezpieczną naturę, ang. dangerous nature) znajdują się w połowie drogi pomiędzy czynami niezakazanymi a sprzecznymi z normami prawa międzynarodowego"21. W 1978 r. KPM rozpoczęła pracę nad odpowiedzialnością międzynarodową za czyny niezakazane prawem międzynarodowym.

\subsection{Zasady odpowiedzialności międzynarodowej za szkodliwe konsekwencje czynów niezakazanych prawem międzynarodowym}

Przyjmując wstępne założenia prac nad zasadami odpowiedzialności międzynarodowej, Quentin-Baxter wskazał na konieczność uwzględnienia w ich toku m.in. rezultatów współpracy państw w zakresie pokojowego wykorzystania energii atomowej, ustaleń dotyczących wykorzystania przestrzeni kosmicznej, środowiska naturalnego oraz zasobów naturalnych, zanieczyszczeń wód morskich oraz wyników toczącej się wówczas debaty dotyczącej ryzyka powodowanego przez transport olejów napędowych drogą morską. Tak określając zakres przyszłych badań, wskazał na trzy wspólne cechy wymienionych reżimów, tj. prawa morza, prawa kosmicznego oraz prawa środowiska. Po pierwsze, każdy z nich określał sposób, w jaki państwa wykorzystywały lub umożliwiały wykorzystanie środowiska naturalnego, znajdującego się w ich władaniu. Ponadto, każdy z nich dotyczył szkodliwych dla innych państw konsekwencji wykorzystania tych zasobów. Wreszcie każdy ze wskazanych reżimów opisywał skutki prawne działań niezakazanych prawem międzynarodowym ${ }^{22}$. Opisane przez

\footnotetext{
${ }^{21} \mathrm{Za}$ : Raport KPM, 1978 r., U.N. Doc. A/33/10, s. 150.

${ }^{22}$ Raport KPM, 1978 r., U.N. Doc. A/33/10, s. 151.
} 
Przewodniczącego grupy roboczej ds. odpowiedzialności międzynarodowej wspólne kryteria obszaru badań stanowiły odzwierciedlenie wcześniejszych prac ONZ, dotyczących ochrony środowiska naturalnego. Jak wspomniano, zasada 21 Deklaracji sztokholmskiej, uznając suwerenne prawo państw do eksploatowania własnych zasobów naturalnych, powiązała je ze zobowiązaniem zapewnienia przez te państwa, że działania podejmowane w ich jurysdykcji lub pod ich kontrolą nie będą skutkować szkodą w środowisku naturalnym innych państw lub na obszarach wspólnych. Quentin-Baxter przyjmował, że w okolicznościach stanowiących przedmiot badań, inaczej niż w przypadku odpowiedzialności za czyn państwa sprzeczny z prawem międzynarodowym, nie mamy do czynienia z domniemaniem zgody na przejęcie przez państwo ryzyka niebezpiecznych działań lub odpowiedzialności za ich szkodliwe konsekwencje. Nie ma tu także wymogu wskazania skutecznego środka odszkodowawczego poszkodowanym, jak ma to miejsce w krajowych systemach prawa cywilnego, o ile nie istnieje stosowny reżim umowny czy zwyczajowy, przyjęty przez państwa, z którego wymóg taki wynika. Ustalając minimalny poziom dolegliwości szkód, za które państwa powinny ponosić odpowiedzialność, wykluczył ich zobowiązanie do naprawienia pomniejszych, przypadkowych ,niedogodności”, wynikających z normalnego i racjonalnego użytkowania terytorium. Jeśli państwa nie uzgodniły innego kryterium oceny progu uciążliwości działań czy dolegliwości szkód, w konkretnej sytuacji rolę takiego kryterium spełniać winna ich milcząca zgoda. Jeśli więc wszystkie państwa zgodnie, milcząco przyjmują, że szkoda nie przekroczyła dopuszczalnego progu, nie ma podstaw do roszczeń prawnych ${ }^{23}$.

Międzynarodowa praktyka dowodzi, że w przypadku braku milczącej zgody ocena stanowisk stron pozostających w sporze opiera się na kryterium racjonalności. Jego stosowanie wymaga od sądów i trybunałów poszukiwania równowagi pomiędzy celem, w jakim państwo korzysta ze swojego terytorium, a niepożądanymi konsekwencjami takiego korzystania dla innych państw. Na podstawie owej praktyki wskazać można na wynikające z niej zobowiązanie do wykazywania umiaru (ang. obligation of moderation), troski czy należytej staranności w realizowaniu przez państwa działań we własnej jurysdykcji czy pod ich kontrolą. Werbalizując owo zobowiązanie, Quentin-Baxter zaznaczał, iż z samego faktu jego sformułowania nie wynika odpowiedzialność za skutki niebezpiecznych działań, stanowiących immanentną część licznych przedsięwzięć, możliwych dzięki najnowszym osiagnięciom technologicznym. Szkoda powstała w wyniku wypadku niemożliwego do przewidzenia i zapobieżenia jest koniecznym elementem rozwoju technologicznego. Niezależnie od dokładanych wysiłków i wcześniejszych osiągnięć w zapobieganiu im, szkody wynikające z realizacji ryzyka niesionego przez nowe technologie będą najprawdopodobniej ogromnych rozmiarów. Co więcej, sama ocena powstałej szkody może w wielu obszarach życia zależeć od przyjętych, względnych kryteriów ${ }^{24}$.

\footnotetext{
${ }^{23}$ Raport KPM, 1978 r., U.N. Doc. A/33/10, s. 151.

${ }^{24}$ Raport KPM, 1978 r., U.N. Doc. A/33/10, s. 151.
} 
Podsumowując dotychczasowe ustalenia państw dotyczące badanego obszaru, Quentin-Baxter wskazywał, iż powszechną praktyką było regulowanie poszczególnych, niebezpiecznych obszarów aktywności w treści postanowień traktatowych. Powstałe reżimy umowne znacząco różniły się między sobą, co wynikało $\mathrm{z}$ potrzeb praktycznych każdego $\mathrm{z}$ regulowanych obszarów, raczej niż z różnic doktrynalnych. W zależności więc od przedmiotu regulacji, państwa przyjmowaly na siebie ciężar odpowiedzialności, choć częściej przerzucały go na podmioty bezpośrednio generujące ryzyko, działające $\mathrm{z}$ ich upoważnienia, zaś prawne środki odszkodowawcze pozostawiały w gestii przepisów wewnętrznych państwa $^{25}$. Występowały w praktyce państw także rozwiązania pośrednie, gdzie, co prawda bezpośrednią odpowiedzialność za powstałe szkody ponosił podmiot realizujący ryzykowane działania, jednak państwo gwarantowało swoim autorytetem i majątkiem spełnienie przez ów podmiot ewentualnych zobowiązań odszkodowawczych.

Elementem takich reżimów umownych bywało przyjęcie zasady odpowiedzialności absolutnej za szkody powstałe $\mathrm{w}$ wyniku spełnienia się określonego ryzyka. Oznaczała ona, że odpowiedzialność państwa wynikała z samego faktu wystąpienia szkodliwych konsekwencji ryzykownych działań, bez potrzeby oceny charakteru czynów prowadzących do ich wystapienia. Zasada ta, wywodzona z systemu prawa anglosaskiego, przewidującego odpowiedzialność absolutną za rzeczy niebezpieczne (ang. absolute liability for dangerous things), uzupełniania była często przez dodatkowe postanowienia umowne, ograniczające zakres faktycznie ponoszonej przez państwa odpowiedzialności ${ }^{26}$. W zależności od przedmiotu regulacji, wprowadzenie zasady odpowiedzialności absolutnej ograniczane bywało poprzez wprowadzenie standardu należytej staranności, dołożenie której ogranicza zakres faktycznej odpowiedzialności państwa ${ }^{27}$. Odpowiedzialność absolutna wynikać mogła jedynie z postanowień traktatu, nie jest bowiem uznaną zasadą prawa zwyczajowego ${ }^{28}$.

Quentin-Baxter zaznaczał, że prowadzone badania muszą opierać się na dotychczasowym dorobku grupy roboczej analizującej zasady międzynarodowej odpowiedzialności państw za działania sprzeczne z prawem międzynarodowym. Podział terminologiczny na „odpowiedzialność państwa” i „odpowiedzialność międzynarodową" niósł za sobą konieczność ustalenia zależności pomiędzy przedmiotem odpowiedzialności opisanym w reżimach traktatowych, dotyczących przede wszystkim odpowiedzialności międzynarodowej za czyny niezakazane prawem międzynarodowym, a substratem zobowiązań państw, ustalonym w treści prawa zwyczajowego. Jednocześnie, z samego pojęcia odpowiedzialności międzynarodowej nie wynikało, iż badania prowadzone mogły

${ }^{25}$ Raport KPM, 1978 r., U.N. Doc. A/33/10, s. 151.

${ }^{26}$ Raport KPM, 1978 r., U.N. Doc. A/33/10, s. 151.

${ }^{27}$ Raport KPM, 1978 r., U.N. Doc. A/33/10, s. 151.

${ }^{28}$ Por.: C. Zemanek, Responsibility of States: General Principles, (w:) Encyclopedia of Public International Law 1987, red. R. Bernhard, s. 365, podaję za: G. T. Hacket, Space Debris and the Corpus Iuris Spatialis, Gif-sur-Yvette 1994, s. 166. 
być jedynie nad treścią traktatowych norm pierwotnych, bez uwzględniania zasad wtórnych, opisanych przez Komisję w treści raportów dotyczących odpowiedzialności państw. Przyjmując takie wstępne założenia, Quentin-Baxter powtarzał za Komisją, że zasadne było opracowanie przedstawionego tematu jako przygotowania do jego przyszłej kodyfikacji ${ }^{29}$.

Pierwotnym celem grupy roboczej było właściwe wyważenie interesów stron, tj. pozostawienie państwom maksymalnie dużej swobody w korzystaniu z własnego terytorium przy jednoczesnym wzmocnieniu praw państw ościennych, potencjalnie poszkodowanych $\mathrm{w}$ wyniku realizacji owej wolności. Sposobem realizacji tego celu był akceptowalny dla wszystkich państw model obowiązków prewencyjnych i odszkodowawczych, stosowany w przypadku podejmowania niebezpiecznych działań przez państwa ościenne. Zasada równoważenia interesów stron w sytuacji wystapienia szkody w środowisku naturalnym dawać miała równe szanse na obronę swoich interesów państwu poszkodowanemu i prowadzącemu czy autoryzującemu szkodliwą działalność w sytuacji, kiedy nie doszło do naruszenia zobowiązania międzynarodowego. Jako taka, powinna być akceptowalna dla szerokiego kręgu państw, dawała im bowiem możliwość aktywnego kształtowania wzajemnych relacji ${ }^{30}$.

Nie było tym samym potrzeby uzasadnienia obowiązku zapobiegania szkodzie albo jej kompensacji, jeśli strony uznały jego istnienie $\mathrm{w}$ treści porozumienia. W przypadku istnienia odpowiedniego traktatu konieczność uzasadniania odpowiedzialności odszkodowawczej państwa nie wymagała odwołania do innych, pierwotnych norm prawa międzynarodowego, ani wykazania ich naruszenia jako przesłanki odpowiedzialności państw według norm wtórnych ${ }^{31}$. Dlatego też Quentin-Baxter skoncentrował się na poszukiwaniach wzorca reżimu pierwotnego, gwarantującego odszkodowanie ofiarom szkodliwych skutków ryzykownych przedsięwzięć, raczej niż na badaniu zależności pomiędzy pierwotną odpowiedzialnością międzynarodową a wtórną odpowiedzialnością państw $^{32}$. Taki kształt zaproponowanego kompromisu rozwiązywał kłopot z jednoznacznym określeniem, które podmioty i państwa zostały poszkodowane i posiadały roszczenie kompensacyjne. Stanowił on rozwiązanie dwóch problemów. Po pierwsze, zazwyczaj państwa, na terytorium których spowodowano szkodliwe zdarzenie, zostawały także najciężej poszkodowane. Co ważniejsze jednak, zwłaszcza w przypadku prawa ochrony środowiska, państwa poszkodowane same zaangażowane były w niebezpieczne działania, powodując niebezpieczeństwo powstania transgranicznych szkód ${ }^{33}$. Nie wystarczało więc ustalenie wyłącznie reguł kompensacji. Niezbędne było uwzględnienie interesów wszystkich stron, a to stawało się możliwe jedynie w drodze ciagłej współpracy,

\footnotetext{
${ }^{29}$ Raport KPM, 1978 r., U.N. Doc. A/33/10, s. 151.

${ }^{30}$ T. Gehring, M. Jachtenfuchs, op.cit., s. 94.

${ }^{31}$ Por.: Ibidem.

32 Por.: Trzeci raport Specjalnego Sprawozdawcy Robera Quentina-Baxtera, 1982, U.N. Doc. A/CN.4/360 (dalej: Trzeci raport Quentina-Baxtera), s. 52-53.

${ }^{33}$ Por.: T. Gehring, M. Jachtenfuchs, op.cit., s. 95.
} 
opartej o dobrze sprecyzowane reguly ${ }^{34}$. Celem takiej współpracy miało być zapobieganie szkodom albo ich ograniczanie. Dlatego też pierwszy projekt konwencji dotyczącej odpowiedzialności międzynarodowej za szkodę transgraniczną zawierać miał jedynie wytyczne proceduralne, pozwalające państwom na dalsze wypracowanie reżimów właściwych dla poszczególnych obszarów aktywności ${ }^{35}$. Aby ten zamiar zrealizować, należało uwzględnić kwestię przyszłej regulacji umownej już na etapie ustalania szczegółów przeprowadzenia niebezpiecznych działań. Zaproponowany przez Quentina-Baxtera „schematyczny zarys" regulacji opierał się na trzech założeniach: gwarancji bezpieczeństwa, wymiany informacji i obowiązku kompensacyjnego ${ }^{36}$. Sprawozdawca wykroczył tym samym poza zakres upoważnienia otrzymany od KPM, który obejmował jedynie zbadanie zasad odpowiedzialności, bez rozważań dotyczących odszkodowania. Poszukując formuły akceptowalnej dla większości państw, zrezygnował $\mathrm{z}$ zamieszczenia $\mathrm{w}$ zarysie proponowanej regulacji egzekwowalnego roszczenia odszkodowawczego. Jedynym bezpośrednim skutkiem szkody zapisanym w projekcie konwencji miało być zobowiązanie do podjęcia rozmów pomiędzy poszkodowanym a państwem pochodzenia ryzyka, zmierzających do naprawienia szkody, jeśli wcześniej strony nie poczyniły stosownych ustaleñ ${ }^{37}$.

Prace Quentina-Baxtera jako Specjalnego Sprawozdawcy ds. odpowiedzialności międzynarodowej od 1985 r. kontynuował Argentyńczyk, Julio Barboza ${ }^{38}$. Wskazywał na zasadniczą różnicę pomiędzy zasadą prewencji a obowiązkiem reparacji, który odnosił jedynie do aktów międzynarodowo bezprawnych ${ }^{39}$. O ile łatwo było mu zidentyfikować istnienie w międzynarodowym prawie zwyczajowym zobowiązań prewencyjnych i obowiązku współpracy w zakresie wymiany informacji, o tyle ustalenie istnienia obowiązku odszkodowawczego było trudniejsze ${ }^{40}$.

\footnotetext{
${ }^{34}$ Por.: Trzeci raport Quentina-Baxtera, U.N. Doc. A/CN.4/360, s. 62. W treści owego raportu Quentin-Baxter zaproponował pierwszy projekt artykułów o odpowiedzialności międzynarodowej za czyny niezakazane prawem międzynarodowym, por. s. 62-64.

${ }^{35}$ Por.: Czwarty raport Specjalnego Sprawozdawcy Robera Quentina-Baxtera, 1983, U.N. Doc. A/CN.4/373, s. 203, 204-205.

${ }^{36}$ Czwarty raport Specjalnego Sprawozdawcy Robera Quentina-Baxtera, 1983, U.N. Doc. A/CN.4/373, s. 223-225; por. też: Trzeci raport Quentina-Baxtera, U.N. Doc. A/CN.4/360, s. 53, gdzie autor opisuje zależność pomiędzy normami pierwotnymi i wtórnymi, o których była mowa $\mathrm{w}$ rozdziale poprzednim.

${ }^{37}$ Por.: T. Gehring, M. Jachtenfuchs, op.cit., s. 95,

${ }^{38}$ Ustanowiony Specjalnym Sprawozdawcą podczas 36. sesji, w 1985 r., Barboza przedstawił Komisji 12 raportów, ostatni złożył w 1996 r. i to ten Raport zawierał jego pierwszą propozycję 20 artykułów o odpowiedzialności międzynarodowej; por.: Dwunasty Raport Specjalnego Sprawozdawcy J. Barbozy, 1996 r., U.N. Doc. A/CN.4/475. Nieco zmodyfikowana wersja owego projektu, zawarta w treści Projektu Barbozy, U.N. Doc. A/51/10, stanowiła podstawę rozważań KPM w latach 1996-1998, prowadzącą do opracowania Projektu artykułów o odpowiedzialności międzynarodowej z 1998 r., U.N. Doc. A/53/10.

39 Por.: Drugi raport Barbozy, U.N. Doc. A/CN.4/402, s. 147.

${ }^{40}$ Por.: T. Gehring, M. Jachtenfuchs, op.cit., s. 96. Por.: rozważania Barbozy dotyczące źródeł obowiązku prewencji: Czwarty raport Specjalnego Sprawozdawcy J. Barbozy, 1988, U.N. Doc. A/CN.4/413 (dalej: Czwarty raport Barbozy), s. 266-267, gdzie znalazł się opis obowiązku prewencji, zawartego w art. 9 projektu oraz obowiązku odszkodowania, zapisanego w art. 10.
} 
Obawiał się, że jeśli połączyłby te trzy zobowiązania, to niezamierzenie osłabiłby moc wiążącą dwóch pierwszych, bowiem trudniej byłoby osiągnąć satysfakcjonujący kompromis ${ }^{41}$. Jednoczesne uznanie obowiązków: prewencji i współpracy za normy pierwotne prawa międzynarodowego dawało możliwość przypisania państwu odpowiedzialności za ich naruszenie według treści norm wtórnych, dotyczących odpowiedzialności państw. Tym samym, jak słusznie wskazuje Hornle, wprowadzenie takiej zależności do tekstu projektu udaremniało pierwotne zamierzenie KPM stworzenia dwóch niezależnych rezimów odpowiedzialności w prawie międzynarodowym. Właśnie obowiązek prewencji, zawierający zobowiązanie do wykazywania należytej staranności przy realizacji zobowiązań miedzynarodowych, obok obowiązku współpracy i wymiany informacji, stanowi konieczny łącznik pomiędzy owymi dwoma reżimami ${ }^{42}$. Kryterium weryfikacji ich spełnienia stanowi natomiast standard należytej staranności.

Barboza obrał sobie za cel przeniesienie ciężaru ekonomicznych konsekwencji szkody na państwo, które inicjowało albo zezwoliło na ryzykowną działalność niosącą ową szkodę. Punktem wyjścia dla ustalenia roszczenia kompensacyjnego poszkodowanego państwa była odpowiedzialność na zasadzie ryzyka państwa autoryzującego lub realizującego szkodliwą działalność i umieszczenie stosownych postanowień w treści projektu ${ }^{43}$. Oznaczałoby to, że celem negocjacji byłoby zidentyfikowanie tych okoliczności, które mogłyby zostać uznane za ograniczenia owej odpowiedzialności na zasadzie ryzyka, wynikającej z traktatu $^{44}$. Tak więc centralnym punktem negocjacji nad potencjalnym traktatem stał się reżim odpowiedzialności za szkodę transgraniczną w środowisku naturalnym, opisujący szczegółowe jej przesłanki, choć Barboza nie porzucił planu Quentina-Baxtera, aby poszczególne obszary aktywności rządziły się swoimi własnymi regułami, odpowiadającymi ich specyfice ${ }^{45}$. Ogólne reguły, opisane $\mathrm{w}$ reżimie międzynarodowej odpowiedzialności, pełniłyby rolę pomocniczą ${ }^{46}$.

${ }^{41}$ Por.: Drugi raport Barbozy, U.N. Doc. A/CN.4/402, s. 258-259.

${ }^{42}$ Por. N.L.J.T. Horbach, The Confusion about State Responsibility and International Liability, Leiden Journal of International Law 1991, nr 4, s. 72. Podobne argumenty przedstawia Boyle, por. A. E. Boyle, State Responsibility..., s. 10, gdzie pisze iż przyjęcie koncepcji odpowiedzialności międzynarodowej za czyny niezakazane prawem miedzyanrodowym jest „zbędne” (ang. redundant).

${ }^{43}$ Por.: Czwarty raport Barbozy, s. 256; T. Gehring, M. Jachtenfuchs, op.cit., s. 96. Oznaczałoby to odejście od sugerowanego przez Quentina-Baxtera rozwiązania na gruncie miękkiego prawa międzynarodowego. Ta diametralna zmiana kierunku prac spotkała się z krytyką, por. np.: C. O'Keefe, Transboundary Pollution and the Strict Liability Issue, The Work of the International Law Commission on the Topic of International Liability for Injurious Consequences Arising Out of Acts Not Prohibited by International Law, Denver Journal of International Law and Policy 1989/90, nr 18, s. 207-208, choć Brownlie wciąż bronił zaproponowanego podziału na dwa niezależne reżimy odpowiedzialności, por. I. Brownlie, System ..., część I, s. 50.

${ }^{44}$ Por.: Czwarty raport Barbozy, s. 258-259; zob. także: T. Gehring, M. Jachtenfuchs, op.cit., s. 96.

${ }^{45}$ Por.: T. Gehring, M. Jachtenfuchs, op.cit., s. 96. Por.: Raport KPM, 1991 r., U.N. Doc. A/46/10, par. 236, s. 115 .

${ }^{46}$ Por.: T. Gehring, M. Jachtenfuchs, op.cit., s. 96. 
Najważniejszą zmianą, którą skutkowała modyfikacja stanowiska Specjalnego Sprawozdawcy, było wzmocnienie odpowiedzialności państwa za działania nieujęte w treści reżimów szczegółowych, choć reguły jej stosowania wciąż były dość elastyczne ${ }^{47}$. W ten sposób wyróżniono dwa obszary badań nad odpowiedzialnością międzynarodową za czyny niezakazane prawem międzynarodowym: zagadnienia związane $\mathrm{z}$ wykonywaniem przez państwa obowiązku prewencji oraz kwestię alokacji strat.

\subsection{Teorie odpowiedzialności międzynarodowej za czyny niezakazane prawem międzynarodowym}

Poszukując uzasadnienia dla odpowiedzialności międzynarodowej za czyny niezakazane prawem międzynarodowym i rekonstruując przebieg historycznej dyskusji nad nią, Lammers, a za nim Boos-Hersberger, przywołują cztery główne teorie ją uzasadniające: ograniczonej suwerenności terytorialnej, absolutnej suwerenności terytorialnej, absolutnej integralności terytorialnej oraz teorię społeczną ${ }^{48}$.

Koncepcja ograniczonej suwerenności terytorialnej oparta jest o założenie, iż na państwach spoczywa pozytywny obowiązek niedopuszczania do znaczących transgranicznych szkód ${ }^{49}$. Zobowiązanie to potwierdzone zostało przez orzecznictwo i doktrynę oraz akty miękkiego prawa międzynarodowego, prowadzące do sformułowania zasady 21 Deklaracji sztokholmskiej ${ }^{50}$. W odniesieniu do wód międzynarodowych Reguły Helsińskie o wykorzystaniu wód i rzek międzynarodowych z 1966 r. potwierdzają ograniczenia suwerenności terytorialnej państw $\mathrm{w}$ związku $\mathrm{z}$ ochroną wodnych zasobów wspólnych ${ }^{51}$. Zasada ograniczonej suwerenności terytorialnej wyrażana jest $\mathrm{w}$ treści zasady dobrego sąsiedztwa i, jako taka, stanowi element prawa zwyczajowego.

Teoria absolutnej suwerenności terytorialnej najchętniej przywoływana bywała w kontekście dyskusji nad odpowiedzialnością za szkody transgraniczne przez państwa, na terytorium których realizowane są niebezpieczne działania, a w kontekście ochrony rzek - przez państwa położone w górnym ich biegu ${ }^{52}$. I tak np. w treści amerykańskiej Doktryny Harmona z końca XIX w. Stany

${ }^{47}$ Por. art. 9 i 21 Projektu Barbozy; zob. także: Siódmy raport Barbozy, 1991, U.N. Doc. A/CN.4/437, s. 84-85.

${ }^{48}$ J. G. Lammers, op.cit., s. 557-578. Por też: A. Boos-Hersberger, op.cit., s. 111-112.

${ }^{49}$ Por. P. Okowa, op.cit., s. 65-66.

${ }^{50}$ Por.: A. Boos-Hersberger, op.cit., s. 111-112.

${ }^{51}$ Helsinki Rules on the Use of the Waters and International Rivers, 1967 r. [online]. International Law Association, Report of the Committee on the Uses of the Waters of International Rivers [dostęp: 2013-01-20]. Dostępny w Internecie: <http://webworld.unesco.org/water/wwap/pccp/cd/ pdf/educational_tools/course_modules/reference_documents/internationalregionconventions/helsinki rules.pdf>, art. IV, IX, X, s. $\overline{477}, 484$.

${ }^{52}$ Por.: J. G. Lammers, op.cit., s. 557. 
Zjednoczone uznały, iż w świetle reguł prawa międzynarodowego nie ponoszą odpowiedzialności względem Meksyku za odprowadzenie wód z koryta rzeki Rio Grande ${ }^{53}$. Lammers wskazuje, że jest to koncepcja wewnętrznie sprzeczna, bowiem nieograniczone korzystanie ze swojego terytorium przez jedno państwo de facto uniemożliwi nieograniczone korzystanie ze swojego terytorium innym $^{54}$. Pomimo powszechnego odrzucenia owego stanowiska wraz z rozwojem reguł odpowiedzialności międzynarodowej przez większość państw, w tym przez Stany Zjednoczone ${ }^{55}$, niektóre wciąż stosują ją w praktyce nie tylko w obszarze międzynarodowego prawa środowiska ${ }^{56}$.

Zasada absolutnej integralności terytorialnej wywodzona jest z zakazu wykorzystania terytorium państwowego do powodowania szkód transgranicznych i oznacza, iż wykonywanie suwerennej władzy względem własnego terytorium możliwe jest jedynie o tyle, o ile nie niesie za sobą szkód terytorialnych ani naruszenia suwerenności innych państw ${ }^{57}$. Regułę tę potwierdził Instytut Prawa Międzynarodowego w treści rezolucji z Aten z 1979 r., której preambuła wzywa państwa do przestrzegania na jego terytorium obowiązku poszanowania suwerenności każdego państwa, w konsekwencji którego to zobowiązania każde z państw powinno wystrzegać się takiego wykorzystania własnego terytorium, które skutkowałoby szkodą na terytorium innego państwa ${ }^{58}$. Stosowana wobec roszczeń dotyczących międzynarodowych cieków rzecznych oznacza, iż państwa położone w dolnym biegu rzek mogą domagać się dostępu do zasobów wodnych nieumniejszonych i niepogorszonych przez państwo położone w jej biegu górnym ${ }^{59}$. Jako przeciwstawna względem teorii terytorialnej, przywoływana jest częściej przez państwa potencjalnie poszkodowane w wyniku działań niebezpiecznych, realizowanych poza ich granicami.

Teoria społeczna to raczej postulat dogmatyczny niż opis dorobku orzecznictwa trybunałów czy miękkiego prawa międzynarodowego. Stanowi ona, iż całość wspólnych zasobów ludzkości powinna być zarządzana jednolicie, niezależnie od granic terytorialnych. Korzystający ze wspólnego zasobu powinni wspólnie go chronić i dzielić się korzyściami, jakie niesie jego eksploatacja ${ }^{60}$. Koncepcja ta, odzwierciedlona np. w treści orzeczenia Trybunału Stanu Rzeszy Niemieckiej z 1927 r. (niem. Staatsgerichtshof für das Deutsche Reich) w sprawie rozlewisk Dunaju, stanowi odniesienie do „ducha międzynarodowej solidar-

${ }^{53}$ Por.: A. Boos-Hersberger, op.cit., s. 112.

${ }^{54}$ Por.: J. G. Lammers, op.cit., s. 557.

55 Por.: S. C. McCaffrey, The Harmon Doctrine One Hundred Years Later: Buried, Not Praised, Natural Resources Journal 1996, nr 36, s. 549-590.

${ }^{56}$ Por.: A. Boos-Hersberger, op.cit., s. 112, J. G. Lammers, op.cit., s. 570.

${ }^{57}$ J. G. Lammers, op.cit., s. 562.

${ }^{58}$ Rezolucja z Aten, Yearbook of the Institute of International Law 1979, nr 58, część II, s. 196-203 .

${ }_{59}$ Jak wskazuje Lammers, niektórzy autorzy nie dopuszczają jej stosowania do szkód transgranicznych innego pochodzenia. J. G. Lammers, op.cit., s. 563-564.

${ }^{60}$ Por.: A. Boos-Hersberger, op.cit., s. 112, J. G. Lammers, op.cit., s. 578. 
ności” Wildhabera czy „teorii solidarności” Hubera ${ }^{61}$. Teoria społeczna to raczej opis pewnej struktury prawnej, opartej o domniemanie istnienia wspólnych instytucji prawnych, procedur i zasad, zmierzających do zabezpieczenia i poszerzania katalogu wspólnych interesów państw, niż uzasadnienie istniejącej prakty$\mathrm{ki}^{62}$. Podobnie jak idea międzynarodowej solidarności państw, jest to postulat dogmatyczny, pozbawiony mocy prawnej.

\subsection{Aplikacja reguł odpowiedzialności międzynarodowej}

Przedstawiciele państw, potwierdzając pierwotne obawy Quentina-Baxtera, byli niechętni przyjmowaniu odpowiedzialności za generowane z terytorium państwowego szkody. Dlatego też $\mathrm{w}$ treści pierwszego projektu artykułów o odpowiedzialności międzynarodowej, Barboza zaproponował katalog środków prywatno-prawnych, mających na celu łagodzenie skutków szkód transgranicznych $^{63}$. Nie planował, aby to rozwiązanie zastapiło zobowiązanie państw do ponoszenia odpowiedzialności międzynarodowej za szkody transgraniczne, miało jedynie stanowić pierwszy krok w jego kierunku ${ }^{64}$. Kiedy na posiedzeniu Szóstego Komitetu przystapiono do omawiania konkretnych reguł międzynarodowej odpowiedzialności za taką szkodę, okazało się, że przedstawiciele państw gotowi są przystać na rozwiązania obciążające odpowiedzialnością podmioty prywatne, realizujące niebezpieczne działania, pozostawiając sobie jedynie odpowiedzialność „szczątkową” (ang. residual) ${ }^{65}$. Kompromis ten został przełożony na język projektu z $1991 \mathrm{r}^{66}$

Zgodzono się, że decyzja dotycząca samych instrumentów, przy pomocy których realizowany będzie obowiązek odszkodowawczy, powinna zostać odroczona. Nadrzędnym celem miało być skonstruowanie elastycznej konwencji ramowej, która opisywałaby ogólne zasady odpowiedzialności. Do nich zaliczono zgodnie osiem elementów ${ }^{67}$. Przede wszystkim zadaniem Komisji miało być

${ }^{61}$ Niem. der Donauversinkungsfall. Okresowe podniesienia poziomu wód Dunaju, prowadzące do podtapiania terenów nadbrzeżnych, przybierały z biegiem lat. W $1921 \mathrm{r}$. podniesiony stan wód utrzymywał się rekordową ilość 309 dni, powodując niedobór wód w niższych odcinkach rzeki, co utrudniało albo uniemożliwiało pracę położonych tam młynów czy tartaków. Trybunał Rzeszy zobowiązał land Badenia, na terytorium którego występowały największe rozlewiska, do usunięcia ich przyczyn, wskutek czego więcej wód rzecznych docierać miało do landów położonych w niższym biegu rzeki. Decyzja Trybunału Rzeszy z 18 czerwca 1927 w sprawie Wurttembergia i Prusy przeciwko Badenii (sprawa rozlewisk Dunaju), Entscheidungen des Reichsgerichts in Zivilsachen 1927, nr 116, Lipsk 1927, załącznik, s. 18-45.

${ }^{62}$ J. G. Lammers, op.cit., s. 578.

${ }^{63}$ Por.: T. Gehring, M. Jachtenfuchs, op.cit., s. 96. Zob. także: Szósty Raport Barbozy, U.N. Doc. A/CN.4/428, art. 28-33, s. 99-100; Raport KPM. 1990 r., U.N. Doc. A/45/10, s. 102-103.

${ }^{64}$ Por.: Szósty Raport Barbozy, U.N. Doc. A/CN.4/428, s. 98.

${ }^{65}$ Por.: Siódmy Raport Barbozy, U.N. Doc. A/CN.4/437, s. 78.

${ }^{66}$ Por.: Raport KPM, 1991 r., U.N. Doc. A/46/10, s. 111.

${ }^{67}$ Raport KPM, 1991 r., U.N. Doc. A/46/10, s. 111. 
opisanie okoliczności rodzących międzynarodową odpowiedzialność. Ponadto, powinna ona określić rolę, jaką odgrywać miałaby należyta staranność w tak skonstruowanym reżimie. Ważne było dla negocjatorów zdefiniowanie sytuacji, w których państwo będzie mogło zostać uznane za zwolnione z odpowiedzialności. Wreszcie opisać należało kryteria istotne przy ustalaniu wysokości zobowiązania reparacyjnego. Ponadto, celem KPM miało stać się zidentyfikowanie roli, jaką w tym nowym reżimie odegra zasada słuszności. Delegaci ustalili zgodnie, że ważną rolę odegra w nim także zobowiązanie państw do pokojowego rozwiązywania sporów międzynarodowych. Niezależnie od treści owego zobowiązania, Komisja miała zbadać także zadania przypadające organizacjom międzynarodowym i innym forom, które kształtują prawo międzynarodowe w przedmiotowym zakresie. Ostatnim elementem przyszłej, potencjalnej regulacji traktatowej miało być wskazanie metod, które, wdrożone do prawa krajowego, pozwolą na działanie agencji monitorujących zagrożenia i na wypracowanie skutecznych standardów międzynarodowej współpracy w przedmiotowej materii ${ }^{68}$.

W kwestii jednostronnych środków prewencyjnych zgłoszono postulat nałożenia na państwa obowiązku dochowania należytej staranności. Miałby on obejmować zobowiązanie państwa, na terytorium którego realizowana jest działalność niosąca za sobą niebezpieczeństwo szkody transgranicznej, do przedsięwzięcia wszelkich niezbędnych środków celem zapobieżenia takiej szkodzie albo ukarania zaniedbań prowadzących do jej powstania, zgodnie z treścią dyspozycji prawa międzynarodowego ${ }^{69}$. Przy takiej definicji należytej staranności, państwom pozostawałby wolny wybór metod, przy pomocy których realizowałyby postawione przed nimi zadanie. Jak krytycznie odnotował Sprawozdawca, podejście takie koncentrowało się jednak raczej na oczekiwanym skutku, niewiele wnosząc do dyskusji nad pożądanym sposobem jego osiagnięcia. W tym samym krytycznym tonie wypowiadał się jeden z członków Komisji wskazując, że działania podjęte po wystąpieniu szkodliwego, ponadgranicznego skutku nie powinny być uznane za środki prewencyjne ${ }^{70}$. Był to pierwszy sygnał badanego później przez Komisję zagadnienia środków prewencyjnych stosowanych post factum $^{71}$. Literalnie pojmowane środki prewencyjne to jedynie te, które przedsiębrane są przed wystąieniem szkody, celem jej zapobieżenia ${ }^{72}$. Co więcej, jeśli zobowiązanie do dołożenia należytej staranności uznać za wynikające z obowiązujących norm prawa międzynarodowego, niezbędne byłoby wprowadzenie towarzyszącego mu, obowiązkowego reżimu pokojowego rozwiązywania

\footnotetext{
${ }^{68}$ Raport KPM, 1991 r., U.N. Doc. A/46/10, s. 111. Ten ostatni postulat popiera także: K. Wolfke, op.cit., s. 38.

${ }^{69}$ Raport KPM, 1991 r., U.N. Doc. A/46/10, s. 111. Niektóre państwa opowiadały się za wprowadzeniem wyraźnego obowiązku dokładania należytej staranności w ramach jednostronnego zobowiązania prewencji.

${ }^{70}$ Raport KPM, 1991 r., U.N. Doc. A/46/10, s. 111.

${ }^{71}$ Por.: Raport KPM, 1993 r., U.N. Doc. A/48/10, s. 21-34.

${ }^{72}$ Raport KPM, 1991 r., U.N. Doc. A/46/10, s. 111.
} 
sporów, jako koniecznego elementu każdego reżimu traktatowego ${ }^{73}$. Specjalny Sprawozdawca uznał, że wszelkie wymagania proceduralne dotyczące mediacji, formułowane względem państw, powinny mieć charakter zaleceń, raczej niż wiążących zobowiązań prawnych. Po raz pierwszy wskazał także, że w odczuciu członków Komisji zasadne było opracowanie dwóch osobnych instrumentów o różnym charakterze prawnym. Jeden z nich dotyczyłby procedur prewencyjnych i miałby charakter wiążący, drugi zaś formułowałby niewiążące zalecenia podjęcia mediacji po powstaniu samej szkody, opisując sugerowane ku temu procedury. Projekty tych instrumentów opracowane zostały przez KPM w latach 2001-2006. Zasadne wydawało się także uproszczenie owych procedur, pozwalające m.in. na zwolnienie państw autoryzujących ryzykowną działalność na swoim terytorium z konieczności uzyskania zgody na udzielenie takiej autoryzacji od państw zagrożonych szkodą ${ }^{74}$.

W toku dalszych prac Komisja zidentyfikowała praktyczną trudność w realizacji obranego kierunku badań. Ustaliła, że nie istnieje reżim prawny, który dopuszczałby wyrządzenie szkody pod warunkiem uiszczenia odszkodowania, a $\mathrm{z}$ takim założeniem przyszło jej się mierzyć odnośnie do odpowiedzialności odszkodowawczej za działania niezakazane prawem międzynarodowym. Tym samym w zakresie jej mandatu znajdowały się dwa odrębne, choć ściśle ze sobą połączone, obszary badawcze. Pomimo iż mandat dotyczył jedynie odpowiedzialności międzynarodowej, Komisja uwzględniła w swoich pracach także badania nad regułami prewencji i weryfikowała istnienie zobowiązania międzynarodowego państw do zapobiegania szkodom transgranicznym. Takie zobowiązanie, gdyby istniało, obligowałoby państwa do dołożenia należytej staranności w realizowaniu swoich uprawnień, celem eliminowania ryzyka szkody transgranicznej. Tymczasem istniejące reżimy odpowiedzialności międzynarodowej za szkody transgraniczne zazwyczaj nie obejmowały procedur prewencji. Co więcej, niejasne było, czy odpowiedzialność za szkodę transgraniczną wynika z samego faktu stworzenia zagrożenia, czy powstaje dopiero wskutek jego materializacji tj. wystapienia owej szkody ${ }^{75}$. Komisja wskazała także na kluczowy dla późniejszej oceny jej badań problem metodologiczny. W treści licznych krajowych reżimów prawnych nie istniało rozróżnienie na odpowiedzialność międzynarodową za czyny niezakazane prawem międzynarodowym a odpowiedzialność państwa, opisywane w języku angielskim odrębnymi terminami: responsibility i liability ${ }^{76}$. Całokształt owych niejasności spowodował, że niektórzy uczestnicy dyskusji opowiadali się zdecydowanie przeciwko utworzeniu prawnie wiążącego reżimu odpowiedzialności de facto absolutnej. Jeśli reżim międzynarodowej odpowiedzialności za szkodę transgraniczną miałby zostać opisany, sugerowali

${ }^{73}$ Stanowisko to uznać należy za zbyt daleko idące, bowiem jak słusznie podnosi Eherlich, „zagadnienie załatwienia sporu jest odrębne od zagadnienia powstania i konsekwencji odpowiedzialności”, L. Ehrlich, Prawo międzynarodowe..., s. 638.

${ }^{74}$ Raport KPM, 1991 r., U.N. Doc. A/46/10, s. 111.

${ }^{75}$ Raport KPM, 1992 r., U.N. Doc. A/47/10, s. 43.

${ }^{76}$ Por.: uwagi wstępne, dotyczące kwestii terminologicznych. 
oni, aby jego formuła była elastyczna, oparta na takich kryteriach jak racjonalność, należyta staranność, równowaga interesów uczestników obrotu i zasada słuszności oraz uwzględniała potrzeby postępu naukowego i rozwoju ekonomicznego. Jednocześnie jednak powinien on przewidywać odszkodowanie dla ofiar transgranicznych szkód, ale i uwzględniać przypadki sabotażu czy konsekwencje działań wojennych, w których to podmiot prowadzący niebezpieczną działalność zwolniony byłby $\mathrm{z}$ odpowiedzialności ${ }^{77}$. W dyskusji nad właściwym modelem kompensacyjnym pojawiały się także głosy za uwzględnieniem reguł reżimu odpowiedzialności cywilnej, w którym operatorzy niebezpiecznych przedsięwzięć ponosiliby odpowiedzialność za wyrządzoną szkodę, w myśl znanej międzynarodowemu prawu środowiska zasady „zanieczyszczający płaci” ${ }^{, 78}$. Proponowany reżim odpowiedzialności cywilnej dotyczyć miał jedynie samych operatorów niebezpiecznych przedsięwzięć, bowiem przeniesienie choćby części odpowiedzialności na władze państwowe stawiałoby w gorszym położeniu kraje rozwijające się. Praktycznym rozwiązaniem miało okazać się zaproponowane w 1992 r. stworzenie systemu obowiązkowych ubezpieczeń dla podmiotów prowadzących działalność obarczoną ryzykiem szkody transgranicznej ${ }^{79}$.

W toku dalszych prac Komisja precyzowała kryteria należytej staranności w przypadku szkody transgranicznej wywołanej niebezpieczną aktywnością operatora realizowaną na terytorium państwa. Wskazała, że przy ocenie dołożenia należytej staranności w konkretnej sprawie istotne będzie np. stosowne (ang. adequate) ubezpieczenie operatora na wypadek wszelkiej możliwej szkody. Specjalny Sprawozdawca uzupełnił tę ogólną konstatację sugestią wprowadzenia obowiązku wypłaty odszkodowania przez państwo autoryzujące szkodliwą działalność, choć sama wysokość owego odszkodowania zależałaby od wyniku negocjacji, prowadzonych w dobrej wierze przez zainteresowane strony. Wzorem dobrych praktyk przemysłu transportowego, zasadne byłoby także wprowadzenie obejmujących całe sektory przemysłu, generujące ryzyko transgranicznej szkody, mechanizmów finansowych, umożliwiającymi wypłatę odszkodowania ewentualnym poszkodowanym ${ }^{80}$.

\subsection{Należyta staranność a ryzyko i szkoda $w$ reżimie odpowiedzialności międzynarodowej}

KPM ściśle powiązała należytą staranność z kwestią ryzyka generowanego przez działania niezakazane prawem międzynarodowym. W drugiej połowie XX w.

\footnotetext{
${ }^{77}$ Raport KPM, 1992 r., U.N. Doc. A/47/10, s. 43.

${ }^{78}$ Raport KPM, 1992 r., U.N. Doc. A/47/10, s. 43, pkt 290. Angielski termin ,operator” tłumaczony jest w polskiej literaturze niejednolicie, np. jako „użytkownik” czy „podmiot prowadzący działalność"; por. M. M. Kenig-Witkowska, Prawnomiędzynarodowa..., s. 318. M. Górski, odwołując się do terminologii prawa wspólnotowego, zamiast terminu „operator” używa terminu „podmiot” i ,podmiot gospodarujący”, por.: M. Górski, op.cit., np. s. 37, 64, 66.

${ }^{79}$ Raport KPM, 1992 r., U.N. Doc. A/47/10, s. 43, pkt 290.

${ }^{80}$ Raport KPM, 1993 r., U.N. Doc. A/48/10, s. 24.
} 
to niebezpieczna aktywność, realizowana przez podmioty prywatne, częściej niż bezpośrednie działania organów państwa, generowała znaczące szkody transgraniczne. Prace nad zasadami odpowiedzialności międzynarodowej za działania niezakazane treścią norm prawa międzynarodowego w 1993 r. kontynuował Specjalny Sprawozdawca Julio Barboza, przedkładając Komisji projekt artykułów o odpowiedzialności międzynarodowej za czyny niezakazane prawem międzynarodowym. Pierwsza propozycja regulacji tego zagadnienia dotyczyła konsekwencji przedsięwzięć niebezpiecznych, choć oparta została na założeniu, iż nie zawsze możliwe jest zidentyfikowanie elementu ryzyka $\mathrm{w}$ danym działaniu. Ocena ryzyka powstania znaczącej szkody transgranicznej wynikającego z danej aktywności, powinna być dokonywana w oparciu o analizę wykorzystywanych przy jej realizacji materiałów i substancji, używanych technologii oraz okoliczności realizacji poszczególnych działań. Analiza uwzględniająca te kryteria w zdecydowanej większości przypadków pozwalała na zidentyfikowanie elementu ryzyka powstania szkody transgranicznej ${ }^{81}$. W pracach KPM zobowiazanie do dołożenia należytej staranności stanowiło treść obowiązku prewencji, tj. wprowadzało konieczność podjęcia przez państwo wszelkich działań zmierzających do zapobieżenia znaczącym szkodom transgranicznym. Doprecyzowaniem zakresu owego obowiązku KPM zajmowała się w latach 1993-2006 ${ }^{82}$. Z prac Komisji wynika dość precyzyjnie określony nakaz wykazywania przez państwa należytej staranności przy realizacji międzynarodowych zobowiązań, niezależnie od ich źródła czy charakteru. Dotyczy on nie tylko zobowiązań traktatowych, ale wszelkich obowiązków państwa nakładanych na nie moca prawa międzynarodowego. Punkt wyjścia rozważań nad należytą starannością w kontekście odpowiedzialności za działania niezakazane prawem międzynarodowym, stanowiło podsumowanie dorobku doktryny i orzecznictwa. Komisja zaproponowała na ich podstawie własną definicję należytej staranności, określanej jako przejaw „rozsądnych wysiłków państwa”, przedsiębranych celem uzyskania informacji co do prawnych i faktycznych okoliczności, pozwalających przewidzieć niepożądane skutki danej procedury oraz podjąć w odpowiednim czasie stosowne działania, mające na celu zapobieżenie tymże skutkom ${ }^{83}$. W 1996 r. Komisja przyjęła projekt 22 artykułów o odpowiedzialności międzynarodowej za szkody wynikające z czynów niezakazanych prawem międzynarodowym ${ }^{84}$. Projekt dotyczył działań i zaniechań niezakazanych prawem międzynarodowym, które zawierały w sobie element ryzyka powstania znaczącej

${ }^{81}$ Raport KPM, 1993 r., U.N. Doc. A/48/10, s. 24.

${ }^{82}$ Por. Raport KPM, 1993 r., s. 22-24; U.N. Doc. A/48/10, Raport KPM, 1994 r., U.N. Doc. A/49/10, s. 155-156, 169-172; Projekt Barbozy, U.N. Doc. A/51/10, s. 110-120; Pierwszy raport Rao, U.N. Doc. A/CN.4/487, s. 8-23; Projekt artykułów o odpowiedzialności międzynarodowej z 1998 r., U.N. Doc. A/53/10, s. 19-24; Drugi raport Rao, U.N. Doc. A/CN.4/501, s. 22-23; Trzeci raport Rao, U.N. Doc. A/CN.4/510, s. 5-10, 17, Projekt artykułów o prewencji z 2001 r., Raport grupy roboczej ds. odpowiedzialności międzynarodowej, 2004 r., U.N. Doc. A/CN.4/L.661, rozdz. VII, paragrafy $170-171$.

${ }^{83}$ Projekt Barbozy, U.N. Doc. A/51/10, komentarz (9), s. 111.

${ }^{84}$ Projekt Barbozy, U.N. Doc. A/51/10. 
szkody transgranicznej. Jak wskazuje Sonnenfeld, oparcie projektu o zasade ryzyka wynikało prawdopodobnie z faktu, iż prawie wszystkie konwencje dotyczące odpowiedzialności za czyny niezakazane prawem międzynarodowym, a więc przede wszystkim porozumienia konstytuujące międzynarodowe prawo środowiska, ustanawiały taką właśnie formę odpowiedzialności państw. Wprowadzały one jedynie „międzynarodowy element ubezpieczeniowy”, tj. obciążały państwa ewentualnym obowiązkiem pokrycia powstałych szkód, niezależnie od ich winy czy możliwości przypisania im szkodliwego działania lub zaniechania $^{85}$. Pierwotnie projekt KPM dotyczył także aktywności niezakazanych w treści norm prawa międzynarodowego i niezawierających w sobie elementu ryzyka powstania znaczącej szkody transgranicznej, o ile działania te faktyczne stały się przyczyną takiej szkody ${ }^{86}$. Ostatecznie jednak państwa nie zgodziły się na przyjęcie odpowiedzialności absolutnej jako jednej z zasad reżimu negocjowanego $\mathrm{w}$ drugiej połowie XX w.

Prace Komisji, dotyczące odpowiedzialności za czyny niezakazane prawem międzynarodowym, obejmowały także kłopotliwe zagadnienie kompensacji szkód transgranicznych. Podczas prac nad tym obszarem omawianego reżimu stało się jasne, że badania objęły dwa odrębne zagadnienia. Regulacja tych dwóch obszarów, tj. odpowiedzialności i prewencji, w treści jednego dokumentu była niewskazana. Dlatego w 1997 r. Komisja zaproponowała podzielenie powierzonego jej przez Zgromadzenie Ogólne tematu badawczego na dwa wątki ${ }^{87}$. Jedna grupa ekspertów miała poddać analizie reguły prewencji, tj. opisać zasady zapobiegania znaczącym szkodom transgranicznym. Zadaniem drugiej było opisanie odpowiedzialności międzynarodowej w przypadku powstania znaczącej szkody transgranicznej, wynikającej z niedopełnienia owych reguł. Na całokształt prac nad odpowiedzialnością za szkodliwe skutki działań niezakazanych prawem międzynarodowym składać się więc miały badania nad: zapobieganiem szkodom transgranicznym, wynikającym z działalności niebezpiecznej oraz nad regułami alokacji powstałych strat ${ }^{88}$.

${ }^{85}$ Por. R. Sonnenfeld, op.cit., s. 20. Zob. także: M. M. Kenig-Witkowska, Prawnomiędzynarodowa..., s. 314-315, która wskazuje na dominującą rolę odpowiedzialności na zasadzie ryzyka w reżimie odpowiedzialności za działania niezakazane prawem międzynarodowym, odnotowuje jednak także istnienie norm traktatowych konstytuujących odpowiedzialność na zasadzie winy.

${ }^{86}$ Projekt Barbozy, U.N. Doc. A/51/10, art. 1.

${ }^{87}$ W 1997 r. KPM podjęła decyzję o podziale tematu „międzynarodowa odpowiedzialność za szkodliwe konsekwencje czynów niezakazanych prawem międzynarodowym" na dwie części: zagadnienie zapobiegania szkodom międzynarodowym, tj. tzw. zasady prewencji oraz zasady alokacji strat powstałych wskutek owych działan. Por.: Rezolucja Zgromadzenia Ogólnego ONZ z 15 grudnia 1997 r., U.N. Doc. G.A. Res. 52/156. O powodach dokonania podziału oraz o jego konsekwencjach por. np.: F. O. Vicuña, Responsibility and Liability under International Law for Environmental Damage Resolution Adopted on September 4, 1997, Georgetown International Environmental Law Review 1997-1998, nr 10, s. 269-278; idem, Responsibility and Liability for Environmental Damage under International Law: Issues and Trends, Georgetown International Environmental Law Review 1997-1998, nr 10, s. 279-308.

${ }^{88}$ Obowiązek prewencji został zapisany w treści art. 3 Projekt artykułów o prewencji z $2001 \mathrm{r}$. oraz art. 3 Projektu zasad alokacji z 2006 r., UN Doc. A/61/10. 
Należyta staranność wpisana została w treść analizy reguł prewencji. Specjalny Sprawozdawca, powołany celem organizacji prac Komisji nad przedmiotową materią, Pemmaraju Sreenivasa Rao z Indii, przedstawił swój pierwszy raport $\mathrm{w} 1998 \mathrm{r} .{ }^{89}$ Podsumował $\mathrm{w}$ nim osiagnięcia poprzedników począwszy od 1978 r., koncentrując się na treści zobowiązania państwa do zapobiegania szkodom transgranicznym, w którego centralnym punkcie znalazł się obowiązek dokładania należytej staranności przy realizacji zobowiązań międzynarodowych. Jego celem było ustalenie treści ewentualnego projektu artykułów dotyczących obowiązku prewencji względem szkód ponadgranicznych. Jako zobowiązania państw dotyczące zasad prewencji szkód transgranicznych, Rao zidentyfikował zasadę przezorności, zasadę „zanieczyszczający płaci” oraz zasady: słuszności, dobrego zarządzania i budowania potencjału (ang. capacity building) ${ }^{90}$. Zobowiązanie do dołożenia należytej staranności powinno być weryfikowane nie tylko w odniesieniu do ogólnie przyjętych reguł i standardów międzynarodowych, ale także uwzględniać obiektywne standardy wymagane in abstracto od dobrego rządu. Z prac Komisji wyłonił się więc teoretyczny model postępowania, przypisany każdemu „dobremu rządowi”, którego realizacja odpowiadała dopełnieniu obowiązku dokładania należytej staranności przy realizacji zobowiązań międzynarodowych ${ }^{91}$. Oparty na tych zasadach projekt artykułów o odpowiedzialności międzynarodowej za szkodliwe konsekwencje czynów niezakazanych prawem międzynarodowym, opisujący reguły zapobiegania szkodom transgranicznym, został przedstawiony podczas 50. sesji KPM w 1998 r., otwierając prace nad zasadami prewencji ${ }^{22}$. Choć wciąż dotyczył „odpowiedzialności międzynarodowej”, opatrzony został podtytułem odzwierciedlającym decyzję Komisji z 1997 r. o podziale tematów badań. W jego treści znalazł się opis zasad prewencji, tj. zapobiegania znaczącym szkodom transgranicznym, wynikającym z czynów niebezpiecznych. Obowiązek prewencji oznaczał zobowiązanie państw do podejmowania wszelkich odpowiednich kroków (ang. appriopriate measures) zmierzających do zapobieżenia powstaniu lub zminimalizowania ryzyka powstania znaczącej szkody transgranicznejej. Ten kształt obowiązku prewencji znalazł swoje odzwierciedlenie w treści Projektu artykułów o odpowiedzialności międzynarodowej z $1998 \mathrm{rr}^{94}$

Szczegółowo treść obowiązku prewencji, jako obejmującego zobowiązanie do wykazywania należytej staranności w stosunkach międzynarodowych, Rao

\footnotetext{
${ }^{89}$ Pierwszy raport Rao, U.N. Doc. A/CN.4/487.

${ }^{90}$ Pierwszy raport Rao, U.N. Doc. A/CN.4/487, s. 8. Ale por.: Z. Bukowski, Prawo międzynarodowe a ochrona środowiska, Toruń 2005, s. 61-78, który wyróżnia zasady: zrównoważonego rozwoju, sprawiedliwości międzypokoleniowej, „zanieszczyszczający płaci”, prewencji, przezorności, publicznej partycypacji, obowiązku niewyrządzania szkód poza granicami państwa (ang. no harm principle).

${ }_{91}^{9}$ Pierwszy raport Rao, U.N. Doc. A/CN.4/487, s. 23.

92 Projekt artykułów o odpowiedzialności międzynarodowej z 1998 r., U.N. Doc. A/53/10, s. 19.

93 Projekt artykułów o odpowiedzialności międzynarodowej z 1998 r., U.N. Doc. A/53/10, art. 3, s. 21.

${ }^{94}$ Por. art. 11 Projektu artykułów o odpowiedzialności międzynarodowej z 1998 r.
} 
opisał w raportach z 1999 r. i 2001 r., formułując jednocześnie odpowiedź na pytanie o właściwą formę projektu artykułów go dotyczących ${ }^{95}$. Zaproponował także procedurę pokojowego rozwiązywania sporów międzynarodowych dotyczących odpowiedzialności międzynarodowej ${ }^{96}$. Specjalny Sprawozdawca zasugerował Komisji tymczasowe zawieszenie prac nad odpowiedzialnościa międzynarodową i poświęcenie pełnej uwagi kwestii prewencji. Celem tych prac byłoby zaproponowanie ostatecznej wersji projektu artykułów dotyczących jej zasad. Wypracowawszy reguły prewencji, Komisja mogłaby wrócić do prac nad odpowiedzialnością ${ }^{97}$. Sugestia dotycząca zmiany nazwy dokumentu z dotyczącego „odpowiedzialności międzynarodowej” na dotyczący bezpośrednio „prewencji" uwzględniona została dopiero w trakcie prac nad Projektem artykułów o prewencji z 2001 r. Szczegółowe rozważania KPM prowadzone w toku badań nad zasadą prewencji, a dotyczące należytej staranności, opisane zostały poniżej. Całokształt obserwacji Komisji opisać można poprzez sekwencję szczegółowych obowiązków, które zrealizować powinno państwo działające z należytą starannością.

Opisując zasady prewencji Komisja opracowała szereg definicji istotnych dla oceny działań i zaniechań państw. Najistotniejszym pojęciem dla rozważań nad odpowiedzialnością międzynarodową za działania niezakazane prawem międzynarodowym było pojęcie ryzyka wywołania znaczącej szkody transgranicznej (ang. risk of causing significant transboundary harm). Zaistnienie ryzyka wywołania znaczącej szkody powodowało powstanie obowiązku prewencji po stronie państwa. Termin ten oznaczał według KPM sytuacje niosące za sobą „niskie prawdopodobieństwo wywołania katastrofalnej szkody oraz wysokie prawdopodobieństwo powstania innej znaczącej szkody"98.

Kluczowe było tu, zdaniem Komisji, zdefiniowanie „działań niebezpiecznych", od treści którego to pojęcia zależał zakres i treść działań prewencyjnych. Uwzględniając różnorodny charakter zachowań realizowanych przez państwa w ich granicach, niemożliwe było sporządzenie wyczerpującej listy działań niosących za sobą niebezpieczeństwo szkody transgranicznej. Komisja zaproponowała więc ich otwarty katalog, zawierający przykłady takich aktywności. Przy definiowaniu zakresu pojęcia niebezpiecznych działań niezbędne było uwzględnienie faktu, iż niektóre przedsięwzięcia okazywały się ryzykowne dopiero, kiedy były realizowane wspólnie z innymi ${ }^{99}$.

${ }^{95}$ Drugi raport Rao, U.N. Doc. A/CN.4/501, s. 20-22; Trzeci raport Rao, U.N. Doc. A/CN.4/510, s. 11. Szczegółowy opis treści zasady prewencji zawarto w rozdz. V.

${ }^{96}$ Drugi raport Rao, U.N. Doc. A/CN.4/501, s. 2. W toku prac uznano, że kwalifikowanie „szkody transgranicznej” jako „znaczącej” może być podstawą sporów, tym trudniejszych do rozwiązania, że nie przewidziano dotyczącej ich obligatoryjnej procedury mediacyjnej. Dlatego też opisane w 1998 r. zasady prewencji dotyczyły szkody transgranicznej, niezależnie od jej rozmiarów. Por.: Pierwszy raport Rao, U.N. Doc. A/CN.4/487, pkt 15, por, przypis 25 , s. 8 .

${ }^{97}$ Drugi raport Rao, U.N. Doc. A/CN.4/501, pkt 67, lit. (b), s. 22.

${ }^{98}$ Projekt Barbozy, U.N. Doc. A/51/10, art. 2 (a).

${ }^{99}$ Pierwszy raport Rao, U.N. Doc. A/CN.4/487, pkt 16, s. 8. 
Zobowiązanie do dokładania należytej staranności spoczywało na państwie „pochodzenia” ryzyka powstania szkody i to ono było zobowiązane do uczynienia zadość obowiązkowi prewencji ${ }^{100}$. „Państwo pochodzenia” to państwo na terytorium którego realizowane były działania pociagające za sobą niebezpieczeństwo powstania szkody transgranicznej lub państwo, które w inny sposób wykonywało nad takimi działaniami uprawnienia jurysdykcyjne lub sprawowało kontrolę $^{101}$. „Państwo poszkodowane” to państwo, na terytorium którego wystąpiła znacząca szkoda transgraniczna lub które posiada uprawnienia jurysdykcyjne lub kontrolne nad obszarem, w którym szkoda taka wystapiła ${ }^{102}$. Terminem „ewentualna szkoda transgraniczna” Komisja określiła niebezpieczeństwo powstania szkody na terytorium lub w innym miejscu pozostającym w jurysdykcji lub pod kontrolą państwa innego niż państwo pochodzenia, niezależnie od tego, czy posiada ono wspólną granicę z państwem poszkodowanym ${ }^{103}$.

Opisując obowiązki państw Komisja określiła także zakres podmiotów, nad działaniami których państwo powinno sprawować kontrolę. Czerpiąc z postanowień Konwencji o odpowiedzialności cywilnej za szkody wyrządzone działalnością niebezpieczną dla środowiska, podpisanej w Lugano w 1993 r. ${ }^{104}$, zdefiniowano „operatora” jako „osobę, która sprawuje kontrolę nad działalnością" generującą ryzyko ${ }^{105}$. Operator ponosić winien odpowiedzialność za znaczącą transgraniczną szkodę wywołaną jego działalnością w okresie, w którym sprawował kontrolę nad ową działalnością. Jeśli kontrolę sprawowało kilku operatorów, ich odpowiedzialność jest wspólna i solidarna, o ile jeden z nich nie będzie w stanie dowieść, że był odpowiedzialny jedynie za pewną część powstałej szkody, w której to sytuacji ponosił będzie odpowiedzialność jedynie w tej części ${ }^{106}$.

Obowiązek wykazania należytej staranności przez państwo względem przedsięwzięć generujących ryzyko pojmowany być winien przede wszystkim terytorialnie, choć termin „ewentualna szkoda transgraniczna” ujmuje w kręgu potencjalnych poszkodowanych nie tylko bezpośrednich sąsiadów adresata dyspozycji formułowanej normy, ale wszystkich tych, których jego działanie lub zaniechanie mogłoby dotknąć bezpośrednio, zaś ich szkodę można było racjonalnie przewidzieć ${ }^{107}$.

${ }^{100}$ Por.: Trzeci raport Rao, U.N. Doc. A/CN.4/510, art. 3, s. 17., który to art. 3 wprowadza obowiązek prewencji, tj. zobowiązanie państwa pochodzenia do podejmowania wszelkich odpowiednich kroków celem zapobieżenia lub minimalizowania ryzyka znaczącej szkody transgranicznej.

${ }^{101}$ Projekt Barbozy, U.N. Doc. A/51/10, art. 2 (c). Por. R. Sonnenfeld, op.cit., s. 22, która thumaczy pojęcie state of origin, tu określone terminem ,państwo pochodzenia”, jako ,państwo ryzyka”.

${ }^{102}$ Projekt Barbozy, U.N. Doc. A/51/10, art. 2 (d).

${ }^{103}$ Projekt Barbozy, U.N. Doc. A/51/10, art. 2 (b).

${ }^{104}$ Konwencja Rady Europy z 21 czerwca 1993 r. o odpowiedzialności za szkody wynikające z działalności niebezpiecznej dla środowiska; ETS nr 150. Konwencja wciąż (2013 r.) nie weszła w życie.

${ }^{105}$ Raport KPM, 1994 r., U.N. Doc. A/49/10, s. 156.

${ }^{106}$ Raport KPM, 1994 r., U.N. Doc. A/49/10, s. 156.

${ }^{107}$ Por.: Raport KPM, 1993 r., U.N. Doc. A/48/10, s. 22. Projekt Barbozy, U.N. Doc. A/51/10, s. 111. 
Państwo powinno podjać wszelkie niezbędne starania celem uniknięcia działań lub zaniechań, które można racjonalnie przewidzieć jako potencjalnie szkodliwe dla „państw poszkodowanych”, tj. tych, które „racjonalnie uznać można za potencjalnie bezpośrednio poszkodowane przewidywalnie szkodliwym działaniem"108.

Obowiązek należytej staranności opisany został w treści artykułów jedynie w kontekście właściwym dla badanej przez Komisję materii, tj. w kontekście reguł prewencji i odpowiedzialności międzynarodowej. Jego zakres nie wpływał na suwerenne uprawnienia państw, określane w innych dokumentach i zasadach prawa międzynarodowego. Opisany w treści projektu reżim miał jedynie stanowić punkt wyjścia do negocjacji szczegółowych umów, zawieranych przez państwa, a dotyczących jednego lub więcej rodzajów działalności, niosącej za sobą niebezpieczeństwo powstania znaczącej szkody transgranicznej ${ }^{109}$.

Najistotniejszy spór podczas obrad Komisji, dotyczący uznania należytej staranności za zasadę pomocniczą w prawie odpowiedzialności międzynarodowej, odnosił się do jej relacji względem zasady suwerennej równości państw. Komisja rozważała obowiązek wykazywania należytej staranności w kontekście suwerennego prawa państwa do korzystania $\mathrm{z}$ zasobów naturalnych, pozostających $\mathrm{w}$ jego dyspozycji ${ }^{110}$. Zasada ,zrównoważonego i rozsądnego wykorzystania" (ang. equitable and reasonable utilization) terytorium, przeciwstawiona została pojęciu „znaczącej” czy „,znacznej” szkody (ang. appreciable or significant harm), jako przesłanki międzynarodowej odpowiedzialności. Obowiązek zapobiegania znaczącym szkodom transgranicznym postrzegany był jako istotne ograniczenie suwerennego prawa państw do korzystania $\mathrm{z}$ ich terytorium, a zwłaszcza $\mathrm{z}$ jego zasobów naturalnych ${ }^{111}$.

Prawo do „zrównoważonego i rozsądnego wykorzystania” terytorium stanowiło jedną z podstaw projektowanego reżimu odpowiedzialności międzynarodowej, ale także dawało możliwość skrajnie odmiennych interpretacji. Dla jednych członków Komisji oznaczało implikowane, komplementarne prawo do wyrządzania pewnych szkód transgranicznych, według drugich zaś pozwalało uznać wykorzystanie terytorium, prowadzące do transgranicznej szkody, za niespełniające kryteriów równowagi i racjonalności. Dlatego też w toku prac Komisji zastapiono wymóg powstrzymania się od wyrządzania znacznej lub znaczącej ewentualnej szkody zobowiązaniem państw do dokładania należytej staranności przy realizacji ich międzynarodowych zobowiązań ${ }^{112}$. W konsekwencji, jeśli wykorzystanie terytorium uznać można było za zrównoważone i racjonalne, dopuszczalne było wyrządzenie pewnej szkody. Nadrzędnym celem powstającego reżimu odpowiedzialności stało się racjonalne i zrównoważone wykorzystanie podległego

\footnotetext{
${ }^{108}$ Pierwszy raport Rao, U.N. Doc. A/CN.4/487, s. 23.

${ }^{109}$ Trzeci raport Rao, U.N. Doc. A/CN.4/510, s. 12.

${ }^{110}$ Trzeci raport Rao, U.N. Doc. A/CN.4/510, s. 5.

${ }^{111}$ Raport KPM, 1993 r., U.N. Doc. A/48/10, s. 22

${ }^{112}$ Raport KPM, 1993 r., U.N. Doc. A/48/10, s. 22.
} 
państwu terytorium, raczej niż całkowite i skuteczne zapobieżenie szkodom $\mathrm{z}$ niego generowanym ${ }^{113}$. Tak sformułowanej hierarchii zasad sprzeciwiło się wielu członków Komisji, gotowych uznać jedynie odwołanie do należytej staranności jako do treści ciążącego na państwach obowiązku prewencji ${ }^{114}$.

Obowiązek podejmowania działań prewencyjnych powinien być tym samym kształtowany z uwzględnieniem nadrzędnego charakteru owego suwerennego prawa państwa do eksploatacji własnego terytorium, które realizowane winno być w celu zapewnienia dobrobytu ekonomicznego społeczeństwa. Zwolennicy takiej hierarchii reguł wskazywali, że zasada suwerenności oraz prawo państwa do samodzielnego kształtowania kierunków jego rozwoju ograniczają zakres obowiązków mieszczących się w treści zasady należytej staranności. Postulowano położenie większego nacisku na zasadę ciągłego rozwoju oraz wprowadzenie zapisów o systemie finansowego lub innego wsparcia dla państw realizujących niebezpieczne przedsięwzięcia ${ }^{115}$. Państwa rozwijające się sygnalizowały potrzebę stworzenia międzynarodowego funduszu, wspierającego je przy wypracowywaniu standardów technicznych, służących zapobieganiu szkodom oraz pomagającego przy zakupie technologii niezbędnych do ich wdrożenia. Postulat ten uznano za wpisujący się w treść zasady ciągłego rozwoju, która oznaczała unikanie sytuacji, w której standardy stosowane przez państwa rozwinięte byłyby niemożliwe do wdrożenia przez państwa rozwijające się, zarówno ze względów ekonomicznych, jak i społecznych ${ }^{116}$. Realizacja tej zasady, w kontekście obowiązku dokładania należytej staranności przy zapobieganiu znaczącym szkodom transgranicznym, pozwalała określić wspólny, choć zróżnicowany zakres obowiązków poszczególnych państw w zakresie ochrony środowiska naturalnego. Zakres owych obowiązków zależny byłby od statusu ekonomicznego i technologicznego państw. W konsekwencji proponowano zastapienie zobowiązania państwa pochodzenia do podjęcia „wszelkich niezbędnych kroków” celem zapobieżenia szkodzie transgranicznej bezpośrednim odniesieniem do konieczności dokładania należytej staranności ${ }^{117}$. Delegacja Rosji podnosiła, że obowiązek prewencji ze swej natury zawiera zobowiązanie do dokładania należytej staranności, podczas gdy jej standard nie może być jednakowy dla wszystkich państw. Standard stosowany do państw rozwiniętych może okazać się niemożliwy do wypełnienia przez państwa w trudnej sytuacji ekonomicznej. Dlatego też przedstawiciele Rosji przedkładali stosowanie procedur współpracy i system zachęt ponad sankcje za brak należytej staranności ${ }^{118}$.

${ }^{113}$ Wyjątek stanowiła szkoda wynikająca z zatrucia środowiska naturalnego, której powstanie stanowiłoby dowód niesprawiedliwego i nieracjonalnego wykorzystania zasobów naturalnych, choć nawet wówczas państwo mogłoby uniknąć odpowiedzialności, jeśli powstała szkoda nie stanowiłaby bezpośredniego zagrożenia dla zdrowia i życia ludzi. Por.: Raport KPM, 1993 r., U.N. Doc. A/48/10, s. 22.

${ }_{114}$ Raport KPM, 1993 r., U.N. Doc. A/48/10, s. 22 i 92.

115 Trzeci raport Rao, U.N. Doc. A/CN.4/510, s. 5.

${ }^{116}$ Trzeci raport Rao, U.N. Doc. A/CN.4/510, s. 11.

117 Trzeci raport Rao, U.N. Doc. A/CN.4/510, s. 6.

${ }^{118}$ Trzeci raport Rao, U.N. Doc. A/CN.4/510, s. 7. 
W toku prac Komisja zastrzegła, że o ile wolność państw do prowadzenia lub zezwalania na prowadzenia na ich terytorium lub w ich jurysdykcji czy pod ich kontrolą wszelkich działań jest nieograniczona, to musi ona być realizowana z uwzględnieniem ogólnego zobowiązania do zapobiegania albo minimalizowania ryzyka powstania znaczącej szkody transgranicznej. Co więcej, wolność ta realizowana może być jedynie $\mathrm{z}$ uwzględnieniem innych, dodatkowych zobowiązań państwa, wynikających $\mathrm{z}$ treści prawa międzynarodowego ${ }^{119}$. Jednym $\mathrm{z}$ takich ograniczeń była konieczność poszanowania zasady równowagi interesów (ang. equitable balance of interests). Komisja wskazała ją jako uzupełnienie treści obowiązku dokładania należytej staranności. Ocena równowagi interesów państwa pochodzenia i państw poszkodowanych wymagała uwzględnienia wszystkich istotnych czynników i okoliczności w danej sprawie. Szczególnie istotny dla dokonania owej oceny był stopień ryzyka powstania znaczącej szkody transgranicznej oraz dostępność środków zapobiegania lub minimalizacji takiego niebezpieczeństwa, ewentualnie możliwości naprawienia powstałych szkód. Przy poszukiwaniu sprawiedliwej równowagi interesów brane pod uwagę być powinno także znaczenie przedmiotowej działalności dla państwa pochodzenia. Taka ocena uwzględnia jego wartość społeczną, gospodarczą i techniczną dla państwa pochodzenia oraz wielkość i prawdopodobieństwo powstania szkód innych podmiotów. Niebezpieczeństwo powstania znaczącej szkody w środowisku naturalnym badane być powinno w kontekście dostępności środków zapobiegania mu lub jego zminimalizowania, albo przywrócenia pierwotnego stanu środowiska. Ważenie interesów państwa pochodzenia i podmiotów poszkodowanych uwzględniać powinno także rentowność niebezpiecznych aktywności, obliczaną z uwzględnieniem kosztów zapobiegania szkodliwym skutkom przy pomocy metod wymaganych przez państwa potencjalnie poszkodowane. Istotne jest również, czy istniała możliwość prowadzenia ryzykownych aktywności gdzie indziej lub w inny sposób, albo zastąpienia jej innym rodzajem działalności. Zasada równowagi interesów uwzględnia też stopień, w jakim poszczególne, potencjalnie poszkodowane państwa są gotowe partycypować w kosztach działań prewencyjnych. W jej treści mieści się konieczność porównania standardów ochrony, jakie stosują państwa poszkodowane do takich samych lub porównywalnych działań w regionie czy na poziomie międzynarodowym ${ }^{120}$.

Zobowiązanie do poszukiwania słusznej równowagi interesów dotyczyło jedynie obowiązku podejmowania przez państwa współpracy, nie odnosiło się natomiast do treści indywidualnego obowiązku dokładania należytej staranności przez każde z państw. Słuszna równowaga interesów w zamierzeniu miała pozwolić na implementację obowiązku prewencji w sposób satysfakcjonujący wszystkie państwa $^{121}$.

\footnotetext{
${ }^{119}$ Projekt Barbozy, U.N. Doc. A/51/10, s. 119.

${ }^{120}$ Projekt Barbozy, U.N. Doc. A/51/10, art. 19, s. 119.

${ }^{121}$ Trzeci raport Rao, U.N. Doc. A/CN.4/510, s. 11.
} 
Komisja użyła zasady dobrej wiary jako wskazówki interpretacyjnej dla zasady słusznej równowagi interesów. Obowiązek prewencji powiązała ze zobowiązaniem do podejmowania w dobrej wierze międzynarodowej współpracy, mającej na celu zapobieganie szkodom transgranicznym. Dobra wiara oznaczała tu m.in. obowiązek zwracania się do organizacji międzynarodowych celem uzyskania pomocy przy zapobieganiu szkodom lub minimalizowaniu ryzyka ich powstania, ewentualnie przy minimalizowaniu ich skutków ${ }^{122}$. Obowiązek wykazywania należytej staranności oznaczał realizację zasady dobrej wiary w relacjach dobrosąsiedzkich ${ }^{123}$. Także zobowiązanie do podejmowania działań prewencyjnych zostało uzupełnione o wyrażoną explicite przesłankę dobrej wiary $^{124}$.

Mimo iż zobowiązanie do podejmowania działań prewencyjnych zamierzone było jako deklaracja zasady prawa międzynarodowego, obowiązek zapobiegania szkodom transgranicznym nie miał według KPM charakteru bezwzględnego ${ }^{125}$. Miał on zastosowanie jedynie względem takich działań państwa, które niosły za sobą niebezpieczeństwo spowodowania znaczącej szkody transgranicznej. Dlatego też, co do zasady, państwo nie odpowiadało za nieprzewidywalne skutki działań niezakazanych prawem międzynarodowym, prowadzonych na jego terytorium, pod jego jurysdykcją lub kontrolą. Jednocześnie państwo nie musiało podejmować środków zapobiegawczych względem aktywności realizowanej na jego terytorium w ukryciu (ang. clandestine activities), o realizacji której nie miało możliwości się dowiedzieć, mimo dołożenia należytej staranności, zaś realizacja owego zobowiązania była ograniczona do działań, związane z którymi niebezpieczeństwo szkody transgranicznej było powszechnie znane ${ }^{126}$. Państwo powinno podejmować starania celem identyfikowania źródeł potencjalnych szkód, acz odpowiedzialność ponosić mogło jedynie wskutek naruszenia zobowiązania do ,podjęcia odpowiednich środków w celu zapobieżenia lub zminimalizowania" ryzyka powstania znaczącej szkody. W konsekwencji, obowiązek zapobiegania znaczącym szkodom transgranicznym opisany został przez Komisję jako zobowiązanie państwa do przedsiębrania wszelkich właściwych środków (ang. all appropriate measures) celem zapobiegania znaczącej szkodzie transgranicznej lub zminimalizowania ryzyka jej powstania, zaś jeśli zapobiec jej się nie udało - do minimalizowania jej skutków ${ }^{127}$. Tak rozumiany obowiązek prewencji inkorporował zasadę należytej staranności ${ }^{128}$. W treści pojęcia wszelkich właściwych środków Komisja zawarła obowiązek wykorzystania najlepszej dostępnej technologii celem zidentyfikowania i zminimalizowania

\footnotetext{
122 Projekt Barbozy, U.N. Doc. A/51/10, art. 6, s. 110.

123 Projekt Barbozy, U.N. Doc. A/51/10, art. 22, s. 119

124 Pierwszy raport Rao, U.N. Doc. A/CN.4/487, s. 9.

125 Projekt Barbozy, U.N. Doc. A/51/10, s. 110.

${ }^{126}$ Projekt Barbozy, U.N. Doc. A/51/10, art. 22, s. 119, s. 110.

127 Projekt Barbozy, U.N. Doc. A/51/10, art. 4, s. 110.

${ }^{128}$ Projekt Barbozy, U.N. Doc. A/51/10, s. 110.
} 
ryzyka znaczącej szkody transgranicznej ${ }^{129}$. Ponadto, prowadzenie działalności niebezpiecznej objęte zostało obowiązkiem zapewnienia ubezpieczenia współmiernego do podejmowanego ryzyka ${ }^{130}$.

Jeśli państwu pochodzenia oferowana była pomoc w zneutralizowaniu powstającej szkody przez organizację międzynarodową lub stronę trzecią, a państwo z takiej pomocy nie skorzystało, czy to w wyniku niedbalstwa czy też lekkomyślności, to wykazało brak należytej staranności. Tej samej interpretacji podlega odmowa przyjęcia pomocy oferowanej przez stronę trzecią czy organizację międzynarodową przy minimalizowaniu szkód. Jeśli natomiast państwo skorzystało $\mathrm{z}$ oferowanej mu pomocy, przyszłe odszkodowanie obliczane być powinno jedynie $\mathrm{z}$ uwzględnieniem faktycznie powstałych szkód, z pominięciem szkód naprawionych czy tych, którym udało się zapobiec ${ }^{131}$. Uznać więc można, iż należyta staranność interpretowana być powinna w odniesieniu do międzynarodowych, raczej niż krajowych standardów postępowania ${ }^{132}$. Świadczy o tym także zalecenie Komisji, w treści którego wskazuje, iż rodzaj i zakres działań prewencyjnych powinny być ustalane przez państwo pochodzenia i państwa potencjalnie poszkodowane wspólnie i objąć ustalenia odnośnie do procedur pozwalających na aplikację międzynarodowych reguł prewencji w konkretnych okolicznościach ${ }^{133}$. Przede wszystkim, państwo zobligowane było podjąć wszelkie niezbędne działania legislacyjne, administracyjne czy inne, zmierzające do zapobiegania szkodom transgranicznym, zgodnie z treścią zobowiązania do wykazywania należytej staranności ${ }^{134}$. Prawo krajowe winno służyć wyegzekwowaniu wprowadzonych przepisów, decyzji i innych instrumentów realizacji polityki wewnętrznej ${ }^{135}$.

Jak już wskazano, Komisja przedkładała obowiązek prewencji, obejmujący zobowiązanie do wykazywania należytej staranności, ponad obowiązki odszkodowawcze. Naczelną zasadą projektowanej regulacji było więc zobowiązanie państw do niewyrządzania znaczących szkód transgranicznych w środowisku naturalnym innych państw czy $\mathrm{w}$ przestrzeniach poza władzą państwową. Wypełnienie owego zobowiązania wymagało od państw podjęcia najlepszych starań, mających na celu zapobieżenie powstaniu szkód ${ }^{136}$. Obowiązek ten

${ }^{129}$ Raport KPM, 1993 r., U.N. Doc. A/48/10, s. 22

${ }^{130}$ Raport KPM, 1993 r., U.N. Doc. A/48/10, s. 22. Por.: R. Wolfrum, International Environmental Law: Purposes, Principles and Means of Ensuring Compliance, (w:) International, Regional and National Environmental Law, red. F. L. Morrison, R. Wolfrum, Haga 2000, s. 15, gdzie autor wskazuje, że obowiązek zastosowania najlepszej dostępnej technologii jest blisko związany z zasadą ostrożności. Jak już wspomniano, obowiązek prewencji budził sprzeciw niektórych członków Komisji, obawiających się ograniczenia prawa państw do racjonalnego korzystania z własnego terytorium. Raport KPM, 1993 r., U.N. Doc. A/48/10, s. 22.

${ }^{131}$ Projekt Barbozy, U.N. Doc. A/51/10, art. 22, s. 119.

${ }^{132}$ Pierwszy raport Rao, U.N. Doc. A/CN.4/487, s. 23.

${ }^{133}$ Pierwszy raport Rao, U.N. Doc. A/CN.4/487, s. 8.

${ }^{134}$ Projekt artykułów o prewencji z 2001 r., art. 5, s. 3.

${ }^{135}$ Pierwszy raport Rao, U.N. Doc. A/CN.4/487, s. 23.

${ }^{136}$ Pierwszy raport Rao, U.N. Doc. A/CN.4/487, s. 12. 
obejmował jednocześnie konieczność podejmowania działań mających na celu zidentyfikowanie nowych rodzajów aktywności, generujących zagrożenie szkodą transgraniczną. Uznać więc można, iż zobowiązanie do podejmowania działań prewencyjnych, a co za tym idzie, obowiązek wykazywania należytej staranności mają charakter ciągły. Państwa są więc zobowiązane do podejmowania jednostronnych działań zmierzających do zapobiegania lub zminimalizowania ryzyka znacznych szkód o charakterze transgranicznym. Środki te obejmowały, zdaniem Komisji, zobowiązanie państwa do tworzenia i implementacji polityk zmierzających do zapobiegania lub minimalizowania szkód transgranicznych ${ }^{137}$. Niedopełnienie owego obowiązku, a więc brak należytej staranności, stwierdzić można, gdy państwo nie podjęło żadnego racjonalnego wysiłku, zmierzającego do przedsięwzięcia takich środków. Zobowiązanie do dołożenia należytej staranności nie może więc zostać uznane za zobowiązanie do realizacji określonego celu, tj. zapobieżenia szkodzie, a raczej do zapobiegania określonym konsekwencjom. Jest natomiast zobowiązaniem do wykazania najlepszych możliwych starań (ang. best efforts obligation) ${ }^{138}$. Wskazując stałe miejsce zasady należytej staranności w porządku traktatowym prawa ochrony środowiska, Komisja przywołała sentencje orzeczeń w sprawie zatrucia Renu przez firmę Sandoz oraz w sprawie statku Alabama. W ich kontekście interpretowała należytą staranność nie tylko jako podjęte działania, ale utożsamiała $\mathrm{z}$ nią także wykazaną przez państwo czujność oraz przedsięwzięcie wszelkich środków, pozostających $\mathrm{w}$ jego dyspozycji, celem zapobiegania szkodom ${ }^{139}$. Obowiązek prewencji, oparty o zasadę należytej staranności, był więc zobowiązaniem do podjęcia określonych działań, nie zobowiązaniem do osiągnięcia określonego celu (ang. obligation of conduct and not of result $)^{140}$.

Opis wymaganych od państwa przedsięwzięć, mających na celu zapobieganie powstaniu znaczących szkód lub minimalizowanie ryzyka ich powstania, zawierał treść standardu należytej staranności. Komisja umieściła tu na pierwszym miejscu zobowiązanie państw do podejmowania działań ustawodawczych, administracyjnych i innych, celem zapewnienia podjęcia wszelkich niezbędnych kroków zmierzających do zapobieżenia lub zminimalizowania ryzyka szkody transgranicznej ${ }^{141}$. Sformułowanie obligujące do „podjęcia wszelkich niezbędnych kroków" Komisja interpretowała jako skierowane do podmiotów prywatnych, a więc dla państw niosące konieczność wprowadzenia legislacji i procedur konstytuujących zobowiązanie podmiotów prywatnych, realizujących niebezpieczne przedsięwzięcia, do podjęcia owych środków celem zapobiegania

${ }^{137}$ Projekt Barbozy, U.N. Doc. A/51/10, s. 110-111.

138 Raport KPM, 1993 r., U.N. Doc. A/48/10, s. 24. Por. Szósty raport Specjalnego Sprawozdawcy R. Ago, KPM, 1977 r., U.N. Doc. A/CN.4/302 (dalej: Szósty raport Ago), s. 4-20, gdzie Ago zawarł propozycje art. 20 i 21 projektu artykułów o odpowiedzialności państwa i Projekt artykułów o odpowiedzialności państw z 2001 r., U.N. Doc. A/56/10, s. 57.

\footnotetext{
${ }^{139}$ Projekt Barbozy, U.N. Doc. A/51/10, s. 110-111.

${ }^{140}$ Pierwszy raport Rao, U.N. Doc. A/CN.4/487, s. 23

${ }^{141}$ Pierwszy raport Rao, U.N. Doc. A/CN.4/487, s. 23.
} 
szkodom. Taka interpretacja zapisu projektu miała na celu pozbawienie zobowiązania państw do dołożenia należytej staranności charakteru absolutnego. Obowiązek podjęcia działań prewencyjnych nie spoczywał bezpośrednio na organach państwa, ale na upoważnionych przez nie podmiotach prywatnych. Zadaniem państwa było natomiast przedsiębranie działań zmierzających do sprawowania kontroli nad podmiotami prywatnymi, generującymi niebezpieczeństwo znaczących szkód. Niedopełnienie owego obowiązku miałoby miejsce, gdyby państwo nie podjęło racjonalnych wysiłków zmierzających do wykonania nadzoru nad przedsięwzięciami generującymi ryzyko, tj. nie wprowadziłoby $\mathrm{np}$. odpowiedniej legislacji, procedur administracyjnych czy nie zastosowało procedur egzekucyjnych względem działań realizowanych na jego terytorium ${ }^{142}$. Przykładami takiego niedopełnienia obowiązku prewencji były opisane wcześniej sprawy dotyczące odmowy wymiaru sprawiedliwości cudzoziemcom, w których międzynarodowe sądy i trybunały często orzekały o odpowiedzialności państwa, w granicach którego cudzoziemiec poniósł szkodę ${ }^{143}$.

Komisja szczegółowo opisała należytą staranność, uzupełniając ogólnie sformułowane zobowiązanie do wprowadzenia i stosowania przepisów krajowych zmierzających do zapobiegania znaczącym szkodom o konieczność wprowadzenia przepisami prawa krajowego obowiązkowej, państwowej autoryzacji działań niosących za sobą niebezpieczeństwo wywołania znaczącej szkody transgranicznej. Autoryzacja powinna zostać udzielona podmiotowi upoważnionemu przed podjęciem owej działalności na terytorium państwa. Jeśli uprawniony podmiot planowałby wprowadzenie znaczących zmian w procedurach realizacji autoryzowanych już działań, zmiany takie mogłyby zostać wprowadzone dopiero po uzyskaniu zgody właściwego organu państwowego ${ }^{144}$. Zgoda wydana mogłaby zostać po weryfikacji planowanych zmian względem procedur przewidzianych przepisami krajowymi, te zaś odzwierciedlać powinny stan aktualnych, międzynarodowych ustaleń w przedmiotowym obszarze. Obowiązek należytej staranności wyraża się także poprzez konieczność dokonania oceny ryzyka, związanego z realizacją danej działalności. Ponadto należyta staranność oznacza konieczność monitorowania realizowanych na terytorium państwa aktywności niebezpiecznych także, jeśli te realizowane byłyby wbrew obowiązującym przepisom i bez państwowej autoryzacji. Państwo zobligowane jest do wyegzekwowania od podmiotów realizujących ową ryzykowną działalność dopełnienia obowiązku uzyskania zezwolenia, a co za tym idzie, do dostosowania procedur do wymagań prawa krajowego, chyba że, pomimo dołożenia należytej staranności, nie było w stanie dowiedzieć się o prowadzeniu działalności niebezpiecznej

\footnotetext{
${ }^{142}$ Raport KPM, 1993 r., U.N. Doc. A/48/10, s. 22.

${ }^{143}$ Por. roz. II. Jak odnotowuje Symonides, propozycje uznania zasady odpowiedzialności państw za szkody poniesione przez cudzoziemców znajdujących się na ich terytorium spotykała się ze zdecydowanym sprzeciwem państw rozwijających się, które postrzegały ją jako przejaw imperializmu państw rozwiniętych, służący „ochronie imperialistycznych interesów międzynarodowej oligarchii”; por. J. Symonides, op.cit., s. 34.

${ }^{144}$ Projekt Barbozy, U.N. Doc. A/51/10, s. 117-118.
} 


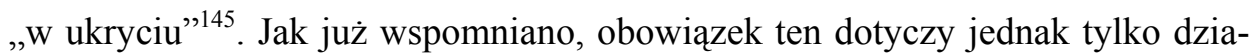
łań, których potencjalnie niebezpieczny charakter jest powszechnie znany ${ }^{146}$.

Obowiązki wynikające z konieczności wykazania należytej staranności ciążą na władzach państwowych od chwili ustalenia, że ryzykowna działalność realizowana jest bez autoryzacji na terytorium, w jurysdykcji lub pod kontrolą państwa. Do chwili uzyskania zezwolenia państwo może na własne ryzyko dopuścić kontynuowanie działalności nieautoryzowanej, przejmując odpowiedzialność za ewentualne powstałe szkody spowodowane taką działalnością. Moment powstania obowiązku egzekwowania prawa krajowego względem podmiotów działających bez uprawnienia Komisja celowo wyznaczyła na chwilę ustalenia faktu prowadzenia nieautoryzowanej działalności, nie zaś jej podjęcia. Jedynie dzięki takiej konstrukcji państwo nie ponosiłoby odpowiedzialności za naruszenie zasady prewencji, tolerując nieautoryzowane działania, realizowane w chwili wejścia w życie projektowanej konwencji, zwłaszcza gdyby nie posiadało o nich informacji. Jednocześnie, jak już wspomniano, brak wiedzy o prowadzonej nieautoryzowanej działalności nie może usprawiedliwiać bierności państwa przy poszukiwaniach o niej informacji ani przyzwolenia na bierne oczekiwanie na ich otrzymanie od stron trzecich. Zastosowana konstrukcja powinna być interpretowana w kontekście obowiązku dokładania należytej staranności, wymagającego od państwa podejmowania w dobrej wierze ciagłych, racjonalnych wysiłków, celem pozyskania informacji o niebezpiecznych przedsięwzięciach ${ }^{147}$.

Komisja uwzględniła $\mathrm{w}$ treści obowiązku prewencji także przesłankę niezwłoczności w realizowaniu współpracy. Oznaczała ona, iż państwa winny zobligować operatorów działających przed wejściem w życie konwencji do niezwłocznego uzyskania autoryzacji. Spełnienie tego wymogu należało także do przejawów należytej staranności ${ }^{148}$.

Barboza utożsamiał obowiązek podejmowania działań prewencyjnych, spoczywający na państwach, ze zobowiązaniem do dołożenia należytej staranności. Oznaczała ona zobowiązanie państw do podejmowania pewnych jednostronnych działań, mających na celu zapobieganie powstaniu lub zminimalizowanie ryzyka powstania znaczącej szkody transgranicznej. Zobowiązanie to nie było zobowiązaniem skutkowym ${ }^{149}$. Podstawą ewentualnej odpowiedzialności państwa za

${ }^{145}$ Projekt Barbozy, U.N. Doc. A/51/10, art. 11, s. 119. Jak już wspomniano, państwo nie musi podejmować środków zapobiegawczych względem aktywności realizowanej na jego terytorium w ukryciu, o realizacji której nie miało możliwości się dowiedzieć, mimo dołożenia należytej staranności. Por. Projekt Barbozy, U.N. Doc. A/51/10, art. 22, pkt (5) komentarza, s. 119.

${ }^{146}$ Projekt Barbozy, U.N. Doc. A/51/10, s. 110.

${ }^{147}$ Projekt Barbozy, U.N. Doc. A/51/10, art. 11, s. 119. Przesłanka „dobrej wiary” została włączona do treści przepisu w 1998 r., kiedy to Komisja zdecydowała połączyć artykuły 9 i 11. Por.: Pierwszy raport Rao o zapobieganiu szkodom transgranicznym, wynikającym z działalności niebezpiecznych, 1998 r., (dalej: Pierwszy raport Rao), U.N. Doc. A/CN.4/487, pkt 20, s. 9. W 2003 r. Rao przedstawił także Pierwszy raport o reżimie prawnym alokacji strat w przypadku powstania szkód transgranicznych wynikających z działalności niebezpiecznej (dalej: Pierwszy raport Rao o alokacji szkód), U.N. Doc. A/CN.4/531.

${ }_{148}$ Pierwszy raport Rao, U.N. Doc. A/CN.4/487, s. 9.

${ }^{149}$ Pierwszy raport Rao, U.N. Doc. A/CN.4/487, s. 9. 
naruszenie owej normy byłaby ocena działań państwa, niezależna od ich skuteczności ${ }^{150}$. Wymagała od państw podjęcia pewnych jednostronnych działań, celem zapobiegania lub zmniejszania ryzyka znaczącej szkody transgranicznej ${ }^{151}$. Taką treść zobowiązania do dołożenia należytej staranności Barboza uzasadniał odwołaniem do postanowień licznych konwencji, zawierających analogiczną treść, szeregu dokumentów miękkiego prawa międzynarodowego, takich jak ustalenia konferencji międzynarodowych oraz akty wewnętrzne organizacji międzynarodowych, dotyczące ochrony środowiska naturalnego, jak również wyroków sądowych, w tym orzeczenia w sprawie zanieczyszczenia Renu przez firmę Sandoz ${ }^{152}$.

Według interpretacji Komisji obowiązek dołożenia należytej staranności przez państwo uznać można było za spełniony, gdy podjęło ono racjonalne starania, zmierzające do uzyskania informacji o faktycznych i prawnych możliwościach wprowadzenia procedur prewencyjnych oraz przedsięwzięło niezbędne kroki zmierzające do ich wprowadzenia w stosownych czasie. Dołożenie należytej staranności oznaczało więc zaprojektowanie i wdrożenie procedur administracyjnych lub egzekucyjnych, niezbędnych do egzekwowania prawa, decyzji administracyjnych i polityk przyjętych przez państwo celem zapobiegania znaczącym szkodom transgranicznym albo zminimalizowania ich skutków ${ }^{153}$. Dopełnienie obowiązku przez państwo oceniane winno być w oparciu o spełnienie standardu należytej staranności ${ }^{154}$.

Interpretacja projektu Komisji nie zawierała jednoznacznej odpowiedzi na pytanie o ewentualną odpowiedzialność państwa, które ustanowiło przepisy i procedury administracyjne względem operatorów niebezpiecznych przedsięwzięć, zmierzając do ograniczenia ryzyka szkody transgranicznej albo jej skali, w sytuacji, gdy ci ostatni nie zastosowali się do nich, powodując powstanie szkody ${ }^{155}$. Barboza wskazywał jednak, iż zobowiązanie państwa do wyegzekwowania odpowiednich procedur od podmiotów prywatnych realizujących ryzykowne przedsięwzięcia, wprowadzało wymóg dochowania przez państwa szczególnie wysokiego poziomu staranności. Oznaczało ono zobowiązanie państwa do starannego projektowania i konsekwentnego implementowania procedur zmierzających do minimalizowania szkód transgranicznych, także z wykorzystaniem najnowszych technologii, dostępnych $\mathrm{w}$ danej dziedzinie aktywności gospodarczej czy naukowej. Jak wspomniano powyżej, zobowiązanie takie było zobowiązaniem ciagłym, które odczytywać można jako zawierające konieczność

${ }^{150}$ Raport KPM, 1994 r., U.N. Doc. A/49/10, s. 169; Projekt Barbozy, U.N. Doc. A/51/10, s. 110 .

${ }^{151}$ Projekt Barbozy, U.N. Doc. A/51/10, s. 110.

${ }^{152}$ Raport KPM, 1994 r., U.N. Doc. A/49/10, s. 169. Sprawa zanieczyszczenia Renu przez firme Sandoz opisana została w rozdz. II.

${ }_{153}$ Raport KPM, 1994 r., U.N. Doc. A/49/10, s. 169; Projekt Barbozy, U.N. Doc. A/51/10, art. 7 i komentarz (3) s. 110.

${ }^{154}$ Projekt Barbozy, U.N. Doc. A/51/10, s. 110.

${ }^{155}$ Raport KPM, 1993 r., U.N. Doc. A/48/10, s. 22. 
ciagłego weryfikowania i ewentualnego nowelizowania obowiązujących już procedur. Ponadto, w odwołaniu do regulacji z zakresu międzynarodowego prawa ochrony środowiska, a zwłaszcza wobec zapisów Deklaracji z Rio, Komisja wskazała na istnienie zobowiązania państw do przyjmowania legislacji skutecznej w przedmiotowym obszarze ${ }^{156}$. W myśl zapisów art. 11 Deklaracji z Rio, standardy bezpieczeństwa oraz krajowe „cele i priorytety zarządzania powinny odzwierciedlać środowiskowy i rozwojowy kontekst" ich stosowania. Komisja odnajdywała podobny język w zapisie zasady 23 Deklaracji sztokholmskiej stanowiącej, iż istniejące krajowe standardy nie mogą uchybiać kryteriom uzgodnionym przez społeczność międzynarodową ${ }^{157}$. Tak więc np. standardy dotyczące ochrony środowiska powinny odzwierciedlać kontekst, którego dotyczą, zaś ich ocena dokonana być powinna $\mathrm{w}$ odniesieniu do aktualnych osiagnięć $\mathrm{w}$ danym obszarze. W przeciwnym razie standardy stosowane samodzielnie przez niektóre państwa mogłyby okazać się niewłaściwe lub nieść za sobą niepożądane konsekwencje ekonomiczne dla innych państw ${ }^{158}$. Zobowiązanie do wprowadzenia stosownych procedur oznacza więc także konieczność stałej międzynarodowej współpracy.

Obowiązek wykazywania przez państwa należytej staranności przy realizacji ich międzynarodowych zobowiązań uzupełniony został przez Komisję o jeszcze jedno szczegółowe zobowiązanie. Komisja wskazała na zakaz dyskryminacji podmiotów prowadzących niebezpieczne aktywności. Jeśli ponosiłyby one odpowiedzialność odszkodowawczą, powinny być traktowane przez państwa pochodzenia na takich samych zasadach, niezależnie od obywatelstwa ich przedstawicieli, siedziby czy miejsca rejestracji, niezależnie także od miejsca, w którym powstała szkoda. Owa równość powinna wyrażać się równością wobec prawa, w tym równym dostępem do sądu czy organów administracyjnych, zwłaszcza w procedurach odszkodowawczych. Reguły te mogą zostać doprecyzowane $\mathrm{w}$ treści porozumienia między zainteresowanymi państwami, zawierającego szczegółowe postanowienia dotyczące ochrony interesów osób, które poniosły znaczące szkody transgraniczne ${ }^{159}$. Obowiązek niedyskryminacji dotyczył także innych podmiotów, w tym poszkodowanych wskutek niebezpiecznej aktywności ${ }^{160}$.

Standard należytej staranności państwa obejmował więc według KPM to, co było powszechnie uważane za właściwe i proporcjonalne i w danej sytuacji zależał do stopnia ryzyka transgranicznej szkody. Działania, które mogły zostać uznane za niosące za sobą duże prawdopodobieństwo wywołania szkody transgranicznej, wymagały znacznie wyższych standardów ostrożności przy tworzeniu polityki ich dotyczącej i wyższego poziomu aktywności państwa celem

${ }^{156}$ Raport KPM, 1994 r., U.N. Doc. A/49/10, s. 169; Projekt Barbozy, U.N. Doc. A/51/10, s. 111 .

${ }^{157}$ Projekt Barbozy, U.N. Doc. A/51/10, s. 111.

${ }^{158}$ Raport KPM, 1994 r., U.N. Doc. A/49/10, s. 169.

${ }^{159}$ Projekt Barbozy, U.N. Doc. A/51/10, art. 20 ust. 2, s. 119.

${ }^{160}$ Pierwszy raport Rao, U.N. Doc. A/CN.4/487, s. 13. 
wdrożenia takich polityk niż te, które niebezpieczeństwa takiego nie wywoływały ${ }^{161}$. W konsekwencji standard należytej staranności uznany został za bezpośrednio proporcjonalny do niebezpieczeństwa powstania szkody, związanego $\mathrm{z}$ daną aktywnością ${ }^{162}$. Przy ocenie poziomu staranności państwa $\mathrm{w}$ danej sytuacji brane więc będą pod uwagę takie kryteria jak skala przedsiębranych działań, ich lokalizacja, szczególne warunki klimatyczne, materiały i środki używane przy realizacji owych działań oraz ewentualne ich konsekwencje. Weryfikacji poddana zostanie także racjonalność i logiczność ciagu przyczynowo-skutkowego, w oparciu o który państwo realizowało działania prewencyjne ${ }^{163}$. Ponadto standard należytej staranności powinien odzwierciedlać znaczenie, jakie ma dla państwa realizacja danej niebezpiecznej działalności oraz jej wartość ekonomiczną, a także uwzględniać środki pozostające w dyspozycji państwa oraz stosowane przez inne państwa $\mathrm{w}$ regionie i na świecie w analogicznych warunkach ${ }^{164}$.

Standard należytej staranności mógł, zdaniem KPM, ulegać zmianie z upływem czasu, podobnie jak treść adekwatnych i racjonalnych procedur, standardów czy regu1 ${ }^{165}$. Obowiązek wykazania należytej staranności zawierał więc także zobowiązanie państwa do śledzenia stanu techniki i aktualnych osiagnięć nauki w danym obszarze. Władze zobowiązane były upewnić się nie tylko, że sprzęt niezbędny do prowadzenia ryzykownych działań spełnia wymogi bezpieczeństwa, ale także, że spełnia najnowsze standardy techniczne i kryteria ich weryfikacji ${ }^{166}$. Elementem polityki prewencyjnej państwa, a więc wypełnieniem zobowiązania do wykazywania należytej staranności, jest także uwzględnienie aktualnych praktyk w danym sektorze działalności, w tym upowszechnianie wiedzy o działaniach prewencyjnych, budowanie wzajemnych zależności pomiędzy partnerami. Działania te powinny być realizowane w skali i na poziomie proporcjonalnym do poziomu technologicznego, naukowego i ekonomicznego państwa ${ }^{167}$. W konsekwencji, podjęcie międzynarodowej współpracy i obowiązek posiadania informacji o aktualnym stanie techniki nie oznaczały bezwzględnego obowiązku implementacji do prawa i praktyki krajowej najnowszych, często kosztownych, technologii analitycznych czy służących minimalizowaniu powstałej szkody, choć przy wprowadzaniu krajowych standardów odzwierciedlających zobowiązanie międzynarodowe do dołożenia należytej staranności, kryteria ustalone przez społeczność międzynarodową powinny stanowić istotny

${ }^{161}$ Raport KPM, 1994 r., U.N. Doc. A/49/10, s. 169; Projekt Barbozy, U.N. Doc. A/51/10,

s. 111; Pierwszy raport Rao, U.N. Doc. A/CN.4/487, s. 21.

162 Pierwszy raport Rao, U.N. Doc. A/CN.4/487, s. 23.

${ }^{163}$ Raport KPM, 1994 r., U.N. Doc. A/49/10, s. 169; Pierwszy raport Rao, U.N. Doc. A/CN.4/487, s. 23.

${ }_{164}$ Pierwszy raport Rao, U.N. Doc. A/CN.4/487, s. 21.

${ }^{165}$ Raport KPM, 1994 r., U.N. Doc. A/49/10, s. 169.

${ }^{166}$ Raport KPM, 1994 r., U.N. Doc. A/49/10, s. 169; Pierwszy raport Rao, U.N. Doc. A/CN.4/487, s. 23.

${ }^{167}$ Pierwszy raport Rao, U.N. Doc. A/CN.4/487, s. 8. 
punkt odniesienia. Jednocześnie Komisja zaznacza, że ocena stopnia odzwierciedlenia tych zobowiązań w treści krajowej legislacji i praktyki zależeć będzie także od poziomu ekonomicznego państwa, jednak ten nie może służyć jako jedyna przesłanka zwolnienia państwa z obowiązku dołożenia należytej staranności, a jest jedynie jednym z czynników branych pod uwagę przy ustalaniu, czy dane państwo dopełniło obowiązku należytej staranności. Obowiązkiem państwa było więc przede wszystkim implementowanie polityki mającej na celu zapobieganie znaczącym szkodom transgranicznym. Jeśli nie było to możliwe, wtedy jego obowiązkiem było próbować minimalizować szkody, gdzie „zminimalizować” oznaczało „realizować cel maksymalnego zmniejszenia możliwości powstania szkody"168. Potwierdzono tym samym, że należyta staranność jest związana z realizacją zasady ciągłego rozwoju, zwłaszcza w kontekście potrzeb państw rozwijających się lub krajów w okresie transformacji gospodarczej. Każde państwo może więc samodzielnie decydować o własnych priorytetach ekonomicznych i odpowiednio wykorzystywać swoje zasoby naturalne ${ }^{169}$. Obowiązek należytej staranności powinien być wykonywany z poszanowaniem prawa państwa do rozwoju, tak jak komplementarne względem siebie są zasady: ciagłego rozwoju i ochrony środowiska naturalnego ${ }^{170}$.

Obowiązek wykazywania należytej staranności przez państwa został ściśle powiązany z koniecznością podejmowania efektywnej współpracy międzynarodowej. Obejmuje ona nie tylko wymianę informacji o aktualnych osiagnięciach technologicznych, ale także obowiązek wymiany i udostępniania informacji o ryzyku znaczącej szkody, przekazywania wiadomości o istnieniu potencjalnych niebezpieczeństw czy konsultowania przedsiębranych działań z potencjalnie poszkodowanymi ${ }^{171}$. Należyta staranność wymaga więc od państw dopełnienia obowiązku informacyjnego rozumianego dwojako. Oznacza on nie tylko wymianę informacji technologicznych na forum organizacji międzynarodowych czy wyspecjalizowanych agend, ale obejmuje także obowiązek niezwłocznego poinformowania potencjalnie poszkodowanych podmiotów. Spoczywa on na państwie, które, w wyniku analizy ryzyka, ustaliło istnienie niebezpieczeństwa powstania znaczącej szkody transgranicznej. Przekaz taki powinien zawierać dane techniczne i inne istotne informacje, na których oparto analizę grożącego ryzyka, w tym aktualne informacje dotyczące zapobiegania lub minimalizowania ryzyka powstania znaczącej szkody transgranicznej. Państwo notyfikujące powinno określić rozsądny okres czasu, w jakim oczekuje odpowiedzi od potencjalnie poszkodowanych. Jeśli po notyfikacji państwo uzyska wiedzę o potencjalnym zagrożeniu dla innych stron, zobowiązane jest także je o nim niezwłocznie poinformować. Obowiązek ten dotyczy wszystkich czynności realizowanych po rozpoczęciu niebezpiecznej aktywności, co potwierdza

\footnotetext{
${ }^{168}$ Projekt Barbozy, U.N. Doc. A/51/10, s. 111.

${ }^{169}$ Trzeci raport Rao, U.N. Doc. A/CN.4/510, s. 11-12.

${ }^{170}$ Trzeci raport Rao, U.N. Doc. A/CN.4/510, s. 12.

${ }^{171}$ Raport KPM, 1993 r., U.N. Doc. A/48/10, s. 24.
} 
wcześniejszą konstatację, iż zobowiązanie do wykazywania należytej staranności jest zobowiązaniem ciagłym ${ }^{172}$. Obowiązek wykazywania należytej staranności nie jest więc realizowany poprzez jednorazowe działanie, ale oznacza zobowiązanie państwa do stałych wysiłków, mających na celu zapobieganie lub minimalizowanie ryzyka szkody transgranicznej, a zwłaszcza obowiązek monitorowania autoryzowanych działań przez cały czas ich wykonywania i przekazywania potencjalnie poszkodowanym informacji o wynikach owych badań, jeśli wskazują one na niebezpieczeństwo powstania znaczącej szkody ${ }^{173}$.

Fakt, iż niektóre przedsięwzięcia okazują się niebezpieczne jedynie wówczas, gdy są realizowane łącznie z innymi przedsięwzięciami, może spowodować rozszerzenie obowiązku informacyjnego na inne obszary aktywności państwa, niż tylko działalność zidentyfikowaną jako niebezpieczna. W takiej sytuacji niezbędny jest otwarty system wymiany informacji oraz szersza analiza ryzyka, obejmująca zarówno skutki działań ryzykownych dla innych państw, a zwłaszcza dla ich środowiska naturalnego, jak i zakres i treść samej niebezpiecznej aktywności. Sytuacja faktyczna może wymagać także, aby analiza ryzyka dotyczyła więcej niż jednego państwa. Stanie się tak na przykład, gdy potencjalnie szkodliwa działalność realizowana będzie wspólnie lub równocześnie przez kilka podmiotów, działających na zlecenie lub z upoważnienia władz różnych państw ${ }^{174}$.

Komisja określa zakres informacji, jakie powinny być wymieniane między państwami. Wskazuje tu na wszystko to, co może okazać się „przydatne” w danych okolicznościach i ma na celu zapobieżenie ryzyku powstania znaczącej szkody ${ }^{175}$. Nie chodzi tu więc jedynie o informacje „niezbędne” czy „konieczne”, ale o wszelkie informacje, które mogą posłużyć do ograniczenia ryzyka powstania znaczącej szkody, o ile ich ujawnienie nie zagraża szeroko pojmowanym interesom państwa informującego. Rozbudowane obowiązki informacyjne nie obejmują konieczności przekazywania danych, które są kluczowe dla obronności i bezpieczeństwa państwowego, ani tych stanowiących tajemnice handlowe. Obowiązek informacyjny względem tego rodzaju przekazów ograniczony jest do konieczności współpracy w dobrej wierze i udostępniania tych informacji, których przekazanie $\mathrm{w}$ danych okolicznościach jest możliwe ${ }^{176}$.

Informacje o potencjalnych zagrożeniach pozostają zazwyczaj w dyspozycji państwa autoryzującego, natomiast jeśli posiada je państwo zagrożone powstaniem szkody, ono także powinno przekazać je państwu, na terytorium którego realizowana jest niebezpieczna działalność. W oparciu o posiadane informacje

${ }^{172}$ Raport KPM, 1994 r., U.N. Doc. A/49/10, s. 172; Projekt Barbozy, U.N. Doc. A/51/10, s. 119.

${ }^{173}$ Raport KPM, 1994 r., U.N. Doc. A/49/10, s. 172; Raport KPM, 1994 r., U.N. Doc. A/49/10, s. 172; Projekt Barbozy, U.N. Doc. A/51/10, art. 14, s. 119.

${ }^{174}$ Pierwszy raport Rao, U.N. Doc. A/CN.4/487, s. 8.

${ }^{175}$ Raport KPM, 1994 r., U.N. Doc. A/49/10, s. 172.

${ }^{176}$ Projekt Barbozy, U.N. Doc. A/51/10, art. 16, s. 119. 
państwa powinny dążyć do dokonania wyboru środków, przy pomocy których będą zapobiegać powstaniu szkód transgranicznych albo minimalizować ich rozmiary ${ }^{177}$.

Obowiązek przekazania informacji o niebezpieczeństwie powstania szkody obejmuje nie tylko władze państw potencjalnie poszkodowanych, ale dotyczy także mieszkańców państwa autoryzującego niebezpieczną działalność, o ile ci zagrożeni są znaczącą szkodą. Przekazana informacja powinna zawierać opis grożącego niebezpieczeństwa oraz potencjalnej szkody, zaś państwo powinno zapoznać się z poglądami mieszkańców, dotyczącymi owego zagrożenia ${ }^{178}$.

Jak wskazano, państwo notyfikujące istnienie niebezpieczeństwa powstania znaczącej szkody transgranicznej może określić rozsądny okres czasu, w jakim oczekuje odpowiedzi od potencjalnie poszkodowanych, celem podjęcia negocjacji właściwego sposobu ograniczania niebezpieczeństwa albo szkód ${ }^{179}$. Należyta staranność oznacza więc także obowiązek podjęcia konsultacji z potencjalnie poszkodowanymi, celem ustalenia właściwych metod prewencji. O ile państwo notyfikujące i państwa potencjalnie poszkodowane zobligowane są wziąć w nich udział, o tyle wolę przystąpienia do konsultacji zgłosić może każde „zainteresowane" państwo. Konsultacje dotyczyć powinny zidentyfikowania właściwych w danej sytuacji środków prewencji oraz sposobów i terminów podjęcia współpracy celem ich implementacji ${ }^{180}$. Wskazówką negocjacyjna, którą kierować się powinny współpracujące państwa, jest wspomniana powyżej zasada równowagi interesów negocjujących. W przypadku fiaska negocjacji państwo notyfikujące istnienie niebezpieczeństwa znaczącej szkody może przystapić do realizacji niebezpiecznego przedsięwzięcia na własne ryzyko, zobligowane jest jednak wziąć pod uwagę interesy innych państw. Komisja nie wskazuje konsekwencji takiej decyzji dla odpowiedzialności owego państwa, pozostawia jedynie innym państwom prawo do niewyrażenia zgody na rozpoczęcie takiej działalności ${ }^{181}$. Nie uzależnia tym samym od zgody innych państw rozpoczęcia niebezpiecznej działalności.

Komisja opisała szczegółowo prawa, jakie przysługują państwu zagrożonemu szkodą transgraniczną ${ }^{182}$. Prawa te przysługują mu także, jeśli nie zostało poinformowane przez państwo pochodzenia o grożącym niebezpieczeństwie. Może ono domagać się wszczęcia konsultacji w oparciu o uzasadnione oceną techniczną przekonanie, że niebezpieczna aktywność jest realizowana na terytorium innego państwa ${ }^{183}$. Powinno jednocześnie przedstawić ocenę techniczną, na podstawie której żywi takie przekonanie. Jeżeli istnieje niebezpieczeństwo znaczącej

${ }^{177}$ Raport KPM, 1994 r., U.N. Doc. A/49/10, s. 172; Projekt Barbozy, U.N. Doc. A/51/10, art. 14, s. 119.

${ }^{178}$ Projekt Barbozy, U.N. Doc. A/51/10, art. 15, s. 119.

${ }^{179}$ Projekt Barbozy, U.N. Doc. A/51/10, art. 13, s. 119.

${ }^{180}$ Projekt Barbozy, U.N. Doc. A/51/10, art. 17, ust. 1, s. 119.

${ }^{181}$ Projekt Barbozy, U.N. Doc. A/51/10, art. 17, ust. 3 s. 119.

182 Projekt Barbozy, U.N. Doc. A/51/10, art. 18, s. 119.

${ }^{183}$ Projekt Barbozy, U.N. Doc. A/51/10, art. 18 ust. 1, s. 119. 
szkody, strona inicjująca procedurę konsultacyjną może domagać się od państwa pochodzenia zwrotu części kosztów wykonania oceny technicznej ${ }^{184}$. Komisja konsekwentnie powstrzymywała się przed określeniem szczegółowych procedur negocjacyjnych, zalecanych $\mathrm{w}$ sytuacji zagrożenia szkodą transgraniczną. Najodważniejszym postulatem była sugestia unikania sporów i zapobiegania im, zaś w przypadku pojawienia się tychże - zobowiązanie do rozwiązywania ich polubownie, zgodnie z ogólnymi zasadami prawa międzynarodowego ${ }^{185}$.

Według interpretacji Komisji, należyta staranność to także nakaz relacji dobrosąsiedzkich, wywodzony z zasady „umiłowania bliźniego”, obejmujący zobowiązanie państw do działań i zaniechań zmierzających do uniknięcia racjonalnie przewidywalnej szkody innego podmiotu ${ }^{186}$.

W toku prac nad odpowiedzialnością międzynarodową Komisja zetknęła się z kilkoma szczególnie kontrowersyjnymi zagadnieniami. Jednym z nich było pytanie o obowiązki państwa pochodzenia w sytuacji, w której znacząca szkoda transgraniczna powstanie, tj. wspomniana już kwestia prewencji post factum, a zwłaszcza pytanie o rolę obowiązku wykazywania należytej staranności po powstaniu szkody ${ }^{187}$. Kompromis $\mathrm{w}$ tej kwestii oznaczał ograniczenie zakresu zobowiązań państw do działań prewencyjnych podejmowanych jedynie przed materializacją niebezpieczeństwa znaczącej szkody transgranicznej. Zagadnienie alokacji strat, tj. roszczeń o zaniechanie szkodliwych działań i restytucję powstałych szkód, Komisja uwzględniła w dokumencie poświęconym obowiązkom reparacyjnym, nie zaś w treści rozważań poświęconych odpowiedzialności międzynarodowej za działania niezabronione prawem międzynarodowym. Przyjęła tym samym wąskie rozumienie zasady prewencji, ograniczając obowiązek należytej staranności wyłącznie do jej aplikacji. W konsekwencji, jak już wspomniano, państwa powinny obligować operatorów niebezpiecznych przedsięwzięć, realizowanych na terytorium podległym ich jurysdykcji, do stosowania wszelkich niezbędnych środków bezpieczeństwa. W tym celu organy państwa powinny wprowadzić odpowiednie przepisy, w tym procedury administracyjne lub inne ${ }^{188}$.

Doprecyzowanie treści standardu należytej staranności oznaczało konieczność określenia konsekwencji jego niedopełnienia. Drugą z kontrowersyjnych kwestii, która ostatecznie nie znalazła miejsca w propozycji Komisji dotyczącej odpowiedzialności międzynarodowej za działania niezakazane prawem międzynarodowym, była odpowiedzialność zastępcza państw. Oznaczałaby ona, że w pewnych okolicznościach państwa ponosiłyby odpowiedzialność za działania podmiotów prywatnych, realizowane na ich terytorium, w ich jurysdykcji lub

\footnotetext{
${ }^{184}$ Projekt Barbozy, U.N. Doc. A/51/10, art. 18 ust. 2, s. 119.

${ }^{185}$ Pierwszy raport Rao, U.N. Doc. A/CN.4/487, s. 13.

${ }^{186}$ Projekt Barbozy, U.N. Doc. A/51/10, s. 111.

${ }^{187}$ Raport KPM, 1994 r., U.N. Doc. A/49/10, s. 153-179.

${ }^{188}$ Raport KPM, 1993 r., U.N. Doc. A/48/10, s. 22.
} 
pod ich kontrolą. Zastrzegając brak zgody państw na stosowanie takiego rozwiązania, Barboza wskazywał, iż możliwe byłoby obciążenie państwa odpowiedzialnością zastępczą za działania osób prywatnych, jeśli jej zakres ograniczony zostałby dwoma warunkami. Po pierwsze, państwo ponosiłoby odpowiedzialność subsydiarna, jeśli wywołanie szkody przez operatora wynikałoby z niewypełnienia przez państwo jego zobowiązań traktatowych. Wysokość potencjalnego odszkodowania, do wypłacenia którego zobowiązane mogłoby zostać państwo, byłaby uzupełnieniem kwoty uiszczonej już przez operatora do pełnej wysokości powstałych szkód. Ten ostatni byłby zaś zobligowany do pokrycia powstałej szkody w wysokości maksymalnie dla niego możliwej. Innymi słowy, odpowiedzialność państwa przywołana mogłaby zostać dopiero w przypadku niewypłacalności operatora szkodliwej działalności ${ }^{189}$. Rozwiązanie to zostało przyjęte w kilku traktatach z zakresu międzynarodowego prawa środowiska, nie znalazło jednak odzwierciedlenia w projekcie ogólnych zasad dotyczących odpowiedzialności międzynarodowej za działania niezakazane prawem międzynarodowym, jako niecieszące się dostatecznie dużym poparciem społeczności międzynarodowej ${ }^{190}$.

Jako bardziej odpowiadającą stanowiskom państw alternatywę dla odpowiedzialności zastępczej Barboza proponował przeniesienie na operatorów całej odpowiedzialności za ewentualne szkody na mocy krajowych przepisów prawa cywilnego, na zasadzie ryzyka obciążając ich odpowiedzialnością za szkody wywołane $\mathrm{w}$ ramach przedsiębiorstwa ${ }^{191}$. Jeśli doszłoby do powstania szkody transgranicznej, operator ponosiłby odpowiedzialność cywilną, zgodnie z przepisami prawa krajowego, zaś państwo powołane mogłoby zostać do międzynarodowej odpowiedzialności za naruszenie obowiązku prewencji. Naruszenie tej traktatowej normy pierwotnej prawa międzynarodowego prowadziłoby do uruchomienia wtórnych reguł międzynarodowej odpowiedzialności państw. Państwa ponosilyby wówczas ewentualną odpowiedzialność za naruszenie pierwotnej normy prawa międzynarodowego, obligującej je do wykazywania należytej staranności przy realizacji zobowiązań międzynarodowych, tj. za brak podjęcia działań prewencyjnych i konsekwencje takiego zaniechania ${ }^{192}$. Państwo poszkodowane miałoby względem państwa niedopełniającego obowiązku prewencji roszczenie o zaprzestanie szkodliwej działalności, roszczenie restytucyjne, kompensacyjne, prawo do żądania satysfakcji i przyrzeczenia powstrzymania się od podobnych szkodliwych zaniechań w przyszłości ${ }^{193}$. W kontekście powyższych rozważań, za naruszenie zobowiązania do wykazania należytej staranności uznana mogłaby zostać zgoda organów państwa na prowadzenie niebezpiecznych

\footnotetext{
${ }^{189}$ Raport KPM, 1994 r., U.N. Doc. A/49/10, s. 155.

${ }^{190}$ Por. szczegółowy opis reżimów kompensacji szkód spowodowanych transportem morskim olejów napędowych, zawarty w rozdz. IV.

${ }^{191}$ Raport KPM, 1994 r., U.N. Doc. A/49/10, s. 155.

192 Projekt Barbozy, U.N. Doc. A/51/10, art. 5 s. 113.

${ }^{193}$ Raport KPM, 1994 r., U.N. Doc. A/49/10, s. 155; Projekt Barbozy, U.N. Doc. A/51/10, art. 5, s. 112 .
} 
przedsięwzięć z pominięciem procedury autoryzacji czy bez zgłoszenia, ewentualnie tolerowanie nieautoryzowanej działalności niebezpiecznej, o której państwo wie lub dokładając należytej staranności mogło się dowiedziećc ${ }^{194}$. Treść obowiązku prewencji staje się coraz łatwiejsza do zidentyfikowania, w miarę jak rośnie wiedza o czynnościach niosących za sobą niebezpieczeństwo szkody transgranicznej, produktów używanych przy ich wykonywaniu czy zarządzaniu procesami na nie się składającymi. Owa pewność i łatwość zidentyfikowania związku przyczynowo-skutkowego pomiędzy realizacją określonych zachowań a szkodliwymi konsekwencjami powoduje, że zapobieżenie szkodzie wymaga podjęcia możliwych do zidentyfikowania, konkretnych działań. Tylko wówczas państwo może wykazać dołożenie należytej staranności i uniknąć przypisania mu odpowiedzialności za naruszenie pierwotnej normy, nakazującej dochowanie reguł prewencji ${ }^{195}$.

Państwo zobowiązane byłoby do działania, kiedy powzięło informację o niebezpiecznej działalności, realizowanej na jego terytorium. Cezura nabycia wiedzy nie mogłaby przy tym być interpretowana jako możliwość pozostawania biernym w oczekiwaniu na przekazanie informacji przez inne państwa lub podmioty prywatne. Odwołanie do niej oznaczało jedynie zobowiązanie do podjęcia racjonalnych wysiłków, realizowanych w dobrej wierze, zmierzających do ustalenia faktu prowadzenia niebezpiecznej działalności bez autoryzacji ${ }^{196}$.

Ta koncepcja dogmatyczna budziła kontrowersje. Przedstawiciele niektórych państw podnosili, że nie sposób określić treści zasady prewencji nie wiedząc, jakie konsekwencje niesie za sobą jej niedopełnienie. Ich zdaniem, niemożliwe było zupełne opisanie zasady prewencji, bowiem najważniejsza konsekwencja jej niedopełnienia - powstanie szkody transgranicznej - wybiegała poza zakres proponowanej regulacji. Nawet jeśli przyjąć, że naruszenie pierwotnego zobowiązania do wykazania należytej staranności pociagnąć mogło za sobą konsekwencje wynikające $\mathrm{z}$ wtórnego reżimu międzynarodowej odpowiedzialności państw, zagadnienie odpowiedzialności międzynarodowej za czyny niezakazane prawem międzynarodowym, stanowiące centralny punkt mandatu Komisji, pozostawało nierozwiązane ${ }^{197}$. Odpierając krytykę, Specjalny Sprawozdawca Rao wskazywał, że od początku prac Komisji przyświecał jej cel uzupełnienia reguł prawa międzynarodowego o zasady odpowiedzialności stosowane w przypadku braku naruszenia międzynarodowego zobowiązania, a także bez konieczności wykazywania winy działającego podmiotu, a jedynie w oparciu o test racjonalności, stosowany względem państwa ${ }^{198}$.

Ten cel został zrealizowany w treści Projektu artykułów o prewencji z 2001 r., w którego centralnym punkcie znalazło się zobowiązanie od wykazywania nale-

\footnotetext{
${ }^{194}$ Raport KPM, 1994 r., U.N. Doc. A/49/10, s. 155.

${ }^{195}$ Pierwszy raport Rao, U.N. Doc. A/CN.4/487, s. 12.

${ }^{196}$ Raport KPM, 1994 r., U.N. Doc. A/49/10, s. 156.

${ }^{197}$ Trzeci raport Rao, U.N. Doc. A/CN.4/510, pkt 17, s. 10.

198 Trzeci raport Rao, U.N. Doc. A/CN.4/510, pkt 31, s. 15.
} 
żytej staranności przy realizacji zobowiązań międzynarodowych. Przedstawiwszy Zgromadzeniu Ogólnemu uzgodniony projekt artykułów dotyczących obowiązku prewencji, Komisja rozpoczęła prace nad zagadnieniem odpowiedzialności międzynarodowej za czyny niebezpieczne, choć niezakazane prawem międzynarodowym, oraz nad problemem alokacji strat, wykonując drugą część udzielonego jej w 1997 r. mandatu. Z prac tych wynika, iż odpowiedzialność na zasadzie ryzyka wywodzona być może, co do zasady, z traktatu zawierającego obowiązek podejmowania działań prewencyjnych z należytą starannością.

Komisja przygotowała raport o zasadach odpowiedzialności międzynarodowej, który przedstawiła podczas 56. sesji KPM w 2004 r. Dotyczył on „odpowiedzialności międzynarodowej za szkodliwe następstwa działań niezakazanych prawem międzynarodowym" i zawierał osiem zasad określających przedmiotową materię ${ }^{199}$. W wyniku prac Komisji w osobnym dokumencie - Projekcie zasad alokacji z 2006 r. - opisana została treść obowiązku kompensacyjnego. Połączenie reżimów dawało, zdaniem Komisji, pełen obraz odpowiedzialności państw za działania niezakazane prawem międzynarodowym. Argumenty te nie odpierały jednak zarzutów krytyków podziału na normy pierwotne i wtórne oraz trudności przy ich praktycznej aplikacji ${ }^{200}$.

Należyta staranność opisywała treść zasady prewencji, ale istotna była także przy ustalaniu istnienia lub zakresu odpowiedzialności odszkodowawczej państwa. Ocena stanu wiedzy o pochodzeniu szkody mogła niekiedy zostać zastąpiona oceną spełnienia kryterium należytej staranności, kiedy to państwo nie miało wiedzy o zdarzeniu, ale dopełniło należytej staranności przy zapobieganiu szkodom transgranicznym, zwalniając się jednocześnie z odpowiedzialności międzynarodowej za naruszenie zobowiązania traktatowego ${ }^{201}$. Innymi słowy, państwo może zwolnić się od międzynarodowej odpowiedzialności za naruszenie normy nakazującej dołożenie należytej staranności przy działaniach prewencyjnych poprzez wykazanie podjęcia określonych czynności wtedy, gdy zrealizowawszy je nie nabyło wiedzy o szkodliwym działaniu lub zaniechaniu, realizowanym w jego jurysdykcji. Czynnością taką będzie np. ciagłe monitorowanie danej niebezpiecznej aktywności oraz podejmowanie wszelkich środków zapobiegawczych, które państwo uzna za konieczne i zasadne (ang. neccesary and feasible) dla ochrony interesów państwa poszkodowanego. Zobowiązania do

${ }^{199}$ Raport grupy roboczej ds. odpowiedzialności międzynarodowej, 2004 r., U.N. Doc. A/CN.4/L.661, s. 1-6. Przedmiotem raportu są reguły „międzynarodowej odpowiedzialności za niezapobieżenie szkodzie międzynarodowej, wynikającej z działań niebezpiecznych”, a więc przede wszystkim zagadnienie kompensacji powstałych już szkód.

${ }^{200}$ Por. dalsza część rozdziału.

${ }^{201}$ Pierwszy raport Rao, U.N. Doc. A/CN.4/487, s. 12. Rao zaznaczył, iż kryterium rzeczywistej wiedzy o źródle potencjalnej szkody zastąpić może ocena należytej staranności przy pozyskiwaniu tejże - państwo ponosić może odpowiedzialność nie tylko, jeśli o potencjalnej szkodzie wie, ale także, jeśli w danych okolicznościach powinno było wiedzieć, dokładając należytej staranności lub zwolnić się z niej, jeśli mimo podjęcia wszelkich racjonalnych kroków nie mogło uzyskać owej wiedzy. Ibidem, s. 263. 
podjęcia środków prewencyjnych podlegają weryfikacji pod kątem dołożenia należytej staranności dopiero wtedy, gdy pojawi się szkoda ${ }^{202}$.

Niedopełnienie obowiązku wprowadzenia stosownej legislacji nie musi oznaczać naruszenia zobowiązania międzynarodowego, ale może skutkować pociagnięciem państwa do odpowiedzialności, jeśli w wyniku owego zaniechania wystapi szkoda $\mathrm{w}$ interesach innego państwa, zwłaszcza szkoda powstała w wyniku działania podmiotów prywatnych w jurysdykcji państwa, które zaniechało wprowadzenia stosownej legislacji ${ }^{203}$. Powyższa analiza dopuszcza, jak się zdaje, pociągnięcie do odpowiedzialności międzynarodowej państwa za niedołożenie należytej staranności, polegające na zaniechaniu wprowadzenia stosownej legislacji także, gdy nie istniała pierwotna norma prawa międzynarodowego nakazująca regulację prawem wewnętrznym określonej, niebezpiecznej działalności, ale jedynie wówczas, gdy owo zaniechanie stało się przyczyną naruszenia interesów innego państwa. Odpowiedzialność za brak jej wprowadzenia wywodzić można bezpośrednio z obowiązku dołożenia należytej staranności, rozumianego jako zobowiązanie do podjęcia działań prewencyjnych oczekiwanych od „dobrego rządu”, jeśli takie zaniechanie pociagnie za sobą powstanie szkody transgranicznej ${ }^{204}$. Jak się wydaje, to ma też na myśli Ehrlich, gdy pisze, iż ,jeżeli państwo ma jakiś obowiązek międzynarodowy, to w myśl zasady dobrej wiary nie może uchylać się od spełnienia tego obowiązku"205.

Jak wspomniano, Komisja odniosła się także do zasad ustalania odszkodowania za powstałą szkodę transgraniczną. Kierowała się przy tym nadrzędnym celem, jakim było zidentyfikowanie zasad reżimu odpowiedzialności odszkodowawczej za szkody transgraniczne. Przyjęła, iż zawsze autoryzowanie niebezpiecznej działalności, powodującej transgraniczne szkody, niesie za sobą obowiązek odszkodowawczy państwa, które ową działalność autoryzowało ${ }^{206}$. Sporna jest kwestia szkody jako warunku koniecznego roszczenia odszkodowawczego,

${ }^{202}$ Pierwszy raport Rao, U.N. Doc. A/CN.4/487, s. 19.

${ }^{203}$ Pierwszy raport Rao, U.N. Doc. A/CN.4/487, s. 23. Tak też pisał w 1958 r. L. Ehrlich, wskazując, iż w braku wyraźnego, odmiennego zobowiązania traktatowego, np. do wprowadzenia krajowej normy prawnej, państwo nie narusza praw innego państwa przez sam fakt nieistnienia w prawie krajowym jakiejś normy, ale czyni to dopiero kiedy działanie lub zaniechanie jego organów narusza prawa drugiego państwa. Por. L. Ehrlich, op.cit., s. 640.

${ }^{204}$ Koncepcja ta znalazła odzwierciedlenie w treści art. 4 rezolucji Instytutu Prawa Międzynarodowego z 1997 r., zatytułowanej „Responsibility and liability under international law for environmental damage", gdzie wskazano, iż państwo może ponosić odpowiedzialność na zasadzie ryzyka, wynikającą z samego faktu powstania szkody. Koncepcja Instytutu idzie nieco dalej niż propozycja KPM, bowiem stanowi, iż zaniechanie wprowadzenia przepisów krajowych zgodnie z międzynarodowymi standardami ochrony środowiska może stać się podstawą odpowiedzialności, nawet jeśli nie będzie uznane za naruszenie prawa miedzynarodowego, ale stanie się źródłem szkody. Por. Instytut Prawa Międzynarodowego, Responsibility and liability under international law for environmental damage, Strasbourg 1997 [online]. IIL [dostęp: 2013-01-20]. Dostępny w Internecie: <http://www.idi-iil.org/idiE/resolutionsE/1997_str_03_en.PDF>. Zob. także: X. Hanquin, op.cit., s. 163 .

${ }^{205}$ Por. L. Ehrlich, Prawo międzynarodowe..., s. 641.

${ }^{206}$ Pierwszy raport Rao, U.N. Doc. A/CN.4/487, s. 8. 
podobnie jak wątpliwości budzi możliwość wysunięcia go w oparciu o naruszenie jedynie interesu prawnego czy moralnego państwa, któremu nie towarzyszy uszczerbek materialny ${ }^{207}$. Potwierdzając istnienie obowiązku odszkodowawczego jako takiego, Komisja pozostawiła państwom sposób ustalenia jego wysokości ${ }^{208}$.

Państwo pochodzenia powinno podjąć negocjacje z państwem poszkodowanym na wniosek którejkolwiek ze stron, zaś w ich toku określić rodzaj i zakres odszkodowania lub innych sposobów kompensacji powstałej szkody transgranicznej. Komisja opracowała natomiast szereg kryteriów, które powinny być brane pod uwage przy prowadzeniu przedmiotowych negocjacji ${ }^{209}$. Zakres odpowiedzialności państwa zależy więc od wykazania przez nie należytej staranności i podjęcia działań prewencyjnych. Należyta staranność uznana jest tu za element dobrej wiary w relacjach dobrosąsiedzkich. Ten czynnik ogranicza odpowiedzialność państwa pochodzenia, gdy po spełnieniu wymogów zasady prewencji podjęło ono dodatkowe środki zapobiegawcze ${ }^{210}$. Komisja podkreśliła jednak, iż obowiązek prewencji ma pierwszeństwo przed zobowiązaniami odszkodowawczymi, bowiem często pełna restytucja szkód powstałych w środowisku naturalnym jest niemożliwa ${ }^{211}$. Niedopełnienie obowiązku dołożenia należytej staranności pociąga więc za sobą konsekwencje prawne, przede wszystkim obowiązki kompensacyjne, nie obejmuje jednak możliwości stosowania sankcji ekonomicznych czy innych ${ }^{212}$.

Mimo iż Komisja przedkładała obowiązek prewencji ponad kwestię odpowiedzialności odszkodowawczej, czyniła odwołania do zasady odpowiedzialności absolutnej, choć ta funkcjonuje w prawie międzynarodowym wyłącznie w oparciu o szczegółowe postanowienia traktatów. Komisja sugerowała możliwość powstania obowiązku kompensacji nawet wówczas, gdy nie sposób wykazać braku należytej staranności państwa. Jeśli szkoda powstała w okolicznościach, w których nawet od ostrożnie działających władz państwowych (ang. a vigilant state) nie można by wymagać jej przewidzenia, zasada słuszności może nakazywać spełnienie przez owo państwo obowiązku restytucji lub uiszczenia odszkodowania, choć ta sama zasada może oznaczać także zwolnienie

${ }^{207}$ Por. W. Czapliński, Odpowiedzialność..., s. 78, 163.

${ }^{208}$ Projekt Barbozy, U.N. Doc. A/51/10, s. 119.

${ }^{209}$ Opisała je w usuniętym z późniejszych wersji projektu art. 22; por.: Projekt Barbozy, U.N. Doc. A/51/10, art. 22. Kryteria te obejmowały m.in. zakres, w jakim państwo pochodzenia dopełniło obowiązku prewencji, zakres wykazanej przez nie należytej staranności, stan jego wiedzy o szkodliwych działaniach realizowanych w jego jurysdykcji lub pod jego kontrolą, lub możliwości jej pozyskania, zyski, jakie państwo czerpało z owych działań, jego udział w zyskach z owej aktywności, skalę pomocy oferowanej państwu pochodzenia lub państwu poszkodowanemu przez państwa trzecie lub organizacje międzynarodowe, zakres racjonalnie możliwej kompensacji szkód osób prywatnych, zakres odszkodowania dostępny poszkodowanym osobom prywatnym według prawa państwa pochodzenia czy zakres ochrony udzielany w podobnych sytuacjach przez państwo poszkodowane osobom prywatnym. Istotne były w myśl owego zapisu także środki, jakie państwo przedsięwzięło dla zapobiegania szkodom.

${ }^{210}$ Projekt Barbozy, U.N. Doc. A/51/10, art. 22, s. 119

${ }^{211}$ Pierwszy raport Rao, U.N. Doc. A/CN.4/487, s. 12.

${ }^{212}$ Pierwszy raport Rao, U.N. Doc. A/CN.4/487, s. 8. 
państwa $\mathrm{z}$ takiego obowiązku ${ }^{213}$. Konstatacjom Komisji wciąż jednak przypisać należy charakter postulatywny, wobec braku zgody państw na uznanie istnienia pozatraktatowej odpowiedzialności absolutnej.

W kontekście omówionych rozważań Komisji, na obowiązek wykazywania przez państwa należytej staranności składają się co najmniej cztery elementy. Należyta staranność oznacza więc taki poziom dbałości o zapobieganie szkodom trangranicznym, jakiego wymagać można od dobrego rządu ${ }^{214}$. Oznacza także konieczność wdrożenia stabilnych gwarancji prawnych i zapewnienia zasobów materialnych umożliwiających realizację zobowiązań międzynarodowych państwa. Spełnienie tego zamierzenia możliwe jest jedynie, gdy państwo zapewnia sprawne funkcjonowanie wydolnego aparatu administracyjnego. Stopień staranności wymagany od państw rozwiniętych jest inny od tego, którego oczekuje się od państw rozwijających się. Względem tych ostatnich wymagany być jednak musi „minimalny poziom czujności” ich organów, zapewnienie sprawnie działającej infrastruktury i monitorowanie działań niebezpiecznych, realizowanych na terytorium państwa. Wymagany poziom należytej staranności musi być proporcjonalny do poziomu niebezpieczeństwa związanego z realizacją danego działania. Obowiązkiem państwa jest także przewidywanie poziomu potencjalnych szkód, generowanych przez niebezpieczną aktywność. Im więc wyższe prawdopodobieństwo powstania znaczącej szkody, tym szerszy zakres działań realizowanych celem zapobieżenia jej, wymaganych od państwa. W szczególności obowiązek ten obejmuje konieczność uzyskania przez podmiot realizujący działalność niebezpieczną wcześniejszego zezwolenia na jej prowadzenie, konieczność dokonywania przez państwo oceny oddziaływania na środowisko i podejmowanie wszystkich niezbędnych i rozsądnych środków ostrożności celem zapobiegania szkodom transgranicznym. Im bardziej niebezpieczne sa realizowane działania, tym wyższa musi być jakość procedur prewencyjnych i staranność przy ich przestrzeganiu. Należyta staranność oznacza także, iż ciężar dowodu wykazania jej dołożenia spoczywa na państwie pochodzenia - to ono musi dowieść, iż jego organy dołożyły należytej staranności w realizowaniu swoich zadañ ${ }^{215}$.

\subsection{Pojęcie szkody transgranicznej}

Jak wskazano w uwagach wstępnych, KPM w toku prowadzonych prac użyła dwóch terminów do określenia „szkody transgranicznej”, zapobieganie której uznała za obowiązek państw. Harm to termin używany dla określenia szkody grożącej, lecz nie powstałej - a więc „szkody ewentualnej”, podczas gdy damage to termin określający faktycznie powstałą, znaczącą "szkodę" wyrządzoną

\footnotetext{
${ }^{213}$ Pierwszy raport Rao, U.N. Doc. A/CN.4/487, s. 12. Podobnie: R. Sonnenfeld, op.cit., s. 22.

${ }^{214}$ Por. X. Hanquin, op.cit., s. 163.

${ }^{215}$ Por.: Trzeci raport Rao, U.N. Doc. A/CN.4/510, s. 10.
} 
ludziom, mieniu lub środowisku naturalnemu ${ }^{216}$. Termin ten obejmował utratę życia lub uszczerbek na zdrowiu, utratę mienia, w tym stanowiącego dziedzictwo kulturowe, uszczerbek w środowisku naturalnym, koszty poniesione $\mathrm{w}$ związku z racjonalnie zastosowanymi środkami restytycji, w tym zasobów naturalnych, jak i koszt podjętych rozsądnych środków reagowania. Komisja wyjaśniała także takie terminy jak ,państwo pochodzenia”, „państwo potencjalnie zagrożone” czy „zainteresowane państwa” oraz „państwo miejsca powstania szkody” i „środki niezbędne do przywrócenia stanu poprzedniego"217. Celem prac Komisji było zapewnienie niezwłocznego i adekwatnego odszkodowania (ang. prompt and adequate compensation) dla ofiar szkód transgranicznych, w tym szkód w środowisku naturalnym ${ }^{218}$. Komisja zidentyfikowała zobowiązanie państw do podjęcia niezbędnych środków w celu zapewnienia niezwłocznego i adekwatnego odszkodowania ofiarom szkód transgranicznych, jeśli szkody te powstały wskutek prowadzenia niebezpiecznej działalności na ich terytorium lub w miejscach będących pod ich jurysdykcją lub kontrolą ${ }^{219}$. W katalogu „niezbędnych środków” KPM umieściła nałożenie odpowiedzialności na operatora lub, jeśli jest to uzasadnione, na inne osoby lub podmioty mocą przepisów prawa wewnętrznego. Odpowiedzialność tych podmiotów nie powinna być oparta o zasadę winy, choć może podlegać prawnie określonym ograniczeniom, jeśli te zbieżne są z celami określonymi przez KPM. „Niezbędne środki” obejmują także obowiązek operatora zapewnienia i posiadania zabezpieczenia finansowego na pokrycie ewentualnych roszczeń odszkodowawczych. Owo zabezpieczenie może przyjąc formę obowiązkowego ubezpieczenia lub innych zabezpieczeń finansowych. W uzasadnionych przypadkach władze państwowe moga wprowadzić obowiązkowo utrzymywane fundusze kompensacyjne, zasilane przez wszystkich przedstawicieli danej gałęzi przemysłu czy podmioty realizujące daną niebezpieczną aktywność. Jednocześnie Komisja wskazała na zobowiązanie państw do zapewnienia dodatkowych środków, jeśli zasoby zgromadzone na podstawie realizacji wcześniejszych dyspozycji okazałyby się niewystarczające. Państwa zobowiązane są także do podjęcia szybkich i skutecznych działań w reakcji na każde potencjalnie niebezpieczne przedsięwzięcie. Działania takie mogą wymagać udziału operatora i mają na celu zminimalizowanie szkód, wynikających z ewentualnego wypadku. Obejmują także szybkie powiadomienie, konsultacje i nawiązanie współpracy z wszystkimi potencjalnie poszkodowanymi podmiotami. Zalecane przez KPM środki zaradcze w przy-

${ }^{216}$ Por. Projekt zasad alokacji z 2006 r., s. 120 oraz uwagi poczynione we wstępie do niniejszego opracowania; zob. też R. Sonnenfeld, op.cit., s. 21-22.

${ }^{217}$ Raport grupy roboczej ds. odpowiedzialności międzynarodowej, 2004 r., U.N. Doc. A/CN.4/L.661, s. 2-3.

${ }^{218}$ Raport grupy roboczej ds. odpowiedzialności międzynarodowej, 2004 r., U.N. Doc. A/CN.4/L.661, s. 3.

${ }^{219}$ Raport grupy roboczej ds. odpowiedzialności międzynarodowej, 2004 r., U.N. Doc. A/CN.4/L.661, s. 3. 
padku wystapienia szkody transgranicznej obejmują wprowadzenie w prawie wewnętrznym skutecznych procedur dochodzenia odszkodowania, w tym procedur zawierających odwołanie do istniejących reżimów międzynarodowych. Realizacja tych procedur spoczywa na sprawnie funkcjonujących krajowych aparatach sądowniczych i administracyjnych o wystarczających kompetencjach. Dostęp do procedur i informacji o nich powinien być równy dla wszystkich poszkodowanych, niezależnie od ich miejsca zamieszkania, siedziby czy formy prawnej ${ }^{220}$. Wdrożenie procedur wspierane może być poprzez równoległy rozwój specjalistycznych międzynarodowych systemów współpracy, zmierzających do naprawiania szkód transgranicznych. Państwa powinny w tym celu wypracowywać umowy międzynarodowe o charakterze powszechnym lub regionalnym, zawierające opis reguł zapobiegania i reagowania na szkody wywołane przez dane kategorie niebezpiecznych działań, system rekompensat i ubezpieczeń. Stronami umów, obok państw, mogłyby być przedsiębiorstwa czy państwowe fundusze kompensacyjne. Taka struktura reżimów traktatowych zapewniłaby poszkodowanym odszkodowanie uzupełniające w przypadku, gdy środki finansowe operatora, $\mathrm{w}$ tym pochodzące $\mathrm{z}$ ubezpieczenia, okazałyby się niewystarczające dla pokrycia szkód powstałych w wyniku wypadku. Zobowiązania państw zidentyfikowane przez KPM obejmowały także obowiązek przyjęcia wszelkich przepisów wykonawczych i administracyjnych, które umożliwiłyby wdrożenie opisanych zasad ${ }^{221}$.

W treści raportu z 2004 r. Rao opisał szczególną postać odpowiedzialności państwa za niedopełnienie obowiązku dołożenia należytej staranności przy zapobieganiu szkodom transgranicznym. Wskazał, że odpowiedzialność za takie zaniechania wywieść można $\mathrm{z}$ norm prawa zwyczajowego ${ }^{222}$. Traktatowe uregulowanie tego rodzaju odpowiedzialności nieznacznie uzupełniałoby istniejące już regulacje ${ }^{223}$. Jednak, jak podnosili przedstawiciele niektórych państw, niesprawiedliwe byłoby przeniesienie odpowiedzialności wynikającej $\mathrm{z}$ traktatowych reżimów odszkodowawczych, a więc z norm pierwotnych, na państwa, w granicach których realizowana była szkodliwa działalność, obligując je do odszkodowania za każdą szkodę transgraniczną przez taką działalność wywołaną skoro zazwyczaj taką działalnością kieruje i zyski z niej czerpie podmiot prywatny, upoważniony przez państwo. $Z$ tych powodów niektórzy uczestnicy obrad KPM podnosili, że odpowiedzialność państwa może być przywołana jedynie jako wyjątek i stosowana zgodnie z treścią nielicznych norm konwencyjnych. Co do zasady więc, szkody powinny być kompensowane przede wszystkim

${ }^{220}$ Raport grupy roboczej ds. odpowiedzialności międzynarodowej, 2004 r., U.N. Doc. A/CN.4/L.661, s. 4-5.

${ }^{221}$ Raport grupy roboczej ds. odpowiedzialności międzynarodowej, 2004 r., U.N. Doc. A/CN.4/L.661, s. 5.

222 Podobnie: P. Okowa, op. cit., s. 60-62.

${ }^{223}$ Drugi raport Rao, U.N. Doc. A/CN.4/501, s. 9. 
przez operatora niebezpiecznej działalności lub wspólnie przez niego i inne, współpracujące $\mathrm{z}$ nim, podmioty ${ }^{224}$. Po dziś dzień model odpowiedzialności przedsiębiorców na zasadzie ryzyka dominuje w traktatowych reżimach dotyczących odpowiedzialności za szkody transgraniczne. Wyrażano jednak także zdanie przeciwne: jeśli za przewodnią zasadę uznać regułę odpowiedzialności na zasadzie ryzyka, państwa powinny być zobowiązane do samodzielnego opracowania reguł alokacji strat i mechanizmów ich kompensacji. Niektórzy uczestnicy dyskusji optowali wręcz za połączeniem odpowiedzialności operatora na zasadzie ryzyka z częściowym obowiązkiem kompensacyjnym państw, bowiem przerzucenie całości obowiązku odszkodowawczego na operatorów mogło okazać się niewystarczające do pokrycia powstałych strat. Włączenie państw w reżim odpowiedzialności wydawało się uzasadnione ze względu na wymaganą od państwa zgodę na podjęcie potencjalnie niebezpiecznej aktywności i niosło dla niego choćby pośrednie korzyści. Także dlatego pierwszeństwo przyznano obowiązkowi niepozostawiania ofiary szkody trangranicznej bez pomocy. Zaproponowano, aby państwo autoryzujące niebezpieczną działalność było zobowiązane do dołożenia wszelkich starań celem wprowadzenia przepisów mających na celu zapobieganie powstawaniu niekompensowanych strat i skuteczną egzekucję świadczeń odszkodowawczych ${ }^{225}$. Te rozważania zdecydowały o ostatecznym kształcie zaproponowanej zasady dotyczącej dostępności procedur odszkodowawczych. Państwa miałyby być zobowiązane do zapewnienia dostępności natychmiastowych, adekwatnych i skutecznych środków zaradczych wszystkim ofiarom szkód transgranicznych spowodowanych realizacją niebezpiecznych działań oraz do informacji o nich, bez względu na pochodzenie czy status poszkodowanego. Zobowiązanie to obejmowało także wyposażenie sądów krajowych $\mathrm{w}$ uprawnienia niezbędne do rozpatrywania roszczeń o odszkodowanie $^{226}$.

Podsumowaniem prac Komisji było przyjęcie podczas drugiego czytania tekstu Projektu zasad alokacji z 2006 r. Stanowił on uzupełnienie Projektu artykułów o prewencji z 2001 r. i dopełnienie mandatu Komisji z 1997 r. Na mocy art. 23 Statutu KPM wezwała ona Zgromadzenie Ogólne do nadania mocy projektowi poprzez przyjęcie go w formie rezolucji, zachęcając (ang. urge) państwa do implementacji jego zapisów ${ }^{227}$. Podjęcie tematu międzynarodowej odpowiedzialności za czyny niezakazane prawem międzynarodowym Zgromadzenie Ogólne zaplanowało na obrady 68. sesji, w 2013 roku. Wtedy zapozna się z uwagami państw i wezwie KPM do ustosunkowania się do nich.

${ }^{224}$ Drugi raport Rao, U.N. Doc. A/CN.4/501, s. 9-10.

${ }^{225}$ Drugi raport Rao, U.N. Doc. A/CN.4/501, s. 10-11. Ta reguła znalazła odzwierciedlenie w treści art. 3 Projektu zasad alokacji z 2006 r.

${ }^{226}$ Drugi raport Rao, U.N. Doc. A/CN.4/501, s. 30.

${ }^{227}$ Zgromadzenie Ogólne przychyliło się do sugestii Komisji, przyjmując 4 grudnia 2006 r. rezolucję 61/36. 


\subsection{Krytyka metodologii KPM}

Zamierzony przez KPM podział reżimów odpowiedzialności oparty o koncepcję zobowiązań pierwotnych i wtórnych poddany został uzasadnionej krytyce jako niejasny i niemożliwy do konsekwentnego wdrożenia. Jak już wspomniano, Komisja Prawa Międzynarodowego opisała oba reżimy odpowiedzialności w szeregu dokumentów. Ich pierwsza, także historycznie, część dotyczyła odpowiedzialności państw za działania zakazane prawem międzynarodowym, podczas gdy druga odwoływała się do zaczerpniętej z prawa cywilnego odpowiedzialności na zasadzie ryzyka i opisywała odpowiedzialność międzynarodową za szkody wywołane przez działania niezakazane prawem międzynarodowym. Badania nad odpowiedzialnością państw podsumowano w omówionym powyżej Projekcie artykułów o odpowiedzialności państw z 2001 r. Zasady odpowiedzialności międzynarodowej za czyny niezakazane prawem międzynarodowym opisano pięć lat później w treści Projektu zasad alokacji z 2006 r. Te dwa dokumenty stanowią podsumowanie stanu debaty toczącej się od 1949 r., dotyczącej granic odpowiedzialności w prawie międzynarodowym. Reżim odpowiedzialności międzynarodowej, opisany w raportach KPM, obejmuje więc dwie grupy reguł: reżim odpowiedzialności państwa za czyny sprzeczne z ich międzynarodowymi zobowiązaniami oraz reżim konstytuujący odpowiedzialność międzynarodową za działania niezakazane prawem międzynarodowym. O ile jednak pierwszy z nich został potwierdzony w treści Rezolucji Zgromadzenia Ogólnego i odczytywany jako trafna interpretacja norm zwyczajowych, o tyle drugi jest przedmiotem krytyki doktryny i brak mu poparcia przedstawicieli państw. Jak wskazano powyżej, drugi z wymienionych porządków oparty jest o zasadę prewencji, której treść stanowi międzynarodowy standard należytej staranności, uzupełniany zaś przez sekwencję reguł odszkodowawczych, opisujących zasady rekompensowania szkód powstałych wskutek jej niedołożenia. KPM w raportach podkreśla dychotomiczny charakter podziału obu reżimów odpowiedzialności, który spotyka się z zasadną, surową krytyką doktryny.

Boyle opiera swoją obszerną krytykę prac Komisji o niezasadność przyjętego przez nią podziału reżimów odpowiedzialności. Identyfikuje, za Oppenheimem i KPM, odpowiedzialność międzynarodową za działania niezakazane prawem miedzynarodowym jako zespół norm „pierwotnych”. Normy te składają się m.in. na treść międzynarodowego prawa środowiska, obejmując zasady przezorności czy prewencji ${ }^{228}$. Odpowiedzialność według norm „wtórnych” przywołana może być jedynie wtedy, gdy państwo nie dopełni wymagań opisanych w treści norm pierwotnych ${ }^{229}$. Innymi słowy, współczesny, zwyczajowy reżim odpowiedzialności międzynarodowej za czyny niezakazane prawem międzynarodowym, opisany przez KPM, oparty został na zasadzie ryzyka, wywodzonej z analizowanych przez Komisję traktatów. W jego treści zawarte zostało pierwotne

\footnotetext{
${ }^{228}$ Podobnie: P. N. Okowa, op.cit., s. 83-84.

${ }^{229}$ A. E. Boyle, State Responsibility..., s. 15-16.
} 
zobowiązanie państw do wynagrodzenia szkód ponadgranicznych, powstałych wskutek naruszenia reguł ostrożności, jak też do współpracy międzynarodowej przy zapobieganiu takim szkodom ${ }^{230}$. Jednocześnie, pierwotnie zaproponowany przez KPM zespół norm, dotyczących międzynarodowej odpowiedzialności za czyny niezakazane prawem międzynarodowym, nie zawierał żadnego odwołania do instrumentów odwetowych czy sankcji za naruszenie zobowiązań opisanych w ich treści ${ }^{231}$, zaś te opisane w licznych porozumieniach dwu- i wielostronnych często pozostawały nieskuteczne ${ }^{232}$. Idąc za głosem krytyków oraz korzystając z dorobku miękkiego prawa międzynarodowego, Komisja włączyła do treści Projektu zasad alokacji z 2006 r. trzy instrumenty dyscyplinowania państw nieprzestrzegających opisanych $\mathrm{w}$ treści dokumentu zobowiązañ ${ }^{233}$. Państwa takie zobowiązane być miały do kompensacji powstałej szkody transgranicznej oraz do podjęcia środków zaradczych, ograniczających jej rozmiary ${ }^{234}$. Trzecim instrumentem, który przywołać mogły państwa poszkodowane, było odwołanie bezpośrednio do reżimu „wtórnego" - międzynarodowej odpowiedzialności państw za czyn niedozwolony ${ }^{235}$. Reżim „wtórnej” odpowiedzialności państw znajdzie zastosowanie względem tych państw, które nie dopełnią „pierwotnego” obowiązku zapobiegania szkodliwym skutkom lub zadośćuczynienia powstałej szkodzie, opisanych przez KPM odpowiednio w projektach z: 2001 i 2006 r.

Boyle trafnie wskazuje, że reżimy te nie mogą być postrzegane niezależnie od siebie i ze swej natury pozostają ściśle związane ${ }^{236}$. Podaje w wątpliwość zasadność i konieczność wyróżnienia odrębnych porządków odpowiedzialności

${ }^{230}$ Por.: Projekt artykułów o prewencji z 2001 r., zas. 3. Istnienie owej zwyczajowej zasady poddawane było w wątpliwość w polskiej literaturze przedmiotu, por. np.: R. Sonnenfeld, op.cit., s. 25, która pisze iż państwa nie godzą się generalnie na uznanie odpowiedzialności za działania prawnie niezakazane. Ale por.: M. M. Kenig-Witkowska, Międzynarodowe..., s. 141-142, która pisze: ,przeważa koncepcja obiektywnej odpowiedzialności za szkodę o charakterze transgranicznym, która jest wynikiem zaniedbania lub braku należytej staranności, złamania postanowień umownych albo dopuszczenia się aktu zabronionego przez prawo międzynarodowe", łącząc normy odpowiedzialności międzynarodowej, uznane przez KPM za „pierwotne” i „wtórne”.

${ }^{231}$ Zaproponowany pierwotnie przez grupę roboczą ds. odpowiedzialności międzynarodowej art. 21, dotyczący „natury i zakresu kompensacji” został ostatecznie usunięty z treści Projektu artykułów o odpowiedzialności międzynarodowej z 1998 r.

${ }^{232}$ Por.: T. Gehring, M. Jachtenfuchs, op.cit., s. 104-107, którzy wskazują na liczne niedociagnięcia istniejących reżimów traktatowych oraz na kłopoty z ich implemetnacją.

${ }^{233}$ Por. np.: F. Orrego Vicuña, Responsibility and Liability under International Law for Environmental Damage, Instytut Prawa Międzynarodowego 1997. Komisja czerpała z propozycji artykułów o odpowiedzialności, zawartej w treści owego opracowania. Art. 1 owego projektu stanowi iż, „naruszenie zobowiązania do ochrony środowiska, ustanowione mocą norm prawa międzynarodowego, niesie ze sobą odpowiedzialność państwa (odpowiedzialność międzynarodową) oraz obowiązek przywrócenia stanu pierwotnego albo wypłaty odszkodowania."

${ }^{234}$ Projekt zasad alokacji z 2006 r., zas. 3 i 5.

${ }^{235}$ Projekt zasad alokacji z 2006 r., s. 118. KPM wskazuje tak, iż projekt dotyczy norm pierwotnych. Niedopełnienie obowiązku prewencji, zapisanego w jego treści, kwalifikowane być może, niezależnie od cywilnej odpowiedzialności operatora, jako naruszenie przez państwo zobowiązania pierwotnego, niosąc za sobą międzynarodową odpowiedzialność państwa, opartą o normy wtórne.

${ }^{236}$ Por. A. E. Boyle, State Responsibility..., s. 21-24. 
w prawie międzynarodowym ${ }^{237}$. Jak słusznie argumentuje, odpowiedzialność państwa za naruszenie prawa międzynarodowego, a więc odpowiedzialność oparta na zasadach wtórnych, przywołana może być jedynie wtedy, gdy możliwe jest zidentyfikowanie pierwotnej normy prawa międzynarodowego, której naruszenia dopuściło się państwo. Jednocześnie reżim odpowiedzialności międzynarodowej za działania niezakazane prawem międzynarodowym to lex imperfecta - istniejące reżimy traktatowe nie nakładają na państwa ogólnego obowiązku prewencji, choć taki wywodzony może być z norm prawa zwyczajowego. Prace Komisji dość długo nie obejmowały w ogóle problematyki odpowiedzialności państwa za szkodę powstałą wskutek niedołżenia należytej staranności, ale opisywane w raportach od 2004 r. konsekwencje naruszenia zarówno reguł ostrożności, jak i sprowadzenia transgranicznej szkody nawiązują wprost do reżimu odpowiedzialności międzynarodowej państw. Jak słusznie wskazują Boyle i Dupuy ${ }^{238}$, reguły odpowiedzialności międzynarodowej za działania niezakazane prawem międzynarodowym opisuja pewne zobowiązania międzynarodowe państw, dotyczące zarówno obowiązku zapobiegania powstaniu transgranicznych szkód, jak i reguły odszkodowania za szkody, którym zapobiec się nie udało. Ten „pierwotny” zbiór reguł może być przywołany celem wskazania treści zobowiązania, za naruszenie którego państwo może być pociagnięte do międzynarodowej odpowiedzialności. Skrupulatnie wytyczony przez KPM podział oparty miał być o kryterium charakteru czynu państwa, stanowiącego podstawę odpowiedzialności. Jeśli państwu można było przypisać ${ }^{239}$ naruszenie ciążącego na nim zobowiązania międzynarodowego, może ono zostać pociaggnięte do odpowiedzialności i stać się adresatem środków odwetowych, opisanych $\mathrm{w}$ treści Projektu artykułów o odpowiedzialności państw z $2001 \mathrm{r}^{240}$ Komisja w treści projektu nie precyzuje, jakiego rodzaju naruszenia prawa są jego przedmiotem. Opisuje jedynie istniejące, powszechne zasady, które stosowane są przez międzynarodową społeczność na podstawie zwyczaju lub traktatu w odpowiedzi na naruszenie międzynarodowych zobowiązań. Rao potwierdził, w treści raportów dotyczących odpowiedzialności za czyny niezakazane prawem międzynarodowym, zwyczajowy charakter obowiązków: prewencji i kompensacji, których niedopełnienie wywołać może odpowiedzialność za naruszenie normy prawa międzynarodowego w myśl Projektu artykułów o odpowiedzialności państw z 2001 r. O ile więc prace Komisji nad zasadami odpowiedzialności międzynarodowej przyczyniły się do sprecyzowania treści owych reguł zwyczajowych, o tyle nie wydaje się konieczne nadawanie im formy traktatu celem

${ }^{237}$ Ibidem, s. 1.

238 Por. P.M. Dupuy, Reviewing the Difficulties of Codification: On Ago's Classification of Obligations of Means and Obligations of Result in Relation to State Responsibility, European Journal of International Law 1999, vol. 10, nr 2, s. 371-385.

${ }^{239}$ Kwestia przypisania odpowiedzialności państwu, zagadnienia jurysdykcyjne oraz następcze uznanie działania jednostki omówione zostały poniżej.

${ }^{240}$ Por. Projekt artykułów o odpowiedzialności państw z 2001 r., art. 28 i n. Zagadnienie omówione szczegółowo w rozdz. VI. 
wyposażenia ich w moc prawną. Naruszenie zwyczajowego obowiązku prewencji, przede wszystkim poprzez brak należytej staranności $\mathrm{w}$ jego realizacji, przejawiający się zaniechaniem organów państwa, spowoduje odpowiedzialność tego państwa na mocy reguł „wtórnych”, czyniąc oba zaproponowane przez KPM reżimy ściśle ze sobą połączonymi ${ }^{241}$. Jak pisze Boyle, cytując Brownliego, podział na działania „zakazane” i „niezakazane” jest „fundamentalnie błędny”, bowiem to treść danego zobowiązania pozwala zdecydować o ocenie czynu państwa jako bezprawnego, a „ogólne rozróżnienie na czyny bezprawne i zgodne z prawem międzynarodowym jest bezużyteczne" ${ }^{242}$. Ze względu na wskazaną powyżej zależność obu zbiorów norm, reżim odpowiedzialności państw za naruszenie prawa międzynarodowego może być przywołany zawsze w sytuacji naruszenia „pierwotnych” reguł, w tym reguł opisanych przez KPM jako zasady odpowiedzialności międzynarodowej, i jako taki pozostaje z nim koniecznie związany. Rozdzielenie reżimów odpowiedzialności dokonane przez KPM już na tym etapie analizy uznać więc można za nieuzasadnione.

Co więcej, podział zaproponowany przez KPM zawiera dwa elementy, które uznać należy za wspólne dla obu - zdaniem KPM rozłącznych - zbiorów zasad odpowiedzialności. Pierwsza kwestia to rola szkody transgranicznej w ustalaniu zakresu i charakteru odpowiedzialności państwa. Druga dotyczy możliwości przypisania mu szkody.

Szkoda powstała lub ewentualna jest istotna dla ustalenia odpowiedzialności państwa mimo, iż Komisja zdecydowała nie włączać owego pojęcia do katalogu przesłanek międzynarodowej odpowiedzialności państwa za naruszenie prawa międzynarodowego ${ }^{243}$. Za wystarczające dla powstania takiej odpowiedzialności uznała naruszenie istniejącego zobowiązania międzynarodowego, niezależnie od tego, czy naruszenie to wywołało szkodę $\mathrm{w}$ chronionych prawem interesach innych stron $^{244}$. Jednocześnie wskazała wystapienie szkody, w tym szkody ewentualnej, jako konieczny element odpowiedzialności międzynarodowej państwa za akt sprzeczny z prawem międzynarodowym, jeśli warunek jej powstania wynika z treści naruszonego zobowiązania „pierwotnego”. Zazwyczaj warunek powstania szkody zawierają zobowiązania do zapobiegania określonym zdarzeniom, a więc zobowiązania o charakterze prewencyjnym, w odróżnieniu od zobowiązań skutkowych do osiagnnięcia określonego rezultatu. W przypadku naruszenia tych pierwszych podstawą odpowiedzialności będzie

${ }^{241}$ Por. A. E. Boyle, State Responsibility..., s. 11.

${ }^{242}$ Ibidem, s. 13. Podobnie twierdzi Dupuy, który pisze: „to co jest legalne dziś, może okazać się nielegalne jutro lub być w trakcie stawania się nielegalnym”, P. Dupuy, The International..., s. 116.

${ }^{243}$ Projekt artykułów o odpowiedzialności państw z 2001 r., art. 2, s. 36.

${ }^{244}$ Por.: Projekt artykułów o odpowiedzialności państw z 2001 r., art. 31, s. 92, gdzie Komisja wyjaśnia, iż szkoda może być postrzegana jako konieczny element naruszenia, wskazany w treści naruszanej normy pierwotnej, jednak o ile $\mathrm{z}$ treści normy wynika jedynie zobowiązanie do zapobiegania danemu zdarzeniu lub wprowadzenia określonych przepisów krajowych, zaniechanie podjęcia owych działań skutkować będzie odpowiedzialnością państwa za działanie sprzeczne z normą międzynarodową mimo braku szkody. 
zazwyczaj zaniechanie organów państwa. Oznacza to, że jeśli z treści spoczywającego na państwie pierwotnego zobowiązania międzynarodowego wynika obowiązek zapobiegania określonym szkodliwym skutkom, np. poprzez podjęcie określonych działań legislacyjnych czy prewencyjnych, to powstała lub ewentualna szkoda jest warunkiem koniecznym pociągnięcia państwa do odpowiedzialności międzynarodowej, opisanej przy pomocy reguł wtórnych.

Wyłączenie szkody z katalogu przesłanek odpowiedzialności państwa, jednak uwzględnienie pojemnego, bowiem obejmującego szereg reżimów traktatowych, obowiązku prewencji wnikającego z prawa zwyczajowego, uznać należy za mankament formułowanej przez Komisję propozycji rozdzielenia dwóch reżimów odpowiedzialności. Podział taki jawi się bowiem praktycznie niemożliwy do przeprowadzenia ${ }^{245}$.

Normy zwyczajowe, dotyczące odpowiedzialności międzynarodowej za działania niezakazane prawem międzynarodowym i opisane przez KPM w projektach z 2001 i 2006 r., uznać można za przykład takiego właśnie, pojemnego wyjątku. Zgodnie $\mathrm{z}$ opisem zawartych $\mathrm{w}$ nim reguł niezpobieżenie szkodom $\mathrm{w}$ chronionych prawem interesach innych państw może, choć nie musi, być warunkiem odpowiedzialności międzynarodowej, jeśli państwo, które dopuściło do powstania szkody, nie dołożyło należytej staranności przy zapobieganiu jej. $Z$ treści owych reguł wynika bowiem zobowiązanie do dołożenia wszelkich starań celem zapobiegania szkodom transgranicznym. Jeśli więc powstaniu szkody towarzyszył brak należytej staranności, państwo ponosić będzie odpowiedzialność.

Punktem wyjścia do zidentyfikowania treści reguł tego reżimu, wywodzonego z norm międzynarodowego prawa środowiska, są konsekwencje działań niezakazanych prawem międzynarodowym. Zgodnie z tymi zasadami, szkoda ponadgraniczna może być podstawą traktatowej odpowiedzialności „za stworzone ryzyko" ${ }^{246}$, jeśli nie towarzyszyły jej powstaniu wyjątkowe okoliczności, zwalniające państwo z obowiązku kompensacji, opisane w poszczególnych reżimach traktatowych. Choć Komisja podkreśla dychotomiczny charakter zidentyfikowanych reżimów odpowiedzialności w prawie międzynarodowym, ich opisana powyżej współzależność uznawana jest przez doktrynę za istotny mankament tej dogmatycznej propozycji ${ }^{247}$.

${ }^{245}$ Projekt artykułów o odpowiedzialności państw z 2001 r., s. 38, gdzie KPM odwołuje się do wyroku w sprawie zakładników w Teheranie. Por. A. E. Boyle, State Responsibility..., s. 21, gdzie autor przedstawia ten argument dla uzasadnienia krytyki podziału zaproponowanego przez Komisję. Wskazuje, że w tym kontekście pojęcie przypisania odpowiedzialności, opisane w art. 2 Projektu jest wystarczające.

${ }^{246}$ Por.: Projekt zasad alokacji z 2006 r., s. 155, gdzie KPM przywołuje termin responsabilité pour risqué crée, opisujący odpowiedzialność na zasadzie ryzyka, jako równoznaczny z liability without fault. Ten sam stan faktyczny opisuja także terminy: ang. negligence without fault (fr. responsabilité sans faute), ang. presumed responsibility, ang. fault per se, czy ang. objective liability (fr. responsabilité objective).

${ }^{247}$ A. E. Boyle, State Responsibility..., s. 13, popierając Brownliego, podobnie: P. Malańczuk, Akehurst's..., s. 13). Choć Rao wskazuje Brownliego jako zwolennika zaproponowanej przez siebie koncepcji odpowiedzialności państwa za szczególnie niebezpieczne przedsięwzięcia niezakazane prawem międzynarodowym, por. Trzeci raport Rao, U.N. Doc. A/CN.4/510, s. 14. 
Drugi problem w praktycznym stosowaniu tych wzajemnie zależnych reżimów dotyczy identyfikacji państwa, któremu przypisać można naruszenie normy prawa międzynarodowego, o którym mowa w Projekcie artykułów o odpowiedzialności państw z 2001 r. i państwa pochodzenia szkody, według reguł opisanych w Projekcie zasad alokacji z 2006 r. Problem stanowi tu kwestia przypisania szkodliwego działania lub zaniechania państwu, które to przypisanie oparte jest o zawarte w Projekcie zasad alokacji z 2006 r. definicje „terytorium”, ,jurysdykcji” i „kontroli” państwa ${ }^{248}$. Komisja celowo unikała tu odwołania to pojęcia „przypisania”, podstawowego dla odpowiedzialności międzynarodowej państw, chcąc podkreślić odrębność obu porządków prawnych. Pytanie, jakie rodzi się z zestawienia tych dwóch konstrukcji teoretycznych, dotyczy możliwości pociągnięcia państwa do odpowiedzialności za naruszenie zobowiązania międzynarodowego, zgodnie z treścią projektu z 2001 r., gdy nie dopełniło ono „pierwotnych” obowiązków zapobiegania szkodom ponadgranicznym i odmawia poniesienia odpowiedzialności odszkodowawczej, według reguł opisanych w wiążących je traktatach. Jak trafnie wskazuje Boyle, KPM usiłowała uniknąć problemów terminologicznych odchodząc od używania terminu „przypisanie” w pracach dotyczących odpowiedzialności za działania niezakazane prawem międzynarodowym $^{249}$. Dlatego też Projekt zasad alokacji z 2006 r. nie zawiera odniesienia do „przypisania” i po rozważeniu wielu propozycji ${ }^{250}$ KPM wskazuje jako podstawy tej kategorii międzynarodowej odpowiedzialności kryteria ,jurysdykcji”, ,terytorium” i „kontroli”.

Ustalić więc należy, czy możliwość przypisania państwu odpowiedzialności za czyn międzynarodowo bezprawny w myśl Projektu artykułów o odpowiedzialności państw z 2001 r. koniecznie oznacza sprawowanie przez państwo władztwa nad terytorium, wykonywanie jurysdykcji czy kontroli, zgodnie z zapisami Projektu zasad alokacji z 2006 r. oraz rozważyć wzajemną relację obu tych kryteriów.

Kluczem do udzielenia odpowiedzi na tak postawione pytanie jest ocena należytej staranności, wymaganej zarówno w działaniach podejmowanych przez „państwo pochodzenia” celem zapobieżenia powstaniu transgranicznych szkód, jak i przywoływana $w$ reżimie odpowiedzialności państw za działania międzynarodowo bezprawne, kiedy mowa o „przypisaniu” państwu odpowiedzialności za zaniechanie.

KPM definiuje „państwo pochodzenia” jako państwo z terytorium którego, w jurysdykcji którego lub pod kontrolą którego są realizowane niebezpieczne

${ }^{248}$ Te trzy kryteria są przedmiotem szczegółowej analizy w rozdziale kolejnym.

${ }^{249}$ A. E. Boyle, State Responsibility..., s. 21. Ten sam autor przypomina jednak także, że ta dystynkcja pojęciowa pojawiła się dopiero w efekcie krytyki prac KPM po przedstawieniu Projektu artykułów o odpowiedzialności międzynarodowej z 1998 r. Ibidem.

${ }^{250}$ A. E. Boyle, State Responsibility..., s. 21 odnosi się do koncepcji „,przypisania zobowiązań” państwu, zastosowanej w art. 3 wersji projektu z 1986 r., ostatecznie zastapionej pojęciem ,państwa pochodzenia" w art. 2 Projektu artykułów o odpowiedzialności międzynarodowej z 1998 r., U.N. Doc. A/53/10. 
działania (ang. hazardous activities) ${ }^{251}$. Komisja wskazuje więc odpowiedzialność międzynarodową państwa za czyny niezakazane prawem międzynarodowym jako pochodną co najmniej jednej z tych trzech form wykonywania suwerennych uprawnień i zalecając poszukiwanie kompromisu przez strony, które wskazując inne, rozbieżne podstawy wykonywania jurysdykcji, znajdą się $\mathrm{w}$ sporze $\mathrm{e}^{252}$. Obok odwołania do znanych prawu międzynarodowemu zasad jurysdykcji, Komisja wskazuje pojęcie „kontroli” państwa jako ostatnie możliwe kryterium identyfikowania „państwa pochodzenia" ${ }^{\text {253 }}$. Podstawa ta ma być używana wtedy, gdy państwo wykonuje swoje uprawnienia, nie mając jednak do tego podstawy znanej prawu międzynarodowemu, np. w przypadku zbrojnej interwencji, okupacji czy bezprawnego zajęcia terytorium ${ }^{254}$.

Jednocześnie $\mathrm{z}$ natury omawianego reżimu i zawartego $\mathrm{w}$ nim obowiązku prewencji odpowiedzialność za czyny niezakazane prawem międzynarodowym powiązana jest nie tyle $\mathrm{z}$ działaniem państwa, co przede wszystkim $\mathrm{z}$ jego zaniechaniem, o czym była już tu mowa. Powstaje w przypadku uchybienia przez państwo obowiązkowi prewencji poprzez niestaranne sprawowanie władzy, kontroli lub wykonywanie jurysdykcji nad podmiotami podejmującymi działania niebezpieczne ${ }^{255}$. Aby państwa mogły uczynić zadość temu obowiązkowi, prawo międzynarodowe obliguje je przede wszystkim do zachowania monopolu na autoryzowanie niebezpiecznych przedsięwzięcéc ${ }^{256}$. Aby ocenić, czy państwa dopełniły obowiązków zapobiegania szkodom transgranicznym, treść obowiązku dokładania należytej staranności musi zostać określona w każdej indywidualnej sprawie, z uwzględnieniem elementów opisanych przez KPM podczas prac nad zasadami prewencji i to na podstawie tak sporządzonego wzorca „dobrego rządu” może zostać ustalona ewentualna odpowiedzialność państwa za uchybienie powszech-

${ }^{251}$ Projekt zasad alokacji z 2006 r., art. 2 (d). W treści zas. 2 „działalność niebezpieczna” jest definiowana jako „działalność niosąca ryzyko powstania znaczącej szkody”. Pojęcie znaczącej szkody omówiono w rozdziale kolejnym.

${ }^{252}$ Projekt artykułów o odpowiedzialności międzynarodowej z 1998 r., U.N. Doc. A/53/10; podobnie: Projekt artykułów o prewencji z 2001 r., s. 151.

${ }^{253}$ Zob.: Projekt artykułów o odpowiedzialności międzynarodowej z 1998 r., U.N. Doc. A/53/10, gdzie KPM wskazywała łącznik terytorialny jako najważniejszy przy ustalaniu odpowiedzialności międzynarodowej, ale por.: Projekt artykułów o prewencji z 2001 r., s. 150 i Projekt zasad alokacji z 2006 r., komentarz (10), s. 120, które potwierdzają odejście od zasady jurysdykcji terytorialnej jako podstawy odpowiedzialności państwa. Komisja zrównała wszystkie trzy podstawy odpowiedzialności jako tak samo ważne.

${ }^{254}$ Projekt artykułów o odpowiedzialności międzynarodowej z 1998 r., U.N. Doc. A/53/10, s. 25. Analogicznie: Projekt artykułów o prewencji z 2001 r., s. 151, cytowany w treści Projektu zasad alokacji z 2006 r., s. 134.

${ }^{255}$ Jak wspomniano, obowiązek prewencji zawarty został pierwotnie w treści art. 3 Projektu artykułów o odpowiedzialności międzynarodowej z 1998 r., U.N. Doc. A/53/10. Nakładał na państwa zobowiązanie do podjęcia wszelkich odpowiednich działań (ang. all appropriate measures) celem zapobiegania lub ograniczenia ryzyka znaczącej szkody transgranicznej. Szczegóły owego zobowiązania opisane zostały w treści Projektu artykułów o prewencji z $2001 \mathrm{r}$.

${ }_{256}$ Projekt artykułów o odpowiedzialności międzynarodowej z 1998 r., U.N. Doc. A/53/10, art. 7; Projekt artykułów o prewencji z 2001 r., art. 6. 
nemu obowiązkowi prewencji ${ }^{257}$. Kryterium ,jurysdykcji” lub „kontroli” przydatne jest więc przy ustalaniu treści obowiązku prewencji w konkretnej sprawie, którego naruszenie może być przypisane państwu. Treścią obowiązku prewencji jest, jak wskazywano, zobowiązanie do wykazywania należytej stranności przy zapobieganiu szkodom transgranicznym.

Oceniając odpowiedzialność państwa za szkodę transgraniczną, wynikającą $\mathrm{z}$ aktywności niezakazanych prawem międzynarodowym, test należytej staranności zawierający schemat właściwego postępowania jest ustalany na podstawie treści obowiązków państwa. Państwo pociagnnięte może zostać do odpowiedzialności za brak należytej staranności przy ich wypełnianiu. Zachowania konstytuujące należytą staranność wynikają więc z treści międzynarodowego zobowiązania do podjęcia określonego działania, a więc z treści zobowiązania pierwotnego. Jeśli ów pierwotny reżim przewiduje prawne konsekwencje braku należytej staranności, co ma miejsce rzadko - te zostaną zastosowane. Jeśli konsekwencji takich brak lub ich wyegzekwowanie okaże się niemożliwe, zastosowanie mogą znaleźć ogólne zasady odpowiedzialności międzynarodowej. Zaniechanie sprzeczne $\mathrm{z}$ treścią międzynarodowego zobowiązania do podjęcia określonego działania uznane być może za naruszenie prawa międzynarodowego, skutkujące odpowiedzialnością państwa na zasadach określonych przez KPM w Projekcie artykułów o odpowiedzialności państw z 2001 r. Ocena zaniechania jako podstawy międzynarodowej odpowiedzialności państwa zależeć będzie od możliwości przypisania mu konkretnego zaniechania zgodnie z jurysprudencją międzynarodowych trybunałów, wypracowaną choćby $\mathrm{w}$ sprawach Tadiča i contras.

Oznacza to, że zasada należytej staranności służy weryfikacji odpowiedzialności międzynarodowej za działania niezakazane prawem międzynarodowym, w oparciu o elementy konkretnego zobowiązania, jak również do ustalenia odpowiedzialności państwa za działania je naruszające. Niedopełnienie obowiązku prewencji, a więc brak należytej staranności przy zapobieganiu znaczącym szkodom transgranicznym, stać się może zarówno podstawą odpowiedzialności międzynarodowej według zapisów poszczególnych traktatów, jak i odpowiedzialności państwa za naruszenie zwyczajowego zobowiązania międzynarodowego. Analizując ten sam stan faktyczny zbadać należy nie tylko naruszenie obowiązku kontroli działań realizowanych na terytorium czy w jurysdykcji państwa, opisanego w treści Projektu zasad alokacji z 2006 r., ale także możliwość przypisania odpowiedzialności państwu na podstawie Projektu artykułów o odpowiedzialności państw z $2001 \mathrm{r}$.

Celem przypisania odpowiedzialności państwu niezbędne jest ustalenie istnienia zobowiązania międzynarodowego, którego niedopełnienie uznane być może za naruszenie prawa międzynarodowego. Jedynie jeśli na podstawie treści

${ }^{257}$ Tak też np.: G. Handl, Liability as an Obligation Established by a Primary Rule of International Law, Netherlands Yearbook of International Law 1985, nr 16, s. 53-54; 57-58; A. E. Boyle, State..., s. 20-21. 
nakazującej normy prawa międzynarodowego uda się ustalić zakres obowiązku państwa, którego niedopełnienie uznane być może za naruszenie międzynarodowego zobowiązania, możliwe będzie zastosowanie „wtórnego" reżimu odpowiedzialności państwa.

Jeśli na podstawie przepisów konstytuujących obowiązek działania zaniechanie może być uznane za naruszenie prawa międzynarodowego, zastosowanie znajdzie reżim odpowiedzialności państwa za czyny sprzeczne z prawem międzynarodowym $^{258}$. Jeśli jednak istnienia lub treści normy obligującej państwo do konkretnego działania nie uda się ustalić albo niespełnienie jej dyspozycji nie zostanie uznane za naruszenie prawa międzynarodowego, np. w przypadku działania siły wyższej, konsekwencje przewidziane reżimem opisanym w Projekcie artykułów o odpowiedzialności państw z 2001 r. nie znajdą zastosowania. Znaleźć je mogą wówczas jedynie ewentualne konsekwencje przewidziane w reżimie pierwotnym. Według treści Projektu zasad alokacji z 2006 r. przesłanka przypisania uzupełniana jest o łącznik jurysdykcyjny i kryterium kontroli państwa nad operatorami niebezpiecznych przedsięwzięć. W przypadku szkodliwych konsekwencji czynów niezakazanych prawem międzynarodowym przypisanie państwu odpowiedzialności możliwe będzie jedynie wobec zaniechań organów państwa, na którym spoczywa obowiązek prewencji. Oznacza to, że kryteria jurysdykcji i kontroli dotyczące odpowiedzialności za czyny niezakazane prawem międzynarodowym są ściśle powiązane, tj. stanowią uzupełnienie kryterium przypisania, opisanego $\mathrm{w}$ art. 2 Projektu artykułów o odpowiedzialności państw z $2001 \mathrm{r}$.

Powyższa konstatacja implikuje, że szkoda transgraniczna wynikać może z dwóch rodzajów sytuacji. Po pierwsze, może być skutkiem zaniechania, które przypisać można państwu niewypełniającemu ciążących na nim zobowiązań międzynarodowych. Jeśli szkodliwe zaniechanie będzie sprzeczne z prawem międzynarodowym, państwo zostanie pociągnięte do odpowiedzialności za naruszenie prawa międzynarodowego.

Szkoda transgraniczna może być także następstwem czynów, które nie są sprzeczne $\mathrm{z}$ prawem międzynarodowym, $\mathrm{tj}$. powstać także pomimo dopełnienia obowiązku prewencji. Wówczas zastosowanie znajdą zapisy konwencji szczegółowych, ewentualnie prawa zwyczajowego, opisane w treści Projektu artykułów o prewencji z 2001 r., takie jak nakładające na państwa obowiązek podjęcia negocjacji czy uiszczenia odszkodowania.

Obie kategorie zdarzeń oceniane będą przy użyciu jednego standardu należytej staranności, jednak nieść ze sobą będą różne konsekwencje. Jeśli szkodliwy skutek, występujący poza granicami państwa, wynika z niebezpiecznej działalności, autoryzowanej i kontrolowanej przez państwo, państwo to może być

${ }^{258}$ Przykładem służyć tu może reżim zamknięty międzynarodowego prawa środowiska, choć nawet $\mathrm{w}$ jego treści nie każda norma opisana została w sposób dostatecznie precyzyjny; por.: P. N. Okowa, op.cit., s. 60-61 i traktatowe zasady odpowiedzialności za zanieczyszczenia środowiska naturalnego, które w znacznej mierze uzupełniane być muszą przez praktykę zwyczajową. 
pociagnięte do odpowiedzialności ,szczątkowej” lub absolutej, przy czym tej ostatniej zawsze na mocy traktatu ${ }^{259}$. Jeśli jednak uda się przypisać mu odpowiedzialność za zaniechanie dopełnienia obowiązku, wynikającego z tak skonstruowanego reżimu „pierwotnego" ${ }^{260}$, przywołać można skutecznie odpowiedzialność za działanie międzynarodowo bezprawne, jako „wtórną” względem obowiązku prewencji i kontroli ${ }^{261}$.

W obu sytuacjach, zobowiązanie państwa do zapobiegania szkodzie transgranicznej oceniane będzie przy użyciu tego samego standardu należytej staranności, który uznać należy za kluczowy dla oceny odpowiedzialności państwa za zaniechanie. Mimo iż treść zobowiązania do dochowania należytej staranności zawsze zależeć będzie od okoliczności konkretnej sprawy, podstawowe cechy tego elastycznego instrumentu prawa międzynarodowego zidentyfikowane zostały w pracach KPM poświęconych odpowiedzialności międzynarodowej za czyny niezakazane prawem międzynarodowym ${ }^{262}$. Rozróżnienie zobowiązań międzynarodowych na „pierwotne” i „wtórne” dokonane przez Komisję, jest

${ }^{259}$ Shaw uważa, że na obecnym etapie rozwoju prawa międzynarodowego odpowiedzialność państwa na zasadzie ryzyka byłaby zbyt trudna do wyegzekwowania poza reżimami traktatowymi, nawet w przypadku powstania faktycznej szkody, por.: M. N. Shaw, Prawo..., s. 451. Innego zdania są autorzy publikacji dotyczących międzynarodowego prawa środowiska, którzy przywołują obecną ich zdaniem w prawie międzynarodowym zasadę odpowiedzialności za ryzyko wywołania szkody (ang. principle of risk-creation liability); por. np. P. W. Birnie, A. E. Boyle, C. Redgwell, op.cit., s. 212; G. Hafner, I. Buffard, Obligations of Prevention and the Precautionary Principle, (w:) The Law of International Responsibility, red. J. Crawford, A. Pellet, S. Olleson, Oksford 2010, s. 521.

${ }^{260}$ Wśród zobowiązań pierwotnych Shaw wymienia obowiązek wprowadzenia odpowiedniej legislacji krajowej, dotyczącej np. toksycznych emisji z terytorium państwa. Państwo ponosiło będzie odpowiedzialność za przekroczenie ich określonego, kumulatywnego poziomu przez podmioty działającego w jego granicach, niezależnie od oceny decyzji organów państwa, dotyczących indywidualnych operatorów. Por.: M. N. Shaw, Prawo..., s 453.

${ }^{261}$ Taka zależność potwierdzona została w treści Projektu zasad alokacji z 2006 r., w komentarzu (6) do Zasady 1, s. 118. Znalazła się także w treści art. 4 rezolucji Instytutu Prawa Międzynarodowego z 1997 r., zatytułowanego „odpowiedzialność za samo ryzyko powstania szkody” (ang. responsibility for harm alone). Zapis ten stanowi, iż „reguły prawa międzynarodowego mogą stanowić o zastosowaniu odpowiedzialności państwa na zasadzie ryzyka na podstawie powstania samego ryzyka wywołania szkody. (...) Niedopełnienie obowiązku wprowadzenia odpowiednich reguł i mechanizmów kontroli zgodnych z reżimami środowiskowymi, nawet jeśli nie doprowadzi do powstania naruszenia owego zobowiązania, może powodować powstanie odpowiedzialności państwa, jeśli konsewkencją owego niedopełnienia obowiązków będzie powstanie ryzyka szkody, w tym powstanie samej szkody spowodowanej przez podmioty działające w jego jurysdykcji". Por.: The Institute of International Law, Resolution on Responsibility and Liability under International Law for Environmental Damage, Review of European Community \& International Environmental Law 1998, Vol. 7, nr 1, s. 99-102.

${ }^{262}$ Bodansky podnosi, że analizując tę konstrukcję można upierać się, że wina i szkoda stanowić mogą elementy odpowiedzialności międzynarodowej państw, bowiem uwzględniane są przy dokonywaniu przypisania naruszenia normy pierwotnej i jako takie stanowić mogą elementy normy „wtórnej”. Jednocześnie możliwość przypisania państwu odpowiedzialności stanowi kryterium kluczowe dla identyfikacji treści normy pierwotnej, bowiem bez uwzględnienia tego kryterium, nie może być mowy o egzekucji owego ,pierwotnego" międzynarodowego zobowiązania. Por.: D. M. Bodansky, J. R. Crook, op.cit., s. 780. 
złudne. Komisja odpierała argumenty tej treści wskazując, że wąski zakres odpowiedzialności państw, oparty o konstrukcję przypisania, rozszerzony może zostać poprzez poszerzanie treści zobowiązań pierwotnych ${ }^{263}$. Przeciwstawiając przesłankę szkody przesłance przypisania odpowiedzialności wskazywała, że w treści Projektu artykułów o odpowiedzialności państw z 2001 r. nie wspomniano o pierwszej $\mathrm{z}$ nich, jako że stanowi ona ewentualny element norm pierwotnych $^{264}$.

Specjalny Sprawozdawca Rao wyjaśniał, że Komisji przyszło zmierzyć się z wyzwaniem prawnej kwalifikacji zaniechania skutkującego szkodą transgraniczną przy badaniach nad odpowiedzialnością państwa ${ }^{265}$. Nie było jasne, czy powinno ono być kwalifikowane jako działanie zakazane prawem międzynarodowym $^{266}$. Dlatego też Komisja zdecydowała pozostawić do osobnego opracowania kwestię zobowiązania państwa do naprawienia szkód transgranicznych wynikających $\mathrm{z}$ działalności pozostających $\mathrm{w}$ jego gestii lub wykonywanych w miejscach pod jego kontrolą ${ }^{267}$. Rao wskazuje, że w punkcie wyjścia do rozważań nad odpowiedzialnością za szkodę transgraniczną leżały dwie konstatacje. Odpowiedzialność państwa dotyczy naruszenia „subiektywnego uprawnienia międzynarodowego" (ang. subjective international right) także wtedy, gdy naruszenie nie wiąże się z powstaniem szkody ${ }^{268}$. Jednocześnie, odpowiedzialność międzynarodowa wynika z wystapienia znaczącej szkody faktycznej lub ewentualnej, nie zaś z faktu naruszenia przez państwo międzynarodowego zobowiązania czy ingerencji w ,subiektywne międzynarodowe uprawnienie innego państwa" ${ }^{\text {269 }}$. Reżim odpowiedzialności międzynarodowej za czyny niezakazane może, zdaniem KPM, obejmować pewne działania nieopisane w treści norm prawa międzynarodowego, dlatego też Komisja unikała określania tych okoliczności jako „zgodnych z prawem”, używając w zamian terminu „czyny

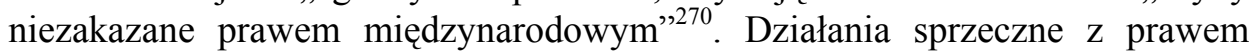

${ }^{263}$ Ibidem.

${ }^{264}$ Ibid., s. 781.

265 Trzeci raport Rao, U.N. Doc. A/CN.4/510, s. 11, pkt 25. Rao cytuje tam Drugi raport Ago, gdzie ten opisuje zagadnienie odpowiedzialności międzynarodowej jako odnoszące się do „odpowiedzialności państwa wynikającej z działań zgodnych z prawem, (...) opartej o zupełnie inne zasady odpowiedzialności, tzw. odpowiedzialności na zasadzie ryzyka". Por. też.: J. Crawford, The ILC's Articles on Responsibility of States for Internationally Wrongful Acts: A Retrospect, American Journal of International Law 2002, nr 96, s. 876.

${ }^{266}$ Por.: Raport KPM, 2000 r., U.N. Doc. A/55/10, s. 11, pkt 25

${ }^{267}$ Por.: Raport KPM, 2000 r., U.N. Doc. A/55/10, s. 11, pkt 25

${ }^{268}$ Por.: Raport KPM, 2000 r., U.N. Doc. A/55/10, s. 12; R. Wolfrum, Internationally Wrongful Acts, (w:) Encyclopedia of Public International Law, red. R. Bernhardt, P. Macalister-Smith, Amsterdam 1995, s. 271-277. Zob. także K. Zemanek, op.cit., s. 319-333.

${ }^{269}$ Por.: Raport KPM, 2000 r., U.N. Doc. A/55/10, s. 12, pkt 27 przyp. 44; Pierwszy raport Rao, U.N. Doc. A/CN.4/487, paragrafy 41-44, s. 16.

${ }^{270}$ Por.: Raport KPM, 2000 r., U.N. Doc. A/55/10, s. 12, pkt 27 przyp. 45. Liczni autorzy kwestionują podział, zaproponowany przez KPM, por. np.: A. E. Boyle, State Responsibility..., s. 1-25, który podaje w wątpliwość zasadność dystynkcji reżimów odpowiedzialności w prawie międzynarodowym. T. A. Berwick, Responsibility and Liability for Environmental Damage: 
międzynarodowym są więc przedmiotem badań nad odpowiedzialnością państw, podczas gdy zagadnienie odszkodowania za szkody transgraniczne pozostaje przedmiotem badań nad odpowiedzialnością międzynarodową ${ }^{271}$. Zagadnienie prewencji dotyczy tymczasem zarządzania ryzykiem ${ }^{272}$. Odpowiadając na pytanie o wzajemną zależność pomiędzy odwołaniem do działań niezakazanych prawem międzynarodowym a wyróżnianym w jego kontekście zasadom prewencji wskazuje, że w prawie międzynarodowym niewiele jest aktywności „zakazanych" jako takich ${ }^{273}$. Problem powiązany z tak dobraną terminologia polega na tym, że dopiero skutki każdej aktywności pozwalają określić jej charakter, tj. ustalić, czy składające się na nią działania są dozwolone, czy zakaza$\mathrm{ne}^{274}$. Podziału tego dokonują same państwa poprzez praktykę traktatową czy zwyczajową, tworząc normy pierwotne. W tym kontekście podział aktywności państwa na „zgodne” i ,niezgodne” z prawem międzynarodowym jawi się jako bezzasadny ${ }^{275}$.

Zaproponowany w toku prac Komisji podział może służyć w międzynarodowej praktyce wytyczaniu granicy pomiędzy wąskim obszarem odpowiedzialności państw a szerokim zakresem odpowiedzialności międzynarodowej, w której kluczową rolę odgrywają zasady prewencji. Podział ten niesie za sobą rozróżnienie na „czyny” (ang. acts) i „działania” (ang. activities). Jak wyjaśniał Barboza, wokół jednego działania wskazać można wiele pojedynczych czynów, ściśle z nim powiązanych. Niektóre z nich mogą być bezprawne, ale nie determinują one charakteru działania jako bezprawnego lub nie ${ }^{276}$. Międzynarodowy konsensus dotyczył więc zakazu realizowania określonych działań (np. testów nuklearnych w atmosferze czy aktów agresji), podczas gdy przedmiotem odpowiedzialności międzynarodowej stać się mogły ich konsekwencje lub przyczyny $^{277}$. Rao konstatuje, że tak przeprowadzony podział oznacza, iż roszczenia

A Roadmap for International Environmental Regimes, Georgetown International Environmental Law Review 1988, nr X, s. 257-267; S. Sucharitkul, State Responsibility and Liability in Transnational Relations, (w:) Theory of International Law at the Thres Hold of the 21st Century: Essays in Honour of Krzysztof Skubiszewski, red. J. Makarczyk, Haga 1996, s. 283-299; S. Sucharitkul, State Responsibility and International Liability under International Law, Loyola Los Angeles International \& Comparative Law Review 1996, nr 18, s. 821-839.

${ }^{271}$ Por.: Raport KPM, 2000 r., U.N. Doc. A/55/10, s. 12, pkt 27.

${ }^{272}$ Por.: Raport KPM, 2000 r., U.N. Doc. A/55/10, s. 12, pkt 27.

${ }^{273}$ Por.: Raport KPM, 2000 r., U.N. Doc. A/55/10, s. 12, pkt 28.

${ }^{274}$ Por.: Raport KPM, 2000 r., U.N. Doc. A/55/10, s. 12, pkt 28.

${ }^{275}$ Por.: Raport KPM, 2000 r., U.N. Doc. A/55/10, s. 12. Tak pisze m.in. Brownlie, por.: I. Brownlie, State Responsibility..., s. 22 i 50, gdzie autor przychyla się do poglądu, iż działania państw pozostają przedmiotem Projektu artykułów o odpowiedzialności państw z 2001 r., ale dopuszcza możliwość przywołania owych norm przy naruszeniach związanych z przedsięwzięciami niosącymi ze sobą niebezpieczeństwo szkody transgranicznej.

${ }^{276}$ Por.: Raport KPM, 2000 r., U.N. Doc. A/55/10, s. 12.

277 Por.: Raport KPM, 2000 r., U.N. Doc. A/55/10, s. 12. Por.: D. B. Magraw, Transboundary harm: The International Law Commission's Study of International Liability, American Journal of International Law 1986, nr 80, s. 305-330. Macgraw przyznaje rację Brownliemu, gdy ten proponuje rozłączne badanie owych dwóch porządków prawnych, rządzących odpowiedzialnością w prawie międzynarodowym. 
wynikające z niedopełnienia obowiązku prewencji i braku należytej staranności nie stanowia podstawy do uznania danego działania za niezgodne $\mathrm{z}$ prawem międzynarodowym lub zakazane ${ }^{278}$. Pozwala on jedynie państwom potencjalnie poszkodowanym skutecznie nalegać na realizację owych obowiązków i zaniechanie niebezpiecznych działałań, jeśli nie zostały one poprzedzone odpowiednimi środkami ostrożności ${ }^{279}$. Odpowiedzialność państwa może więc być skutecznie przywoływana celem implementacji zobowiązań międzynarodowych, w tym cywilno-prawnego obowiązku odszkodowania spoczywającego na podmiocie prywatnym ${ }^{280}$. Niezasadne jest utożsamianie odpowiedzialności za czyn niezgodny z prawem międzynarodowym $\mathrm{z}$ zakazem podejmowania określonych działań, który miałby wynikać z prawa międzynarodowego. Podział zaproponowany przez komisję nie ma, zdaniem Rao, oznaczać konieczności kwalifikacji danego działania jako zgodnego albo niezgodnego $\mathrm{z}$ prawem międzynarodowym. Istnieje bowiem, jego zdaniem, możliwość równoważenia korzyści i strat wynikających z każdej społecznie pożytecznej działalności. Decydująca będzie tu bowiem treść danej normy prawa międzynarodowego i absolutny lub względny charakter zawartego $\mathrm{w}$ jej treści zobowiązania. W przypadku orzeczenia w sprawie huty w Trail, zakazane zostało powodowanie szkód, nie zaś samo podejmowanie działalności owe szkody generującej ${ }^{281}$.

Zwyczajowy reżim odpowiedzialności międzynarodowej, opisany przez KPM, jest przydatny dla uzupełnienia treścią poszczególnych zobowiązań pierwotnych, zawierających obowiązek prewencji, ale jednocześnie jest nierozłącznie związany z odpowiedzialnością państw za czyny sprzeczne z prawem międzynarodowym, co omówione zostanie w rozdziale kolejnym.

${ }^{278}$ Por.: Raport KPM, 2000 r., U.N. Doc. A/55/10, s. 12

${ }^{279}$ Por.: Raport KPM, 2000 r., U.N. Doc. A/55/10, s. 12. Por.: Drugi raport Rao, U.N. Doc. A/CN.4/501, s. 11.

${ }^{280}$ Por.: Raport KPM, 2000 r., U.N. Doc. A/55/10, s. 12. Por.: A. Rosas, State Responsibility and Liability under Civil Liability Regimes, (w:) Current International Law Issues: Nordic Perspectives. Essays in honour of Jerzy Sztucki, red. O. Bring, S. Mahmoudi, Dordrecht 1994, s, 161-163, który uznaje dwa rezimy odpowiedzialności w prawie międzynarodowym za uzupełniające się, raczej niż odrebne; por. też: A. Rosas, Z. Brodecki, State Liability for Transboundary Environmental Damage, Kopenhaga 1990, s. 1-15.

${ }^{281}$ Por.: Raport KPM, 2000 r., U.N. Doc. A/55/10, s. 12. 


\section{Rozdzial V}

\section{NALEŻYTA STARANNOŚĆ W REŻIMACH TRAKTATOWYCH}

\subsection{Uwagi wstępne}

Jak wskazano w rozdziale poprzednim, należyta staranność stanowi treść zasady prewencji. Wywodzona jest z zasady dobrego sąsiedztwa, opisującej granice suwerenności państw, korzystających z własnych zasobów naturalnych ${ }^{1}$. Zasada dobrego sąsiedztwa znalazła swoje odzwierciedlenie w treści zasady 21 Deklaracji sztokholmskiej i została powtórzona w treści zasady 2 Deklaracji z Rio ${ }^{2}$.

Jednocześnie na mocy traktatów obowiązujących w wielu obszarach prawa międzynarodowego, wystapienie transgranicznej szkody może skutkować pociągnięciem państwa do odpowiedzialności na zasadzie ryzyka, jeśli podmioty prywatne, działające w jego jurysdykcji lub pod jego kontrolą, nie byłyby w stanie ponieść kosztów odszkodowania ${ }^{3}$. Tak opisany mechanizm odszkodowawczy abstrahuje od ewentualnego naruszenia przez państwa obowiązku wykazania ostrożności, które to naruszenie skutkowałoby odpowiedzialnością państwa na mocy norm wtórnych. W przypadku tak rozumianej zastępczej odpowiedzialności

${ }^{1}$ Zob.: M. M. Kenig-Witkowska, Międzynarodowe prawo..., s. 118, gdzie autorka przywołuje opinię doradczą MTS w sprawie legalności użycia broni jądrowej jako potwierdzenie zwyczajowego statusu zasady 21 Deklaracji sztokholmskiej. Zob. także: P. N. Okowa, op.cit., s. 79.

${ }^{2}$ Pojawia się również w licznych dokumentach prawa Unii Europejskiej, np. w treści art. 3 dyrektywy Rady 80/779/EWG z dnia 15 lipca 1980 r. w sprawie dopuszczalnych i zalecanych wartości jakości powietrza dla dwutlenku siarki i pyłów zawieszonych. Dz.U. L z 30.8.1980, nr 299, str. 30., którego ust. 1 stanowi: „Państwa Członkowskie podejmują właściwe środki zapewniające, że począwszy od dnia 1 kwietnia 1983 r. stężenia dwutlenku siarki i zawieszonych w powietrzu cząstek stałych nie będą przekraczać wartości dopuszczalnych podanych w załączniku I (...)”.

${ }^{3}$ Zgodnie z definicją zawartą w Projekcie zasad alokacji z 2006 r, gdzie zasada 4 przewiduje prawo do „niezwłocznego i odpowiedniego odszkodowania” przysługujące ofiarom szkód transgranicznych, wyrządzonych przez niebezpieczne działania (pkt 1). Odszkodowanie takie uiszczone być powinno przez przedsiębiorcę realizującego działalność powodującą szkodę (pkt 2). Państwa winny wymagać od operatorów działań generujących ryzyko ustanowienia i utrzymania finansowego zabezpieczenia dla pokrycia roszczeń odszkodowawczych (pkt 3), w tym tworzenie branżowych funduszów kompensacyjnych na szczeblu krajowym (pkt 4). Jeżeli jednak środki w funduszach okazałyby się niewystarczające "do naprawienia szkody, państwo pochodzenia powinno zapewnić dodatkowe zasoby finansowe" (pkt 5). Jak pisze Sonnenfeld, państwo ma tu więc rolę „ubezpieczyciela”, działającego dopiero w sytuacji, gdy szkoda nastąpi; por. R. Sonnenfeld, op.cit., s. 25. Zob. także: T. Gehring, M. Jachtenfuchs, op.cit., s. 99. 
międzynarodowej państwa, wywodzonej z traktatu, jego odpowiedzialność odszkodowawcza względem poszkodowanych jest niezależna od działań lub zaniechań jego organów. Reżimy traktatowe konstytuują więc podstawy odpowiedzialności na zasadzie ryzyka, zaś w wyjątkowych sytuacjach wymagają od państw odpowiedzialności absolutnej, jak np. w przypadku prawa kosmicznego ${ }^{4}$.

Niedołożenie należytej staranności może natomiast, jak wskazano w rozdziale poprzednim, świadczyć o naruszeniu międzynarodowego obowiązku prewencji. KPM opisała mechanizm rozwiązywania sporów międzypaństwowych, dotyczących zaistnienia czy treści obowiązku prewencji, zachęcając państwa pozostające $\mathrm{w}$ sporze do podjęcia negocjacji lub skorzystania $\mathrm{z}$ innych metod pokojowego rozwiązywania sporów, znanych prawu międzynarodowemu, celem zidentyfikowania takiego obowiązku lub ustalenia jego treści. Jako podstawowy sposób rozwiązywania sporów projekt przywołuje komisje śledcze, w skład których wchodzić powinni przedstawiciele spierających się stron oraz reprezentanci uzgodnionej przez nich, neutralnej strony trzeciej. W wyniku przeprowadzonych czynności komisja przedstawić powinna raport, przyjęty większością głosów jej członków, który to raport nie ma mocy wiążącej dla państw-stron sporu. Jeśli ta metoda pokojowego rozwiązywania sporów okazałaby się nieskuteczna, tj. zaproponowane rozwiązanie zostałoby odrzucone przez którąkolwiek ze stron lub okazało się niemożliwe do zrealizowania z powodu np. braku dobrej woli stron, mogą być brane pod uwagę inne metody pokojowego rozwiązywania sporów, w tym arbitraż czy postępowanie sądowe ${ }^{5}$. W toku postępowania sądowego zbadany zostać powinien poziom wykazanej staranności, jeśli zaś badanie wykaże, iż poziom ów był zbyt niski, konsekwencją może być międzynarodowa odpowiedzialność państwa zgodnie $\mathrm{z}$ treścią Projektu artykułów o odpowiedzialności państwa z $2001 \mathrm{r}$. Ocena ta dokonywana będzie z uwzględnieniem poziomu niebezpieczeństwa lub szkody faktycznie zaistniałej, w ślad za rozważaniami KPM dotyczącymi pojęcia znaczącej szkody transgranicznej ${ }^{6}$. „Znaczące” niebezpieczeństwo powstania szkody oznacza „zagrożenie rzeczywistymi, szkodliwymi konsekwencjami dla zdrowia ludzi, przemysłu, praw własności, środowiska czy rolnictwa innych państw", mierzalnymi poprzez odniesienie do faktycznych, obiektywnych standardów ${ }^{7}$. Ów „szkodliwy” charakter działania może być przedmiotem sporów ekspertów, przez co stanowić trudność przy ocenie sądowej. Jak wskazuje się w doktrynie, pojęcie „znaczącej” szkody, mimo iż wszechstronnie zdefiniowane w szeregu aktów prawa międzynarodowego, w implementacji napotyka praktyczne trudności ${ }^{8}$. Praktyka traktatowa

\footnotetext{
${ }^{4}$ Por. R. Sonnenfeld, op.cit., s. 25.

${ }^{5}$ Projekt artykułów o prewencji, 2001 r., art. 19.

${ }^{6}$ Por.: rozdz. IV powyżej.

${ }^{7}$ Projekt artykułów o prewencji z 2001 r., komentarz (4) do art. 2, s. 152.

${ }^{8}$ Por.: np.: A. Trouwborst, Precautionary Rights and Duties of States, Haga 2006, s. 44-52. P. W. Birnie, A. E. Boyle, C. Redgwell, op.cit., s. 152-153. Ci ostatni autorzy porównują orzeczenie w sprawie huty w Trail, z którego wywodzą obowiązek starannej kontroli w sytuacji prawodopodo-
} 
często odnosi się do pojęcia „najlepszych dostępnych technologii”, których użyć powinno państwo wykazujące należytą staranność przy analizie ryzyka lub zapobieganiu niebezpieczeństwom ${ }^{9}$, czy do „najnowszych osiagnięć technologicznych", wykorzystywanych celem zapobiegania i eliminacji zanieczyszczenia środowiska naturalnego, jako wpisujących się w ten sam standard ${ }^{10}$. KPM celowo nadała tworzonym definicjom elastyczny charakter, pozostawiając decyzje co do charakteru grożącej szkody w znacznej mierze w rękach sędziego, oceniającego konkretną sytuację faktyczną, ponieważ „ocena musi być dokonana z uwzględnieniem specyfiki każdej konkretnej sytuacji. Wymaga to przede wszystkim uwzględnienia okoliczności faktycznych, raczej niż kwalifikacji prawnej." 11

Realizacja zasady należytej staranności jest kluczowa dla wdrożenia norm wymagających od państw podjęcia określonych działań - realizacji ich pozytywnych obowiązków. Kiedy uda się ustalić treść zasady w danej sytuacji, rozstrzygać można kwestię wypełnienia przez państwo obowiązków zawartych w treści zasady. Jak już wspomniano, współczesne prawo międzynarodowe pozwala skorzystać z dwóch mechanizmów odpowiedzialności państwa dla ustalenia prawnych konsekwencji niedopełnienia obowiązków. Opis KPM dotyczący odpowiedzialności międzynarodowej nie zawiera szczególnych prawnych konsekwencji niewypełnienia dyspozycji norm pierwotnych, wymagających wykazania należytej staranności, odwołując się do poszczególnych reżimów traktatowych, właściwych dla danego rodzaju niebezpiecznej aktywności i do ewentualnych opisanych tam sankcji ${ }^{12}$. Takie reżimy traktatowe niejednokrotnie przewidują odpowiedzialność odszkodowawczą podmiotów prywatnych, czerpiących zyski z owych aktywności. Jeśli reżim norm pierwotnych nie zawiera reguł, na jakich dochodzić można odszkodowania, możliwe jest odwołanie do zasad międzynarodowej odpowiedzialności państwa za naruszenie zobowiązania pierwotnego, wymagającego zapobiegania określonym niebezpieczeństwom i szkodom, zgodnie z treścią projektu z 2006 r. ${ }^{13}$ Szczegółowe mechanizmy

bieństwa powstania znaczącej szkody, z orzeczeniem w sprawie cieśniny Korfu, gdzie obowiązek ów powstaje, jeśli państwo wie lub powinno było wiedzieć o grożących innym państwom szkodach.

${ }^{9}$ Por.: art. 6 Konwencji w sprawie transgranicznego zanieczyszczania powietrza na dalekie odległości sporządzonej w Genewie dnia 13 listopada 1979 r. Dz.U. 1985, nr 60, poz. 311, który zobowiązuje państwa-strony do zastosowania „najlepszych, dostępnych i możliwych z ekonomicznego punktu widzenia technologii" w celu zwalczania zanieczyszczeń powietrza.

${ }^{10}$ Por.: art. 3 pkt a) Konwencji o ochronie środowiska morskiego obszaru północno-wschodniego Atlantyku Dz.U. Unii Europejskiej C 285 E/24 listopada 2009 r, s. 122.

${ }^{11}$ Projekt artykułów o prewencji z 2001 r., komentarz (4) to Art. 2, s. 152.

${ }^{12}$ Por.: art. 18 Projekt artykułów o prewencji z 2001 r., U.N. Doc. A/56/10, który stanowi o poszanowaniu przez postanowienia projektu innych reguł prawa międzynarodowego, w tym norm zwyczajowych, oraz Zasada 7 Projektu zasad alokacji z 2006 r., U.N. Doc. A/61/10, w treści której zalecane jest rozwijanie szczegółowych reżimów regionalnych, dotyczących zapobiegania szkodom transgranicznym.

${ }^{13}$ Por.: komentarz (6) i (7) do preambuły Projektu zasad alokacji z 2006 r., U.N. Doc. $\mathrm{A} / 61 / 10$. W treści komentarza (6) zapisano, iż preambuła nakazuje stosowanie norm odpowie- 
odszkodowawcze, oparte o zapisane $\mathrm{w}$ traktatach zasady odpowiedzialności międzynarodowej i ogólne reguły wtórnego reżimu odpowiedzialności państw, opisano poniżej.

KPM dokonała podsumowania treści obowiązku prewencji w dokumentach omówionych w rozdziale poprzednim, w oparciu o bogaty dorobek orzeczniczy, ale także czerpiąc z szeregu zapisów traktatowych. Obok umów z zakresu międzynarodowego prawa środowiska, standard należytej staranności przywoływany jest także w traktatach dotyczących ochrony cudzoziemców i przedstawicieli dyplomatycznych państw obcych ${ }^{14}$. Obszarem prawa międzynarodowego, w którym znaczenie zasady należytej staranności rośnie, zaś jej treść jest przedmiotem ożywionej debaty, jest obowiązek ochrony bezpieczeństwa państw obcych przed zagrożeniami inicjowanym z terytorium państwa pochodzenia niewykazującego należytej staranności przy zapobieganiu takim zagrożeniom ${ }^{15}$.

Wszystkie te obszary międzynarodowych interakcji, w których należyta staranność odgrywa istotną rolę, opisane zostały poniżej. Ogólne rozważania poczynione powyżej, oparte o analizę międzynarodowego orzecznictwa dokonaną przez KPM, zestawione zostaną poniżej z treścią obowiązujących umów międzynarodowych, dotyczących międzynarodowego prawa środowiska, prawa morza, prawa dyplomatycznego, dyspozycji dotyczących ochrony cudzoziemców oraz obowiązku ochrony suwerenności innych państw. Należyta staranność opisana $\mathrm{w}$ treści dotyczących tych obszarów traktatów precyzuje znaczenie zasady prewencji, omówionej przez KPM.

\subsection{Należyta staranność $w$ międzynarodowym prawie środowiska}

Wspomniana już zasada dobrego sąsiedztwa, zapisana w Deklaracji sztokholmskiej i w treści Deklaracji z Rio, wywarła znaczący wpływ na treść obowiązku wykazywania należytej staranności uznanego w międzynarodowym prawie środowiska. Zawarty $\mathrm{w}$ tym reżimie obowiązek zapobiegania szkodom transgranicznym oznacza, że państwa powinny działać z należytą starannością ${ }^{16}$, choć przez niektórych autorów formułowany jest postulat de lege ferenda uznania odpowiedzialności absolutnej za szkody ekologiczne, zwłaszcza względem czynności szczególnie niebezpiecznych (ang. ultra-hazardous activities) ${ }^{17}$.

\footnotetext{
dzialności państw, zgodnie z treścią projektu KPM z 2001 r. w przypadku naruszenia obowiązku prewencji.

${ }^{14}$ Por.: R. Pisillo Mazzeschi, op.cit., s. 22 lub wyrok w sprawie zakładników w Teheranie.

${ }^{15}$ V. J. Proulx, op.cit., s. 659-666, R. Pisillo Mazzeschi, op.cit., s. 31-32.

${ }^{16} \mathrm{~Np}$.: Konwencja o ochronie warstwy ozonowej z 1985 r., Konwencja o zmianach klimatycznych wraz z Protokołem z Kioto. Por. P. W. Birnie, A. E. Boyle, C. Redgwell, op.cit., s. 110-12.

${ }^{17}$ Por. M. M. Kenig-Witkowska, Prawnomiędzynarodowa..., s. 312-313.
} 
Shaw twierdzi, że należyta staranność w prawie międzynarodowym nie powinna być identyfikowana $\mathrm{z}$ reżimem odpowiedzialności absolutnej ani odpowiedzialności na zasadzie ryzyka sensu stricto ${ }^{18}$. Przywołując przesłankę winy twierdzi, że państwa nie powinny być pociągane do odpowiedzialności niezależnie od możliwości wskazania jej po ich stronie, choć jak wskazano wcześniej, wina nie może być bez wątpliwości uznana za przesłankę odpowiedzialności państwa. Ów dowód winy w prawie środowiska polega, jego zdaniem, na wykazaniu braku należytej staranności po stronie państwa. Będzie więc ono ponosiło międzynarodową odpowiedzialność jedynie wówczas, gdy nie dołoży staranności należytej w danych okolicznościach. Badanie poziomu staranności obejmuje identyfikację i weryfikację treści zobowiązania państwa do współpracy w dobrej wierze i w celu zapobiegania znaczącej szkodzie transgranicznej z innymi państwami, korzystając $\mathrm{z}$ pomocy właściwych organizacji międzynarodowych ${ }^{19}$. Zobowiązanie państwa do dołożenia należytej staranności uznać można za wypełnione, kiedy wprowadzi ono stosowną legislację, procedury administracyjne i podejmie inne właściwe kroki, w tym wdroży system monitorowania i autoryzowania działań niosących niebezpieczeństwo szkody transgranicznej ${ }^{20}$. Weryfikacja taka oparta być musi na właściwej ocenie ryzyka i wpływu oddziaływania na środowisko ${ }^{21}$. Jeśli stosowane procedury pozwolą wykryć niebezpieczeństwo powstania znaczącej szkody transgranicznej, państwa nią zagrożone powinny zostać poinformowane o zagrożeniu i skonsultowane celem uzgodnienia sposobów zminimalizowania ewentualnej lub rzeczywistej szkody ${ }^{22}$. Jak wspomniano w rozdziale poprzednim, KPM tworząc Projekt artykułów prewencji $2001 \mathrm{r}$. wskazała cztery rodzaje działań, wymaganych od państw jako elementy należytej staranności. Państwa winny więc podejmować niezbędne kroki zmierzające do zapobiegania niebezpieczeństwu, współpracować ze sobą i kompetentnymi organizacjami międzynarodowymi, wdrożyć niezbędne procedury administracyjne i wykonawcze, w tym procedury monitorowania, oraz przeprowadzać ocenę oddziaływania na środowisko niebezpiecznych przedsięwzięć przed udzieleniem zgody na ich prowadzenie. Elastyczny charakter tak sformułowanej należytej staranności w międzynarodowym prawie środowiska najlepiej uwidoczniony jest $\mathrm{w}$ treści ostatniego $\mathrm{z}$ elementów testu weryfikującego jej dołożenie: obowiązku uwzględnienia i zrównoważenia interesów wszystkich stron, których dotyczy niebezpieczeństwo powstania szkody, przed rozpoczęciem potencjalnie szkodliwej działalności ${ }^{23}$.

${ }^{18}$ Ale por. art. II Konwencji o międzynarodowej odpowiedzialności za szkody wyrządzone przez obiekty kosmiczne, konstytuującej odpowiedzialność absolutną państwa rejestracji obiektu.

${ }^{19}$ M. N. Shaw, Prawo międzynarodowe..., s. 451-452. Por.: uwagi wstępne.

${ }^{20}$ Projekt artykułów o odpowiedzialności międzynarodowej z 1998 r., U.N. Doc. A/53/10, art. 5 i 6.

${ }^{21}$ Projekt artykułów o odpowiedzialności międzynarodowej z 1998 r., U.N. Doc. A/53/10, art. 7.

22 Projekt artykułów o odpowiedzialności międzynarodowej z 1998 r., U.N. Doc. A/53/10, art. 8 i 17.

${ }^{23}$ Projekt artykułów o odpowiedzialności międzynarodowej z 1998 r., U.N. Doc. A/53/10, art. 9. 
Okowa podnosi obowiązek dokonania oceny oddziaływania na środowisko do rangi zasady międzynarodowego prawa środowiska ${ }^{24}$, wśród których to zasad identyfikuje także: zasadę ciagłego rozwoju oraz zasadę przezorności ${ }^{25}$. Pierwsza z nich nakłada na państwo zobowiązanie do uwzględniania interesów ochrony środowiska naturalnego we wszystkich ich działaniach ${ }^{26}$, podczas gdy druga zobowiązuje władze do przeprowadzenia niezbędnych badań, celem zapobiegania degradacji środowiska naturalnego, niezależnie od ich kosztów ${ }^{27}$.

Tak formułowane obowiązki państw nie mają na celu faktycznego uniemożliwienia realizacji niebezpiecznych przedsięwzięć przez państwa, a jedynie ograniczenie ewentualnej szkody, wynikającej $\mathrm{z}$ wpisanego w nie zagrożenia ${ }^{28}$. $\mathrm{Na}$ taką interpretację owych zasad pozwala odwołanie od testu de minimis. Zgodnie z treścią owego formalnego ograniczenia zasady prewencji, państwa są zobowiązane zapobiegać jedynie „znaczącym, poważnym lub istotnym” szkodom (ang. appreciable, significant or substantial) ${ }^{29}$, o których mowa $\mathrm{w}$ treści zasady 1 Projektu zasad alokacji z 2006 r. $^{30}$, nie zaś wszelkim szkodom transgranicznym. Zasada ogranicza zakres obowiązku prewencji jedynie do „szkody trangranicznej wywołanej przez działania niebezpieczne niezakazane prawem międzynarodowym”, gdzie „działanie niebezpieczne” oznacza przedsięwzięcie, które „obejmuje ryzyko powstania znaczącej szkody”31. Jak wspomniano, KPM nie zdecydowała się załączyć do projektu listy takich przedsięwzięć, w zamian definiując szczegółowo przesłanki, które muszą być spełnione, aby aktywność uznać za niebezpieczną ${ }^{32}$. Terminem kluczowym dla ustalenia obowiązku prewencji jest samo pojęcie szkody ${ }^{33}$.

${ }^{24}$ Chodzi tu raczej, jak się zdaje, o zasadę miękkiego prawa międzynarodowego, niż o zasadę uznaną przez narody cywilizowane, do których odwołuje sie Statut MTS w art. 38. Por. P. N. Okowa, op.cit., s. 87.

${ }^{25}$ P. N. Okowa, op.cit., s. 83-84.

${ }^{26}$ Zgodnie z treścią zasady 4 Deklaracji z Rio, która stanowi, iż celem osiąnnięcia zrównoważonego rozwoju ochrona środowiska stać się powinna integralną częścią procesu rozwoju międzynarodowej społeczności i nie może być postrzegana w oderwaniu do niego. Jak słusznie wskazuje Okowa, stanowi to potwierdzenie względności należytej staranności wobec faktycznie dostępnych państwu środów i zasobów; por. P. N. Okowa, op.cit., s. 83.

${ }^{27}$ Ta zasada jest przedmiotem ożywionej akademickiej dyskusji oraz rozbieżnych interpretacji doktryny; por.: P. N. Okowa, op.cit., s. 84, która przedstawia dotyczące jej, rozbieżne, poglądy doktryny.

${ }^{27}$ Ibidem, przyp. 107, s. 87.

${ }^{28}$ Ibidem, s. 87.

${ }^{29}$ Ibidem, s. 88.

${ }^{30}$ Por.: rozdz. IV.

${ }^{31}$ Projekt zasad alokacji z 2006 r., U.N. Doc. A/61/10, zasada 2, pkt (c).

${ }^{32}$ Komisja wskazała, iż stworzenie takiej listy niosłoby za sobą nieuniknione ryzyko pominięcia istotnych jej elementów, pojawiających się wraz z rozwojem technologicznym. Por.: Projekt zasad alokacji z 2006 r., s. 117.

${ }^{33}$ Por. uwagi wstępne, dotyczące kwestii terminologicznych. 


\subsection{Odpowiedzialność państwa $w$ międzynarodowym prawie środowiska}

W międzynarodowym prawie środowiska można zidentyfikować trzy najważniejsze reżimy traktatowe, opisujące reguły odpowiedzialności za szkody transgraniczne dotyczące odpowiednio: transportu olejów napędowych droga morska, wytwarzania i wykorzystania energii atomowej oraz badań kosmosu. Trafnie podsumowują specyfikę owych reżimów Gehring i Jachtenfuchs wskazując, iż państwa niechętnie przyjmują odpowiedzialność za szkodę transgraniczną w środowisku naturalnym, przenosząc ciężar odpowiedzialności na podmioty prywatne, czerpiące korzyści z niebezpiecznych aktywności ${ }^{34}$. Dlatego też za istotne uznać należy kłopoty terminologiczne związane z zagadnieniem cywilnej odpowiedzialności państw ${ }^{35}$. Naruszenie obowiązku wykazywania należytej staranności może prowadzić do odpowiedzialności państwa za czyny sprzeczne $\mathrm{z}$ treścią jego międzynarodowych zobowiązań ${ }^{36}$, jednak mocą traktatów szczegółowych, państwa mogą przyjąć na siebie dodatkowe zobowiązania kompensacyjne, często oparte o zasadę ryzyka, rzadziej konstytuujące ich odpowiedzialność absolutną.

Reguły odpowiedzialności międzynarodowej, opisane w treści traktatów, powielają chronologicznie najwcześniejszy spośród nich, tj. model stosowany do kompensacji szkód powstałych przy transporcie ropy naftowej drogą morska, opracowany po katastrofie statku Torrey Canyon w 1967 r. ${ }^{37}$ Wówczas Międzyrządowa Morska Organizacja Doradcza (ang. Intergovernmental Maritime Consultative Organisation, dalej: IMCO $)^{38}$ otrzymała zadanie wypracowania zasad reparacji szkód powstałych wskutek awarii tankowców, zaś wyniki jej pracy stały się podstawą negocjacji dotyczących reguł odszkodowawczych w innych obszarach międzynarodowego prawa środowiska. Podczas negocjacji na forum IMCO stało się jasne, że państwa rejestrujące floty tankowców nie zgodzą się na przejęcie bezpośredniego obowiązku odszkodowawczego za szkody wyrządzone przez armatorów ${ }^{39}$. Dyplomaci negocjujących państw zgodzili się jedynie na przeniesienie odpowiedzialności na przedstawicieli sektora transportu morskiego, zgodnie z zasadą „zanieczyszczający płaci”, bowiem to przedsiębiorcy czerpali zyski z generowanego przez tankowce niebezpieczeństwa szkód w środowisku naturalnym. Jednocześnie państwa przybrzeżne, bezpośrednio zagrożone katastrofami morskimi, domagały się ustanowienia odpowiedzialności na zasadzie

\footnotetext{
${ }^{34}$ T. Gehring, M. Jachtenfuchs, op.cit., s. 97.

${ }^{35}$ Por. M. M. Kenig-Witkowska, Międzynarodowe prawo..., s. 144.

${ }^{36}$ Por. A. C. Kiss, D. Shelton, Guide to International Environmental Law, Haga 2007, s. 92.

${ }^{37}$ T. Gehring, M. Jachtenfuchs, op.cit., s. 97.

38 Od 1982 r. Międzynarodowa Organizacja Morska (ang. International Maritime Organisation; dalej: IMO).

${ }^{39}$ Negocjacje dotyczyły późniejszej Konwencji o odpowiedzialności cywilnej za szkody spowodowane zanieczyszczeniami olejami z 1969 r., 9 ILM (1970) 45. Por.: T. Gehring, M. Jachtenfuchs, op.cit., s. 98.
} 
ryzyka państw rejestrujących tankowce, bowiem tylko w takiej sytuacji ich roszczenia odszkodowawcze zawsze znalazłyby pokrycie ${ }^{40}$. Osiagnięty kompromis uwzględniał odpowiedzialność na zasadzie ryzyka, przypisaną właścicielom tankowców, zaś w przypadku ich niewypłacalności roszczenia odszkodowawcze miałyby zostać pokryte z funduszu odszkodowawczego, służącego kompensacji szkód wywołanych zatruciem środowiska naturalnego olejami napędowymi, zasilanego przez przedstawicieli przemysłu transportowego. Proponowano, aby państwa, gwarantując realizację obowiązku odszkodowawczego przez przedstawicieli przemysłu, ponosiły odpowiedzialność na zasadzie ryzyka, ale dopiero wówczas, gdy przedsiębiorcy okazaliby się niewypłacalni, zaś w funduszu zabrakłoby środków ${ }^{41}$, jednak negocjatorzy nie zgodzili się na wprowadzenie zastępczej odpowiedzialności (ang. subsidiary liability) państwa bandery ani na udział państw w funduszu, natomiast ów prywatny model odszkodowawczy został zaakceptowany przez przedstawicieli przemysłu ${ }^{42}$. W konsekwencji szybko rozwinął się sektor ubezpieczeń transportowych, które oferowały pomoc finansową podmiotom świadczącym usługi transportowe, de facto zobligowanym do udziału w tak skonstruowanym reżimie odpowiedzialności ${ }^{43}$.

Jak wskazują niektórzy autorzy, przeniesienie odpowiedzialności na zasadzie ryzyka na podmioty prywatne spowodowało przeniesienie kwestii odpowiedzialności z poziomu dyskusji międzynarodowej, na którym podmioty prywatne odgrywały rolę pomocnicza, na poziom prywatnoprawny ${ }^{44}$. Taki model odpowiedzialności na zasadzie ryzyka, ponoszonej przez podmioty prywatne, choć znacznie obciąża przedstawicieli przemysłu, wydaje się właściwy w dobie glo-

${ }^{40}$ T. Gehring, M. Jachtenfuchs, op.cit., s. 98.

${ }^{41}$ Międzynarodowa konwencja o utworzeniu międzynarodowego funduszu odszkodowań za szkody spowodowane zanieczyszczeniami olejami z 1971 r., 11 ILM 284 (1972), zmieniona protokołem z 1992 r. Por. M. M. Kenig-Witkowska, Międzynarodowe..., s. 145.

${ }^{42}$ T. Gehring, M. Jachtenfuchs, op.cit., s. 99 piszą o „resztkowej odpowiedzialności” (ang. residual liability), pozostawionej państwom. Efektem kompromisu była Umowa dotycząca przejściowego wsparcia odpowiedzialności za zanieczyszczenie olejami (ang. Contract Regarding an Interim Supplement to Tanker Liability for Oil Pollution; CRISTAL). Ibidem. Obecnie CRISTAL, jak i konkurencyjny względem niej reżim umowy TOVALOP (Dobrowolne zobowiązanie właścicieli tankowców dotyczące odpowiedzialności za zanieczyszczenia olejami, The Tank Owners Voluntary Agreement Concerning Liability for Oil Pollution z 1969 r.) mają znaczenie historyczne, obie wygasły w 1977 r. Ich miejsce zajęły wspomniane powyżej: Konwencja o odpowiedzialności cywilnej za szkody spowodowane zanieczyszczeniami olejami z 1969 r. oraz Międzynarodowa konwencja o utworzeniu międzynarodowego funduszu odszkodowań za szkody spowodowane zanieczyszczeniami olejami z 1971 r. Por. X. Chen, Limitation of Liability for Maritime Claims: A Study of U.S. Law, Chinese Law, and International Conventions, Haga 2001, s. 139.

${ }^{43}$ T. Gehring, M. Jachtenfuchs, op.cit., s. 99. Zob. także: H. Smets, The Oil Spill Risk: Economic Assessment and Compensation Limit, Journal of Maritime Law \& Commerce1983, nr 14, s. 23.

${ }^{44}$ Tak np.: T. Gehring, M. Jachtenfuchs, op.cit., s. 97. Podobnie J. Barboza, op.cit., s. 3, który pisze o „skanalizowaniu” odpowiedzialności na podmioty prywatne. Zob też. R. Majda, Cywilna odpowiedzialność za szkodę jadrowa w polskim prawie atomowym, Łódź 2006, s. 31, który wśród zasad międzynarodowego reżimu odpowiedzialności za szkodę jądrową wymienia „,channeling, canalisation”, tj. zasadę w myśl której odpowiedzialność na zasadzie ryzyka ponosi wyłącznie operator obiektu jądrowego. 
balizacji, gdy międzynarodowe koncerny dysponują często większymi zasobami finansowymi i organizacyjnymi czy możliwościami negocjacyjnymi, niż małe państwa. Należy jednak odnotować, iż model ten zwalnia państwa z materialnej odpowiedzialności za szkody powstałe $\mathrm{w}$ wyniku autoryzowanych przez nie aktywności, pozbawiając decyzję o autoryzacji konsekwencji ekonomicznych ${ }^{45}$. Tak skonstruowany, złożony mechanizm odpowiedzialności odszkodowawczej, choć pozostaje w zgodzie z projektem KPM z 2006 r., znacząco utrudnia dochodzenie roszczeń odszkodowawczych ${ }^{46}$. Pozostawia poszkodowanym państwom przywołanie odpowiedzialności państwa pochodzenia szkody za brak należytej staranności, zgodnie z zasadami odpowiedzialności państw za działania niezgodne $\mathrm{z}$ treścią ciążących na nich zobowiązań międzynarodowych ${ }^{47}$. Podmioty prywatne odwołać się mogą jedynie do przepisów prawa krajowego, z uwzględnieniem skomplikowanych zasad międzynarodowej jurysdykcji $\mathrm{w}$ sprawach cywilnych.

Ten model odpowiedzialności odszkodowawczej, opracowany dla potrzeb transportu olejów napędowych drogą morska, został wykorzystany dla regulacji transportu morskiego ${ }^{48}$ i powierzchniowego ${ }^{49}$ towarów niebezpiecznych, jak też wydobycia olejów napędowych ${ }^{50}$, ale także stał się wzorem dla odpowiedzialności za szkody powstałe przy produkcji energii atomowej czy badań kosmosu, opisanych poniżej.

Odpowiedzialność międzynarodowa za szkody nuklearne uregulowana została w treści Konwencji paryskiej z 1960 r. ${ }^{51}$ i oparta o zasadę ryzyka. Zgodnie z jej zapisami odpowiedzialność za szkodę transgraniczną ponosi operator instalacji nuklearnej, której działanie wywołało szkodę. Choć nie wprowadzono mocą konwencji obowiązkowego ubezpieczenia dla przedstawicieli tej branży, stało

\footnotetext{
${ }^{45}$ Praktyka stosowania skomplikowanych postanowień umownych jest bardzo trudna, co pokazała choćby sprawa odszkodowania za katastrofę platformy Deepwater Horizon z 2010 r.; por. np.: R. Abeyratne, The Deepwater Horizon Disaster - Some Liability Issues, Tutlus Maritime Law Journal 2010, nr 35, s. 125 i n.

${ }^{46} \mathrm{O}$ roli ubezpieczeń $\mathrm{w}$ międzynarodowym prawie środowiska pisze J. Łopuski, por. J. Łopuski, Rola ubezpieczenia $w$ ochronie środowiska człowieka przed zanieczyszczeniami, PiP 1978, s. $27-41$.

${ }^{47}$ Zasady odpowiedzialności międzynarodowej państwa opisane zostały w rozdz. III, zaś odpowiedzialności międzynarodowej za czyny niezakazane prawem międzynarodowym - w rozdz. IV.

${ }^{48}$ Por. np. tekst wciąż nieobowiązującej Międzynarodowej konwencji z 1996 r. w sprawie odpowiedzialności i rekompensaty za szkody związane z przewozem morzem substancji niebezpiecznych i szkodliwych (Konwencja HNS) wraz z poprawkami wprowadzonymi Protokołem z 2010 r. [online]. HNS [dostęp: 2013-01-20]. Dostępny w Internecie: <http://www.hnsconvention.org/ Pages/TheConvention.aspx>.

${ }^{49}$ Konwencja o odpowiedzialności cywilnej za szkody wyrządzone podczas przewozu towarów niebezpiecznych transportem drogowym, kolejowym lub żeglugą śródlądową, 1989, United Nations Economic Commission for Europe Doc. ECE/TRANS/84.

${ }^{50}$ Konwencja o odpowiedzialności cywilnej za szkody olejowe, 1976, 16 ILM (1977) 1451. Por.: T. Gehring, M. Jachtenfuchs, op.cit., s. 99.

${ }^{51}$ Konwencja wiedeńska o odpowiedzialności cywilnej za szkody jądrowe, UNTS 1063, nr 16197; por.: T. Gehring, M. Jachtenfuchs, op.cit., s. 100.
} 
się ono powszechną praktyką tego sektora przemysłu i usług. Ponieważ państwa nadal nie zgadzały się na przejęcie roszczeń odszkodowawczych, załącznik II do Konwencji zawierał bezpośrednie odniesienie do odpowiedzialności państwa za działania sprzeczne z prawem międzynarodowym jako do właściwego mechanizmu dochodzenia roszczeń odszkodowawczych za szkodę jądrową. Zgodnie z jego postanowieniami, niedochowanie należytej staranności uznane być powinno za element decydujący o możliwości przypisania państwu odpowiedzialności za zaniechanie.

W treści konwencji wprowadzone zostały dwa dodatkowe instrumenty, służące ochronie ofiar transgranicznych szkód nuklearnych, konstytuujące ograniczoną odpowiedzialność odszkodowawczą państwa autoryzującego szkodliwą działalność ${ }^{52}$. W przypadku wyczerpania zasobów funduszu prywatnego, państwo autoryzujące niebezpieczne działania ponosiłoby współodpowiedzialność. Gdyby i przywołanie państwa jako współodpowiedzialnego nie przyniosło zaspokojenia roszczeń poszkodowanego, mógłby on skorzystać $\mathrm{z}$,trzeciej warstwy” kompensacji, powstałej na mocy konwencji, która inicjowała powołanie funduszu zasilanego przez państwa, na wzór prywatnych funduszy ubezpieczeniowych ${ }^{53}$. Jednocześnie traktatowy reżim odpowiedzialności za szkodę jądrową przewiduje możliwość ograniczenia kwoty odszkodowania, jakie przedsiębiorcy są w stanie uiścić i nie zawiera egzekwowalnego reżimu odpowiedzialności państwa na zasadzie ryzyka ${ }^{54}$.

Wskazując na zasady odpowiedzialności za szkodę transgraniczną w prawie środowiska warto wspomnieć o badaniach przestrzeni kosmicznej. Ten obszar aktywności poddany został wyjątkowemu reżimowi traktatowemu, konstytuującemu absolutną odpowiedzialność państw ${ }^{55}$. Kompromis ten wynikał z faktu, iż ów obszar aktywności pozostaje wyłączną domeną państw ${ }^{56}$. Dlatego też Kon-

\footnotetext{
${ }^{52} \mathrm{O}$ systemach „międzynarodowego prawa odpowiedzialności cywilnej za szkodę jądrową”: R. Majda, op.cit., s. 29-31.

${ }^{53}$ T. Gehring, M. Jachtenfuchs, op.cit., s. 101.

${ }^{54}$ Propozycje wprowadzenia absolutnej odpowiedzialności międzynarodowej państw za szkody transgraniczne pojawiały się po katastrofie w Czarnobylu, nie spotkały się jednak z aprobata władz krajowych. Udało się jedynie skorelować dwa dotąd konkurencyjne reżimy międzynarodowej odpowiedzialności za szkody jądrowe; por. R. Majda, op.cit., s. 30.

${ }^{55}$ Projekty takie jak Google Lunar X PRIZE zmierzają ku przełamaniu tego państwowego monopolu, prywatyzując badania kosmosu. Strona domowa projektu [online]. Googlelunarxprize [dostęp: 2013-01-20]. Dostępny w Internecie: <http://www.googlelunarxprize.org/>.

${ }^{56}$ Zgodnie z zapisem zawartym w Układzie o zasadach działalności państw w zakresie badań i użytkowania przestrzeni kosmicznej łącznie z Księżycem i innymi ciałami niebieskimi, 1967 r., Dz.U. 1968, nr 14, poz. 82 (dalej: Traktat o przestrzeni kosmicznej), którego art. VI stanowi, iż „działalność pozarządowych osób prawnych w przestrzeni kosmicznej, łącznie z Księżycem i innymi ciałami niebieskimi, wymaga upoważnienia i stałego nadzoru ze strony danego Państwa Strony Układu", zaś państwa-strony ponoszą odpowiedzialność międzynarodową za swoją działalność w przestrzeni kosmicznej, łącznie z Księżycem i innymi ciałami niebieskimi, niezależnie od tego, czy jest ona prowadzona przez instytucje rządowe lub pozarządowe, osoby prawne". Państwa ponoszą odpowiedzialność także za zapewnienie zgodności tej działalności z postanowieniami niniejszego Układu. Traktat wprowadza tym samym odpowiedzialność absolutną państw.
} 
wencja o międzynarodowej odpowiedzialności za szkody wyrządzone przez obiekty kosmiczne rozwiązuje problem odpowiedzialności za szkody transgraniczne inaczej niż traktaty wyżej opisane, przypisując za nie wyłącznie państwom odpowiedzialność absolutną. Art. 2 Konwencji o międzynarodowej odpowiedzialności za szkody wyrządzone przez obiekty kosmiczne stanowi, iż państwo wypuszczające obiekt jest bezwzględnie zobowiązane do zapłacenia odszkodowania za szkodę, którą wypuszczony przez nie obiekt kosmiczny wyrządził na powierzchni Ziemi lub statkowi powietrznemu podczas lotu.

$\mathrm{Z}$ wyjątkiem dwóch ostatnich porządków traktatowych, wynikających z kompromisu państw dotyczącego owych szczegółowych obszarów aktywności międzynarodowej, obowiązek kompensacji szkód wynikał będzie zawsze z odpowiedzialności państwa przypisywalnej mu jedynie, gdy możliwe jest wykazanie jego zaniechania, sprzecznego z normą międzynarodową. Orzecznictwo sądów międzynarodowych pokazuje, że ocena dołożenia należytej staranności może być czyniona jedynie w oparciu o istniejący standard międzynarodowy ${ }^{57}$. Ocena ta $\mathrm{w}$ znacznej mierze odwołuje się do faktycznych możliwości zapobieżenia szkodzie, potwierdzonych w treści specjalistycznych analiz, a więc do zasady prewencji opisanej szczegółowo na potrzeby prawa środowiska ${ }^{58}$. Uznanie zasady prewencji przez KPM pozwala tym samym uniknąć konieczności każdorazowego odwołania do analizy orzecznictwa dla wykazania obowiązku państwa, polegającego na zapobieganiu szkodom transgranicznym ${ }^{59}$.

Zasada prewencji wynika $\mathrm{z}$ obawy przed spowodowaniem nieodwracalnych szkód w środowisku. Pomimo jej werbalizacji w treści Zasady 15 Deklaracji z Rio oraz treści postanowień traktatowych ${ }^{60}$, zasięg powstałego z jej mocy obowiązku budzi wątpliwości. Dzieje się tak dlatego, iż jej stosowanie w reżimach traktatowych, w których nie zawarto explicite obowiązku prewencji, wywodzić można jedynie z ramowego charakteru Deklaracji z Rio ${ }^{61}$. Różnie są opisywane $\mathrm{w}$ treści traktatów tworzących międzynarodowe prawo środowiska niebezpieczeństwa, którym państwa winny zapobiegać i rzadko pojawiają się opisy metod zapobiegania im, co w praktyce zmniejsza możliwość aplikacji reguł wtórnych odpowiedzialności państw za naruszenie ich międzynarodowych zobowiązań. W konsekwencji, różnią się także krajowe normy implementujące owe ogólnie sformułowane międzynarodowe zobowiązania. Jedynie kilka

${ }^{57}$ P. N. Okowa, op.cit., s. 82 .

${ }_{58}^{58}$ P. W. Birnie, A. E. Boyle, C. Redgwell, op.cit., s. 152-154.

${ }^{59}$ Ibidem, s. 153.

${ }^{60}$ Zasada prewencji zawarta została m.in. w treści Konwencji o ochronie i użytkowaniu cieków transgranicznych i jezior międzynarodowych z 1992 r. (Dz. U. 2003, nr 78, poz. 703), art. 2 (5) lit. a, jak i w art. 3 Ramowej konwencji Narodów Zjednoczonych w sprawie zmian klimatu z 1992 r. (Dz.U. 1996, nr 53, poz. 239), czy konwencji o różnorodności biologicznej z 1992 r. (Dz.U. 2002, nr 184, poz. 1532, art. 14). Por. szczegółowo: P. W. Birnie, A. E. Boyle, C. Redgwell, op.cit., s. 157.

${ }^{61}$ Por. np.: M. Pallemaerts, International Legal Aspects of Long-Range Transboundary Air Pollution, (w:) Hague Yearbook of International Law, red. A. C. Kiss, J. G. Lammers, tom 17-18, Haga 1989, s. 214; P. W. Birnie, A. E. Boyle, C. Redgwell, op.cit., s. 154-158. 
państw stosuje zasadę prewencji jako normę prawa krajowego, podczas gdy w większości jest ona jednym z wielu czynników, którym powinien kierować się krajowy prawodawca ${ }^{62}$.

Jak już wspomniano, elementem zasady należytej staranności jest obowiązek podejmowania i realizowania międzynarodowej współpracy celem minimalizowania niebezpieczeństwa transgranicznych szkód. Obowiązek ten jest szczególnie istotny przy dokonywaniu ocen oddziaływania na środowisko. Konwencja o ocenach oddziaływania na środowisko w kontekście transgranicznym (dalej: Konwencja z Espoo) ${ }^{63}$ definiuje ocenę oddziaływania na środowisko jako „krajową procedurę szacowania prawdopodobnego oddziaływania planowanej działalności na środowisko" "64. Celem oceny jest zapobieganie, minimalizowanie i kontrolowanie znaczących szkodliwych skutków międzynarodowych danej działalności ${ }^{65}$. Sposób wykonania owego zobowiązania zależy od wymagań prawa krajowego oraz zasobów technologicznych i finansowych pozostających w dyspozycji państwa. Jak twierdzi Hanquin, o ile wykorzystuje ono najlepsze dostępne mu środki w dobrej wierze, przyjąć należy, że spełniło swoje międzynarodowe zobowiązania ${ }^{66}$. W kontekście rozważań z rozdziału poprzedniego uznać jednak należy, że ocena oddziaływania na środowisko odzwierciedlać powinna dobre praktyki międzynarodowe, a przynajmniej regionalne, zgodnie $\mathrm{z}$ treścią zasady 11 Deklaracji z Rio ${ }^{67}$. Zobowiązanie do przeprowadzania oceny oddziaływania na środowisko odnaleźć można w przepisach prawa krajowego ${ }^{68}$, orzecznictwie $^{69}$, umowach dwustronnych ${ }^{70}$ i prawie wspólnotowym ${ }^{71}$. Obowiązek przeprowadzania oceny oddziaływania na środowisko może zostać wywiedziony także z treści zasady 17 Deklaracji z Rio, stanowiącej potwierdzenie obowiązującej normy zwyczajowej. Zapisano tam, iż ocenę oddziaływania na

\footnotetext{
${ }^{62}$ Por.: P. W. Birnie, A. E. Boyle, C. Redgwell, op.cit., s. 153-154.

${ }^{63}$ Konwencja o ocenach oddziaływania na środowisko w kontekście transgranicznym, sporządzona w Espoo dnia 25 lutego 1991 r., Dz.U. 1999, nr 96, poz. 1110 (dalej: Konwencja z Espoo).

${ }_{64}^{64}$ Art. 1 (vi) Konwencji z Espoo.

${ }^{65}$ Art. 2 (1) Konwencji z Espoo.

${ }^{66}$ X. Hanqin, op.cit., s. 167-8.

${ }^{67}$ KPM obowiązek ten potwierdziła także w treści art. 11 Projektu artykułów o odpowiedzialności międzynarodowej z 1998 r.

${ }^{68}$ Por. np. polska ustawa o udostępnianiu informacji o środowisku i jego ochronie, udziale społeczeństwa w ochronie środowiska oraz o ocenach oddziaływania na środowisko, Dz.U. 2008, nr 199, poz. 1227 z późń. zm. Podobne regulacje obecne są w porządkach krajowych Stanów Zjednoczonych czy Kanady oraz w treści dyrektyw wspólnotowych. Por. np. M. Górski, op.cit., s. 100.

${ }^{69} \mathrm{~Np}$. sprawa Gabcíkovo-Nagymaros, par. 112 i 140. Por. szerzej np.: C. M. Kersten, Rethinking Transboundary Environmental Impact Assessment, Yale Journal of International Law 2009, nr 34 (173), s. 174-185.

${ }^{70}$ Lista takich umów została zawarta w treści opracowania przygotowanego przez Komisję Europejska, por.: Komisja Europejska, How Successful Are Member States in Implementing the EIA Directive, COM (2003) 334 final [online]. EC 2003 [dostęp: 2013-01-20]. Dostępny w Internecie: $<$ http://ec.europa.eu/environment/eia/pdf/report_en.pdf>, s. 80. Umowy te często powstawały w ramach wykonywania postanowień Konwencji z Espoo, por.: C. M. Kersten, op.cit., s. 179.

${ }^{71}$ Por. np. Dyrektywa 2011/92/UE w sprawie oceny skutków wywieranych przez niektóre przedsięwzięcia publiczne i prywatne na środowisko naturalne, Dz. U. L z 28 stycznia 2012 r., s. 1.
} 
środowisko, jako element krajowego porządku prawnego, przeprowadza się względem działań, które mogą mieć znaczący wpływ na środowisko i podlegają decyzji właściwego organu krajowego.

Hanquin twierdzi, że weryfikacja sposobu przeprowadzenia owej oceny pozostaje $\mathrm{w}$ gestii władz krajowych, nie czyniąc odwołania do np. zasad 7 i 9 Deklaracji z Rio, które konstytuują komplementarny obowiązek współpracy międzynarodowej przy ochronie środowiska naturalnego. Jej zdaniem, nie można uznać, iż brak obowiązku przeprowadzania oceny oddziaływania na środowisko w prawie krajowym tożsamy jest $\mathrm{z}$ brakiem należytej staranności po stronie państwa $^{72}$. Stanowisko to wydaje się sprzeczne z treścią art. 8 Konwencji z Espoo, art. 20 i 21 Deklaracji sztokholmskiej oraz zasady 17 Deklaracji z Rio, które potwierdzają istnienie obowiązku implementacji do prawa krajowego zasady prewencji. Obowiązek międzynarodowej współpracy w zakresie jej standardów KPM zapisała w treści art. 11 Projektu artykułów o odpowiedzialności międzynarodowej z 1998 r. Koncepcja KPM znajduje poparcie wśród przedstawicieli doktryny, którzy uznają obowiązek oceny potencjalnych szkód transgranicznych, wynikających z niebezpiecznej działalności, tj. oceny oddziaływania na środowisko za obowiązek wynikający z reguł prawa międzynarodowego, co najmniej w odniesieniu do zagrożeń dla środowiska naturalnego ${ }^{73}$. Obowiązek ten wydaje się potwierdzać także orzecznictwo MTS, zwłaszcza w omawianej tu już sprawie prób atomowych na Pacyfiku.

Obowiązek prewencji w prawie środowiska obejmuje jeszcze dwa elementy: notyfikację zagrożeń i konsultacje z państwami potencjalnie zagrożonymi szkodą. Państwa, pod kontrolą których realizowane są niebezpieczne aktywności, winny notyfikować zaistnienie owego niebezpieczeństwa państwom potencjalnie zagrożonym jego skutkami. Obowiązek ten oznacza, że jeśli w wyni$\mathrm{ku}$ analizy oddziaływania na środowisko organy państwa posiądą wiedzę o zagrażającym niebezpieczeństwie szkody transgranicznej, winny podzielić się z potencjalnie poszkodowanymi państwami informacją o planowanej działalności albo o szkodzie, którą realizowana już działalność może spowodować na ich terytorium. Notyfikacja potencjalnej szkody ma na celu wspólną ocenę sytuacji oraz przedsięwzięcie kroków zmierzających do ograniczenia niebezpieczeństwa albo minimalizowania jego skutków ${ }^{74}$.

Konsekwencją notyfikacji potencjalnego zagrożenia jest obowiązek podjęcia konsultacji z państwami zagrożonymi szkodą oraz przysługujące tymże prawo sprzeciwu wobec planowanych niebezpiecznych aktywności. W przypadku sporu co do możliwości podjęcia szkodliwej działalności, albo co do właściwych sposobów zapobiegania transgranicznej szkodzie, państwa winny odwołać się do pokojowych metod rozwiązywania sporów, znanych prawu międzynarodowemu. Jak już wskazywano, niezależnie od podjętych negocjacji czy mediacji, państwo

\footnotetext{
${ }^{72}$ Tak np.: X. Hanqin, op.cit., s. 167.

${ }^{73}$ Por. np.: P. W. Birnie, A. E. Boyle, C. Redgwell, op.cit., s. 173.

${ }^{74}$ X. Hanqin, op.cit., s. $168-170$.
} 
planujące podjęcie niebezpiecznej działalności może ją rozpocząć także bez zgody państwa potencjalnie poszkodowanego ${ }^{75}$. Żadna z norm prawa środowiska nie zakazuje podjęcia działalności niebezpiecznej wobec sprzeciwu potencjalnie poszkodowanych. Oznacza to, iż odpowiedzialność państwa przywołana może zostać dopiero po rozpoczęciu owej działalności i dotyczyć może np. zaniechania przeprowadzenia oceny oddziaływania na środowisko lub szkód przez taką działalność wywołanych, jeśli ich powstanie było skutkiem braku należytej stranności po stronie organów państwa.

Obok regulacji prawnych, zmuszających państwa do wykazywania należytej staranności przy zapobieganiu szkodom transgranicznym, istotny jest wkład miękkiego prawa międzynarodowego i dobrych praktyk, na podstawie których możliwe jest zidentyfikowanie dotyczącej jej zasady ${ }^{76}$. System zachęt, raczej niż opatrzony sankcjami reżim konwencyjny, mógłby okazać się skuteczny względem państw rozwijających się, wymagających i oczekujących wsparcia we wdrożeniu standardów należytej staranności, także jako sposobu na lepsze wykorzystanie dostępnych im od niedawna technologii i zrozumienie towarzyszących im nowych sposobów organizacji krajowych społeczności ${ }^{77}$.

Oceniając skuteczność egzekucji zobowiązań obejmujących obowiązek wykazywania należytej staranności, czerpiąc przykłady z prawa ochrony środowiska, Rao wskazuje, że jest ona tym wyższa, im bardziej precyzyjna jest ich treść. Ważnym czynnikiem jest także wydolność samego aparatu państwowego, zwłaszcza jego struktur administracyjnych, oraz zasoby finansowe i infrastrukturalne przeznaczone na realizację obowiązku monitorowania zgodności praktyki z wymaganymi procedurami. Istotnym elementem zasady należytej staranności są także czynniki ekonomiczne, w tym PKB, technologie produkcyjne, udział $\mathrm{w}$ handlu międzynarodowym, podział władzy pomiędzy jednostki państwa, w tym decentralizacja władzy państwowej. Uzupełniającą rolę odgrywają tu także organizacje pozarządowe oraz postawa jednostek, kształtujących politykę państwa. Jako najważniejsze spośród wszystkich wymienionych, Rao wskazuje: kompetencje administracyjne państwa, postawę przywódców, organizacji pozarządowych oraz dostęp do aktualnego stanu wiedzy i wymianę informacji. Działania nakierowane na podniesienie poziomu należytej staranności powinny być dostosowane do specyfiki państwa-adresata i uwzględniać dwa kluczowe elementy: wolę oraz zdolność wypełnienia standardu przez państwo ${ }^{78}$. Te dwa czynniki pozwalają stworzyć sześć permutacji, charakteryzujących stosunek państw do realizacji omawianego tu obowiązku ${ }^{79}$. W zależności od specyfiki

75 Ibidem, s. 173-5.

${ }^{76}$ Drugi raport Rao, U.N. Doc. A/CN.4/501, s. 11, por.: Pierwszy raport Rao, U.N. Doc. A/CN.4/487, s. 18, gdzie Rao odnosi się aprobująco do stanowiska Barbozy, dotyczącego zasad prewencji.

${ }^{77}$ Drugi raport Rao, U.N. Doc. A/CN.4/501, s. 12.

${ }^{78}$ Drugi raport Rao, U.N. Doc. A/CN.4/501, s. 11.

${ }^{79}$ Ibidem. Te kategorie obejmują państwa: (1) zamierzające i mogące wypełnić standard należytej staranności, (2) które nie rozważały możliwości spełnienia standardu, ale byłyby w stanie go 
państwa, od którego wymagana jest należyta staranność, praktyka międzynarodowego prawa środowiska pozwala zidentyfikować trzy metody egzekwowania wykonania owego wymagania opisywane jako: podejście „słoneczne”, zachęcające i sankcjonujące. W prawie środowiska najczęściej stosowane są dwie pierwsze metody, w odróżnieniu od powszechnej praktyki w międzynarodowym prawie handlowym, którego postanowienia egzekwowane są przede wszystkim poprzez sankcje. Podejście „słoneczne” (ang. sunshine approach) oznacza realizację szeregu działań, zmierzających do ujawniania aktywności stron i poszczególnych podmiotów, od których działań lub zaniechań zależy wypełnienie treścią zobowiązania do wykazywania należytej staranności, tj. przestawienia ich czynów „w słońcu”, w świetle dnia. Działania te obejmują regularną sprawozdawczość państw w postaci raportów weryfikowanych przez inne państwa (ang. peer scrutiny), ustanowienie wyspecjalizowanych organizacji i ich sekretariatów, w tym podmiotów regionalnych i międzynarodowych. „Naświetleniu” działań państw autoryzujących niebezpieczne aktywności służyć ma także udział organizacji pozarządowych w życiu społecznym, w tym umożliwianie owym organizacjom wglądu w dokumenty rządowe czy ministerialne, opisujące realizację stosownych procedur oraz udział $\mathrm{w}$ weryfikacji spełniania przepisanych prawem wymagań przez upoważnione podmioty ${ }^{80}$. Także regularny monitoring i wymiana informacji pomiędzy państwami mają służyć polityce prewencyjnej. Światło dnia, na które wydobywane są fakty o aktywności państw w zakresie zapobiegania szkodom, ma być, w myśl rozważań Komisji, skutecznym środkiem do celu. Ten model realizacji obowiązku prewencji Rao przywołuje w oparciu o zapisy art. 8 Protokołu montrealskiego w sprawie substancji zubożających warstwę ozonową $^{81}$ do Konwencji wiedeńskiej ${ }^{82}$, który jako pierwszy zawierał

wypełnić, (3) nie zamierzające go wypełnić, ale posiadające taką potencjalną możliwość, (4) zamierzające spełnić standard, ale nie będące w stanie tego uczynić z powodów obiektywnych, (5) te, które nie rozważały możliwości spełnienia standardu i nie są w stanie tego uczynić i (6) nie zamierzające go przestrzegać $\mathrm{i}$ nie będące w stanie tego uczynić.

${ }^{80}$ Por.: Drugi raport Rao, U.N. Doc. A/CN.4/501, s. 11.

${ }^{81}$ Por.: Protokół Montrealski w sprawie substancji zubożających warstwę ozonową, sporządzony w Montrealu dnia 16 września 1987 r., Dz.U. 1992, nr 98, poz. 490, art. 8 przewiduje rozważenie i zaaprobowanie przez strony „procedur i mechanizmów instytucjonalnych” dla określenia stanu niezgodności z postanowieniami protokołu oraz sposób postępowania wobec stron, które przejawiły niezgodność. Celem realizacji owego zamierzenia, art. $10 \mathrm{w}$ par. 5 przewiduje, iż strony powołają Komitet Wykonawczy dla rozwoju i kontroli realizacji szczególnej polityki działania. Procedury non-compliance obejmują obowiązek składania przez państwa-strony co 4 lata raportów o zużyciu określonych substancji. Podobny, bardziej szczegółowy, mechanizm znalazł się treści Konwencji w sprawie transgranicznego zanieczyszczania powietrza na dalekie odległości (LRTAP). Por. szczegółowo: M. M. Kenig-Witkowska, Międzynarodowe prawo..., s. 133-134, 165-168; M. Górski, op.cit., s. 243.

${ }^{82}$ Konwencja o ochronie warstwy ozonowej, sporządzona w Wiedniu dnia 22 marca 1985 r., Dz. U. 1992, nr 98, poz. 488. Por. także poprawki do Protokołu Montrealskiego w sprawie substancji zubożających warstwę ozonowa, sporządzone w Londynie dnia 29 czerwca 1990 r., sporządzone w Kopenhadze dnia 25 listopada 1992 r., Dz. U. 2001, nr 44, poz. 491 i 492. Zob.: M. Górski, op.cit., s. 243-244. 
opis procedury non-compilance, art. 5 Konwencji bezpieczeństwa jądrowego ${ }^{83}$, treść Protokołu z Oslo w sprawie dalszego ograniczenia emisji siarki ${ }^{84}$, czy art. 13 Ramowej konwencji Narodów Zjednoczonych w sprawie zmian klimatu ${ }^{85}$. Przykłady te pozwalają wskazać, iż istotnym elementem tego najpopularniejszego mechanizmu wdrażania zasad ochrony środowiska są procedury non-compliance, stanowiące, jak już wskazano, element wykonywania prawa traktatów i wywodzone $\mathrm{z}$ zasady pacta sunt servanda ${ }^{86}$. Jak podkreśla Kenig-Witkowska, procedury te są zazwyczaj ogólne i mało sformalizowane, które to cechy przesądzają o ich niskiej skuteczności ${ }^{87}$.

Metoda zachęcająca (ang. incentive approach), mająca na celu zmotywowanie państw do wykazywania należytej staranności w zapobieganiu szkodom transgranicznym obejmuje szereg zachęt finansowych i technologicznych dla państw, które konsekwentnie realizują procedury prewencyjne ${ }^{88}$. Na podstawie stosownych porozumień międzynarodowych powstały: Fundusz protokołu montrealskiego, Fundusz światowego dziedzictwa czy Fundusz Bali, utworzony moca Międzynarodowej umowy dotyczącej drewna tropikalnego ${ }^{89}$. Utworzone zostały także fundusze w ramach organizacji powstałych na mocy traktatów, takie jak Fundusz na rzecz Globalnego Środowiska, wielostronne projekty bankowe, umowy bilateralne o wzajemnej pomocy międzyrządowej czy środki pomocy technicznej, oferowane przez przedstawicieli sektora prywatnego, funkcjonujące np. w oparciu o Protokół Montrealski. Środki stosowane w konsekwencji braku należytej staranności różnią się $\mathrm{w}$ poszczególnych reżimach traktatowych. Obejmują one np. zakaz handlu z państwem naruszającym prawo dla państwstron czy utratę wyjątkowego statusu, nadawanego mocą traktatu, tak jak np. ten nadawany mocą art. 5 Protokołu Montrealskiego, który pozwala państwom-

${ }^{83}$ Drugi raport Rao, U.N. Doc. A/CN.4/501, s. 11. Rao przywołuje tutaj jako przykład Konwencję bezpieczeństwa jądrowego sporządzoną w Wiedniu 20 września 1994 r., Dz. U. 1997, nr 42, poz. 262, która w art. 5 wprowadza mechanizm wzajemnej kontroli państw-stron, oparty o raporty państw dotyczące spełniania przez nie obowiązków wynikających z konwencji (ang. peer review mechanism), przedstawiane podczas „spotkań okresowych”, odbywających się co najmniej raz na trzy lata (art. 20 i 22). Art. 29 przewiduje, iż w przypadku powstania niezgodności pomiędzy stronami konwencji, będą one podejmować konstulacje celem ich rozwiązania. Konwencja nie przewiduje bezpośredniego odwołania do mechanizmów międzynarodowego rozstrzygania sporów. Jak wskazuje Kenig-Witkowska, mimo iż praktyka stosowania traktatów pozwala na odwołanie do nich, państwa rzadko decydują się rozwiązywać na drodze sądowej spory dotyczące procedur non-compliance; por.: M. M. Kenig-Witkowska, Międzynarodowe..., s. 136.

${ }^{84}$ Ibidem; Drugi raport Rao, U.N. Doc. A/CN.4/501, s. 11. Protokół przewiduje wprowadzenie mechanizmów wzajemnej współpracy i wsparcia przy realizacji jego celów, procedurę badania skarg wzajemnych stron oraz obowiązek okresowego składania przez nie raportów.

${ }^{85}$ M.M. Kenig-Witkowska, Międzynarodowe..., s. 136-137; Drugi raport Rao, U.N. Doc. A/CN.4/501, s. 11 .

${ }^{86}$ Por. ibidem, s. 133.

${ }^{87}$ Por. ibid., s. 135-136.

${ }^{88}$ Drugi raport Rao, U.N. Doc. A/CN.4/501, s. 11.

${ }^{89}$ Dz.U. 2007, nr 224, poz. 1656; por.: Drugi raport Rao, U.N. Doc. A/CN.4/501, s. 11. 
-stronom ubiegać się o dodatkowe fundusze, choć środki takie są w praktyce rzadko stosowane ${ }^{90}$.

\subsection{Prawo morza}

Szczególny reżim odpowiedzialności za naruszenie zasady prewencji sformułowany został względem środowiska morskiego. Potrzeba doprecyzowania zasady należytej staranności dla tego obszaru wiązała się przede wszystkim z rozwojem technologii, umożliwiających wykorzystanie mórz na nowe sposoby $^{91}$. Obowiązek dokładania należytej staranności przy zapobieganiu szkodom w środowisku morskim zawarty został w treści KoPM.

Odwołanie do reguł prewencji zawarto w treści art. 192, nakładającego na państwa ogólne zobowiązanie do „ochrony i zachowania środowiska morskiego"92, korespondujące z zapisem preambuły, która wzywa państwa do ,pokojowego korzystania z mórz i oceanów, sprawiedliwego i efektywnego wykorzystania ich zasobów, zachowania ich zasobów żywych oraz badania, ochrony i zachowania środowiska morskiego". Zapis art. 192 ma charakter obligatoryjny i tak też interpretować należy wiele zapisów Konwencji dotyczących prewencji zawartych w jej części XII, zatytułowanej „ochrona i zachowanie środowiska morskiego" 93 . Treść art. 193 odzwierciedla wspomnianą już ideę dobrosąsiedztwa zawartą w treści zasady 21 Deklaracji sztokholmskiej ${ }^{94}$. Państwa mają więc suwerenne prawo do ,eksploatacji swoich zasobów naturalnych stosownie do ich polityki w dziedzinie ochrony środowiska", lecz winny to czynić zgodnie z „obowiązkiem ochrony i zachowania środowiska morskiego". Co więcej, stosując środki zmierzające do zapobiegania, zmniejszania lub kontroli zanieczyszczenia środowiska morskiego, państwa nie powinny w sposób nieuzasadniony zakłócać prowadzonej przez inne państwa eksploatacji ich morskich zasobów ${ }^{95}$.

${ }^{90}$ Por.: Drugi raport Rao, U.N. Doc. A/CN.4/501, s. 11.

${ }^{91}$ Por.: L. Juda, International Law and Ocean Use Management, The Evolution of Ocean Governance, Londyn 1996, s. 285.

92 Obligatoryjna formuła zawarta została także w angielskim tekście oryginalnym, który stanowi iż: „States have the obligation”, por. art. 192 KoPM.

${ }^{93}$ Polskie „państwa stosuja” w art. 194 KoPM w angielskim tekście oryginalnym to „states shall take (...) all measures". Por.: art. 194 KoPM; por. też: M. H. Nordquist, United Nations Convention on The Law of the Sea 1982 A Commentary, Leiden 1991, s. xiv-xvi, który wyjaśnia, iż państwa uzgodniły, aby słowu shall nadać charakter imperatywny i stosować jako sposób wyrażenia obowiązku.

${ }^{94}$ J. Brunee, Structure and Processes of International Environmental Law, (w:) Stockholm Papers, red. M. H. Nordquist, J. N. Moore, S. Mahmoudi, Haga 2003, s. 68-69. Por. też: uwagi wstępne do rozdz. poprzedniego.

95 Art. 194 ust. 4. KoPM; por.: P. Birnie, Impact on the Development of International Law on Cooperation: The UN Law of the Sea, Straddling Stocks and Biodiversity Convention, (w:) The Stockholm Declaration and Law of the Marine Environment, red. M. H. Nordquist, Haga 2003, s. 92. 
Odzwierciedlenie zasady prewencji, opisywanej przez KPM w raportach omawianych $\mathrm{w}$ rozdziałach poprzednich ${ }^{96}$, widoczne jest w treści art. 194 KoPM, opisującego środki zmierzające do zapobiegania, zmniejszania i kontroli zanieczyszczenia środowiska morskiego. Zgodnie z jego dyspozycją, państwa „stosują”, wszelkie środki konieczne dla zapobiegania, zmniejszania i kontroli zanieczyszczenia środowiska morskiego z jakiegokolwiek źródła. Czynić to winny w granicach własnych możliwości i zależnie od okoliczności, działając samodzielnie lub wspólnie ${ }^{97}$. Tak określona treść zobowiązania nakłada na wszystkie państwa, tj. nie tylko na państwa-strony Konwencji, ale także na państwa trzecie, odwołując się do generowanej przez Konwencję normy zwyczajowej, szeroki obowiązek wykorzystania „wszelkich” środków dla przeciwdziałania szkodom w środowisku morskim ${ }^{98}$. Katalog owych środków w danej sytuacji powinien wynikać z negocjacji przeprowadzonych z innymi państwami, zarówno w ramach współpracy regionalnej, jak i powszechnej ${ }^{99}$. Zapis odwołujący się do możliwości państw, względem których kształtowana jest treść obowiązku, uwzględnia, jak już wspomniano, sytuację państw rozwijających się, dla których treść zobowiązania rozumiana powinna być węziej niż w przypadku państw rozwiniętych. Należyta staranność oznacza przy tym wykorzystanie „najlepiej nadających się do zastosowania sposobów", pozostających w dyspozycji państw oraz uzgadnianie przez nie wspólnych polityk kontroli zanieczyszczeń. Zobowiązanie państw dotyczy wszelkich działań prowadzonych w ich jurysdykcji lub pod ich kontrolą ${ }^{100}$. Odzwierciedla ono tym samym zakaz wykorzystania własnego terytorium ze szkodą dla innych ${ }^{101}$. Państwa muszą więc stosować wszelkie konieczne środki, aby działania realizowane w ich władzy nie powodowały szkód transgranicznych w środowisku morskim, czy to bezpośrednio, tj. poprzez emitowane zanieczyszczenia, czy to jako źródło wypadków, skutkujących ich powstaniem. Należyta staranność powinna być wykazywana przy zapobieganiu szkodom z jakichkolwiek źródeł, przede wszystkim zaś wynikającym z wprowadzania do środowiska morskiego toksycznych, szkodliwych lub niebezpiecznych substancji, zanieczyszczeniom powodowanym przez statki, zanieczyszczeniom $z$ instalacji i urządzeń używanych do badania lub eksploatacji zasobów naturalnych dna i podziemia morskiego, jak i zanieczyszczeniom pochodzącym $z$ innych instalacji i urządzeń eksploatowanych $\mathrm{w}$ środowisku morskim ${ }^{102}$. Taka konstrukcja art. 194 pozwala wskazać trzy elementy zasady należytej staranności w prawie morza: obowiązek prewencji, zmniejszania szkodliwych skutków oraz kontroli zanieczyszczeń środowiska morskiego. Zasada prewencji w przy-

\footnotetext{
${ }^{96}$ Por.: rozdz. III in fine.

${ }^{97}$ Por.: P. Birnie, op.cit., s. 92.

${ }^{98}$ Por.: J. Brunee, The Stockholm declaration and the Structure and Processes of International Environmental Law, (w:) Stockholm Popers, red. M. H. Nordquist, s. 76.

${ }^{99}$ Por.: J. Brunee, Structure..., s. 76-77.

${ }^{100}$ Art. 194 ust. 2 KoPM.

${ }^{101}$ Por.: J. Brunee, Structure..., s. 77. Por. orzeczenie w sprawie huty w Trail, omówione w rozdz. II.

${ }^{102}$ Art. 194 ust. 3. KoPM.
} 
padku środowiska morskiego obejmuje także obowiązek nieprzemieszczania szkody lub zagrożeń i nieprzekształcania jednego typu zanieczyszczenia w inny sposób $^{103}$. Zobowiązanie to wymaga od państw zapewnienia realizacji wszelkich przedsięwzięć w ich jurysdykcji lub pod ich kontrolą z uwzględnieniem owego celu $^{104}$. Jednocześnie Konwencja określa, jakie technologie i w jaki sposób moga być wykorzystane przez państwa celem wykonania obowiązku prewencji. Państwa zobligowane są więc do stosowania wszelkich środków koniecznych do zapobiegania, zmniejszania i kontroli zanieczyszczenia środowiska morskiego, które powstało wskutek stosowania technologii w jurysdykcji państwa lub pod jego kontrola, ale także w przypadku umyślnego lub przypadkowego wprowadzenia obcych lub nowych gatunków do obszaru morskiego, w którym ich obecność może powodować znaczne i szkodliwe zmiany ${ }^{105}$. Tak sformułowana dyspozycja przepisu stanowi połączenie dwóch reguł. Obejmuje obowiązek zapobiegania, ograniczania i kontrolowania zatrucia środowiska morskiego, wynikającego z wykorzystania technologii, połączony z obowiązkiem dbałości o zachowanie naturalnych zasobów obszarów morskich. Drugi z obowiązków nie jest bezpośrednio związany z problemem zanieczyszczenia środowiska morskiego, przyjąć więc można, że celem twórców dokumentu było powiązanie obowiązku dbałości o środowisko morskie $\mathrm{z}$ konsekwencjami ingerencji $\mathrm{w}$ jego naturalny $\operatorname{stan}^{106}$. Art. 145 KoPM ustanawia ponadto obowiązek podjęcia przez państwa „wszelkich niezbędnych środków w celu zapewnienia skutecznej ochrony środowiska morskiego przed szkodliwymi następstwami”. Następstwa te mogą wynikać z aktywności wpływających na stan dna mórz i oceanów oraz ich podziemia, znajdujących się poza granicami jurysdykcji państwowej. Realizacji tego celu służy ustanowiona mocą konwencji Międzynarodowa Organizacja Dna Morskiego, która tworzy „odpowiednie zasady, przepisy i procedury”, których celem jest m.in. „zapobieganie, zmniejszanie i kontrola zanieczyszczenia środowiska morskiego oraz innych niebezpieczeństw dla tego środowiska, łącznie z wybrzeżem”107. Jako niepożądane „zanieczyszczenie środowiska morskiego” zgodnie z dyspozycją art. 1 ust. 4 Konwencji, rozumieć należy wprowadzanie przez człowieka substancji lub energii do środowiska morskiego, o ile powoduje ono lub może powodować szkodliwe następstwa, np.: szkody w żywych zasobach, zagrożenie zdrowia człowieka, utrudnienia w żegludze czy połowach lub obniżanie jakości użytkowej wody morskiej.

Postrzeganie morza otwartego jako przestrzeni, o stan której dbać powinny wszystkie państwa, odzwierciedla podejście międzynarodowej społeczności do wyzwań ochrony środowiska. Przestrzeń mórz i oceanów winna stać się przedmiotem troski wszystkich państw w tej samej mierze. Wyraz owej troski stanowi także fakt, że treść licznych i szczegółowych ustaleń, dotyczących ochrony śro-

\footnotetext{
${ }^{103}$ Art. 195 KoPM.

${ }^{104}$ Art. 195 KoPM.

${ }^{105}$ Art. 196 KoPM.

${ }^{106}$ Por.: J. Brunee, Structure..., s. 76.

${ }^{107}$ Art. 145 pkt a) KoPM.
} 
dowiska morskiego, zapisana została w szeregu konwencji, z których najważniejsza wskazana została powyżej ${ }^{108}$. W jej treści potwierdzono ogólne zasady korzystania z morza otwartego i jego zasobów. Zidentyfikowanie owych zasad, wspólnych dla wszystkich członków międzynarodowej społeczności, odzwierciedla powszechny obowiązek troski o stan morskiego środowiska naturalnego i wykazywania należytej staranności przy jego realizacji.

Obowiązki dotyczące ochrony środowiska morskiego, opisane w art. 194 i 196 KoPM, odnaleźć można w treści innych traktatów, jak np. Międzynarodowa konwencja o zapobieganiu zanieczyszczaniu morza przez statki z 1972 r. Zobowiązuje ona państwa-strony do zapobiegania zanieczyszczeniom środowiska morskiego przez zrzuty szkodliwych substancji ${ }^{109}$. Zawarta w jej treści zasada prewencji wymaga podjęcia współpracy w wykrywaniu naruszeń prawa i zapewnianiu przestrzegania postanowień konwencji, z użyciem „wszystkich właściwych i dostępnych środków wykrywania i kontroli środowiska"110. Zobowiązanie to obejmuje także obowiązek wykorzystania odpowiednich sposobów przekazywania informacji i gromadzenia dowodów.

Zasada prewencji doprecyzowana została także w treści Konwencji o ochronie środowiska morskiego obszaru Morza Bałtyckiego z 1992 r. ${ }^{111}$ Zawarty w niej obowiązek ochrony przyrody i różnorodności biologicznej zobowiązuje państwa-strony do podjęcia, ,indywidualnie i wspólnie, wszelkich właściwych środków”, które będą miały na celu ochronę środowiska przyrodniczego i różnorodności biologicznej oraz procesów ekologicznych w obszarze Morza Bałtyckiego i jego ekosystemów ${ }^{112}$. Zasada dobrosąsiedztwa odzwierciedlona jest w tym samym przepisie, który stanowi o konieczności podjęcia wszelkich właściwych środków w celu zapewnienia zrównoważonego wykorzystania zasobów naturalnych na obszarze Morza Bałtyckiego, w oparciu o wytyczne i kryteria przyjmowane przez państwa $\mathrm{w}$ toku dalszej współpracy ${ }^{113}$. Analogiczne zapisy znalazły się w treści Konwencji o ochronie środowiska morskiego i regionu przybrzeżnego Morza Śródziemnego z 1976 r. (tzw. konwencji barcelońskiej), której art. 4 zobowiązuje państwa-strony do podjęcia „wszelkich właściwych środków” zmierzających do zapobiegania, zmniejszania i zwalczania zanieczysz-

108 Por.: Międzynarodowa Konwencja o zapobieganiu zanieczyszczaniu morza przez statki sporządzona w Londynie dnia 2 listopada 1973 r., Dz.U. 1987, nr 17, poz. 101 (ang. International Convention for the Prevention of Pollution From Ships, dalej: MARPOL); Konwencja o ochronie środowiska morskiego obszaru Morza Bałtyckiego, sporządzona w Helsinkach dnia 9 kwietnia 1992 r., Dz.U. 2000, nr 28, poz. 346; Konwencja o ochronie środowiska morskiego i regionu przybrzeżnego Morza Śródziemnego (konwencja barcelońska), sporządzona w Barcelonie w 1976 r., zmieniona 10 czerwca 1995 r., weszła w życie 9 lipca 2004 r. przyjęta przez Unię Europejską mocą Decyzji 77/585/EEC; Dz. U, L 240, z 19 września 1977, s. 1-2. 1102 UNTS, 15 ILM 290 (1976).

${ }_{109}$ Art. 1 MARPOL.

${ }^{110}$ Art. 6 MARPOL.

${ }^{111}$ Konwencja o ochronie środowiska morskiego obszaru Morza Bałtyckiego, sporządzona w Helsinkach dnia 9 kwietnia 1992 r., Dz.U. 2000, nr 28, poz. 346 (dalej: Konwencja o ochronie środowiska morskiego obszaru Morza Bałtyckiego).

${ }^{112}$ Konwencja o ochronie środowiska morskiego obszaru Morza Bałtyckiego, art. 15.

${ }^{113}$ Konwencja o ochronie środowiska morskiego obszaru Morza Bałtyckiego, art. 15. 
czenia obszaru Morza Śródziemnego oraz do ochrony i poprawy stanu środowiska morskiego w tym obszarze ${ }^{114}$. Uznać więc można, iż zasada należytej staranności obecna jest w prawie morza, zarówno w jego źródłach traktatowych, jak i w treści powszechnych norm zwyczajowych, opartych o praktykę państw.

\subsection{Prawo międzynarodowych cieków wodnych}

Ujęcie zasady należytej staranności w swoich raportach i projektach Komisja oparła w znacznej mierze na treści ustaleń dotyczących projektu artykułów o prawie nieżeglownego wykorzystania międzynarodowych cieków wodnych $^{115}$. Zarówno Quentin-Baxter, jak i Barboza, opisując treść należytej staranności i obowiązku prewencji przyjęli, że powinna ona być proporcjonalna do stopnia niebezpieczeństwa powstania szkody transgranicznej w konkretnych okolicznościach ${ }^{116}$. Standard należytej staranności powinien być ustalany z uwzględnieniem znaczenia i wartości ekonomicznej danej niebezpiecznej działalności oraz środków pozostających w dyspozycji państwa ją autoryzującego ${ }^{117}$. Identyfikując treść zasady należytej staranności w danej sytuacji faktycznej należy także wziąć pod uwagę standardy stosowane przez państwo poszkodowane oraz praktykę krajową i międzynarodową ${ }^{118}$.

Opierając się na ustaleniach KPM wskazać można trzy przesłanki, których weryfikacja pozwoli ustalić, czy państwo dopełniło należytej staranności. Należyta staranność oznacza wykazywanie przez państwa takiego poziomu troski, którego oczekiwać można od dobrego rządu. Innymi słowy, rząd lub państwo powinno posiadać ,stale funkcjonujący system prawny i środki materialne, które wystarczą, aby zapewnić spełnienie zobowiązań międzynarodowych tych państw w normalnych warunkach" ${ }^{119}$. W szczególności, państwo powinno stworzyć i utrzymywać aparat administracyjny, który spełnia minimalne wymogi, wystarczające do wykonywania tych obowiązków ${ }^{120}$. Jak wyjaśniał sędzia Huber w uzasadnieniu rozstrzygnięcia sporu pomiędzy Marokiem i Wielką Brytanią w 1925 r., żaden system administracyjny ani policyjny państwa nie jest doskonały i pewien margines tolerancji musi być uwzględniany przy ocenie wysiłków państw, nawet tych posiadających wyjątkowo sprawne aparaty państwowe ${ }^{121}$.

${ }^{114}$ Konwencja o ochronie środowiska morskiego i regionu przybrzeżnego Morza Śródziemnego (konwencja barcelońska), sporządzona w Barcelonie w 1976 r., zmieniona 10 czerwca 1995 r., weszła w życie 9 lipca 2004 r. przyjęta przez Unię Europejską mocą Decyzji 77/585/EEC; Dz. U, L 240, z 19 września 1977, s. 1-2. 1102 UNTS, 15 ILM 290 (1976).

115 Projekt artykułów o prawie nieżeglownego wykorzystania międzynarodowych cieków wodnych, KPM, 1993 r., U.N. Doc. A/CN.4/L.489.

${ }_{116}$ Drugi raport Rao, U.N. Doc. A/CN.4/501, s. 6.

${ }^{117}$ Drugi raport Rao, U.N. Doc. A/CN.4/501, s. 6.

${ }^{118}$ Drugi raport Rao, U.N. Doc. A/CN.4/501, s. 6.

${ }^{119}$ Drugi raport Rao, U.N. Doc. A/CN.4/501, s. 6. Por. X. Hanquin, Transboundary..., s. 163.

${ }^{120}$ Drugi raport Rao, U.N. Doc. A/CN.4/501, s. 6.

${ }^{121}$ Sprawa roszczeń brytyjskich w Maroku, s. 641-642. 
Jednak ograniczenia wynikające $\mathrm{z}$ owych niedociągnięć nie mogą prowadzić do sytuacji, w której ogólna ochrona interesów mieszkańców owego państwa spadnie poniżej pewnego poziomu, stając się jedynie iluzją ${ }^{122}$. Drugim kryterium weryfikacji należytej staranności państwa jest określenie, na ile wykorzystanie pozostającej $\mathrm{w}$ dyspozycji państwa infrastruktury odzwierciedlało potrzeby danych okoliczności, biorąc pod uwagę wykazaną przez władze państwowe czujność ${ }^{123}$. Trzecia przesłanka obejmuje obowiązek weryfikacji samego szkodliwego działania i ustalenie, czy jego szkodliwy skutek mógł był zostać przewidziany ${ }^{124}$. Jak pisze Rao, im „wyższy stopień niedopuszczalnego zanieczyszczenia (...), tym większa będzie staranność wymagana ze strony państwa dla zapobieżenia mu"125. Stosowanie niebezpiecznych technologii lub metod produkcji przemysłowej niesie za sobą obowiązek państwa wykazywania wyższej czujności, niezależnie od ogólnego poziomu rozwoju państwa ${ }^{126}$. Co więcej, zobowiązanie do wykazania należytej staranności nie powinno być interpretowane jako podstawa odpowiedzialności na zasadzie ryzyka państwa za szkodę wywołaną zatruciem środowiska, ta bowiem wynikać może jedynie $\mathrm{z}$ treści traktatu ${ }^{127}$.

Zdaniem niektórych członków Komisji, tak sformułowany standard należytej staranności powinien zostać uzupełniony o dodatkowe elementy. Jednym z nich jest obowiązek wykazania czujności stosownej do poziomu rozwoju państwa. Wskazywano również, że ze względów pragmatycznych stopień wymaganej należytej staranności powinien zależeć od okoliczności faktycznych ${ }^{128}$. Okoliczności, w których jej dopełnienie powinno być weryfikowane, to tylko te, w których prawdopodobieństwo wywołania znaczącej szkody w wyniku realizacji danej aktywności było przewidywalne. Państwo byłoby więc zobligowane do wykazania należytej staranności jedynie wtedy, gdy wiedziało lub powinno było wiedzieć, że dana działalność może wywołać szkodę. Niektórzy członkowie Komisji wskazywali także, że łączenie standardu należytej staranności z międzynarodowym minimalnym standardem zachowania oczekiwanego od „dobrego rządu” czy „cywilizowanego państwa” nawiązywało do kontrowersyjnej doktryny minimalnego standardu międzynarodowego w tradycyjnym prawie międzynarodowym ${ }^{129}$.

W projekcie artykułów o prawie nieżeglownego wykorzystania międzynarodowych cieków wodnych ${ }^{130}$ należyta staranność została zdefiniowana jako „staranność proporcjonalna do wielkości jej przedmiotu oraz do autorytetu i siły

${ }^{122}$ Sprawa roszczeń brytyjskich w Maroku, s. 641-642.

${ }^{123}$ Drugi raport Rao, U.N. Doc. A/CN.4/501, s. 7.

${ }^{124}$ Drugi raport Rao, U.N. Doc. A/CN.4/501, s. 7.

${ }^{125}$ Drugi raport Rao, U.N. Doc. A/CN.4/501, s. 7.

${ }^{126}$ Drugi raport Rao, U.N. Doc. A/CN.4/501, s. 7.

${ }^{127}$ Por.: Drugi raport Rao, U.N. Doc. A/CN.4/501, s. 6.

${ }^{128}$ Drugi raport Rao, U.N. Doc. A/CN.4/501, s. 7-8.

${ }^{129}$ Drugi raport Rao, U.N. Doc. A/CN.4/501, s. 7-8. Zob. także M. N. Shaw, Prawo..., s. 435.

${ }^{130}$ Art. 7. Projektu artykułów o prawie nieżeglownego wykorzystania międzynarodowych cieków wodnych, KPM, 1993 r., U.N. Doc. A/CN.4/L.489 
władzy, która powinna ową staranność wykazywać”, jak również jako „taka troska, jaką rządy zazwyczaj wykazują w swoich zwykłych sprawach krajowych" ${ }^{\prime 31}$. Standard ten nie oznaczał, iż podczas korzystania z międzynarodowego cieku wodnego nie mogą wystąpić żadne znaczące szkody ${ }^{132}$. Naruszenie zobowiązania do wykazywania należytej staranności stwierdzone mogło zostać w sytuacjach, w których ,państwo celowo albo niedbale spowodowało zdarzenie, któremu należało zapobiec"133. Taką samą ocenę prawną wywoła celowe lub niedbałe niezapobieżenie takiemu działaniu, realizowanemu przez inne podmioty na terytorium państwa. To założenie potwierdza wcześniejsze rozważania Komisji, w treści których wskazywała, że państwo może zostać uznane za odpowiedzialne za fakt niewprowadzenia stosownej legislacji, niewykonywania obowiązujących aktów prawnych czy też niezapobiegania lub niepowstrzymania bezprawnej działalności lub nieukarania osób za nią odpowiedzialnych. Naruszenie zobowiązania należytej staranności stwierdzone może zostać także wtedy, gdy państwo wiedziało albo powinno było wiedzieć, że dany sposób wykorzystania międzynarodowego ciągu wodnego może wywołać znaczącą szkodę innych państw.

Uzupełniając rozważania oparte na dorobku Komisji w obszarze prawa międzynarodowych cieków wodnych, Rao przywołuje rozważania dotyczące orzeczenia MTS w sprawie cieśniny Korfu. W jego treści Trybunał wskazał, że sam fakt sprawowania kontroli przez państwo nad danym obszarem czy akwenem nie może oznaczać, że państwo to wiedziało czy powinno było wiedzieć o niezgodnej z prawem aktywności tam realizowanej czy jej wykonawcach.

W toku wykładni Konwencji z 1997 r. o nieżeglownym wykorzystaniu międzynarodowych cieków wodnych kłopotliwe okazało się zaproponowane przez m.in. Kanadę i Szwajcarię odwołanie do „właściwych środków” (ang. appropriate measures), które zastosować powinno państwo, aby zwolnić się z zarzutu niedołożenia należytej staranności. Proponujący owo sformułowanie przedstawiciele państw argumentowali, że jego niejednoznaczność i niedoprecyzowanie są celowe, pozwolą bowiem na adekwatne dostosowanie tak opisanego standardu do różniących się od siebie okoliczności faktycznych, w kontekście opisanych powyżej konstatacji. Zarówno Quentin-Baxter, jak i Barboza, opierając opisywane koncepcje na wcześniejszym dorobku Komisji dotyczącym wykorzystania międzynarodowych ciągów wodnych, przyjmowali, że standard należytej staranności przy obowiązku prewencji powinien być proporcjonalny do stopnia niebezpieczeństwa powstania szkody transgranicznej w danych okolicznościach, precyzując ogólne zapisy konwencji ${ }^{134}$. Standardy stosownej ochrony identyfikować należy z uwzględnieniem znaczenia, jakie dana niebezpieczna aktywność

${ }^{131}$ Drugi raport Rao, U.N. Doc. A/CN.4/501, s. 8 .

${ }^{132}$ Drugi raport Rao, U.N. Doc. A/CN.4/501, s. 8. Wykazywana staranność powinna być proporcjonalna do jej przedmiotu i powagi władzy ją wykazującej. Nie było celem sformułowanego obowiązku zagwarantowanie, iż szkoda nie wystąpi podczas wykorzystywania cieków wodnych.

${ }^{133}$ Drugi raport Rao, U.N. Doc. A/CN.4/501, s. 8 .

${ }^{134}$ Drugi raport Rao, U.N. Doc. A/CN.4/501, s. 8. 
ma dla gospodarki kraju oraz uwzględniając środki pozostające w dyspozycji państwa. Ustalenia te czynione być powinny w kontekście praktyki regionalnej i międzynarodowej.

\subsection{Ochrona cudzoziemców}

Jak już wskazano, koncepcja odpowiedzialności państwa wywodzi się nie z odpowiedzialności za szkody wyrządzone na dobrach innych suwerenów, ale z pierwotnego, uznawanego powszechnie, obowiązku rekompensaty strat poniesionych przez cudzoziemców na terytorium suwerena ${ }^{135}$. Wśród norm prawa międzynarodowego, dotyczących statusu cudzoziemców, zobowiązanie państwa pobytu do czynnej ochrony ich bezpieczeństwa i dobytku zajmuje znaczące miejsce. Wynika ono z faktu, że państwo nie musi wyrazić zgody na pobyt cudzoziemca na swoim terytorium, jeśli jednak zgody takiej udzieli, musi traktować go z poszanowaniem minimalnego międzynarodowego standardu ochrony, przy zapewnianiu bezpieczeństwa osobistego, jak też gwarantując prawo własności ${ }^{136}$. Szczególną formą tego obowiązku jest zobowiązanie do wykazania szczególnej troski przy zapewnianiu cudzoziemcom sprawującym w państwie pobytu funkcje dyplomatyczne, o których mowa będzie dalej. Jak w 1946 r. pisał Jessup, „odpowiedzialność państwa za szkodę wyrządzoną cudzoziemcowi opierać się może na grzechu zaniechania albo działania" "137.

Termin „minimalny standard międzynarodowy”, jak już wspomniano, opisuje treść podstawowych praw cudzoziemców na terytorium państwa pobytu, niezależnie od poziomu ochrony praw obywateli tego państwa ${ }^{138}$. Przyjęcie owego standardu było alternatywą dla traktowania narodowego cudzoziemców przez państwo goszczące ${ }^{139}$. Zgodnie z tym ostatnim, cudzoziemcy traktowani być winni nie gorzej niż obywatele goszczącego państwa ${ }^{140}$. Wśród jego zwolenników większość stanowili przedstawiciele państw rozwijających się, upatrujący w przyjęciu standardu minimalnego zagrożenie dla lokalnych demokracji ${ }^{141}$. Praktyka międzynarodowa przyjęła minimalny międzynarodowy standard

\footnotetext{
${ }^{135}$ Por. Oppenheim, International law..., s. 495.

${ }^{136}$ Por. np.: F.V. Garcia-Amador, Draft Articles on the Responsibility of the State for Injuries Caused in its Territory to the Person or Property of Aliens, (w:) Recent Codification of the Law of State Responsibility for Injuries to Aliens, red. F. V. García Amador, L. B. Sohn, R. R. Baxter, Haga 1974, s. 3-4.

${ }^{137}$ R. Jessup, Responsibility of States for Injuries to Individuals, Columbia Law Review 1946, nr 46, s. 912.

${ }^{138}$ Por. ogólnie: M. Paparinskis, The International Minimum Standard and Fair and Equitable Treatment, Oksford 2013; zob. także: R. Kläger, 'Fair and Equitable Treatment' in International Investment Law, Cambridge 2011, s. 48-61; M. N. Shaw, Prawo..., s. 434-436; I. Brownlie, Principles..., s. 425-428.

${ }^{139}$ Por. np.: Por. np.: F.V. Garcia-Amador, Draft Articles..., s. xviii-xix, 41, 51.

${ }^{140}$ Por. np.: Por. np.: ibidem, s. 161.

${ }^{141}$ Por.: M. N. Shaw, Prawo międzynarodowe..., s. 434-436.
} 
ochrony cudzoziemców dopiero w XX w., za dowód czego służyć może rozstrzygnięcie amerykańsko-meksykańskiej komisji dwustronnej w sprawie małżeństwa Neer z $1926 \mathrm{r}^{142}$ Komisja uznała, że „zasadność działań rządu powinna być weryfikowana względem standardów międzynarodowych" "143, a zasada ta została potwierdzona w treści wyroku w sprawie przeciwko Polsce, dotyczącej pewnych interesów niemieckich na polskim Górnym Śląsku ${ }^{144}$. STSM uznał, że istnieje wspólny i ogólnie przyjęty zbiór norm prawa międzynarodowego, dotyczący sposobu traktowania cudzoziemców przebywających na terytorium państwa ${ }^{145}$. Treść minimalnego międzynarodowego standardu ochrony cudzoziemców została uzupełniona o zobowiązanie do ochrony ich życia w treści wyroku w sprawie Garcia ${ }^{146}$, zaś w sprawie Roberts komisja dwustronna wskazała, że traktowanie cudzoziemców powinno być zgodne ze „zwykłymi standardami cywilizacyjnymi"147. Minimalny standard międzynarodowy nie jest jednak zdefiniowany w doktrynie ani w orzecznictwie. W sprawie Neer Komisja wskazała, że sposób traktowania obcokrajowca uznać można za naruszenie międzynarodowego zobowiązania wówczas, gdy osiaga on skalę „skandaliczną, jest przejawem złej wiary, umyślnego zaniedbania obowiązków lub braku działań organów państwowych tak dalece odbiegajacych od standardów międzynarodowych, że każdy bezstronny i rozsądnie myślący człowiek uznałby podjęte działania za niewystarczające" ${ }^{148}$. Shaw podsumowuje dorobek orzecznictwa, z którego standard ów wywodzi, opisując międzynarodowy standard minimalny jako „dosyć wysoki próg”, który spełnić winny państwa przy ochronie cudzoziemców $^{149}$. Inni autorzy opisują ów standard jedynie jako wynik procesu decyzyjnego, właściwego dla pojedynczej sprawy, wynikającego z analizy jej okoliczności ${ }^{150}$. Analiza taka może prowadzić do uznania odpowiedzialności państwa za szkodę poniesioną przez cudzoziemca, np. w efekcie odmowy prawa do sądu ${ }^{151}$. García-Amador wskazał w treści przedstawionego KPM w 1956 r. raportu dwie zasady, w oparciu o które odtworzyć można minimalny standard międzynarodowej ochrony praw człowieka, a w konsekwencji - praw gwarantowanych obcokrajowcom w każdym państwie ich pobytu. Przede wszystkim,

${ }^{142}$ L. F. H. Neer i Pauline Neer przeciwko Stanom Zjednoczonym Meksyku, R.I.A.A. 1926, s. 60-66 (sprawa Neer).

${ }^{143}$ Por. np. sprawa Janesa, opisana w rozdz. II, sprawa Neer, s. 214; por. też M.N. Shaw, Prawo międzynarodowe..., s. 435.

${ }^{144}$ Sprawa pewnych interesów niemieckich na polskim Górnym Śląsku, Stały Trybunał Sprawiedliwości Międzynarodowej 1926, PCIJ Series 1926, seria A, nr 6.

${ }^{145}$ Por.: M. N. Shaw, Prawo międzynarodowe..., s. 434.

146 Sprawa Macedonio J. García przeciwko Stanom Zjednoczonym Meksyku, R.I.A.A. 1926, tom IV, s. 108-110. Por.: M.N. Shaw, Prawo międzynarodowe..., s. 434-435 (sprawa Garcíi).

${ }^{147}$ Sprawa Harry Roberts przeciwko Stanom Zjednoczonym Meksyku, R.I.A.A. 1926, tom IV, s. 77-81. Por.: M.N. Shaw, Prawo międzynarodowe..., s. 435 (sprawa Roberts).

${ }^{148}$ Sprawa Neer, s. 61-62.

${ }^{149}$ M.N. Shaw, Prawo międzynarodowe..., s. 435.

${ }^{150}$ Por. ibidem, s. 435 i cytowana tam literatura.

${ }^{151}$ Ibid. 
standard ten oznacza przyznanie równych praw obywatelom i cudzoziemcom, zaś ich katalog powinien odzwierciedlać fundamentalne prawa człowieka, uznane i opisane $w$ traktatach dotyczących praw człowieka ${ }^{152}$. Ponadto, omawiany standard obejmuje możliwość pociagnięcia do międzynarodowej odpowiedzialności państwa, które narusza powszechnie uznane prawo człowieka ${ }^{153}$. Jak wskazuje Shaw, mimo iż przesłanki zaproponowane przez Garcíę-Amadora nie zostały uwzględnione w ostatecznym projekcie artykułów, znalazły swoje odzwierciedlenie w kilku umowach międzynarodowych, odwołujących się do minimalnego międzynarodowego standardu ochrony praw człowieka ${ }^{154}$.

Analizując m.in. treść omówionego powyżej standardu, Pisillo Mazzeschi wskazuje, że ogólne zobowiązanie państw do ochrony praw cudzoziemców obejmuje dwa szczególne obowiązki: negatywny obowiązek powstrzymania się od naruszania ich praw (ang. duty to abstain) oraz wąsko rozumiany pozytywny obowiązek ochrony (ang. duty to protect) ${ }^{155}$. Pierwszy z nich rozumiany być powinien jako obowiązek negatywny, tj. wymaganie względem państwa, aby to powstrzymywało się przed wywoływaniem zagrożeń dla bezpieczeństwa cudzoziemców na jego terytorium lub w jego jurysdykcji. Drugi obowiązek powinien być rozumiany jako pozytywne zobowiązanie państwa do podjęcia aktywnych starań celem zapewnienia bezpieczeństwa przebywającym w jego jurysdykcji cudzoziemcom, zwłaszcza przed atakami osób prywatnych czy przedstawicieli państw trzecich ${ }^{156}$. Obowiązek ten obejmuje zarówno konieczność zapobiegania szkodliwym zdarzeniom, jak i ukarania ich sprawców, jeśli nie udało się zapobiec realizacji zagrożenia.

Naruszenie negatywnego zobowiązania państwa do powstrzymania się od naruszania praw cudzoziemców zawsze dotyczy działania lub zaniechania organów państwa, choć - jak wskazuje Pisillo Mazzeschi - należyta staranność nie zawsze jest przywoływana $\mathrm{w}$ orzeczeniach dotyczących odpowiedzialności państwa w takich sytuacjach. Nie była przywoływana w orzeczeniach dotyczących użycia broni przeciwko cudzoziemcom przez członków krajowych sił zbrojnych czy porządkowych, w sprawach dotyczących bezpodstawnego czy przedłużającego się aresztowania cudzoziemców, ani w tych dotyczących niewłaściwego ich traktowania podczas stosowania aresztu ${ }^{157}$. Nie dotyczy także bezpośrednio naruszenia prawa własności czy innych praw rzeczowych przez organy państwa, niezależnie od tego, czy naruszenie prawa nastapiło w wyniku działania organów sądowych czy administracyjnych ${ }^{158}$. Zdaniem Pisillo Mazzesiego, należyta staranność przy naruszeniach obowiązku negatywnego nie jest istotna - wykaza-

\footnotetext{
${ }^{152}$ Por. Pierwszy raport F.V. Garcíi-Amadora, U.N. Doc. A/CN.4/96, s. 200.

${ }^{153}$ M.N. Shaw, Prawo międzynarodowe..., s. 435.

${ }^{154}$ Ibidem, s. 435-436.

${ }^{155}$ R. Pisillo Mazzeschi, op.cit., s. 22.

${ }^{156}$ Ibidem.

${ }^{157}$ Ibid., s. 23, przypis 41 i sprawy tam cytowane.

${ }^{158}$ Ibid.
} 
nie jej powiązane musiałoby być z wykazaniem winy umyślnej lub niedbalstwa po stronie osoby pełniącej funkcję organu państwa czy działającą w jego imieniu.

Dlatego też należyta staranność przywoływana jest w orzecznictwie zazwyczaj w kontekście realizacji bądź niedopełnienia pozytywnego obowiązku prewencji ${ }^{159}$. Ten autor znajduje potwierdzenie owej tezy w orzecznictwie międzynarodowym, gdzie sądy wymagają wykazania należytej staranności organu państw jako okoliczności egzoneracyjnej w przypadku naruszenia minimalnego międzynarodowego standardu ochrony. Dzieje się tak nawet wtedy, gdy organy państwa działały w dobrej wierze i z należytą starannością przy implementacji norm międzynarodowych do prawa krajowego ${ }^{160}$.

Także w kontekście szkód ponoszonych przez cudzoziemców nie budzi wątpliwości brak odpowiedzialności państw za czyny osób prywatnych. Podobnie, bez wątpliwości można przyjąć, że państwo może ponosić odpowiedzialność za sprzeczne $\mathrm{z}$ treścią jego zobowiązań międzynarodowych zaniechanie, jeśli osoby prywatne, znajdujące się na jego terytorium lub pod jego kontrolą, dopuściły się zachowania skutkującego naruszeniem przez państwo obowiązku prewencji. Odpowiedzialność za działania osób prywatnych wynika bezpośrednio z obowiązku prewencji, spoczywającego na państwie, w granicach którego przebywa poszkodowany cudzoziemiec. Przy ochronie praw cudzoziemców zobowiązanie państwa obejmuje jednocześnie dwa obowiązki: obowiązek zapobiegania szkodliwym działaniom osób prywatnych oraz zobowiązanie do ukarania winnych szkód, którym zapobiec się nie udało. Pisillo Mazzeschi dowodzi, iż te dwa zobowiązania winny być badane niezależnie od siebie ${ }^{161}$. Państwo nie jest więc zobowiązane zapobiec wszelkim szkodom wyrządzonym cudzoziemcom, ale jest zobowiązane szkodom takim zapobiegać, wykazując należytą starannośćc ${ }^{162}$. Treść zobowiązania, okoliczności konstytuujące jego naruszenie oraz rola należytej staranności w ocenie owego naruszenia analizowane być powinny jedynie w odniesieniu do konkretnego stanu faktycznego. Od treści konkretnego zobowiązania zależeć będzie wymagany normą międzynarodową poziom należytej staranności po stronie państwa. Należyta staranność przywoływana być powinna jedynie w przypadku naruszenia zobowiązania starannego postępowania (ang. diligent conduct), nigdy zaś w przypadku naruszenia zobowiązania do osiagnnięcia określonego rezultatu (ang. obligation of result) ${ }^{163}$.

${ }^{159}$ Por.: ibid., s. 24, przyp. 46 i sprawy tam cytowane, np. wspomniana powyżej sprawa Roberts.

${ }^{160}$ Ibid., s. 24, przyp. 46 i sprawy tam cytowane.

161 Ibid., s. 25-26.

162 Ibid., s. 26.

${ }^{163}$ Pisillo Mazzeschi odróżnia tak rozumiane zobowiązanie państwa do osiagnięcia określonego skutku od rozumienia tego pojęcia opisanego w treści Projektu artykułów o odpowiedzialności międzynarodowej z 1998 r., gdzie w treści art. 20 i 21 Komisja ogranicza jego zakres do skutku $\mathrm{w}$ postaci wprowadzenia stosownej legislacji w wewnętrznym porządku prawnym i jedynie za jej brak przewiduje odpowiedzialność państwa. Por.: R. Pisillo Mazzeschi, op.cit., s. 26. Krytycznie 
Sformułowany przez KPM jako zobowiązanie ciagłe obowiązek wykazywania należytej staranności pojawił się także w treści akademickiego projektu Konwencji o międzynarodowej odpowiedzialności państw za szkody poniesione przez cudzoziemców, przygotowanego przez Sohna i Baxtera z Uniwersytetu Harvarda w $1961 \mathrm{r}^{164} \mathrm{~W}$ treści art. 13 owego projektu znalazł się opis braku należytej staranności przy zapewnianiu ochrony cudzoziemcom, który uznany może zostać za naruszenie międzynarodowego zobowiązania państwa. Niedołożenie należytej staranności, przejawiające się brakiem środków prewencyjnych lub deterencyjnych, stosowanych wobec czynów bezprawnych osób działających samodzielnie lub $\mathrm{w}$ grupie, narusza prawo międzynarodowe, jeśli: czyn stanowi przestępstwo $\mathrm{w}$ myśl prawa krajowego oraz jest powszechnie uznawany za przestępny $\mathrm{w}$ głównych porządkach prawnych świata ${ }^{165}$. Art. 35 projektu przewidywał konsekwencje braku należytej staranności, zobowiązanie wykazywania której zawarto explicite w treści art. 13. Odpowiedzialność taka wynikałaby z braku ochrony zapewnianej cudzoziemcom lub wobec niepojmania lub nieosądzenia sprawcy przestępstwa, popełnionego na szkodę cudzoziemcy. Konsekwencje owego zaniechania przypisywane miałyby być państwu tak, jakby powstały w bezpośrednim następstwie jego własnych działań ${ }^{166}$. Państwo ponosiłoby więc odpowiedzialność za szkody wyrządzone przez osoby prywatne, którym mogło było zapobiec, wykazując należytą starannośćc ${ }^{167}$. Podobne zapisy znalazły się w treści Projektu zasad prawa międzynarodowego, rządzących odpowiedzialnością państwa, opracowanego przez Międzyamerykańską Komisję Prawniczą ${ }^{168}$. Wyjątki od zasady nieponoszenia przez państwa odpowiedzialności za działania podmiotów prywatnych opisane zostały w treści zaproponowanej zasady $\mathrm{V}$ i obejmowały sytuacje, w których państwo nie dołożyło należytej staranności przy chronieniu życia i mienia cudzoziemców lub nie wykazało jej przy pojmaniu i osądzeniu sprawcy naruszenia ${ }^{169}$.

Szeroko rozumiany obowiązek prewencji w prawie międzynarodowym ma szczególne znaczenie dla analizy obowiązków państwa względem goszczących na jego terytorium cudzoziemców. Pozwala zidentyfikować treść zasady należytej staranności względem tej kategorii podmiotów i aplikować reguły odpowiedzialności państwa za jego niedopełnienie. Podwyższony standard ochrony prawo międzynarodowe przewiduje bowiem względem szczególnej kategorii

o rozróżnieniu na zobowiązanie do określonego postępowania (ang. obligations of conduct) i zobowiązanie skutkowe (ang. obligations of result), I. Brownlie, State..., s. 244-245.

${ }^{164}$ Por. L. B. Sohn, R. Baxter, Convention on the International responsibility of states for injuries to aliens, Harward 1961, (w:) Recent Codification of the Law of State Responsibility for Injuries to Aliens, red. F. V. García-Amador, L. B. Sohn, R. R. Baxter, Haga 1974, s. 230 i n.

${ }^{165}$ Ibidem, s. 234.

${ }^{166}$ Ibid., s. 337.

${ }^{167}$ Ibid., s. 337.

${ }^{168}$ Inter-American Juridical Committee, Principles of International Law That Govern the Responsibility of State, Caracas 1954, (w:) Recent Codification of the Law of State Responsibility for Injuries to Aliens, red. F. V. García-Amador, L. B. Sohn, R. R. Baxter, Haga 1974, s. 359 i n.

${ }^{169}$ Ibidem, s. 364. 
cudzoziemców - tych, którzy zostali wybrani przez organy innych państw, aby je reprezentować. Należyta staranność odgrywa szczególnie ważną rolę w normach prawa dyplomatycznego, które formułują podwyższony standard ochrony, wymaganej od państw realizujących bierne prawo legacji. W tym obszarze międzynarodowej współpracy państwa często pociagane były do odpowiedzialności międzynarodowej za niewypełnienie treści zobowiązania do starannego postępowania, którego to przypisania odpowiedzialności sądy międzynarodowe dokonywały analizując stopień należytej staranności w działaniach organów państwa.

\subsection{Należyta staranność $w$ prawie dyplomatycznym}

Zgodnie z treścią omawianego już orzeczenia w sprawie Tellini, państwo ponosi odpowiedzialność za popełnione na jego terytorium przestępstwa o charakterze politycznym, których ofiarami są cudzoziemcy, jeśli zaniedbało obowiązek podjęcia wszelkich racjonalnych działań celem zapobieżenia przestępstwu albo pojmania oraz osądzenia sprawców ${ }^{170}$. Obowiązek dołożenia szczególnej staranności pojawia się wówczas, gdy ów cudzoziemiec sprawuje oficjalną funkcję, uznaną przez państwo jego pochodzenia. Mimo iż państwo nie odpowiada za czyny osób prywatnych, to, jak wskazuje Sutor: „ponosi odpowiedzialność za wszystko, co dzieje się w granicach jego zwierzchnictwa terytorialnego", a w konsekwencji zobowiązane jest zapewnić całkowite bezpieczeństwo misjom dyplomatycznym ${ }^{171}$. Naruszenie przywilejów i immunitetów dyplomatycznych i konsularnych, wynikające z działania lub zaniechania organów państwa, stanowić może naruszenie jego międzynarodowego zobowiązania. Przypisanie naruszenia warunkowane jest analizą reguł opisanych w Projekcie artykułów o odpowiedzialności państw z 2001 r., które, zdaniem cytowanego autora, stanowią podsumowanie powszechnego prawa zwyczajowego ${ }^{172}$.

Znaczenie należytej staranności przy ocenie ochrony personelu dyplomatycznego przywołane zostało bezpośrednio w omawianym tu już orzeczeniu MTS w sprawie amerykańskich zakładników w Teheranie. Trybunał zidentyfikował w jego treści istnienie pozytywnego obowiązku ochrony personelu dyplomatycznego, przebywającego na terytorium państwa. Zobowiązanie to wynikało $\mathrm{z}$ treści art. 22 ust. $2 \mathrm{KWSD}^{173}$. Trybunał wskazał w uzasadnieniu wyroku, iż „wyraźne pogwałcenie zobowiązania Iranu wobec Stanów Zjednoczonych i Konwencji wiedeńskiej o stosunkach dyplomatycznych” polegało na „bezczynności władz Iranu"174. Ów brak działania doprowadził bezpośrednio do naruszenia immunitetu misji dyplomatycznej Stanów Zjednoczonych w Tehera-

\footnotetext{
${ }^{170}$ Por.: sprawa Tellini, s. 114.

${ }^{171}$ Por. J. Sutor, op. cit., s. 234. Nie oznacza to jednak odpowiedzialności absolutnej, o czym mowa dalej.

${ }^{172}$ J. Sutor, op. cit, s. 225.

${ }^{173}$ Por.: sprawa zakładników amerykańskich w Teheranie, s. 29.

${ }^{174}$ Sprawa zakładników amerykańskich w Teheranie, s. 29.
} 
nie, a w konsekwencji - do naruszenia immunitetu personalnego pracowników misji przez osoby prywatne, niedziałające na polecenie ani pod kontrolą rządu ${ }^{175}$. W konsekwencji, MTS uznał Iran za odpowiedzialny za naruszenie zobowiazzania traktatowego do zapewnienia poszanowania dyplomatycznych immunitetów rzeczowych i personalnych, które to naruszenie polegało na braku należytej staranności. MTS podkreślił, że „nie istnieje bardziej podstawowy warunek wzajemnej relacji między państwami, niż poszanowanie nietykalności dyplomatów i misji, co potwierdza wzajemne zobowiązanie o tej treści, dopełniane na przestrzeni wieków przez narody każdego pochodzenia i kultury" ${ }^{" 176}$. Jak słusznie zauważają Bratspies i Miller, Trybunał utożsamił istnienie zobowiązania do dołożenia należytej staranności przez państwo z możliwością przypisania mu odpowiedzialności za konsekwencje działań osób fizycznych ${ }^{177}$.

Dyplomatyczny immunitet rzeczowy, opisany w treści art. 22 KWSD, dotyczy nietykalności misji dyplomatycznej. Zgodnie $\mathrm{z}$ treścią tego przepisu „pomieszczenia misji są nietykalne”, zaś funkcjonariusze państwa przyjmującego nie mogą do nich wkraczać bez uzyskanej uprzednio zgody szefa misji dyplomatycznej. Ustęp 2 cytowanego przepisu ustanawia "szczególny obowiązek” państwa przyjmującego „przedsięwzięcia wszelkich stosownych kroków dla ochrony pomieszczeń misji przed jakimkolwiek wtargnięciem lub szkodą oraz zapobieżenia jakiemukolwiek zakłóceniu spokoju misji lub uchybieniu jej godności”. Reżim traktatowy nie przewiduje wyjątków od tak sformułowanej zasady - nietykalność siedziby misji jest absolutna ${ }^{178}$. Obowiązuje także, gdy państwo wysyłające wykorzystuje pomieszczenia niezgodnie $\mathrm{z}$ celem przewidzianym dla nich w art. 41 ust. $3 \mathrm{KWSD}^{179}$. Praktyka stosunków dyplomatycznych odnotowała kilka wyjątków od stosowania tej zasady w sytuacjach zagrożenia bezpieczeństwa wewnętrznego państwa przyjmującego lub rażącego naruszenia

${ }^{175}$ Sutor wskazuje, że działania osób prywatnych przypisane zostały państwu, zaś „bojówki stały się przedstawicielami państwa irańskiego"; por.: J. Sutor, op. cit., s. 226, ale por.: wyrok w sprawie zakładników w Teheranie, s. 29, opisany w rozdz. II powyżej, gdzie MTS stwierdza, iż nie można uznać rebeliantów za przedstawicieli państwa, a przypisanie mu odpowiedzialności za ich działania mogłoby nastąpić jedynie wówczas, gdyby zostało wykazane, że bojownicy działali w imieniu państwa, otrzymawszy pełnomocnictwo od uprawnionego organu irańskiego państwa do przeprowadzenia konkretnych operacji. Nie oznacza to, że państwo nie może ponosić odpowiedzialności za konsekwencje ich działań.

${ }^{176}$ Por.: sprawa zakładników amerykańskich w Teheranie, s. 42.

${ }^{177}$ R. M. Bratspies, R. A. Miller, Transboundary harm in international law: lessons from the Trail Smelter arbitration, Cambridge 2006, s. 233.

${ }^{178}$ Por. np.: R. Bierzanek, J. Symonides, op.cit., s. 179, gdzie autorzy piszą: „nietykalność nakłada obowiązek podjęcia wszystkich stosownych środków w celu ochrony pomieszczeń misji przed jakimkolwiek natręctwem, szkodą oraz zakłóceniem spokoju i naruszeniem jej powagi. Państwo powinno zapobiegać wszelkim zamachom skierowanym przeciwko misji”. Podobnie W. Góralczyk, S. Sawicki, op.cit., s. 281; J. Barcik, T. Srogosz, op.cit., s. 339, którzy piszą o odpowiedzialności państwa za naruszenie owego obowiązku.

${ }^{179}$ Art. 41 KWSD stanowi: „Pomieszczeń misji nie wolno użytkować w jakikolwiek sposób niezgodny z funkcjami misji określonymi bądź w niniejszej Konwencji, bądź w innych normach powszechnego prawa międzynarodowego lub w specjalnych umowach obowiązujących między państwem wysyłającym a państwem przyjmującym." 
immunitetu dyplomatycznego, jednak te incydenty pozostały bez wpływu na interpretacje jej treści ${ }^{180}$. Interpretowana jest ona przede wszystkim jako zobowiązanie państwa przyjmującego do podjęcia należytych starań celem zapewnienia bezpieczeństwa siedzibie misji, zwłaszcza przed wtargnięciem nieupoważnionych osób lub powstaniem szkód, jak też przed naruszeniem spokoju placówki czy „uchybieniu jej godności”181. Odnotować można jedynie kilka przypadków, w których władze państwa przyjmującego czuły się w obowiązku interweniować celem utrzymania bezpieczeństwa misji ${ }^{182}$. Naruszenie spokoju misji pozostaje w ścisłym związku z naruszeniem jej godności, choć nie odwrotnie - naruszenie godności nie musi oznaczać naruszenia spokoju. Jak podnosił przedstawiciel Francji w rozprawie apelacyjnej przed australijskim sądem w sprawie Minister Spraw Zagranicznych i Handlu przeciwko Magno i in.: „obraźliwe lub znieważające zachowanie $\mathrm{w}$ sąsiedztwie misji lub do niej skierowane może zostać tak zakwalifikowane. Spalenie flagi państwa wysyłającego lub kukły reprezentującej głowę tego państwa, popełnione $\mathrm{w}$ bezpośrednim sassiedztwie misji, może być z powodzeniem traktowane jako atak na jej godność" ${ }^{183}$.

Poszanowanie immunitetów personalnych przedstawiciela dyplomatycznego jest jednym z obowiązków państwa przyjmującego, zapisanym w art. 29 KWSD. Zgodnie $\mathrm{z}$ jego treścią osoba przedstawiciela dyplomatycznego jest nietykalna, co m.in. oznacza, że dyplomata nie podlega aresztowaniu ani zatrzymaniu. Co więcej, państwo przyjmujące winno traktować go z należytym szacunkiem, w tym przedsięwziąć „wszelkie odpowiednie kroki, aby zapobiec wszelkiemu zamachowi na jego osobę, wolność lub godność" ${ }^{\prime 184}$. Ten obowiązek państwa przyjmującego obejmuje konieczność ochrony dyplomatów przed działaniami stwarzającymi dla nich bezpośrednie niebezpieczeństwo ${ }^{185}$. Państwo przyjmujące powinno ponadto zapewnić dodatkową ochronę, tj. podjąc działania prewencyjne celem zapobieżenia jakimkolwiek naruszeniom nietykalności cielesnej dyplomaty ${ }^{186}$. Ten zapis odczytywany jest jako konstytuujący bezwzględny

${ }^{180}$ Por. np.: J. Barcik, T. Srogosz, op.cit., s. 338-340.

${ }^{181}$ Por.: omówiony powyżej art. 22 ust. 2 KWSD.

${ }^{182}$ Por. np.: J. Barcik, T. Srogosz, op.cit., s. 339-340, którzy przytaczają przykład przeszukania ambasady Libii w Londynie w 1984 r. Zob. także: I. Roberts, Satow's Diplomatic Practice, Oksford 2009, s. 105, który opisuje uwolnienie zakładników z zajętej przez terrorystów siedziby ambasadora Japonii w Peru w 1996 r. Po czterech miesiącach siły specjalne Peru odbiły siedzibę dyplomaty, bez uprzedniej zgody władz Japonii.

${ }^{183}$ Minister for Foreign Affairs and Trade and Others v. Magno and Another (Vol.) 101 International Review of Law 202, za: J. D'Aspremont, Diplomatic Premises in International Law [online]. Max Planck Encyclopedia of International Law, red. R. Wolfrum, Oksford 2009 [dostęp: 2013-01-20]. Dostępny w Internecie: <http://mpepil.oup.com>.

${ }^{184}$ Art. 29 KWSD.

${ }^{185}$ Por. J. Sutor, op.cit., s. 226-229, 231-236. Zob. także np.: J. Barcik, T. Srogosz, op.cit., s. 344 i podane tam przykłady naruszeń immunitetu osobowego; W. Góralczyk, S. Sawicki, op.cit., s. 276; R. Bierzanek, J. Symonides, op.cit., s. 180. Szczegółowo o obowiązkach państwa przyjmującego względem przedstawicieli dyplomatycznych zob: F. Przetacznik, op.cit., s. 39-41.

${ }^{186}$ F. Przetacznik, op.cit., s. 39. 
obowiązek prewencji, uznawany w treści orzeczeń sądów krajowych, praktyce państw, prawie traktatowym i dorobku doktryny ${ }^{187}$.

Odpowiedzialność państwa za naruszenie omawianego zobowiązania wynika z faktu powstania szkody, choć przy jej przypisywaniu będą brane pod uwage towarzyszące mu okoliczności ${ }^{188}$. O wyłączeniu odpowiedzialności państwa zdecydować może działanie siły wyższej, tj zdarzenia nadzwyczajnego, którego nie dało się przewidzieć, ani któremu nie można było zapobiec. Odpowiedzialność ta nie ma więc charakteru absolutnego. Aby móc skutecznie przywołać działanie siły wyższej jako przesłankę zwalniającą od odpowiedzialności, państwo musi przedstawić niezbite dowody, zaś wystapienie okoliczności o takim charakterze nie może wynikać z jego działania lub zaniechania, w tym braku należytej staranności ${ }^{189}$. Takie same konsekwencje dla odpowiedzialności państwa będzie mieć powodujący powstanie naruszenia prawa przypadek, wynikający z wyłącznej winy poszkodowanego. Jeśli zaś powodem naruszenia omawianego zobowiązania będzie ochrona „żywotnych interesów” państwa przyjmującego, w szczególnych sytuacjach także ona może zostać uznana za okoliczność wyłączającą odpowiedzialność ${ }^{190}$. Za naruszenie zobowiązania do ochrony dyplomatów nie będzie także uważane stosowanie retorsji względem państwa wysyłającego, polegające np. na ograniczeniu ochrony, choć stosowanie retorsji musi spełniać wymogi proporcjonalności ${ }^{191}$. Do okoliczności ograniczających zakres odpowiedzialności państwa zaliczyć można sytuacje, w których dyplomata sam naraża się na niebezpieczeństwo, ingeruje w sprawy wewnętrzne państwa przyjmującego, prowadzi działalność estradową czy handlową jako osoba prywatna albo ignoruje kierowane do niego zalecenia i ostrzeżenia ${ }^{192}$.

Szczególnie trudne jest ustalenie zakresu owego zobowiązania w sytuacji zamieszek, powstania czy wojny domowej. Decydującym elementem przy ocenie odpowiedzialności państwa za naruszenie immunitetów osobistych w sytuacji niepokojów wewnętrznych jest wykazywana przez organy państwa dobra wiara, przejawiająca się dołożeniem należytej staranności przy zapewnianiu ochrony dyplomatom ${ }^{193}$.

Zobowiązanie do podejmowania wszelkich niezbędnych kroków celem zapobiegania atakom na dyplomatów zawarte zostało w każdej z czterech konwen-

${ }^{187}$ Ibidem, s. 4, ale por.: art. 41 par. 1 KWSD, zobowiązujący dyplomatę do przestrzegania prawa i obyczajów państwa przyjmującego.

${ }^{188}$ Por. J. Sutor, op.cit., s. 230-231. W opinii autora odpowiedzialność nie powstaje w przypadku szkody ewentualnej.

${ }^{189}$ Ibidem, s. 232.

${ }^{190}$ Ibid.

${ }^{191}$ Ibid., s. 232-234.

192 Ibid., s. 233.

${ }^{193}$ Por. J. Sutor, op.cit., s. 226-227. Autor wskazuje, że niezmiernie rzadko działania państw przyjmujących, przedsiębrane celem dopełnienia owego zobowiązania, nie wywołują protestów państw wysyłających. Ibidem, s. 233-234. 
cji tworzących traktatowe podstawy prawa dyplomatycznego (KWSD, KWSK, Konwencji z 1969 r. o misjach specjalnych ${ }^{194}$ i Konwencji wiedeńskiej o przedstawicielstwach państw $\mathrm{w}$ ich stosunkach $\mathrm{z}$ organizacjami międzynarodowymi o charakterze powszechnym z 1975 r.) ${ }^{195}$. Jednak żadna z nich nie definiuje, jakie działania mieszczą się w treści tego zobowiązania ani nie wskazuje podmiotów uprawnionych do dokonania takiej interpretacji, pozostawiając tę kwestię ocenie państw przyjmujących ${ }^{196}$. Ocena taka dokonywana jest przez sąd w konkretnych okolicznościach faktycznych, z uwzględnieniem specyfiki państwa przyjmującego, $\mathrm{w}$ tym np. działających na jego terytorium grup rewolucyjnych czy band zbrojnych. W tym ostatnim przypadku, zakres wymaganych od państwa środków będzie szerszy niż od państw cieszących się względnym bezpieczeństwem wewnętrznym ${ }^{197}$. Nie ulega jednak wątpliwości, że z pewnością w zakres obowiązku ochrony wchodziło będzie podjęcie działań prewencyjnych, w tym przekazanie dyplomatom informacji o istniejących zagrożeniach i niebezpieczeństwach. Jak wskazuje Przetacznik, działania te mogą obejmować policyjne przeszukanie okolicy i, za zgodą szefa misji, jej pomieszczeń, ochronę dyplomatów podczas podróży czy kontrolę poczty przychodzącej na zawartość substancji szkodliwych ${ }^{198}$. W granicach wymaganej prawem międzynarodowym należytej staranności zawsze mieścić się będzie obowiązek udzielenia przez państwo przyjmujące wszelkiej pomocy szefowi misji na jego wezwanie lub na wezwanie państwa wysyłającego, a jej nieudzielenie rodziło będzie odpowiedzialność państwa przyjmującego ${ }^{199}$. Przypisanie odpowiedzialności zależne będzie od możliwości przypisania działania lub zaniechania konkretnemu organowi państwa. Jeśli zaś zagrożenia dla dyplomaty nie uda się uniknąć, obowiązek państwa obejmuje bez wątpienia podjęcie wszelkich niezbędnych kroków zmierzających do postawienia sprawcy przed wymiarem sprawiedliwości ${ }^{200}$. Państwo przyjmujące powinno także posiadać w krajowym systemie prawa przepisy pozwalające postawić sprawcę w stan oskarżenia za naruszenie nietykalności dyplomaty oraz dysponować sprawnym wymiarem sprawiedliwości, pozwalającym na niezwłoczną i zgodną z prawem ocenę takiego zachowania ${ }^{201}$. Jeśli pań-

${ }^{194}$ Konwencja o misjach specjalnych, otwarta do podpisu w Nowym Jorku dnia 16 grudnia 1969 r., Dz.U. 1985, nr 48, poz. 245.

${ }^{195}$ U.N. Doc. A/CONF.67/16.

${ }^{196}$ Por. J. Sutor, op.cit., s. 237.

${ }^{197}$ Por.: F. Przetacznik, op.cit., s. 50.

${ }^{198}$ Ibidem, s. 52.

${ }^{199}$ Por. J Sutor, op. cit., s 235, który wskazuje, że pojęcie „wszelkiej koniecznej pomocy” w interpretacji niektórych państw obejmuje konieczność spełniania żądań porywaczy, okupujących siedzibę misji.

${ }^{200}$ Por. F. Przetacznik, op.cit., s. 73. J. Sutor przywołuje tu przykłady ataków na dzieci rosyjskich dyplomatów w Polsce i polskich dyplomatów w Rosji z 2005 r., wskazując, iż Polska doprowadziła do ujęcia i osądzenia sprawców pobicia w Warszawie. Por. J. Sutor, op.cit., s. $227,235$.

${ }^{201}$ F. Przetacznik, op.cit., s. 65-69; J. Sutor, op. cit., s. 233. 
stwo zaniecha podjęcia tych kroków, może być pociagnnięte do odpowiedzialności za zaniechanie sprzeczne $\mathrm{z}$ treścią jego międzynarodowego zobowiązania ${ }^{202}$.

Ochrona członków korpusu dyplomatycznego stała się przedmiotem wzmożonej aktywności traktatowej państw - szereg umów międzynarodowych wprowadza szczególne zasady, na jakich powinna być realizowana ochrona przedstawicieli dyplomatycznych ${ }^{203}$. Jak wskazuje Przetacznik, wywodzić można także z obowiązujących zasad prawa międzynarodowego, że państwa pozostają w obowiązku współpracy celem zapobiegania czynom zakazanym, skierowanym przeciwko przedstawicielom dyplomatycznym i karania osób za nie odpowiedzialnych $^{204}$. Zasada należytej staranności obecna jest więc także w treści norm prawa dyplomatycznego.

\subsection{Ochrona cudzoziemców a obowiązki państwa wysylającego}

Obowiązek ochrony cudzoziemców oznacza, obok wcześniej wymienionych, zobowiązanie państwa pobytu do umożliwienia państwu obywatelstwa wykonywania opieki dyplomatycznej. Jego istotą jest więc konkurencja zasad jurysdykcji: terytorialnej i personalnej. O ile podstawy prawne do jej świadczenia oraz zakres udzielanej pomocy zidentyfikowane zostały zarówno w treści konwencji, jak i wynikają z wielowiekowego zwyczaju, o tyle pytanie o granice opieki dyplomatycznej nad lokalnymi oddziałami przedsiębiorstw mających swoją siedzibę w państwie wysyłającym wciąż nie doczekało się satysfakcjonującej odpowiedzi. Watpliwości budzi sama zasadność udzielania pomocy dyplomatycznej osobom prawnym $^{205}$. Nie ma wątpliwości jedynie co do tego, że osoby prawne nie moga korzystać ze statusu, a co za tym idzie - z immunitetu dyplomatycznego.

Jak wskazał MTS w sprawie Barcelona Traction, aby państwo mogło świadczyć pomoc dyplomatyczną przedsiębiorstwu, podmioty te musi łączyć rzeczywista więź, w szczególności powinno ono być zarejestrowane zgodnie z przepisami wewnętrznymi prawa państwa wysyłającego lub na jego terytorium mieć swoją siedzibę ${ }^{206}$. W treści tego orzeczenia MTS udzielił odpowiedzi także na

${ }^{202}$ Por. np.: J. Barcik, T. Srogosz, op.cit., s. 339.

${ }^{203} \mathrm{~Np}$. Konwencja o zapobieganiu przestępstwom i karaniu sprawców przestępstw przeciwko osobom korzystającym z ochrony międzynarodowej, w tym przeciwko dyplomatom, sporządzona w Nowym Jorku dnia 14 grudnia 1973 r, Dz. U. 1983, nr 37, poz. 168; Europejska konwencja o zwalczaniu terroryzmu, sporządzona w Strasburgu dnia 27 stycznia 1977 r., Dz.U. 1996, nr 117, poz. 557 , art. 1 .

${ }^{204}$ F. Przetacznik, op.cit., s. 87-98.

${ }^{205}$ Por. F. Seyersted, Common Law of International Organizations, Haga 2008, s. 81; A. Aust, op.cit., 168-169.

${ }^{206}$ Belgia przeciwko Hiszpanii, wyrok MTS z 5 lutego 1970 r., ICJ Reports 1970 (dalej: sprawa Barcelona Traction), s. 3, 42. Sprawa dotyczyła firmy zarejestrowanej w Kanadzie, której udziałowcami byli Belgowie. Firma świadczyła swoje usługi w Hiszpanii i postępowanie tam prowadzone doprowadziło do ogłoszenia jej upadłości. Belgia wystąpiła z roszczeniem przeciwko 
pytanie o podmioty uprawnione do korzystania z opieki dyplomatycznej. Wskazał, że jest to sama osoba prawna, nie zaś jej udziałowcy czy pracownicy. Kiedy sprawa dotyczy bezprawnego zachowania względem firmy reprezentującej obcy kapitał, ogólna zasada prawa międzynarodowego upoważnia wyłącznie państwo siedziby tej firmy (ang. the national State of the company) do formułowania roszczeń ${ }^{207}$. Jak wskazuje Brownlie, interesy udziałowców mogą być chronione jedynie w ramach ochrony dyplomatycznej realizowanej przez państwo siedziby firmy, chyba że udziałowcy są jednocześnie obywatelami państwa wysyłające$\mathrm{go}^{208}$. W takiej sytuacji mogą korzystać z opieki dyplomatycznej państwa swojego obywatelstwa, ale jedynie wtedy, gdy sami poniosą szkodę, nie zaś gdy poszkodowana jest reprezentowana przez nich spółka ${ }^{209}$.

Zapewnienie szczególnej ochrony przedstawicielom dyplomatycznym przez państwo goszczące stanowi jeden z wyrazów obowiązku poszanowania suwerenności innych państw, stanowiącego fundament wszelkich międzynarodowych relacji. Obowiązek ten znajduje swój bardziej bezpośredni wyraz w treści ciążącego na państwach zobowiązania do ochrony suwerenności innych państw przed zagrożeniami wywoływanymi przez osoby prywatne, przebywające w ich jurysdykcji lub pod ich kontrolą. Treść i zakres tego obowiązku opisano poniżej.

\subsection{Bezpieczeństwo międzynarodowe a należyta staranność}

Paradygmatem prawa międzynarodowego jest zapewnienie społeczności międzynarodowej pokojowej koegzystencji. Jej dogmatyczną podstawą jest koncepcja suwerenności państwa ${ }^{210}$. Choć niezapisany explicite w treści Karty Narodów Zjednoczonych, obowiązek poszanowania suwerenności innych państw wywodzony jest m.in. $\mathrm{z}$ zasady nieinterwencji, tj. $\mathrm{z}$ zakazu użycia siły lub jej groźby w stosunkach międzynarodowych, zawartego w treści art. 2 ust. $4 \mathrm{KNZ}^{211}$. Użycie siły względem innego suwerena, wbrew normie peremptoryjnej zawartej we wskaza-

Hiszpanii w obronie interesów swoich obywateli, właścicieli firmy. Hiszpania podnosiła, że Belgia nie posiada jurysdykcji względem firmy z siedzibą w Kanadzie.

${ }^{207}$ Sprawa Barcelona Traction, s. 46; zob. też: M.N. Shaw, Prawo międzynarodowe..., s. 566.

${ }^{208}$ I. Brownlie, Principles..., op.cit., s. 477.

${ }^{209}$ Sprawa Barcelona Traction, s. 36.

${ }^{210}$ Por.: R. Kwiecień, Suwerenność państwa: rekonstrukcja i znaczenie idei w prawie międzynarodowym, Kraków 2004, s. 13-14; zob. ogólnie: J. Helios, W. Jedlecka, Suwerenność w dobie procesów integracyjnych i globalizacyjnych, Wrocław 2004.

${ }^{211}$ K. Nowrot, E. W. Schabacker, The Use of Force to Restore Democracy: International Legal Implications of the ECOWAS Intervention in Sierra Leone, American University International Law Review 1998, nr 2(14), s. 373; C. Harding, Renegotiating Westphalia, Haga 1999, s. 369; F. K. Abiew, The Evolution of the Doctrine and Practice of Humanitarian Intervention, Haga 1999, s. 64-65. Zależność pomiędzy suwerennością a zasadą nieingerencji odnotował już Oppenheim, wskazując iż żadne państwo, wykonując swoją zwierzchność terytorialną, nie może zmieniać warunków naturalnych tak, aby zmiany te skutkowały negatywnie dla innych państw; por.: L. Oppenheim, International Law..., s. 211. 
nym przepisie, oznacza naruszenie zobowiązania międzynarodowego, prowadzące do odpowiedzialności państwa odwołującego się do użycia siły w kształtowaniu swoich międzynarodowych relacji ${ }^{212}$. Jeśli natomiast $\mathrm{w}$ danych okolicznościach użycie siły uznane może zostać za „zbrojną napaść” (ang. an armed attack), ów zakaz może ustąpić miejsca prawu do samoobrony ${ }^{213}$. O użyciu siły zbrojnej w stosunkach międzynarodowych zdecydować może także Rada Bezpieczeństwa, zgodnie z treścią rozdziału VII KNZ ${ }^{214}$. Sytuacje, w których siła zbrojna może być stosowana $\mathrm{w}$ relacjach międzynarodowych, stanowią wąsko interpretowane wyjątki ${ }^{215}$. Regułą jest wyrzeczenie się przez państwa siły w stosunkach międzynarodowych i zmierzanie do pokojowego rozwiązywania powstałych sporów.

Za niezgodne $\mathrm{z}$ dyspozycją normy peremptoryjnej zapisanej w art. 2 ust 4 uznać więc należy każde „użycie siły lub jej groźby” przez państwo, jeśli nie mieści się w dyspozycji przepisów rozdziału VII. Choć w treści KNZ pojęcie siły nie zostało zdefiniowane, wskazówki co do jego interpretacji zawierają inne dokumenty prawa międzynarodowego ${ }^{216}$. Z zapisów Zasad Prawa Międzynarodowego Dotyczących Przyjaznych Stosunków i Współdziałania Państw Zgodnie z Kartą Narodów Zjednoczonych wynika, iż wszelkie formy ingerencji lub gróźb względem państwowości lub przeciwko politycznym, gospodarczym lub kultu-

${ }^{212}$ O szerokiej i wąskiej interpretacji owego zakazu por. W. Czapliński, Odpowiedzialność za naruszenie..., s. 21-23. O konsekwencjach naruszenia zobowiązania międzynarodowego: zob. rozdz. VI.

${ }^{213}$ Art. $51 \mathrm{KNZ}$, który stanowi, iż postanowienia Karty nie uchybiają niepozbywalnemu prawu do samoobrony indywidualnej lub zbiorowej w przypadku napaści zbrojnej na któregokolwiek członka Narodów Zjednoczonych. Prawo to przysługuje państwu napadniętemu do czasu, aż Rada Bezpieczeństwa nie podejmie niezbędnych zarządzeń w celu utrzymania międzynarodowego pokoju i bezpieczeństwa.

${ }^{214}$ Por.: art. 39, 41 i $42 \mathrm{KNZ}$, które stanowią, iż w przypadku stwierdzenia zagrożenia lub naruszenia pokoju bądź aktu agresji Rada Bezpieczeństwa decyduje, jakie środki należy zastosować. Jeśli środki niewymagające użycia siły zbrojnej, opisane w art. $41 \mathrm{KNZ}$, okażą się niewystarczające, Rada Bezpieczeństwa może legitymizować użycie sił powietrznych, morskich lub lądowych, konieczne do utrzymania albo przywrócenia międzynarodowego pokoju i bezpieczeństwa.

${ }^{215}$ Oprócz art. 42, uzasadnienie do jej stosowania zawarte jest także w art. 107, choć przyjąć należy, iż zapis ten ma charakter historyczny, dotyczy bowiem akcji zbrojnej w odpowiedzi na akcję któregokolwiek państwa, które w ciagu drugiej wojny światowej było nieprzyjacielem sygnatariuszy Karty, jeżeli ich akcja stanowiła następstwo tej wojny.

${ }^{216}$ Znaczenie oraz wzajemna zależność terminów: „siła”, zawartego w art. 2 ust. 4 KNZ oraz „napaść zbrojna”, zapisanego w dyspozycji art. 51 stały się przedmiotem licznych i obszernych rozpraw naukowych. Por.: np.: I. Brownlie, The Use of Force in Self-Defense, British Yearbook of International Law 1961, nr 37, s. 183 i n.; R. Higgins, Legal Limits to the Use of Force by Sovereign States United Nations Practice, British Yearbook of International Law 1961, nr 37, s. 269-319; A. C. Arend, R. J. Beck, International Law and the Use of Force: Beyond the UN Charter Paradigm, Routledge 1993; M. W. Reisman, Criteria for the Lawful Use of Force in International Law, Yale Journal of International Law 1984-1985, nr 10, 279-285; C. D. Gray, International Law and the Use of Force, Oksford 2008; W. E. Butler, The Non-Use of Force in International Law, Haga 1989; T. Gazzini, The Changing Rules on the Use of Force in International Law, Haga 2005; E. V. Rostow, Legality of the International Use of Force by and from States, Yale Journal of International Law 1984-1985, nr 10, s. 286-290. 
ralnym składnikom państwa, stanowią pogwałcenie prawa międzynarodowego ${ }^{217}$. Żadnemu państwu nie wolno używać lub zachęcać do użycia gospodarczego, politycznego lub ,jakiegokolwiek innego rodzaju środków przymusu”, jeśli ich użycie ma na celu podporządkowanie drugiego państwa w wykonywaniu jego suwerennych praw oraz zapewnienie jakiegokolwiek rodzaju korzyści dla państwa dopuszczającego się ingerencji ${ }^{218}$. Analogiczną przesłankę zawiera Karta Praw i Obowiązków Gospodarczych Państw, która w art. 32 stanowi, iż żadne państwo nie może stosować ani zachęcać do stosowania gospodarczych, politycznych lub ,jakichkolwiek innych środków" celem podporządkowania sobie innego państwa w wykonywaniu jego suwerennych praw ${ }^{219}$. Na podstawie treści tych dokumentów możliwe jest uznanie wszelkich form ingerencji w państwowość lub sposób funkcjonowania jego politycznych, gospodarczych lub kulturalnych składników za użycie ,innych środków”. Może ono stanowić pogwałcenie prawa międzynarodowego, o ile wykazane zostanie, że ingerencja miała na celu ,zmuszenie innego państwa do podporządkowania w wykonywaniu jego suwerennych praw” oraz ,zapewnienie sobie od niego jakiegokolwiek rodzaju korzyści" ${ }^{220}$.

Odpowiedzialność państwa za działania osób prywatnych zagrażające międzynarodowemu pokojowi i bezpieczeństwu ukształtowana została przez MTS wąsko, ograniczając ją do odpowiedzialności za działania osób prywatnych pozostających ,pod kontrolą” państwa. Granice tej odpowiedzialności zidentyfikować można w oparciu o wspomniane już koncepcje: „skutecznej kontroli” sprawowanej przez państwo nad działaniami grupy zbrojnej, wywodzoną z orzeczenia w sprawie contras oraz ,kontroli ogólnej”, opisaną w orzeczeniu w sprawie Tadiča, w istotny sposób ograniczającą katalog sytuacji, w których państwa mogą być pociagnięte do odpowiedzialności za działania osób prywatnych ${ }^{221}$. O ile w 1986 r. MTS wskazał, że państwu przypisać można odpowiedzialność za działania grupy zbrojnej, jeśli sprawuje ono efektywną kontrolę nad takimi działaniami stanowiącymi pogwałcenie zobowiązania międzynarodowego ${ }^{222}$, o tyle w 1999 r. w orzeczeniu w sprawie Tadiča ograniczył możliwość przypisania odpowiedzialności państwu za działania grupy zbrojnej do sytuacji, w których sprawuje ono „kontrolę ogólną”, tj. kontroluje działania wszystkich członków owej grupy, dopuszczając się naruszenia zobowiązania międzynarodowego. Jak już wspomniano, wąsko rozumiane granice odpowiedzialności państwa za działania osób prywatnych są niesatysfakcjonujące dla tych przedstawicieli doktryny,

${ }^{217}$ Rezolucja Zgromadzenia Ogólnego ONZ nr 2625 (XXV), z dnia 24 października 1970 r.

${ }^{218}$ Rezolucja Zgromadzenia Ogólnego ONZ nr 2625 (XXV), z dnia 24 października 1970 r.

${ }^{219}$ Rezolucja Zgromadzenia Ogólnego ONZ nr 3281 (XXIX), z dnia 12 grudnia 1974 r.

${ }^{220}$ Por.: J. Kulesza, J. Kulesza: Odpowiedzialność państw za podejmowane w cyberprzestrzeni działania zagrażajace międzynarodowemu pokojowi i bezpieczeństwu, Studia Prawno-Ekonomiczne 2011, nr 83, s. 149-168;

${ }^{221}$ Por.: rozdział III powyżej.

${ }^{222}$ Por.: sprawa contras, par. 115 , s. 65 
którzy poszukują dogmatycznego uzasadnienia dla walki z międzynarodowym terroryzmem. Proponują oni koncepcję odpowiedzialności „pośredniej” czy „zastępczej” państwa za działania podmiotów prywatnych zagrażające międzynarodowemu bezpieczeństwu, realizowane na jego terytorium lub ,z jego wsparciem". Wskazują, że w dobie walki z terroryzmem odpowiedzialność państwa za działania osób fizycznych winna być rozumiana jako odpowiedzialność państw, w jurysdykcji których przygotowywane są ataki terrorystyczne lub z terytorium których są przeprowadzane. Ich zdaniem, państwa takie powinny być pociaggane do międzynarodowej odpowiedzialności za naruszenie zobowiązania międzynarodowego do poszanowania pokoju i utrzymywania bezpieczeństwa, niezależnie od możliwości przypisania im odpowiedzialności za działania podmiotów prywatnych. Koncepcja odpowiedzialności pośredniej krytykowana jest jednak w doktrynie ${ }^{223}$.

Odpowiedzialność państwa za działania osób prywatnych wynikać może jednak nie tylko z objęcia ich kontrolą czy poleceniem państwa, ale także z zaniechania jego organów, skutkującego niezapobieżeniem takim szkodliwym działaniom. W świetle decyzji MTS w sprawie zakładników amerykańskich w Teheranie można przypisać państwu odpowiedzialność za brak działań zmierzających do udaremnienia szkodliwych czynów osób prywatnych, w tym za ich tolerowanie. Stanie się tak wówczas, jeśli owe działania będą sprzeczne z treścią międzynarodowego zobowiązania państwa. Identyfikacja treści takiego zobowiązania na podstawie normy peremptoryjnej, zapisanej w art. 2 ust $4 \mathrm{KNZ}$, może budzić wątpliwości. Uznać można bowiem, że zobowiązanie państwa do zapobiegania szkodliwym działaniom osób prywatnych, znajdujących się w jego jurysdykcji lub pod jego kontrolą, istniałoby jedynie wówczas, gdy z treści owego zobowiązania wynikałby szczególny obowiązek prewencji. Liczni autorzy zasadnie dowodzą jednak, że obowiązek taki może być implikowany z treści i kontekstu art. 2 ust. $4 \mathrm{KNZ}$, przywołując np. orzeczenia w sprawach: statku Alabama i cieśniny Korfu ${ }^{224}$.

W tym drugim orzeczeniu MTS wskazał na pozytywny obowiązek państwa, które wiedziało lub powinno było wiedzieć o potencjalnie szkodliwym wykorzystaniu jego terytorium, podjęcia wszelkich stosownych działań celem zapobieżenia takim szkodom. Istnienie takiego obowiązku MTS wywodził m.in. $\mathrm{z}$ „elementarnych względów człowieczeństwa” oraz z obowiązku każdego państwa do nieudostępniania świadomie swojego terytorium dla realizacji działań sprzecznych z prawami innych państw ${ }^{225}$.

Jak już wskazano, dla potrzeb odpowiedzialności międzynarodowej za czyny niezakazane prawem międzynarodowym, KPM określa jako państwo pochodzenia, potencjalnie odpowiedzialne za transgraniczną szkodę to państwo, na teryto-

\footnotetext{
${ }^{223}$ Por.: roz. III powyżej.

${ }^{224}$ R. M. Bratspies, R. A. Miller, op.cit., s. 233. Por. R. Pisillo Mazzeschi, op.cit., s. 34.

${ }^{225}$ Sprawa cieśniny Korfu, s. 22.
} 
rium którego, w którego jurysdykcji lub pod którego kontrolą niebezpieczne działanie było realizowane ${ }^{226}$. KPM uzależnia tym samym odpowiedzialność państwa za szkode transgraniczną od zaistnienia przynajmniej jednego z owych trzech łączników ${ }^{227}$. Ostatni z nich: „kontrola” państwa, dotyczy okoliczności, w których państwo sprawuje władzę nad określonym terytorium czy osobami, nie posiadając po temu podstawy jurysdykcyjnej, takie jak okupacja, interwencja zbrojna czy bezprawne zajęcie ${ }^{228}$. Z tak sformułowanego katalogu podstaw odpowiedzialności wywodzić można odpowiedzialność nie tylko za działania organów państwa, ale także za ich zaniechania, polegające na niezapobieżeniu albo niezapobieganiu znaczącym szkodom transgranicznym ${ }^{229}$. Państwa mogą ponosić odpowiedzialność także za niezminimalizowanie niebezpieczeństwa szkód transgranicznych, jeśli wynikało ono z braku należytej staranności ich organów przy wykonywaniu władzy na terytorium państwa, sprawowaniu w nim jurysdykcji lub kontroli. KPM opisała tak rozumiany obowiązek prewencji w treści Projektu zasad prewencji z 2001 r. ${ }^{230}$ Jak już wspomniano, państwa winny realizować obowiązek prewencji przede wszystkim poprzez wprowadzenie mechanizmów autoryzacji działań niebezpiecznych ${ }^{231}$. Ocena realizowanych działań czyniona będzie względem treści należytej staranności, wymaganej w danych okolicznościach od sprawnie funkcjonującego rządu.

Pierwotne zobowiązanie do poszanowania suwerenności innych państw, zawarte w art. 2 ust. $4 \mathrm{KNZ}$, może więc zostać naruszone zarówno poprzez działa-

${ }^{226}$ Projekt zasad alokacji z 2006 r., art. 2 (d), gdzie „działalność niebezpieczna” to taka, która „niesie ze sobą ryzyko wywołania znaczącej szkody”. Zagadnienie to omówiono w rozdz. IV powyżej.

${ }^{227}$ W treści komentarzy do Projektu zasad alokacji z 2006 r. Komisja nie zawarła zalecanej sekwencji stosowania zasad jurysdykcji. Wskazała jedynie, iż pojęcie szkody „transgranicznej” dotyczy wykonywania przez państwa kompetencji względem jego „terytorium, jurysdykcji” oraz sprawowania przez nie „kontroli”. Aby móc przypisać państwu odpowiedzialność za określone działania, wywołujące skutki poza jego granicami, muszą one być realizowane na jego terytorium lub w innych przestrzeniach, znajdujących się pod jego jurysdykcją lub kontrolą. Por.: Projektu zasad alokacji z 2006 r., s. 120.

${ }^{228}$ Projekt artykułów o odpowiedzialności międzynarodowej z 1998 r., s. 25, pt. (10). Podobnie: Projekt artykułów o prewencji z 2001 r., s. 151, gdzie Komisja odnosi się do treści zawartej póżniej w zasadzie 2 Projektu zasad alokacji z 2006 r., która definiuje „państwo pochodzenia” jako to, na którego terytorium, w którego jurysdykcji lub pod którego kontrolą realizowana była niebezpieczna działalność.

${ }^{229} \mathrm{~W}$ przypadku odpowiedzialności za niezapobieganie, mamy do czynienia $\mathrm{z}$ odpowiedzialnością państwa za brak należytej staranności po stronie organów państwa, zaś w przypadku odpowiedzialności za konsekwencje naruszenia, niezależnej od aktywności przedsięwziętych przez organy państwa, państwa odpowiadać mogą na zasadzie ryzyka albo ponosząc odpowiedzialność absolutną. Ta ostatnia wynikać może jedynie z ustaleń traktatowych.

${ }^{230}$ Zobowiązanie prewencji zawarte zostało w treści art. 3 Projektu artykułów o odpowiedzialności międzynarodowej z 1998 r. i zawierało zobowiązanie do podjęcia wszelkich niezbędnych kroków celem zapobiegania lub minimalizowania ryzyka znaczącej szkody transgranicznej. Treść owego zobowiązania opisana została szczegółowo w Projekcie artykułów o prewencji z $2001 \mathrm{r}$.

${ }^{231}$ Projekt artykułów o odpowiedzialności międzynarodowej z 1998 r., art. 7 i Projekt artykułów o prewencji z 2001 r., art. 6. 
nia władz, jak i ich zaniechania. W przypadku zagrożeń dla bezpieczeństwa lub suwerenności innych państw wywołanych przez działania osób prywatnych, weryfikacji podlegają czyny organów państwa, w szczególności ich zaniechania. Aplikując reguły prewencji, opisane przez KPM w dokumencie z 2001 r., w połączeniu z regułami odpowiedzialności za działania międzynarodowo bezprawne, weryfikacja dopełnienia obowiązku zapisanego w art. 2 ust. 4 powinna być dokonana w oparciu o zasadę należytej staranności ${ }^{232}$.

$\mathrm{W}$ dobie walki z międzynarodowym terroryzmem rośnie znaczenie odpowiedzialności państwa za zaniechanie, polegające na tolerowaniu szkodliwej działalności na swoim terytorium. W kategoriach odpowiedzialności owo zaniechanie państw kwalifikować można jako brak należytej staranności przy zapobieganiu szkodliwym działaniom osób prywatnych działających $\mathrm{z}$ jego terytorium ${ }^{233}$. Koncepcja ta znajduje oparcie przede wszystkich w konwencjach dotyczących międzynarodowej walki z terroryzmem. To $\mathrm{z}$ ich treści wywodzone jest zobowiązanie nie tylko do aktywnej walki z przestępstwami o charakterze terrorystycznym, ale także do dokładania należytej staranności przy zapobieganiu aktom terrorystycznym ${ }^{234}$. Zagadnienie to zostało szczegółowo omówione poniżej.

\subsection{Należyta staranność przy zapobieganiu przestępstwom o charakterze terrorystycznym}

Jak twierdzi Higgins, „terroryzm to termin bez znaczenia prawnego”. Jej zdaniem, to skrót myślowy, pozwalający na nawiązanie do szeregu problemów, które mają wiele wspólnych elementów oraz sposób wyrażania potępienia dla określonych działań ${ }^{235}$. Tym samym, prawo międzynarodowe nie wypracowało legalnej definicji terroryzmu. Pomimo obowiązywania licznych konwencji i rezolucji $O N Z^{236}$, dotyczących zapobiegania i zwalczania terroryzmu między-

${ }^{232}$ R. Pissilo Mazzeschi, op.cit., s. 34-36.

${ }^{233}$ Por. np.: S. M. Malzahn, State Sponsorship and Support of International Terrorism: Customary Norms of State Responsibility, Hastings International \& Comparative Law Review 2002-2003, nr 26, s. 83-114; V. J. Proulx, op.cit., s. 615-668; S. A.Barbour, Z. A. Salzman, Tangled Web: The Right of Self-Defense against Non-State Actors in the Armed Activities Case, The New York University Journal of International Law and Politics 2008, nr 40, s. 53-106.

${ }^{234}$ Por. np.: Rezolucja 56/1 Zgromadzenia Ogólnego ONZ z 12 września 2001 r., która w oparciu o cele i zasady KNZ wzywa do międzynarodowej współpracy, mającej na celu zapobieganie aktom terrorystycznym i przesądza o odpowiedzialności tych, którzy wspierają lub chronią sprawców, organizatorów lub „sponsorów” takich przestępstw. Podobnie Rezolucja 1368 z 2001 r., w treści której ONZ uznała akty terrorystyczne za zagrożenie dla pokoju i bezpieczeństwa na świecie.

${ }^{235}$ R. Higgins, The General International Law of Terrorism, (w:) Terrorism and International Law, red. R. Higgins, M. Flory, New York 199, s. 28 i n. Negatywnie o pojęciu terroryzmu, jako o terminie ocennym i immanentnie pejoratywnym, wypowiada się także Lambert, wskazując że jest on raczej wyrazem oceny społecznej niż opisem zjawiska. Por.: J. Lambert, Terrorism and Hostages in International Law, Cambridge 1990, s. 13.

${ }^{236}$ Por.: np.: Konwencja o przestępstwach i innych bezprawnych aktach dokonanych na pokładzie samolotu z 1963 r.; Konwencja o zwalczaniu bezprawnego zawładnięcia statkami powietrznymi z 1970 r.; Konwencja o zwalczaniu bezprawnych czynów przeciwko bezpieczeństwu 
narodowego, próba stworzenia traktatu dotyczącego wszelkich jego przejawów: Kompleksowa konwencja ws. zwalczania terroryzmu (ang. Comprehensive Convention on International Terrorism; dalej: CCIT), podjęta przez ONZ w 1996 r. z inicjatywy Indii, wciąż nie zakończyła się sukcesem - negocjacje utknęly w martwym punkcie ${ }^{237}$. Utrzymujący się brak konsensusu co do możliwości jej przyjęcia wynika przede wszystkim z krajowych, regionalnych i globalnych różnic kulturowych $\mathrm{w}$ interpretacji pojęcia terroryzmu ${ }^{238}$. To, co dla władz jednych państw jest walką o niepodległość czy obroną suwerenności, dla innych oznacza akt terrorystyczny ${ }^{239}$. Państwa gotowe są zaakceptować jako legalne, różne sposoby realizacji postawionych sobie celów, zaś ich prawna kwalifikacja wynika $\mathrm{z}$ interpretacji szeregu norm prawa międzynarodowego. W wyniku owych trudności definicyjnych dotyczących pojęcia terroryzmu, prawo międzynarodowe wykształciło szereg szczegółowych definicji przestępstw uznawanych za przestępstwa o charakterze terrorystycznym ${ }^{240}$.

W oparciu o ich zapisy pojęcie terroryzmu opisują przedstawiciele doktryny. Brownlie zaprzecza istnieniu osobnego pojęcia „terroryzmu” i aplikowanego do niego „prawa terroryzmu”. Wskazuje, że w zależności od okoliczności faktycznych, zdarzenia takie powinny być kwalifikowane przy użyciu reguł odpowiedzialności państwa, jurysdykcji, międzynarodowej współpracy w sprawach karnych i innych ${ }^{241}$. W podobnym tonie wypowiada się Aust, który uważa, że przestępstwa o charakterze terrorystycznym to przestępstwa pospolite, nawet wówczas, jeśli popełniane są z pobudek politycznych czy ideologicznych. Jako

lotnictwa cywilnego z 1971 r.; Konwencja o zapobieganiu i karaniu za przestępstwa wobec osób korzystających z ochrony międzynarodowej z 1973 r.; Konwencja o zakazie brania zakładników 1979 r.; Konwencja o ochronie materiałów nuklearnych z 1980 r.; Protokół o zwalczaniu bezprawnych aktów wobec lotnisk służących międzynarodowemu lotnictwu cywilnemu z $1988 \mathrm{r}$.; Konwencja o przeciwdziałaniu bezprawnym czynom przeciwko bezpieczeństwu żeglugi morskiej z 1988 r.; Protokół o zwalczaniu bezprawnych aktów przeciwko stałym platformom zlokalizowanym na szelfie kontynentalnym z 1988 r.; Konwencja o znakowaniu plastikowych substancji wybuchowych w celach ich detekcji z 1991 r.; Konwencja o zwalczaniu terrorystycznych zamachów bombowych 1997 r.; Konwencja o zwalczaniu finansowania terroryzmu z 1999 r.; Konwencja o zwalczaniu aktów terroryzmu nuklearnego z 2005 r. Por. np. J. W. Wójcik, Przeciwdziałanie finansowaniu terroryzmu, Warszawa 2007, s. 133. Wymienić tu także należy przyjętą 13 października 2010 r. przez Zgromadzenie Ogólne ONZ w formie rezolucji Globalną Strategię Zwalczania Terroryzmu (United Nations Global Counter-Terrorism Strategy; GCTS), por.: Rezolucja Zgromadzenia Ogólnego ONZ z 13 października 2010 r., U.N. Doc. A/RES/64/297.

${ }^{237}$ Projekt zaproponowany przez Indie stanowi załącznik do Raportu grupy roboczej z 2000 r., U.N. Doc. A/C.6/55/L.2. Opis prac zawarty został w Raporcie grupy roboczej, 2002 r., U.N. Doc. A/C.6/57/L.4, s. 1-2. Zob też: A. Conte, Security In The 21st Century: The United Nations, Afghanistan And Iraq, Aldershot 2005, s. 19.

${ }^{238}$ Por.: A. Cassese, International Law..., s. 449; A. Aust, op.cit., s. 266, 269.

239 Por.: R. Higgins, The General International..., s. 16, gdzie autorka pisze: „kiedy Zachód martwił się, że definicja terroryzmu obejmie „terroryzm państwowy” (ang. ,state terrorism”), państwa trzeciego świata martwiły się, że każda inna definicja, która obejmowałaby działania podejmowane przez podmioty pozapaństwowe, nie pozwoliłaby na rozróżnienie przejawów terroryzmu od walki narodowo-wyzwoleńczej".

${ }^{240}$ Por. przypis 1278 powyżej.

${ }^{241}$ I. Brownlie, Principles..., s. 745. 
takie, powinny być przedmiotem postępowania prowadzonego zgodnie z powszechnymi zasadami jurysdykcji, w tym jurysdykcji uniwersalnej ${ }^{242}$. Cassese natomiast identyfikuje z definicją terroryzmu zapis Rezolucji 49/60 Zgromadzenia Ogólnego ONZ z 1994 r., gdzie wskazano, iż czyny wywołujące lub mające w zamierzeniu sprawców wywołać strach ogółu społeczeństwa, grupy ludzi lub poszczególnych osób, motywowane politycznie, nie znajdują usprawiedliwienia w treści prawa międzynarodowego ${ }^{243}$. Także Shaw opisuje zjawisko terroryzmu w odniesieniu do prac ONZ, choć nie formułuje jego definicji ${ }^{244}$.

Wspomniany projekt CCIT zawiera definicję terroryzmu. Zaczerpnięta $\mathrm{w}$ znacznej mierze z Międzynarodowej konwencji o zwalczaniu ataków terrorystycznych z użyciem bomb z 1997 r., opisuje ona akty terroryzmu jako czyny osób fizycznych wywołujące umyślnie lub nieumyślnie śmierć lub uszczerbek na zdrowiu innej osoby lub znaczną szkodę w majątku prywatnym lub publicznym, w tym w miejscach użyteczności publicznej, obiektach państwowych lub rządowych, systemach transportu publicznego, infrastrukturze lub środowisku naturalnym. Zakazane jako przejawy terroryzmu miałyby być także czyny wywołujące uszczerbek w mieniu, przestrzeni, obiektach czy ww. systemach transportu publicznego, skutkujące znaczną szkodą ekonomiczną lub, co istotne dla czynionych tu rozważań, wywołujące prawdopodobieństwo jej powstania. Decydujący dla kwalifikacji czynu jako aktu terrorystycznego byłby cel jego popełnienia. Za akt terrorystyczny uznane zostałyby zachowania spełniające powyższe kryteria, o ile z ich natury lub kontekstu wynikałoby, że miały na celu wywołanie strachu ogółu lub skłonienie rządu lub organizacji międzynarodowej do powstrzymania się od jakiegokolwiek działania ${ }^{245}$ i dotyczyły więcej niż jednego państwa ${ }^{246}$. Uznane za przestępstwo terrorystyczne byłoby także formułowanie gróźb popełnienia powyższych czynów lub ich usiłowanie ${ }^{247}$.

Jak już wspomniano, obowiązek prewencji nie wynika wprost z zapisu normy peremptoryjnej zawartej w art. 2 ust. $4 \mathrm{KNZ}$, dotyczącej zakazu użycia siły $\mathrm{w}$ stosunkach międzynarodowych. Zawarty on został jednak explicite w więk-

${ }^{242}$ A. Aust, op.cit., s. 264-265.

${ }^{243}$ Por.: A. Cassese, International Law..., s. 449; Rezolucja Zgromadzenia Ogólnego ONZ 49/60 z 9 grudnia 1994 r., Measures to eliminate international terrorism, U.N. Doc. A/RES/49/60.

244 Por. M.N. Shaw, International law..., s. 1159-1166. Definicji terroryzmu poświęcona została obszerna monografia B. Saula, por. ogólnie: B. Saul, Defining Terrorism in International Law, Oksford 2008. Por. także: B. Saul, Definition of ,,Terrorism” in the UN Security Council: 1985-2004, Chinese Journal of International Law 2005, Vol. 4, nr 1, s. 141-166. Bogaty wybór źródeł, w których poruszona została kwestia definicji terroryzmu podaje Diaz-Barrado: C.M. DiazBarrado, The Definition of Terrorism and International Law, (w:) Interantional Legal Dimension of Terrorism, red. P. Antonio, F. Sánchez, Haga 2009, s. 27-28. O współczesnych definicjach terroryzmu pisze także J. W. Wójcik, op.cit., s. 33-35.

${ }^{245}$ CCIT, art. 2.
${ }^{246}$ CCIT, art. 3 .
${ }^{247}$ CCIT art. 2, pkt 2-3. 
szości konwencji dotyczących terroryzmu ${ }^{248}$ i odzwierciedlającej ich postanowienia treści art. 8 projektu CCIT. Artykuł ten stanowi, że państwa-strony Konwencji miałyby współpracować celem zapobiegania naruszeniom poprzez przedsiębranie „wszelkich możliwych środków” (ang. all practicable measures) obejmujących, jeśli to niezbędne i stosowne, przyjmowanie regulacji krajowych, mających na celu zapobieganie i udaremnianie realizowanych na terytorium państwa przygotowań zmierzających do popełnienia określonych w konwencji działań. Obowiązek ten istniałby niezależnie od zamierzonego miejsca popełnienia czynu terrorystycznego ${ }^{249}$. Działania wymagane od państw-stron obejmować miałyby wysiłki zmierzające do zakazania nielegalnych działań osób, grup lub organizacji, które namawiają, zachęcają, organizuja, świadomie finansują lub angażują się w dokonanie czynów opisanych powyżej ${ }^{250}$. W szczególności, państwa powinny podjąć odpowiednie kroki celem zakazania tworzenia i działania obozów szkoleniowych, których zadaniem jest szkolenie do popełniania aktów terrorystycznych ${ }^{251}$. Obowiązek prewencji obejmowałby także wymianę dokładnych i sprawdzonych informacji oraz koordynację działań administracyjnych i innych, jeśli te okażą się stosowne, zważywszy na cel, jakim jest zapobieganie przestępstwom terrorystycznym ${ }^{252}$. W szczególności, działania te objąć powinny ustanowienie i utrzymywanie kanałów komunikacji pomiędzy organami i służbami administracyjnymi państw-stron w celu ułatwienia bezpiecznej i szybkiej wymiany informacji, dotyczących wszystkich aspektów przestępstw terrorystycznych $^{253}$. Państwa powinny ponadto podjąć współpracę w celu prowadzenia dochodzeń dotyczących przestępstw terrorystycznych, zwłaszcza w zakresie ustalania tożsamości, miejsc pobytu i charakteru działalności osób, wobec których istnieją uzasadnione podejrzenia, że są one zaangażowane w popełnianie takich przestępstw, jak również identyfikowanie kanałów przepływu funduszy, mienia, sprzętu lub innych narzędzi związanych z (ang. relating to) popełnia-

${ }^{248}$ Obowiązek prewencji wskazany został np. bezpośrednio w tytule konwencji dotyczącej przestępstw wobec osób korzystających z ochrony międzynarodowej z 1973 r.; Wymieniony został także w preambule rezolucji Zgromadzenia Ogólnego ONZ pt.: Globalna Strategia Zwalczania Terroryzmu (UN Global Counter-Terrorism Strategy; GCTS), U.N. Doc. A/RES/60/288, s. 2 oraz w pkt. I, II i III załączonego do niej Planu działania, s. 4-9. Por. także Raport Sekretarza Generalnego ONZ z 21 września 1981, U.N. Doc. A/36/425, dotyczący środków zapobiegania międzynarodowemu terroryzmowi, pkt. 11, s. 5 oraz przypis 236 powyżej.

${ }^{249}$ CCIT, art. 8, ust. 1, który stanowi, iż państwa będą współpracować celem zapobiegania przestępstwom opisanym $\mathrm{w}$ art. 2 CCIT. Współpraca obejmować miałaby „wszelkie możliwe środki” (ang. all practicable measures), w tym, jeśli to „konieczne i stosowne” (ang. necccesary and appriopriate), przyjęcie wewnętrznych regulacji prawnych, zmierzajacych do zapobiegania i zwalczania przygotowań prowadzonych na terytorium państwa-strony do popełnienia, w nim lub poza nim, przestępstw, o których mowa konwencji.

\footnotetext{
${ }^{250} \mathrm{CCIT}$, art. 8 pkt 1 lit a).

${ }^{251}$ CCIT, art. 8 pkt 1 lit b).

${ }^{252}$ CCIT, art. 8 pkt 2.

${ }^{253}$ CCIT, art. 8 pkt 2 lit a).
} 
niem takich przestępstw ${ }^{254}$. Mimo iż projekt CCIT nigdy nie został przyjęty ${ }^{255}$, służyć może za dowód istnienia praktyki zwyczajowej oraz opis stanowiska doktryny, które potwierdzają istnienie obowiązku prewencji w zapobieganiu międzynarodowej przestępczości o charakterze terrorystycznym ${ }^{256}$. Najdalej w interpretacji owego obowiązku posunął się Zanardi, proponując konstrukcję „pośredniej agresji zbrojnej” jako obejmującej także przestępstwa terrorystyczne ${ }^{257}$. Pojęciem tym autor określa użycie siły zbrojnej przez jedno państwo przeciwko drugiemu potajemnie, albo poprzez wysyłanie uzbrojonych grup osób prywatnych na terytorium innego państwa celem przeprowadzenia operacji zbrojnych, albo poprzez wspieranie ich działalności w inny sposób, w tym pozwalanie na ich działalność na swoim terytorium ${ }^{258}$.

W świetle powyższych rozważań przyjąć można, że istnieje w prawie międzynarodowym obowiązek zapobiegania szkodom transgranicznym, w tym przestępstwom o charakterze terrorystycznym, zaś ocena działania organów państwa, na którym ów obowiązek spoczywa, oparta będzie o analizę wykazanej przez nie należytej staranności ${ }^{259}$. Granice należytej staranności w zapobieganiu przestępstwom wytyczane winny być przez możliwości ekonomiczne, techniczne i faktyczne państw, na których spoczywa ów obowiązek, ale także przez uznane w prawie międzynarodowym gwarancje praw człowieka, takie jak prawo do prywatności czy wolności osobistej, w tym wolność wypowiedzi ${ }^{260}$.

${ }^{254}$ CCIT, art. 8 pkt 2 lit b).

${ }^{255}$ Wśród najważniejszych powodów zawieszenia prac nad projektem, wskazać można zawarte w jego treści, szeroko zdefiniowane wyjątki od stosowania przyszłego traktatu oraz zawarta tam zasadę pierwszeństwa porozumień szczegółowych, dotyczących przestępstw o charakterze terrorystycznym przesądzającą o braku potrzeby tworzenia umowy ogólnej (por., art. 2 bis). Por. [online]. Legal Committee Urges Conclusion of Draft Comprehensive Convention on International Terrorism, Delegates Urge Clear Definition, 8 października 2012 r. [dostęp: 2013-01-20]. Dostępny w Internecie: $<$ http://www.un.org/News/Press/docs/2012/gal3433.doc.htm>.

${ }^{256}$ Por. np.: D. Delibasis, The Right to National Self-Defense: In Information Warfare Operations, Bury St. Edmonds 2007, s. 227, który identyfikuje obowiązek przeciwdziałania przestępstwom terrorystycznym z zapobieganiem wykorzystywaniu terytorium państwa do ich przygotowywania lub popełniania. Por. też: K. N. Trapp, op.cit., s. 80-82, gdzie autorka opisuje ewolucje należytej staranności przy zapobieganiu przestępstwom terrorystycznym, jaka miała miejsce po 11 września 2001 r. Por. też ibidem, s. 64, gdzie autorka potwierdza, iż już od lat 70 . XX w. należyta staranność uznana była w orzecznictwie za element obowiązku prewencji, dotyczącego przestępstw terrorystycznych.

${ }^{257}$ Por.: P. Zanardi, Indirect Military Aggression, (w:) The Current Legal Regulation of the Use of Force, red. A. Cassese, Haga 1986, s. 112.

${ }^{258}$ Ibidem.

${ }^{259}$ Por. np.: J. M. Sorel, Some Questions About the Definition of Terrorism and the Fight Against Its Financing, European Journal of International Law 2003, Vol. 14, nr 2, s. 365-378; L. Jarvis, The Spaces and Faces of Critical Terrorism Studies, Security Dialogue 2009, nr 40(1), s. 5-27; M. De Goede, The Politics of Preemption and the War on Terror in Europe, European Journal of International Relations 2008, $\mathrm{nr}$ 14(1), s. 161-185. O istnieniu obowiązku zapobiegania „przygotowywanym na terytorium jednego państwa spiskom przeciwko drugiemu” pisał w $1958 \mathrm{r}$. L. Ehrlich, por.: idem, Prawo międzynarodowe..., s. 643.

${ }^{260} \mathrm{O}$ problemach z praktyczną aplikacją owej równowagi pomiędzy bezpieczeństwem a prawami jednostki zob. ogólnie np.: B. J. Goold, L. Lazarus, Security \& Human Rights, Portland 


\subsection{Cyberterroryzm i cyberbezpieczeństwo a zasada należytej staranności ${ }^{261}$}

XXI w. przyniósł nowe oblicze międzynarodowego terroryzmu. Wymieniany wśród zagrożeń asymetrycznych termin „cyberterroryzm” opisuje zagrożenia dla międzynarodowego pokoju i bezpieczeństwa wywołane przy użyciu globalnej sieci informatycznej urządzeń połączonych protokołem internetowym (TCP/IP) oraz protokołami z nim kompatybilnymi ${ }^{262}$. To skala potencjalnego zagrożenia bezpieczeństwa wewnętrznego i międzynarodowego, jakie mogą nieść za sobą przestępne zachowania realizowane on-line powoduje, że często kwalifikowane są one jako akty terrorystyczne ${ }^{263}$. Próby opisania cyberterroryzmu przy użyciu terminów prawnych odwołują się do traktatowego dorobku ONZ, dotyczącego

2007. Zagadnienie to pojawia się w opinii MTS z 2004 r. w sprawie okupacji Palestyny przez Izrael, gdzie MTS wskazuje, iż ograniczenia praw człowieka, stosowane celem zapobiegania przestępstwom, muszą być niezbędne dla osiągnięcia zamierzonego celu. Odwołując się do opinii Komitetu Praw Człowieka, wskazuje iż środki te muszą zadośćuczynić zasadzie proporcjonalności i muszą być jak najmniej inwazyjne spośród możliwych do zastosowania celem osiągnięcia zamierzonego celu. Por.: Komitet Praw Człowieka, General Comment No. 27, 1999 r., par. 14. Zgodnie z treścią art. 4 Paktu Praw Ekonomicznych, Społecznych i Kulturalnych, państwa mogą wprowadzać tylko takie ograniczenia, jakie przewiduje ustawa, i tylko w stopniu, w jakim jest to zgodne $\mathrm{z}$ istotą tych praw, oraz wyłącznie w celu popierania powszechnego dobrobytu w społeczeństwie demokratycznym. Międzynarodowy Pakt Praw Ekonomicznych, Społecznych i Kulturalnych, Dz.U. 1977, nr 38, poz. 169, zał.

${ }^{261}$ Zważywszy na ramy niniejszego opracowania oraz jego cel, przedmiotem poniżej analizy nie jest próba kwalifikacji prawnej ataków na suwerenność państwa, dokonywanych z wykorzystaniem globalnej sieci elektronicznej i protokołów internetowych, jako aktów terrorystycznych, aktów międzynarodowej agresji czy przykładów użycia siły zbrojnej. Liczne przykłady ich kwalifikacji prawnej łatwo zidentyfikować w doktrynie anglosaskiej. Por. np.: M. N. Schmitt, Bellum Americanum: the U.S. View..., s. 1051-1090, gdzie autor wskazuje na konieczność modyfikacji zakresu pojęcia „wojny” we współczesnym prawie międzynarodowym tak, aby weryfikacja działań dokonywana była nie w oparciu o ich charakter, ale o skutki, jakie wywołują. M. N. Schmitt potwierdza, że działania realizowane z wykorzystaniem sieci globalnej, skutkujące transgraniczna szkodą, nie mogą zostać zakwalifikowane jako wpisujące się w uznaną, aktualną definicję wojny. Podobnie: W. Czapliński, Odpowiedzialność za..., op.cit., s. 49. Schmitt wskazuje na rosnącą potrzebę renegocjacji międzynarodowego konsensusu dotyczącego użycia siły zbrojnej w samoobronie jako reakcji na bezprawne zachowania innych podmiotów prawa międzynarodowego, w oparciu o opisane przez siebie „kryteria” oceny międzynarodowych cyberataków jako ataków zbrojnych. Por.: M. N. Schmitt, Bellum Americanum Revisited..., s. 364. Por. też: M. E. O’Connell, Cyber Security without Cyber War, Journal of Conflict and Security Law 2012, Vol. 17, nr 2, s. 187-209, która opisuje argumenty przeciwników „kryterium Schmitta”.

${ }^{262}$ Por.: M. Madej, Transatlantic Perspectives on Asymmetric Threats - Their Essence, Nature and Scope, (w:) Transatlantic Perspectives on Security Imperatives, Transatlantic Policy Consortium. Annual Colloquium, red. S. Dębski, Münster 2007, s. 52-66. Por. ogólnie: S. Jajodia, Moving Target Defense: Creating Asymmetric Uncertainty for Cyber Threats, Springer, 2011. O definicji Internetu, por. J. Kulesza, Międzynarodowe prawo Internetu, Poznań 2010, s. 55-56. O transgranicznych szkodach związanych $\mathrm{z}$ przestępstwami popełnianymi z użyciem Internetu zob: H. P. Hestermeyer, Transboundary Harm: Internet Torts, (w:) Transboundary Harm in International Law, Lessons from the Trail Smelter Arbitration, red. R. M. Bratspies, R. M. Miller, Cambridge 2006, s. 268-280.

${ }^{263}$ Ale por.: M. E. O'Connell, op.cit., s. 189-190. 
międzynarodowego terroryzmu. Jak słusznie wskazuje O'Connell, dzieje się tak prawdopodobnie dlatego, że pierwsi prawnicy międzynarodowi, parający się zagadnieniami z zakresu cyberbezpieczeństwa, jak Schmitt, Sharp czy Walker wywodzili się z kręgów wojskowych ${ }^{264}$.

Zaproponowana w 2000 r. przez grupę amerykańskich naukowców z Uniwersytetu Stanforda ${ }^{265}$ definicja cyberterroryzmu opisuje go jako użycie systemu cyfrowego do popełnienia czynu uznanego za karalny lub zakazany w świetle wskazanych powyżej konwencji antyterrorystycznych ONZ. Według zaproponowanej definicji, akt cyberterrorystyczny to umyślne, podejmowane bez zgody organów władzy, użycie lub groźba użycia siły, spowodowanie zakłóceń $\mathrm{w}$ funkcjonowaniu lub ingerencja $\mathrm{w}$ funkcjonowanie systemów cyfrowych. Działania takie mogłoby być uznane za akt cyberterroryzmu jedynie wtedy, gdy niosłoby ze sobą prawdopodobieństwo śmierci lub uszczerbku na zdrowiu ludzi, znaczących szkód materialnych, niepokoju publicznego lub znacznej szkody ekonomicznej i podejmowane byłyby „w celu dokonania ataku na krytyczną infrastrukturę któregokolwiek państwa-strony"266. W myśl definicji zawartej w projekcie, termin ,infrastruktura krytyczna” oznacza wzajemnie połączone sieci urządzeń, ludzi i komputerów, które pozwalają na szybkie pełnienie swoich funkcji przez administrację rządową, służbę zdrowia, ochronę ludności przez organy władzy wykonawczej, straż pożarną, usługi transportowe, żywieniowe, w tym przewóz ludzi i dóbr drogą morską, powietrzną i lądową; dostawę energii, w tym prądu, benzyny, ropy i gazu; usługi bankowe, usługi informacyjne i komunikacyjne ${ }^{267}$. Obowiązek prewencji względem cyberprzestępstw i cyberterroryzmu zawarty został $\mathrm{w}$ treści art. 11 projektu stanfordzkiego ${ }^{268}$.

Zasady prewencji względem międzynarodowych cyberprzestępstw i generowanych przez nie szkód odnaleźć można w szeregu dokumentów miękkiego prawa międzynarodowego. Dotyczą one przede wszystkim ochrony „,infrastruktury krytycznej”. W krajowych porządkach prawnych ten ostatni termin wywodzi się z praktyki obrony cywilnej i dotyczy wszelkich systemów oraz wchodzących w ich skład, powiązanych ze sobą funkcjonalnie obiektów, w tym obiektów budowlanych, urządzeń, instalacji, usług kluczowych dla bezpieczeń-

\footnotetext{
${ }^{264}$ Por.: ibidem, s. 199.
}

265 Opracowany przez pracowników Universytetu Stanforda Projekt międzynarodowej konwencji o wzmożonej ochronie przed cyberprzestępczością i cyberterroryzmem (ang. Draft International Convention to Enhance Protection from Cyber Crime and Terrorism, 2000 r. [online]. STANFORD [dostęp: 2013-01-20]. Dostępny w Internecie: <http://iis-db.stanford.edu/pubs/11912/ sofaergoodman.pdf> (dalej: projekt stanfordzki).

${ }^{266}$ Projekt stanfordzki, art. 1 ust. 2. Ta definicja została usunięta z późniejszych wersji projektu, por. np. projekt z 2001 r., [online]. Draft International Convention To Enhance Protection from Cyber Crime and Terrorism [dostęp: 2013-01-20]. Dostępny w Internecie: <http://media .hoover.org/sites/default/files/documents/0817999825_249.pdf>, co świadczyć może o trudności sformułowania wszechstronnej, wyczerpującej i aktualnej definicji omawianego pojęcia.

${ }^{267}$ Projekt Stanfordzki, art. 1 pkt 7.

${ }^{268}$ Projekt Stanfordzki, art. 11, dotyczący współpracy sił policyjnych. 
stwa państwa i jego obywateli, służących zapewnieniu sprawnego funkcjonowania organów administracji publicznej, a także instytucji i przedsiębiorców ${ }^{269}$. Termin ten zdefiniowany został $\mathrm{w}$ wielu porządkach prawa krajowego, $\mathrm{w}$ tym także w ustawodawstwie polskim. Dla przykładu, polska ustawa o zarządzaniu kryzysowym opisuje „infrastrukturę krytyczną” jako systemy zaopatrzenia w energię i paliwa, łączności i sieci teleinformatycznych, finansowe, zaopatrzenia w żywność i wodę, ochrony zdrowia, transportowe i komunikacyjne, ratownicze, zapewniające ciągłość działania administracji publicznej, produkcji, składowania, przechowywania i stosowania substancji chemicznych i promieniotwórczych ${ }^{270}$. Postępująca informatyzacja wszystkich gałęzi przemysłu i usług, zwłaszcza usług telekomunikacyjnych, spowodowała, że znacząca część systemów wchodzących w skład tak definiowanej infrastruktury krytycznej jest zagrożona działaniami przestępnymi, realizowanymi przy wykorzystaniu sieci telekomunikacyjnych i informatycznych, a przede wszystkim Internetu ${ }^{271}$. Jeśli

${ }^{269}$ Por.: Ustawa z dnia 26 kwietnia 2007 r. o zarządzaniu kryzysowym, Dz.U. 2007, nr 89, poz. 590 (dalej: uzk), art. 3, ust. 2. Zob także: Narodowy Program Ochrony Infrastruktury Krytycznej, Dz.U. 2010, nr 135, poz. 906; Rozporządzenie Prezesa Rady Ministrów z dnia 14 lipca 2010 r. w sprawie pełnomocnika do spraw ochrony infrastruktury krytycznej Dz.U. 2010, nr 83, poz. 542; Rozporządzenie Rady Ministrów z dnia 30 kwietnia 2010 r. w sprawie planów ochrony infrastruktury krytycznej, Dz.U. 2010, nr 83, poz. 541.

${ }^{270}$ Art. 3 ust. 2 uzk.

${ }^{271}$ Przykładem posłużyć tu może choćby wirus Stuxnet, którego umieszczenie w Internecie w 2009 r. na polecenie rządu Stanów Zjednocznych i Izraela spowodowało w 2010 r. poważną awarię irańskiej instalacji w Natanz, wykorzystywanej do produkcji wzbogaconego uranu. Por.: J. P. Farwell, R. Rohozinski, Stuxnet and the Future of Cyber War, Survival 2011, nr 1(53), s. 25; N. Falliere, L. O. Murchu, E. Chien, W32. Stuxnet Dossier [online]. Symantech Security Response 2010, nr 1, s. 2, [dostęp: 2013-01-20]. Dostępny w Internecie: <http://www.symantech.com/ content/en/us/enterprise/media/security_response/whitepapers/w32_stuxnet_dossier.pdf $>$; C. A. Theohary, P. K. Kerr, J. Rollins, The Stuxnet Computer Worm Harbinger Of An Emerging War, Waszyngton 2010, s. 4 [online]. FAS [dostęp: 2013-01-20]. Dostępny w Internecie: <www.fas. $\mathrm{org} / \mathrm{sgp} / \mathrm{crs} /$ natsec/R41524.pdf>. Mimo, że irańscy urzędnicy twierdzili, że Stuxnet spowodował jedynie drobne zakłócenia $\mathrm{w}$ realizacji programu nuklearnego (C. A. Theohary, P. K. Kerr, J. Rollins, op.cit., s. 1) 23 listopada 2010 r. ogłoszono, że prace w zakładzie wzbogacania uranu w Natanz ustały kilka razy z powodu szeregu poważnych problemów technicznych (por.: Y. Melman, Iran pauses uranium enrichment at Natanz nuclear plant [online]. Haaretz, 24 listopada 2010 [dostęp: 2013-01-20]. Dostępny w Internecie: <http://www.haaretz.com/news/international/iranpauses-uranium-enrichment-at-natanz-nuclear-plant-1.326276>, w tym ,poważnej awarii jądrowej” w pierwszej połowie 2009 roku (por.: T.S., The Stuxnet worm: A cyber-missile aimed at Iran? [online]. The Economist, 24 września 2010 [dostęp: 2013-01-20]. Dostępny w Internecie: $<$ http://www.economist.com/blogs/babbage/2010/09/stuxnet_worm>. Amerykańscy urzędnicy nie zaprzeczają zarzutom o zaangażowaniu USA w powstanie wirusa; zob. W. J. Broad, J. Markoff, D. E. Sanger, Israeli Test on Worm Called Crucial in Iran Nuclear Delay [online]. N.Y. Times, 15 stycznia 2011 [dostęp: 2013-01-20]. Dostępny w Internecie: <http://www.nytimes.com/2011/ 01/16/world/middleeast/16stuxnet.html?pagewanted=all>; K. Zetter, Senior Defense Official Caught Hedging on U.S. Involvement in Stuxnet [online]. Wired Magazine, 26 maja 2011, [dostęp: 2013-01-20]. Dostępny w Internecie: <http://www.wired.com/threatlevel/2011/05/defensedepartment-stuxnet/>. Autorzy raportu firmy produkującej oprogramowanie antywirusowe Symantec w treści obszernego opracowania dotyczącego sposobu funkcjonowania wirusa napisali, iż Stuxnet stanowi pierwszy z wielu kamieni milowych w historii złośliwego oprogramowania, 
więc pod pojęciem ochrony infrastruktury krytycznej rozumieć „wszelkie działania zmierzające do zapewnienia funkcjonalności, ciagłości działań i integralności infrastruktury krytycznej", zmierzające do zapobiegania niebezpieczeństwom, jak również ograniczenie i neutralizację skutków takich zagrożeń oraz szybkie odtworzenie tej infrastruktury w przypadku awarii, ataków oraz innych zdarzeń zakłócających jej prawidłowe funkcjonowanie, to ochrona infrastruktury krytycznej oparta być musi o zasadę należytej staranności, bowiem międzynarodowy charakter Internetu powoduje, że szkody wywołane wskutek zakłócenia w jej funkcjonowaniu będą nieść za sobą zazwyczaj szkody transgraniczne ${ }^{272}$.

Specyfika Internetu - międzynarodowej sieci informatycznej wykorzystywanej także do nieuprawnionej ingerencji w funkcjonowanie infrastruktury krytycznej państw - wymaga międzynarodowej współpracy dla zapewnienia tej ostatniej skutecznej ochrony. Internet jest siecią zdecentralizowaną i nienawiązującą w swej architekturze do tradycyjnych, geograficznych podziałów władzy terytorialnej państw ${ }^{273}$. Ta właśnie jego szczególna cecha niesie za sobą duże wyzwanie dla skutecznej międzynarodowej współpracy zmierzającej do zapewnienia pokoju i bezpieczeństwa, zwłaszcza że władza nad krytycznymi zasobami Internetu, takimi jak system nazw domenowych czy adresy IP, celowo pozostawiona została poza zakusami rządów krajowych ${ }^{274}$. Zagadnienie bezpieczeństwa sieci globalnej jako elementu zarządzania Internetem pojawiło się na agendzie ONZ w 2003 r. za sprawą zwołanego w Genewie Światowego Szczytu Społeczeństwa Informacyjnego (ang. World Summit on the Information Society,

który pokazał, że bezpośrednie ataki na infrastrukturę krytyczną „są możliwe nie tylko w teorii czy filmach fantastycznych. Konsekwencje Stuxneta dla świata pozawirtualnego przekraczają znane dotąd skutki wywoływane przez złośliwe oprogramowanie.", zob.: N. Falliere, L. O Murchu, E. Chien, op.cit., s. 55; ale por.: T. Rida, Cyber War Will Not Take Place, Journal of Strategic Studies 2012, nr 1(39), s. 5-32; J. P. Farwell, R. Rohozinski, op.cit., s. 33.

${ }^{272}$ Art. 3, ust. 3 uzk.

${ }^{273}$ Por.: opis historii Internetu stworzonego jako zdecentralizowana sieć informatyczna: M. Waldrop, DARPA and the Internet Revolution, Arlington 2008, s. 80-83 [online]. DARPA [dostęp: 2013-01-20]. Dostępny w Internecie: <http://www.darpa.mil/About/History/PARTIAL BIBLIOGRAPHY_OF_THE_INTERNETARPANET.aspx $>$, opis modelu decyzyjnego stosowanego do technicznego zarządzania siecią, opartego o działania Zespołu ds. Inżynierii Internetu (ang. Internet Engineering Task Force; dalej: IETF), organizacji non-profit z siedzibą w Stanach Zjednoczonych, działającej z pomocą wolontariuszy z całego świata: P. Mockapetris, RFC 1035, Domain names - implementation and specification [online]. IETF 1984 [dostęp: 2013-01-20]. Dostępny w Internecie: <http://www.ietf.org/rfc/rfc1035.txt>; J. Mogul, RFC 922, Broadcasting Internet Datagrams In The Presence Of Subnets, Stanford 1984.

${ }^{274}$ Bill Clinton zmuszony był podjąć decyzję co do sposobu zarządzania ogromnym komercyjnym potencjałem Internetu. Przedstawiając założenia polityki dotyczącej zarządzania nim celowo wyłączył z kręgu decydentów agendy rządowe i przedsiębiorców, przekazując władzę w ręce powołanej specjalnie w celu zarządzania zasobami sieci organizacji non-profit: Internetowej Korporacji ds. Przyznanych Nazw i Numerów (ang. Internet Corporation for Assigned Names and Numbers, ICANN), z siedzibą w stanie Kalifornia. Por.: W. J. Clinton, A. Gore, Jr., A Framework for Global Electronic Commerce, 1 lipca 1997 [online]. CLINTON [dostęp: 2013-01-20]. Dostępny w Internecie: $<$ http://clinton4.nara.gov/WH/New/Commerce/>. 
dalej: WSIS) ${ }^{275}$. W treści Raportu z 2005 r. powołana przez WSIS grupa robocza ds. zarządzania Internetem (ang. Working Group on Internet Governance, dalej: WGIG) zdefiniowała „zarządzanie Internetem” (ang. Internet governance) jako „coś więcej niż tylko nadawanie nazw i adresów internetowych”, obejmując tym terminem także kwestie dotyczące bezpieczeństwa Internetu, w tym zagadnienia z zakresu dostępności i niezawodności usług świadczonych on-line ${ }^{276}$. Pomimo poczynionych ustaleń międzyrządowych, dotyczących walki z międzynarodową przestępczością czy terroryzmem, struktura sieci globalnej uniemożliwia ich skuteczną implementację, bowiem w Internecie to kod komputerowy urasta do rangi prawa ${ }^{277}$. Bliżej mu jednak do praw fizyki niż postaci realizacji umowy społecznej J.J. Rousseau ${ }^{278}$. Dlatego też pojęcie infrastruktury krytycznej, dotychczas definiowane na potrzeby bezpieczeństwa wewnętrznego, posłużyło do ustalenia zakresu „krytycznych zasobów internetowych” (ang. Critical Internet Resources, dalej: CIRs) ${ }^{279}$.

Treść zasady prewencji w zakresie cyberbezpieczeństwa jako pierwszy opisał Komitet Ministrów Rady Europy w treści dokumentu dotyczącego szkód transgranicznych, wywołanych z wykorzystaniem sieci globalnej. Koncepcja Rady Europy oparta jest o odpowiedzialność państwa za zaniechanie sprzeczne z ciążącym na państwie zobowiązaniem międzynarodowym do zapobiegania wykorzystaniu jego terytorium celem wywołania szkód transgranicznych.

Obowiązek zapobiegania szkodom wywołanym z wykorzystaniem sieci elektronicznej dotyczyć może dwóch rodzajów zdarzeń. Może wynikać z nieuprawnionego, przestępnego wykorzystania elementów sieci globalnej, zlokali-

${ }^{275}$ Światowy Szczyt Społeczeństwa Informacyjnego, Tunis Agenda, 2005 r. [online]. ITU [dostęp: 2013-01-20]. Dostępny w Internecie: <http://www.itu.int/wsis/docs2/tunis/off/6rev1 .html>, (dalej: Tunis Agenda), pkt 58. „Uznajemy, że zarządzanie Internetem obejmuje coś więcej niż jedynie nazwy i adresy internetowe. Obejmuje również inne istotne kwestiami polityki społecznej, takie jak, między innymi, krytyczne zasoby internetowe, bezpieczeństwo i ochrona sieci oraz jego rozwojowe aspekty i kwestie związane z korzystaniem z Internetu."

${ }^{276}$ Ibidem, pkt 29.

277 Jak zauważył L. Lessig „w cyberprzestrzeni kod jest prawem”. Taki tytuł miała opinia jego autorstwa zamieszczona 9 kwietnia 1999 r. w serwisie The Standard; L. Lessig, The Code Is the Law [online]. The Standard, 9 kwietnia 1999 r. [dostęp: 2013-01-20]. Dostępny w Internecie: $<\mathrm{http}: / /$ www.lessig.org/content/standard/0,1902,4165,00.html $>$.

${ }^{278}$ IETF to początkowo kilkudziesięcioosobowa społeczność wolontariuszy, którym w odpowiedzi na publikacje kolejnych „próśb o komentarze” (ang. Requests for Comments, RfC), udawało się znaleźć kompromisowe, funkcjonalne rozwiązania techniczne, tworzące podstawy działania Internetu. Por. np.: P. Mockapetris, RFC 1035, Domain names - implementation and specification [online]. IETF 1984, [dostęp: 2013-01-20]. Dostępny w Internecie: $<\mathrm{http} / / / \mathrm{www}$.ietf.org/rfc/rfc1035.txt>. Liczący obecnie ponad tysiąc wolontariuszy IETF publikuje RfC, w treści których tworzy nowe standardy techniczne, tzw. standardy de facto. Muszą je uwzględniać wszyscy, którzy zamierzają przyłączyć swoje urządzenia: komputery, telefony, telewizory czy lodówki do Internetu. Choć RfC nie mają mocy prawnej, są faktycznie ,prawem” sieci.

${ }^{279}$ Por. Rada Europy, Media and Information Society Division, Directorate General of Human Rights and Legal Affairs, Internet governance and internet critical resources - Report, Strasbourg 2009 [online]. COE [dostęp: 2013-01-20]. Dostępny w Internecie: <http://www.coe.int/t/ informationsociety/documents/internetcriticalresources_en.pdf>, s. 5. 
zowanych na terytorium państwa, powodujących transgraniczne szkody, jak miało to miejsce np. w kwietniu 2007 r. względem Estonii ${ }^{280}$. Grupa młodych ludzi zrealizowała wówczas z terytorium Rosji serię ataków DDoS (ang. Distributed Denial of Service) na zasoby elektroniczne estońskich banków i ministerstw $^{281}$. Dali $w$ ten sposób wyraz niezadowoleniu $z$ decyzji władz Tallina o przeniesieniu pomnika-symbolu wdzięczności żołnierzom Armii Czerwonej $\mathrm{z}$ centrum miasta na jego obrzeża ${ }^{282}$. Ataki cybernetyczne wywołały częściowy paraliż estońskiej administracji państwowej i instytucji kluczowych dla sprawowania przez państwo funkcji rządzenia na ponad dwa tygodnie. Były inicjowane $\mathrm{z}$ terytorium Rosji, ale władze rosyjskie jeszcze w trakcie trwania ataków odmówiły pomocy w ich powstrzymaniu, później - w pojmaniu i osądzeniu sprawców ${ }^{283}$, mimo iż do przeprowadzenia serii ataków DDoS na elektroniczną infrastrukturę Estonii przyznała się pro-kremlowska organizacja młodzieżowa „Nasi”284.

Szkoda transgraniczna może wynikać nie tylko z działalności przestępczej, ale także z przypadkowego uszkodzenia internetowej infrastruktury krytycznej, tj. np. przewodów światłowodowych, zapewniających dostęp do Internetu państwom ościennym, jak miało to miejsce w Gruzji 28 marca 2011 r. Wtedy to

${ }^{280}$ Jeśli szkody wywołane zostały poza granicami państwa na jego zlecenie lub z jego upoważnienia, ponosi ono odpowiedzialność za własne działania. Pomimo iż państwa coraz powszechniej zatrudniają specjalistów od cyberwojny, udowodnienie zleconego przez władze państwowe ataku jest praktycznie niemożliwe. Por. np.: T. Zakaria, NSA is looking for a few good hackers [online]. Washington Post z 2 sierpnia 2011 [dostęp: 2013-01-20]. Dostępny w Internecie: $<$ http://articles.washingtonpost.com/2011-08-02/politics/35271956_1_defcon-hackers-nsa $>$. Tym samym przypisanie państwu bezpośrednio odpowiedzialności jest dowodowo wyjątkowo trudne, jeśli nie niemożliwe.

${ }^{281}$ Por.: W. Goodman, Cyber Deterrence Tougher in Theory than in Practice?, Strategic Studies Quarterly 2010, nr 3, s. 110.

${ }^{282}$ Estoński premier Andrus Ansip początkowo twierdził, że Estonia uważa atak za „atak zbrojny" w myśl artykułu 51 Karty Narodów Zjednoczonych (stanowiącego o prawie do samoobrony), ale takie stwierdzenie zostało później wycofane przez Jaaka Aaviksoo, estońskiego Ministra Obrony, po konsultacjach z przedstawicielami UE i NATO. NATO nie uznało cyberataków za jednoznaczne działanie sił zbrojnych. Por.: I. Traynor, Russia accused of unleashing cyberwar to disable Estonia [online]. The Guardian, 17 maja 2007 [dostęp: 2013-01-20]. Dostępny w Internecie: $<$ http://www.guardian.co.uk/world/2007/may/17/topstories3.russia $>$.

283 S. J. Shackelford, From Nuclear War To Net War: Analogizing Cyber Attacks In International Law, Berkeley Journal of International Law 2009, nr 27(1), s. 207.

${ }^{284}$ Poniższe oświadczenie Siergieja Markowa, członka Dumy Państwowej, posła prokremlowskiej Zjednoczonej Rosji i rosyjskiej delegacji do Zgromadzenia Parlamentarnego Rady Europy, jednego z bliskich współpracowników premiera Putina, choć kontrowersyjne, nie powinno być postrzegane jako uznanie ataku post factum przez władze rosyjskie, ponieważ Markow nie został upoważniony do wypowiadania się w imieniu władz. Podczas radiowej dyskusji panelowej rosyjskich i amerykańskich ekspertów ds. wojny informacyjnej w XXI w. Markow stwierdził: „Cyberatakiem w Estonii (...) nie martw się, atak został przeprowadzony przez mojego asystenta, ale nie powiem wam jego nazwiska, bo będzie miał kłopoty z otrzymywaniem wiz". Por.: R. Coalson, Behind The Estonia Cyberattacks, Radio Free Europe, 6 marca 2009 r. [online]. RFERL [dostęp: 2013-01-20]. Dostępny w Internecie: <http://www.rferl.org/Content/Behind_The_Estonia_Cyberattacks/1505613.html>. 
75-letnia mieszkanka gruzińskiej wioski Armazi, Hayastan Shakaryan, poszukując resztek materiałów wtórnych wykopała spod ziemi fragment miedzianego przewodu, który, jak się niebawem okazało, stanowił jedynie połączenie z globalną siecią Armenii, korzystającej z usług gruzińskiego monopolisty na rynku usług telekomunikacyjnych. Shakaryan, bez użycia wyszukanego oprogramowania czy armii anonimowych hakerów, skutecznie uniemożliwiła realizację tej usługi, całkowicie odcinając Armenię od Internetu. Gruzja niezwłocznie zidentyfikowała sprawczynię i postawiła ją przed sądem ${ }^{285}$.

Niezależnie od charakteru zdarzenia, będącego przyczyną powstania szkody, a więc niezależnie od tego, czy wynika ono z działania przestępnego, realizowanego na terytorium lub w jurysdykcji państwa, czy z przypadkowego uszkodzenia zlokalizowanej na jego terytorium infrastruktury, ocena odpowiedzialności państwa zależeć będzie od postawy jego organów. Jeśli w danej sytuacji organy państwa nie podjęły należnych działań, tj. nie wykazały staranności wymaganej i możliwej w konkretnych okolicznościach faktycznych, państwo ponosić może międzynarodową odpowiedzialność za zaniechanie jego organów. Zaniechanie to może polegać na nieściganiu sprawców przestępstw, którzy wywołali szkodę innego państwa, jak np. miało to miejsce w przypadku Rosji, niepodejmującej żadnych działań po powzięciu informacji o atakach na estońską infrastrukturę, realizowanych $\mathrm{z}$ jej terytorium. Jeśli $\mathrm{w}$ danej sytuacji organy państwa podjęły wszelkie niezbędne kroki, a szkodzie nie udało się zapobiec, może ono zwolnić się z międzynarodowej odpowiedzialności. Kryterium „okoliczności obciążających", zaproponowane przez Garcíę-Amadora, a więc okoliczności, których wystąpienie niesie za sobą „wyższy stopień odpowiedzialności” państwa, wydaje się tutaj spełnione, bowiem władze Rosji konsekwentnie odmawiały podjęcia jakichkolwiek działań, zmierzających do udaremnienia ataków, a później do ścigania i osądzenia sprawców ${ }^{286}$.

Ogólne zobowiązanie państw do zapobiegania szkodom transgranicznym, w tym szkodom wywołanym przy użyciu sieci globalnej, wywodzić można z normy peremptoryjnej art. 2 ust. $4 \mathrm{KNZ}$. Zaniechanie państwa, skutkujące wywołaniem przez jego mieszkańców szkody trangranicznej, może być uznane za naruszenie zobowiązania państwa do poszanowania suwerenności innych stron KNZ. Jak wspomniano, aby zweryfikować istnienie odpowiedzialności państwa za zaniechanie, niezbędne jest odwołanie do standardu należytej staranności.

${ }^{285}$ Por.: anonim, Woman who cut internet to Georgia and Armenia 'had never heard of web' [online]. The Daily Telegraph, 11 kwietnia 2011 r. [dostęp: 2013-01-20]. Dostępny w Internecie: $<$ http://www.telegraph.co.uk/news/worldnews/europe/georgia/8442056/Woman-who-cut-internet -to-Georgia-and-Armenia-had-never-heard-of-web.html>. Po stronie armeńskiej pojawiają się podejrzenia, że za atakami faktycznie stały gruzińskie służby specjalne, por: S. Musayelyan, Hayastan cut Hayastan's web?: „Shovel-wielding” cyber granny in Georgia identified as Armenian [online]. ArmeniaNow, 8 kwietnia 2011 r. [dostęp: 2013-01-20]. Dostępny w Internecie: $<$ http://armenianow.com/news/28871/hasaystan_shakayan_internet_cable_cut_georgia_armenia $>$.

${ }^{286}$ Por.: Drugi raport Garcíi-Amadora, U.N. Doc. A/CN. 
Tak czyni RE, przywołując prace KPM, dotyczące należytej staranności $\mathrm{w}$ relacjach międzynarodowych, zwłaszcza $\mathrm{w}$ obszarze ochrony środowiska. Wzorując się na zapisach traktatów międzynarodowego prawa ochrony środowiska, wytycza standard należytej staranności dla cyberprzestrzeni. Opisuje, jakie działania przedsięwziąć winno państwo, aby wykazać, iż dołożyło należytej staranności w zapobieganiu szkodom transgranicznym, inicjowanym z wykorzystaniem Internetu ${ }^{287}$. Komitet Ministrów Rady Europy uczynił przedmiotem przyjętego 11 września 2011 r. zalecenia w sprawie ochrony bezpieczeństwa globalnego Internetu, opartego o wartości wspólne państwom-stronom $\mathrm{EKPC}^{288}$. W treści tego dokumentu miękkiego prawa międzynarodowego Komitet wskazuje, że na państwach-członkach EKPC spoczywa obowiązek nieszkodliwego korzystania ze znajdującej się na ich terytorium telekomunikacyjnej infrastruktury Internetu, wynikający z powszechnej zasady nieszkodzeniaa ${ }^{289}$, tj. obowiązek zapewnienia innym członkom międzynarodowej wspólnoty bezpieczeństwa przed zagrożeniami, generowanymi $\mathrm{z}$ ich terytorium $\mathrm{z}$ wykorzystaniem międzynarodowej sieci elektronicznej ${ }^{290}$. Państwa powinny angażować się w międzynarodową współpracę, mającą na celu wypracowanie i wdrożenie polityk dotyczących Internetu, i realizować tę współpracę w dobrej wierze i wspólnie z innymi podmiotami, sprawującymi funkcje techniczne w koordynacji zasobów sieciowych $^{291}$. Celem tych polityk powinno być zapobieganie skutkom niepożądanym z punktu widzenia dostępności i funkcjonalności Internetu, w szczególności ze względu na bezpieczeństwo sieci ${ }^{292}$.

Rada Europy opisała treść zasady należytej staranności, właściwej dla ochrony bezpieczeństwa elektronicznej sieci światowej. Państwa powinny wspólnie, ale we współpracy ze wszystkimi zainteresowanymi podmiotami (ang. all relevant stakeholders $)^{293}$, podjać „,wszelkie niezbędne środki” mające na celu

${ }^{287}$ Recommendation $\mathrm{CM} / \operatorname{Rec}(2011) 8$ of the Committee of Ministers to member states on the protection and promotion of the universality, integrity and openness of the Internet, adopted by the Committee of Ministers on 21 September 2011 at the 1121st meeting of the Ministers' Deputies, (dalej: Zalecenie Rady Europy CM/Rec(2011)8) [online]. COE [dostęp: 2013-01-20]. Dostępny w Internecie: $<$ https://wcd.coe.int/ViewDoc.jsp?id=1835707\&Site=COE $>$.

${ }^{288}$ Zalecenie Rady Europy CM/Rec(2011)8.

${ }^{289}$ To pierwszy podtytuł „,zasad ogólnych” (ang. general principles) opisanych w pkt 1; Zalecenie Rady Europy CM/Rec(2011)8.

${ }^{290}$ Zalecenie Rady Europy CM/Rec(2011) 8, pkt 1.1.

${ }^{291}$ Zalecenie Rady Europy CM/Rec(2011) 8, pkt 1.2. zatytułowany „współpraca”.

${ }^{292}$ Zalecenie Rady Europy CM/Rec(2011) 8, pkt 1.2.

${ }^{293}$ Zasada wielopodmiotowości, nazywana też zasadą zarządzania wielopodmiotowego (ang. multistakeholderism, multistakeholder governance) to jedna $\mathrm{z}$ zasad zarządzania Internetem. Została ona zapisana $\mathrm{w}$ treści wszystkich dokumentów miękkiego prawa międzynarodowego, dotyczących owego zagadnienia, począwszy od pkt. 17 Deklaracji Zasad WSIS z 2003 r. Wskazano tam, iż celem wszystkich uczestników elektronicznej wymiany jest budowanie otwartego społeczeństwa informacyjnego, z wykorzystaniem nowych modeli demokracji, partnerstwa i współpracy, pomiędzy rządami i innymi podmiotami, takimi jak przedstawiciele sektora prywatnego, społeczeństwa obywatelskiego i organizacje międzynarodowe. Por.: Światowy Szczyt Społeczeństwa Informacyjnego, Declaration of Principles; Building the Information Society: 
zapobieganie i reagowanie w przypadku wystąpienia znaczących zakłóceń (ang. disruptions) i interferencji (ang. interferences) w działaniu sieci globalnej, o ile zakłócenia i interferencje takie wywoływać będą znaczące zakłócenia transgraniczne (ang. significant transboundary disruptions). Zadaniem państw ma być minimalizowanie niebezpieczeństwa powstania takich zdarzeń i ograniczanie ich konsekwencji. Działania te państwa powinny realizować bez ingerencji w sprawowanie przez podmioty prywatne przydzielonych im funkcji technicznych w ramach ich zwykłych czynności ${ }^{294}, \mathrm{tj}$. np. bez narzucania dostawcom usług elektronicznych obowiązku filtrowania treści elektronicznych czy inwigilacji usługobiorców wbrew gwarancjom prawa do prywatności, określonym w art. 8 EKPC. Aby spełnić standard należytej staranności państwa nie muszą więc śledzić zachowań wszystkich mieszkańców ich terytorium czy działań każdego dostawcy usług elektronicznych. Co więcej, świadczenie usług drogą elektroniczną nie podlega i podlegać nie musi autoryzacji państw. Przy implementacji zasady należytej staranności w cyberprzestrzeni państwa powinny realizować określone przez Komitet Ministrów procedury współpracy, mające na celu utrzymanie integralności i nienaruszalności Internetu ${ }^{295}$. Powinny więc opracować i wdrożyć plany awaryjne, wspólne dla wszystkich zainteresowanych stron, a więc także podmiotów prywatnych, zarządzających infrastrukturą elektroniczna. Plany te zawierać winny opis sposobów działania w przypadku wystąpienia zakłóceń w funkcjonowaniu globalnej sieci oraz reakcje na nieuprawnione ingerencje $\mathrm{w}$ jej działanie ${ }^{296}$. W szczególności państwa powinny współpracować w celu wypracowania i wdrożenia wspólnych norm, zasad i praktyk, mających na celu ochronę i wzmacnianie stabilności Internetu, jego niezawodności i odporności na ataki (ang. stability, robustness and resilience) ${ }^{297}$. Państwa powinny ponadto tworzyć warunki współpracy sprzyjające wymianie informacji i koordynacji działań pomiędzy wszystkimi zainteresowanymi stronami, w szczególności poprzez tworzenie partnerstwa publiczno-prywatnego, nakierowanego na ograniczanie niebezpieczeństwa zakłóceń w działaniu Internetu, powodujących

a global challenge in the new Millennium, 2003 r. [online]. WSIS [dostęp: 2013-01-20]. Dostępny w Internecie: <http://www.itu.int/wsis/docs/geneva/official/dop.html>. Zasada ta została zapisana także w treści Planu Działań, por.: Światowy Szczyt Społeczeństwa Informacyjnego, Plan Działań [online]. WSIS 2003 r. [dostęp: 2013-01-20]. Dostępny w Internecie: <http://www.itu.int/wsis/ docs/geneva/official/poa.html $>$ i w treści Raportu Grupy Roboczej ds. Zarządzania Internetem (ang. Report of the Working Group on Internet Governance), 2005 r., (dalej: Raport WGIG) [online]. WGIG [dostęp: 2013-01-20]. Dosteppny w Internecie: <www.wgig.org/docs/WGIGREPORT.pdf $>$. Zagadnienie to zostało już omówione; por.: J. Kulesza, International Internet law, Global Change, Peace \& Security 2012, nr 24(3), s. 351-364. Zob. także: W. Kleinwächter, Multistakeholderism in Internet Governance: the Role of Governments, (w:) Internet Governance and the Information Society: Global Perspectives and European Dimension, red. W. Benedek, V. Bauer, M.C. Kettemann, Utrecht 2008, s. 9-30.

${ }^{294}$ Zalecenie Rady Europy CM/Rec(2011)8, pkt 1.3. zatytuowany „należyta staranność”.

${ }^{295}$ Zalecenie Rady Europy CM/Rec(2011)8, pkt. 2.

${ }^{296}$ Zalecenie Rady Europy CM/Rec(2011)8, pkt. 2.1.1.

${ }^{297}$ Zalecenie Rady Europy CM/Rec(2011)8, pkt. 2.1.2. 
niepożądane skutki transgraniczne ${ }^{298}$. W dokumencie określono także sposoby pożądanej reakcji państw na informację o możliwości wystąpienia transgranicznych skutków działań inicjowanych za pośrednictwem Internetu z ich terytorium $^{299}$. Powinny one niezwłocznie notyfikować potencjalnie zagrożonym powstanie niebezpieczeństwa wystapienia znaczących transgranicznych zakłóceń lub ingerencji $\mathrm{w}$ działanie infrastruktury Internetu ${ }^{300}$. Ponadto, państwastrony zobowiązane są w odpowiednim czasie (ang. in timely manner) zapewnić potencjalnie poszkodowanym państwom wszelkie dostępne informacje, dotyczące sposobów reagowania na zakłócenia ${ }^{301}$. Zasada należytej staranności dotycząca cyberbezpieczeństwa obejmuje także obowiązek bezzwłocznego podjęcia konsultacji pomiędzy państwem z terytorium którego generowane jest zakłócenie a poszkodowanym, celem których ma być ustalenie działań realizowanych przez oba państw w odpowiedzi na powstałe lub mogące powstać zakłócenia ${ }^{302}$. Ponadto, państwa powinny w ramach ich możliwości i w dobrej wierze służyć pomoca państwom poszkodowanym ${ }^{303}$. Pomoc ta powinna przede wszystkim zmierzać do ograniczenia niepożądanych skutków zakłóceń lub nieupoważnionych ingerencji $\mathrm{w}$ funkcjonowanie sieci globalnej ${ }^{304}$. Implementacja tak ustalonych reguł staranności powinna nastapić poprzez wprowadzenia racjonalnych środków legislacyjnych, administracyjnych i innych, z poszanowaniem zasady nieingerencji $\mathrm{w}$ codzienne wykonywanie funkcji technicznych przez podmioty prywatne $^{305}$. Komitet Ministrów, mimo iż tak precyzyjnie określił treść zasady należytej staranności w zapobieganiu niebezpieczeństwom wynikającym z wykorzystania sieci globalnej, odżegnuje się od wskazania treści tego dokumentu jako identyfikującego treść zwyczajowej normy pierwotnej, której naruszenie powodowałoby odpowiedzialność państwa. Wskazuje jedynie, że państwa winny podjąc dalsze kroki celem pogłębiania dialogu i współpracy w zakresie odpowiedzialności międzynarodowej i odpowiedzialności państw, jak też sposobów pokojowego rozwiązywania sporów związanych z tego rodzaju zagrożeniami $^{306}$. Podobne zapisy znalazły się w projekcie Dyrektywy dotyczącej

${ }^{298}$ Zalecenie Rady Europy CM/Rec(2011)8, pkt. 2.1.3.

${ }^{299}$ Zalecenie Rady Europy CM/Rec(2011)8, pkt. 2.2.

${ }^{300}$ Zalecenie Rady Europy CM/Rec(2011)8, pkt. 2.2.1.

${ }^{301}$ Zalecenie Rady Europy CM/Rec(2011)8, pkt. 2.2.2.

${ }^{302}$ Zalecenie Rady Europy CM/Rec(2011)8, pkt. 2.2.3.

${ }^{303}$ Zalecenie Rady Europy CM/Rec(2011)8, pkt. 2.2.4.

${ }^{304}$ Zalecenie Rady Europy CM/Rec(2011)8, pkt. 2.2.4.

${ }^{305}$ Zalecenie Rady Europy CM/Rec(2011)8, pkt. 2.3. Zasada ta także wywodzona jest $\mathrm{z}$ dorobku miękkiego prawa międzynarodowego, dotyczącego zarządzania Internetem.

${ }^{306}$ Zalecenie Rady Europy CM/Rec(2011)8, pkt. 2.4. Por. też: International and multi-stakeholder co-operation on cross-border Internet [online]. Interim report of the Ad-hoc Advisory Group on Cross-border Internet to the Steering Committee on the Media and New Communication Services incorporating analysis of proposals for international and multi-stakeholder co-operation on cross-border Internet, H/Inf (2010) 10 [dostęp: 2013-01-20]. Dostępny w Internecie: <http:// www.coe.int/t/dghl/standardsetting/media/mc-s-ci/Interim\%20Report.pdf $>$. 
środków zapewniających wspólny wysoki poziom bezpieczeństwa informacyjnego w przestrzeni Unii z 7 lutego $2013 \mathrm{r}^{307}$

Walka z międzynarodowym terroryzmem niesie za sobą naglącą konieczność zintensyfikowania współpracy w zakresie cyberterroryzmu. Standard należytej staranności, zidentyfikowany dla cyberprzestrzeni przez Radę Europy, pozwala wskazać działania, jakie podjąć powinny władze państw wykazując należyta staranność przy zapobieganiu szkodom wywołanym z wykorzystaniem elektronicznej infrastruktury zlokalizowanej w ich terytorium. Ów standard należytej staranności identyfikowany jest jako zobowiązanie państw do podejmowania „wszelkich koniecznych działań” we współpracy z innymi państwami, ale także ze wszystkimi innymi zainteresowanymi stronami ${ }^{308}$. To zobowiązanie, znane międzynarodowemu prawu Internetu jako zasada wielopodmiotowości, wynika z konieczności uwzględnienia architektury Internetu przy próbach zabezpieczenia usług, realizowanych za jego pomocą ${ }^{309}$. Zintensyfikowanie współpracy międzynarodowej oznaczać więc musi nie tylko ustalenia na płaszczyźnie międzyrządowej, ale także aktywny udział innych podmiotów w prewencji i postępowaniu dowodowym. Jak w epoce testów nuklearnych pisał García-Amador, proponując odpowiedzialność państw na zasadzie ryzyka w przypadku szkód wywołanych implementacją nowych technologii, „,nowe kategorie obiektywnej odpowiedzialności będą musiały zostać skonstruowane, aby sprostać rosnącej ilości zagrożeń, niesionych przez rozwój technologiczny" ${ }^{\text {310 }}$. Konstatacja ta jest aktualna także $\mathrm{w}$ dobie zagrożenia cyberterroryzmem, zaś cel ochrony przed zagrożeniami związanymi z nowymi technologiami wydaje się spełniać także konstrukcja odpowiedzialności obiektywnej.

${ }^{307}$ Por.: Proposal for a Directive of the European Parliament and of the Council concerning measures to ensure a high common level of network and information security across the Union, $\operatorname{COM}(2013) 48$ final [online]. EC [dostęp: 2013-01-20]. Dostępny w Internecie: <http://ec.europa .eu/digital-agenda/en/news/eu-cybersecurity-plan-protect-open-internet-and-online-freedom-andopportunity-cyber-security>.

${ }^{308}$ KPM definiuje ,,wszelkie konieczne środki” (ang. all appriopriate measures) jako działania oczekiwane od racjonalnego rządu, z uwzględnieniem okoliczności faktycznych i ekonomicznych w danej sprawie. Por.: np. art. 3 Projektu artykułów o prewencji z 2001 r.

${ }^{309}$ Por.: J. Kulesza, International Internet Law, Global Change, Peace \& Security 2012, nr 3 (24), s. 351-364.

${ }_{310}$ Piaty raport Garcíi-Amadora, U.N. Doc. A/CN.4/125, pkt 91, s. 64. 



\section{Rozdzial VI}

\section{ZASADA NALEŻYTEJ STARANNOŚCI W PRAWIE MIECDZYNARODOWYM}

\subsection{Zasady ogólne prawa międzynarodowego}

W treści artykułu 38 Statutu MTS ${ }^{1}$, obok traktatów, zwyczaju, doktryny i orzecznictwa, wskazano ,zasady ogólne prawa, uznane przez narody cywilizowane" (ang. general principles of law recognized by civilized nations) jako jedno ze źródeł, do których sięga Trybunał rozstrzygając spory międzynarodowe i wydając opinie. Ten artykuł, uznawany za katalog źródeł prawa międzynarodowego, wskazuje więc, obok precyzyjnych zapisów traktatowych, potwierdzonych praktyką zwyczajów czy wydawanych w konkretnych stanach faktycznych orzeczeń sądowych, ogólnie pojmowane zasady, uznane przez państwa cywilizowane za jedną $\mathrm{z}$ podstaw rozstrzygania sporów i interpretacji norm prawa międzynarodowego. W treści Statutu pojęcie zasady ogólnej prawa międzynarodowego nie zostało doprecyzowane, jednak jego opis i liczne definicje zaproponowali przedstawiciele nauki prawa międzynarodowego ${ }^{2}$. Katalog owych zasad pojmować należy jako otwarty i zmienny, bowiem, jak pisał Makowski, najogólniejszą zasadą prawa międzynarodowego jest prawo ciągłej zmienności ${ }^{3}$.

Odwołanie do ogólnych zasad jako logicznych źródeł norm prawnych odnaleźć można u schyłku XVII w. u Leibniza ${ }^{4}$. Odmiennie niż Puffendorf dowodził, że źródłem prawa międzynarodowego jest konsensus państw, raczej niż prawnonaturalny rozsądek ${ }^{5}$. Uczeń Leibniza, Wolff, rozwijając myśl swojego mistrza dowodził, że międzynarodowy porządek oparty jest na regułach wspólnych międzynarodowej społeczności, tworzących katalog zasad akceptowalnych dla każdego $\mathrm{z}$ nich $^{6}$. Odmiennie na źródła prawa międzynarodowego zapatrywał się de

\footnotetext{
${ }^{1}$ Karta Narodów Zjednoczonych, Statut Międzynarodowego Trybunału Sprawiedliwości i Porozumienie ustanawiające Komisję Przygotowawczą Narodów Zjednoczonych, Dz.U. 1947, nr 23, poz. 90.

${ }^{2}$ Skurupulatna analiza poglądów doktryny na kontrowersyjną kwestię ,zasad prawa międzynardowego": B. Vitanyi, Les positions doctrinale concernant le sens de la notion de 'principes generaux reconnus par les nations civilisees, RGDIP 1982, nr 1, s. 48-116.

${ }^{3}$ Por. J. Makowski, op.cit., s. 245.

${ }^{4}$ Por.: W. J. Jones, Leibniz as International Lawyer, British Yearbook of International Law 1945, nr 1(22), s. 2. podaję za: J. O'Brien, International Law, London 2001, s. 15.

${ }^{5}$ Por.: W. J. Jones, op.cit., s. 2, podaję za: J. O’Brien, International Law, London 2001, s. 15.

${ }^{6}$ Ch. J. Wolff, op.cit., s. 10-11.
} 
Vattel, który podkreślał rolę praktyki państw w kształtowaniu norm prawa międzynarodowego ${ }^{7}$.

Zasady prawa międzynarodowego pojmowane są więc dwojako: pojęcie to obejmować może zasady właściwe wyłącznie porządkowi międzynarodowemu, jak i te, które wspólne są porządkom krajowym i z nich przejęte zostały przez system prawa narodów. Rola zasad prawa międzynarodowego jako jednego z jego źródeł budziła szczególnie wiele wątpliwości w czasie opracowywania regulaminu STSM, w treści którego ostatecznie zapisano odwołanie do nich, jako do jednej z podstaw rozstrzygnięć Trybunału ${ }^{8}$. Niektórzy autorzy podnosili wówczas, że sformułowanie to dotyczyć może jedynie zasad właściwych wyłącznie prawu międzynarodowemu, zaś do reguł wywodzonych z porządków krajowych odnosić się może tylko w pomocniczym zakresie, podczas gdy inni wskazywali, że zasady nieuznane w prawie wewnętrznym nie mogą być stosowane przez sądy krajowe i jako takie nie mogą stanowić podstaw oceny czynów państw ${ }^{9}$. Sporna była także kwestia charakteru owych zasad. Jedni autorzy uznawali, że zasady takie wywodzić można jedynie z prawa natury, inni, iż mogą one być zaledwie $\mathrm{z}$ niego wywodzone, ale pochodzić mogą także z woli państw. Niektórzy zaprzeczali natomiast jakiemukolwiek związkowi prawa międzynarodowego z prawem natury, uznając jego prywatnoprawną genezę $e^{10}$. Sporna była także kwestia mocy wiążącej owych zasad: niejasne było, czy wywodzone one mogą być z samej specyfiki porządku prawa międzynarodowego, czy raczej niezbędne byłoby wskazanie normy prawa zwyczajowego, z której owa moc wiążąca każdej z zasad mogłaby być interpretowana ${ }^{11}$. Niektórzy autorzy twierdzili wprost, że zasady prawa międzynarodowego nie stanowią elementu prawa międzynarodowego, a wyłącznie jedną z podstaw orzekania STMS na mocy zapisów jego Statutu, przyjętego przez państwa ${ }^{12}$.

Najwięcej sporów budziła rola, jaką zasady prawa międzynarodowego odgrywać powinny w międzynarodowym porządku prawnym. Jedni autorzy nadawali im jedynie rolę pomocniczą przy interpretacji zwyczajowych czy traktatowych norm prawa międzynarodowego, podczas gdy inni postrzegali je jedynie jako pomocnicze źródło tego prawa ${ }^{13}$. Współcześnie, zasady prawa międzynarodowego uznawane są za zbiór najważniejszych norm prawa międzynarodowego, czy wręcz przepisy jego „konstytucji”, ${ }^{\prime 4}$.

\footnotetext{
${ }^{7}$ E. de Vattel, op.cit., tom I, s. 55-56.

${ }^{8}$ B. Cheng, op.cit., s. 2.

${ }^{9}$ Ibidem, s. $2-3$ i podana tam literatura; Por. też: V. D. Degan, Developments in International Law: Sources of International Law, Haga 1997, s. 15.

${ }^{10}$ B. Cheng, op.cit., s. 3-4 i podana tam literatura.

${ }^{11}$ Ibidem, s. 4 i podana tam literatura.

${ }^{12}$ Ibid., s. 4 i podana tam literatura.

${ }^{13}$ ibid., s. 4-5 i podane tam źródła; Por. też: V. D. Degan, op.cit., s. 15-16.

${ }^{14}$ Por.: ibid., s. 5; Por. też: V. D. Degan, op.cit., s. 16.
} 
W toku dyskusji nad metodą identyfikacji zasad prawa międzynarodowego, która towarzyszyła przyjęciu Statutu STMS, przedstawiciele państw reprezentowali rozbieżne stanowiska. La Pradelle i Phillimore wskazywali, że nie należało narzucać Trybunałowi zasad, z jakich powinien korzystać. Przedkładali nad nie odwołanie do słuszności i obowiązujących norm traktatowych i zwyczajowych $^{15}$. Skandynawowie i Szwajcarzy także przedkładali normy traktatowe i zwyczajowe ponad zasady prawa międzynarodowego, ale godzili się na włączenie tych ostatnich do katalogu źródeł, z których korzystał Trybunał, o ile pozostawiona mu zostanie swoboda co do ich identyfikacji i aplikacji. To Trybunał winien wskazywać, które $\mathrm{z}$ zasad znajdą zastosowanie $\mathrm{w}$ danej sprawie i jaka będzie ich treść, a odwoływać się do nich jedynie, jeśli normy traktatowe i zwyczajowe okazałyby się niewystarczające ${ }^{16}$. Propozycję tę jednak odrzucono, jako de facto przekazującą Trybunałowi władzę prawotwórczą ${ }^{17}$. Deschamps, odwołując się do zwyczaju międzynarodowego jako do powszechnej praktyki wszystkich państw, uznanej przez nie za prawo, zaproponował przyjęcie jako zasad prawa międzynarodowego tych reguł, które odzwierciedlają „świadomość prawną" (fr. conscience juridique) ludów cywilizowanych ${ }^{18}$. Jako takie, zasady prawa międzynarodowego obecne były już, jego zdaniem, w porządku międzynarodowym, stanowiąc jego konieczny element. Deschamps nazywał je „ogólnymi zasadami prawa”. Jako przykład wskazywał zasadę powagi rzeczy osądzonej, wywodzoną z porządków krajowych, a stosowaną z powodzeniem w rozstrzygnięciach sporów międzynarodowych ${ }^{19}$. Do poglądu tego przyłączył się Phillimore i to ostatecznie spod jego pióra wyszła formuła zawarta w Statucie STMS $^{20}$. Ogólne zasady prawa, w formule zawartej w Statucie, odwołującej się do „uznania państw cywilizowanych”, nie są koniecznie warunkowane praktyką sądową ${ }^{21}$. Włączenie ogólnych zasad do katalogu źródeł prawa, uwzględnianych przez Trybunał, odzwierciedlało zarówno specyfikę common law, gdzie sędzia może uzupełniać luki w prawie pozytywnym odwołaniami do praktyki i zwyczaju, jak i stanowisko teorii i filozofii prawa, których istotna rola przy wykładni przepisów prawa stanowionego była odpowiedzią Europy kontynentalnej przełomu wieków na ekscesywną fascynację prawniczym pozytywizmem ${ }^{22}$. Odwołania do filozoficznych podstaw prawodawstwa pozwalały dowodzić

${ }^{15}$ Ibid., s. 10.

${ }^{16}$ Ibid., s. 11.

${ }^{17}$ Ibid.

${ }^{18}$ Ibid., s. 11-12.

${ }^{19}$ Ibid., s. 12, przyp. 47.

${ }^{20}$ Ibid., s. 15. Por.: Statut Stałego Trybunału Sprawiedliwości Międzynarodowej, Dz.U. 1923, nr 106, poz. 839, którego art. 38 ust. 3 stanowi, iż „Trybunał stosuje (...) ogólne zasady prawa, uznane przez narody cywilizowane". Ten sam zapis powtórzony został w treści art. 38 statutu MTS.

${ }^{21}$ Por.: B. Cheng, op.cit., s. 24.

${ }^{22}$ Por.: ibidem, s. 15, który wskazuje na źródła fascynacji prawem pozytywnym w pracach Montesquieu i Rousseau. 
zupełności systemu prawa stanowionego czy korygować jego $w^{23}{ }^{23}$, na co dowodem jest popularność pracy Geny o interpretacji prawa pozytywnego ${ }^{24}$.

Jako pierwszy zagadnieniu zasad prawa międzynarodowego monografię poświęcił Schwarzenberger w 1955 r. w ramach wykładów Haskiej Akademii Prawa Międzynarodowego ${ }^{25}$. Ten autor definiuje zasady prawa międzynarodowego jako abstrahowanie i uogólnienie czynione na podstawie indywidualnych rozstrzygnięć lub reguł o ograniczonym zasięgu obowiązywania ${ }^{26}$. Rosnąca liczba umów międzynarodowych spowodowała, że wiele zawartych w ich treści zasad (ang. principles) uzyskało charakter reguł prawnych (ang. rules of law) ${ }^{27}$. W rozwiniętych systemach prawnych zasady wykształcane były w drodze orzecznictwa oraz $\mathrm{w}$ treści traktatów dotyczących poszczególnych obszarów prawa $^{28}$. Zasady abstrahowane były przez sądy międzynarodowe oraz przedstawicieli doktryny z zapisów konwencji i treści wyroków sądów krajowych i międzynarodowych. Interpretacja tych ostatnich dokonywana była często $\mathrm{z}$ nieuświadomionym przez autora interpretacji uwzględnieniem specyfiki systemu prawnego, w ramach którego on działa lub w którym został wykształcony. Treść tak identyfikowanych zasad może więc zawierać postulaty de lege ferenda ${ }^{29}$.

Zdaniem Schwarzenbergera, poprawne identyfikowanie zasad prawa międzynarodowego wymaga uwzględnienia odpowiedniego poziomu uogólnienia, który nie może być zbyt ogólny, ani zbyt szczegółowy. Tak ustalone kryterium zostanie spełnione, jeśli celem identyfikacji treści zasady uwzględnione zostanie orzecznictwo MTS, łącznie ze zdaniami odrębnymi. Zasady prawa mogą więc zostać zidentyfikowane poprzez uogólnienie efektów jednego lub kilku procesów prawotwórczych, tj. w wyniku analizy formalnych źródeł prawa międzynarodowego, wskazanych $w$ art. 38 Statutu MTS. Zasada może także narodzić się w wyniku podjęcia świadomej decyzji przez organ sądowy, formułujący ją w treści orzeczenia ${ }^{30}$.

Zasady prawa międzynarodowego mogą być identyfikowane celem ich stosowania jedynie do pewnych obszarów prawa międzynarodowego, jak np. prawo dyplomatyczne. W oparciu o poziom ogólności zasady i zakres jej stosowa-

${ }^{23}$ Por.: B. Cheng, op.cit., s. 15.

${ }^{24}$ Por. ogólnie: F. Geny, Methode d' interpretation et sources en droit prive positif, Paryż 1899; zob. też : V. Eycken, Methode positive de l'interpretation juridique, Bruksela 1907.

${ }^{25} \mathrm{G}$. Schwarzenberger, The fundamental principles of international law, RdC 87, Haga 1955.

${ }^{26}$ Ibidem, s. 201.

${ }^{27} \mathrm{O}$ wzajemnej zależności pomiędzy zasadami a regułami prawnymi Por.: np.: R. Dworkin, Law's Empire, Harvard 1986 s. 211 i R. Dworkin, Imperium prawa, Warszawa 1986, s. 212. Tu w jednym z trzech opisywanych modeli funkcjonowania społeczeństw „zasady” (ang. principles) odzwierciedlane są w treści „reguł uświęconych politycznym kompromisem” (ang. rules hammered out in political compromise).

${ }^{28}$ G. Schwarzenberger, op.cit., s. 200.

${ }^{29}$ Ibidem, s. 201.

${ }^{30}$ Ibid., s. 202. 
nia Schwarzenberger wyróżnia wśród zbioru zasad prawa międzynarodowego, spełniających powyższe kryteria, „zasady fundamentalne”, których zakres obowiązywania i poziom ogólności są najwyższe. Zastrzegając, że jest to podział nieostry, odrzuca jako zbyt ogólną zasadę sformułowaną przez Kelsena, który wskazał na istnienie ,zobowiązania państw do zachowania zgodnego z dotychczasowym zwyczajem" ${ }^{31}$.

Zasada uznana za fundamentalną winna spełniać trzy kryteria. Po pierwsze musi ona być „szczególnie ważna” dla praktyki i teorii prawa międzynarodowego $^{32}$. Musi wyróżniać się spośród innych zasad, znajdując „naturalne” zastosowanie do szerokiego wachlarza norm prawa międzynarodowego. Wreszcie musi stanowić podstawowy element każdego reżimu prawa międzynarodowego albo być tak istotną dla współczesnego systemu prawa międzynarodowego, że przy jej pominięciu utracona zostałaby jedna $\mathrm{z}$ podstawowych cech tego systemu ${ }^{33}$. Proponując podział, Schwarzenberger wskazuje, iż MTS używa zamiennie terminów „ogólne” i „fundamentalne” dla określenia przywoływanych w swoich orzeczeniach zasad prawa międzynarodowego ${ }^{34}$. Jego zdaniem „ogólna zasada” to termin równoważny „zasadzie ogólnie uznanej” w prawie międzynarodowym, w odróżnieniu od zasad uznanych jedynie w praktyce stosowania określonych reżimów traktatowych. Termin ten opisuje więc „ogólnie przyjętą” lub „ogólnie uznaną" zasadę prawa międzynarodowego, niezależnie od jej miejsca w hierarchii tych zasad ${ }^{35}$.

Twierdzi także, że należy unikać zbędnego mnożenia zasad, jak również nadmiernego formalizmu w stosowaniu elastycznej formuły prawa międzynarodowego. Zasady winny więc stanowić jedynie abstrakcyjne uogólnienia, wywodzone $\mathrm{z}$ uznanych już reguł prawa międzynarodowego, wyrażanych $\mathrm{w}$ postaci norm traktatowych lub zwyczajowych ${ }^{36}$. Za Gutteridgem, przestrzega przed przedwczesnym uznawaniem zasad prawa prywatnego, a zwłaszcza „luźnych maksym prawa wewnętrznego" jako zasad międzynarodowych oraz zbyt szerokim ich zastosowaniem ${ }^{37}$. Praktyka taka niesie za sobą niebezpieczeństwo zawoalowanego tworzenia prawa ${ }^{38}$.

${ }^{31}$ Ibid., s. 203-204.

${ }^{32}$ Ibid., s. 204.

${ }^{33}$ Ibid.

${ }^{34}$ Ibid., s. 205. Przywołuje także sformułowanie zawarte w treści art. 1 Protokołu Dodatkowego EKPC, zawierające zakaz pozbawiania prawa własności, o ile wywłaszczenie nie zostało przewidziane $\mathrm{w}$ treści przepisów prawa oraz nie jest zgodne $\mathrm{z}$ ogólnymi (ang. general) zasadami prawa międzynarodowego. W polskim piśmiennictwie występuje tłumaczenie tego zapisu jako zgodność $\mathrm{z}$,podstawowymi” zasadami prawa międzynarodowego. Por.: A. Przyborowska Klimczak, Prawo międzynarodowe publiczne, wybór dokumentów, Lublin 1996, s. 247.

${ }^{35}$ G. Schwarzenberger, op.cit., s. 205.

${ }^{36}$ Ibidem, s. 204.

${ }^{37}$ Ibid., s. 209. Por. także: H. C. Gutteridge, Comparative Law: An Introduction to the Comparative Method of Legal Study and Research, Cambridge 1971.

${ }^{38}$ G. Schwarzenberger, op.cit., s. 209. 
Nie oznacza to, że zasady prawa międzynarodowego nie mogą być tożsame z zasadami uznanymi w krajowych porządkach prawnych. Mogą one stanowić ich wierne odzwierciedlenie albo być identyfikowane wyłącznie w oparciu o praktykę i jurysprudencję międzynarodową. Tak rozumiana geneza zasady prawa międzynarodowego pozostaje bez wpływu na jej stosowanie i charakter ${ }^{39}$. Jako osobne kategorie, niezależne od opisanych powyżej, wskazuje „równe i niezbywalne prawa wszystkich członków wspólnoty ludzkiej”, do których odwołanie poczynili twórcy Powszechnej Deklaracji Praw Człowieka ${ }^{40} \mathrm{w}$ jej Preambule oraz „podstawowe prawa i obowiązki państw” (ang. fundamental rights and duties of States), opisane w projekcie deklaracji o prawach i obowiazkach państw z 1949 r. ${ }^{41}$ Postrzega je jako wytwory myśli naturalizmu prawniczego, dla swej skuteczności niewymagające potwierdzenia w praktyce ${ }^{42}$. Bez wątpienia jednak wskazuje zasadę suwerenności jako fundamentalną dla prawa międzynarodowego, podobnie jak zasadę swobody umów (ang. principle of consent), która pozwala tę pierwszą ograniczać ${ }^{43}$. Ustalenie granic stosowania zasady wynikać musi zawsze ze szczegółowej analizy rzeczywistej praktyki państw ${ }^{44}$. Normy zawarte $\mathrm{w}$ treści Karty, stanowiącej podstawę Organizacji Narodów Zjednoczonych, powstałej kilka lat wcześniej niż jego monografia, Schwarzenberger postrzega jeszcze jako potencjalne zasady prawa międzynarodowego ${ }^{45}$. Z biegiem czasu zyskały one bez watpienia charakter norm peremptoryjnych i zasad prawa międzynarodowego ${ }^{46}$. Pozostałe zasady prawa międzynarodowego są według niego „efektem następczych dedukcji o charakterze pomocniczym" "47. Dedukcja ta może być oparta o analizę jednego z trzech źródeł: traktatów, zwyczaju lub norm krajowych ${ }^{48}$. Zasady dotyczące szczególnego reżimu traktatowego Schwarzenberger proponuje kwalifikować w kategoriach „zasad opcjonalnych” (ang. optional principles), przestrzegając przed prawniczym konceptualizmem (niem. Begriffsjurisprudenz) jako przed ukrytym prawotwórstwem ${ }^{49}$.

${ }^{39}$ Ibidem, s. 205.

${ }^{40}$ G.A. Res. 217A (III) z 10 grudnia 1948 r., U.N. Doc A/810, s. 71.

${ }^{41}$ Projekt KPM deklaracji praw i obowiązków państw z 1949 r. G. A. Res. 375 (IV) z 6 grudnia 1949 r., U.N. Doc. A/RES/375(IV), zał.

${ }^{42}$ G. Schwarzenberger, Ibidem, s. 206.

${ }^{43}$ Ibidem, s. 211.

${ }^{44}$ Ibid., s. 212.

${ }^{45}$ Ibid., s. 207.

${ }^{46}$ Por.: B. Fassbender, The United Nations Charter As the Constitution of the International Community, Haga 2009, s. 164-165; E. de Wet, The Emergence of International and Regional Value Systems as a Manifestation of the Emerging International Constitutional Order, Leiden Journal of International Law 2006, nr 19, s. 611-632; P. M. Dupuy, L'unite de l'ordre juridique international, RdC 2002, nr 297, s. 215-221.

${ }^{47}$ G. Schwarzenberger, op.cit., s. 206.

${ }^{48}$ Ibidem, s. 207.

${ }^{49}$ Ibid., s. 208. 
Identyfikując zasadę prawa międzynarodowego, uwzględnić należy jej dwa aspekty. Po pierwsze, jej treść analizowana winna być niezależnie od innych zasad i reguł prawa międzynarodowego. Po drugie, opisana powinna zostać w korelacji z innymi zasadami ${ }^{50}$. O ile nie uda się zidentyfikować domniemania pierwszeństwa jednej z zasad, o tyle wzajemna relacja pomiędzy konkurującymi zasadami opisana być może jedynie poprzez ich wyważenie w danej sytuacji ${ }^{51}$. Zadanie to często pozostaje w gestii sądów międzynarodowych, którym przychodzi określać zarówno rzeczywisty zakres stosowania zasady, jak i jej relację względem regut, leżących u jej podstaw oraz innych, powiązanych z nią zasad prawa międzynarodowego ${ }^{52}$.

Cheng natomiast identyfikuje zasady prawa międzynarodowego metodą indukcji, w ślad za rozumowaniem meksykańsko-amerykańskiej komisji ds. roszczeń wzajemnych w sprawie Dujay ${ }^{53}$. Opiera się przy tym na analizie orzecznictwa międzynarodowego, wskazując, że jedynie ono stanowi potwierdzenie roli zasad prawa międzynarodowego w praktyce państw ${ }^{54}$. Jego zdaniem zasady (ang. principles) odróżnić należy od reguł (ang. rules) ${ }^{55}$. Dla poparcia tej tezy przywołuje sentencję decyzji arbitrażowej w sprawie Gentini z 1903 r., gdzie sędzia Ralston, przywołując prace Bourguignona i Bergerola, uznał, iż o ile reguła prawa ma charakter praktyczny i wiążący, o tyle jego zasada wyraża ogólną prawdę, na podstawie której kształtować należy swoje postępowanie w różnych obszarach życia, a jej stosowanie przynosić ma określony skutek ${ }^{56}$. Zdaniem Chenga, ten obszar prawa międzynarodowego nie składa się z konkretnych reguł postępowania, ale $\mathrm{z}$ ogólnych dyrektyw, stanowiących podwaliny systemu normatywnego ${ }^{57}$. Podobnie twierdzi Boyle, wskazując, iż o ile jasne i szczegółowe reguły stanowią część „twardego” prawa międzynarodowego, zapisanego w traktatach, o tyle bardziej ogólne w treści i formie ,zasady” czy

${ }^{50}$ Ibid., s. 210.

${ }^{51}$ Ibid., s. 210.

${ }^{52}$ Ibid., s. 211.

${ }^{53}$ Por. sprawa Fannie P. Dujay, w imieniu Gilberta F. Dujay przeciwko Stanom Zjednoczonym Meksyku, Meksykańsko-amerykańska komisja roszczeń wzajemnych, 8 kwietnia 1929 r., R.I.A.A. 1929 r., nr 4, s. 452, gdzie komisja wskazała, iż istnienie lub brak reguły (ang. rule) prawa jest wynikiem rozumowania indukcyjnego, $\mathrm{tj}$. identyfikowana jest ona $\mathrm{w}$ wyniku analizy różnorodnych dowodów międzynarodowej praktyki, dokonywanej celem ustalenia istnienia ogólnego konsensusu, stanowiącego podstawę prawa narodów. Por. też G. Schwarzenberger, The Inductive Approach to International Law, Harvard Law Review 1946-47, nr 60, s. 539.

${ }^{54}$ B. Cheng, op.cit., s. xiv, 1, 5. Choć ten sam autor pisze, iż sformułowanie zawarte w Statucie MTS odnosi się nie tylko do praktyki orzeczniczej sądów i trybunałów międzynarodowych, por. ibidem, s. 24.

${ }^{55}$ B. Cheng, op.cit., s. 24.

${ }^{56}$ Ibidem; sprawa Gentini, Komisja arbitrażowa włosko-wenezuelska, R.I.A.A. 1903, nr 10, s. 556.

${ }^{57}$ Cheng pisze o ,zasadniczych cechach prawdy prawniczej” (ang. essential qualities of juridical truth), jako o podwalinach owego systemu, s. 24. Wskazuje, że Phillimore, proponując sformułowanie zawarte w art. 38 Statutu STSM miał na myśli „maksymy prawne”. Ibidem. 
„normy” stanowią element miękkiego prawa międzynarodowego, nawet gdy zostały zapisane w treści umowy międzynarodowej ${ }^{58}$. Wśród „ogólnych zasad miękkiego prawa" cytowany autor wymienia zasadę ostrożności i zasadę ciagłego rozwoju ${ }^{59}$.

Zasady systemu prawa odróżnić można od zasad moralnych czy religijnych poprzez odwołanie do uznania ich przez narody cywilizowane na forum wewnętrznym $^{60}$. Stanowią one podstawy krajowych porządków prawnych prawie wszystkich państw na świecie. Uznanie zasady w porządku wewnętrznym państw rozwiniętych pozwala uznać ją za zasadę o międzynarodowej mocy obowiązywania $^{61}$. Jednocześnie, odwołanie do takiego właśnie charakteru zasad miało chronić przed arbitralną władzą sędziego, rozstrzygającego spór ${ }^{62}$. Potwierdzenie treści danej zasady $\mathrm{w}$ krajowych porządkach prawnych większości państw cywilizowanych miało pozwolić na zobiektywizowanie oceny sędziego $^{63}$. Obecnie uznać należy przymiotnik „cywilizowane” za zbędny anachronizm, bowiem za takie uchodzi każde państwo jako członek międzynarodowej wspólnoty. W wykładzie haskim z 1947 r. Kryłow pominął go ${ }^{64}$, uczynił to także w zdaniu odrębnym do rozstrzygnięcia MTS z 1949 r. w sprawie odszkodowań dla przedstawicieli dyplomatycznych ${ }^{65}$. Przyjąć więc można, iż źródłem prawa międzynarodowego są ogólne zasady prawa uznane przez narody, tj. przez zdecydowaną większość państw na świecie, znajdując swoje odzwierciedlenie także, choć niekoniecznie, w treści norm prawa wewnętrznego.

Przywołując prace twórców statutu STMS wśród zasad spełniających owe kryteria Cheng wymienia: zasadę powagi rzeczy osądzonej, zasadę dobrej wiary, zasadę nullum crimen sine lege, zakaz nadużywania praw, zasadę wykładni lex specialis derogat legi generali oraz kontrowersyjne, aplikowalne w szczególnych przypadkach prawo silniejszego ${ }^{66}$. Na podstawie analizy orzecznictwa tworzy on katalog zasad prawa międzynarodowego, do których zalicza: prawo do samoobrony (ang. principle of self-preservation) ${ }^{67}$, zasadę dobrej wiary ${ }^{68}$,

${ }^{58}$ A. E. Boyle, Soft Law in International Law making, (w:) International Law, red. A. Evans, Oksford 2010, s. 122. Jako przykład zasad miękkiego prawa, zawartych w treści traktatu podaje zapisy art. 3 Konwencji klimatycznej, zawierający m.in. zobowiązanie państw (,państwa-strony powinny”, ang. parties should) podejmować działania zapobiegające zmianom klimatu. Por.: s. 131.

${ }^{59}$ A. E. Boyle, Soft Law..., s. 133.

${ }^{60}$ B. Cheng, op.cit., s. 24-25.

${ }^{61}$ Ibidem, s. 25.

${ }^{62}$ Choć jak twierdzi Boyle, odwołanie do zasad ogólnych jest dopuszczeniem prawa precedensowego, tworzonego na salach sądowych. Por.: A. E. Boyle, Soft Law..., s. 132.

${ }^{63}$ B. Cheng, op.cit., s. 25.

${ }^{64}$ Por.: S. B. Krylov, Les notions principales du droit des gens (La doctrine soviétique du droit international), RdC 1947, tom 70, s. 449.

${ }^{65}$ Sprawa reparacji za szkody przedstawicieli ONZ (Reparation for injuries suffered in the service of the United Nations), zdanie odrębne sędziego Kryłowa, ICJ Reports 1949, s. 219.

${ }^{66}$ Por.: B. Cheng, op.cit., s. 25-26.

${ }^{67}$ Ibidem, s. 29-104.

${ }^{68}$ Ibid., s. 105-162. 
zasady odpowiedzialności międzynarodowej państw ${ }^{69}$ i zasady międzynarodowej procedury ${ }^{70}$. Wśród zasad odpowiedzialności międzynarodowej państw identyfikuje zasadę odpowiedzialności indywidualnej ${ }^{71}$, zasadę winy ${ }^{72}$, zasadę integralnego odszkodowania ${ }^{73}$ oraz zasadę bliskiej przyczynowości (ang. proximal causality $)^{74}$.

Należyta staranność omawiana jest przy okazji zasady winy. Brak należytej staranności wskazywany jest jako jedna $\mathrm{z}$ jej postaci, tj. jako wyraz niedbalstwa $^{75}$. Cheng konstatuje, że niedbalstwo (ang. negligence) czy świadoma nieumyślność (dosł. zawinione niedbalstwo, ang. culpable negligence) ${ }^{76}$ to niedopełnienie obowiązku prawnego, np. wykazania określonego stopnia staranności $^{77}$. Niedbalstwo jest więc postacią winy, choć nie jej immanentną częścią ${ }^{78}$. Świadoma nieumyślność będzie podstawą odpowiedzialności państwa wówczas, gdy jest ono zobowiązane do wykazania określonego stopnia staranności ${ }^{79}$. Winę może ono jednak ponosić także, jeśli zobowiązanie międzynarodowe nie zawiera odniesienia do wymaganego poziomu staranności. Pojawia się ona zawsze, gdy państwo dopuści się naruszenia zobowiązania międzynarodowego, z wyjątkiem działania siły wyższej, której państwo nie mogło zapobiec ${ }^{80}$. Zdaniem Chenga, przypisanie odpowiedzialności w przypadku naruszenia zobowiązania międzynarodowego nie wymaga dowodu złej wiary czy braku należytej staranności ${ }^{81}$. Państwo ponosi bowiem odpowiedzialność za błędy jego organów, nawet jeśli te popełnione zostały w dobrej wierze ${ }^{82}$. Dowód złej wiary czy niedbalstwa wymagany może być jedynie wówczas, gdy wynika to z treści naruszonej normy międzynarodowo prawnej ${ }^{83}$. Przypisanie państwu odpowiedzialności, jego zdaniem,

\footnotetext{
${ }^{69}$ Ibid., s. 163-256.

${ }^{70}$ Ibid., s. 257-386.

${ }^{71}$ Ibid., s. 208-217.

${ }^{72}$ Ibid., s. 218-232.

${ }^{73}$ Ibid., s. 233-240.

${ }^{74}$ Ibid., s. 241-256.

${ }^{75}$ Ibid., s. 227.
}

${ }^{76}$ Jak wskazują Czapliński i Wyrozumska, odpowiedzialność za brak należytej staranności jest bliska cywilistycznej konstrukcji winy nieumyślnej; por.: W. Czapliński, A. Wyrozumska, op.cit., s. 437. Por.: uwagi wstepne.

${ }^{77}$ B. Cheng, op.cit., s. 227.

${ }^{78}$ Ibidem, s. 227-228.

${ }^{79}$ Por.: Projekt Barbozy, U.N. Doc. A/51/10, art. 22, pkt (9), s. 119. Jeśli państwu pochodzenia oferowana była pomoc $\mathrm{w}$ zneutralizowaniu powstającej szkody przez organizację międzynarodową lub stronę trzecią, a państwo z takiej pomocy nie skorzystało, czy to w wyniku niedbalstwa czy też lekkomyślności, to wykazało brak należytej staranności.

${ }^{80}$ B. Cheng, op.cit., s. 227.

${ }^{81}$ Ibidem. Jako przykład wskazuje sprawę Wielkiej Brytanii, Francji i Włoch przeciwko Japonii i Niemcom (sprawa statku Wimbledon), STSM 1923, gdzie dowód złej wiary czy niedbalstwa nie był konieczny dla ustalenia przez STSM odpowiedzialności Niemiec. Por.: P.C.I.J., seria A, 1923, nr 1 .

${ }^{82}$ Pierwszy raport Rao, U.N. Doc. A/CN.4/487, pkt 20, s. 9, gdzie zobowiązanie do podejmowania działań prewencyjnych zostało uzupełnione o wyrażoną explicite przesłankę dobrej wiary.

${ }^{83}$ Por. art. 2 Projektu artykułów o odpowiedzialności państw z 2001 r. 
nie wymaga więc co do zasady dowodu złej wiary czy niedbalstwa, zależy jedynie od istnienia woli (ang. will) ${ }^{84}$. Zła wiara czy brak należytej staranności nie stanowią jego zdaniem ograniczenia zobowiązań międzynarodowych, stanowi je jedynie stan obiektywnej niemożności ich spełnienia, tj. działanie siły wyższej ${ }^{85}$.

Trudno zgodzić się $\mathrm{z}$ tą tezą $\mathrm{w}$ świetle orzecznictwa przedstawionego $\mathrm{w}$ rozdziale II niniejszego opracowania, gdzie wykazano, iż dopiero brak działania po stronie organów państwa, do którego zobowiązane one były mocą międzynarodowych zobowiązań państwa, może stać się podstawą jego odpowiedzialności ${ }^{86}$. Jednocześnie, to raczej obiektywne przypisanie, niż wina po stronie państwa, stanowić będzie podstawe jego odpowiedzialności. Przypisanie to nie będzie możliwe w okolicznościach opisanych w Projekcie artykułów o odpowiedzialności państw z 2001 r., gdzie katalog przesłanek egzoneracyjnych jest szerszy niż jedynie stan wyższej konieczności. Sam fakt naruszenia międzynarodowej normy nie może być uznany za podstawę odpowiedzialności, z wyjątkiem nielicznych sytuacji opisanych $\mathrm{w}$ treści traktatów, kiedy to państwo ponosi odpowiedzialność na zasadzie ryzyka.

\subsection{Zasada odpowiedzialności międzynarodowej}

Jak wskazano powyżej, należyta staranność często omawiana jest przy okazji opisu treści zasad odpowiedzialności państw za czyny sprzeczne z treścią ich międzynarodowych zobowiązań, ale pojawia się także przy okazji omawiania kwestii winy w prawie międzynarodowym. Wśród możliwych do zidentyfikowania zasad prawa międzynarodowego większość autorów bez wątpliwości wymienia zasadę odpowiedzialności międzynarodowej ${ }^{87}$. Naruszenie przez państwo zarówno zobowiązań traktatowych, jak i norm prawa zwyczajowego czy samych zasad ogólnych prawa niesie za sobą jego odpowiedzialność. Odpowiedzialność ponosić ono będzie nie tylko za działania swoich organów, ale także za ich zaniechania niezgodne $\mathrm{z}$ treścią międzynarodowego zobowiązania ${ }^{88}$. Zasada odpowiedzialności międzynarodowej wywodzona jest $\mathrm{z}$ wielowiekowej praktyki stosowania norm prawa międzynarodowego. Zasada ta oznacza konieczność ponoszenia odpowiedzialności przez podmioty prawa międzynarodo-

${ }^{84}$ B. Cheng, op.cit., s. 227.

${ }^{85}$ Ibidem, s. 228.

${ }^{86}$ Ibid.

${ }^{87}$ Por. np.: G. Schwarzenberger, op.cit., s. 349 i n. Autor wymienia także inne elementy międzynarodowego systemu prawnego, w tym zasady: suwerenności, swobodnego uznania, zgody, dobrej wiary, prawa do samooobrony i wolności mórz. Wspomina także o kształtujących się zasadach i procesach prawotwórczych, towarzyszącej im analizie prawnoporównawczej oraz podstawowych zasadach międzynarodowego porządku, współtworzących ów system w oparciu o równowagę międzynarodowego prawa i społeczności (ang. Equilibrium of International Law and Society).

${ }^{88}$ G. Schwarzenberger, op.cit., s. 349. 
wego za „niewybaczalne” (ang. inexcusable) naruszenia ich międzynarodowych zobowiązañ ${ }^{89}$. Praktyka stosowania tej zasady musi być jednolita, niezależnie od różnic pomiędzy krajowymi normami odpowiedzialności cywilnej czy karnej. Jednocześnie Schwarzenberger odnotowuje, że w czasach mu współczesnych trudno wskazać reguły dające dogmatyczne podstawy do opisania owej jednolitości ${ }^{90}$.

Zemanek, przedstawiciel niemieckiej doktryny lat 80 . XX w., krytykował kwalifikowanie należytej staranności jako elementu odpowiedzialności państwa $^{91}$. To wina, raczej niż należyta staranność, stanowiła jego zdaniem konieczny element wnioskowania prawniczego zawsze wtedy, gdy odpowiedzialność wynikała $\mathrm{z}$ zaniechania stanowiącego naruszenie prawa międzynarodowego. Wówczas rolę należytej staranności pełniła „zobiektywizowana” wina ${ }^{92}$. Tę ogólną dystynkcję popierają także niektórzy przedstawiciele doktryny brytyjskiej. Brownlie uwzględnia rolę tak pojmowanej winy, choć w marginalnym zakresie. Definiuje on winę jako termin używany do opisu przypisywalności (ang. blamewothiness) czynu, wynikającej z jego przewidywalnych konsekwencji albo lekkomyślności (ang. recklessness, łac. culpa lata), tj. świadomości nieuchronnych konsekwencji i zgody na nie ${ }^{93}$. Tak pojmowana wina może odegrać istotną rolę przy ustalaniu istnienia odpowiedzialności państwa wtedy, gdy z treści normy międzynarodowej wynika jego obowiązek zapobiegania określonemu zdarzeniu. Jeśli więc szkoda powstanie wskutek działania osób prywatnych, niedziałających z upoważnienia ani na zlecenie państwa, państwo to może odpowiadać za zaniechanie, stanowiące naruszenie jego międzynarodowego zobowiązania. Wskazuje jednak, że takie rozumienie winy nie powinno być utożsamiane $\mathrm{z}$ nastawieniem psychicznym osób pełniących funkcje w imieniu państwa, ale $\mathrm{z}$ brakiem ich właściwego działania, wymaganego treścią normy międzynarodowo prawnej. Sądy i trybunały mogą więc zidentyfikować standard należytej staranności i według niego oceniać istnienie lub brak zaniechania po stronie konkretnych organów państwa. Chodzi tu więc raczej o zależność przyczynowo-skutkową pomiędzy zaniechaniem organu państwa, a powstaniem szkodliwego skutku, z której wynika możliwość postawienia mu konkretnego zarzutu $^{94}$.

Inną rolę należytej staranności przypisuje Pissilo Mazzeschi. Jego zdaniem uwzględnienie tego kryterium nie będzie zależało od charakteru naruszenia prawa, ale od kategorii pierwotnych norm postępowania ${ }^{95}$. O ile niektóre normy,

\footnotetext{
${ }^{89}$ Ibidem, s. 349-350.

${ }^{90}$ Ibid., s. 352.

${ }^{91}$ K. Zemanek, E. Diez (red.), Schuld- Und Erfolgshaftung der Völkerrechtskommission über Staatenverantwortlichkeit, (w:) Festschrift für R. Bindschedler, Bern 1980, s. 315.

${ }^{92}$ Ibidem, s. 322-323.

${ }^{93}$ I. Brownlie, Principles..., s. 440.

${ }^{94}$ Ibidem.

${ }^{95}$ R. Pisillo Mazzeschi, op.cit., s. 19.
} 
zawierające szczególnie ważną treść, wymagały będą wykazania przez państwo dołożenia należytej staranności przy ich przestrzeganiu, o tyle inne, nieposiadające owego szczególnego charakteru, wymogu takiego nie zawierają. Jeśli z charakteru normy taki szczególny obowiązek nie wynika, należyta staranność nie będzie brana pod uwagę przy ocenie działania państwa - ocena taka dokonywana będzie wyłącznie w oparciu o kryteria „obiektywne” ${ }^{96}$.

Przywołując wielowiekowy spór oraz niejednolite orzecznictwo, uwzględniające rolę psychologicznie pojmowanej winy w ocenie międzynarodowej odpowiedzialności państw ${ }^{97}$, Delbruck i Wolfrum sprzeciwili się uwzględnianiu winy jako przesłanki odpowiedzialności międzynarodowej państw ${ }^{98}$. Wzorzec wzmaganego prawem zachowania państw, działających poprzez swoje organy, wynika bowiem, ich zdaniem, nie z charakteru normy wtórnej, ale z treści normy pierwotnej ${ }^{99}$. Państwo ponosi więc odpowiedzialność za działania osób prywatnych jedynie, jeśli nie dołoży należytej staranności przy wypełnianiu obowiązków przypisanych mu treścią pierwotnych norm prawa międzynarodowego, a zasada winy nie znajduje tu zastosowania ${ }^{100}$. Jakakolwiek odpowiedzialność za działania niebezpieczne koniecznie wiąże się z ograniczeniem jej zakresu i wynika $\mathrm{z}$ treści szczegółowego zobowiązania ${ }^{101}$. Analiza traktatów zawierających reguły, których naruszenie niesie za sobą odpowiedzialność międzynarodową pozwala wskazywać na ich wspólną cechę, którą opisać można terminem „należyta staranność" i wywodzić z prawa zwyczajowego ${ }^{102}$. Należyta staranność jest więc elementem zobowiązania międzynarodowego, nie zaś częścią dowodu winy ${ }^{103}$. Wskazywali słusznie, że rolę owego obiektywnego kryterium pełnić powinna należyta staranność. Standard należytej staranności ze sprawy Alabama został uszczegółowiony i obecnie obejmuje zobowiązanie państw do zapewnienia standardu minimalnej ochrony (niem. Mindeststandard), zarówno w treści prawa wewnętrznego, jak i w jego wykonywaniu ${ }^{104}$. Treść tego zobowiązania w konkretnej sytuacji określana będzie na podstawie analizy towarzyszących mu norm traktowych i zwyczajowych ${ }^{105}$. Wymagania względem państwa będą tym wyższe, im ważniejsze interesy państwa chronione będą przez daną normę, któ-

${ }^{96}$ Ibidem, przyp. 32.

${ }^{97}$ J. Delbrück, R. Wolfrum, op.cit., s. 945.

${ }^{98}$ Ibidem, par. 183, s. 946.

${ }^{99}$ Ibid.

${ }^{100}$ Ibid., s. 947.

${ }^{101}$ Ibid.

102 Ibid., par. 183, s. 947-948. Zob. też: G. Handl, State Liability For Accidental Transnational Environmental Damage By Private Persons, American Journal of International Law 1980, nr 74, s. 564; A. E. Boyle, Saving the World - Implementation and Enforcement of International Environmental Law through International Institutions, Journal of Environmental Law 1991, nr 3, s. 240.

103 J. Delbrück, R. Wolfrum, op.cit., par. 183, s. 948.

${ }^{104}$ Ibidem.

${ }^{105}$ Ibid. Por.: A. E. Boyle, Saving the World ..., s. 272. 
rej standard ów w danej sytuacji dotyczy ${ }^{106}$. Niespełnienie standardu należytej staranności będzie więc mieć miejsce zawsze wtedy, gdy prawo wewnętrzne państwa nie odzwierciedla elementów owego międzynarodowego minimalnego standardu $\mathrm{w}$ swoim prawie wewnętrznym albo gdy pomimo wprowadzenia stosownych norm, nie egzekwuje ich skutecznie ${ }^{107}$. Jeśli państwo wprowadzi stosowne przepisy i zastosuje je, nie będzie ponosić odpowiedzialności za brak należytej staranności, niezależnie od wyniku takiego krajowego postępowania ${ }^{108}$.

\subsection{Zasada należytej staranności}

Dorobek prawa międzynarodowego obfituje w terminologię dotyczącą należytej staranności, choć, jak podkreśla Brownlie, żadne ze źródeł nie zawiera jej definicji ${ }^{109}$. W sprawie cieśniny Korfu MTS wskazał, że należyta staranność jest źródłem zwyczajowej zasady prewencji ${ }^{110}$. W piśmiennictwie używane sa pojęcia „,doktryna”, „wymóg”, „koncepcja”, „obowiązek” czy „zobowiązanie” należytej staranności ${ }^{111}$. Co znamienne, niektórzy autorzy, jak twórca najpopularniejszego anglojęzycznego podręcznika prawa międzynarodowego Malanczuk, pomijają $\mathrm{w}$ swoim wywodzie zagadnienie należytej staranności ${ }^{112}$. Podobnie czyni Cassese, wspominając o należytej staranności jedynie jako o przymiocie zaniechania organów państwa, niezgodnego z międzynarodowymi standardami prawnymi, skutkującego szkodą cudzoziemca ${ }^{113}$. W pracach KPM określana była najczęściej jako „standard”114, choć przy okazji opisu zasady prewencji, Komisja wskazała stałe miejsce zasady należytej staranności w porządku traktowym prawa ochrony środowiska ${ }^{115}$. O ,zasadzie należytej staranności” pisał natomiast obszernie w swoim czwartym raporcie z 1957 r. pierwszy Specjalny Sprawozdawca KPM ds. odpowiedzialności międzynarodowej, García-Amador ${ }^{116}$. W drugiej połowie XX w. należyta staranność uznana została za element zasady

\footnotetext{
${ }^{106}$ J. Delbrück, R. Wolfrum, op.cit., par. 183, s. 948.

${ }^{107}$ Ibidem.

108 Ibid.

${ }^{109}$ Por.: M. N. Shaw, Prawo międzynarodowe..., s. 455.

${ }^{110}$ Sprawa cieśniny Korfu, s. 22. Por.: także sprawa młynów rzecznych na rzece Urugwaj,
} s. 38. Oba orzeczenia zostały omówione w rozdz. II.

${ }^{111}$ Por. uwagi wstępne.

${ }^{112}$ P. Malanczuk wspomina o należytej stranności jedynie jako o synonimie „rozsądnej troski” (ang. reasonable care), pisząc o obowiązku zapewnienia ochrony cudzoziemcom, P. Malanczuk, op.cit., s. 259. Nie wspomina o niej w ogóle, omawiając zasadę dobrosąsiedztwa (s. 245) czy odpowiedzialność międzynarodową (s. 241).

${ }^{113}$ A. Cassese, op.cit., s. 250.

${ }^{114}$ Por. uwagi wstępne. Tak też np. I. Brownlie, Principles..., s. 440, 455; M. N. Shaw, Prawo międzynarodowe..., s. 451; K. N. Trapp, op.cit., s. 64; F. F. Martin, op.cit., s. 72; B. A. Boczek, op.cit., s. 235; A. T. Gallagher, op.cit., s. 241.

${ }_{115}$ Projekt Barbozy, U.N. Doc. A/51/10, komentarz (5), s. 110

${ }^{116}$ Por.: Drugi raport Garcíi-Amadora, U.N. Doc. A/CN.4/106, komentarz do art. 10 i 11, pkt 15 , s. $122-123$. 
dobrej wiary w relacjach dobrosąsiedzkich ${ }^{117}$. W XXI-wiecznych opracowaniach dotyczących prawa międzynarodowego, a w szczególności międzynarodowego prawa środowiska, często pojawia się odwołanie do „zasady” należytej staranności ${ }^{118}$.

Pisillo Mazzeschi, obszernie opisując należytą staranność jako zasadę prawa międzynarodowego w 1992 r, wskazał cztery kluczowe problemy ${ }^{119}$. Po pierwsze, dla jej stosowania należy ustalić, jaki poziom należytej staranności wymagany jest od państw w ich aktywności na arenie międzynarodowej. Czy poziom ów powinien być determinowany w oparciu o ogólnie rozumianą zasadę należytej staranności, czy raczej w odniesieniu do indywidualnej praktyki krajowej? Ponadto, zobowiązanie wynikające z zasady należytej staranności wymaga określenia jego subiektywnego albo obiektywnego charakteru. Ustalić więc należy, czy odpowiedzialność państwa za brak należytej staranności zależna jest od winy jego organów, czy raczej wynika z obiektywnej oceny działań czy zaniechań tychże lub ich konsekwencji. Należy także ustalić, czy treść zobowiązania jest stała, czy elastyczna, zależna od faktycznych okoliczności, których zobowiązanie dotyczy. Wreszcie, odpowiedzi wymaga pytanie o granice należytej staranności, jaką wykazywać powinny państwa ${ }^{120}$.

Należyta staranność powinna być weryfikowana względem teoretycznego wzorca „dobrego rządu” raczej niż w odniesieniu do działania danego państwa w sprawach własnych. Pisillo Mazzeschi, analizując przedmiotowe orzecznictwo i wywodząc z niego normę zwyczajową zasadnie wskazuje, że międzynarodowy standard należytej staranności nie odnosi się do praktyki wewnętrznej państwa $^{121}$. Prace KPM potwierdzają ową konstatację, jednak, jak wskazano powyżej, oceniając wysiłki państwa mające na celu dołożenie należytej staranności, uwzględniać należy także jego poziom ekonomiczny czy rozwój społeczny, pomimo iż nie będą to elementy o charakterze decydującym dla ustalenia jego odpowiedzialności za ewentualne zaniechanie. Zasada należytej staranności konstytuuje więc obowiązek obiektywny, choć analiza jego dopełnienia w określonym stanie faktycznym uwzględniać powinna pomocniczo sytuację ekonomiczną i społeczną państwa sprawcy.

Konsekwencją powyższego wniosku jest obiektywny charakter obowiązku wykazywania należytej staranności. Treść zobowiązania powinna być identyfi-

${ }^{117}$ Projekt Barbozy, U.N. Doc. A/51/10, artykuł 22, pkt (3), s. 119; tak też J. Sutor, op.cit., s. 226-227, który wskazuje należytą staranność jako element decydujący przy ocenie dobrej wiary, wykazywanej przez organy państwa zapewniającego ochronę dyplomatom podczas zamieszek. Brak dobrej wiary może zostać uznany za przesłankę decydującą o przypisaniu państwu międzynarodowej odpowiedzialności.

${ }^{118}$ G. Dahm, J. Delbrück, op.cit, s. 948; T. Gazzini, op.cit, s.187; R. P. Barnidge Jr., op.cit, s. 81 i n.; L. Viikari, op.cit., s. 155; N. Schrijver, Sovereignty..., s. 127; N. Schrijver, Development..., s. 50; O. Yoshida, op.cit, s. 65; C. Lehnardt, op.cit, s. 87.

${ }^{119}$ Por. też: R. P. Barnidge Jr., op.cit, s. 81 i n.

${ }^{120}$ R. Pisillo Mazzeschi, op.cit., s. 40.

${ }^{121}$ Ibidem. 
kowana jako obiektywny standard zachowania. Subiektywne nastawienie jednostek działających w imieniu lub z upoważnienia państwa może mieć znaczenie dla przypisania mu odpowiedzialności, ale raczej jako okoliczność dowodowa, potwierdzająca naruszenie treści obiektywnego obowiązku dołożenia należytej staranności. Jak wskazuje Pisillo Mazzeschi, „znaczenie ma nie subiektywne nastawienie winnej jednostki działającej jako organ państwa, ale naruszenie obiektywnego standardu zachowania państwa, pojmowanego jako całość" jego organów i kompetencji ${ }^{122}$. Wywodzi z międzynarodowej praktyki przekonanie, że dla przypisania odpowiedzialności państwu wystarczające jest wykazanie „ogólnej niedostateczności działań rządowych” w wypełnianiu dyspozycji zobowiązania międzynarodowego albo „ogólny brak staranności po stronie władz państwa pojmowanych jako całość” weryfikowany względem treści „międzynarodowego standardu" ${ }^{\prime 23}$. Wykazanie takiego uchybienia nie wymaga każdorazowego wykazania indywidualnej winy osoby działającej w imieniu państwa, co potwierdza obiektywny charakter zobowiązania do wykazywania należytej staranności.

Pisillo Mazzeschi podkreśla jednak także elastyczny i względny charakter treści omawianej reguły. Stopień wykazywanej przez państwo staranności zależy w znacznej mierze od okoliczności sprawy, dlatego też niemożliwe jest szczegółowe opisanie treści dotyczącej jej zasady ${ }^{124}$. Jednocześnie, na podstawie praktyki międzynarodowej, zidentyfikować można trzy ogólne, obiektywne kryteria weryfikacji staranności wykazywanej przez państwo ${ }^{125}$. Decydując, czy państwo wykazało należytą staranność, należy zbadać skuteczność kontroli państwowej. Jak wskazano wcześniej, państwo zobowiązane jest podjąć wszelkie niezbędne kroki celem zapewnienia owej skuteczności względem aktywności na jego terytorium, w jego jurysdykcji lub pod jego kontrola. Drugim kryterium będzie badanie znaczenia interesów, które państwo zobligowane było chronić. Wreszcie na zasadę należytej staranności składa się weryfikacja możliwości przewidzenia powstania szkody, którą państwo powinno było posiadać, podjąwszy wszelkie możliwe i racjonalne wysiłki celem jej zdobycia ${ }^{126}$.

Elastyczna treść zasady należytej staranności pozwala różnicować wymagany poziom staranności w zależności od przedmiotu zobowiązania, jakiego ona dotyczy. Z reguły oczekiwany od państwa będzie ,przeciętny ogólny standard” (ang. average general standard) staranności, właściwy „cywilizowanym” czy „dobrze zorganizowanym” państwom ${ }^{127}$. Standard ów odpowiada modelowi

122 Ibid., s. 42 .

${ }^{123}$ Ibid., s. 43.

${ }^{124}$ Ibid., s. 44; por. też X. Hanquin, op.cit., s. 162-165; P. N. Okowa, op.cit., s. 83.

${ }^{125}$ R. Pisillo Mazzeschi, op.cit., s. 44.

${ }^{126}$ Ibidem i orzeczenia tam cytowane.

${ }^{127}$ Ibid., s. 45. Por. T. Honoré, Responsibility..., s. 34, gdzie autor omawia logiczne trudności przy ustalaniu treści ,przeciętnego” standardu. 
„dobrego ojca rodziny”, właściwemu krajowym systemom prawa cywilnego ${ }^{128}$. W niektórych obszarach prawa międzynarodowego standard ten będzie zawyżony, obligując państwa do „dobrego" czy wręcz ,znakomitego” działania ${ }^{129}$. Przykładem służyć tu może pozytywne zobowiązanie państwa do ochrony interesów cudzoziemców przed szkodą, gdzie wymagany jest ogólny, przeciętny poziom staranności, zestawiony z wyższym, szczególnym zobowiązaniem do lepszej, skuteczniejszej ochrony przedstawicieli zagranicznych służb dyplomatycznych ${ }^{130}$. Ów szczególny, wyższy poziom staranności może wynikać z treści zobowiązania traktatowego, jak w przypadku prawa dyplomatycznego i szczególnego obowiązku ochrony personelu dyplomatycznego, ale może być także następstwem charakteru samego zobowiązania, np. do wykonywania nadzoru nad wykorzystaniem potencjalnie szkodliwej technologii, wynikać z wyjątkowo dużego rozmiaru potencjalnych szkód czy wyjątkowego charakterem chronionego prawa czy interesu, jak np. ochrona środowiska naturalnego ${ }^{131}$. W tej pierwszej sytuacji, dotyczącej nadzoru nad procesami technologicznymi, zobowiązanie do dokładania należytej staranności opisane może zostać bardzo precyzyjnie, przy odwołaniu do danych technicznych, w oparciu o najnowszy stan wiedzy. Pisillo Mazzeschi wywodzi z tego stanu rzeczy słuszną konstatację, iż treść niektórych zobowiązań, obejmujących obowiązek wykazywania należytej staranności, ustalić można w sposób bardzo precyzyjny i szczegółowy ${ }^{132}$.

Ogólny charakter opisywanego tu zobowiązania niesie za sobą konieczność wskazania tych sytuacji, w których nie znajduje on zastosowania, a więc wskazania granic obowiązku ustanawianego przez zasadę należytej staranności.

Państwo zwolnione jest z odpowiedzialności za naruszenie zobowiązania międzynarodowego, kiedy wykaże zaistnienie jednej z okoliczności uchylających bezprawność, takich jak niemożność spełnienia zobowiązania czy działanie siły wyższej. Okoliczności te muszą zostać uwzględnione także przy naruszeniu zasady należytej staranności ${ }^{133}$. Szczególnie ważne jest doprecyzowanie treści zasady międzynarodowej staranności przy jej stosowaniu dla zapewnienia bezpieczeństwa innych państw. Jak wskazuje Pisillo Mazzeschi, granice należytej staranności określane są przez faktyczną możliwość działania państwa, który to wniosek opiera o treść decyzji MTS w sprawie oddziałów contras ${ }^{134}$.

Pisillo Mazzeschi proponuje wprowadzenie podziału wśród międzynarodowych zobowiązań państw w zależności od aplikowalności do nich zasady nale-

${ }^{128}$ Ibidem, s. 17-18, gdzie autor omawia treść tego i jemu podobnych standardów, tj. np. wzorca dobrego lekarza czy dobrego urzędnika, oraz wątpliwości dotyczące ich stosowania.

${ }^{129}$ Ibidem.

130 Ibid.

${ }^{131}$ Ibid.

${ }^{132}$ Ibid.

${ }^{133}$ Ibid. Por. Projekt artykułów o odpowiedzialności państw z 2001 r., rozdz. V i rozdz. III powyżej, gdzie omówione zostały okoliczności zwalniające państwa od odpowiedzialności.

${ }^{134}$ Ibid., s. 46. 
żytej staranności ${ }^{135}$. Wskazuje, że zasada ta ma zastosowanie do wybranych zobowiązań, właściwych niektórym obszarom prawa międzynarodowego. Co więcej, dotyczy ona jedynie zobowiązań pozytywnych z tej grupy, tj. formułujących konieczność ochrony interesów innych podmiotów, nie zaś tych, które dotyczą negatywnych obowiązków państwa, tj. obowiązek powstrzymania się od naruszania chronionych prawem interesów innych podmiotów ${ }^{136}$. Ponadto, nawet względem zobowiązań z tej pierwszej grupy treść omawianej zasady dotyczyć będzie jedynie zobowiązania do odpowiedniego wykorzystania aparatu państwowego celem zapobiegania szkodzie czy wymierzenia sprawiedliwości sprawcom, nie zaś samego obowiązku powołania owego aparatu czy zapobieżenia naruszeniu ${ }^{137}$. Tak więc Pisillo Mazzeschi formułuję zasadę należytej staranności jako aplikowalną jedynie do ograniczonej kategorii zobowiązań, których naruszenie rodzi międzynarodową odpowiedzialność państwa ${ }^{138}$. Ta konkluzja pozostaje w zgodzie ze stanowiskiem Brownlie'go, który uważa należytą staranność jedynie za jedno z kryteriów pozwalających na przypisanie państwu odpowiedzialności międzynarodowej ${ }^{139}$. Konieczność dołożenia należytej staranności postrzegana winna być jako element zobowiązania międzynarodowego, którego to zobowiązania państwo nie wypełnia, jeśli nie przejawia należytej staranności ${ }^{140}$. Nie w każdej więc sytuacji międzynarodowo bezprawnego zaniechania państwa może zostać zasadnie przywołana zasada należytej staranności, choć zawsze gdy jest ona stosowana, mamy do czynienia $\mathrm{z}$ odpowiedzialnością państwa za zaniechanie ${ }^{141}$. Należyta staranność nie musi dotyczyć jedynie nienależytego zapobiegania szkodom wywołanym przez osoby fizyczne. Ocenie podlegać będzie działanie aparatu państwowego nie tylko, jeśli ten niedostatecznie starannie zrealizuje obowiązek prewencji, ale także, gdy państwo nie podejmie działań wymaganych od jego organów, tj. np. nie rozpocznie ścigania sprawców czy nie wymierzy im sprawiedliwości ${ }^{142}$. Pisillo Mazzeschi twierdzi, że nie wszystkie zobowiązania do realizacji działań prewencyjnych oparte są na zasadzie należytej staranności ${ }^{143}$. Proponuje, za Reuterem i Combacau, przyjęcie podziału na dwie kategorie zobowiązań państw, znanego w kilku systemach prawa wewnętrznego ${ }^{144}$. W pierwszej umieszcza zobowiązania państw do starannego postępowania (ang. obligations of diligent conduct), w drugiej zaś zobowiązania do osiagnięcia określonego skutku (ang. obligations of result) ${ }^{145}$.

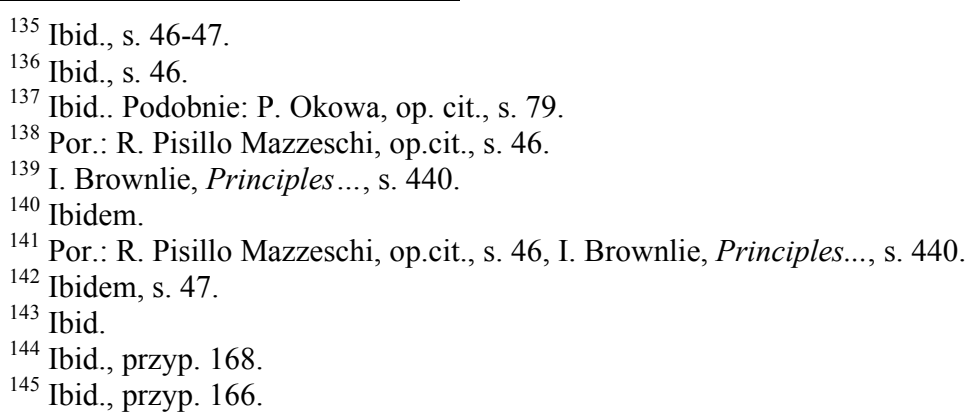


W wyniku tak poprowadzonego podziału zasada należytej staranności stosowana będzie jedynie przy weryfikacji odpowiedzialności państwa za naruszenie zobowiązań do starannego postępowania, nadając samym regułom odpowiedzialności szczególny charakter. Pisillo Mazzeschi odróżnia zaproponowany od opisanego przez KPM podział na zobowiązania do podjęcia określonych działań i zobowiązaniach do osiagnięcia określonego celu ${ }^{146}$.

Zasada należytej staranności stosowana więc będzie jego zdaniem jedynie przy ocenie dopełnienia zobowiązań obejmujących obowiązek starannego postępowania, niezależnie od skutków wywołanych przez owo postępowanie. Odmiennie niż w przypadku zobowiązań skutkowych, w przypadku tej kategorii obowiązków państw istotna będzie jedynie weryfikacja sposobu postępowania organów państwa, które ponosić będzie odpowiedzialność za uchybienie standardowi należytej staranności, odpowiedniemu do konkretnej sytuacji ${ }^{147}$. Państwo zobowiązane więc będzie do „podjęcia wszelkich starań”, nie zaś do skutecznego zapobieżenia szkodliwym skutkom ${ }^{148}$. W konsekwencji, powstanie szkody nie będzie konieczną przesłanką odpowiedzialności, która powstanie już w chwili zaistnienia zagrożenia szkodą. Jak już wspomniano, trudno wskazać dowody akceptacji takiej koncepcji w praktyce państw.

Konsekwencją tak przyjętego podziału jest różnica w postępowaniu dowodowym, mającym doprowadzić do ustalenia odpowiedzialności państwa za naruszenie międzynarodowego zobowiązania. Odpowiedzialność za niedołożenie należytej staranności wynikać może z elementu ryzyka zawartego w konkretnym zobowiązaniu do starannego postępowania ${ }^{149}$. O ile samo istnienie niebezpieczeństwa powstania szkody nie przesądza o odpowiedzialności państwa za niedopełnienie zobowiązania do osiagnięcia określonego skutku ${ }^{150}$, powstaje ona bowiem dopiero, jeśli niebezpieczeństwo to się ziści powstaniem szkody, to w przypadku zobowiązań do dołożenia należytej staranności niebezpieczeństwo powstania szkody determinuje treść konkretnego zobowiązania, tj. decyduje o faktycznych działaniach, które podjać powinno „staranne” państwo ${ }^{151}$. Poprzez sformułowanie treści zwyczajowej zasady należytej staranności prawo międzynarodowe de facto uwzględniło podział znany krajowym porządkom prawnym, determinujący różną treść zobowiązań należących do każdej ze wskazanych powyżej dwóch grup ${ }^{152}$. O ile więc $\mathrm{w}$ przypadku zobowiązań do zapobieżenia określonym skutkom łatwo jest przewidzieć działania pozwalające na dopełnienie zobowiązania, o tyle w niektórych sytuacjach, zwłaszcza np. dotyczących ochrony środowiska czy bezpieczeństwa innych państw, zobowiązanie między-

\footnotetext{
${ }^{146}$ Ibid., przyp. 167.

${ }^{147}$ Ibid., s. 48.

148 Ibid.

149 Ibid.

${ }^{150}$ Ibid., s. 49.

151 Ibid., s. 48

${ }^{152}$ Ibid.
} 
narodowe obejmuje tak wiele czynników ryzyka, że może ono odnosić się jedynie do „dołożenia wszelkich starań” celem wypełnienia jego treści ${ }^{153} . \mathrm{Na}$ podstawie analizy międzynarodowej praktyki Pisillo Mazzeschi dowodzi, że należyta staranność przywoływana jest jedynie w treści tych zobowiązań, realizacja których obarczona jest istotnym niebezpieczeństwem powstania znaczącej szkody, które to stanowisko należy podzielić. Konkluduje, że zasada należytej staranności aplikowalna jest jedynie względem zobowiązań, realizacja celu których trudna jest do przewidzenia ${ }^{154}$. O zawartości katalogu owych zobowiązań przesądza sekwencja okoliczności faktycznych, których one dotyczą. Zasada należytej staranności wprowadza tym samym modyfikację do modelu odpowiedzialności państwa za naruszenie obowiązku prewencji. Ów dodatkowy element dotyczy sposobu przypisania odpowiedzialności państwu, której wykazanie wymaga - inaczej niż w przypadku zobowiązań do osiąnięcia określonego skutku - wykazania przez państwo poszkodowane niedołożenia należytej staranności, wymaganej w określonych okolicznościach faktycznych ${ }^{155}$. Odpowiedzialność państwa pochodzenia szkody ustalić będzie można w oparciu o analizę szeregu abstrakcyjnych obowiązków, konstytuujących pierwotne zobowiązanie do dołożenia należytej staranności i zestawienie jej wyników z działaniami podjętymi w konkretnej sytuacji przez organy państwa lub osoby działające z jego upoważnienia czy też w jego imieniu. Wykazanie odpowiedzialności państwa za naruszenie zobowiązania do dołożenia należytej staranności będzie więc zawsze bardziej wymagające dowodowo ${ }^{156}$.

W najnowszej literaturze problem kwalifikacji należytej staranności jako zasady prawa międzynarodowego analizował Barnidge ${ }^{157}$. Czynił to w kontekście odpowiedzialności państwa za działania osób prywatnych, dopuszczających się na jego terytorium czynów sprzecznych z treścią norm prawa międzynarodowego. Jego zdaniem, zasada należytej staranności ma szczególne znaczenie praktyczne, bowiem może być $\mathrm{z}$ powodzeniem stosowana $\mathrm{w}$ różnorodnych stanach faktycznych ${ }^{158}$. Wskazuje jednak także na niebezpieczeństwo jej nadmiernie ekstensywnej albo wąskiej interpretacji, czyniąc ją podatną na polityczne wplywy ${ }^{159}$.

Zdaniem autorki należyta staranność postrzegana może być jako element międzynarodowo prawnej zasady odpowiedzialności państwa ${ }^{160}$, ewentualnie, przywołując terminologię Schwarzenbergera, jako wpisywana w jej ramy

\footnotetext{
153 Ibid.

154 Ibid., s. 49.

${ }^{155}$ Ibid.

${ }^{156}$ Pissilo Mazzeschi nazywa zaproponowaną koncepcję odpowiedzialności państw teorią „eklektyczno-obiektywną”. Por.: R. Pisillo Mazzeschi, op.cit., s. 49-50.

${ }^{157}$ R. P. Barnidge Jr., op.cit., s. 81-121.

${ }^{158}$ Ibidem, s. 121.

${ }^{159}$ Ibid., s. 81 i 121.

${ }^{160}$ Por.: ibid., s. $82-83$.
} 
zasada „pomocnicza”161. Stosując kategoryzację Boyle’a, uznać ją można za zasadę miękkiego prawa międzynarodowego, kształtującą zarówno orzecznictwo, jak i praktykę traktatową ${ }^{162}$. Bez wątpienia stanowi zasadę międzynarodowego prawa środowiska, wywodzoną $\mathrm{z}$ prawa zwyczajowego ${ }^{163}$. Zważywszy jednak na jej znaczenie dla realizacji zobowiązań z innych dziedzin prawa międzynarodowego, uznać można za zasadne postrzeganie należytej staranności jako zasady prawa międzynarodowego ${ }^{164}$.

O należytej staranności jako o zasadzie prawa wywodzonej z międzynarodowego prawa zwyczajowego pisze Yoshida, wywodząc ją z zasady dobrosasiedztwa, zapisanej w treści zasady 21 Deklaracji sztokholmskiej ${ }^{165}$. Uznanie należytej staranności za zasadę prawa jest jej zdaniem konieczne dla nadania praktycznego znaczenia odpowiedzialności państw za szkody transgraniczne w środowisku naturalnym. W obecnym kształcie zasada 21 dotyczy jedynie szkód materialnych, czyniąc powstanie szkody niezbędnym elementem odpowiedzialności państwa za naruszenie rzeczonej zasady. Konstrukcja ta potwierdza wyrażaną podczas negocjacji zgodę państw na objęcie nią jedynie skutków niedbalstwa organów państwa, nie zaś wszelkich form odpowiedzialności międzynarodowej ${ }^{166}$. Odpowiedzialność za szkody w środowisku naturalnym wynikać więc może jedynie $\mathrm{z}$ naruszenia pierwotnego zobowiązania międzynarodowego ${ }^{167}$. Braki w dogmatyce odpowiedzialności międzynarodowej czy aplikacji zasady odpowiedzialności obiektywnej wymagają uzupełnienia, zaś elastyczny charakter zasady należytej staranności może posłużyć temu celowi ${ }^{168}$.

Elastyczna treść owej zasady, choć postrzegana może być także jako wada, bowiem niesie za sobą niebezpieczeństwo nieprzewidywalnej oceny sędziowskiej $\mathrm{w}$ przypadku sporu oraz trudności $\mathrm{z}$ ustaleniem wymaganego $\mathrm{w}$ danych okolicznościach zachowania organów państwa, jest jej zaletą ${ }^{169}$. Niebezpieczeństwo jest minimalizowane przez dokumenty opracowywane przez organizacje międzynarodowe, takie jak Międzynarodowa Organizacja Standaryzacyjna, Światowa Organizacja Zdrowia czy Międzynarodowa Organizacja Morska,

161 Zasady pomocnicze stanowią uzupełnienie podziału zasad prawa międzynarodowego, współtworzonego z zasadami „fundamentalnymi”. Jak już wspomniano, według Schwarzenbergera zasada uznana za fundamentalną winna spełniać trzy kryteria: musi być szczególnie ważna, obejmować dyspozycją szeroki wachlarz norm prawa międzynarodowego i stanowić podstawowy element każdego reżimu prawa międzynarodowego albo być tak istotna dla współczesnego systemu prawa międzynarodowego, że przy jej pominięciu utracona zostałaby jedna z podstawowych cech tego systemu. G. Schwarzenberger, op.cit., s. 204.

162 A. E. Boyle, Soft Law..., s. 133. Podobnie: P. Okowa, op.cit., s. 83-84.

${ }^{163}$ Por.: P. Sands, Principles of International Environmental Law, Cambridge 2003, s. 882.

${ }^{164}$ Por. C. Lehnardt, op.cit., s. 87.

${ }^{165}$ O. Yoshida, op.cit., s. 64-65.

166 Takie było też założenie Komisji podczas podejmowania prac nad zagadnieniem odpowiedzialności międzynarodowej, por.: Por. A. E. Boyle, State Responsibility ..., s. 3.

${ }^{167}$ O. Yoshida, op.cit, s. 65.

${ }^{168}$ Ibidem, s. 65, 66.

${ }^{169}$ Por.: ibid., s. 67. 
opisujące treść „minimalnych międzynarodowych standardów środowiskowych" ${ }^{, 70}$. Istnienie owych standardów jest koniecznym warunkiem praktycznej aplikacji zasady prewencji i zasady należytej staranności ${ }^{171}$. Powszechna recepcja treści zasady 21 Deklaracji sztokholmskiej w licznych dokumentach międzynarodowego prawa środowiska jest zdaniem Yoshidy dowodem na zwyczajowe ustanowienie obowiązku prewencji, ograniczanego treścią zasady należytej staranności ${ }^{172}$. Konstatację tę należy podzielić. Należyta staranność oznacza tu zobowiązanie do stosowania niezbędnych i praktycznych środków (ang. neccesary and practicable measures), czy inaczej: do dobrych praktyk środowiskowych (ang. good environmental conduct) ${ }^{173}$. Państwa nie ponoszą więc odpowiedzialności za szkody środowiskowe, o ile nie wynikają one z braku należytej staranności ${ }^{174}$. Zasada należytej staranności, wywodzona z prawa zwyczajowego, wymaga od państw jedynie podjęcia odpowiednich działań i wszelkich wysiłków w ramach środków pozostających w ich dyspozycji i własnych możliwości ${ }^{175}$. Jej szczegółowa treść wypracowywana jest w drodze współpracy i wymiany informacji z innymi państwami ${ }^{176}$.

Viikari w ten sam sposób interpretuje treść zasady 21 Deklaracji sztokholmskiej $^{177}$. Zasada należytej staranności stanowi alternatywę dla kontrowersyjnej „pośredniej” odpowiedzialności państwa za działania osób prywatnych. Zasada ta zwalnia państwa od odpowiedzialności absolutnej za powstałą szkodę, ograniczając ją jedynie do sytuacji, w których organy państwa nie podjęły działań wymaganych od „dobrego rządu”, celem zapobiegania jej powstaniu ${ }^{178}$. Jako taka, zasada należytej staranności jest bliska zasadzie wspólnych choć zróżnicowanych obowiązków (ang. principle of Common But Differentiated Responsibility; CBDR), składowej zasady ciagłego rozwoju ${ }^{179}$, inaczej jednak niż ta ostatnia nie odwołuje się do solidarnej odpowiedzialności państw czy odpowiedzialności warunkowanej zaistnieniem danych okoliczności. Viikari przypisuje KPM znaczącą rolę w identyfikacji zasady należytej staranności przy jej pracach dotyczących szkód transgranicznych ${ }^{180}$. Wskazuje, że według KPM na zasadę należytej staranności składają się cztery elementy. Po pierwsze, zasada należytej staranności obejmuje zobowiązanie państwa do podjęcia wszelkich odpowiednich

170 Ibid., s. 66.

171 Ibid., odwołując się do katastrofy w Czarnobylu i braku międzynarodowych standardów wymaganego zachowania, dotyczących działań, które spowodowały owo zdarzenie. Brak stosownych ustaleń nie przeszkodził jednak w rozstrzygnięciu sprawy huty w Trail.

172 Ibidem, s. 65.

173 Ibid., odwołując się do orzeczenia w sprawie Alabama, wyroku w sprawie zakładników w Teheranie oraz omówionego powyżej wywodu Pisillo Mazzeschiego.

${ }^{174}$ Ibidem; L. Viikari, op.cit., s. 156.

175 Ibid., s. 67.

176 Ibid., s. 68.

${ }^{177}$ L. Viikari, op.cit., s. 151.

178 Ibidem, s. 155.

${ }^{179}$ Por.: zasada 7 Deklaracji z Rio; M. M. Kenig-Witkowska, Koncepcja..., s. 48-50.

${ }^{180}$ L. Viikari, op.cit., s. 156. 
środków celem zapobiegania albo minimalizowania niebezpieczeństwa znaczącej szkody transgranicznej. Po drugie, wymaga od państwa zaangażowania w międzynarodową współpracę, służącą realizacji owego celu. Wymaga także implementacji treści dokumentów KPM za pomocą środków prawnych, administracyjnych i innych, w tym wprowadzenia stosownych mechanizmów monitorowania. Wreszcie, zasada należytej staranności oznacza konieczność uprzedniej autoryzacji działań, potencjalnie niosących niebezpieczeństwo znaczącej szkody transgranicznej ${ }^{181}$. Podobnie odpowiedzialność państwa za naruszenie zasady należytej stranności postrzegają Kiss i Sheldon ${ }^{182}$. Sonnenfeld wskazuje, iż państwa nie godzą się na uznanie odpowiedzialności za działania prawnie niezakazane $^{183}$. Kenig-Witkowska natomiast zasadnie podnosi, iż przeważa koncepcja obiektywnej odpowiedzialności za szkodę o charakterze transgranicznym, która jest wynikiem zaniedbania lub braku należytej staranności, złamania postanowień umownych albo dopuszczenia się aktu zabronionego przez prawo międzynarodowe ${ }^{184}$. Lehnardt rozciąga ów obowiązek, potwierdzony w prawie środowiska, na inne obszary praktyki międzynarodowej, takie jak prawo dyplomatyczne czy normy gwarantujące międzynarodowe bezpieczeństwo ${ }^{185}$. Rozważania potwierdzające ów wniosek stanowią treść niniejszej rozprawy.

\subsection{Konsekwencje naruszenia zasady należytej staranności}

Pozbawienie reżimu międzynarodowej odpowiedzialności prawnych konsekwencji dla naruszających go podmiotów oznaczałoby zrównanie omawianego

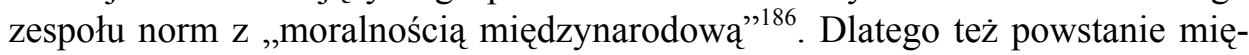
dzynarodowej odpowiedzialności państwa niesie za sobą zwyczajowy obowiązek reparacji powstałych szkód oraz szereg innych konsekwencji, przewidzianych prawem zwyczajowym, jak i w treści traktatów ${ }^{187}$. Jak wskazał STMS W orzeczeniu w sprawie fabryki chorzowskiej fakt naruszenia prawa międzynarodowego niesie za sobą zobowiązanie do usunięcia konsekwencji naruszenia i przywrócenia sytuacji, która istniałaby, gdyby naruszenie nie powstało ${ }^{188}$. Jeśli państwo-sprawca nie dopełni obowiązku kompensacyjnego, poszkodowane

\footnotetext{
${ }^{181}$ Ibidem, 156-157.

${ }^{182}$ Por. A. C. Kiss, D. Shelton, op.cit., s. 92.

${ }^{183}$ R. Sonnenfeld, op.cit., s. 25.

${ }^{184}$ M. M. Kenig-Witkowska, Międzynarodowe..., s. 141-142.

185 Por. C. Lehnard, op.cit., s. 87.

${ }^{186}$ Por. J. Symonides, op.cit., s. 33.

${ }^{187}$ Por.: G. Schwarzenberger, op.cit., s. 533. J. Symonides wskazywał, że naruszenie interesów cudzoziemców przebywających na terytorium państwa niesie za sobą wyłącznie obowiązek naprawienia szkody, podczas gdy naruszeniu przez nie jego zobowiązań międzynarodowych, godzących bezpośrednio $\mathrm{w}$ interesy innych państw, towarzszy także konieczność uiszczenia reparacji lub dopełnienia satysfakcji. J. Symonides, op.cit., s. 34.

${ }^{188}$ Niemcy przeciwko Polsce, STSM, 1928, sprawa fabryki chorzowskiej, P.C.I.J. seria A, nr 17 , s. 47 , s. 204 i 248.
} 
państwo ma prawo szukać sprawiedliwości na drodze sądowej lub z wykorzystaniem innych sposobów pokojowego rozwiązywania sporów międzynarodowych. Jeśli te natomiast nie przyniosą oczekiwanego skutku, może ono odwołać się do znanych prawu międzynarodowemu środków odwetowych, celem wyegzekwowania należnego roszczenia ${ }^{189}$. Reguły te dotyczą także naruszeń obowiązku wykazywania należytej staranności przy realizacji międzynarodowych zobowiązań.

Reżimy traktatowe, opisujące treść pierwotnych zobowiązań prewencyjnych, zawierają nieliczne dyspozycje dotyczące konsekwencji ich naruszenia, choć takie szczegółowe dyspozycje wskazać można w kilku umowach z zakresu międzynarodowego prawa środowiska. Cechą wspólną tej grupy norm jest przeniesienie ciężaru odpowiedzialności z państwa na podmioty prywatne, czerpiące zyski z działalności generującej niebezpieczeństwo szkody. Obowiązek państwa, ograniczony do zapobiegania szkodom i wykonywania kontroli nad sposobem realizacji niebezpiecznych przedsięwzięć, nie znajduje bezpośredniego przełożenia na odpowiedzialność materialną czy prawną państwa autoryzującego tego rodzaju działania, z wyjątkiem potwierdzonej traktatem odpowiedzialności absolutnej za szkody kosmiczne. Projekt artykułów o prewencji z 2001 r. przywołuje pełen wachlarz znanych prawu międzynarodowemu instrumentów pokojowego rozwiązywania sporów jako remedium na rozbieżne interpretacje treści przedmiotowego obowiązku przez państwa ${ }^{190}$, nie zawiera jednak opisu środków odwetowych czy sankcji, stosowanych względem państw dopuszczających się naruszenia tego obowiązku. Prawo międzynarodowe nie przewiduje więc, co do zasady, bezpośredniej odpowiedzialności państwa za skutki szkodliwych działań, realizowanych na ich terytorium. Koniecznym warunkiem takiej odpowiedzialności jest, jak już powiedziano, przypisanie państwu zaniechania, sprzecznego $\mathrm{z}$ treścią międzynarodowego zobowiązania państwa ${ }^{191}$. Traktaty oraz generowany przez nie zwyczaj przewidują odpowiedzialność

${ }^{189}$ G. Schwarzenberger, op.cit., s. 534.

${ }^{190}$ Projekt artykułów o prewencji z 2001 r., art. 19.

${ }^{191}$ Wyjątek od zasady odpowiedzialności na zasadzie ryzyka stanowi odpowiedzialność absolutna za szkody kosmiczne, wynikająca $\mathrm{z}$ ustaleń traktatowych pomiędzy państwami. Por.: cytowany już art. II Konwencji o międzynarodowej odpowiedzialności za szkody wyrządzone przez obiekty kosmiczne, który stanowi, iż państwo wypuszczające obiekt jest bezwzględnie zobowiązane do zapłacenia odszkodowania za szkodę, którą wypuszczony przez nie obiekt kosmiczny wyrządził na powierzchni Ziemi lub statkowi powietrznemu podczas lotu. Zob. też: M. Fitzmaurice, International protection of the environment, RdC, Haga 2002, s, 233; gdzie odpowiedzialność opisana w art. II opisana została jako „absolutna” (ang. absolute). Drugim przykładem odpowiedzialności absolutnej w prawie międzynarodowym jest także wspomniany już Układ o zasadach działalności państw w zakresie badań i użytkowania przestrzeni kosmicznej łącznie z Księżycem i innymi ciałami niebieskimi z 1967 r. Fitzmaurice wskazuje, iż zapisom traktatów nie towarzyszy świadcząca o ich skuteczności praktyka państw, uniemożliwiająca, jak się zdaje, uznanie owych norm za normy zwyczajowe. Jej zdaniem ogólną zasadą prawa międzynarodowego jest odpowiedzialność za czyn niezakazany prawem międzynarodowym, wynikająca „,z deliktu” i braku spełnienia „wymogu należytej staranności”. Ibidem. 
państwa według norm wtórnych za niedołożenie należytej staranności przy zapobieganiu czy kontrolowaniu działań potencjalnie szkodliwych, realizowanych na jego terytorium przez podmioty prywatne. Ów obowiązek prewencji wykonywany być powinien, jak już wspomniano, poprzez wprowadzenie i wykonywanie odpowiednich przepisów prawa wewnętrznego i towarzyszących im procedur technologicznych ${ }^{192}$.

Pociągnięcie do odpowiedzialność państwa, z terytorium którego generowana jest transgraniczna szkoda za niezgodne $\mathrm{z}$ prawem międzynarodowym zaniechanie na podstawie norm wtórnych zostało zapisane w treści Projektu zasad alokacji z 2006 r. Obok pierwotnego zobowiązania kompensacji powstałych szkód, zawiera on bezpośrednie odniesienie do wtórnych zasad odpowiedzialności międzynarodowej państw ${ }^{193}$. W myśl postanowień tego dokumentu miękkiego prawa międzynarodowego, jeśli brak należytej staranności państwa wskazać można jako sprzeczny z pierwotnym obowiązkiem prewencji, opisanym w treści traktatów, państwo takie może zostać pociagnięte do międzynarodowej odpowiedzialności, zgodnie z Projektem artykułów o odpowiedzialności państwa z 2001 r.

Zgodnie z treścią art. 30 tego projektu, w przypadku naruszenia pierwotnego zobowiązania państwa do dołożenia należytej staranności w wykonywaniu kontroli nad potencjalnie szkodliwą aktywnością, podstawowym roszczeniem poszkodowanego państwa jest żądanie jej zaniechania i powstrzymania się od dalszych naruszeń. Zobowiązanie to stosowane wobec bezprawnych zaniechań oznaczać będzie żądanie od państwa zainicjowania i przeprowadzenia wszelkich niezbędnych środków zaradczych, opisanych w treści poszczególnych reżimów traktatowych. Jeśli szkodliwa aktywność wciąż trwa, państwo pochodzenia zobowiązane będzie spowodować jej zaprzestanie oraz, stosownie do okoliczności, zapewnić, że naruszenia takie nie będą występowały w przyszłości ${ }^{194}$. Stan naruszenia zobowiązania nie może przesądzać o jego wygaśnięciu ${ }^{195}$. Wątpliwości budzi możliwość egzekwowania owego roszczenia, gdy potencjalnie szkodliwa działalność nie wywoła jeszcze szkód. Nie było bowiem zamierzeniem Komisji połączenie samego naruszenia norm prewencji z odpowiedzialnością państw, choć nie wykluczała takiej możliwości ${ }^{196}$. Ciekawą propozycję poszerzenia kręgu państw poszkodowanych przedstawił Dupuy, sugerując, iż w przypadku

${ }^{192}$ J. Ciechanowicz-McLean pisze o „wolunatryzmie” państw przy realizacji zobowiązań międzynarodowego prawa środowiska, wskazując na kryzys tej gałęzi prawa, objawiający się niskim stopniem skuteczności obszernych traktatów i bogatego dorobku zwyczajowego. Por. J. Ciechanowicz-McLean, Tendencje rozwoju międzynarodowego prawa środowiska. Bezpieczeństwo ekologiczne czy terroryzm ekologiczny, (w:) Prawo międzynarodowe-problemy i wyzwania. Księga Pamiatkowa Profesor Renaty Sonnenfeld-Tomporek, red. J. Menkes, Warszawa 2006, s. 118.

${ }^{193}$ Projekt zasad alokacji z 2006 r., uwagi wstępne, s. 111.

${ }^{194}$ Projekt artykułów o odpowiedzialności państw z 2001 r., art. 30.

${ }^{195}$ Por. Projekt artykułów o odpowiedzialności państw z 2001 r., art. 29. Jak wskazuje W. Czapliński, jest to rozwiązanie wywodzone z aktualnej praktyki międzynarodowej państw, por. W. Czapliński, Kodyfikacja ..., s. 41.

${ }^{196}$ Por. Por. A. E. Boyle, State Responsibility..., s. 3-4. 
czynów szkodliwych dla „podstawowych interesów społeczności międzynarodowej” wszystkim państwom, będącym jej członkami, przysługują roszczenia reparacyjne ${ }^{197}$.

Jeśli naruszenie obowiązku dołożenia należytej staranności przyniesie szkodę, państwo pochodzenia zobligowane będzie do dopełnienia obowiązku reparacji. Kenig-Witkowska wskazuje, że roszczenie reparacyjne niekiedy uważane jest za zobowiązanie wynikające z zasad odpowiedzialności cywilnej ${ }^{198}$. Formą reparacji jest restytucja, czyli przywrócenie stanu sprzed powstania uszczerb$\mathrm{ku}^{199}$. Jeśli restytucja okaże się niemożliwa, co np. w przypadku szkody w środowisku naturalnym jest wysoce prawdopodobne, na państwie pochodzenia ciążył będzie obowiązek odszkodowania, tj. pokrycia kosztów poniesionych przez państwo poszkodowane w związku z powstałą szkodą ${ }^{200}$. Roszczenie takie obejmuje zarówno koszty wynikłe bezpośrednio z powstania szkody, niepodlegające restytucji, jak i wartość utraconych przyszłych korzyści, spowodowanych powstaniem szkody ${ }^{201}$. Każdej z tych dwóch form reparacji towarzyszyć może satysfakcja, a więc przeprosiny za powstałą w wyniku naruszenia szkodę niematerialną. Może ona mieć postać przyznania dokonania naruszenia, wyrażenia żalu, przeprosin albo inną, ustaloną przez strony właściwą formę $e^{202}$.

Jeśli państwa pozostają w sporze co do samego wystapienia naruszenia prawa albo do jego charakteru i zakresu, a pokojowe sposoby rozstrzygania sporów międzynarodowych nie przyniosą rezultatu, prawo międzynarodowe przewiduje możliwość stosowania środków odwetowych celem zmuszenia państwa-sprawcy do przestrzegania jego międzynarodowych zobowiązań. Projekt artykułów o odpowiedzialności państw z $2001 \mathrm{r}$. w art. 49 zawiera opis przedmiotu i granic stosowania środków odwetowych, pozostających w dyspozycji państwa poszko-

197 Odwołuje się tym samym do kontrowersyjnego i odrzuconego przez Komisję pojęcia „zbrodni międzynarodowych”. Por.: P. Dupuy, The International Law..., s. 119.

${ }^{198}$ Por.: M. M. Kenig-Witkowska, Międzynarodowe..., s. 140, choć o trudnościach ze stosowaniem dogmatyki prawa cywilnego do prawa odpowiedzialności międzynarodowej wspomniano już w uwagach wstępnych do niniejszej rozprawy.

${ }^{199}$ Projekt artykułów o odpowiedzialności państw z 2001 r., art. 35, gdzie uszczerbek (ang. injury) obejmuje wszelkie szkody (ang. damage), materialne i moralne, spowodowane aktem międzynarodowo bezprawnym, przypisywalnym państwu. Ale por. K. Wolfke, op.cit., s. 50, który, przywołując sprawę tankowca Torrey Canyon rozważa możliwość użycia zbrojnej ,agresji środowiskowej" w samoobronie przed grożącą katastrofą ekologiczną, wywołaną działaniami realizowanymi w obcej jurysdykcji.

${ }^{200}$ Projekt artykułów o odpowiedzialności państw z 2001 r., art. 31.

${ }^{201}$ Projekt artykułów o odpowiedzialności państw z 2001 r., art. 36. Reparacje mogą przyjąć postać kompensacji, pokrywającej wszelkie szkody, których rozmiar można oszacować w pieniądzu (w tym utracone korzyści). Reparacje stosowane winny być wówczas, gdy niemożliwa jest restytucja. Obszernie o obowiązku odszkodowawczym w prawie międzynarodowym: J. Ciechanowicz, Zasady ustalania odszkodowania w prawie międzynarodowym publicznym, Gdańsk 1989. Por. zwłaszcza s. 124-140, gdzie autorka pisze o metodach szacowania wysokości odszkodowania. Zob. także: Czwarty raport Ago, U.N. Doc. A/CN.4/264, s 109, gdzie Specjalny Sprawozdawca opisuje stanowiska państw w kwestii sposobów obliczania odszkodowania.

${ }^{202}$ Projekt artykułów o odpowiedzialności państw z 2001 r., art. 37. 
dowanego. Środki te mogą być przedsiębrane jedynie celem zobligowania państwa-sprawcy do respektowania jego międzynarodowych zobowiązań ${ }^{203}$ i muszą mieć pokojowy charakter ${ }^{204}$. Środki odwetowe stosowane zgodnie z prawem nie będą uznane za akt międzynarodowo bezprawny ${ }^{205}$ pomimo faktu, iż ze swojej natury są niezgodne z zasada pacta sunt servanda ${ }^{206}$. Choć prawo międzynarodowe nie zawiera definicji „środków odwetowych”, a sam termin nie był powszechnie używany do lat 70 . minionego wieku ${ }^{207}$, treść tego pojęcia, jak wiele innych $\mathrm{w}$ prawie międzynarodowym, określić można poprzez odwołanie do zbioru utrwalonych praktyk ${ }^{208}$. Alland definiuje je jako ,pokojowe reakcje jednostronne" (ang. pacific unilateral reactions), ze swej natury bezprawne, przyjmowane i stosowane przez jedno państwo względem innego, o ile to ostatnie dopuściło się naruszenia prawa międzynarodowego, uzasadniającego taką reakcję $^{209}$. KPM podkreśla istnienie wyraźnej różnicy pomiędzy „środkami odwetowymi” a „sankcjami”, opisując te ostatnie jako „środki przedsiębrane zgodnie z (...) Rozdziałem VII KNZ”,210, podczas gdy „środki odwetowe” lokuje w kategoriach prawa do samopomocy (ang. self-protection, self-help) ${ }^{211}$. Komisja odżegnuje się od użycia terminu „represalia” jako synonimu „środków odwetowych", wskazując, iż termin ten wiąże się ściśle z prawem wojny i konfliktów zbrojnych $^{212}$. Shaw odróżnia środki odwetowe od retorsji, które to stanowią zgodne z prawem międzynarodowym, choć niepożądane reakcje na działania innego państwa ${ }^{213}$.

Środki odwetowe definiować należy poprzez określenie zakresu ich stosowania, zważywszy na fakt, że zakres ten ograniczony jest do sytuacji wyjątkowych. Mogą one więc być stosowane jedynie wówczas, gdy są konieczne, tzn. gdy zamierzony cel nie może zostać osiagnięty przy wykorzystaniu innych metod. Nie mogą one mieć funkcji penalnej, tj. stanowić kary dla państwa-sprawcy, a ich stosowania należy zaprzestać niezwłocznie po tym, kiedy uda się osiagnąć

203 Stosowanie środków odwetowych powinno umożliwić przywrócenie wykonywania naruszonego zobowiązania. Por.: Projekt artykułów o odpowiedzialności państw z 2001 r., art. 37 . Zob. także W. Czapliński, Odpowiedzialność za ..., s 83.

${ }^{204}$ D. Alland, The Definition of Countermeasures, (w:) The Law of International Responsibility, red. J. Crawford, A. Pellet, S. Olleson, K. Parlett, Oksford 2010, s. 1130.

${ }^{205}$ Projekt artykułów o odpowiedzialności państw z 2001 r., art. 22.

${ }^{206}$ O ryzyku dotyczącym i konterowersjach wokół stosowania środków odwetowych por: A. Aust, op. cit., s. 390.

${ }^{207}$ Por.: D. Alland, op.cit., s. 1126.

${ }^{208}$ Ibidem, s. 1126. Por.: cytowane prace przedstawicieli doktryny, utożsamiających środki odwetowe wyłącznie z refleksem prawa do samoobrony.

${ }^{209}$ Ibid., s. 1135.

${ }^{210}$ Pomimo, iż w Karcie użyto terminu „środki” (ang. measures), nie „sankcje”; por.: Projekt artykułów o odpowiedzialności państw z 2001 r., komentarz do art. 22, s. 75.

${ }^{211}$ Por.: Projekt artykułów o odpowiedzialności państw z 2001 r., komentarz do art. 22, s. 75.

${ }^{212}$ Por.: Projekt artykułów o odpowiedzialności państw z 2001 r., komentarz do art. 22, s. 75: „belligerent reprisals involving the use of force”; zob. także: A. Aust, op.cit., s. 391; M. N. Shaw, Prawo międzynarodowe..., s. 1129-1130.

${ }^{213}$ M.N. Shaw, Prawo międzynarodowe..., s. 1128-9; A. Aust, op.cit., s. 391. 
pożądany skutek, tj. gdy państwo-sprawca zaniecha naruszeń lub doprowadzi do usunięcia stanu niezgodnego $\mathrm{z}$ treścią jego międzynarodowych zobowiązań. Państwo poszkodowane może swobodnie wybrać sposób, w jaki chce poinformować państwo pochodzenia szkody o niezadowoleniu z działań czy skutków zaniechań tego ostatniego, bowiem środki odwetowe nie są ograniczone zasadą wzajemności (ang. not in-kind) ${ }^{214}$, choć można zidentyfikować katalog zachowań, które nigdy nie mogą być realizowane jako środki odwetowe ${ }^{215}$. Ich stosowanie, jako instytucji wyjątkowej dla prawa międzynarodowego, ograniczone jest poprzez szereg przesłanek formalnych, dotyczących zarówno procedur przed przedsięwzięciem tych środków, jak i stosowanych w trakcie ich realizacji ${ }^{216}$. Podstawowym warunkiem stosowania środków odwetowych jest konieczność uwzględniania zasady proporcjonalności, wynikającej z norm międzynarodowego prawa zwyczajowego ${ }^{217}$. Norma ta została przełożona na język Projektu artykułów o odpowiedzialności państw z 2001 r. W treści art. 51 KPM wskazuje, że proporcjonalność w stosowaniu środków odwetowych oznacza, że środki te muszą być „proporcjonalne do powstałego uszczerbku”, uwzględniać „wagę czynu międzynarodowo bezprawnego" do którego się odnoszą oraz interesów państwa poszkodowanego ${ }^{218}$. Jeśli ten warunek nie zostanie spełniony, środki odwetowe uznać należy za nielegalne, zaś państwo je stosujące uznane zostać powinno za naruszające prawo międzynarodowe ${ }^{219}$. Ocena proporcjonalności przeprowadzana jest z uwzględnieniem wielu czynników, spośród których najważniejsze to: rozmiar powstałej szkody materialnej, powstanie szkód moralnych, powaga zarzucanego czynu niezgodnego $\mathrm{z}$ prawem, $\mathrm{z}$ uwzględnieniem charakteru samego naruszenia, w tym braku należytej staranności w postaci niedbalstwa $^{220}$. Specjalny Sprawozdawca Arangio-Ruiz opisuje proporcjonalność jako zbiór nie tylko ,ilościowych” elementów zaistniałej szkody, ale także czynników ,jakościowych”, takich jak wartość naruszonych interesów państwa czy samego naruszenia ${ }^{221}$. Te czynniki okazały się wystarczające dla ustalenia treści

${ }^{214}$ A. Aust, op.cit., s. 392.

${ }^{215}$ Projekt artykułów o odpowiedzialności państw z 2001 r., art. 50. Środki odwetowe nie mogą wpływać na realizację zakazu użycia siły, zgodnie z zapisami KNZ, obowiązku ochrony podstawowych praw człowieka, ograniczeń prawa humanitarnego, dotyczących stosowania represaliów, jak i innych norm peremptoryjnych, znanych prawu międzynarodowemu. Co więcej, państwo stosujące środki odwetowe zobowiązane jest dopełnić wszelkich ciążących na nim obowiązków, związanych z trwającą procedurą pokojowego rozwiązywania sporów oraz szanować nietykalność misji i personelu dyplomatycznego i konsularnego.

${ }^{216}$ Projekt artykułów o odpowiedzialności państw z 2001 r., art. 52-53, zob. także: A. Aust, op.cit., s. 392-393.

${ }^{217}$ R. O'Keefe, Proportionality, (w:) The Law of International Responsibility, red. J. Crawford, A. Pellet, S. Olleson, K. Parlett, s. 1157.

${ }_{218}^{218}$ Projekt artykułów o odpowiedzialności państw z 2001 r., art. 51.

${ }^{219}$ A. Aust, op.cit., s. 392.

${ }^{220}$ R. O'Keefe, op.cit., s. 1160-61.

${ }^{221}$ Czwarty raport Specjalnego Sprawozdawcy G. Arangio-Ruiza, KPM, 1992 r., U.N. Doc. A/CN.4/444, s. 23. Zob. także: R. O’Keefe, op.cit., s. 1161. 
zasady proporcjonalności $\mathrm{w}$ wielu sprawach dotyczących powstania szkody transgranicznej $\mathrm{w}$ środowisku naturalnym ${ }^{222}$. Jak wynika $\mathrm{z}$ interpretacji Specjalnego Sprawozdawcy, dopuścić należy możliwość stosowania środków odwetowych także w sytuacji, gdy naruszenie zobowiązania międzynarodowego powoduje jedynie zagrożenie dla interesów państwa ofiary, niezależnie od powstania szkody. Naruszenie zasady należytej staranności skutkujące powstaniem szkody, przypisywalne państwu, pod nieobecność przesłanek egzoneracyjnych, pociaga za sobą możliwość aplikacji roszczeń odszkodowawczych, na zasadach znanych prawu międzynarodowemu. Przy ich stosowaniu uwzględniana musi być zasada proporcjonalności.

${ }^{222}$ R. O'Keefe, op.cit., s. 1161. 


\section{Podsumowanie}

Zasada należytej staranności opisana została przez KPM szczegółowo w treści dokumentów, raportów i projektów poświęconych odpowiedzialności międzynarodowej za działania niezakazane prawem międzynarodowym. Z całokształtu owych prac wyłania się dziewięć elementów owej zasady, która uznana może być za ogólną zasadę prawa, ściśle powiązaną z zasadami: odpowiedzialności państwa, dobrej wiary i dobrosąsiedztwa.

Po pierwsze zasada należytej staranności wymaga od państwa działania w dobrej wierze przy realizacji jego międzynarodowych zobowiązań, przede wszystkim tych, które obejmują obowiązek prewencji, tj. obowiązek zapobiegania znaczącym szkodom transgranicznym. Po drugie, obowiązek ten jest emanacją zasady dobrosąsiedztwa, która wymaga od państw powstrzymania się od wyrządzania szkód na terytorium lub w interesach innych państw oraz na obszarach wspólnych. Ocena realizacji owego obowiązku dokonana może być jedynie w oparciu o weryfikację poziomu staranności, wykazanego przez organy państwa przy zapobieganiu transgranicznym szkodom. Po trzecie, ocena realizacji zasady należytej staranności dokonywana winna być terytorialnie, ale także z uwzględnieniem aktywności realizowanych w jurysdykcji lub po kontrolą państwa. Po czwarte, wskazówką interpretacyjną dla zasady należytej staranności jest zasada ciagłego rozwoju, bowiem, tak jak ona, należyta staranność powinna stanowić kryterium wszelkich planowanych i przedsiębranych działań organów państwowych. Po piąte, dla wykazania należytej staranności państwa zobligowane są przedsięwziąć „wszelkie niezbędne środki”, znaczenie którego to pojęcia weryfikowane jest względem okoliczności faktycznych. Zawsze jednak oznacza ono konieczność wprowadzenia stosownych procedur administracyjnych lub innych, których celem będzie np. realizacja obowiązku autoryzacji działań niebezpiecznych, realizowanych na terytorium, w jurysdykcji lub pod kontrolą państwa. Przepisy materialne i proceduralne egzekwowane być powinny w sposób, którego wymagać można od „dobrego rządu”. Po szóste, treść zasady należytej staranności $\mathrm{w}$ danych okolicznościach identyfikować należy z uwzględnieniem aktualnego stanu techniki. Powinny to być środki, których stosowanie jest uzasadnione aktualnym stanem wiedzy technicznej, aplikowane przez inne państwa na świecie lub $\mathrm{w}$ regionie w podobnych okolicznościach, jednak pozostające $w$ granicach technicznych, ekonomicznych i społecznych możliwości danego państwa. Tym samym ich zakres weryfikowany winien być także względem poziomu ekonomicznego i technologicznego państwa, którego 
obowiązek dotyczy oraz skali potencjalnych szkód, wywoływanych niebezpiecznym działaniem. Po siódme więc, obowiązek wykazywania należytej staranności spełniony może być jedynie wtedy, gdy państwa wymieniają informacje o aktualnym stanie techniki, a więc zasada należytej staranności implikuje obowiązek wymiany informacji, w tym podejmowania konsultacji z państwami potencjalnie zagrożonymi znaczącą szkodą transgraniczną. Po ósme, przy realizacji zasady należytej staranności państwa zobowiązane są powstrzymać się od jakiejkolwiek dyskryminacji, zarówno przy udzielaniu pomocy potencjalnie lub faktycznie poszkodowanym, jak i innym podmiotom prywatnym, prowadzącym działalność niebezpieczną. Po dziewiąte wreszcie, zaznaczyć należy, iż wszystkie wskazane powyżej obowiązki szczegółowe mają charakter ciągły. Obowiązek wykazywania należytej staranności nie jest spełniony przez jednorazowe działanie organów państwa, wymaga od nich ciagłego weryfikowania istnienia niebezpieczeństwa znaczących transgranicznych szkód, w tym aktywnego poszukiwania wiedzy o jego źródłach.

W obecnym stanie nauki prawa międzynarodowego uznać należy, że obowiązek dokładania należytej staranności przy realizacji zobowiązań międzynarodowych nie dotyczy tzw. prewencji post factum, tj. środków podejmowanych po powstaniu szkody. Nie ma także zgody co do odpowiedzialności zastępczej państwa, opartej na zasadzie ryzyka, chyba że odpowiedzialność taka zostanie przyjęta przez państwo $\mathrm{w}$ treści szczegółowego zobowiązania.

Nie ma wątpliwości, że powstanie szkody niesie za sobą obowiązek odszkodowania. Obowiązek ten spoczywał będzie na państwie, jeśli jego organy nie wykazały staranności, wymaganej w danych okolicznościach faktycznych, czy inaczej: zaniechały działania, do którego państwo zobligowane było mocą wiążącego je zobowiązania międzynarodowego. W oparciu o teorię obiektywnego przypisania uznać należy, iż państwo ponosi odpowiedzialność za naruszenie zobowiązania międzynarodowego, w treści którego zawarty został, bepośrednio lub pośrednio, obowiązek prewencji, jeśli można wykazać związek przyczynowo-skutkowy pomiędzy zaniechaniem jego organów a powstaniem szkody. Dyskusyjne jest, czy samo niedopełnienie obowiązku starannego działania, opisanego $\mathrm{w}$ treści normy prewencyjnej, ale nieskutkujące powstaniem znaczącej szkody transgranicznej, uznane być może za naruszenie normy międzynarodowo prawnej, prowadzące do odpowiedzialności państwa. O ile przedstawiciele doktryny skłonni są przychylić się do takiej interpretacji, o tyle nie ma na nią zgody wśród państw. Nie ma natomiast wątpliwości, iż zasada należytej stranności przywołana może być jedynie względem realizacji zobowiązań ciagłych, tj. zobowiązań do określonego działania, nie będzie natomiast pomocna przy ocenie zobowiązań skutkowych. Ocena naruszenia normy konstytuującej obowiązek ciagły dokonywana będzie z uwzględnieniem standardu należytej staranności, który stanowi treść wszelkich zobowiązań o charakterze prewencyjnym. Kształt owego standardu zapisany został $\mathrm{w}$ treści zasady należytej staranności, która 
nakłada na państwa obowiązek starannego działania przy realizacji ich międzynarodowych zobowiązań o charakterze ciągłym. Zasada należytej staranności oznacza obowiązek podjęcia wszelkich działań, które podjęłyby odpowiedzialne władze państwa w normalnych okolicznościach towarzyszących danej sytuacji, wykorzystując najlepsze dostępne im środki celem realizacji ciążących na państwie międzynarodowych zobowiązań ${ }^{1}$.

\footnotetext{
${ }^{1}$ Por. X. Hanquin, Transboundary..., s. 163.
} 



\section{Bibliografia}

\section{Akty prawa krajowego}

Narodowy Program Ochrony Infrastruktury Krytycznej, Dz. U. 2010, nr 135, poz. 906.

Rozporządzenie Prezesa Rady Ministrów z dnia 14 lipca 2010 r. w sprawie pełnomocnika do spraw ochrony infrastruktury krytycznej Dz. U. 2010, nr 83, poz. 542.

Rozporządzenie Rady Ministrów z dnia 30 kwietnia 2010 r. w sprawie planów ochrony infrastruktury krytycznej, Dz. U. 2010, nr 83, poz. 541.

Ustawa o udostępnianiu informacji o środowisku i jego ochronie, udziale społeczeństwa w ochronie środowiska oraz o ocenach oddziaływania na środowisko, Dz. U. 2008, nr 199, poz. 1227.

Ustawa z dnia 26 kwietnia 2007 r. o zarządzaniu kryzysowym, Dz. U. 2007, nr 89, poz. 590.

\section{Umowy międzynarodowe i inne źródła prawa międzynarodowego}

Dyrektywa 2011/92/UE w sprawie oceny skutków wywieranych przez niektóre przedsięwzięcia publiczne i prywatne na środowisko naturalne, Dz. U. L z 28 stycznia 2012 r., s. 1.

Europejska konwencja o zwalczaniu terroryzmu, sporządzona w Strasburgu dnia 27 stycznia 1977 r., Dz. U. 1996, nr 117, poz. 557.

Karta Narodów Zjednoczonych, Statut Międzynarodowego Trybunału Sprawiedliwości i Porozumienie ustanawiające Komisję Przygotowawczą Narodów Zjednoczonych, Dz. U. 1947, nr 23, poz. 90.

Konwencja genewska w sprawie transgranicznego zanieczyszczania powietrza na dalekie odległości dotyczącego kontroli emisji tlenków azotu oraz ich przepływu o charakterze transgranicznym z 1979 r., Dz. U. 1985, nr 60, poz. 311.

Konwencja o międzynarodowej odpowiedzialności za szkody wyrządzone przez obiekty kosmiczne, sporządzona w Moskwie, Londynie i Waszyngtonie dnia 29 marca 1972 r., Dz. U. 1973, nr 27, poz. 154 .

Konwencja o misjach specjalnych, otwarta do podpisu w Nowym Jorku dnia 16 grudnia 1969 r., Dz. U. 1985, nr 48, poz. 245.

Konwencja o ocenach oddziaływania na środowisko w kontekście transgranicznym, sporządzona w Espoo dnia 25 lutego 1991 r., Dz. U. 1999, nr 96, poz. 1110.

Konwencja o ochronie i użytkowaniu cieków transgranicznych i jezior międzynarodowych z 1992 r., Dz. U. 2003, nr 78, poz. 703.

Konwencja o ochronie Renu przed zanieczyszczeniami chemicznymi (reńska konwencja chemiczna), 1977 r., 16 ILM (1977) 242.

Konwencja o ochronie środowiska morskiego i regionu przybrzeżnego Morza Śródziemnego (konwencja barcelońska), sporządzona w Barcelonie w 1976 r., 15 ILM (1976) 290.

Konwencja o ochronie środowiska morskiego obszaru Morza Bałtyckiego, sporządzona w Helsinkach dnia 9 kwietnia 1992 r., Dz. U. 2000, nr 28, poz. 346.

Konwencja o ochronie środowiska morskiego obszaru północno-wschodniego Atlantyku, Dz. U. Unii Europejskiej C 285 E/24 listopada 2009 r., s. 122.

Konwencja o ochronie warstwy ozonowej, sporządzona w Wiedniu dnia 22 marca 1985 r., Dz. U. 1992, nr 98, poz. 488.

Konwencja o odpowiedzialności cywilnej za szkody olejowe, 1976, 16 ILM (1977) 1451.

Konwencja o odpowiedzialności cywilnej za szkody spowodowane zanieczyszczeniami olejami z 1969 r., 9 ILM (1970) 45. 
Konwencja o odpowiedzialności cywilnej za szkody wyrządzone podczas przewozu towarów niebezpiecznych transportem drogowym, kolejowym lub żeglugą śródlądową, 1989, United Nations Economic Commission for Europe Doc. ECE/TRANS/84.

Konwencja o różnorodności biologicznej z 1992 r., Dz. U. 2002, nr 184, poz. 1532.

Konwencja o zapobieganiu przestępstwom i karaniu sprawców przestępstw przeciwko osobom korzystającym z ochrony międzynarodowej, w tym przeciwko dyplomatom, sporządzona w Nowym Jorku dnia 14 grudnia 1973 r., Dz. U. 1983, nr 37, poz. 168.

Konwencja ONZ w sprawie zapobiegania i karania zbrodni ludobójstwa z dnia 9 grudnia 1948 r. Dz.U. 1950, nr 36, poz. 325.

Konwencja Rady Europy z 21 czerwca 1993 r. o odpowiedzialności za szkody wynikające z działalności niebezpiecznej dla środowiska. ETS nr 150.

Konwencja w sprawie transgranicznego zanieczyszczania powietrza na dalekie odległości sporządzona w Genewie dnia 13 listopada 1979 r., Dz. U. 1985, nr 60, poz. 311.

Konwencja wiedeńska o ochronie warstwy ozonowej z 1985 r., Dz. U. 1992, nr 98, poz. 488.

Konwencja wiedeńska o odpowiedzialności cywilnej za szkody jądrowe, UNTS 1063, nr 16197, s. $265 \mathrm{i} \mathrm{n.}$

Konwencja wiedeńska o stosunkach dyplomatycznych z 18 kwietnia 1961 r., Dz. U. 1965, nr 37, poz. 233.

Konwencja wiedeńskiej o prawie traktatów z 23 maja 1969 r., Dz. U. 1990, nr 74, poz. 439.

Konwencja wiedeńskiej o stosunkach konsularnych z 24 kwietnia 1963 r., Dz. U. 1982, nr 13, poz. 98.

Międzynarodowa konwencja o utworzeniu międzynarodowego funduszu odszkodowań za szkody spowodowane zanieczyszczeniami olejami z 1971 r., 11 ILM 284 (1972).

Międzynarodowa Konwencja o zapobieganiu zanieczyszczaniu morza przez statki sporządzona w Londynie dnia 2 listopada 1973 r., Dz. U. 1987, nr 17, poz. 101.

Międzynarodowa konwencja z 1996 r. w sprawie odpowiedzialności i rekompensaty za szkody związane z przewozem morzem substancji niebezpiecznych i szkodliwych [online]. Konwencja HNS [dostęp: 2013-01-20]. Dostępny w Internecie: <http://www.hnsconvention.org/ Pages/TheConvention.aspx>.

Międzynarodowy Pakt Praw Ekonomicznych, Społecznych i Kulturalnych, Dz. U. 1977, nr 38, poz. 169 , zał.

Międzynarodowy Pakt Praw Gospodarczych, Społecznych i Kulturalnych otwarty do podpisu w Nowym Jorku dnia 19 grudnia 1966 r., Dz. U. 1977, nr 38, poz. 169.

Poprawki do Protokołu Montrealskiego w sprawie substancji zubożających warstwę ozonową, sporządzone w Londynie dnia 29 czerwca 1990 r., sporządzone w Kopenhadze dnia 25 listopada 1992 r., Dz. U. 2001, nr 44, poz. 491 i 492.

Porozumienie berneńskie o ochronie Renu (niem. Übereinkommen zum Schutz des Rheins) z 12 kwietnia 1999 r. [online]. IKSR [dostęp: 2013-01-20]. Dostępny w Internecie: <http:// www.iksr.org/index.php?id=33>.

Protokół montrealski do Konwencji wiedeńskiej o ochronie warstwy ozonowej w sprawie substancji zubożających warstwę ozonową z 1987 r., Dz. U. 1992, nr 98, poz. 490.

Protokół z Kyoto z 1998 r., Dz. U. 2002, nr 144, poz. 1207.

Ramowa Konwencja Narodów Zjednoczonych w sprawie zmian klimatu z 1992 r., Dz. U. 1996, nr 53, poz. 238.

Statut Stałego Trybunału Sprawiedliwości Międzynarodowej, Dz. U. 1923, nr 106, poz. 839.

The National Security Strategy of the United States if America, Waszyngton 2002 r. [online]. US [dostęp: 2013-01-20]. Dostępny w Internecie: <http://www.state.gov/documents/organization/ 63562.pdf $>$.

Układ o zasadach działalności państw w zakresie badań i użytkowania przestrzeni kosmicznej łącznie z Księżycem i innymi ciałami niebieskimi, 1967 r., Dz. U. 1968, nr 14, poz. 82.

Umowa w sprawie Międzynarodowej Komisji ds. Ochrony Renu przed zanieczyszczeniem (konwencja berneńska), 1963 r. 994 UNTS 3. 


\section{Raporty Komisji Prawa Międzynarodowego i inne dokumenty miękkiego prawa międzynarodowego}

Czwarty raport Specjalnego Sprawozdawcy J. Barbozy, U.N. Doc. A/CN.4/413.

Czwarty raport Specjalnego Sprawozdawcy R. Ago, U.N. Doc. A/CN.4/264, tom II.

Czwarty raport Specjalnego Sprawozdawcy R. Quentina-Baxtera, U.N. Doc. A/CN.4/373 [online]. Hoover Institution [dostęp: 2013-04-05]. Dostępny w Internecie: <http://media.hoover.org/ sites/default/files/documents/0817999825_249.pdf>.

Draft International Convention To Enhance Protection from Cyber Crime and Terrorism [online]. [dostęp: 2013-01-20]. Deklaracja Konferencji Narodów Zjednoczonych w sprawie Naturalnego Środowiska Człowieka, podpisana w Sztokholmie w 1972 r., U.N. Doc. A/CONF.48/14/Rev. 1.

Drugi raport Specjalnego Sprawozdawcy F.V. Garcíi-Amadora, U.N. Doc. A/CN.4/106.

Drugi raport Specjalnego Sprawozdawcy J. Barbozy, U.N. Doc. A/CN.4/402.

Drugi raport Specjalnego Sprawozdawcy J. Crawforda, U.N. Doc. A/CN.4/498.

Drugi raport Specjalnego Sprawozdawcy P. S. Rao, U.N. Doc. A/CN.4/501.

Drugi raport Specjalnego Sprawozdawcy R. Ago, U.N. Doc. A/CN.4/233.

Drugi raport Specjalnego Sprawozdawcy W. Riphagena, U.N. Doc. A/CN.4/344.

Dwunasty Raport Specjalnego Sprawozdawcy J. Barbozy, U.N. Doc. A/CN.4/475.

Globalna Strategia Zwalczania Terroryzmu (UN Global Strategy to Combat Terrorism; GCTS), U.N. Doc. A/RES/60/288.

Helsinki Rules on the Use of the Waters and International Rivers, 1967 r., International Law Association, Report of the Committee on the Uses of the Waters of International Rivers [online]. UNESCO [dostęp: 2013-01-20]. Dostępny w Internecie: <http://webworld.unesco.org/water/ wwap/pccp/cd/pdf/educational_tools/course_modules/reference_documents/internationalregio nconventions/helsinkirules.pdf $>$.

Instytut Prawa Międzynarodowego, Responsibility and liability under international law for environmental damage, Strasbourg 1997 [online]. ILL [dostęp: 2013-04-05]. Dostępny w Internecie; $<$ http://www.idi-iil.org/idiE/resolutionsE/1997_str_03_en.PDF>.

International and multi-stakeholder co-operation on cross-border Internet, Interim report of the Ad-hoc Advisory Group on Cross-border Internet to the Steering Committee on the Media and New Communication Services incorporating analysis of proposals for international and multi-stakeholder co-operation on cross-border Internet, H/Inf (2010) 10 [online]. COE [dostęp: 2013-01-20]. Dostępny w Internecie: <http://www.coe.int/t/dghl/standardsetting/media/mc-s-ci/ Interim\%20Report.pdf $>$.

Odpowiedzialność organizacji międzynarodowych, Projekt artykułów, U.N. Doc. A/CN.4/L.778.

Opinia doradcza MTS w sprawie legalności użycia broni nuklearnej, ICJ Reports 1996, nr 1, s. 226-242.

Ósmy raport Specjalnego Sprawozdawcy R. Ago, U.N. Doc. A/CN.4/318.

Piąty raport Specjalnego Sprawozdawcy F.V. Garcíi-Amadora, U.N. Doc. A/CN.4/125, tom II.

Pierwszy raport Specjalnego Sprawozdawcy F.V. Garcíi-Amadora, U.N. Doc. A/CN.4/96, zał. 2.

Pierwszy Raport Specjalnego Sprawozdawcy J. Crawforda, U.N. Doc. A/CN.4/490.

Pierwszy raport Specjalnego Sprawozdawcy P. S. Rao, U.N. Doc. A/CN.4/487.

Pierwszy raport Specjalnego Sprawozdawcy R. Ago, U.N. Doc. A/CN.4/217.

Podsumowanie obrad pierwszej sesji ONZ, U.N. Doc. A/CN.4/Ser.A/194.

Projekt artykułów o prawie nieżeglownego wykorzystania międzynarodowych cieków wodnych, KPM, 1993 r., U.N. Doc. A/CN.4/L.489.

Projekt międzynarodowej konwencji o wzmożonej ochronie przed cyberprzestępczością i cyberterroryzmem (ang. Draft International Convention to Enhance Protection from Cyber Crime and Terrorism), 2000 r. [online]. STANFORD [dostęp: 2013-01-20]. Dostępny w Internecie: $<$ http://iis-db.stanford.edu/pubs/11912/sofaergoodman.pdf $>$.

Raport grupy roboczej ds. odpowiedzialności międzynarodowej, 2004 r., U.N. Doc. A/CN.4/L.661. Raport grupy roboczej ds. zarządzania Internetem, Genewa 2005 [online]. WGIG [dostęp: 2013-01-20]. Dostępny w Internecie: <www.wgig.org/docs/WGIGREPORT.pdf>.

Raport grupy roboczej KPM ds. walki z międzynarodowym terroryzmem z 19 października 2000 r., U.N. Doc. A/C.6/55/L.2. 
Raport Konferencji ONZ ds. środowiska i rozwoju, 1992 r., U.N. Doc A/CONF.151/26, tom I, zał. 1. Raport KPM, 1973 r., U.N. Doc. A/9010/Rev. 1.

Raport KPM, 1976 r., U. N. Doc. A/31/10.

Raport KPM, 1978 r., U.N. Doc. A/33/10, zał.

Raport KPM, 1980 r., U.N. Doc. A/35/10.

Raport KPM, 1991 r., U.N. Doc. A/46/10.

Raport KPM, 1992 r., U.N. Doc. A/47/10.

Raport KPM, 1993 r., U.N. Doc. A/48/10.

Raport KPM, 1994 r., U.N. Doc. A/49/10.

Raport KPM, 1998 r., U.N. Doc. A/53/10.

Raport KPM, 2000 r., U.N. Doc. A/55/10.

Raport KPM, 2001 r., U.N. Doc. A/56/10, zał. 10.

Raport KPM, 2006 r., U.N. Doc. A/61/10.

Raport podkomitetu ekspertów ds. postępowej kodyfikacji prawa międzynarodowego Ligii Narodów, 1926 r., U.N. Doc A/CN.4/96, zał. 1.

Raport R. Ago, przewodniczącego podkomitetu ds. odpowiedzialności państwa, 1963 r., U.N. Doc. A/CN.4/152.

Raport Sekretarza Generalnego KPM, 2000 r., U.N. Doc. A/CN.4/509.

Raport Sekretarza Generalnego ONZ z 21 września 1981, U.N. Doc. A/36/425.

Raport wstępny R. Quentina-Baxtera o odpowiedzialności międzynarodowej za szkodliwe skutki wynikające z czynów niezakazanych prawem międzynarodowym, 1980 r., U.N. Doc. $\mathrm{A} / \mathrm{CN} .4 / 334$.

Raport z 64. konferencji ILA, Queensland 1990 [online]. ILA [dostęp: 2013-04-05]. Dostępny w Internecie: $<$ http://www.ila-hq.org/en/publications/order-reports.cfm>.

Recommendation $\mathrm{CM} / \operatorname{Rec}(2011) 8$ of the Committee of Ministers to member states on the protection and promotion of the universality, integrity and openness of the Internet, adopted by the Committee of Ministers on 21 September 2011 at the 1121st meeting of the Ministers' Deputies [online]. COE [dostęp: 2013-01-20]. Dostępny w Internecie: <https://wcd.coe.int/ViewDoc .jsp?id $=1835707 \&$ Site $=\mathrm{COE}>$.

Rezolucja Instytutu Prawa Międzynarodowego, Yearbook of the Institute of International Law 1979, nr 58, część II, s. 196-203.

Rezolucja Zgromadzenia Ogólnego ONZ nr 1368 z 12 września 2001 r. U.N. Doc. S/RES/1368.

Rezolucja Zgromadzenia Ogólnego ONZ nr 1902 (XVIII) z 18 listopada 1963 r., U.N. Doc. A/CN.4/163.

Rezolucja Zgromadzenia Ogólnego ONZ nr 2400 (XXIII) z 11 grudnia 1968 r., Y.I.L.C. 1969, tom II.

Rezolucja Zgromadzenia Ogólnego ONZ nr 2625 (XXV) z 24 października 1970 r., U.N. Doc. $\mathrm{A} / 8028$.

Rezolucja Zgromadzenia Ogólnego ONZ nr 3281 (XXIX) z 12 grudnia 1974 r., U.N. Doc. $\mathrm{A} / \mathrm{RES} / 29 / 3281$.

Rezolucja Zgromadzenia Ogólnego ONZ nr 375 (IV) z 6 grudnia 1949 r., U.N. Doc. A/RES/375(IV), zał.

Rezolucja Zgromadzenia Ogólnego ONZ nr 49/60 z 9 grudnia 1994 r., U.N. Doc. A/RES/49/60.

Rezolucja Zgromadzenia Ogólnego ONZ nr 56/1 z 12 września 2001 r. [online]. UN [dostęp: 2013-01-20]. Dostępny w Internecie: <http://www.un.org/documents/ga/docs/56/agresolution .htm>.

Rezolucja Zgromadzenia Ogólnego ONZ z 13 października 2010, U.N. Doc. A/RES/64/297.

Rezolucja Zgromadzenia Ogólnego ONZ z 15 grudnia 1997 r., U.N. Doc. G.A. Res. 52/156.

Rezolucja Zgromadzenia Ogólnego ONZ z 19 grudnia 1978 r., U.N. Doc. A/RES/33/139.

Rezolucja Zgromadzenia Ogólnego ONZ z 28 stycznia 2002 r., U.N. Doc. A/RES/56/83.

Rezolucja Zgromadzenia Ogólnego ONZ z 30 listopada 1973 r., U.N. Doc. A/RES/3071.

Rezolucja Zgromadzenia Ogólnego ONZ z 6 grudnia 2010 r., U.N. Doc. A/65/463.

Siódmy raport Specjalnego Sprawozdawcy J. Barbozy, U.N. Doc. A/CN.4/437.

Siódmy raport Specjalnego Sprawozdawcy W. Riphagena, U.N. Doc. A/CN.4/397.

Szósty raport Specjalnego Sprawozdawcy J. Barbozy, U.N. Doc. A/CN.4/428. 
Szósty raport Specjalnego Sprawozdawcy R. Ago, U.N. Doc. A/CN.4/302.

Światowy Szczyt Społeczeństwa Informacyjnego, Declaration of Principles; Building the Information Society: a global challenge in the new Millennium, 2003 r. [online]. ITU [dostęp: 2013-01-20]. Dostępny w Internecie: <http://www.itu.int/wsis/docs/geneva/official/dop.html $>$.

Światowy Szczyt Społeczeństwa Informacyjnego, Plan Działań, 2003 r. [online]. ITU [dostęp: 2013-01-20]. Dostępny w Internecie: <http://www.itu.int/wsis/docs/geneva/official/poa.html .

Światowy Szczyt Społeczeństwa Informacyjnego, Tunis Agenda, 2005 r. [online]. ITU [dostęp: 2013-01-20]. Dostępny w Internecie: < http://www.itu.int/wsis/docs2/tunis/off/6rev1.html>.

Trzeci raport Specjalnego Sprawozdawcy F.V. Garcíi-Amadora, U.N. Doc. A/CN.4/111.

Trzeci raport Specjalnego Sprawozdawcy P. S. Rao, U.N. Doc. A/CN.4/510.

Trzeci raport Specjalnego Sprawozdawcy R. Quentina-Baxtera, U.N. Doc. A/CN.4/360.

\section{Artykuły i monografie}

Abeyratne R., The Deepwater Horizon Disaster - Some Liability Issues, Tutlus Maritime Law Journal 2010, nr 35, s. 125-152.

Abiew F. K., The Evolution of the Doctrine and Practice of Humanitarian Intervention, Haga 1999.

Ago R., Le delit international, RdC 1939, $\mathrm{nr} 68$, s. 419-554.

Alland D., The Definition of Countermeasures, (w:) Crawford, J. Pellet, A. Olleson, S. Parlett, K. The Law of International Responsibility, Oksford 2010.

Allum J. R., ,An Outcrop of Hell”: History, Environment and the Politics of the Trail Smelter Dispute, (w:) Transboundary Harm in International Law, Lessons from the Trail Smelter Arbitration, red. R. M. Bratspies, R. A. Miller, Cambridge 2006, s. 13-26.

Anzilotti, D. Lehrbuch des Völkerrechts, Berlin-Lipsk 1929.

Arend A. C., Beck R. J., International Law and the Use of Force: Beyond the UN Charter Paradigm, Routledge 1993.

Aust A., Handbook of Internationa Law, Cambridge 2011.

Aust H. P., Complicity and the Law of State Responsibility, Cambridge 2011.

Barbour S., Salzman, A. Z., Tangled Web: The Right of Self-Defense against Non-State Actors in the Armed Activities Case, The New York University Journal of International Law and Politics 2008, nr 40, s. 53-106.

Barboza J., The environment, risk and liability in international law, Haga 2011.

Barcik J., Srogosz T., Prawo międzynarodowe publiczne, Warszawa 2007.

Barker J. C., The Protection of Diplomatic Personnel, Aldershot 2006.

Barnidge Jr. R. P., The Due Diligence Principle Under International Law, International Community Law Review 2006, nr 8, s. 81-121.

Barwina, Z. Zasada wzajemnego uznawania w sprawach karnych, Warszawa 2012.

Bassiouni, M. C. Wise, E. M. Aut Dedere Aut Judicare: The Duty to Extradite Or Prosecute in International Law, Haga 1995.

Beaman C. C., The national and private „Alabama claims” and their ,final and amicable settlement", Waszyngton 1871.

Belch, S. F., Paulus Vladimiri and his doctrine concerning international law and politics, LondynHaga-Paryż 1965.

Benvenisti, E. Sharing Transboundary Resources: International Law and Optimal Resource Use, Cambridge 2002.

Berman, H. J., Law and Revolution: The Formation of the Western Legal Tradition, Harvard 1983.

Berwick T. A., Responsibility and Liability for Environmental Damage: A Roadmap for International Environmental Regimes, Georgetown International Environmental Law Review 1988, nr X, s. 257-267.

Bierzanek R., Symonides J., Prawo międzynarodowe publiczne, Warszawa 2005.

Bird F., Moral Universalities as Cultural Commonalities, (w:) Ethical Universals in International Business, red. F. N. Brady, Berlin-Heidelberg 1996, s. 97-150.

Birnie P. W., Boyle A. E., Redgwell C., International Law and the Environment, Oksford 2009. 
Birnie P., Impact on the Development of International Law on Cooperation: The UN Law of the Sea, Straddling Stocks and Biodiversity Convention, (w:) The Stockholm Declaration and Law of the Marine Environment, red. M. H. Nordquist, Haga 2003, s. 85-100.

Boczek B. A., International Law: A Dictionary, Oksford 2005.

Bodansky D. M., Crook J. R., Symposium on the ILC's State Responsibility Articles: Introduction and Overview, American Journal of International Law 2002, nr 96, s. 773-791.

Bonafè, B. I., The Relationship Between State and Individual Responsibility for International Crimes, Haga 2009, s. 121.124.

Boos-Hersberger A., Transboundary Water Pollution and State Responsibility: The Sandoz Spill, Annual Survey of International and Comparative Law 1997, nr 4(1), s. 103-131.

Borchard E. M., „Responsibility of States”, at the Hague Codification Conference, American Journal of International Law 1930, nr 3(24), s. 517-540.

Bowett D. W., Self-Defence in International Law, New Jersey 2009.

Boyle A. E., Soft Law in International Law making, (w:) International Law, red. A. Evans, Oksford, 2010, s. 122-140.

Boyle A. E., State Responsibility and International Liability for Injurious Consequences of Acts not Prohibited by International Law: A necessary distinction?, International and Comparative Law Quarterly 1990, nr 39, s. 1-25.

Boyle A.E., Globalising Environmental Liability: The Interplay of National and International Law, Journal of Environmental Law 2005, nr 1(17), s. 3-26.

Boyle, A. E. Saving the World - Implementation and Enforcement of International Environmental Law through International Institutions, Journal of Environmental Law 1991, nr 3, s. 229-245.

Bratspies R. M., Miller R. A., Transboundary harm in international law: lessons from the Trail Smelter arbitration, Cambridge 2006.

Broad W. J., Markoff J., Sanger D. E., Israeli Test on Worm Called Crucial in Iran Nuclear Delay, N.Y. Times, 15 stycznia 2011 [online]. NYTIMES [dostęp: 2013-01-20]. Dostępny w Internecie: $<$ http://www.nytimes.com/2011/01/16/world/middleeast/16stuxnet.html?pagewanted=all $>$.

Brownlie I., Principles of Public International Law, Oksford 2008.

Brownlie I., System of the Law of Nations: State Responsibility, Oksford 1983.

Brownlie I., The Use of Force in Self-Defense, British Yearbook of International Law 1961, nr 37, s. 183-268.

Brunee J., The Stockholm declaration and the Structure and Processes of International Environmental Law, (w:) The Stockholm Declaration and Law of the Marine Environment, red. M. H. Nordquist, Haga 2003, s. 67-84.

Bukowski Z., Prawo międzynarodowe a ochrona środowiska, Toruń 2005.

Burlamaqui J. J., Burlemaqui's principles of natural law, Londyn 1763.

Butler W. E., The Non-Use of Force in International Law, Haga 1989.

Cançado Trindade, A.A. International Law for Humankind: Towards a New Jus Gentium, Haga 2010.

Caron, D. D. The ILC Articles on State Responsibility: The Paradoxical Relationship Between Form and Authority, American Journal of International Law 2002, nr 96, s. 857-873.

Cassese A., The Nicaragua and Tadič Tests Revisited in Light of the ICJ Judgment on Genocide in Bosnia, The European Journal of International Law 2007, nr 18(4), s. 649-668.

Cassesse A., International Law, Oksford 2005.

Chen X., Limitation of Liability for Maritime Claims: A Study of U.S. Law, Chinese Law, and International Conventions, Haga 2001.

Cheng B., General Principles of Law as Applied by International Courts and Tribunals, Cambridge 2006.

Ciechanowicz J., Zasady ustalania odszkodowania $w$ prawie międzynarodowym publicznym, Gdańsk 1989.

Ciechanowicz-McLean J., Tendencje rozwoju międzynarodowego prawa środowiska. Bezpieczeństwo ekologiczne czy terroryzm ekologiczny, (w:) Prawo międzynarodowe-problemy $i$ wyzwania. Ksiega Pamiqtkowa Profesor Renaty Sonnenfeld-Tomporek, red. J. Menkes, Warszawa 2006, s. 116-130. 
Clinton W. J., A. Gore, Jr., A Framework for Global Electronic Commerce, 1 lipca 1997 [online]. CLINTON [dostęp: 2013-01-20]. Dostępny w Internecie: <http://clinton4.nara.gov/WH/New/ Commerce/>.

Combacau J., Alland D., „Primary” and „Secondary” Rules in the Law of State Responsibility: Categorizing International Obligations, Netherlands Yearbook of International Law 1981, nr 16, s. 95-107.

Conte A., Security In The 21st Century: The United Nations, Afghanistan And Iraq, Aldershot 2005.

Coquillette, D. R. The civilian writers of Doctors' Commons, London: three centuries of juristic innovation in comparative, commercial, and international law, Berlin 1988.

Crawford J., Olleson S, , The nature and forms of International responsibility, (w:) International Law, red. M. D. Evans, Oksford 2010.

Crawford J., The ILC's Articles on Responsibility of States for Internationally Wrongful Acts: A Retrospect, American Journal of International Law 2002, nr 96, s. 874-890.

Crawford J., The International Law Commission's Articles on State Responsibility: Introduction, Text and Commentaries, Cambridge 2002.

Crawford J., Pellet A., Olleson S., Parlett K., The Law of International Responsibility, Oksford 2010.

Czapliński W., Wyrozumska A., Prawo międzynarodowe publiczne, Warszawa 2004.

Czapliński W., Kodyfikacja prawa o odpowiedzialności międzynarodowej, Studia Prawnicze 2003, nr 4(154), s. 31-52.

Czapliński W., Odpowiedzialność za naruszenie prawa międzynarodowego w zwiazku z konfliktem zbrojnym, Warszawa 2009.

Dahm G., Delbrück J., Voelkerrecht, Berlin 2002.

Daranowski P., Połatyńska J., Prawo międzynarodowe publiczne, Warszawa 2011.

D’Aspremont, J., Diplomatic Premises in International Law, (w:) Max Planck Encyclopedia of International Law, red. R. Wolfrum, Oksford 2009 [online]. MPEPIL [dostęp: 2013-01-20]. Dostępny w Internecie: <http://mpepil.oup.com>.

de Arechaga E. J., International Law in the Part Third of a Century, RdC 1978, tom I, nr 159, s. 99-119.

de Goede M., The Politics of Preemption and the War on Terror in Europe, European Journal of International Relations 2008, nr 14(1), s. 161-185.

de Vattel E., Prawo narodów, Warszawa 1958.

de Wet E., The Emergence of International and Regional Value Systems as a Manifestation of the Emerging International Constitutional Order, Leiden Journal of International Law 2006, nr 19, s. 611-632.

Degan V. D., Developments in International Law: Sources of International Law, Haga 1997.

Delibasis D., The Right to National Self-Defense: In Information Warfare Operations, Bury St. Edmonds 2007.

Departament Informacji Publicznej ONZ, Legal Committee Urges Conclusion of Draft Comprehensive Convention on International Terrorism, Delegates Urge Clear Definition, 8 października 2012 r. [online]. UN [dostęp: 2013-01-20]. Dostępny w Internecie: <http://www.un.org/ News/Press/docs/2012/gal3433.doc.htm>.

Diaz-Barrado C.M., The Definition of Terrorism and International Law, (w:) International Legal Dimension of Terrorism, red. F. Sánchez, P. Antonio, Haga 2009; s. 27-41.

Domingo R., The New Global Law, Cambridge 2010.

Duffy H., The 'War on Terror' and the Framework of International Law, Cambridge 2005.

Dupuy P. M., L'unite de l'ordre juridique international, RdC 2002, nr 297, s. 215-221.

Dupuy P. M., Reviewing the Difficulties of Codification: On Ago's Classification of Obligations of Means and Obligations of Result in Relation to State Responsibility, European Journal of International Law 1999, nr 2(10), s. 371-385.

Dupuy P. M., Dionisio Anzillotti and the Law of International Responsibility of States, European Journal of International Law 1992, nr 3, s. 139-148.

Dupuy, P. M., The International Law of State Responsibility: Revolution or Evolution, Michigan Journal of International Law 1989, nr 11, s. 105-128. 
Dworkin R., Imperium prawa, Warszawa 1986.

Dworkin R., Law's Empire, Harvard 1986.

Dyson R. W., Stirk P. M. R., Natural Law And Political Realism In The History Of Political Thought: From The Sophists To Machiavelli, Londyn-Paryż-Nowy Jork 2005.

Dzikiewicz L., O pojęciu winy i jej trzech odmianach, PiP 1977, nr 1, s. 87-98.

Eagleton C., Denial of Justice in International Law, American Journal of International Law 1928, nr 2(22), s. 538-559.

Ehrlich L., Works of Paul Wladimiri; a Selection, Warszawa 1969.

Ehrlich, L., Prawo międzynarodowe, Warszawa 1958.

Ellis J., Has International Law Outgrown Trail Smelter?, (w:) Transboundary Harm in International Law, Lessons from the Trail Smelter Arbitration, red. R. M. Bratspies, R. A. Miller, Cambridge 2006, s. 56-65.

Esperanza B., International Law Human Rights, and Latcrit Theory: Civil and Political Rights An Introduction, University of Miami Inter-American Law Review 1996-1997, nr 28, s. 226-235.

Eycken V., Methode positive de l'interpretation juridique, Bruksela 1907.

Falliere N., L. O Murchu, E. Chien, W32. Stuxnet Dossier, Symantech Security Response 2010, nr 1, s. 2 [online]. SYMANTECH [dostęp: 2013-01-20]. Dostępny w Internecie: <http://www .symantech.com/content/en/us/enterprise/media/security_response/whitepapers/w32_stuxnet dossier.pdf $>$.

Farwell J. P., Rohozinski R., Stuxnet and the Future of Cyber War, Survival 2011, nr 1, s. 23-40.

Fassbender B., The United Nations Charter As the Constitution of the International Community, Haga 2009.

Fitzmaurice M., Contemporary Issues in International Environmental Law, Cheltenham-Northampton 2009.

Fitzmaurice M., International protection of the environment, RdC, Haga 2002.

Franck T. H., Terrorism And the Right of Self Defense, American Journal of International Law 2001, nr 95, s. 839-843.

Freestone D., E. Hey, The Precautionary Principle and International Law: The Challenge of Implementation, Alphen aan den Rijn 1996.

Fullam G. T., The journal of George Townley Fullam, boarding officer of the Confederate sea raider Alabama, Alabama 1973.

Fürst H., The Hungarian-Slovakian Conflict over the Gabcikovo-Nagymaros Dams: An Analysis, Intermarium 2003, nr 2(6), s. 1-15.

Gajusz, Instytucje, 1.1, Warszawa 1982.

Gallagher A. T., The International Law of Human Trafficking, Cambridge 2010.

García Amador F. V., The changing law of international claims, Nowy Jork 1984.

García-Amador F. V., Sohn L. B., Baxter R. R., Recent codification of the law of state responsibility for injuries to aliens, Haga 1974.

García-Amador, F.V. Draft Articles on the Responsibility of the State for Injuries Caused in its Territory to the Person or Property of Aliens, (w:) Recent Codification of the Law of State Responsibility for Injuries to Aliens, red. F. V. García Amador, Louis B. Sohn, Richard R. Baxter, Haga 1974, s. 111-135.

Gazzini T., The Changing Rules on the Use of Force in International Law, Manchester 2005.

Gehring T., Jachtenfuchs M., Liability for Transboundary Environmental Damage towards a General Liability Regime, European Journal of International Law 1993, nr 4, s. 92-106.

Gelberg L., Prawo międzynarodowe i historia dyplomatyczna. Wybór dokumentów, Warszawa 1954.

Geny F., Méthode d'interpretation et sources en droit privé positif, Paryż 1899.

Goldie L. F. E., Concepts of Strict and Absolute Liability and the Ranking of Liability in Terms of Relative Exposure to Risk, Netherlands Yearbook of International Law 1985, nr 16, s. 175-248.

Goldie M., Edmund Bohun And Jus Gentium In The Revolution Debate 1689-1693, The Historical Journal 1977, nr 3(20), s. 569-586.

Goodman W., Cyber Deterrence Tougher in Theory than in Practice?, Strategic Studies Quarterly 2010, nr 3, s. 102-135.

Goold B. J., L. Lazarus, Security \& Human Rights, Portland 2007. 
Górski M., Prawo ochrony środowiska, Warszawa 2009.

Grafton A., Most G. W., Settis S., The Classical Tradition, Harvard 2010.

Gray C. D., International Law and the Use of Force, Oksford 2008.

Grocjusz H., Trzy ksiegi o prawie wojny i pokoju, Warszawa 1957.

Grosz M., Sustainable Waste Trade under WTO Law: Chances and Risks of the Legal Frameworks' Regulation of Transboundary Movements of Wastes, Haga 2011.

Gutteridge H. C., Comparative Law: An Introduction to the Comparative Method of Legal Study and Research, Cambridge 1971.

Hacket G. T., Space Debris and the Corpus Iuris Spatialis, Gif-sur-Yvette 1994.

Hafner G., Buffard I., Obligations of Prevention and the Precautionary Principle, (w:) The Law of International Responsibility, red. J. Crawford, A. Pellet, S. Olleson, Oksford 2010, s. 522-533.

Hall W. E., A Treatise on International Law, Oksford 1895.

Halleck H. W., International Law: Or, Rules Regulating the Intercourse of States in Peace and War, San Francisco 1861.

Handl G., State Liability For Accidental Transnational Environmental Damage By Private Persons, American Journal of International Law 1980, nr 74, s. 525-565.

Handl G., Liability as an Obligation Established by a Primary Rule of International Law, Netherlands Yearbook of International Law 1985, nr 16, s. 49-78.

Hanquin X., Transboundary Damage in International Law, Cambridge 2009.

Harding C., Renegotiating Westphalia, Haga 1999.

Hatschek J., Strupp, K. Woerterbuch des Voelkerrechts und der Diplomatie, Berlin 1925.

Helios J., Jedlecka W., Suwerenność w dobie procesów integracyjnych i globalizacyjnych, Wrocław 2004.

Hessbruegge J. A., The Historical Development of the Doctrines of Attribution and Due Diligence in International Law, New York University Journal of International Law and Politics 2004, nr 36, s. 265-306.

Hestermeyer H. P., Transboundary Harm: Internet Torts, (w:) Transboundary Harm in International Law, Lessons from the Trail Smelter Arbitration, red. R. M. Bratspies, R. M. Miller, Cambridge 2006.

Higgins R., Legal Limits to the Use of Force by Sovereign States United Nations Practice, British Yearbook of International Law 1961, nr 37, s. 269-319.

Higgins R., The General International Law of Terrorism, (w:) Terrorism and International Law, red. R. Higgins, M. Flory, Nowy Jork 1997, s. 13-28.

Holland, T. E., An inaugural lecture on Albericus Gentilis, delivered at All Souls college, November 7, 1874, Londyn 1847.

Honoré T., Responsibility and Fault, Portland 1999.

Horbach N. L. J. T., The confusion about State Responsibility and Liability, Leiden Journal of International Law 1991, nr 4, s. 47-74.

Horbach N. L. J. T., Bekker, P. H. F., State responsibility for injurious transboundary activity in retrospect, Netherland International Law Review 2003, s. 327-371.

Hunter H. M., The Hague Codification Conference, American Journal of International Law 1930, nr 24, s. 674-693.

Institute of International Law, Resolution on Responsibility and Liability under International Law for Environmental Damage, Review of European Community \& International Environmental Law 1998, Vol. 7, nr 1, s. 99-102.

Jajodia S., Moving Target Defense: Creating Asymmetric Uncertainty for Cyber Threats, Berlin 2011.

Jarvis L., The Spaces and Faces of Critical Terrorism Studies, Security Dialogue 2009, nr 40(1), s. 5-27.

Jasudowicz T., Włodkowica wizja porzqdku prawnego, PiP 1993, nr 8, s. 27-39.

Jasudowicz T., Śladami Ludwika Ehrlicha: Do Pawła Włodkowica po nauke o prawach człowieka, Toruń 1995.

Jennings R. Y., The Caroline and McLeod Cases, American Journal of International Law 1938, nr 32, s. 82-99. 
Jessup R., Responsibility of states for injuries to individuals, Columbia Law Review 1946, nr 46, s. 903-928.

Jones T. L., Historical Dictionary of the Civil War, tom 1, Lanham 2011.

Juda L., International Law and Ocean Use Management, The Evolution of Ocean Governance, Londyn 1996.

Kaser M., Ius Gentium, Kolonia 1993.

Kaser M., Römische Rechtsquellen und angewandte Juristenmethode: ausgewählte, zum Teil grundlegend erneuerte Abhandlungen, Wiedeń 1986.

Kelsen H., General Theory of Law And State, New Jersey 2007.

Kelsen H., Principles of International Law, New Jersey 1952.

Kenig-Witkowska M. M., Międzynarodowe prawo środowiska. Wybrane zagadnienia systemowe, Warszawa 2011.

Kenig-Witkowska M.M., Prawnomiędzynarodowa odpowiedzialność za szkody transgraniczne $w$ środowisku. Uwagi na marginesie projektu zasad dotyczacych alokacji strat wynikajacych ze szkód transgranicznych spowodowanych dziatalnościq niebezpiecznq, (w:) red. J. Menkes, Prawo międzynarodowe - problemy i wyzwania; Prawo międzynarodowe - problemy $i$ wyzwania. Ksiegga pamiatkowa profesor Renaty Sonnenfeld-Tomporek, Warszawa 2006, s. 311-355.

Kenig-Witkowska, M. M. Koncepcja „sustainable development” w prawie międzynarodowym, Państwo i Prawo 1998, nr 8, s. 45-51.

Kersten C. M., Rethinking Transboundary Environmental Impact Assessment, Yale Journal of International Law 2009, nr 34 (173), s. 174-185.

Khan J. A., The International Law of Joint Resource Development: With Special Reference to Its Functional Role in the Management and Resolution of Boundary and Territorial Disputes Involving Natural Resources, Medford 1991.

Kläger R., 'Fair and Equitable Treatment' in International Investment Law, Cambridge 2011.

Kleinwächter W., Multistakeholderism in Internet Governance: the Role of Governments, (w:) Internet Governance and the Information Society: Global Perspectives and European Dimension, red. W. Benedek, V. Bauer, M.C. Kettemann, Utrecht 2008, s. 9-30.

Kodeks karny. Część ogólna. Komentarz, red. Giezek J., Warszawa 2007, s. 73.

Kodeks karny. Część ogólna. Komentarz, red. Zoll A., Warszawa 2007, tom I, s. 119.

Komisja Europejska, How Successful Are Member States in Implementing the EIA Directive, COM (2003) 334 final, 2003 [online]. EC [dostęp: 2013-01-20]. Dostępny w Internecie: <http://ec .europa.eu/environment/eia/pdf/report_en.pdf>, s. 80 .

Krech S., McNeill J. R., Merchant C., Encyclopedia of World Environmental History, Nowy Jork 2004.

Krylov S. B., Les notions principales du droit des gens (La doctrine soviétique du droit international), RdC 1947, tom 70, s. 411-475.

Kulesza J., International Internet law, Global Change, Peace \& Security 2012, nr 24(3), s. 351-364.

Kulesza J., Kulesza J., Odpowiedzialność państw za podejmowane $w$ cyberprzestrzeni działania zagrażajace międzynarodowemu pokojowi $i$ bezpieczeństwu, Studia Prawno-Ekonomiczne 2011, nr 83, s. 149-168.

Kulesza J., Międzynarodowe prawo Internetu, Poznań 2010.

Kuryłowicz M., Wiliński A., Rzymskie prawo prywatne: zarys wykładu, Kraków 2008.

Kuźmicka-Sulikowska J., Zasady odpowiedzialności deliktowej $w$ świetle nowych tendencji w ustawodawstwie polskim, Warszawa 2011.

Kwiecień R., Suwerenność państwa: rekonstrukcja i znaczenie idei w prawie międzynarodowym, Kraków 2004.

La Fontaine H., Pasicrisie internationale historie documentaire des arbitrages internationaux, Haga 1902.

Lachs M., Rzecz o nauce prawa międzynarodowego, Wrocław 1986.

Lachs M., The Teacher In International Law: Teachings And Teaching, Haga 1987.

Lambert J., Terrorism and Hostages in International Law, Cambridge 1990.

Łapicki B., Poglady prawne niewolników i proletariuszy rzymskich: studium historyczne na tle bazy gospodarczej i antagonizmów klasowych, Wrocław 1955. 
Lehnardt C., Private Militarfirmen und volkerrechtliche Verantwortlichkeit: Eine Untersuchung aus humanitar-voelkerrechtlicher und menschenrechtlicher Perspektive, Berlin 2011.

Lessig L., The Code Is the Law, The Standard, 9 kwietnia 1999 [online]. LESSING [dostęp: 2013-01-20]. Dostępny w Internecie: <http://www.lessig.org/content/standard/0,1902,4165,00 .html>.

Lewaszkiewicz-Petrykowska B., Cywilna odpowiedzialność za szkode jądrowa w polskim prawie atomowym, PiP 1987, $\mathrm{nr}$ 4, s. 30-42.

Lewaszkiewicz-Petrykowska B., Wina jako podstawa odpowiedzialności z tytułu czynów niedozwolonych, Studia Prawniczo Ekonomiczne 1969, nr 2, s. 87-104.

Leybold-Johnson I., Kontroverse um Brandplatz Schweizerhalle dauert an, swissinfo.ch, z 31.10.2011 [online]. SWISSINFO [dostęp: 2013-01-20]. Dostępny w Internecie: <http://www.swissinfo .ch/ger/politik_schweiz/Kontroverse_um_Brandplatz_Schweizerhalle_dauert_an_.html?cid= 31466146>.

Lillich R., Paxman J., State Responsibility for Injuries to Aliens Occasioned by Terrorist Activities, American University Law Review 1977, nr 26, s. 217-313.

Linos-Alexander S., The Classification of Obligations and the Multilateral Dimension of the Relations of International Responsibility, European Journal of International Law, 2002, Vol. 13, Issue 5, s. 1127-1145.

Lobingier C. S., The Evolution of the Roman Law: From Before the Twelve Tables to the Corpus Juris, Nowy Jork 1923.

Łopuski J., Rola ubezpieczenia $w$ ochronie środowiska czlowieka przed zanieczyszczeniami, PiP 1978, s. 27-41.

Lubell N., Extraterritorial Use of Force Against Non-State Actors, Oksford 2010.

Macdonald R. A., Metaphors of Multiplicity: Civil Society, Regimes and Legal Pluralism, Arizona Journal of International \& Comparative Law 1998, nr 15, s. 69-91.

Madej M., Transatlantic Perspectives on Asymmetric Threats - Their Essence, Nature and Scope, (w:) Transatlantic Perspectives on Security Imperatives, Transatlantic Policy Consortium. Annual Colloquium, red. S. Dębski, Münster 2007, s. 52-66.

Magraw D. B., Transboundary harm: The International Law Commission's Study of International Liability, American Journal of International Law 1986, nr 80, s. 305-330.

Maihold H., Die Sippenhaft: Begründete Zweifel an einem Grundsatz des „deutschen Rechts”, Mediaevistik 2005, nr 18, s. 117-144.

Maine H. S., Ancient Law: Its Connection with the Early History of Society and its Relation to Modern Ideas, Londyn 1861.

Majda R., Cywilna odpowiedzialność za szkodęadrowq w polskim prawie atomowym, Łódź 2006.

Makowski J., Prawo międzynarodowe, Warszawa 1922.

Malanczuk P., Akehurst's Modern Introduction to International Law, Londyn-Nowy Jork 2007.

Malanczuk P., Akehurst's Modern Introduction to International Law, Londyn-Nowy Jork 1987.

Malzahn S. M., State Sponsorship and Support of International Terrorism: Customary Norms of State Responsibility, Hastings International \& Comparative Law Review 2002-2003, nr 26, s. 83-114.

Martin F. F., International Human Rights And Humanitarian Law: Treaties, Cases And Analysis, Cambridge 2006.

McCaffrey S. C., The Harmon Doctrine One Hundred Years Later: Buried, Not Praised, Natural Resources Journal 1996, nr 36, s. 549-590.

Miller H., The Hague Codification Conference, American Journal of International Law 1930, nr 24, s. 674-693.

Mockapetris P., RFC 1035, Domain names - implementation and specification [online]. IETF 1984 [dostęp: 2013-01-20]. Dostępny w Internecie: <http://www.ietf.org/rfc/rfc1035.txt>.

Mogul J., RFC 922, Broadcasting Internet Datagrams in the Presence of Subnets [online]. IETF, Stanford 1984 [dostęp: 2013-01-20]. Dostępny w Internecie: <http://www.ietf.org/rfc/rfc922.txt>.

Moore J. B., A Digest of International Law, Waszyngton 1906, tom II.

Moore J. B., History and Digest of the International Arbitrations to which the United States Has Been a Party, Together with Appendices Containing the Treaties Relating to Such Arbitrations, and Historical and Legal Notes on Other International Arbitrations Ancient and 
Modern, and on The Domestic Commissions of the United States for the Adjustment of International Claims. Waszyngton 1898.

Mosler H., The International Society As a Legal Community, Alphen aan der Rijn 1980.

Nolte G., From Dionisio Anzilotti to Roberto Ago: The Classical International Law of State Responsibility and the Traditional Primacy of a of a Bilateral Conception of Inter-state Relations, European Journal of International Law 2002, nr 5(13), s. 1083-1098.

Nowrot K., Schabacker E. W., The Use of Force to Restore Democracy: International Legal Implications of the ECOWAS Intervention in Sierra Leone, American University International Law Review 1998, nr 2(14), s. 321-412.

O'Connell M. E., Cyber Security without Cyber War, Journal of Conflict and Security Law 2012, nr 2(17), s. 187-209.

O'Keefe C., Transboundary Pollution and the Strict Liability Issue, The Work of the International Law Commission on the Topic of International Liability for Injurious Consequences Arising Out of Acts Not Prohibited by International Law, Denver Journal of International Law and Policy 1989/90, nr 18, s. 145-208.

Oppenheim L., International law: a treatise, Londyn-Nowy Jork-Bombaj-Kalkuta-Madras 1920.

Orakhelashvili A., Research Handbook on the Theory and History of International Law, Northampton 2011.

Pająkowski W., Ilirowie, Toruń 1981, s. 185.

Pallemaerts M., International Legal Aspects of Long-Range Transboundary Air Pollution, (w:) red. A. C. Kiss, J. G. Lammers, Hague Yearbook of International Law 1989, tom 17-18, s. $189-224$.

Paparinskis M., The International Minimum Standard and Fair and Equitable Treatment, Oksford 2013.

Paust J., Use of Armed Force against Terrorist in Afghanistan, Iran and Beyond, Cornell International Law Journal 2002, nr 35, s. 532-557.

Paust J., Self-Defense Targetings of Non-State Actors and Permissibility of U.S. Use of Drones in Pakistan, Journal of Transnational Law \& Policy 2010, nr 19(2), s. 238-258.

Phillimore R., Commentaries upon international law, Londyn 1871.

Phillipson C., The International Law and Custom of Ancient Greece and Rome, Londyn 1911.

Pisillo Mazzeschi R., The „Due Diligence” Rule and the Nature of the International Responsibility of States, German Yearbook of International Law 1992, nr 35, s. 9-49.

Płachta M., Zasada aut dedere aut iudicare $w$ dziedzinie międzynarodowej wspótpracy $w$ sprawach karnych, Palestra 2000, nr 7-8, s. 34-43.

Przetacznik F., Protection of Officials of Foreign States According to International Law, Haga 1983.

Przyborowska-Klimczak A., Prawo międzynarodowe publiczne, wybór dokumentów, Lublin 1996.

Pufendorf S., [Elementorum jurisprudentiae universalis libri duo] Two books of the Elements of universal jurisprudence, Indianapolis 2009.

Reisman M. W., Criteria for the Lawful Use of Force in International Law, Yale Journal of International Law 1984-1985, nr 10, 279-285.

Rida T., Cyber War Will Not Take Place, Journal of Strategic Studies 2012, nr 1(35), s. 5-32.

Rommen H. A., Die Staatslehre des Franz Suarez S.J., Monachium 1947.

Rosas A., Brodecki Z., State Liability for Transboundary Environmental Damage, International Association for Insurance Law General Reports: Damage from International Disasters, Kopenhaga 1990, s. 1-15.

Rosas A., State Responsibility and Liability under Civil Liability Regimes, (w:) Current International Law Issues: Nordic Perspectives, Essays in honour of Jerzy Sztucki, red. O. Bring and Said Mahmoudi, Dordrecht 1994, s. 161-182.

Rosenne S., The International Law Commission's Draft Articles on State Responsibility: Part 1, Articles 1-35, Haga 1991.

Rostow E. V., Legality of the International Use of Force by and from States, Yale Journal of International Law 1984-1985, nr 10, s. 286-290.

Ruys T., 'Armed Attack' and Article 51 of the UN Charter: Evolutions in Customary Law and Practice, Cambridge 2010. 
Sabahi B., Compensation and Restitution in Investor-State Arbitration: Principles and Practice, Oksford 2011.

Safjan M., Wyzwania dla państwa prawa, Kraków 2007.

Sands P., Principles of International Environmental Law, Cambridge 2003.

Saul B., Defining Terrorism in International Law, Oksford 2008.

Saul B., Definition of ,,Terrorism” in the UN Security Council: 1985-2004, Chinese Journal of International Law 2005, Vol. 4, nr 1, s. 141-166.

Schmitt M. N., Bellum Americanum Revisited: U.S. Security Strategy and the Jus Ad Bellum, Military Law Review 2003, nr 176, s. 364-421.

Schmitt M. N., Bellum Americanum: the U.S. View of Twenty-First Century War and Its Possible Implications for the Law of Armed Conflict, Michigan Journal of International Law 1998, nr 19, s. 1051-1090.

Schrijver N., Development Without Destruction: The UN and Global Resource Management, Indiana 2010.

Schrijver N., Sovereignty over Natural Resources: Balancing Rights and Duties, Cambridge 2008.

Schrijver N., Weiss F., International Law And Sustainable Development: Principles And Practice, Haga 2004.

Schüpbach W., Sippenhaftung: Roman, Zwickau 1996.

Schwarzenberger G., The Inductive Approach to International Law, Harvard Law Review 1946-47, nr 60 , s. 539-570.

Scott J. B., Law, the State, and the International Community, Nowy Jork 2002.

Scott J. B., The Catholic Conception of International Law: Francisco de Vitoria, Founder of the Modern Law of Nations, Francisco Suárez, Founder of the Modern Philosophy of Law in General and in Particular of the Law of Nations: a Critical Examination and a Justified Appreciation, Nowy Jork 1934.

Shackelford S. J., From Nuclear War To Net War: Analogizing Cyber Attacks In International Law, Berkeley Journal of International Law 2009, nr 27(1), s. 191-252.

Shaw M. N., Prawo międzynarodowe, Warszawa 2005.

Shaw M.N., International Law, Cambridge 2010.

Simma B., Pulkowski D., Of Planets and the Universe: Self-contained Regimes in International Law, European Journal of International Law 2006, nr 3(17), s. 483-529.

Simma B., Self-Contained Regimes, Netherlands Yearbook of International Law 1985, nr 16, s. 111-136.

Smets H., The Oil Spill Risk: Economic Assessment and Compensation Limit, Journal of Maritime Law \& Commerce 1983, nr 14, s. 23-43.

Somer J., Acts of Non-State Armed Groups and the Law Governing Armed Conflict, „American Society of International Law Insight” 24 sierpnia 2006 [online]. CIGILIBRARY [dostęp: 2013-01-20]. Dostępny w Internecie: <http://dspace.cigilibrary.org/jspui/bitstream/123456789/ 13168/1/Acts\%20of\%20Non\%20State\%20Armed\%20Groups\%20and\%20the\%20Law\%20Go verning\%20Armed\%20Conflict.pdf? $1>$.

Sonnenfeld R., Kodyfikacja odpowiedzialności międzynarodowej państw, Warszawa 2002.

Sorel J. M., Some Questions About the Definition of Terrorism and the Fight Against Its Financing, European Journal of International Law 2003, Vol. 14, nr 2, s. 365-378.

Sucharitkul S., State Responsibility and International Liability under International Law, Loyola Los Angeles International \& Comparative Law Review 1996, nr 18, s. 821-839.

Sucharitkul S., State Responsibility and Liability in Transnational Relations, (w:) Theory of International Law at the Threshold of the 21st Century:Essays in Honour of Krzysztof Skubiszewski, red. J. Makarczyk, Haga 1996, s. 283-299.

Sutor J., Prawo dyplomatyczne i konsularne, Warszawa 2012, s. 255.

Symonides J., Odpowiedzialność państwa w prawie międzynarodowym, Studia Prawnicze 1971, nr 30, s. 31-64.

Szabó K. T., Anticipatory Action in Self-Defence: Essence and Limits under International Law, Berlin 2011.

Tarwacka A., O sprawiedliwości i prawie. 1 tytul 1 księgi Digestów. Tekst-tlumaczenie - komentarz, Zeszyty Prawnicze UKSW 2003, nr 3(2), s. 357-370. 
Textor J. W., Synopsis of the Law of Nations, Waszyngton 1916.

Theohary C. A., Kerr P. K., Rollins J., The Stuxnet Computer Worm Harbinger Of An Emerging War, Waszyngton 2010, s. 4 [online]. FAS [dostęp: 2013-01-20]. Dostępny w Internecie: $<$ www.fas.org/sgp/crs/natsec/R41524.pdf>

Thuau E., Raison d'Etat et Penseé Politique à l'epoque de Richelieu, Paris 1966.

Tierney B., The Idea of Natural Rights: Studies on Natural Rights, Natural Law, and Church Law, Grand Rapids 1997.

Trapp K. N., State Responsibility for International Terrorism. Problems and Prospects, Oksford 2011.

Trouwborst A., Precautionary Rights and Duties of States, Haga 2006.

Tsagourias T., International Peace and Security, (w:) Participants in the International Legal System, red. J. D’Aspremont, Londyn-Nowy Jork 2011, s. 326-341.

Tsaogurias N., Necessity and the Use of Force: a Special Regime, Netherlands Yearbook of International Law 2010, nr 4, s. 11-44.

Verheyen R., Climate Change Damage And International Law: Prevention Duties And State Responsibility, Haga 2005.

Vicuña F. O., Responsibility and Liability for Environmental Damage under International Law: Issues and Trends, Georgetown International Environmental Law Review 1997-1998, nr 10, s. 269-308.

Vicuña F. O., Responsibility and Liability under International Law for Environmental Damage, Haga 1997.

Viikari L., The Environmental Element in Space Law: Assessing the Present and Charting the Future, Haga 2008.

Vitanyi B., Les positions doctrinale concernant le sens de la notion de 'principes generaux reconnus par les nations civilisees, RGDIP 1982, nr 1, s. 48-116.

Waldrop M., DARPA and the Internet Revolution, Arlington 2008, s. 80-83 [online]. DARPA [dostęp: 2013-01-20]. Dostępny w Internecie: <http://www.darpa.mil/About/History/ PARTIAL_BIBLIOGRAPHY_OF_THE_INTERNETARPANET.aspx $>$,

Warkałło W., Gradacja winy a obowiazek naprawienia szkody w świetle przepisów kodeksu cywilnego, Studia Prawnicze 1970, nr 26-27, s. 292-309.

Wheaton H., Elements of International Law, Boston 1866.

Wheaton H., History of the Law of Nations in Europe and America, Nowy Jork 1845.

Whittaker S., Good Faith in European Contract Law, Cambridge 2000.

Wielgus S., Polska średniowieczna doktryna ius gentium, Lublin 1996.

Willisch J., State Responsibility for Technological Damage in International Law, Berlin 1978.

Wójcik J. W., Przeciwdziałanie finansowaniu terroryzmu, Warszawa 2007.

Wójcik Z., Historia powszechna XVI-XVII wieku, Warszawa 2001.

Wolff Ch. J., Jus gentium methodo scientifica pertractatum, Buffalo-Nowy Jork 1995.

Wolfke K., Some Reflections on International Environmental Law-Making and Enforcement, Polish Yearbook of International Law 1976, nr VIII, s. 33-54.

Wolfrum R., International Environmental Law: Purposes, Principles and Means of Ensuring Compliance, (w:) International, Regional and National Environmental Law, red. F. L. Morrison, R. Wolfrum, Haga 2000, s. 15-23.

Wolfrum R., Internationally Wrongful Acts, (w:) Encyclopedia of Public International Law, red. R. Bernhardt, P. Macalister-Smith, Amsterdam 1995, s. 271-277.

Wolfrum R., Means of Ensuring Compliance and Enforcement in International Environmental Law, RdC 1998, nr 272 (1998), s. 9-154.

Wołodkiewicz W., Europa i prawo rzymskie. Szkice z historii europejskiej kultury prawnej, Kraków 2009.

Wroczyński K., O źródłach treści praw człowieka, Człowiek w Kulturze 1998, nr 11, s. 165-166.

Yearwood P. J., 'Consistently with Honour': Great Britain, the League of Nations and the Corfu Crisis of 1923, Journal of Contemporary History 1986, nr 4(21), s. 559-579.

Yoshida O., The International Legal Régime for the Protection of the Stratospheric Ozone Layer: International Law, International Régimes, and Sustainable Development, Haga 2001. 
Zbaraszewska A., Prawnomiędzynarodowa odpowiedzialność za szkody transgraniczne $w$ środowisku - problem prewencji, Ruch Prawniczy, Ekonomiczny i Socjologiczny 2008, nr 2, s. 109-123.

Zemanek K., Causes and Forms of International Liability, (w:) Contemporary Problems of International Law: Essays in honour of George Schwarzenberger on his eightieth birthday, red. B. Cheng, E. D. Brown, Londyn 1988, s. 319-333.

Zouch R., Iuris et iudicii Fecialis, sive, Iuris inter Gentes, et Quaestionum de Eoden Explication, Waszyngton 1911.

\section{Orzeczenia}

Adams przeciwko Panamie, R.I.A.A. 1933, nr VI, s. 321-324.

Annie Bella Graham Kidd przeciwko Stanom Zjednoczonym Meksyku, R.I.A.A. 1931, nr V, s. 142-144.

Argentyna przeciwko Urugwajowi, MTS, sprawa młynów rzecznych na rzece Urugwaj, ICJ Reports 2010, s. 1-80.

Argentyna przeciwko Urugwajowi, nakaz tymczasowy w sprawie młynów rzecznych na rzece Urugwaj, MTS, ICJ Reports 2006, s. 113-135.

Australia przeciwko Francji, Nowa Zelandia przeciwko Francji, MTS, ICJ Reports 1975, s. 253-274.

Belgia przeciwko Hiszpanii, MTS, ICJ Reports 1970, s. 3-53.

Bośnia i Hercegowina przeciwko Serbii i Czarnogórze, MTK, orzeczenie w sprawie stosowania konwencji o zapobieganiu i karaniu zbrodni ludbójstwa, ICJ Reports 2007, s. 43-240.

Canahl przeciwko Stanom Zjednoczonym Meksyku, R.I.A.A. 1928, nr IV, s. 389-391.

Davis przeciwko Wenezueli, R.I.A.A. 1903, nr IX, s. 460-464.

Denham i Denham przeciwko Panamie, R.I.A.A. 1933, nr VI, s. 312-313.

Dujay, w imieniu Gilberta F. Dujay (U.S.A.) przeciwko Stanom Zjednoczonym Meksyku, Komisja roszczeń wzajemnych meksykańsko-amerykańska, 8 kwietnia 1929 r., R.I.A.A. 1929, nr 4, s. 452.

García przeciwko Stanom Zjednoczonym Meksyku, R.I.A.A. 1926, nr IV, s. 108-110.

Hiszpania przeciwko Wielkiej Brytanii, STSM, sprawa roszczeń brytyjskich w Maroku, R.I.A.A. 1924, tom 2, s. 615-742.

Irlandia przeciwko Wielkiej Brytanii, Międzynarodowy Trybunał Prawa Morza, 2001, sprawa elektrowni MOX.

Janes i in. przeciwko Stanom Zjednoczonym Meksyku, R.I.A.A. 1925, nr IV, s. 60-66.

Kennedy przeciwko Stanom Zjednoczonym Meksyku, R.I.A.A. 1927, nr IV, s. 194-203.

Lovett i in. przeciwko Chile, R.I.A.A. 1894, nr XXIX, s. 319-321.

Mieszkańcy Bikini przeciwko Stanom Zjednoczonym Ameryki, United States Court Of Federal Claims 1996 r. [online]. BIKINIATOLL [dostęp: 2013-01-20] Dostępny w Internecie: <http:// www.bikiniatoll.com/7-18-06\%20Amended\%20complaint.pdf $>$.

Nakaz z 12 maja 1980 r., w sprawie amerykańskiego personelu dyplomatycznego i konsularnego w Teheranie, ICJ Reports, $1981 \mathrm{r}$.

Nakaz zastosowania środków tymczasowych z 15 grudnia 1979 r., sprawa amerykańskiego personelu dyplomatycznego i konsularnego w Teheranie, ICJ Reports, $1979 \mathrm{r}$.

Neer i Neer przeciwko Stanom Zjednoczonym Meksyku, R.I.A.A. 1926, s. 60-66.

Niemcy przeciwko Polsce, STSM, 1928, sprawa fabryki chorzowskiej, P.C.I.J. seria A, nr. 17.

Nikaragua przeciwko Stanom Zjednoczonym, ICJ Reports 1986.

Nowa Zelandia p. Francji, MTS, Request for an Examination of the Situation in Accordance with the Court's Judgment in the Nuclear Tests Case, ICJ Reports 1995, s. 288-308.

Nowa Zelandia p. Francji, MTS, Request for an Examination of the Situation in Accordance with the Court's Judgment in the Nuclear Tests Case, ICJ Reports 1995, zdanie odrębne sędziego Weeramantry, s. 317-362.

Nowa Zelandia p. Francji, Request for an Examination of the Situation in Accordance with the Court's Judgment in the Nuclear Tests Case, ICJ Reports 1995.

Nowa Zelandia przeciwko Francji, MTS, stosowanie środków tymczasowych, ICJ Reports 1995, s. 288-308. 
Poggioli przeciwko Wenezueli, R.I.A.A. 1903, nr X, s. 669-692.

Prokurator przeciwko Dusko Tadič, wyrok MTKJ z 7 maja 1997 r., 35 ILM (1996) 32.

Roberts przeciwko Stanom Zjednoczonym Meksyku, R.I.A.A. 1926, nr IV, s. 77-81.

Robinson Smith Putnam przeciwko Stanom Zjednoczonym Meksyku, R.I.A.A. 1927, nr IV, s. 151-155.

Sentence arbitrale sur la réclamation numéro 54, présentée par Don Aquilino Capalleti, R.I.A.A. 1901, nr XV.

Sprawa pewnych interesów niemieckich na polskim Górnym Śląsku, Stały Trybunał Sprawiedliwości Międzynarodowej, PCIJ Series 1926, seria A, nr 6.

Sprawa reparacji za szkody przedstawicieli ONZ, zdanie odrębne sędziego Kryłowa, ICJ Reports 1949, s. 219.

Sprawa terytorium Saary, League of Nations Official Journal 1933, nr 14, s. 1046-1051.

Stany Zjednoczone przeciwko Iranowi, MTS, sprawa amerykańskiego personelu dyplomatycznego i konsularnego w Teheranie, ICJ Pleadings 1982 r.

Stany Zjednoczone przeciwko Iranowi, wyrok MTS z 24 maja 1980 r. w sprawie amerykańskiego personelu dyplomatycznego i konsularnego w Teheranie, Recueil Des Arrêts, Avis Consultatifs Et Ordonnances 1980 r., s. 3-46.

Trail Smelter Arbitral Decision, American Journal of International Law 1939, nr 33, s. 182-212.

Trail Smelter Arbitral Tribunal Decision, American Journal of International Law 1941, nr 35, s. 684-736.

Venable przeciwko Stanom Zjednoczonym Meksyku, R.I.A.A. 1927, nr IV, s. 219-261.

Walter A. Noyes przeciwko Panamie, R.I.A.A. 1933, nr VI, s. 308-312.

West przeciwko Stanom Zjednoczonym Meksyku, R.I.A.A. 1927, nr IV, s. 270-272.

Węgry przeciwko Słowacji, MTS, sprawa projektu Gabcikovo-Nagymaros, ICJ Reports 1997, nr 92, s. 7-84.

Wielka Brytania przeciwko Albanii, STSM, sprawa Cieśniny Korfu, International Court of Justice Reports 1949, s. 4-169.

Wielka Brytania, Francja i Włochy przeciwko Japonii i Niemcom, STSM, sprawa statku Wimbledon, PCIJ Series 1923, seria A, 1923, nr 1.

Wurttembergia i Prusy przeciwko Badenii, Annual Digest of Public International Law Cases 1927-28 (1931), nr 86, s. 128-155.

\section{Artykuły prasowe i inne źródła}

Anonim, Woman who cut internet to Georgia and Armenia 'had never heard of web', The Daily Telegraph, 11 kwietnia 2011 r. [online]. TELEGRAPH [dostęp: 2013-01-20]. Dostępny w Internecie: <http://www.telegraph.co.uk/news/worldnews/europe/georgia/8442056/Woman-whocut-internet-to-Georgia-and-Armenia-had-never-heard-of-web.html>.

Coalson R., Behind The Estonia Cyberattacks, Radio Free Europe, 6 marca 2009 r. [online]. DFERL [dostęp: 2012-01-20]. Dostępny w Internecie: <http://www.rferl.org/Content/Behind The_Estonia_Cyberattacks/1505613.html $>$.

Melman Y., Iran pauses uranium enrichment at Natanz nuclear plant [online]. Haaretz, 24 listopada 2010 r. [dostęp: 2013-01-20]. Dostępny w Internecie: <http://www.haaretz.com/news/ international/iran-pauses-uranium-enrichment-at-natanz-nuclear-plant-1.326276>.

Musayelyan S., Hayastan cut Hayastan's web?: „Shovel-wielding” cyber granny in Georgia identified as Armenian [online]. ArmeniaNow, 8 kwietnia 2011 r. [dostęp: 2013-01-20]. Dostępny w Internecie: <http://armenianow.com/news/28871/hasaystan_shakayan_internet_cable cut_georgia_armenia $>$.

T.S., The Stuxnet worm: A cyber-missile aimed at Iran? [online]. The Economist, 24 września 2010 r. [dostęp: 2013-01-20]. Dostępny w Internecie: <http://www.economist.com/blogs/ babbage/2010/09/stuxnet_worm>.

Traynor I., Russia accused of unleashing cyberwar to disable Estonia [online]. The Guardian, 17 maja 2007 r. [dostęp: 2013-01-20]. Dostępny w Internecie: <http:/www.guardian.co.uk/world/ 2007/may/17/topstories3.russia>. 
Wir sollten aufwachen und überlegen [online]. Der Spiegel 1986 r., $\mathrm{nr}$ 47, s. 138-147 [dostęp: 2013-01-20]. Dostępny w Internecie: <http://www.spiegel.de/spiegel/print/d-13521501.html>.

Zakaria T., NSA is looking for a few good hackers [online]. Washington Post z 2 sierpnia $2011 \mathrm{r}$. [dostęp: 2013-01-20]. Dostępny w Internecie: <http://articles. washingtonpost.com/2011-08-02/politics/35271956 1 defcon-hackers-nsa>.

Zetter K., Senior Defense Official Caught Hedging on U.S. Involvement in Stuxnet [online]. Wired Magazine, 26 maja 2011 r. [dostęp: 2013-01-20]. Dostępny w Internecie: <http://www.wired .com/threatlevel/2011/05/defense-department-stuxnet/>. 
